\author{
UNIVERSIDADE DE SÃO PAULO \\ INSTITUTO DE RELAÇÕES INTERNACIONAIS
}

MARIANA MIDEA CUCCOVIA CHAIMOVICH

\title{
LEGISLATIVO E EXECUTIVO BRASILEIROS NA INTERNALIZAÇÃO DE TRATADOS DE DIREITOS HUMANOS: \\ CONVERGÊNCIAS E DIVERGÊNCIAS \\ NA DITADURA E NA DEMOCRACIA
}




\section{LEGISLATIVO E EXECUTIVO BRASILEIROS NA INTERNALIZAÇÃO DE TRATADOS DE DIREITOS HUMANOS: \\ CONVERGÊNCIAS E DIVERGÊNCIAS NA DITADURA E NA DEMOCRACIA}

Tese apresentada ao Programa de PósGraduação em Relações Internacionais do Instituto de Relações Internacionais da Universidade de São Paulo como exigência parcial para a obtenção do título de Doutor em Ciências.

Orientador: Professor Doutor Amâncio Jorge Silva Nunes de Oliveira

\section{Versão corrigida}

A versão original encontra-se disponível na Biblioteca do Instituto de Relações Internacionais e na Biblioteca Digital de Teses e Dissertações da USP, documentos impresso e eletrônico.

SÃO PAULO 
Autorizo a reprodução e divulgação total ou parcial deste trabalho, por qualquer meio convencional ou eletrônico, para fins de estudo e pesquisa, desde que citada a fonte.

Catalogação da Publicação

Instituto de Relações Internacionais da Universidade de São Paulo

Chaimovich, Mariana Midea Cuccovia

Legislativo e Executivo brasileiros na internalização de tratados e Direitos Humanos: convergências e divergências na ditadura e na democracia / Mariana Midea Cuccovia Chaimovich. -- Orientador Professor Doutor Amâncio Jorge Silva Nunes de Oliveira. São Paulo: 2017.

$573 \mathrm{p}$.

Tese (doutorado). Universidade de São Paulo. Instituto de Relações Internacionais.

1. Processo Legislativo - Brasil. 2. Tratados Internacionais. 3. Poderes Executivo e Legislativo. 4. Direitos Humanos. 5. Democracia e Ditadura.

Chaimovich, Mariana Midea Cuccovia.

CDD 328.81 
Significantly, the international system has had implications at the national level. A multitude of domestic legal systems have been affected by the treaties. The treaties form the basis of a significant number of the world's bills of rights. (..) The treaties have sometimes been incorporated into national law, had direct application through constitutional provisions to national law, and been used to interpret domestic law through judicial intervention. In theory, the subsidiary nature of international implementation to national mechanisms should permit a reduction of the burdens at the international level. In our time, however, this programme remains unachieved.

Anne Bayefsky

The UN Human Rights Treaty System: Universality at the Crossroads

The study of human rights makes unlikely bedfellows.

Andrew Moravcsik

The Origins of Human Rights Regimes: Democratic Delegation in Postwar Europe 


\section{BANCA EXAMINADORA:}

Prof. Dr.

Julgamento:

Prof. Dr.

Julgamento:

Prof. Dr.

Julgamento:

Prof. Dr.

Julgamento:

Prof. Dr.

Julgamento:
Instituição:

Assinatura:

Instituição:

Assinatura:

Instituição:

Assinatura:

Instituição:

Assinatura:

Instituição:

Assinatura: 


\section{AGRADECIMENTOS}

O caminho que culminou nesta tese foi rodeado de familiares, de amigos e de professores, que me ajudaram, de maneiras muito diferentes, a terminar esse árduo trabalho. Tentei, aqui, demonstrar o quanto todos aqueles que me acompanharam nessa jornada contribuíram para o resultado final. Desculpo-me, antecipadamente, por eventual esquecimento.

À Universidade de São Paulo (USP) e ao Instituto de Relações Internacionais (IRI), pela oportunidade de integrar o programa de pós-graduação do IRI-USP.

Ao meu orientador, professor Amâncio Jorge Silva Nunes de Oliveira, por todas as reuniões de discussão de projeto, de tese, e por lidar com a teimosia inerente à orientanda. Suas ponderações foram essenciais para que ideias esparsas pudessem ser transformadas, efetivamente, em um trabalho.

Ao professor Pedro Bohomoletz de Abreu Dallari, pela "mudança de ares", da Faculdade de Direito para o IRI. Isso não teria acontecido sem os seus conselhos e sem a sua orientação, seja oficial, no mestrado, seja extraoficial, ajudando uma recém-formada - e, depois, uma mestre e doutoranda - a vislumbrar diferentes perspectivas para tentar solucionar os problemas que surgem na vida.

Agradeço aos coordenadores e membros do Fundo Ryoichi Sasakawa, na pessoa do professor Adalberto Fischman, pelo contato que tive, desde 2010, com todos aqueles que participaram das seleções dos futuros membros do Fundo. Gostaria de agradecer aos colegas que conheci e aos amigos que fiz, particularmente a Arthur Capella, Camila Perruso, Fabia Veçoso, Paulo Nascimento, Priscila Beltrame e Thiago Nogueira. Um agradecimento especial a Matheus Hardt, que, na última reunião do Fundo, teve a delicadeza de ajudar a organizar os dados das minhas diversas tabelas, ao que sou extremamente grata.

À Coordenação de Aperfeiçoamento de Pessoal de Nível Superior (CAPES), pelo auxílio financeiro durante o doutorado.

Aos membros da minha banca de qualificação, professores Leany Lemos e Pedro Feliú Ribeiro, pelas contribuições valiosas, que muito me ajudaram a definir este trabalho. À professora Suely Mara Vaz Guimarães de Araújo, cujas observações foram importantes para o desenvolvimento desta tese. Aos profissionais dos arquivos da Câmara dos Deputados e 
do Senado Federal, agradeço, nas pessoas de Alexandre Gomes Alves e de Rosa Maria Gonçalves Vasconcelos, a atenção e o cuidado dispensados durante a visita aos arquivos.

Aos funcionários do IRI, agradeço, na pessoa de Giselle de Castro, a paciência com as diversas perguntas relacionadas às aulas, aos períodos de matrícula e às (muitas) normas da pós-graduação. À Adriana Vargas de Castilho e à Maria Cristina Bonavita, agradeço todo o suporte e atenção, institucional e pessoal, que me dispensaram ao longo dos últimos anos.

Aos membros do GACInt, agradeço, na pessoa de Ricardo Sennes, a oportunidade de participar de um grupo tão ativo e com reuniões tão intelectualmente estimulantes. Aos queridos André Michelin, André Siciliano, Bruno Brasil e Victor Tibau, agradeço o companheirismo nas reuniões matutinas e nos merecidos encontros de comemoração pelo trabalho feito.

Aos colegas da pós-graduação, agradeço o contato nos últimos anos, os encontros dentro e fora da USP, para estudar, para reclamar e para comemorar. Agradeço especialmente às amigas Daniele Gave, Mônica Sodré, Patrícia Tambourgi e Tamya Rebelo. À Mônica, agradeço as conversas sobre as (muitas) possibilidades para o futuro. À Pati, pela amizade sincera, na USP e fora dela. À Tamya, a oportunidade de participar de momentos tão importantes da sua história, e pela chance de conhecer a linda Belém do Pará. A todas, agradeço os conselhos, as conversas e as broncas.

Ao eterno professor Francisco "Chico" Marto de Moura, que me ensinou a escrever em uma época em que eu, inocente ou arrogantemente, acreditava que sabia. Muito obrigada pela paciência com minha impaciência, pela clareza e por ter sido um grande amigo em uma fase tão difícil.

À Miriam Dohlnikoff, sem a qual a história do Brasil seria, apenas, um amontoado de fatos desconexos: obrigada por tudo. Mesmo.

Ao Alexandre Pacheco, Daniel Tavela Luís, Juliana Villa Mello, Marina Bozzola, Thais Lina, amigos que ganhei de brinde, e que espero que permaneçam.

Ao André Cordelli, amigo de presença contínua, apesar de menos constante do que eu gostaria, nos últimos dez anos.

À Paula Gorzoni, amiga da SBDP, da São Francisco e da vida.

Ao José André Stucchi Fernandes, amigo de longa data. Admiro a sua força frente a todos os desafios que a vida teima em oferecer. Obrigada por todo o carinho. 
Ao Bruno Gonçalves, minha dupla e companheiro de longos dias de estudos, de alegrias e de decepções. Chegaremos onde temos que chegar. Se não chegamos ainda, basta fazer chegar. Você é incrível, e o seu futuro guarda uma história cada vez mais brilhante.

À Karina Martins Araújo Santos, Marina Fontão Zago e Paola Moraes. Sem vocês, o caminho percorrido desde a graduação até o fim desta tese não teria sido tão divertido e leve. Obrigada pelo amor, pela paciência, pelas (necessárias) correções de rumo, pessoais e profissionais. À Marina, por aguentar, e superar, as idiossincrasias e a desorganização da minha pessoa, com mais amor do que eu poderia merecer. À Karina, pela cumplicidade e pelos sábios conselhos, sempre. À Paola, por ter compartilhado, com conhecimento de causa e com muito companheirismo, situação profissional - e de vida - tão sui generis.

À minha família em geral, e a alguns membros em particular, meus mais profundos agradecimentos.

Aos meus pais, Iolanda Midea Cuccovia e Hernan Chaimovich Guralnik, que me deram todos os instrumentos para chegar até aqui, e que me influenciaram em todas (todas) as decisões. Sem eles, nada disso seria possível.

À Nazilda Santana de Oliveira, invariavelmente em casa para me amparar.

Aos meus irmãos, meus mais sinceros agradecimentos. Ao Marcos Chaimovich, por todo o apoio, pela Ana e pelas minhas duas sobrinhas lindas. Ao Felipe "Pipo" Chaimovich, irmão e amigo querido, cuja trajetória e história de vida é uma inspiração, desde sempre. Saber que tenho em minha vida alguém como você me inspira a querer ser você quando crescer. Ou algo assim, bem parecido.

À minha tia, Margherita Midea Cuccovia, e à minha avó, "mamá" Donata. Ao Fernando e ao Raphael M C V Reis. O primeiro, por ter me possibilitado esse contato maravilhoso no último ano, com um primo que eu conhecia, mas via pouco demais. $\mathrm{O}$ segundo, por ter trazido à família dois novos membros, Lu e Gabi, que nos alegram cada vez mais.

À família do Victor Nóbrega Luccas, muito obrigada pelo filho, irmão e neto maravilhoso. E por me permitirem fazer parte da família de vocês.

Ao Victor. Faltam palavras, sobra felicidade. Você aguentou todas as mudanças nos últimos anos, manteve a posição de melhor amigo, e acumulou a - árdua - função de noivo e de pilar de sustentação. Não sei o que aconteceria sem você. O plano é nunca ter que saber. 


\section{RESUMO}

Esta tese tem dois objetivos. O primeiro deles é verificar se os membros do Poder Legislativo são apáticos em sua atuação no processo de internalização de tratados internacionais. A apreciação desta questão deu-se mediante o estudo da participação dos parlamentares no processo de internalização de tratados; das propostas para alterar as competências no que se refere às suas capacidades, atribuídas pela legislação constitucional e infraconstitucional brasileira, de atuar em temas afetos à política externa, e, consequentemente, no processo de internalização de tratados; e do uso de tratados como fonte de inspiração para a legislação interna. Para o estudo dos processos de internalização foram selecionados tratados multilaterais de Direitos Humanos celebrados internacionalmente após criação da Organização das Nações Unidas, marco temporal de extrema relevância para a formação do Direito Internacional dos Direitos Humanos. Essa análise demonstrou que os parlamentares não são apáticos em relação às suas atribuições nesses temas, ao contrário do que afirma parte da literatura. O segundo objetivo consistirá em verificar se o regime - democrático ou ditatorial, influencia os intervalos temporais de tramitação desses tratados no Brasil, o teor e a quantidade de argumentos proferidos, durante o processo, por membros dos Poderes Executivo e Legislativo brasileiros. Cada intervalo de tempo relativo ao processo de internalização desses instrumentos foi selecionado por ser relevante para a tramitação de tratados nos âmbitos nacional e internacional. A hipótese inicial, confirmada pelos dados da pesquisa, é a de que a quantidade de argumentos proferidos e os intervalos de tempo, durante a ditadura, seriam menores, se comparados aos da democracia. Isso porque, no período de exceção, haveria menos discussão entre os membros dos Poderes Executivo e Legislativo, e entre membros de um mesmo Poder. No regime democrático existiriam mais interesses discrepantes, o que ensejaria maiores discussões e, portanto, maior tempo de tramitação para cada fase analisada. Os argumentos proferidos durante a tramitação foram separados conforme seu teor, e divididos em argumentos de Política Externa, de Política Interna, de Direito Interno, de Direito Internacional, e de Direitos Humanos. Observou-se que membros do Poder Legislativo, particularmente da Câmara dos Deputados, tendem a tratar, primordialmente, de questões relacionadas às consequências internas do processo de internalização de tratados, particularmente da política e do direito nacionais, do que de questões externas. Os representantes do Poder Executivo, por sua vez, estariam mais focados em questões externas e internacionais. Ao analisar as convergências e as divergências entre os Poderes nos diferentes regimes, e estabelecer um padrão de comportamento, a autora verificou que os membros do Poder Legislativo não são apáticos nesse processo, o que pode ser comprovado, igualmente, pelas iniciativas institucionais de alteração de sua regulamentação, como a propositura de Emendas Constitucionais ou Regimentais por parlamentares brasileiros. A influência de instrumentos internacionais na legislação brasileira demonstra, ainda, a disposição de Deputados e de Senadores de utilizar o Direito Internacional como meio de aprimorar a legislação interna que protege os Direitos Humanos. Percebe-se, ademais, que existem nuances entre as diversas classes de direitos protegidos pelos tratados analisados, e que o Direito Internacional influencia o direito interno, justamente em virtude da atuação parlamentar nesse sentido.

Palavras-chave: 1. Processo Legislativo - Brasil. 2. Tratados Internacionais. 3. Poderes Executivo e Legislativo. 4. Direitos Humanos. 5. Democracia e Ditadura. 


\section{ABSTRACT}

This thesis has two objectives. The first one is to verify if the members of the Legislative branch are apathetic about their role in the process of internalization of international treaties. The consideration of this matter was made through the study of the participation of congressmen in the process of internalization of treaties; of the proposals to change the competences regarding their capacities, attributed by the Brazilian constitutional and infraconstitutional legislation, to act on issues related to foreign policy, and, consequently, in the process of internalization of treaties; and in the use of treaties as a source of inspiration for domestic legislation. For the study of the internalisation process, multilateral Human Rights treaties concluded internationally after the creation of the United Nations, a milestone for the formation of International Human Rights Law, were selected. This analysis showed that congressmen are not apathetic about their attributions in these subjects, which is contrary to what is stated in the literature. The second objective will be to verify if the regime - democratic or dictatorial, influences the temporal intervals of processing of these treaties in Brazil, the content and quantity of arguments made during the process by members of the Brazilian Executive and Legislative Branches. Each time interval related to the process of internalization of these instruments was selected because of its relevance for the processing of treaties at the national and international levels. The initial hypothesis, confirmed by the data obtained, is that the number of arguments would be smaller and the time intervals would be shorter during the dictatorship, if compared with those of the democratic period. This happens because, during a dictatorship, there would be less discussion between members of the Executive and Legislative Branch, and between members of the same Branch. In the democratic regime, there would be more conflicting interests, which would lead to greater discussions and, therefore, a longer processing time for each analyzed phase. The arguments put forward during the proceedings were separated according to their content, and divided into arguments of Foreign Policy, Domestic Policy, Domestic Law, International Law, and Human Rights. I observed that members of the Legislative Branch, particularly the Chamber of Deputies, tend to deal primarily with issues related to the internal consequences of the process of internalising treaties, particularly national policy and domestic law, rather than external issues. Representatives of the Executive Branch, on the other hand, would be more focused on external and international issues. Analyzing the convergences and divergences between the Branches in the different regimes, and establishing a pattern of behavior, the author verified that the members of the Legislative Branch are not apathetic in this process, which can also be proved by the institutional initiatives to change its regulation, such as the introduction of Constitutional or Regimental Amendments by Brazilian parliamentarians. The influence of international instruments in Brazilian legislation also demonstrates the willingness of Deputies and Senators to use International Law as a means of improving domestic legislation that protects Human Rights. There are nuances between the different classes of rights protected by the treaties analyzed, and that International Law influences domestic law, precisely because of the parliamentary action in this regard.

Keywords: 1. Legislative process - Brazil. 2. International treaties. 3. Executive and Legislative Branches. 4. Human Rights. 5. Democracy and Dictatorship. 


\section{RÉSUMÉ}

Cette thèse a deux objectifs. Le premier est savoir si les membres du Pouvoir Législatif sont apathiques en relation a sa rôle dans le processus d'internalisation des traités internationaux. L'appreciation de cette question a été fait par l'étude de la participation des parlamentaires dans le processus d'internalisation des traités; des propositions visant à modifier ses competences par rapport à leurs capacités, attribuées par la législation constitutionnelle et infra-constitutionnel brésilienne, d'actuer sur des sujets liés aux affaires étrangères, et, donc, sur le processus d'internalisation des traités; et de l'utilisation des traités comme une source d'inspiration pour la législation nationale. Pour étudier les processus d'internalisation, traités multilatéraux de droits de l'Homme conclu à l'échelle internationale après l'établissement de l'Organisation des Nations Unies, ont été sélectionnés, en raison de son importance pour la formation de la loi internationale des Droits de L'homme. Cette analyse a montré que les parlementaires ne sont pas apathiques par rapport à ses responsabilités en la matière, contrairement aux affirmations de la littérature. Le deuxième objectif est vérifier si le régime - démocratique ou dictatorial, influe sur le traitement des intervalles temporels de ces traités au Brésil, le contenu et le montant d'arguments faits au cours du processus par les membres des Pouvoirs Exécutif et Législatif du Brésil. Chaque intervalle de temps a été sélectionné pour être pertinent pour le processus de délibération des traités aux niveaux national et international. L'hypothèse initiale, confirmée par la recherche, est que la quantité d'arguments fournis et les intervalles de temps pendant la dictature sont inférieur si comparés a ceux pendand la démocratie. En effet, dans le période d'exception, il y aurait moins de discussions entre les membres des Pouvoirs Exécutif et Législatif, et entre les membres d'un même Pouvoir. Dans la démocratie, il y aurait plus d'intérêts disparates, ce qui provoquerait de nouvelles discussions et donc plus de temps de traitement pour chaque étape analysée. Les arguments fournis dans le cours -du processus de délibération ont été séparés en fonction de leur contenu, et divisés en arguments de Affairs Étrangères, de Politique Intérieure - Droit interne, Droit International et Droits de L'Homme. Les membres du Pouvoir Legislatif, en particulier la Chambre des Deputats, ont la tendance à traiter principalement les questions liées aux conséquences internes du processus d'internalisation des traités, en particulier la politique et le droit national, e pas les affaires étrangères. Les représentants du Exécutive, à son tour, seraient plus axé sur les questions extérieures et internationales. Après l'analyse des convergences et des divergences entre les Pouvoirs dans les différents régimes, et d'établir un modèle de comportement, l'auteur a constaté que les membres du Législatif ne sont pas apathiques dans ce processus, ce que peut être éprouvé aussi par le changement dans les initiatives institutionnelles de sa réglementation, comme l'introduction d'amendements constitutionnels ou régimentaire par les parlementaires brésiliens. L'influence des instruments internationaux dans la législation brésilienne démontre également la volonté des Deputés et des Sénateurs d'utiliser le Droit International comme un moyen d'améliorer la législation nationale qui protège les droits de l'homme. Il est clair, en outre, qu'il ya des nuances entre les différentes catégories de droits protégés par les traités analysés, et que le Droit International influe sur la législation nationale, précisément à cause de l'action parlementaire en conséquence.

Mots-clés: 1. Processus législatif - Brésil. 2. Traités internationaux. 3. Pouvoirs Exécutif et Législatif. 4. Droits de l'Homme. 5. Démocratie et dictature. 


\section{SIGLAS E ABREVIAÇÕES UTILIZADAS}

ACNUR: Alto Comissariado das Nações Unidas para Refugiados

ADCT: Ato das Disposições Constitucionais Transitórias

ADI: Ação Direta de Inconstitucionalidade

AGNU: Assembleia Geral das Nações Unidas

AI: Ato Institucional

ALCA: Área de Livre Comércio das Américas

Art:: Artigo

BIRD: Banco Internacional para Reconstrução e Desenvolvimento

CADH: Convenção Americana de Direitos Humanos ("Pacto de São José da Costa Rica")

- $\quad$ CC: Código Civil

- CCJ: Comissão de Constituição, Justiça e Cidadania (Senado Federal)

- CCJC: Comissão de Constituição e Justiça e de Cidadania (Câmara dos Deputados)

- CCT: Convenção contra a Tortura e Outros Tratamentos ou Penas Cruéis, Desumanos ou Degradantes

- CD: Câmara dos Deputados

- $\quad$ CDC: Convenção sobre os Direitos das Crianças

- $\quad$ CDHM: Comissão de Direitos Humanos e Minorias

- CEDAW: Convenção sobre a eliminação de todas as formas de discriminação contra a mulher

- CEPAL: Comissão Econômica para a América Latina

- CER: Convenção relativa ao Estatuto dos Refugiados

- CF: Constituição da República Federativa do Brasil

- CIDH: Comissão Interamericana de Direitos Humanos

- CIEDR: Committee on the Elimination of Discrimination against Women relacionado à Convenção Internacional sobre a eliminação de todas as formas de Discriminação Racial

CIJ: Corte Internacional de Justiça

CIPT: Convenção Interamericana para Prevenir e Punir a Tortura

CJ/MRE: Consultoria Jurídica do Ministério das Relações Exteriores 
CLT: Consolidação das Leis do Trabalho

- CN: Congresso Nacional

- CNBB: Conferência Nacional dos Bispos do Brasil

- CNDH: Conselho Nacional dos Direitos Humanos

- Col.: Coluna

- COMDIP: Comissão de Diplomacia

- CONTAG: Confederação Nacional dos Trabalhadores na Agricultura

- $\quad$ CP: Código Penal

- CPD: Comissão de Defesa dos Direitos das Pessoas com Deficiência

- CPI: Comissão Parlamentar de Inquérito

- CPRG: Convenção para a prevenção e a repressão do crime de Genocídio

- CRE: Comissão de Relações Exteriores da Câmara dos Deputados

- CREDN: Comissão de Relações Exteriores e de Defesa Nacional da Câmara dos Deputados

- CSNU: Conselho de Segurança da Organização das Nações Unidas

- CUT: Central Única dos Trabalhadores

- CVDT: Convenção de Viena sobre o Direito dos Tratados

- DAI: Divisão de Atos Internacionais do Ministério das Relações Exteriores (Brasil)

- DBR: Direito Brasileiro (Direito interno)

- DCN: Diário do Congresso Nacional

- DCD: Diário da Câmara dos Deputados

- DH: Direitos Humanos

- DIN: Direito Internacional

- DLG: Decreto Legislativo

- DOU: Diário Oficial da União

- DSF: Diário do Senado Federal

- DUDH: Declaração Universal dos Direitos Humanos (antes: do Homem)

- $\quad$ EC: Emenda Constitucional

- $\quad$ ECOSOC: Conselho Econômico e Social da Organização das Nações Unidas

- $\quad$ EUA: Estados Unidos da América

- FMI: Fundo Monetário Internacional

- GRULAC: Grupo de países da América Latina e do Caribe 


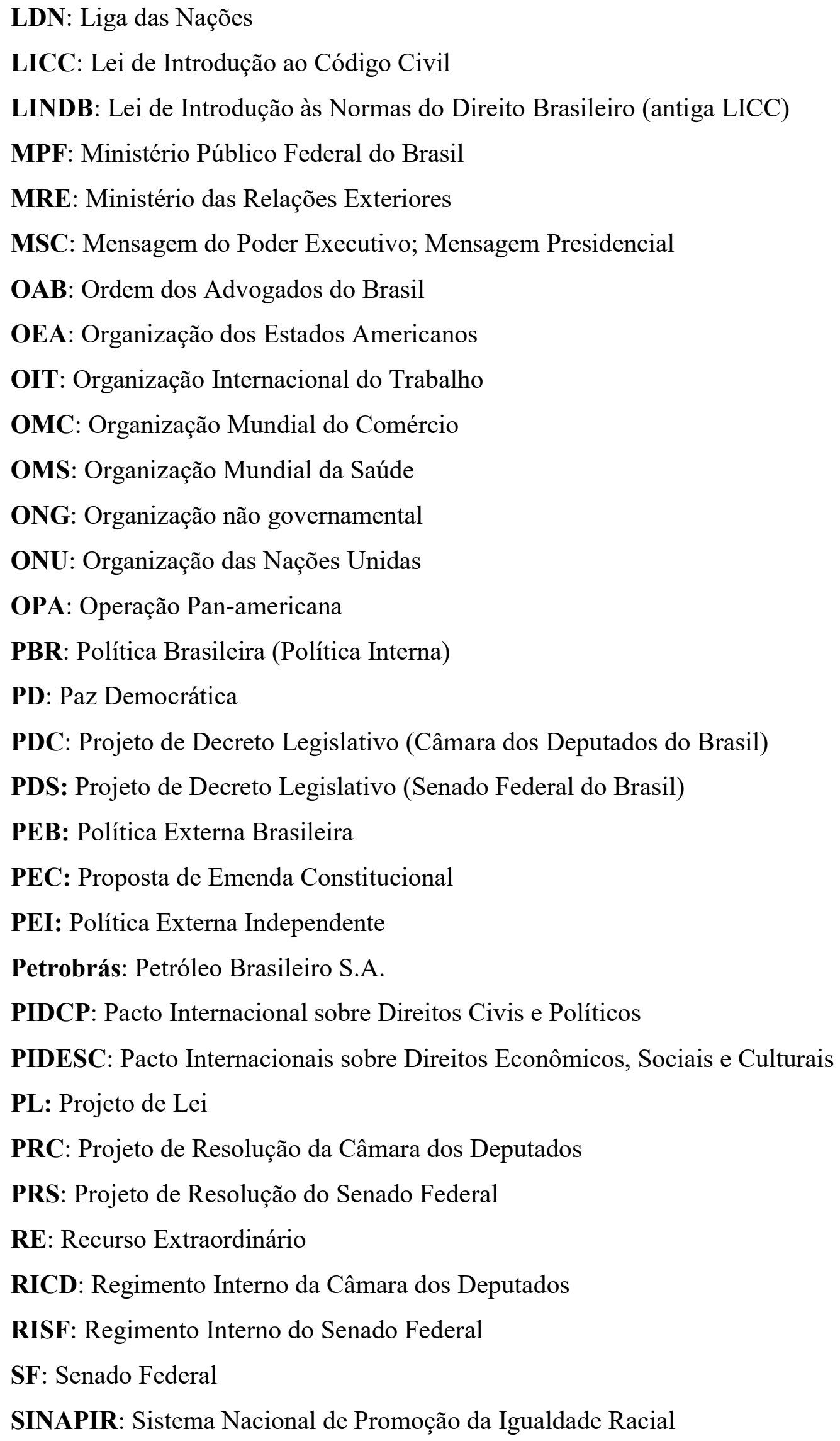


- $\quad$ STF: Supremo Tribunal Federal

- $\quad$ STJ: Superior Tribunal de Justiça

- $\quad$ SUMOC: Superintendência da Moeda e do Crédito

- $\quad$ TCU: Tribunal de Contas da União

- $\quad$ TPI: Tribunal Penal Internacional

- $\quad$ UE: União Europeia

- $\quad$ UNESCO: Organização das Nações Unidas para a Educação, a Ciência e a Cultura

- $\quad$ UPR: Universal Periodic Review (português: RPU - Revisão Periódica Universal)

- $\quad$ URSS: União das Repúblicas Socialistas Soviéticas 


\section{LISTA DE FIGURAS}

Figura 1: Processo de elaboração e de internalização de tratados ........................................... 47

Figura 2: Tramitação de tratados na Câmara dos Deputados................................................ 211

Figura 3: Tramitação de tratados no Senado Federal ........................................................... 212

\section{LISTA DE TABELAS}

Tabela 1: Ministros das Relações Exteriores do Brasil e diferentes etapas dos tratados de Direitos Humanos 144

Tabela 2: Cálculo das médias de cada etapa de tramitação dos tratados internacionais analisados. 165

Tabela 3: Datas do tratado e assinatura, na Ditadura e na Democracia: dados e cálculo dos intervalos.

Tabela 4: Argumentos presentes nas Mensagens Presidenciais (em \%)

Tabela 5: Tratados com mais argumentos do que a média

Tabela 6: Correlações para todos os tratados analisados

Tabela 7: Correlações para tratados com Reservas

Tabela 8: Correlações em tratados que demoraram mais do que a média para tramitar em diversas etapas da tramitação

Tabela 9: Estatísticas 1945-64 G1

Tabela 10: Estatísticas 1964-85 G2.. 570

Tabela 11: Estatísticas 1985-2016 G3.

Tabela 12: Data $x$ Assinatura na Ditadura e na Democracia

Tabela 13: Assinatura x Ratificação na Ditadura e na Democracia

Tabela 14: Assinatura x Data MSC.

Tabela 15: MSC x Decreto Presidencial na Ditadura e na Democracia 


\section{SUMÁRIO}

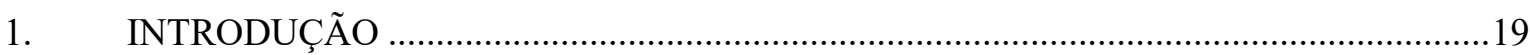

1.1. JUSTIFICATIVA DA ESCOLHA E DA RELEVÂNCIA DO TEMA............................ 38

1.2. METODOLOGIA E ESTRUTURA DA TESE ……...................................................... 42

2. PROCESSO DE ELABORAÇÃO E DE TRAMITAÇÃO DE TRATADOS .......................47

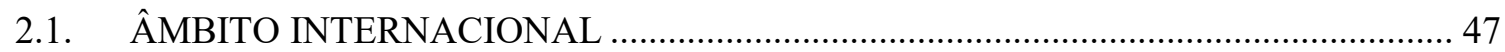

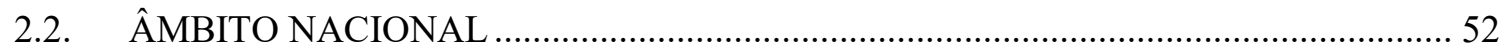

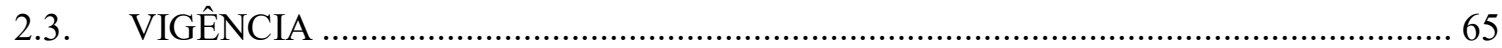

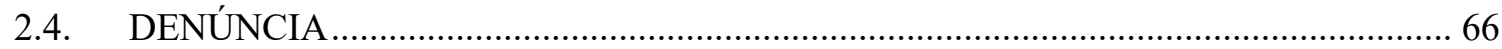

2.5. HISTÓRICO E PROPOSTAS PARA ALTERAÇÃO DO PROCEDIMENTO DE

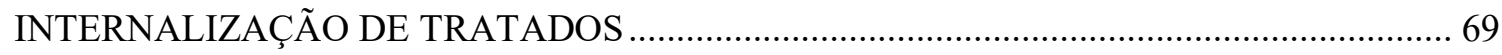

2.5.1. EVOLUÇÃO DAS DISPOSIÇÕES CONSTITUCIONAIS BRASILEIRAS SOBRE POLÍTICA EXTERNA E SOBRE A INTERNALIZAÇÃO DE TRATADOS ......................... 69

2.5.1.1. PROPOSTAS DE EMENDAS CONSTITUCIONAIS........................................ 73

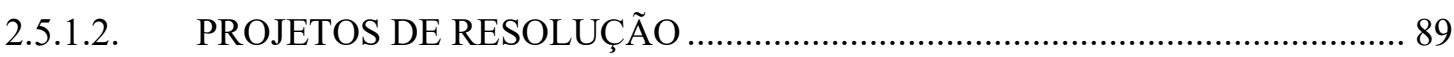

3. RELAÇÃO ENTRE O EXECUTIVO E O LEGISLATIVO NA INTERNALIZAÇÃO DE TRATADOS E NA ELABORAÇÃO DA POLÍTICA EXTERNA …………....................................95

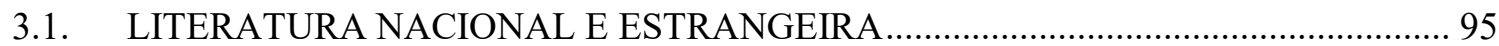

3.2. A INFLUÊNCIA DO DIREITO INTERNACIONAL NAS LEIS BRASILEIRAS E SUA RELAÇÃO COM TRATADOS DE DIREITOS HUMANOS ............................................. 113

4. PANORAMA DA POLÍTICA EXTERIOR BRASILEIRA NOS PERÍODOS ESTUDADOS

4.1. TRATADOS DE DIREITOS HUMANOS E MINISTROS DAS RELAÇÕES EXTERIORES

5. A TRAMITAÇÃO DE TRATADOS DE DIREITOS HUMANOS NO BRASIL: ASPECTOS TEMPORAIS E ARGUMENTOS UTILIZADOS NA DITADURA E NOS PERÍODOS DEMOCRÁTICOS 148

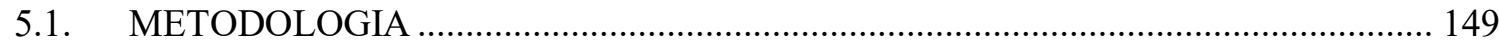

5.1.1. SELEÇÃO DE TRATADOS DE DIREITOS HUMANOS.................................... 150

5.1.2. INTERVALOS REFERENTES ÀS ETAPAS DE TRAMITAÇÃO DOS TRATADOS

5.1.3. CONTAGEM DE ARGUMENTOS DOS DOCUMENTOS ANALISADOS ...... 156

5.2. ASPECTOS TEMPORAIS: ANÁLISE DO TEMPO DE TRAMITAÇÃO................... 161

5.2.1. CONSIDERAÇÕES A RESPEITO DOS DADOS OBTIDOS 179 
5.3. ARGUMENTOS UTILIZADOS NA DITADURA E NOS PERÍODOS DEMOCRÁTICOS

5.3.1. CONSIDERAÇÕES A RESPEITO DOS DADOS OBTIDOS 206

5.4. TRATADOS INTERNALIZADOS COM RESERVAS E COM DECLARAÇÕES INTERPRETATIVAS

5.4.1. DISCUSSÃO DOS RESULTADOS EMPÍRICOS ............................................. 220

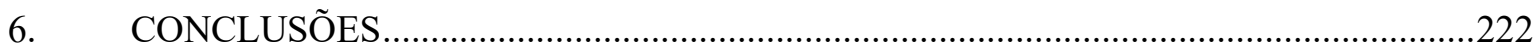

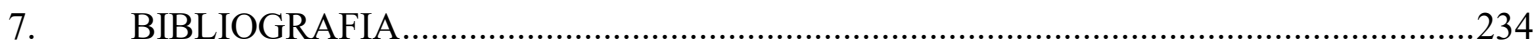

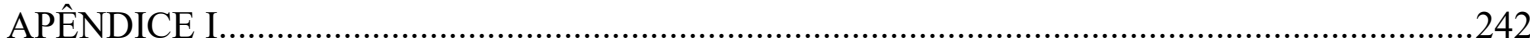

ANÁLISE TEXTUAL DA TRAMITAÇÃO DOS TRATADOS SELECIONADOS .....................242

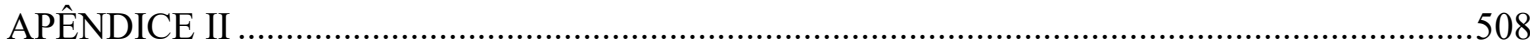

TABELA DOS DADOS AGREGADOS REFERENTES AOS ARGUMENTOS UTILIZADOS .508

APÊNDICE III 512

TABELA DOS ARGUMENTOS UTILIZADOS PELOS MEMBROS DOS PODERES EXECUTIVO E LEGISLATIVO 512

APÊNDICE IV 520

TABELAS REFERENTES AOS ATOS INTERNACIONAIS E INTERNOS ANALISADOS ...520 APÊNDICE V 550

PROPOSTAS DE EMENDAS CONSTITUCIONAIS DO SENADO FEDERAL .........................550

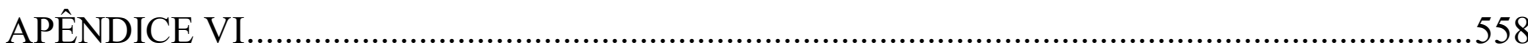

PROPOSTAS DE EMENDAS CONSTITUCIONAIS DA CÂMARA DOS DEPUTADOS.........558

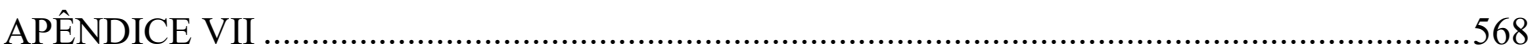

TABELAS RELATIVAS AOS INSTRUMENTOS INTERNACIONAIS ...................................568 


\section{INTRODUÇÃO}

A relação entre os Poderes Executivo e Legislativo é tema atual e deve ser explorado. Os membros dos Poderes Executivo e Legislativo, representantes diretos da população brasileira, integram as instâncias responsáveis pelas decisões relativas aos tratados internacionais, nos âmbitos interno e internacional.

Este trabalho tem dois objetivos principais. O primeiro deles refere-se à atuação dos membros do Poder Legislativo no processo de internalização de tratados no Brasil. Existe a percepção, em parte da literatura, ${ }^{1}$ de baixa assertividade e de desinteresse dos integrantes do Legislativo em relação à temática internacional. Essa percepção será contestada empiricamente nesta tese. A hipótese que se deseja testar é a de que os membros do Poder Legislativo não são apáticos em relação aos temas internacionais, particularmente ao processo de incorporação de tratados ao ordenamento jurídico nacional. Irei demonstrar essa hipótese com base em três aspectos da atuação legislativa: (i) a participação ativa no processo de internalização de tratados, mesmo durante o regime autoritário; (ii) a realização de propostas com o objetivo de alterar o procedimento de internalização de tratados (via Propostas de Emendas Constitucionais ou projetos de resolução, que alteram os Regimentos da Câmara dos Deputados e do Senado Federal); e (iii) a utilização de tratados como base para elaborar a legislação interna relativa aos Direitos Humanos.

A noção de que os integrantes do Poder legislativo são apáticos, encontrada em parte da literatura, é bem representada por Francisco Rezek. Segundo o autor, em períodos autoritários, o chefe do Poder Executivo tomava as decisões a respeito dos tratados sem qualquer participação do Legislativo:

\footnotetext{
"Nos períodos da história do Brasil em que, desativado o Congresso, assumiu o Executivo seus poderes, teria sido lógico que o chefe de Estado simplesmente prescindisse de qualquer substituto formal do decreto legislativo de aprovação. Os juristas da época assim não entenderam. No Estado Novo desencontraram-se, ademais, quanto ao diploma executivo preferível: alguns tratados foram aprovados por decreto simples, outros por decreto-lei. Esta última foi também a forma adotada pela junta governativa no recesso parlamentar compulsório de 1969. Em todos esses casos observou-se um curioso processo de determinação da vontade
}

\footnotetext{
${ }^{1}$ Consultar item 3.1. LITERATURA NACIONAL E ESTRANGEIRA.
} 
nacional: o Executivo negociava e firmava o compromisso. Analisava-o depois e, se disposto a ir adiante, editava o decreto ou decreto-lei aprobatório. Em seguida, munido de sua própria aprovação, ratificava o tratado...".

(grifo nosso)

A citação de Rezek chama atenção para o fato de que o regime político pode influenciar a participação do Legislativo de maneira geral, e os processos de internalização de tratados em particular. Ao que tudo indica, o que ocorreu na citação de Rezek não pode ser aplicado aos tratados analisados nesta tese. No mínimo, a participação de membros do Legislativo na internalização de tratados durante a ditadura demonstra a intenção dos governantes de manter a aparência de normalidade democrática, ao menos no que se refere ao funcionamento do Congresso.

Isso nos leva ao segundo objetivo desta tese, testar a hipótese de que o regime político interfere no processo de internalização de tratados. Isso será demonstrado com base na discrepância entre os intervalos de tempo durante o processo de internalização de tratados, durante a democracia e a ditadura, e nos argumentos utilizados durante esse processo.

A verificação das hipóteses de que o Legislativo não é apático, e de que o regime político influencia o processo de internalização de tratados, será realizada por intermédio de pesquisa empírica, que buscará descrever o processo de internalização de tratados de Direitos Humanos no Brasil. Será feita análise dos tempos de tramitação, bem como dos motivos para a assinatura e para a posterior ratificação de tratados pelo Executivo, por um lado, e os motivos apontados pelo Legislativo para a rejeição, aprovação e proposta de ressalvas aos tratados, por outro. Mais especificamente, serão analisadas as tramitações dos tratados multilaterais de Direitos Humanos internalizados no país, assinados a partir da criação da Organização das Nações Unidas (ONU), em 1945, marco histórico extremamente relevante para a positivação dos Direitos Humanos no âmbito internacional, no cenário do pósSegunda Guerra Mundial.

A proteção aos Direitos Humanos é tema de patente importância para a diplomacia brasileira. A compreensão do processo nacional de análise de tratados de Direitos Humanos nos âmbitos Executivo e Legislativo é essencial para compreender a internalização dos compromissos assumidos perante a comunidade internacional. São apresentados com mais

\footnotetext{
2 REZEK, Francisco. Parlamento e Tratados Internacionais: o modelo constitucional do Brasil. Revista de Direitos Fundamentais e Democracia, 2013, p. 65.
} 
detalhes os motivos que justificam a escolha e a relevância do tema escolhido no item 1.1. JUSTIFICATIVA DA ESCOLHA E DA RELEVÂNCIA DO TEMA.

Imprescindível fazer nota a respeito da definição de "Direitos Humanos" adotada nesta tese para a seleção dos tratados analisados. Serão considerados tratados de Direitos Humanos em sentido estrito aqueles que geram a responsabilização dos Estados, e surgem a partir do marco temporal da Segunda Guerra Mundial, como maneira de rever a noção tradicional de soberania estatal, que passa a ser cada vez mais relativizada. A partir desse momento, particularmente após a criação da ONU, o indivíduo passa a ser protegido pelo sistema internacional, e a ele são conferidos direitos, conforme Flávia Piovesan. ${ }^{3}$

Os tratados de Direitos Humanos em sentido estrito, portanto, não equivalem àqueles que, ao versarem sobre Direito Internacional Penal, protegem a área dos Direitos Humanos em sentido mais amplo, justamente por responsabilizarem indivíduos (e não Estados) pela violação desses direitos, como é o caso do Tribunal Penal Internacional (TPI). Como se verá adiante, não foram selecionados para a análise nesta tese apenas tratados de Direitos Humanos em sentido estrito, mas, também, tratados de Direito Internacional Penal que tratam de temas materialmente afetos aos Direitos Humanos. Na percepção da autora, a análise de rol maior de tratados justifica-se porque esses instrumentos tratam de áreas superpostas e, em grande medida, complementares.

Destaco que a questão em pauta não é tratar da discussão sobre a incorporação de tratados de Direitos Humanos ao ordenamento com base no art. $5^{\circ}, \S 3^{\circ}, \mathrm{CF}$, inserido pela Emenda Constitucional (EC) 45/2004. Não se deseja elaborar apenas estudo de Direito Constitucional, mas também da relação entre a atuação externa e interna, Direito Internacional e Direito interno na prática legislativa brasileira. Serão analisados os processos de internalização de tratados independentemente de seguirem o dispositivo constitucional ora mencionado.

O presente trabalho tampouco tem como foco a matéria dos tratados de proteção dos Direitos Humanos. Não tratarei dos direitos das minorias protegidas pelos tratados aqui analisados, apesar de mencioná-los, ainda que resumidamente, na parte inicial na qual descrevo cada um deles (APÊNDICE I). Tratarei, sim, do seu processo de internalização. A

\footnotetext{
${ }^{3}$ PIOVESAN, Flávia. "Tratados Internacionais de proteção dos Direitos Humanos: jurisprudência do STF". Artigo disponível em: http://www.oas.org/es/sadye/inclusion-social/protocolo-ssv/docs/piovesan-tratados.pdf. Acesso: 29.08.2016.
} 
matéria dos tratados será apresentada se e na medida em que for discutida pelos parlamentares. Entretanto, reitero, esse não é o escopo desta tese.

A pesquisa empírica a respeito da participação do Legislativo no processo de internalização de tratados desdobra-se em dois aspectos principais, procedimental e substantivo. O primeiro deles, o aspecto procedimental, pressupõe a observação das mudanças constitucionais, regimentais e legais no país durante o período analisado. Com base nas propostas legislativas de alteração da Constituição Federal de 1988 e dos Regimentos Internos da Câmara dos Deputados e do Senado Federal, principalmente em relação às atribuições dos parlamentares, tentarei demonstrar que os membros do Poder Legislativo não são apáticos em relação a temas afetos às relações internacionais do Brasil. Também demonstrarei a patente influência material do Direito Internacional na legislação brasileira, particularmente no que se refere à sua relação com tratados de Direitos Humanos. O segundo aspecto é substantivo, e tem como objetivo a análise do tempo de tramitação e dos argumentos proferidos durante o processo de internalização dos tratados definidos a seguir.

Com relação ao aspecto procedimental da internalização de tratados internacionais, existe patente necessidade de normatização mais detalhada a respeito desse procedimento. A Constituição Federal brasileira de 1988 não define procedimento para a apreciação interna de tratados. Tampouco existe lei nacional que trate, específica e unicamente, do processo de internalização de tratados, finalizado por intermédio de Decreto Presidencial, publicado pelo Presidente da República. Esse processo, na prática, segue a lógica dos projetos de lei de iniciativa do Presidente da República, do Supremo Tribunal Federal (STF) e dos Tribunais Superiores, que têm início na Câmara dos Deputados, conforme disposição do art. 64 da Constituição da República Federativa do Brasil (CF). ${ }^{4}$

A lacuna nas normas nacionais referentes à internalização de tratados é tema de diversas discussões quando da internalização de instrumentos internacionais, como será

\footnotetext{
${ }^{4}$ Conforme GABSCH, Rodrigo D’Araújo. Aprovação de tratados internacionais pelo Brasil: possíveis opções para acelerar o seu processo, 2010, p. 100. Para informações mais detalhadas a respeito da tramitação dos tratados na Câmara e no Senado, vide GABSCH, 2010, pp. 100-105. Segundo o art. 64, "A discussão e votação dos projetos de lei de iniciativa do Presidente da República, do Supremo Tribunal Federal e dos Tribunais Superiores terão início na Câmara dos Deputados. (...).
} 
possível verificar na parte substancialmente descritiva desta tese, apresentada no APÊNDICE I. Para Flávia Piovesan, a Constituição de 1988 apresenta sistemática “(...) lacunosa, falha e imperfeita", por não prever prazo para o encaminhamento de tratado assinado por membro do Poder Executivo ao Legislativo. ${ }^{5}$ Tampouco existe prazo determinado para que o Parlamento aprecie um tratado, ou para a ratificação de tratado aprovado pelo Congresso.

Existem, porém, mudanças constitucionais feitas na passagem entre as distintas constituições brasileiras, ${ }^{6}$ bem como Emendas Constitucionais elaboradas para facilitar o processo de internalização de tratados e para aumentar a proteção dos Direitos Humanos no país. A análise dessas mudanças servirá para verificar como ocorre a atuação dos membros do Legislativo na internalização de tratados, e as eventuais consequências dessa atuação nas discussões nas Comissões dessas Casas.

Apesar de não existir lei específica que trate do processo de internalização de tratados, existem leis que regulamentam a matéria tratada em alguns dos instrumentos internacionais assinados (e internalizados) pelo Brasil; o modo como determinados tratados deveriam ser aplicados no território nacional (como é o caso do Estatuto do Refugiado); ou que mencionam, expressamente, um tratado, com o objetivo de aprimorar a sua implementação no país. Essas leis aprimoram o arcabouço jurídico nacional de proteção aos Direitos Humanos. Ao investigá-las, foi possível demonstrar a íntima relação - e não apatia - dos integrantes do Poder Legislativo com a incorporação de tratados ao ordenamento jurídico pátrio. Ademais, percebe-se a ostensiva influência do Direito Internacional no Direito interno, conforme será destacado a seguir, em capítulo próprio.

A escassez de normas que descrevem a recepção de tratados no ordenamento brasileiro contrasta com a abundância de preceitos positivados no restante da ordem jurídica nacional. Esse aspecto poderia ser interpretado como concessão de maior autonomia para os membros do Poder Executivo, não sujeitos a procedimento estanque para a internalização de tratados;

\footnotetext{
${ }^{5}$ PIOVESAN, Flávia. Temas de Direitos Humanos, 1998, p. 71.

6 Serão indicadas as distintas Constituições brasileiras mencionadas neste trabalho, quais sejam, as Constituições de 1946 (Constituição dos Estados Unidos do Brasil); de 1967 (Constituição da República Federativa do Brasil de 1967) e de 1988 (Constituição da República Federativa do Brasil de 1988). Quando não especificada a data da Constituição de que se trata, ou estiver, apenas, mencionado o artigo da "CF", refirome à $\mathrm{CF} / 1988$.
} 
ou como maneira de o Poder Legislativo apreciá-los com maior discricionariedade. Existe relativo consenso a respeito da preponderância do Executivo na condução da política externa do país, entretanto, não há concordância a respeito da abrangência da atuação do Poder Legislativo. $^{7}$

Os membros do Poder Executivo não têm o dever constitucional de consultar o Poder Legislativo antes da assinatura de um tratado e, tampouco, de submeter o instrumento assinado ao Legislativo nacional imediatamente após a assinatura. Segundo Rodrigo Gabsch:

\footnotetext{
“A remessa ao Poder Legislativo não é, todavia, automática ou obrigatória. O chefe de Estado é livre para simplesmente arquivá-lo ou postergar a sua submissão à apreciação legislativa, caso considere insatisfatório o resultado da negociação ou razões de política externa ou interna o levem a decidir-se pela não remessa de imediato. É dele, e apenas dele, o sentido de conveniência e oportunidade do envio do acordo ao Congresso (...)." 8
}

Entretanto, essa consulta prévia ocorre em alguns casos, nos quais a adesão do Brasil é posterior à Mensagem Presidencial, e não há assinatura do instrumento internacional antes disso. Qual seria o motivo da consulta prévia nesses casos específicos? Imagina-se que seriam instrumentos controversos, e, portanto, evitou-se frustrar o objetivo do compromisso internacional. Ao antecipar a consulta ao Congresso Nacional $(\mathrm{CN})$, o Executivo resguardase de eventual pressão que a comunidade internacional poderia exercer, caso assinasse e, posteriormente, não ratificasse determinado instrumento.

Apesar da escassa definição jurídica de competências no âmbito de internalização de tratados, é possível efetuar a análise textual do controle legislativo dos atos do Poder Executivo. Existiria efetivo diálogo e equilíbrio entre os Poderes no âmbito da internalização de tratados, ou esse controle é apenas formal? O Executivo pode, por exemplo, ter motivos de cunho político para assinar determinado tratado, mas não para enviá-lo para a apreciação do Legislativo ou mesmo para ratificá-lo. Nesse sentido, esta tese analisará o controle legislativo dos atos internacionais do Estado em casos concretos. Serão estudados os motivos apontados pelo Executivo nas Mensagens para a aprovação de tratados, e quais as causas mais comuns para imposição de ressalvas por parte do Legislativo. Na prática, porém,

\footnotetext{
${ }^{7}$ Para referências, consultar o item 3.1. LITERATURA NACIONAL E ESTRANGEIRA.

${ }^{8}$ GABSCH, 2010, p. 46/47.
} 
existem poucos casos na história de rejeição de tratado internacional por parte do Poder Legislativo brasileiro. ${ }^{9}$ Não há casos de rejeição integral dentre os tratados analisados, apenas casos de reserva, como se verá a seguir.

Deseja-se demonstrar se existe controle legislativo do exercício da atividade do Executivo que, em última análise, relaciona-se com a política externa, verificando em que medida a atuação internacional do Executivo é controlada pelo Legislativo. A aprovação é um meio de controle dos Poderes, mas, também, uma maneira de postergar a aprovação de tratados, posto que não existe limite de tempo para a tramitação. Tampouco existe limite de tempo para a apreciação do tratado uma vez assinado. Falta regulação normativa adequada e coesa para incorporação de tratados no Brasil.

Para além do controle da atuação internacional do Executivo, outras questões relevantes surgem na análise do procedimento de internalização dos tratados. Seria a demora na internalização de tratados resultado da atuação do Poder Legislativo ou do Poder Executivo? Serão apreciadas a demora na assinatura; no envio da MSC; na tramitação no Legislativo, nas duas Casas do Congresso; e na ratificação do tratado no âmbito internacional por parte do Executivo; enfim, a interação entre os Poderes no processo de aprovação de tratados.

Um tratado vincula o Estado juridicamente, no âmbito internacional, a partir do momento de sua ratificação ou adesão, ambas efetivadas pelo Presidente da República. ${ }^{10}$ Esses atos devem ser precedidos, no Brasil, pela aprovação do texto do tratado pelo Congresso. $\mathrm{O}$ tratado produz efeitos na ordem interna a partir da vigência determinada pelo Decreto Presidencial que o promulga, elaborado pelo Presidente da República. ${ }^{11}$ Não existe, porém, limite temporal determinado em lei para a apreciação de tratados pelo Legislativo. Consequentemente, alguns deles aguardam aprovação por décadas.

No caso de tratados que levaram décadas para serem internalizados, podemos verificar que a discussão não é, necessariamente, a respeito da política externa brasileira, mas sobre a relação entre o Direito interno e o tratado em questão. A princípio, o governo que demonstra,

\footnotetext{
9 Sob a Constituição de 1988, Cristina Alexandre menciona apenas dois casos, relativos à Convenção Interamericana sobre conflitos de leis em matéria de letras de câmbio, notas promissórias e faturas (de 1975, rejeitado em 1995) e à Convenção 153 da OIT (de 1979, rejeitada em 1997). ALEXANDRE, Cristina Vieira Machado. O Congresso brasileiro e a política externa (1985-2005), 2006, p. 77.

${ }^{10} \mathrm{O}$ Estado que adere ao tratado internacional (i) não participou da negociação do tratado; (ii) perdeu o prazo para sua ratificação ou (iii) denunciou o tratado e pretende voltar a assiná-lo.

${ }^{11}$ DALLARI, Pedro B. A. Constituição e Tratados Internacionais, 2003, p. 86-87.
} 
internacionalmente, a intenção de internalizar um tratado, com sua assinatura, deveria ter como objetivo a aprovação desse mesmo tratado por parte do Poder Legislativo. Entretanto, em alguns casos, o processo de internalização não se inicia justamente por inércia do Executivo. Seria interessante que essa apreciação fosse feita antes, e não depois, da assinatura dos tratados? Essa é a sugestão de alguns parlamentares nos projetos de mudança das normas que tratam do assunto. A análise, via de regra posterior, atrasaria ainda mais o processo de incorporação ao ordenamento interno. Nesse sentido, destaca-se a propositura de 37 (trinta e sete) projetos de emenda constitucional, entre 1992 e 2015, para regulamentar a consulta ao Congresso, ou mesmo a autorização congressual, antes da assinatura de tratado. Esse dado demonstra o interesse dos integrantes do Poder Legislativo na área de política externa, e a insatisfação dos membros desse Poder com seu papel e sua atuação nesse âmbito. $^{12}$

O segundo aspecto da pesquisa empírica servirá de substrato para a investigação do segundo objetivo da tese, a relação entre o regime político e a tramitação de tratados no Brasil. Sustentarei que o regime político vigente interfere na relação entre os Poderes Legislativo e Executivo brasileiros, tomando como ponto de partida o processo de internalização de tratados de Direitos Humanos no país. Será testada a hipótese de que os tratados internalizados durante a ditadura tramitaram mais rapidamente do que aqueles internalizados durante períodos democráticos, por não ensejarem discussões intensas. Esse fato poderá ser comprovado utilizando como substrato o tempo de tramitação e a quantidade de argumentos utilizados durante a tramitação dos tratados. Para testar essa hipótese, e demonstrar ou refutar a veracidade da tese, analisarei os documentos oficiais presentes nos dossiês relativos aos processos de internalização dos tratados de Direitos Humanos, a partir da fundação da ONU.

Trata-se, portanto, de discussão com dois níveis distintos. A variável do regime político configura o primeiro nível, e nessa análise tentarei descobrir se os regimes impactam a internalização de tratados. O subnível que decorre dessa análise tem como objetivo verificar de que maneira o regime está relacionado com a quantidade de argumentos proferidos e com o quesito temporal, relativo ao tempo de tramitação.

12 Os itens 2.5.1.1 PROPOSTAS DE EMENDAS CONSTITUCIONAIS e 2.5.1.2. PROJETOS DE RESOLUÇÃO apresentam as propostas parlamentares de alteração legislativa. 
Verificarei na tese, assim, o contraste entre as razões de aprovação de tratados pelo Legislativo em relação às oferecidas pelo Executivo. Essa parte da pesquisa tem dois objetivos principais. O primeiro deles é verificar a diferença de tempo para a internalização de tratados de Direitos Humanos durante os períodos de democracia e de ditadura no Brasil. O segundo, analisar a relação entre os argumentos proferidos pelo Poder Executivo brasileiro para assinar tratados e as razões pelas quais o Poder Legislativo os aprova ou os rejeita, integral ou parcialmente. Deseja-se determinar se a discussão no âmbito das Comissões, que analisam as Mensagens Presidenciais que encaminham ao Legislativo propostas de aprovação de tratados e determinam se há interesse em internalizar o tratado no ordenamento jurídico brasileiro, tem como foco a política externa ou interna, o direito interno ou internacional, ou a matéria dos tratados em si. A principal pergunta que se pretende responder é se o regime político impacta a tramitação de tratados de Direitos Humanos no Brasil, e qual a relação entre os argumentos dos membros dos Poderes Executivo e Legislativo nos diferentes regimes.

Foi efetuada, para verificar a influência do regime político no processo de internalização de tratados, análise quantitativa dos intervalos de tempo (em dias) das diversas etapas de tramitação dos tratados internacionais selecionados. Reunidos todos os documentos referentes à tramitação, foi feita análise qualitativa dos motivos para a assinatura de tratados de Direitos Humanos, e das razões da aprovação desses tratados por membros do Poder Legislativo. Serão investigados os argumentos proferidos durante essa análise, feita, na maior parte dos casos, posteriormente à assinatura dos tratados pelo Executivo. A pesquisa concentrou-se em fontes primárias, o que atribuiu aspecto prático à tese $\mathrm{e}$ possibilitou averiguar os argumentos proferidos nas discussões travadas no âmbito dos Poderes Executivo e Legislativo brasileiro.

Foram examinados documentos oficiais relacionados ao processo de internalização de cada um dos tratados e protocolos selecionados. Esses documentos foram separados temporalmente, conforme o início da tramitação interna, marcada pela data de envio da Mensagem Presidencial (ou Mensagem do Poder Executivo, MSC) para o Congresso Nacional; mais especificamente, para a Câmara dos Deputados, Casa na qual se inicia o processo de internalização. Isso ocorreu graças à necessidade de se diferenciar o processo de internalização dos instrumentos internacionais em período de exceção (entre 1964 e 1985) 
e em períodos de normalidade democrática (respectivamente, entre 1945 e 1964; 1985 e 2016).

No Brasil, durante o processo de tramitação interna de tratados, os membros do Poder Executivo indicam motivos para que os integrantes do Poder Legislativo concordem com a incorporação de determinado tratado ao direito pátrio. Os parlamentares, por sua vez, elegem motivos para rejeitar ou para internalizar um tratado, sendo possível efetuar ressalvas ao seu conteúdo. Esses motivos serão separados em cinco categorias nesta tese: (i) Política Externa (PEB); (ii) Política Brasileira (interna) (PBR); (iii) Direito Internacional (DIN); (iv) Direito Brasileiro (interno) (DBR) e (v) Direitos Humanos (DH). Essa categorização, qualitativa, será a base para determinar a relação entre os motivos para a assinatura de um tratado, apontados pelo Executivo, e os motivos mencionados na tramitação legislativa da questão. Apesar de a análise basear-se, apenas, em tratados de Direitos Humanos, foi mantida essa alternativa para a categorização dos argumentos, que contempla as hipóteses nas quais o tema específico do tratado é utilizado como argumento para sua internalização. Serão destacados, nos tratados analisados, os temas específicos de Direitos Humanos abordados pelo Parlamentar ou por membro do Executivo, como, por exemplo, "DH - refugiados" ou "DH - tortura".

Almeja-se, com isso, utilizar o regime político como variável em relação à tramitação de tratados, especificamente em relação a tratados de Direitos Humanos. O fato de não serem distintas as discussões a respeito da internalização desse tipo de tratado no regime democrático ou no ditatorial demonstraria que a discussão entre os Poderes a respeito dos Direitos Humanos poderia ser realizada independentemente da real situação no país, e da vontade política de cumprir esses tratados. As principais perguntas a serem respondidas são: de que maneira o regime político impacta a tramitação de tratados de Direitos Humanos? Qual a relação entre Executivo e Legislativo nos diferentes regimes? É intuitivo acreditar que o debate seria mais intenso, e, portanto, mais prolongado, em período democrático do que em momentos de exceção. Para descobrir se o regime político interfere na tramitação dos tratados, observarei se existem diferenças temporais e de quantidade de argumentos proferidos na discussão entre os Poderes nos diferentes regimes.

Será necessário verificar, ademais, se os motivos elencados pelo Legislativo para não aceitar determinada disposição de tratado relacionam-se com a substância do tratado. Quais 
os motivos apontados quando ocorre uma oposição à internalização de tratado ou de parcela deste? Com quais temas estes motivos estão, prioritariamente, relacionados?

Acredita-se que as razões utilizadas por membros do Legislativo, particularmente por Deputados, são, principalmente, de caráter interno - nacional, e não consideram as razões destacadas pelo Executivo como prioridade para a internalização dos tratados. O presente estudo verificará a veracidade dessa afirmação. A intenção é descobrir se as razões do Legislativo para internalizar tratados de Direitos Humanos são, efetivamente, predominantemente de Direito interno; em contraposição às do Executivo, predominantemente de caráter internacional. Isso ocorreria pois o Executivo, diferentemente do que ocorre com o Legislativo, estaria, invariavelmente, preocupado com a atuação no âmbito interno e internacional, o chamado "jogo de dois níveis", ${ }^{13}$ e, por isso, seria compelido a atuar, simultaneamente, em dois contextos, sendo o nacional mais circunscrito e o internacional mais abrangente. Quanto mais abrangente for a atuação da instituição, mais amplo seria o alcance de seus argumentos. Isso corroboraria com a percepção do paroquialismo do legislador, apontada por parte da literatura consultada. ${ }^{14}$

A conjunção entre os aspectos procedimental e substantivo da pesquisa dará à autora substrato para verificar as iniciativas do Poder Legislativo em relação à participação na política externa nacional, além da relação entre os Poderes no processo de internalização de instrumentos de Direitos Humanos, em diferentes momentos históricos, contribuindo para os dois objetivos desta tese. Com base nos resultados obtidos, serão apresentadas propostas para que a atuação dos membros dos Poderes Executivo e Legislativo seja mais expedita.

A hipótese da eventual diferença da condução dos processos de internalização de tratados em democracias ou ditaduras é fundamentada na literatura positivista das Relações Internacionais, segundo a qual as democracias tendem a aderir a regimes de Direitos Humanos e as ditaduras tendem a rejeitá-los.

Para as teorias positivistas das Relações Internacionais, o Estado é um ente que protege seus cidadãos de ameaças externas, e regulamenta as relações sociais dentro de seu território.

\footnotetext{
${ }^{13}$ Remeto o leitor ao item 3.1. LITERATURA NACIONAL E ESTRANGEIRA, para o detalhamento da teoria elaborada por Robert Putnam.

${ }^{14}$ Conforme o item 3.1. LITERATURA NACIONAL E ESTRANGEIRA,.
} 
Dentre as teorias positivistas, que se pretendem teorias científicas - ou seja, capazes de, por meio da observação, chegar a leis gerais e a teorias universalmente aplicáveis - destaco, para fins de embasamento teórico desta tese, a corrente liberal (liberalismo). Esta corrente integra as teorias de Innenpolitik, expressão em alemão para "política doméstica", que enfatizam a relevância da política doméstica na formulação da política externa. ${ }^{15}$ Segundo Andrew Moravcsik, "Liberal international relations theory focuses on state behavior driven by variation in the economic interests and conceptions of public goods provision on the part of societal groups, as well as by the nature of domestic political institutions". ${ }^{16}$

A base filosófica do liberalismo pode ser encontrada em pensadores como Adam Smith, Immanuel Kant, Hugo Grócio e Montesquieu. ${ }^{17}$ Segundo Smith, indivíduos livres, buscando seus interesses individuais, produzem resultados sociais positivos, o que culminaria no fato de que sociedades bem organizadas tenderiam a ser autorreguladas. Para Kant, a origem da guerra estaria nas formas imperfeitas de governo. A Paz Perpétua poderia, portanto, ser atingida se houvessem somente Repúblicas no mundo, em virtude da menor tendência ao conflito entre Estados. As Repúblicas, mais sensíveis à opinião pública do que os Estados autoritários, seriam intrinsicamente menos agressivas. O conceito de Paz Democrática (PD), que utilizarei em seguida, foi influenciado pela perspectiva kantiana. Conforme Grócio, o Direito Internacional seria fonte relevante para a estabilidade do sistema internacional. Montesquieu, por sua vez, acreditava que a paz seria o resultado natural do livre comércio, percebido como um intercâmbio entre nações que culminaria em uma relação pacífica entre elas.

Conforme as vertentes liberais, as democracias seriam mais pacíficas, se comparadas às autocracias. Isso porque responderiam à opinião pública, e seriam mais transparentes. As instituições, por sua vez, serviriam para criar canais de comunicação e de regras, que diminuiriam a assimetria de informações e mitigariam a anarquia no sistema internacional e

\footnotetext{
${ }^{15}$ ROSE, Gideon. Neoclassical realism and theories of foreign policy. World politics, v. 51, n. 01, p. 144-172, 1998. Apud HARDT, Matheus S. Os determinantes que influenciam na adesão aos regimes internacionais de Direitos Humanos, Dissertação de Mestrado, IRI-USP, 2014.

${ }^{16}$ MORAVCSIK, Andrew. The Origins of Human Rights Regimes: Democratic Delegation in Postwar Europe, 2000, p. 225.

${ }_{17}$ Panorama elaborado com base nas aulas de Teoria das Relações Internacionais, do curso de Política Internacional do professor Felipe Bernardo Estre, ministrada no Instituto de Desenvolvimento e Estudos de Governo, 2014-2015.
} 
no nacional. Os regimes internacionais seriam, portanto, necessários para um sistema internacional mais harmonioso.

A afirmação a respeito da conexão entre o regime político de determinado país e a adesão a regimes internacionais é explorada por autores que tratam da Paz Democrática, que se insere no contexto do liberalismo nas Relações Internacionais. Regimes internacionais são definidos por Stephen Krasner como:

\begin{abstract}
“(...) princípios, normas, regras e procedimentos de tomada de decisões de determinada área das relações internacionais em torno dos quais convergem as expectativas dos atores. (...) Os princípios são crenças em fatos, causas e questões morais. As normas são padrões de comportamento definidos em termos de direitos e obrigações. As regras são prescrições ou proscrições especificas para a ação. Os procedimentos para tomada de decisões são práticas predominantes para fazer e executar a decisão coletiva." ${ }^{18}$
\end{abstract}

A literatura que trata do conceito de Paz Democrática pergunta-se, fundamentalmente, se os países democráticos são mais pacíficos em suas relações com outros Estados. A resposta à indagação, subsidiada por dados empíricos, destaca a correlação positiva entre as variáveis “paz”, em oposição à “guerra"; e "democracia”, em oposição à “autocracia. ${ }^{19}$ Parte significativa dessa literatura observa a redução de conflitos entre democracias. ${ }^{20}$ Estas teriam menor propensão a entrar em guerra com outras democracias, e essas relações, consequentemente, estabeleceriam bases para um ambiente internacional menos beligerante, ou mais pacífico. Conforme a tese da Paz Democrática, “(...) a incidência de conflitos internacionais entre países democráticos é significativamente menor que qualquer outra combinação interregimes". ${ }^{21}$ Janina Onuki não pretende, em sua análise, estabelecer relações causais entre tipos de regimes políticos e a adesão a regimes internacionais, mas sim demonstrar, empiricamente, a premissa da literatura, segundo a qual as democracias seriam mais propensas à adesão a regimes internacionais.

A noção de "adesão democrática", que acompanha a tese da Paz Democrática, fundamenta-se na atuação dos grupos de interesse domésticos. As ditaduras, regimes

\footnotetext{
18 Definição obtida em KRASNER, Stephen D. "Causas estruturais e Consequências dos regimes Internacionais: regimes como variáveis interveniente", p. 93/94.

${ }^{19}$ MANSFIELD \& SNYDER, 1995, p. 3. Apud ONUKI, Janina. O elo entre regimes políticos domésticos e adesão a regimes internacionais, 2013.

${ }^{20}$ MANSFIELD \& SNYDER, 1995, p. 3. Apud ONUKI, Janina, 2013.

${ }^{21}$ ONUKI, 2013, p. 3.
} 
autoritários, seriam responsáveis perante grupos muito específicos de apoio político (a chamada accountability restrita). As democracias, por sua vez, responderiam domesticamente a um rol mais amplo de forças, uma vez que a tomada de decisões é feita por mais atores, avaliadores do processo decisório relacionado à política externa, e o sucesso de determinada decisão política relaciona-se diretamente com a reeleição dos integrantes do Poder Executivo. $^{22}$

Onuki utiliza como base para seu trabalho a literatura de teorias dos regimes internacionais e da Paz Democrática, para analisar os fatores determinantes para a adesão dos países a regimes internacionais. Apesar de estudar os regimes internacionais relacionados à segurança, como o de não proliferação de armas nucleares, conclui que países democráticos são significativamente mais propensos a aderir a esses regimes, se comparados com autocracias. Sua pesquisa aponta para a patente influência da variável "sistema internacional" como determinante do comportamento dos países.

A adesão a regimes internacionais por parte de países democráticos poderia ser explicada por diversos fatores, como pressão por parte dos seus pares na comunidade internacional, a potencial melhora na cooperação com outros Estados, ou mesmo em virtude dos benefícios que esses países poderiam alcançar em um ambiente com regras claras e estáveis, aumentando o grau de reciprocidade entre eles. A cultura política democrática também favoreceria a resolução de disputas; e a estrutura institucional democrática, erigida sobre um sistema eleitoral, restringiria a liberdade de o governante declarar guerra a outras nações. $^{23}$

A autora aponta, porém, que:

\footnotetext{
"Embora a premissa de variações nos graus de demandas de accountability entre regimes políticos seja verdadeira, a conclusão de que os regimes democráticos são mais cooperativos carece de fundamento. A título de exemplo basta dizer que os regimes democráticos são mais suscetíveis a grupos de pressão pacifistas da mesma forma que são suscetíveis a grupos de interesses militares. Por essência, os regimes democráticos são mais abertos e permeáveis às forças societais, sem discriminação de um viés específico". (grifo nosso)
}

\footnotetext{
22 ONUKI, 2013, p. 3-4.

${ }^{23}$ ONUKI, 2013, p. 2 e 7.
} 
Parte da literatura que trata do tema também entende que os regimes autoritários são menos suscetíveis aos ônus provenientes da adequação (compliance) aos regimes internacionais. $\mathrm{O}$ baixo custo de aderir aos regimes internacionais, associado aos eventuais (ou esperados) ganhos em termos de credibilidade internacional, explicariam a adesão por parte dos governos autoritários. Essa adesão ocorre, apesar de contraintuitiva, pois não se espera que regimes autoritários abdiquem de parte de sua liberdade de ação, comprometendo-se a respeitar compromissos internacionais. No caso do regime internacional de proteção de Direitos Humanos, poderemos perceber que, nas ocasiões em que o regime de exceção no Brasil entendeu não haver conflito entre determinado tratado, celebrado internacionalmente, e sua assinatura, esse tratado foi assinado e prontamente internalizado. O restante dos instrumentos, como se verá, foi simplesmente ignorado pelo regime. Há apenas uma exceção dentre os tratados analisados, a Convenção de Viena sobre Direito dos Tratados (CVDT), Convenção assinada durante a ditadura no Brasil, mas não internalizada durante esse regime.

O regime dos Direitos Humanos é particularmente distinto de todos os outros regimes internacionais, pois, diferentemente dos temas de segurança, de comércio ou de meio ambiente, por exemplo, não tem como objetivo prevenir disputas interestatais, mas responsabilizar os Estados pela condução de suas atividades internas, garantindo a vida digna dos cidadãos dentro das fronteiras de um Estado. ${ }^{24}$ Em virtude dessa peculiaridade, e com base no fato de que os países não têm interesse em se preocupar com o tratamento dado aos estrangeiros nos Estados em que se encontram, não há reciprocidade em relação ao tema, o que diminui eventuais benefícios de acordos interestatais. ${ }^{25}$ Além disso, muitos tratados de Direitos Humanos estabelecem mecanismos institucionais responsáveis por interpretar, e aplicar, em benefício dos indivíduos, os direitos por eles protegidos, o que restringe a noção clássica westphaliana de soberania estatal.

Nesse sentido, Andrew Moravcsik é um dos autores que questiona o porquê de governos, democráticos ou ditatoriais, aceitarem, voluntariamente, a jurisdição de autoridades internacionais sobre seus territórios, com o único propósito de restringir a soberania doméstica. Segundo ele, cientistas políticos tendem a responder essa questão de

\footnotetext{
${ }^{24}$ MORAVCSIK, 2000, p. 217.

${ }^{25}$ HATHAWAY, Oona A. Why do countries commit to Human Rights Treaties? Journal of Conflict Resolution Vol. 51, N. 4, 2007, p. 596.
} 
maneira realista ou idealista: os governos e os membros ativos da sociedade civil no âmbito transnacional precisariam coagir (perspectiva realista) ou persuadir (perspectiva idealista) os outros governos a submeterem-se aos regimes internacionais. Para Moravcsik, essas soluções para a questão têm embasamento empírico frágil, não suportado pelos dados obtidos em sua pesquisa sobre a adesão ao Tribunal Europeu dos Direitos do Homem. Embora as democracias estabelecidas apoiem determinados regimes de Direitos Humanos, estas aliaram-se a ditaduras e a regimes de transição em oposição aos mecanismos vinculantes de proteção dos Direitos Humanos. ${ }^{26}$ De fato, os proponentes principais de obrigações vinculantes relacionadas aos Direitos Humanos eram os governos de democracias recém-estabelecidas. $\mathrm{O}$ autor chama de "the domestic political self-interest of national governments" o mecanismo por meio do qual os governos recorrem aos regimes internacionais ao perceberem que um compromisso internacional vinculante efetivamente reforçaria suas preferências políticas, em momento futuro no tempo que esse governo pretendesse resguardar a democracia, ou evitar um retrocesso da democracia (e, assim, proteger os seus cidadãos). Trata-se de proteção contra ingerências domésticas futuras contrárias a esse interesse, e, nesse sentido, independe se o governo futuro será democrático ou não, uma vez que ambos estariam constrangidos pela comunidade internacional.

Essa medida seria eficaz em dois níveis, lembrando a metáfora de Putnam, ${ }^{27}$ pois comprometeria o Estado no âmbito nacional e internacional, restringindo (o autor usa a expressão "locking in", ou "trancando") os futuros governantes e fortalecendo a

\footnotetext{
${ }^{26} \mathrm{O}$ autor apenas define o que seriam democracias estabelecidas ("long-established democracies"), democracias recentes ("newly established democracies") ou regimes de transição (que ainda não completaram a transição para a democracia) e ditaduras para o caso europeu. Justamente por analisar o regime europeu de Direitos Humanos, divide as democracias em três grupos: as democracias estabelecidas seriam aquelas sob regime democrático contínuo desde antes da década de 1920 até os dias atuais; as democracias atuais seriam aquelas estabelecidas entre 1920 e 1950; e as "semidemocracias" ou ditaduras seriam os governos não integralmente democráticos na década de 1950, em virtude de guerra civil (MORAVCSIK, 2000, p. 231/232). Oona Hathaway (HATHAWAY, 2007, p. 597) apresenta os países pesquisados em uma escala de democracia (que vai de 1 a 10, sendo considerados democráticos os países com "nota" acima de 6), baseada nas instituições do país, nas violações de Direitos Humanos ocorridas em seu território e na comparação entre as taxas de alfabetização de homens e mulheres. Essa autora tampouco define, com clareza, a diferença entre os regimes democráticos mais novos e mais antigos e países em transição, mas aponta que, diferentemente de Moravcsik (2000), ela não espera que haja relação entre a adesão a regimes de Direitos Humanos e o quão nova é a democracia em determinado Estado.

${ }^{27}$ Para referência, consultar o item 3.1. LITERATURA NACIONAL E ESTRANGEIRA.
} 
credibilidade das instituições do governo estatal. ${ }^{28}$ Isso fortaleceria, inclusive, a aplicação dos regimes de Direitos Humanos em geral. ${ }^{29}$ Ao transferir parcela de sua soberania a um órgão internacional, os governos buscam estabelecer restrições confiáveis ao futuros governos, sejam eles não democráticos ou mesmo a governos democráticos que tenham o objetivo de subverter a democracia. ${ }^{30}$ Moravcsik argumenta que os governos apenas recorreriam a essa tática se os benefícios de reduzir a incerteza política no futuro superassem os "custos de soberania" da adesão ao regime internacional. ${ }^{31}$

Conforme a percepção da teoria da Paz Democrática, a década de 1990 é o momento de dominância do padrão pacífico da relação entre as nações democráticas, justamente porque nessa década coincidem o crescimento do número de países democráticos, o aprofundamento da interdependência entre esses países e a expansão, ou o aprimoramento, da normatização internacional em temáticas diversas, como, exemplificativamente, os Direitos Humanos. ${ }^{32} \mathrm{O}$ final do regime militar no Brasil, entretanto, foi temporalmente próximo ao momento em que os tratados de Direitos Humanos passaram a ser celebrados em número cada vez maior no âmbito internacional.

Ao analisar os motivos pelos quais ditaduras passam a integrar a Convenção das Nações Unidas contra a Tortura, James Vreeland considera baixo o custo de adesão a esse tratado, em virtude da capacidade limitada de sanções aos violadores no âmbito internacional. As ditaduras nas quais a prática de tortura é mais intensa teriam, inclusive, tendência maior a ingressar no tratado, se comparadas às com níveis mais baixos de tortura, o que poderia ser explicado por dois motivos principais, e coincidentes, que ocorrem no âmbito doméstico. O primeiro deles é o fato de que ditaduras que permitem a existência de partidos políticos, ironicamente, apresentam níveis mais elevados de prática de tortura, pois a violência é maior quando o poder está dividido. Em segundo lugar, as ditaduras com partidos políticos são pressionadas a adotar políticas para angariar suporte, inclusive

\footnotetext{
${ }^{28}$ EVANS, Peter B., JACOBSON, Harold K., PUTNAM, Robert D., Double-Edged Diplomacy: International Bargaining and Domestic Politics. Berkeley: University of California Press. 1993. Apud HARDT, Matheus S. Os determinantes que influenciam na adesão aos regimes internacionais de Direitos Humanos, p. 13.

${ }^{29}$ MORAVCSIK, 2000, p. 244.

${ }^{30}$ MORAVCSIK, 2000, p. 228.

${ }^{31}$ MORAVCSIK, 2000, p. 220 e 228.

${ }^{32}$ ONUKI, 2013, p. 5.
} 
internacional, para o regime. Governantes de ditaduras que, simplesmente, não se importam com a opinião, ou a pressão, internacional abstém-se de assinar tratados como a Convenção contra a Tortura, justamente por serem parte de um regime sustentado pelo medo para governar. Na ausência de pressões externas e internas, mesmo o custo ínfimo de ratificar um tratado contra a tortura é alto demais. ${ }^{33} \mathrm{O}$ autor destaca, então, a necessidade de atentar às instituições domésticas para compreender as Relações Internacionais, particularmente nas ditaduras. Ditaduras com partidos políticos - como foi o caso no Brasil durante 1964 e 1985 - são mais propensas a ingressar em outros tipos de acordos internacionais, particularmente relativos aos Direitos Humanos. Segundo o autor, "Multiple political parties under dictatorship may represent more than just window dressing. International organizations may find domestic allies organized under dictatorial institutions." ${ }^{34}$

Ao analisar empiricamente dados relativos aos motivos pelos quais os países se comprometem com tratados de Direitos Humanos, Oona Hathaway entende que os efeitos dos tratados em determinado país, e a intenção do governo de se comprometer a um tratado, também são dependentes da sua aplicação doméstica, ou seja, das potenciais consequências internas de sua assinatura. Estados com instituições menos democráticas não são, necessariamente, menos propensos a se comprometer a tratados de Direitos Humanos, mesmo se tiverem um histórico ruim nessa seara, porque a perspectiva de aplicação ou cumprimento (enforcement) desses tratados é baixa. Por outro lado, seria menos provável que Estados com instituições mais democráticas se comprometam a tratados de Direitos Humanos se eles tiverem um histórico ruim na área, porque os tratados podem ser eficazes, e culminar em mudanças de comportamento. Para a autora, "the very factors that lead countries to comply with treaties can cause those same states not to commit". ${ }^{35}$ Países democráticos, como o Brasil, nos quais ocorrem violações dos Direitos Humanos, seriam menos propensos a assinar tratados internacionais do que democracias sem violações, ou do que democracias mais fracas e com histórico semelhante de violações. ${ }^{36}$ Hathaway demonstra que os efeitos dos tratados para ditaduras são menos importantes do que para as democracias, porque não existem mecanismos de enforcement dos tratados nas primeiras.

\footnotetext{
${ }^{33}$ VREELAND, James. Political Institutions and Human Rights: Why Dictatorships Enter into the United NationsConvention against Torture, 2008, pp. 65-101.

${ }^{34}$ VREELAND, 2008, p. 94.

${ }^{35}$ HATHAWAY, 2007, p. 612.

${ }^{36}$ HATHAWAY, 2007, p. 594 e 613.
} 
Apesar disso, muitos tratados de Direitos Humanos são aplicados de maneira bemsucedida em países apesar da inexistência (ou da existência exígua) de mecanismos internacionais de enforcement, em virtude da aplicação pelas instituições domésticas. $\mathrm{O}$ Direito Internacional serviria para moldar as atitudes dos países em relação ao regime de Direitos Humanos de duas maneiras: (i) por intermédio do enforcement dos termos do tratado pelas instituições domésticas, internacionais ou transnacionais ${ }^{37}$ e (ii) em virtude das consequências que surgem quando os atores mudam o modo como eles agem em relação ao Estado, como resultado da decisão deste de aceitar (ou não) determinado regime internacional. A autora lida com a relação entre o comprometimento jurídico com tratados e a efetiva aplicação (compliance) no âmbito nacional.

Apesar de esse último tema (compliance) fugir ao escopo desta tese, é importante atentar à noção de que a falta de mecanismos de monitoramento e de aplicação (enforcement) dos tratados de Direitos Humanos pode incentivar Estados violadores a assiná-los, justamente porque a assinatura ou ratificação não trazem desvantagem real, como a perspectiva de sanção. Hathaway observa, porém, que, apesar da veracidade dessa afirmação, também é possível que tratados mudem o comportamento de um país mesmo sem que haja enforcement internacional, dependendo da atuação, e da capacidade de pressão, das instituições domésticas nesse sentido. ${ }^{38}$ Governantes de países em transição para a democracia, inclusive, teriam mais motivos para tentar se distanciar dos ditadores que os antecederam, o que culminaria na ampla aceitação dos tratados de Direitos Humanos. ${ }^{39}$

Desde 2006, com a criação do Conselho de Direitos Humanos pela Resolução 60/251 da Assembleia Geral da Organização das Nações Unidas (AGNU), tem ocorrido na ONU um movimento pelo maior monitoramento da situação dos Direitos Humanos nos países que integram a Organização. ${ }^{40}$ Trata-se do mecanismo de Universal Periodic Review (UPR, ou RPU - Revisão Periódica Universal), no qual os países têm a situação dos Direitos Humanos em seu território colocada sob o escrutínio da ONU, de organizações não governamentais

\footnotetext{
${ }^{37}$ A autora menciona a necessidade de Estados que desejam integrar a União Europeia (UE) integrem a Convenção Europeia de Direitos Humanos, classificando a UE como organismo transnacional - apesar de se tratar, na verdade, de uma organização internacional com aspectos supranacionais. Menciona, também, o fato de que o Banco Mundial considera a situação dos Direitos Humanos nos países que desejam obter empréstimos do banco. HATHAWAY, 2007, p. 596.

${ }^{38}$ HATHAWAY, 2007, p. 593.

${ }^{39}$ HATHAWAY, 2007, p. 597.

40 Informação obtida em: http://www.ohchr.org/EN/HRBodies/UPR/Pages/UPRMain.aspx. Acesso: 28.01.2017.
} 
(ONGs) acreditadas na Organização e do próprio governo do Estado. Apesar desse movimento, e de o UPR consubstanciar avanço significativo no sistema internacional de proteção dos Direitos Humanos, ainda carece da possibilidade de aplicar medidas coercitivas aos países violadores - o que foge do escopo e das atribuições do Conselho, sendo necessário avançar como mecanismo de proteção efetiva da comunidade internacional.

A literatura apresentada acima lida, primordialmente, com a questão dos tratados na relação entre Estados. O governo de cada país, além de lidar com a pressão de seus pares no âmbito internacional, precisa justificar o comprometimento a determinado tratado no âmbito doméstico. Em geral, nos países democráticos com regime presidencial, um Poder separado do Executivo - via de regra, o Legislativo - inicia o processo de elaboração de leis. Nesses Estados, geralmente é permitido ao Executivo negociar e assinar tratados e submetê-los à apreciação legislativa, para posterior ratificação pelo próprio Executivo. Esse processo torna-se, portanto, mais uma ferramenta do Executivo para atingir objetivos políticos em temas que poderia ter dificuldade de abordar de outra maneira. ${ }^{41}$

\subsection{JUSTIFICATIVA DA ESCOLHA E DA RELEVÂNCIA DO TEMA}

A importância da análise do processo legislativo para a internalização de tratados é manifesta. Pesquisadores têm estudado essa questão em distintas áreas do conhecimento. A compreensão da internalização de tratados no Brasil pode auxiliar a elaboração de diretrizes mais pragmáticas a respeito de sua apreciação por parte do Poder Legislativo.

Foram realizados diversos estudos a respeito do papel do Legislativo na apreciação de tratados no Brasil. ${ }^{42}$ Destaca-se a necessidade de esclarecer o processo de internalização de tratados no Brasil, que, embora estudado em sua forma, não foi, até o momento, analisado no mérito como se pretende. Os estudos realizados, nas áreas de Ciência Política, Ciências Sociais, Direito, História e Relações Internacionais, fizeram recortes temporais por legislatura, por período histórico ou por tema. Foram, igualmente, encontradas análises quantitativas da internalização de tratados no país que, apesar de viabilizarem estudos mais

\footnotetext{
${ }^{41}$ Em contraposição, nos sistemas parlamentares, não existe separação tão clara entre esses Poderes, o que culmina em uma dinâmica menos segregada. HATHAWAY, 2007, p. 596 e 616.

${ }^{42}$ Para uma análise detalhada a respeito desta literatura, remeto ao item 3.1. LITERATURA NACIONAL E ESTRANGEIRA.
} 
aprofundados, não se ativeram à descrição do mérito das discussões na Câmara dos Deputados (CD) ou no Senado Federal (SF). Os autores desses trabalhos fizeram análises quantitativas ou procedimentais, e outros delimitaram o escopo a períodos curtos. A intenção da presente tese é verificar se as razões apontadas pelo Legislativo no processo de internalização de certos tratados relacionam-se com os motivos pelos quais o tratado foi assinado, encontrados nas manifestações oficiais do Executivo. Foram separados os momentos históricos entre período democrático e regime militar para verificar se há diferenças no relacionamento entre os Poderes nesses momentos. Em caso negativo, demonstrar-se-ia que a internalização de tratados de Direitos Humanos ocorre independentemente do contexto político e da situação fática dos Direitos Humanos no país.

O tema da internalização de tratados ao ordenamento brasileiro e da relação, nesse âmbito, entre o Poder Executivo e o Legislativo, não é propriamente novo. Apesar disso, o que aqui se pretende é fundamentar a relação entre a apreciação executiva e legislativa de tratados de maneira diferente, considerando a condução da política externa brasileira e os motivos de política interna apontados pelo Legislativo para aprovar integralmente ou para apor ressalvas a tratados.

A interação entre o Congresso Nacional e o Poder Executivo no processo de internalização de tratados, especificamente na figura do Ministério das Relações Exteriores (MRE), principal formulador da política externa brasileira, não é clara. Identificar a relação entre esses atores, e propor alternativas para abreviar o trâmite prolongado de tratados internacionais, especificamente aqueles de Direitos Humanos, ajudará a compreender e a sanar os problemas provenientes da não ratificação de determinados tratados pelo Brasil.

No caso de tratados internacionais, o Legislativo pode aprovar, rejeitar ou apor ressalvas aos tratados. É importante verificar se o Legislativo realiza discussão séria a respeito do tema do tratado em pauta e entender como esse Poder auxilia a consecução dos objetivos da política externa do país, uma vez que seus membros podem discutir a temática do tratado, o âmbito jurídico, e as questões de política externa que levaram o Executivo a assinar o tratado. Para isso, serão analisados os instrumentos de Direitos Humanos indicados no item 1.2. METODOLOGIA E ESTRUTURA DA TESE.

O tema dos Direitos Humanos foi escolhido pois a política externa do Brasil para a matéria é de extrema relevância para as relações do país com a comunidade internacional. A Constituição Federal, no art. $4^{\text {o }}$, estabelece os princípios que regem as relações internacionais 
do Brasil, e entre eles (inciso II) está "a prevalência dos direitos humanos". ${ }^{43} \mathrm{O}$ tema recebe, inclusive, tratamento especial na Constituição Federal, que protege especificamente as obrigações decorrentes de tratados de Direitos Humanos dos quais o Brasil é parte integrante. $\mathrm{O}$ art. $109, \S 5^{\circ}, \mathrm{CF}$, determina a possibilidade de o Procurador Geral da República suscitar, perante o Superior Tribunal de Justiça, o deslocamento de caso da justiça comum para a Justiça Federal, a chamada Federalização de graves violações aos Direitos Humanos. ${ }^{44}$

\begin{abstract}
Art. 109. Aos juízes federais compete processar e julgar: (...)
III - as causas fundadas em tratado ou contrato da União com Estado estrangeiro ou organismo internacional; (...)

$V$ - os crimes previstos em tratado ou convenção internacional, quando, iniciada a execução no País, o resultado tenha ou devesse ter ocorrido no estrangeiro, ou reciprocamente; (...)

$\S 5^{\circ}$ Nas hipóteses de grave violação de direitos humanos, o Procurador-Geral da República, com a finalidade de assegurar o cumprimento de obrigações decorrentes de tratados internacionais de direitos humanos dos quais o Brasil seja parte, poderá suscitar, perante o Superior Tribunal de Justiça, em qualquer fase do inquérito ou processo, incidente de deslocamento de competência para a Justiça Federal. (Incluido pela Emenda Constitucional no 45, de 2004) (grifo nosso).
\end{abstract}

A importância do tema dos Direitos Humanos na política externa brasileira resultou em mudança de paradigmas quanto ao grau de responsabilidade dos Estados em sua proteção. O discurso da Presidenta Dilma Rousseff, na 67 AGNU, em 2011, ressaltou a importância da responsabilidade ao proteger, em acréscimo à responsabilidade de proteger. Este conceito, mencionado pelo relatório intitulado "A responsabilidade de proteger", ${ }^{45}$ foi estabelecido no sexagésimo aniversário de criação da ONU, e incorporado aos parágrafos 138 e 139 da resolução 60/1 da Assembleia Geral. ${ }^{46}$ Conforme a "responsabilidade de

\footnotetext{
${ }^{43}$ Art. $4^{\text {o }}$ : A República Federativa do Brasil rege-se nas suas relações internacionais pelos seguintes princípios: I. independência nacional; II. prevalência dos direitos humanos; III. autodeterminação dos povos; IV. nãointervenção; V. igualdade entre os Estados; VI. defesa da paz; VII. solução pacífica dos conflitos; VIII. repúdio ao terrorismo e ao racismo; IX. cooperação entre os povos para o progresso da humanidade; X. concessão de asilo político.

Parágrafo único. A República Federativa do Brasil buscará a integração econômica, política, social e cultural dos povos da América Latina, visando à formação de uma comunidade latino-americana de nações.

${ }^{44}$ Para maiores informações a respeito do tema: Estudo sobre a federalização de graves violações aos direitos humanos / coordenação, Olívia Alves Gomes, Guilherme de Assis Almeida; [autores] Roberta Corradi Astolfi, Pedro Lagatta, Amanda Hildebrand Oi. - Brasília : Ministério da Justiça, Secretaria de Reforma do Judiciário, 2014. Disponível em: http://www.andhep.org.br/arquivos/Federalizacao_boneco_final_09012014.pdf. Acesso: 10.02.2016.

${ }^{45}$ Relatório elaborado pela Comissão Internacional de Intervenção e Soberania Estatal (2001).

46 Disponível em: http://daccess-dds-ny.un.org/doc/UNDOC/GEN/N05/487/60/PDF/N0548760.pdf?Open Element. Acesso: 08.06.2015.
} 
proteger", os Estados devem, individualmente, proteger sua população contra o genocídio, os crimes de guerra, a limpeza étnica e os crimes contra a humanidade. A soberania estatal não é ilimitada, e pressupõe a responsabilidade de garantir os direitos dos cidadãos. $\mathrm{A}$ comunidade internacional deve, conforme apropriado, e sempre respeitando a soberania estatal, encorajar e auxiliar Estados a exercer essa responsabilidade. Caso não sejam capazes de exercê-la, a comunidade internacional, conforme a responsabilidade de proteger, deveria utilizar os meios diplomáticos e humanitários apropriados para proteger as populações daqueles crimes.

O conceito de responsabilidade de proteger está estruturado, portanto, em três pilares. O primeiro identifica o Estado como o principal responsável por proteger sua população. $\mathrm{O}$ segundo destaca o papel da comunidade internacional na cooperação que permita ao Estado exercer suas responsabilidades. O terceiro aplica-se a circunstâncias excepcionais, quando as medidas dos dois primeiros pilares falham, e permite à comunidade internacional recorrer a ações coletivas para assegurar a proteção da população de determinado Estado. A responsabilidade de proteger pressupõe três responsabilidades centrais: a de prevenir violações aos Direitos Humanos, a de reagir frente a elas e a de reconstruir, após a necessidade de intervenção. Não se trata de direito de ingerência, mas de responsabilidade compartilhada entre os Estados, que devem envidar esforços para impedir violações aos Direitos Humanos.

A responsabilidade ao proteger, conceito suplementar, e não concorrente, à responsabilidade de proteger, surgiu de um esforço da diplomacia brasileira ao perceber que esta última poderia ser utilizada como pretexto para alcançar propósitos distintos ao de resguardar a integridade de civis, como a modificação do regime de governo em determinado país. Nesse sentido, o Ministro das Relações Exteriores, Antônio de Aguiar Patriota, apontou que, enquanto exerce a responsabilidade de proteger, a comunidade internacional deve demonstrar a responsabilidade ao proteger, trabalhando interdisciplinarmente em prol das populações locais, para a melhoria nas condições de vida, com a intervenção de profisssionais das áreas de medicina, de engenharia, de segurança, de direito, entre outras. ${ }^{47}$ É necessário

\footnotetext{
${ }^{47}$ Discurso proferido pela Embaixadora Maria Luiza Ribeiro Viotti, representante permanente do Brasil na Organização das Nações Unidas, na $66^{\text {a }}$ Sessão da AGNU, elaborado pelo Ministro das Relações Exteriores, Antônio Patriota, intitulado "Representative Responsibility while protecting: elements for the development and promotion of a concept". Disponível em: http://responsibilitytoprotect.org/concept-paper- rwp(1).pdf. Acesso: 12.09.2016
} 
ter como foco a diplomacia preventiva, exaurindo, previamente, os meios pacíficos de solução de controvérsias antes de iniciar ação militar, uma vez que o uso de força pode causar instabilidade.

O Ministério das Relações Exteriores brasileiro (MRE) entende ser necessário manter relações diplomáticas com Estados violadores dos direitos de sua população. Retirar um país dos fóruns internacionais não traria melhorias para a população, e, portanto, seria preferível manter um governo, mesmo violador dos Direitos Humanos, como participante dos órgãos multilaterais. Desse entendimento decorre a defesa, no Resumo Executivo do Balanço de Política Externa brasileira (2003-2010) de “(...) que a paz sustentável e duradoura é função não somente de solução de problemas de Segurança, mas também da superação de desafios nas áreas de Direitos Humanos e de Desenvolvimento Econômico e Social." $" 48$

O regime político geralmente está atrelado à restrição de Direitos Humanos dos cidadãos de um país, e, portanto, é interessante verificar se a positivação desses direitos, com a incorporação de tratados internacionais ao ordenamento jurídico, ocorre independentemente do regime político do país.

Finalmente, a dicotomia entre ditadura e democracia precisa ser mais explorada nas pesquisas no campo das Relações Internacionais. Conforme James Vreeland, "The field of international relations needs to take variations among dictatorships seriously and consider the importance of domestic institutions under authoritarian regimes..${ }^{49} \mathrm{O}$ presente trabalho, ao considerar os diferentes regimes na apreciação do processo de tramitação de tratados, demonstra que existe discussão parlamentar na ditadura, e que a democracia no Brasil pode ser, ao menos no que se refere ao tempo de tramitação de tratados, menos eficiente.

\subsection{METODOLOGIA E ESTRUTURA DA TESE}

Este item apresenta breve descrição metodológica a respeito de cada um dos capítulos desta tese. Destaco, de antemão, que a metodologia detalhada a respeito do capítulo quinto, parte principal da pesquisa empírica, encontra-se no início do próprio capítulo. Optou-se por

\footnotetext{
48 Resumo Executivo do Balanço de Política Externa (2003-2010). Disponível em: http://www.itamaraty.gov.br/temas/balanco-de-politica-externa-2003-2010/resumo-executivo/view. Acesso: 04.04.2015.

${ }^{49}$ VREELAND, 2008, p. 93.
} 
manter a descrição próxima à apresentação dos resultados obtidos na pesquisa, para facilitar a compreensão do leitor.

Esta tese foi estruturada em seis capítulos, sendo o último deles a apresentação das conclusões obtidas. Em suma, é possível apresentar a estrutura da tese da seguinte maneira:

Dois objetivos principais:

1. Em relação à apatia dos membros do Poder Legislativo:

(i) Participação ativa no processo de internalização de tratados de Direitos Humanos;

(ii) Propostas para alterar os procedimentos de internalização de tratados (PECs, propostas de Resolução);

(iii) Utilização de tratados como base para a legislação nacional;

2. Em relação ao regime político:

(i) Tempo de tramitação;

(ii) Argumentos utilizados.

Aspectos da pesquisa empírica (recorte: tratados de Direitos Humanos)

(i) Aspecto procedimental

- Escassez de normas;

- Atuação legislativa;

- Direito interno influenciado pelo Direito Internacional;

(ii) Aspecto Substantivo

- Tempo;

- Argumentos.

Esta introdução apresentou noções preambulares a respeito do tema, além dos motivos para sua escolha e as justificativas da pesquisa. Foi feita seleção de bibliografia que abordasse aspectos relacionados ao trâmite da internalização de tratados no ordenamento interno, seja em obras de Direito Internacional Público, seja em textos de Ciência Política relativos à atuação dos Poderes Executivo e Legislativo nesse processo. Também foram selecionadas obras que tratassem da literatura da Paz Democrática, essencial para a 
justificativa teórica sobre a adesão a regimes de Direitos Humanos, por parte de ditaduras e de democracias.

O segundo capítulo apresenta o sistema de elaboração e de tramitação dos instrumentos internacionais. Foram consultados a literatura sobre o processo de elaboração de tratados, bem como instrumentos normativos, nacionais e internacionais, aplicáveis ao tema. Particularmente em relação ao Brasil, apresento perspectiva histórica a respeito dos dispositivos das Constituições nacionais que tratam da internalização de tratados e da condução da política externa. À evolução constitucional é acrescentado o rol de propostas de Emendas Constitucionais e de Resoluções, que têm como objetivo propor alterações à Constituição e aos Regimentos das Casas Legislativas do Brasil, respectivamente.

O terceiro capítulo apresenta apontamentos da literatura a respeito da relação entre o Executivo e o Legislativo no processo de internalização de tratados e de elaboração da política externa. Esse capítulo traz exemplos concretos da influência do Direito Internacional no Direito brasileiro, influência que pode ser percebida nas leis nacionais que tratam de temas variados, afetos aos Direitos Humanos. Este capítulo, bem como o capítulo 2 descrito acima, apresenta argumentos para sustentar a hipótese da não apatia dos membros do Poder legislativo em relação aos temas internacionais, particularmente ao processo de internalização de tratados.

O quarto capítulo serve de substrato para a análise que o segue, ao trazer o panorama da política exterior brasileira durante os períodos nos quais tramitaram os tratados. A política externa brasileira dos períodos históricos relevantes para este estudo será descrita em capítulo próprio, com o objetivo de situar historicamente o momento da discussão dos tratados. Esse capítulo não tem o objetivo de analisar com profundidade a política externa de cada um dos governos que se seguiram desde a fundação da ONU até o período atual, mas, apenas, de apresentar o cenário da política externa existente à época, para o conhecimento do leitor.

O quinto capítulo traz os dados relativos aos aspectos temporais e aos argumentos presentes na tramitação de tratados de Direitos Humanos no país. Apresento, na primeira parte do capítulo, a metodologia para a seleção dos tratados analisados, dos dados referentes aos aspectos temporais das etapas de tramitação interna desses tratados e dos argumentos destacados. Em seguida, são apresentadas informações referentes aos argumentos utilizados nos períodos analisados, ditadura e democracia. Esse capítulo, além de dar susbtrato material 
contra a noção de apatia dos membros do poder Legislativo, também embasa o segundo objetivo da tese, sobre a relação entre a internalização de tratados e o regime político vigente no país.

O último capitulo apresenta as conclusões obtidas pela autora, com base nos dados coletados na pesquisa e na literatura estudada, e as propostas para aprimorar o processo de internalização de tratados no Brasil. 


\section{PROCESSO DE ELABORAÇÃO E DE TRAMITAÇÃO DE TRATADOS}

Destaco, de antemão, a exígua legislação a respeito de temática de extrema relevância para a política exterior do país, em ordenamento que tende à legislação excessiva na maioria dos temas. A Constituição Federal brasileira é considerada extensa, com 250 artigos até o depósito da versão final desta tese, ${ }^{50}$ e o rol normativo pátrio é, no geral, abundante. $\mathrm{O}$ processo de internalização dos tratados, e sua integração ao ordenamento jurídico pátrio, são, cada vez mais, objeto de atenção dos parlamentares e dos governantes nacionais. Isso poderá ser verificado particularmente na segunda parte do presente capítulo.

\section{1. ÂMBITO INTERNACIONAL}

O processo que se desenvolve desde a elaboração de um tratado internacional até sua internalização no ordenamento jurídico de um país envolve o interesse de diversos atores, nos âmbitos nacional e internacional. Internacionalmente, encontramos práticas com consequências diretas nesse âmbito, como os atos de negociação, adoção, autenticação, assinatura e ratificação do tratado internacional. No contexto nacional, ocorre a aprovação parlamentar, a promulgação (após a ratificação, que se opera internacionalmente) e a publicação interna de legislação referente ao ato. O quadro abaixo separa os atos internacionais dos atos internos:

Figura 1: Processo de elaboração e de internalização de tratados

\begin{tabular}{|c|c|c|c|c|}
\hline $\begin{array}{l}\text { ATOS } \\
\text { INTERNACIONAIS }\end{array}$ & NEGOCIAÇÃO $\Rightarrow$ & ADOÇÃo $\Rightarrow$ AUTENTICAÇÃO $\Rightarrow$ & ASSINATURA & RATIFICAÇÃo \\
\hline $\begin{array}{l}\text { ATOS } \\
\text { INTERNOS }\end{array}$ & & & $\begin{array}{l}\text { APROVAÇÃO } \\
\text { PARLAMENTAR }\end{array}$ & $\begin{aligned} \text { PROMULGAÇÃO } \Rightarrow & \text { PUBLICAÇÃO } \\
& \text { NO DOU }\end{aligned}$ \\
\hline
\end{tabular}

Fonte: Quadro elaborado conforme aula de Direito Internacional Público do professor de Direito Internacional da Universidade Federal do Rio de Janeiro, Pedro Muniz Pinto Sloboda.

50 Informação obtida em: http://www.planalto.gov.br/ccivil_03/constituicao/constituicao.htm. Acesso: 30.05.2017. 
No âmbito internacional, o processo de elaboração de tratados começa com uma negociação, bilateral ou multilateral, sem forma específica. Atingido o texto com o qual os atores envolvidos estão de acordo, o tratado é adotado. Nesse momento, a redação definitiva do acordo é chancelada, o que culmina no término do processo de negociação. A adoção de tratado está prevista no art. 9 da Convenção de Viena sobre o Direito dos Tratados:

\begin{abstract}
Art. 9: Adoção do Texto
1. A adoção do texto do tratado efetua-se pelo consentimento de todos os Estados que participam da sua elaboração, exceto quando se aplica o disposto no parágrafo 2.

2. A adoção do texto de um tratado numa conferência internacional efetua-se pela maioria de dois terços dos Estados presentes e votantes, salvo se esses Estados, pela mesma maioria, decidirem aplicar uma regra diversa.
\end{abstract}

A adoção do texto, conforme a própria CVDT, tem como efeito jurídico a aplicabilidade imediata das cláusulas finais.

\begin{abstract}
Art. 24.4: Aplicam-se desde o momento da adoção do texto de um tratado as disposições relativas à autenticação de seu texto, à manifestação do consentimento dos Estados em obrigarem-se pelo tratado, à maneira ou à data de sua entrada em vigor, às reservas, às funções de depositário e aos outros assuntos que surjam necessariamente antes da entrada em vigor do tratado.
\end{abstract}

Após a adoção do texto do acordo, ocorre sua autenticação, formalidade que legitima o texto anteriormente adotado, prevista no art. 10, CVDT:

\footnotetext{
Art. 10: Autenticação do Texto

O texto de um tratado é considerado autêntico e definitivo:

a) mediante o processo previsto no texto ou acordado pelos Estados que participam da sua elaboração; ou

b) na ausência de tal processo, pela assinatura, assinatura ad referendum ou rubrica, pelos representantes desses Estados, do texto do tratado ou da Ata Final da Conferência que incorporar o referido texto.
}

Uma vez determinada a redação definitiva do acordo, ocorre sua assinatura, que, via de regra, configura a aceitação do tratado. Trata-se, porém, de aceite precário, que gera para o Estado a obrigação de não frustrar o objeto e a finalidade do tratado antes de sua entrada em vigor, conforme o art. 18, CVDT: 
Art. 18: Obrigação de Não Frustrar o Objeto e Finalidade de um Tratado antes de sua Entrada em Vigor

Um Estado é obrigado a abster-se da prática de atos que frustrariam o objeto e a finalidade de um tratado, quando:

a) tiver assinado ou trocado instrumentos constitutivos do tratado, sob reserva de ratificação, aceitação ou aprovação, enquanto não tiver manifestado sua intenção de não se tornar parte no tratado; ou

b) tiver expressado seu consentimento em obrigar-se pelo tratado no periodo que precede a entrada em vigor do tratado e com a condição de esta não ser indevidamente retardada.

Finalmente, temos, como derradeiro ato internacional de comprometimento de Estado a um instrumento, a ratificação, aceitação ou aprovação do tratado, previstas no art. 14, CVDT.

\footnotetext{
Art. 14: Consentimento em Obrigar-se por um Tratado Manifestado pela Ratificação, Aceitação ou Aprovação

1. O consentimento de um Estado em obrigar-se por um tratado manifesta-se pela ratificação:

a) quando o tratado disponha que esse consentimento se manifeste pela ratificação;

b) quando, por outra forma, se estabeleça que os Estados negociadores acordaram em que a ratificação seja exigida;

c) quando o representante do Estado tenha assinado o tratado sujeito a ratificação; ou

d) quando a intenção do Estado de assinar o tratado sob reserva de ratificação decorra dos plenos poderes de seu representante ou tenha sido manifestada durante a negociação.

2. O consentimento de um Estado em obrigar-se por um tratado manifesta-se pela aceitação ou aprovação em condições análogas às aplicáveis à ratificação.
}

A ratificação é a manifestação definitiva de vontade de um Estado, realizada por seu plenipotenciário. Mediante a troca ou o depósito do instrumento de ratificação, o Estado passa a obrigar-se internacionalmente pelos dispositivos do tratado, desde que este esteja em vigor internacionalmente. A ratificação é ato irretroativo, passando a valer a partir da data do ato de ratificação; e irretratável, pois o Estado apenas poderá se desvincular do tratado mediante sua denúncia. Inexiste ratificação condicional, o que demonstra a importância desse ato para a segurança jurídica dos Estados.

São legitimados para adotar ou autenticar o texto de um tratado aqueles indivíduos indicados pela CVDT, em seu art. 7:

Art. 7: Plenos Poderes 
1. Uma pessoa é considerada representante de um Estado para a adoção ou autenticação do texto de um tratado ou para expressar o consentimento do Estado em obrigar-se por um tratado se:

a) apresentar plenos poderes apropriados; ou (...)

2. Em virtude de suas funções e independentemente da apresentação de plenos poderes, são considerados representantes do seu Estado:

a) os Chefes de Estado, os Chefes de Governo e os Ministros das Relações Exteriores, para a realização de todos os atos relativos à conclusão de um tratado;

b) os Chefes de missão diplomática, para a adoção do texto de um tratado entre o Estado acreditante e o Estado junto ao qual estão acreditados;

c) os representantes acreditados pelos Estados perante uma conferência ou organização internacional ou um de seus órgãos, para a adoção do texto de um tratado em tal conferência, organização ou órgão.

A adesão é o ingresso ao tratado ex post facto, seja porque o representante do Estado não tenha participado das negociações, seja porque terminou o prazo para sua ratificação, seja porque o Estado renunciou ao tratado, mas deseja voltar a integrá-lo. A adesão não pressupõe que o tratado esteja em vigor, e pode ser feita sob reserva de ratificação.

Ressalto aqui aspecto extremamente relevante para a aplicação de tratados internacionais, que, apesar de não se relacionar com a sua elaboração, está intimamente ligado à sua aplicação: a necessidade de interpretação. As regras internacionais de interpretação de tratados relacionam-se, na doutrina internacionalista, com a necessidade de evolução dos tratados, produtos de processos extensos e formais de negociação entre Estados. Justamente porque envolvem Estados como autores, o que dificulta o processo de negociação e, consequentemente, de adaptação às novas realidades, tratados dependem de processos menos formais para que possam se adaptar às constantes mudanças no cenário internacional e, por que não, nacional de cada um de seus signatários. A CVDT apresenta regras expressas para a interpretação de tratados:

\footnotetext{
Interpretação de Tratados

Art. 31: Regra Geral de Interpretação

1. Um tratado deve ser interpretado de boa-fé segundo o sentido comum atribuível aos termos do tratado em seu contexto e à luz de seu objetivo e finalidade. (...)

3. Serão levados em consideração, juntamente com o contexto: (...)

b) qualquer prática seguida posteriormente na aplicação do tratado, pela qual se estabeleça o acordo das partes relativo à sua interpretação;

c) quaisquer regras pertinentes de Direito Internacional aplicáveis às relações entre as partes.

4. Um termo será entendido em sentido especial se estiver estabelecido que essa era a intenção das partes.
} 
Quais seriam, entretanto, os limites para a interpretação? Existe uma linha tênue entre a interpretação de cláusula e a modificação parcial ou completa de seu significado. A boa-fé é, igualmente, discricionária. Para interpretar tratados, Estados utilizam o que se convencionou chamar de cláusulas ou declarações interpretativas. São manifestações, por parte de signatário de acordo internacional, com o objetivo de esclarecer a interpretação de determinada cláusula por parte de um Estado. Ressalto, entretanto, que deve haver limite, nem sempre claro, entre o que pode ser considerado uma cláusula interpretativa e uma reserva a tratado. ${ }^{51}$

Para Tarciso dal Maso Jardim, consultor legislativo do Senado Federal na área de Relações Exteriores e Defesa Nacional, ressalvas, reservas e declarações interpretativas teriam em comum o fato de serem procedimentos usados para facilitar a adesão a tratados. Entretanto, as consequências desses institutos são distintas. Em primeiro lugar, as reservas nem sempre são permitidas (conforme o art. 19, CVDT). Ademais, os Estados signatários de um tratado podem impor objeções a reservas, principalmente se a considerarem incompatíveis com o objetivo do tratado. ${ }^{52}$ Apesar das discussões a respeito das ressalvas, a prática legislativa demonstra que elas têm sido propostas pelos integrantes do Poder Legislativo, e aceitas pelos membros do Executivo, conforme será possível perceber no item 5.3. TRATADOS INTERNALIZADOS COM RESERVAS desta tese.

Por motivos de desconhecimento, de erros de interpretação ou, inclusive, de má-fé, os Estados podem valer-se de cláusulas interpretativas que são verdadeiras reservas, limitando a aplicação de dispositivo do tratado sem o ônus que pode advir da imposição de reserva a seu texto. Esse ônus não existe, apenas, no âmbito internacional, mas no nacional, uma vez que, no Brasil, as reservas precisam da conjunção de vontades dos dois Poderes, enquanto não existe disposição nesse sentido com relação às declarações interpretativas. Em alguns tratados analisados nesta tese, inclusive, não há menção à inserção de cláusulas

\footnotetext{
${ }^{51}$ Discussão inspirada em série de palestras ministrada pelo professor Roger O'Keefe, professor da Universidade de Cambridge e Diretor do Centro Lauterpacht de Direito Internacional, sobre a interpretação e a aplicação de tratados, ministrada em dezembro de 2014, na Faculdade de Direito da Universidade de São Paulo. Para aprofundar os conhecimentos a respeito do tema, segue o material recomendado pelo professor: GARDINER, "The Vienna Convention Rules on Treaty Interpretation" e ULFSTEIN, "Treaty Bodies and Regimes", ambos em Hollis (ed), The Oxford Guide to Treaties (2012). O programa do curso está disponível na íntegra em: http://www.iri.usp.br/documentos/DIN5905.pdf. Acesso: 21.09.2016.

52 JARDIM, Tarciso Dal Maso. Condicionantes impostas pelo Congresso Nacional ao Executivo Federal em matéria de celebração de tratados, 2011, p. 292. Disponível em: http://www2.senado.leg.br/ bdsf/item/id/243243. Acesso: 21.09.2016.
} 
interpretativas em relação ao tratado durante a sua tramitação e, mesmo assim, é possível encontrar manifestação desse tipo no endereço eletrônico da organização internacional depositária do acordo. As cláusulas interpretativas são, portanto, instrumento poderoso, previsto no rol normativo de Direito Internacional, e explorado pelos integrantes dos Poderes Executivo e Legislativo brasileiros, na sua atuação em temas afetos às relações do Brasil com seus pares.

\section{2. ÂMBITO NACIONAL}

O constituinte nacional não escolheu inserir na Carta Magna pátria, expressamente, a quem caberia a responsabilidade para a elaboração da política externa brasileira. A Constituição, entretanto, prevê que compete à União manter relações com outros Estados e participar de organizações internacionais (art. 21, I). No âmbito da União, o Poder Executivo é exercido pelo Presidente da República, com o auxílio dos Ministros de Estado (art. 76, CF). Compete ao Presidente da República celebrar tratados, conforme os artigos mencionados abaixo. O Brasil vincula-se a tratado internacional mediante o concurso de dois Poderes, o Executivo e o Legislativo. A internalização de tratados é, portanto, ato classificado como complexo, pois pressupõe a soma das vontades desses dois Poderes. Se um deles não proferir decisão positiva a respeito de determinada disposição, ou da totalidade de um tratado, este não poderá integrar a ordem jurídica nacional. O terceiro Poder da República, o Judiciário, apenas atuará nesse processo após a incorporação do tratado no ordenamento jurídico pátrio. Exemplificativamente, caberá ao STF julgar, mediante recurso extraordinário, as causas quando a decisão recorrida declarar a inconstitucionalidade de tratado (art. 102, III, "b", CF). ${ }^{53}$

Os tratados são, em regra, celebrados sob reserva de ratificação, e, portanto, a mera assinatura não vincula o Estado internacionalmente. Este deverá manifestar seu

\footnotetext{
53 O art. 105, III, “a”, CF, trata das competências do Superior Tribunal de Justiça para julgar, em recurso especial, causas nas quais a decisão recorrida contrariar tratado ou lei federal, ou negar-lhes vigência. O art. 109, III, CF, refere-se às competências dos juízes federais de processar e julgar causas fundadas em tratado ou em contrato da União com Estado estrangeiro ou com organismo internacional.
} 
consentimento definitivo por intermédio da ratificação. O lapso temporal entre esses dois momentos teria como objetivo permitir que fossem avaliadas, internamente, a conveniência e a oportunidade de aceitar os compromissos previstos no tratado. ${ }^{54}$ Segundo a Constituição Federal de 1988:

\footnotetext{
Art. 84, CF. Compete privativamente ao Presidente da República: (...)

VII - manter relações com Estados estrangeiros e acreditar seus representantes diplomáticos;

VIII - celebrar tratados, convenções e atos internacionais, sujeitos a referendo do Congresso Nacional; (...)
}

A competência privativa, mencionada no artigo acima, diferentemente da exclusiva, pode ser delegada. Conforme o artigo 49, I, CF, o Congresso Nacional é responsável por "resolver definitivamente sobre tratados, (...) que acarretem encargos ou compromissos gravosos ao patrimônio nacional". Não existiria tratado internacional que não imponha encargos ou compromissos gravosos às partes, ainda que não de cunho pecuniário. ${ }^{55} \mathrm{~A}$ expressão "resolver definitivamente", entretanto, é imprecisa, uma vez que, no sistema brasileiro, não implica em ratificação, ato privativo do Presidente da República. O Chefe do Poder Executivo decide a respeito da conveniência e da oportunidade de iniciar negociações internacionais; e, após a elaboração de tratado e de sua apreciação pelo Poder Legislativo, decide a respeito da conveniência de ratificar o ato internacional. Incumbe ao Parlamento aprovar ou não os instrumentos internacionais, apenas resolvendo definitivamente em caso de rejeição completa, o que impede o Executivo de proceder à ratificação.

O modo como ocorrerá a apreciação parlamentar do ato, entretanto, não é definido pela Constituição. Essa competência, porém, não se resume à aprovação ou à rejeição total de determinado acordo internacional. Apesar de a Constituição não conferir aos integrantes das duas Casas do Congresso Nacional a possibilidade de participar das negociações internacionais, é possível verificar a participação do Legislativo na etapa posterior, de internalização dos compromissos assinados pelo Presidente ou por plenipotenciário. A aposição de ressalvas, que podem ser transformadas em reservas pelo Poder Executivo, retira a obrigatoriedade em relação a determinadas disposições de um tratado, sempre que o tratado

\footnotetext{
${ }^{54}$ Ponderação feita por GABSCH, 2010, p. 13.

${ }^{55}$ REZEK, 2013, p. 51.
} 
permitir. Os limites dessa atuação, entretanto, não são claros, e, tampouco, seus efeitos jurídicos nacionais e internacionais.

A Constituição prevê a possibilidade de qualquer das Casas do Congresso Nacional, por suas Comissões especializadas, exigir dos órgãos do Executivo envolvidos em política externa - e, portanto, inclusive do MRE - que prestem contas das decisões feitas em âmbito internacional.

Art. 50, CF. A Câmara dos Deputados e o Senado Federal, ou qualquer de suas Comissões, poderão convocar Ministro de Estado ou quaisquer titulares de órgãos diretamente subordinados à Presidência da República para prestarem, pessoalmente, informações sobre assunto previamente determinado, importando crime de responsabilidade a ausência sem justificação adequada. (Redação dada pela Emenda Constitucional de Revisão $n^{\circ} 2$, de 1994)

$\S 1^{\circ}$ - Os Ministros de Estado poderão comparecer ao Senado Federal, à Câmara dos Deputados, ou a qualquer de suas Comissões, por sua iniciativa e mediante entendimentos com a Mesa respectiva, para expor assunto de relevância de seu Ministério.

$\S 2^{\circ}$ - As Mesas da Câmara dos Deputados e do Senado Federal poderão encaminhar pedidos escritos de informações a Ministros de Estado ou a qualquer das pessoas referidas no caput deste artigo, importando em crime de responsabilidade a recusa, ou o não - atendimento, no prazo de trinta dias, bem como a prestação de informações falsas. (Redação dada pela Emenda Constitucional de Revisão $n^{\circ} 2$, de 1994)

$\mathrm{O}$ art. 52, IV, CF, prevê a competência do Senado Federal de aprovar, em sessão secreta e por voto secreto, a escolha de chefes de missão diplomática permanente, o que indica a participação dessa Casa em escolha relevante concernente à política externa brasileira. A Constituição, em seu artigo 84, VII, ao determinar que compete privativamente ao Presidente da República celebrar tratados, sujeitos a referendo do Congresso Nacional, não menciona limite de tempo para essa apreciação. Esse é um dos aspectos fundamentais para a demora injustificada para a tramitação de tratados, que, muitas vezes, passam anos sem serem enviados para a apreciação do Poder Legislativo, como veremos em parte dos casos concretos apreciados.

A Constituição, entretanto, detalha com maior especificidade o procedimento de aprovação de tratado da temática de objeto desta tese: os Direitos Humanos:

Art. 5', CF. Todos são iguais perante a lei, sem distinção de qualquer natureza, garantindo-se aos brasileiros e aos estrangeiros residentes no País a inviolabilidade do direito à vida, à liberdade, à igualdade, à segurança e à propriedade, nos termos seguintes: 
$\S 1^{\circ}$ As normas definidoras dos direitos e garantias fundamentais têm aplicação imediata.

$\S 2^{\circ}$ Os direitos e garantias expressos nesta Constituição não excluem outros decorrentes do regime e dos princípios por ela adotados, ou dos tratados internacionais em que a República Federativa do Brasil seja parte.

$\S 3^{\circ}$ Os tratados e convenções internacionais sobre direitos humanos que forem aprovados, em cada Casa do Congresso Nacional, em dois turnos, por três quintos dos votos dos respectivos membros, serão equivalentes às emendas constitucionais. (Incluído pela Emenda Constitucional $n^{\circ} 45$, de 2004)

$\S 4^{\circ} \mathrm{O}$ Brasil se submete à jurisdição de Tribunal Penal Internacional a cuja criação tenha manifestado adesão. (Incluído pela Emenda Constitucional $n^{\circ} 45$, de 2004) (grifo nosso).

Apesar dessa inovação constitucional, não existe indicação de prazo determinado no qual os tratados devem ser enviados para o Congresso, para tramitarem conforme o rito descrito. Tampouco está claro quem é o responsável pela definição do modo de apreciação do tratado, ou seja, se deve ou não ser considerado como possível "aspirante" a emenda constitucional. Essa omissão é objeto de extensa discussão durante a tramitação da Convenção sobre os Direitos das Pessoas com Deficiência, único tratado internalizado com equivalência a Emenda Constitucional até o depósito desta tese. ${ }^{56}$ Particularmente, discutese se o Executivo, na figura do Ministro das Relações Exteriores, geralmente o responsável por elaborar a MSC, poderia sugerir ao Congresso a incorporação de tratado sob esse rito.

A declaração de voto dos Deputados Gustavo Fruet e Bruno Araújo durante a tramitação interna da aprovação desse tratado é sintomática nesse sentido. Os Deputados não discutem o mérito da questão, ou seja, se a Convenção, considerada extremamente benéfica para a consolidação e a proteção dos direitos das pessoas com deficiência, deveria ser, efetivamente, internalizada como Emenda Constitucional. Discutem, porém, dois aspectos cruciais em relação à sua incorporação ao ordenamento jurídico brasileiro: em primeiro lugar, questionam o fato de que é possível propor emendas a PECs, o que não é verdadeiro para o texto de tratados internacionais. Tendo a aprovação do tratado tramitado em regime de urgência, o que tampouco seria permitido para PECs, argumentam que não teria sido possível emendar o projeto de decreto legislativo, mesmo que, em momento posterior, os

\footnotetext{
${ }^{56}$ A MSC 696/2010, redigida pelo Ministro das Relações Exteriores, senhor Celso Amorim, que encaminhou ao Congresso Nacional a apreciação da Convenção Internacional sobre a proteção dos direitos de todos os Trabalhadores Migrantes e dos membros das suas famílias, também sugere que essa Convenção tramite como emenda constitucional. A Convenção, entretanto, ainda não teve seu processo de internalização finalizado, e tampouco foi assinada pelo Brasil; tendo sido enviada anteriormente à apreciação parlamentar. Por esse motivo, não foi considerada para fins desta tese. De qualquer modo, é possível obter mais informações a respeito de sua tramitação até o depósito desta tese no item 17 do APÊNDICE I.
} 
nobres Deputados concluíssem pela incompatibilidade das emendas com a natureza do instrumento internacional em pauta.

Em segundo lugar, os Deputados indagam sobre a capacidade de iniciativa para apresentar ao Congresso Nacional o tratado de Direitos Humanos como potencialmente equivalente a emenda constitucional. Diversos parlamentares apontam que não caberia ao Executivo sugerir a aprovação de determinado tratado como EC; mas que essa análise caberia aos próprios congressistas. A introdução de novos dispositivos na Carta Magna, fato que seria decorrência lógica da aprovação do tratado por três quintos dos parlamentares, em dois turnos, nas duas Casas do Congresso, ${ }^{57}$ também os preocupa, pois as disposições de tratados multilaterais podem ser muito vagas, de interpretação complexa e, potencialmente, menos protetivas dos direitos fundamentais do que as normas inscritas na Constituição.

Araújo e Fruet manifestam, ainda, estranhamento em relação à possibilidade de o instrumento, uma vez aprovado conforme procedimento do art. $5^{\circ}, \S 3^{\circ}, \mathrm{CF}$, não ser prontamente ratificado pelo Presidente da República, ou, ainda, não ter entrado em vigor internacionalmente. Estaríamos, em ambos os casos, em situação sui generis, na qual um tratado, apesar de não estar vigente no âmbito internacional, tem status constitucional no Brasil. $^{58}$

Francisco Rezek, em ponderação que retrata de maneira fiel o que ocorre na prática nacional em relação a tratados, ressalta que, uma vez concluída a negociação, o chefe do Poder Executivo está livre para dar curso, se desejar, ao processo parlamentar que determinará o consentimento ao tratado. Como responsável constitucional pela dinâmica das relações exteriores do país, o Presidente poderia não ter, sequer, iniciado as negociações, ou ter, inclusive, interrompido a participação brasileira. Desse modo, o chefe do Executivo tem a faculdade de arquivar o resultado das negociações, sejam elas bilaterais ou coletivas, simplesmente por tê-las como insatisfatórias. ${ }^{59}$ Não há, afinal, dispositivo legal que o impeça de tomar atitudes semelhantes; salvo no que se refere às Convenções da Organização internacional do Trabalho (OIT), conforme explanado a seguir.

\footnotetext{
${ }^{57}$ Combinação dos artigos $5^{\circ}, \S 3^{\circ}$ e $60 . \S 2^{\circ}, \mathrm{CF}$.

${ }^{58}$ A descrição completa da tramitação desse tratado nas Comissões do Congresso Nacional encontra-se no APÊNDICE I, item 20.

${ }^{59}$ REZEK, Francisco. Direito Internacional Público: curso Elementar, p. 88
} 
O Poder Executivo não é obrigado a enviar o tratado para a apreciação do Congresso Nacional, com exceção das Convenções da OIT. Isso é consequência da Constituição da própria Organização, que determina, em seu art. 19, que os governos de seus Estadosmembros devem encaminhar às autoridades nacionais competentes os textos das Convenções adotadas na Conferência Internacional do Trabalho dentro do prazo máximo de um ano após o término da conferência na qual foram celebradas. ${ }^{60} \mathrm{O}$ Brasil ratificou essa Convenção, e deve, portanto, seguir suas disposições. Destaco, ainda, particularidade das Convenções da OIT, que justifica a inexistência de data de assinatura para as Convenções provenientes da Organização: elas são adotadas por meio de procedimento próprio, sem previsão de assinatura por parte de seus membros, conforme o art. 19 de sua Constituição. Consta no endereço eletrônico da Organização, apenas, a data de ratificação pelos países.

O Decreto 8.817, de 21.07.2016, que aprova a estrutura regimental e o quadro demonstrativo dos cargos em comissão e das funções em confiança do MRE, menciona a competência do Ministério para participar das negociações com governos estrangeiros (art. $\left.1^{\mathrm{o}}, \mathrm{III}\right)$. Caberia ao Ministério ajudar o Presidente a formular a política exterior brasileira, além de assegurar sua execução e manter relações com países e organismos/organizações internacionais (art. $1^{\mathrm{o}}$, parágrafo único). $\mathrm{O}$ art. $7^{\circ}$, II, que estabelece a estrutura regimental do MRE, estabelece que compete à Consultoria Jurídica, órgão setorial da Advocacia-Geral da União, "fixar a interpretação da Constituição, das leis, dos tratados e dos demais atos normativos a ser uniformemente seguida na área de atuação do Ministério, quando não houver orientação normativa do Advogado-Geral da União; (...)”.

\footnotetext{
${ }^{60}$ Artigo 19.1. Se a Conferência pronunciar-se pela aceitação de propostas relativas a um assunto na sua ordem do dia, deverá decidir se essas propostas tomarão a forma: a) de uma convenção internacional; b) de uma recomendação, quando o assunto tratado, ou um de seus aspectos não permitir a adoção imediata de uma convenção.

5. Tratando-se de uma convenção: (...)

(b) cada um dos Estados-Membros compromete-se a submeter, dentro do prazo de um ano, a partir do encerramento da sessão da Conferência (ou, quando, em razão de circunstâncias excepcionais, tal não for possível, logo que o seja, sem nunca exceder o prazo de 18 meses após o referido encerramento), a convenção à autoridade ou autoridades em cuja competência entre a matéria, a fim de que estas a transformem em lei ou tomem medidas de outra natureza; (...). Grifos nossos.

Informação obtida em: http://www.oitbrasil.org.br/sites/default/files/topic/decent_work/doc/constituicao_oit_ 538.pdf. Acesso: 18.03.2016.
} 
Na prática nacional, os tratados assinados são analisados pelo departamento jurídico do Ministério das Relações Exteriores. Se esse departamento entende que acarretam encargo gravoso ao Estado, é elaborada exposição de motivos para a aprovação do tratado em pauta, encaminhada para a Casa Civil da Presidência da República. Esta, por intermédio de Mensagem Presidencial (Mensagem, MSC), assinada pelo Presidente da República, envia a matéria para a apreciação da Câmara dos Deputados. A Mensagem é acompanhada do inteiro teor do tratado internacional submetido à apreciação parlamentar, devidamente traduzido. ${ }^{61}$

A Câmara dos Deputados é a primeira Casa legislativa a apreciar o tratado internacional, que lhe é apresentado acompanhado da exposição de motivos, geralmente de autoria do Ministro das Relações Exteriores. Apesar de a Constituição não definir o iter procedimental para a apreciação de tratados pelo Legislativo, esse processo segue, por analogia legislativa, a disposição do art. 64, caput, CF, combinado com o art. 134 do Regimento Comum do Congresso Nacional, artigo mencionado por diversos Deputados e Senadores no que se refere à tramitação de tratados, que reza:

Art. 134: O projeto de lei, aprovado em uma das Casas do Congresso Nacional, será enviado à outra Casa, em autógrafos assinados pelo respectivo Presidente. Parágrafo único. O projeto terá uma ementa e será acompanhado de cópia ou publicação de todos os documentos, votos e discursos que o instruíram em sua tramitação.

O tratado, em seu processo de internalização, passa por, ao menos, duas comissões permanentes, a Comissão de Relações Exteriores e de Defesa Nacional e a Comissão de Constituição, Justiça e Redação. ${ }^{62} \mathrm{O}$ texto pode, também, passar por comissões temáticas, conforme a matéria do tratado, sendo possível criar comissões especiais para tratar do tema. Na Mensagem, são encaminhados aos Senadores e aos Deputados Federais (i) o texto do tratado celebrado pelo Presidente da República ou por plenipotenciário; (ii) o texto do tratado multilateral que, mesmo sem a participação do Brasil no ato de celebração, merece, sob a

\footnotetext{
${ }^{61}$ Não serão oferecidos maiores detalhes a respeito da tramitação de tratados no âmbito do MRE, pois não se trata do escopo desta tese. Para informações a respeito dessa tramitação, é possível acessar o Manual de Procedimentos da Divisão de Atos Internacionais, em: http://dai-mre.serpro.gov.br/clientes/dai/dai/manual-deprocedimentos/manual-de-procedimentos-pratica-diplomatica. Acesso: 29.09.2016.

${ }^{62}$ Conforme interpretação do art. 139, II, "a" e "c", do Regimento Interno da Câmara dos Deputados.
} 
discricionariedade do Presidente da República, apreciação legislativa para eventual adesão; ou (iii) texto de tratado da OIT proveniente da Conferência do Trabalho, instância superior da Organização. ${ }^{63}$

Na Câmara, a Mensagem é encaminhada diretamente para a Comissão de Relações Exteriores e Defesa Nacional (CREDN) ${ }^{64}$ na qual é designado relator (art. 32, XV, "c" do Regimento Interno da Câmara dos Deputados - RICD). Os tratados são submetidos à CREDN porque as matérias submetidas à Câmara dos Deputados sem projeto formulado, e das quais venha a resultar DLG, como é o caso dos tratados, serão inicialmente distribuídas à comissão encarregada de proferir parecer sobre o mérito da questão; e, se entender cabível, elaborar o projeto de diploma correspondente (artigos 129, § $2^{\circ}$ e 139, II “d”, RICD).

Como a CREDN é competente para pronunciar-se a respeito de instrumentos internacionais, é a primeira a fazer essa análise. Após apreciação dessa Comissão, em caso de parecer favorável do relator e aprovação por seus membros, a Comissão de Constituição e Justiça e Cidadania é informada, a Mensagem é modificada e torna-se um Projeto de Decreto Legislativo da Câmara dos Deputados (PDC). O PDC, por sua vez, é encaminhado para a Secretaria da Mesa, que numera o PDC e o encaminha para o Plenário. Caso a matéria seja admitida pela primeira comissão de mérito, ela é apresentada à Mesa Diretora e remetida, pelo Presidente da Câmara, às demais comissões a que havia sido distribuída. Nesse momento, o regime de tramitação passa a ser urgente, conforme disposição do art. 151, I, “j”, RICD, ${ }^{65}$ o que dispensa parte significativa das exigências regimentais (art. 152, RICD).

${ }^{63}$ Conforme DALLARI, 2003, p. 89.

${ }^{64}$ A Comissão de Relações Exteriores e de Defesa Nacional foi criada por Resolução de 15.09.1936, com a denominação de "Diplomacia e Tratados". Em 05.09.1947, teve a denominação alterada pelo Regimento Interno da Câmara dos Deputados, passando a chamar-se "Diplomacia" - Resolução no 10, art. 20, III. A Resolução $\mathrm{n}^{\circ} 115$, de 12.11.1957, deu nova denominação à Comissão de Diplomacia, que passou a chamar-se "Comissão de Relações Exteriores". Por fim, com a Resolução 15/1996, passou a denominar-se "Comissão de Relações Exteriores e de Defesa Nacional", conforme o art. 32, inciso XI do atual Regimento Interno da Câmara dos Deputados. Informação obtida em: http://www2.camara.leg.br/atividade-legislativa/comissoes/ comissoes-permanentes/credn/conheca-a-comissao. Acesso: 02.03.2016.

${ }^{65}$ Capítulo VI - Do Regime de Tramitação

Art. 151. Quanto à natureza de sua tramitação podem ser:

I - urgentes as proposições: (...)

j) oriundas de mensagens do Poder Executivo que versem sobre acordos, tratados, convenções, pactos, convênios, protocolos e demais instrumentos de política internacional, a partir de sua aprovação pelo órgão 
Projetos relativos à internalização de tratados deverão ser aprovados na Câmara dos Deputados e no Senado Federal por maioria simples. A rejeição do PDC na Câmara impede seu envio ao Senado. Destaco que tratado não pode versar sobre tema de lei complementar, conforme pode ser percebido pela leitura da ADI 1.480, que fez essa determinação por ser distinto o quórum para aprovação de lei complementar (maioria absoluta) daquele exigido para aprovação de lei ordinária (maioria simples). ${ }^{66}$

O PDC, uma vez aprovado pelas Comissões que o apreciaram e em plenário, é enviado para o Senado, onde é renumerado e transformado em Projeto de Decreto do Senado Federal (PDS). A tramitação de PDS relativo a tratado internacional é regulamentada expressamente pelo Regimento Interno do Senado Federal (RISF). ${ }^{67}$ Após a tramitação do PDS no Senado, ele é referendado pelo Presidente do Senado Federal, que promulga o Decreto Legislativo respectivo. ${ }^{68}$ Apenas após a finalização da tramitação dos Projetos de Decreto na Câmara e no Senado, e a promulgação do DLG pelo Senado Federal, é facultado (ou seja, não obrigatório) ao Presidente da República publicar o Decreto Presidencial, que dá publicidade ao tratado no âmbito nacional; e, ademais, proceder à sua ratificação no âmbito internacional. A promulgação do Decreto Legislativo, portanto, não obriga o Poder Executivo a tomar

técnico específico, através de projeto de decreto legislativo, ou que sejam por outra forma apreciadas conclusivamente; (...).

${ }^{66}$ ADI 1.480-DF, acórdão publicado em 26 de junho de 2001.

DECISÃO: Trata-se de ação direta de inconstitucionalidade, ajuizada com o objetivo de questionar a validade jurídico-constitucional do Decreto Legislativo $n^{\circ}$ 68/92, que aprovou a Convenção $n^{\circ} 158$ da Organização Internacional do Trabalho (OIT), e do Decreto $\mathrm{n}^{\circ} 1.855 / 96$, que promulgou esse mesmo ato de direito internacional público. O Plenário do Supremo Tribunal Federal, ao deferir, parcialmente, sem redução de texto, o pedido de medida cautelar, proferiu decisão que restou consubstanciada em acórdão assim ementado:

“Ação direta de inconstitucionalidade - convenção n ${ }^{\circ}$ 158/OIT - proteção do trabalhador contra a despedida arbitrária ou sem justa causa - arguição de ilegitimidade constitucional dos atos que incorporaram essa convenção internacional ao direito positivo interno do brasil (decreto legislativo $\mathrm{n}^{\mathrm{o}} 68 / 92$ e decreto $\mathrm{n}^{\mathrm{o}} 1.855 / 96$ ) - possibilidade de controle abstrato de constitucionalidade de tratados ou convenções internacionais em face da constituição da república - alegada transgressão ao art. $7^{\circ}$, i, da Constituição da República e ao art. 10, i do $\mathrm{ADCT} / 88$ - regulamentação normativa da proteção contra a despedida arbitrária ou sem justa causa, posta sob reserva constitucional de lei complementar - consequente impossibilidade jurídica de tratado ou convenção internacional atuar como sucedâneo da lei complementar exigida pela constituição (cf, art. $7^{\circ}$, i) - consagração constitucional da garantia de indenização compensatória como expressão da reação estatal à demissão arbitrária do trabalhador (cf, art. $7^{\circ}, \mathrm{i}, \mathrm{c} / \mathrm{c}$ o art. 10, i do ADCT/88) - conteúdo programático da convenção $\mathrm{n}^{\circ} 158 / \mathrm{OIT}$, cuja aplicabilidade depende da ação normativa do legislador interno de cada país - possibilidade de adequação das diretrizes constantes da convenção $\mathrm{n}^{\circ}$ 158/OIT às exigências formais e materiais do estatuto constitucional brasileiro - pedido de medida cautelar deferido, em parte, mediante interpretação conforme à constituição. Procedimento constitucional de incorporação dos tratados ou convenções internacionais. Ementa disponível em: http://www.stf.jus.br/arquivo/informativo/documento/informativo236.htm. Acesso: 08.06.2015.

${ }^{67}$ RISF, art. 376

${ }^{68}$ O Projeto de Decreto Legislativo é aprovado pelo Congresso Nacional e promulgado pelo Presidente do Senado Federal. 
qualquer atitude para finalizar o processo de vinculação ao instrumento internacional, pois pode optar por, simplesmente, não ratificar o tratado.

O RISF aponta que "Art. 171. A matéria dependente de exame das comissões só será incluída em Ordem do Dia depois de emitidos os pareceres, (...) observado o interstício regimental (...)". Conforme o art. 172:

\footnotetext{
Art. 172, RISF. A inclusão em Ordem do Dia de proposição em rito normal, sem que esteja instruida com pareceres das comissões a que houver sido distribuida, só é admissivel nas seguintes hipóteses:

II - por ato do Presidente, quando se tratar:

c) de projeto de decreto legislativo referente a tratado, convênio ou acordo internacional, se faltarem dez dias, ou menos, para o término do prazo no qual o Brasil deva manifestar-se sobre o ato em apreço; (...) (grifo nosso).
}

Apesar da menção, no artigo acima, de prazo dentro do qual o Brasil deveria manifestar-se a respeito de algum instrumento internacional, esse prazo apenas existe no âmbito internacional no caso das convenções da OIT.

O RISF, diferentemente do RICD, tem disposição que trata, especificamente, dos projetos referentes a atos internacionais, remetendo, inclusive, ao art. 49, I, CF, sobre a competência do Congresso Nacional em resolver definitivamente a respeito de tratados. $\mathrm{O}$ artigo define a tramitação do projeto de decreto legislativo referente a atos internacionais:

Art. 376, RISF. O projeto de decreto legislativo referente a atos internacionais terá a seguinte tramitação:

I - só terá iniciado o seu curso se estiver acompanhado de cópia autenticada do texto, em português, do ato internacional respectivo, bem como da mensagem de encaminhamento e da exposição de motivos;

II - lido no Período do Expediente, será o projeto publicado e distribuído em avulso eletrônico, acompanhado dos textos referidos no inciso I e despachado à Comissão de Relações Exteriores e Defesa Nacional;

III - perante a Comissão, nos cinco dias úteis subsequentes à publicação de avulso eletrônico, poderão ser oferecidas emendas; a Comissão terá, para opinar sobre o projeto, e emendas, o prazo de quinze dias úteis, prorrogável por igual período; IV - publicados o parecer e as emendas e o avulso eletrônico, decorrido o interstício regimental, a matéria será incluída em Ordem do Dia;

$V$ - não sendo emitido o parecer, conforme estabelece o inciso III, aplicar-se-á o disposto no art. 172, II, c.

(grifo nosso). 
Destaco que a menção a "emendas" no texto do artigo refere-se a modificações no texto do projeto de decreto legislativo, e não ao tratado apreciado. ${ }^{69} \mathrm{O}$ Congresso Nacional não tem a prerrogativa de emendar tratados, mas pode fazer aprovação condicionada ou apor ressalvas. As ressalvas foram a maneira encontrada por integrantes do Poder Legislativo de participar mais ativamente do processo de internalização dos tratados. Ao discutir a possibilidade de o Brasil não se obrigar a determinada disposição de tratado, os parlamentares demonstram seu interesse em lidar com temas afetos, primordialmente, às relações internacionais do país. Essas ressalvas podem ser transformadas em reservas pelo Poder Executivo, caso as acate.

Tarciso dal Maso Jardim separa em quatro espécies as ressalvas feitas sob a égide da Constituição de 1988. A primeira delas diz respeito às correções na tradução dos textos dos tratados, que podem ser imprecisas. Essa classe de ressalva não vincularia o Executivo a redigir reservas ou declarações interpretativas, nem possuiria maior impacto nas relações internacionais do país. O segundo tipo de ressalvas refere-se às restrições propostas pela própria MSC, e, nesse caso, a ressalva é de criação do Executivo. O autor acredita, porém, que é facultado ao Legislativo aprovar o tratado com as reservas propostas pelo Executivo: recusada a proposta de reserva, o Executivo seria obrigado a ratificar o tratado sem ela. $\mathrm{O}$ terceiro tipo é caracterizado pela transformação das ressalvas, propostas pelo Legislativo, em reservas, no momento de ratificação do tratado. A quarta classe de ressalvas seriam as chamadas “declarações interpretativas", declarações unilaterais do Estado, que interpreta os efeitos jurídicos de determinada norma prevista pelo tratado.

Os membros do Congresso podem, ademais, exigir a retirada de reserva feita por parte do Poder Executivo quando da assinatura do tratado. Essa exigência vincula o Poder Executivo. A aprovação pode ser retratada, sempre que o tratado não tenha sido ratificado. A rejeição de reserva a tratado é feita por mensagem ao Presidente da República, que, nesse caso, apenas poderá ratificar o tratado quando, por ser ato complexo, houver a exata conjunção de duas vontades: a do Poder Executivo e a do Poder Legislativo.

Com razão, é difícil aceitar a possibilidade de Deputados ou de Senadores poderem emendar tratados, pois essa ação exigiria a concordância de todas as partes contratantes.

\footnotetext{
${ }^{69}$ Entendimento corroborado por Tarciso dal Maso Jardim, consultor legislativo do Senado Federal, em "Condicionantes impostas pelo congresso nacional ao executivo federal em matéria de celebração de tratados", p. 288; e por Valerio Mazzuoli, em “Treaty making power”, p. 99.
} 
Quem negocia o acordo internacional é o plenipotenciário brasileiro, geralmente - mas não necessária ou exclusivamente - membro do Poder Executivo. O Legislativo, por sua vez, não é competente para negociar com sujeitos de Direito Internacional. Dallari prevê a possibilidade de "aprovação condicionada" por parte do Poder Legislativo, pela qual o Congresso autoriza o Presidente, por decreto legislativo, a ratificar o tratado apenas após a aquiescência das outras partes, devidamente informadas de eventual alteração proposta pelo Congresso brasileiro. Em última análise, nesse caso, seria o Estado brasileiro, acionado pelo Congresso, quem proporia a emenda ao texto do tratado no âmbito internacional. ${ }^{70}$

A aprovação condicionada, porém, não deve ser confundida com as ressalvas. As “ressalvas" são a denominação, no âmbito Legislativo, daquilo que poderá ser transformado em reserva a tratado no momento de sua ratificação, pelo Executivo. A reserva é admitida somente quando estiver prevista, implícita ou explicitamente, no tratado. Previsão implícita é aquela que considera a letra da CVDT, que veda a apresentação de reservas quando (i) proibidas pelo texto convencional; (ii) não se enquadrem nas hipóteses permitidas pelo tratado ou (iii) sejam incompatíveis com o seu objeto e finalidade (art. 2.1.d e art. 19, CVDT). Em regra, não é possível que os Estados contratantes objetem a uma reserva formulada a tratado que preveja essa possibilidade e, por isso, não há de se falar em necessidade de concordância das outras partes. Existe discussão, apenas, em casos nos quais o tratado não prevê reservas expressamente, o que pode culminar em objeção de signatário que considere uma reserva feita incompatível com o tratado.

Em caso de rejeição de tratado, conforme previamente apontado, a decisão nesse sentido é comunicada ao chefe do Poder Executivo por intermédio de mensagem. Caso o tratado seja aprovado pelo Congresso com ressalvas, que podem ser transformadas em reservas pelo Executivo quando da ratificação do instrumento internacional, o Presidente da República precisa de nova apreciação por parte dos integrantes do Poder Legislativo caso queira retirar essas reservas. ${ }^{71}$

\footnotetext{
${ }^{70}$ DALLARI, 2003, p. 94.

${ }^{71}$ Esse procedimento ocorreu no caso da Convenção sobre a Eliminação de todas as formas de discriminação contra a mulher, ratificada com reservas posteriormente retiradas. A descrição desse caso é feita no APÊNDICE I, e são feitas considerações adicionais a esse respeito no Capítulo 4. RELAÇÃO ENTRE O EXECUTIVO E
} 
A aprovação parlamentar é retratável, mediante decreto legislativo que revogue o diploma de mesmo nível hierárquico que tenha abonado um tratado anteriormente. A retratação, porém, apenas é possível antes da ratificação do tratado, que exprime o consentimento definitivo por parte do Poder Executivo, com consequências no âmbito internacional. ${ }^{72}$ Caso contrário, encontrar-nos-íamos em situação sui generis, na qual o país está obrigado internacionalmente às obrigações advindas de um tratado, sem que fosse possível aplicá-lo internamente.

O tratado, porém, apenas será exigível no âmbito interno após a sua promulgação e a publicação do Decreto Presidencial, conforme o princípio da publicidade. ${ }^{73}$ A partir dessa publicação, incumbência do Poder Executivo, ${ }^{74}$ o tratado passa a integrar o ordenamento jurídico nacional, e habilita-se ao cumprimento no país e às garantias que a esse cumprimento podem ser oferecidas pelos integrantes do Poder Judiciário. Mesmo com a publicação do tratado em âmbito nacional, ele apenas será aplicado no Brasil se ou quando estiver em vigor internacionalmente.

A ratificação, ato privativo do Presidente da República e de caráter internacional, é duplamente discricionária. Sob a perspectiva internacional, é o ato pelo qual o Estado expressa seu consentimento em obrigar-se a determinado tratado, caso o responsável por esse ato (no caso brasileiro, o Presidente da República) entenda por sua conveniência. Sob

O LEGISLATIVO NA INTERNALIZAÇÃO DE TRATADOS E NA ELABORAÇÃO DA POLÍTICA EXTERNA.

72 REZEK, 2013, p. 66-67.

${ }^{73}$ A "promulgação" é o instrumento que declara a existência da lei e ordena sua execução. A "publicação", por sua vez, complementa a promulgação, é o ato mediante o qual se transmite a promulgação do ato normativo aos seus destinatários, tornando-o público mediante publicação no Diário Oficial da União. Trata-se de condição de eficácia e de vigência da lei. Informação obtida em: http://www12.senado.leg.br/noticias/glossario-legislativo/publicacao http://www12.senado.leg.br/noticias/glossario-legislativo/promulgacao. Acesso: 06.06.2016.

${ }^{74}$ Segundo o Decreto 4.520, de 16.12.2002, que dispõe sobre a publicação do Diário Oficial da União e do Diário da Justiça pela Imprensa Nacional da Casa Civil da Presidência da República:

Art. $1^{\circ}$ Incumbe ao Poder Executivo, por intermédio da Imprensa Nacional da Casa Civil da Presidência da República, a publicação: (...)

II - dos tratados, convenções e outros atos internacionais aprovados pelo Congresso Nacional; (...)

Art. $2^{\circ}$ São obrigatoriamente publicados, na íntegra, no Diário Oficial da União: (...)

II - os tratados, as convenções e outros atos internacionais aprovados pelo Congresso Nacional e os respectivos decretos de promulgação; (...).

Informação disponível em: http://www.planalto.gov.br/ccivil_03/decreto/2002/D4520.htm\#art3. Acesso: 27.09.2016. 
o aspecto constitucional, o Presidente é competente para decidir o momento da ratificação (quando) e sua conveniência (se). Inexiste, assim, obrigação de ratificar um tratado por parte do Poder Executivo, mesmo que tenha sido aprovado pelo Congresso. ${ }^{75}$

Em suma, uma vez formalizado o texto do tratado pelo Chefe do Poder Executivo ou por plenipotenciários, torna-se vinculante internacionalmente apenas após a sua ratificação pelo Presidente da República. A ratificação apenas é possível após a apreciação pelos parlamentares do texto do acordo internacional.

\subsection{VIGÊNCIA}

O tratado internacional está vinculado a três tipos distintos de vigência: a vigência do tratado no âmbito internacional; a vigência do tratado para o país no âmbito internacional e a vigência do tratado no país, ou vigência interna. ${ }^{76}$

A primeira delas, a vigência internacional, dá-se no momento em que o tratado atingiu todas as condições explicitadas em seu texto para sua entrada em vigor. O próprio tratado pode estabelecer, por exemplo, que entrará em vigor após o depósito de número específico de ratificações ou de adesões por parte dos Estados signatários. A vigência internacional, portanto, pode ocorrer antes da ratificação de um tratado por parte de todos aqueles que o assinaram.

A vigência de tratado para o país no âmbito internacional ocorre com a ratificação do instrumento ou após o decurso de prazo estabelecido no texto convencional para essa ratificação. Não é possível, entretanto, que tratado entre em vigor para o Brasil sem que esteja em vigor internacionalmente. A vigência de tratado para o Estado brasileiro, portanto, ocorre com a soma da vigência internacional e a ratificação.

No momento em que o tratado estiver em vigor internacionalmente e esteja vigente para o Brasil no plano internacional, deverá ingressar na ordem jurídica nacional. A vigência no Estado brasileiro, ou vigência interna, pressupõe a publicidade interna da assunção de obrigação, por parte do país, no âmbito internacional. No Brasil, isso ocorre com a promulgação e a publicação desse tratado no âmbito interno, por Decreto Presidencial. O

\footnotetext{
${ }^{75}$ GABSCH, 2010, p. 50.

${ }^{76}$ Conforme DALLARI, 2003, p. 98.
} 
Decreto Presidencial apresenta o inteiro teor do instrumento convencional, e é publicado no Diário Oficial da União (DOU).

\subsection{DENÚNCIA}

A denúncia de tratado internacional é o ato unilateral, pelo qual o Estado se desobriga em relação ao instrumento. Conforme disposição do art. 56, CVDT, não é possível a um país denunciar ou retirar-se de tratado que não preveja procedimento para isso, a não ser que as partes assim o estabeleçam, ou seja possível deduzir direito à renúncia ou à retirada da natureza do tratado.

Existe significativa discussão no Brasil a respeito da necessidade de o Executivo consultar o Legislativo quando tiver intenção de denunciar tratado. Apesar do silêncio constitucional acerca da matéria, esta foi apreciada em parecer da década de 1920, elaborado por Clóvis Bevilaqua, consultor jurídico do Itamaraty. O parecer tem como questão de fundo a intenção do governo brasileiro retirar-se da Liga das Nações, e Bevilaqua opinou pela desnecessidade de o Presidente da República obter autorização do Poder legislativo para retirar-se de tratado que, no caso concreto, estabelecia o próprio procedimento de denúncia. Precisamente por ter consultado o Legislativo para inserir o tratado na ordem interna, essa ação pressuporia um direito a efetuar todas as ações possíveis em relação a determinado tratado, o que incluiria desobrigar-se em relação a ele.

A posição de Bevilaqua é refutada, em parte, pelo consultor legislativo Tarciso dal Maso Jardim. Para este,

\footnotetext{
"Guardadas as realidades institucionais e constitucionais dos anos trinta e os atuais, o ônus e o impacto legislativo da decisão do Executivo de deixar de ser parte de um organismo internacional, já seriam motivos suficientes para submeter o caso ao Legislativo. Principalmente se contrariassem princípios constitucionais, como os de incentivo à integração regional, de defesa da paz e de promover os direitos humanos". ${ }^{77}$
}

${ }^{77}$ JARDIM, 2011, p. 286. 
Rezek, por sua vez, acredita que, por ser a internalização de tratados um procedimento complexo, conjugando as vontades dos Poderes Executivo e Legislativo, em caso de retirada de uma das vontades, o instrumento internacional não pode ser sustentado no âmbito interno, devendo, assim, ser denunciado. ${ }^{78}$

Em parecer, Antônio Augusto Cançado Trindade lembra que a aprovação legislativa de tratado ocorre por Decreto Legislativo, que possui hierarquia de lei; e a denúncia é feita por Decreto Presidencial, ato administrativo hierarquicamente inferior a lei. Esse ato administrativo não poderia invalidar a aprovação parlamentar, apenas a vigência subjetiva do tratado. ${ }^{79}$ A denúncia faria cessar, apenas, os efeitos da ratificação, pois ambos são atos privativos do Poder Executivo. A aprovação legislativa, aliás, não cria compromisso de ratificação, sendo, tão somente, condição necessária para ela. O resultado disso é a existência de acordos aprovados pelo Poder Legislativo, mas não ratificados - como é o caso de alguns dos tratados analisados nesta tese; e que, por isso, não geram obrigação no direito nacional. ${ }^{80}$

Antônio Paulo Cachapuz de Medeiros, ao tratar em parecer do reconhecimento da competência do Comitê Internacional para a Eliminação da Discriminação Racial, opção voluntária dos signatários da Convenção com o mesmo tema, explicita que, no momento em que o Poder Legislativo brasileiro concordou em aprovar a Convenção, conferiu ao Poder Executivo a prerrogativa de reconhecer a competência obrigatória do Comitê a qualquer momento. Segundo o consultor, portanto, seria faculdade do Presidente da República dar execução à Convenção, tratado aprovado pelo Congresso Nacional. Destaca, porém, que em caso análogo ${ }^{81}$ apesar de ter sido exarado parecer semelhante, opinando pela desnecessidade da submissão do ato de reconhecimento ao Congresso, o governo da época pediu a autorização do Legislativo. ${ }^{82}$

Existe discussão a respeito da denúncia de tratados nos âmbitos Legislativo e, inclusive, Judiciário brasileiros. Na ADI 1.625, de 1997, ajuizada pela Confederação

\footnotetext{
${ }^{78} \mathrm{GABSCH}, 2010$, p. 60 e 61.

79 Trindade diferencia a vigência objetiva, ou internacional, da vigência subjetiva, que seria a vigência no Estado e para o Estado.

80 TRINDADE, Antonio Augusto Cançado. Parecer do Consultor Jurídico do Ministério das Relações Exteriores, de 24.11.1987. In: Pareceres dos consultores jurídicos do Itamaraty, v. VIII (1985-1990), pp. 416423. Trata-se de parecer a respeito da Convenção n. 81 da OIT.

${ }^{81}$ Parecer sobre o reconhecimento da competência obrigatória da Corte Interamericana de Direitos Humanos, conforme disposição do art. 62 do Pacto de São José da Costa Rica.

82 Parecer n. 45, de 04.09.2000, solicitado ao consultor jurídico do Itamaraty, Antônio Paulo Cachapuz de Medeiros, pelo Subsecretário-geral de assuntos políticos.
} 
Nacional dos Trabalhadores na Agricultura (Contag) e pela Central Única dos Trabalhadores (CUT), as autoras contestam o Decreto Federal 2.100/1996, que informa a retirada do Brasil de tratado relativo ao término da relação de trabalho por iniciativa do empregador. As entidades argumentam que ato unilateral do Presidente da República (à época, Fernando Henrique Cardoso) relativo a acordo internacional fere o art. 49, I, CF, que trata das competências do Congresso Nacional. Em voto-vista, de 11.04.2015, a Ministra Rosa Weber entendeu que o Decreto seria inconstitucional, partindo da premissa que, nos termos da Constituição, leis ordinárias não poderiam ser revogadas pelo Presidente da República, e que o Decreto responsável por formalizar a adesão do Brasil a um tratado internacional, aprovado pelo Congresso, equivaleria a lei ordinária. ${ }^{83} \mathrm{O}$ julgamento da Ação não foi finalizado até o depósito desta tese, mas ressalto a importância da discussão a respeito da necessidade de autorização prévia do Congresso em caso de denúncia de tratado, discussão igualmente travada na literatura. ${ }^{84}$

A prática brasileira consagrou, até o presente momento, o Presidente como titular do poder de denúncia dos tratados. ${ }^{85}$ Apresentarei, a seguir, propostas legislativas que têm como objetivo esclarecer o procedimento de denúncia de tratados internacionais, não abordado pela legislação pátria.

83 Informação obtida em: http://www.stf.jus.br/portal/cms/verNoticiaDetalhe.asp?idConteudo=303837. Acesso: 21.09.2016.

${ }^{84}$ Tramitação da ADI 1.625 disponível em: http://www.stf.jus.br/portal/processo/verProcessoAndamento.asp? numero $=1625 \&$ classe $=$ ADI\&codigoClasse $=0 \&$ origem $=J U R \&$ recurso $=0 \&$ tipoJulgamento $=M . \quad$ Acesso: 21.09.2016.

${ }^{85}$ DALLARI, 2003, p. 115. 


\subsection{HISTÓRICO E PROPOSTAS PARA ALTERAÇÃO DO PROCEDIMENTO DE INTERNALIZAÇÃO DE TRATADOS}

\subsubsection{EVOLUÇÃO DAS DISPOSIÇÕES CONSTITUCIONAIS \\ BRASILEIRAS SOBRE POLÍTICA EXTERNA E SOBRE A INTERNALIZAÇÃO DE TRATADOS}

Apesar de fugir do escopo temporal deste trabalho, destaco que a Constituição do Império do Brasil, outorgada em 25.05.1824, conferiu ao Imperador, chefe do Poder Executivo, as prerrogativas de direcionar as relações exteriores com outros Estados, conforme seu art. 102 , item $7^{\circ}$; além de celebrar tratados, que deveriam ser levados ao conhecimento da Assembleia Geral "quando o interesse e segurança do Estado o permitirem" ${ }^{86}$ Apenas os tratados que envolvessem troca ou cessão de territórios do Império deveriam ser aprovados pela Assembleia Geral antes de serem ratificados. Ou seja, a participação do Legislativo nesse processo era, à época, uma exceção à regra. Em 1891, adotou-se a fórmula, mantida, com variação mínima, nas Constituições seguintes, de que caberia ao Presidente da República efetuar negociações internacionais e celebrar acordos $a d$ referendum do Congresso. O Parlamento passa, então, e como regra, a ser competente para apreciar os acordos celebrados pelo Poder Executivo. Trata-se de mudança importante para desenvolver a participação parlamentar nos assuntos de política externa, e corrigir eventual déficit democrático ${ }^{87}$ relacionado à questão. ${ }^{88}$

Rodrigo D’Araujo Gabsch ressalta, porém, que a expressão "resolver definitivamente", inserida no ordenamento nacional pela Carta Magna de 1891 e mantida pelas Cartas subsequentes, é imprecisa. O Congresso apenas decide em caráter definitivo em caso de rejeição de tratado. Em caso de aprovação, o responsável por vincular

\footnotetext{
${ }^{86}$ Constituição Política do Império do Brasil, art. 102, item $8^{\circ}$.

${ }^{87}$ Apesar de anacrônico - pois não podemos falar em uma discussão a respeito do "déficit democrático", expressão do século XX, no Brasil Império - a autora pretende, com essa ponderação, ressaltar que restringir as decisões a respeito de tratados ao chefe do Poder Executivo limita a sua discussão em um âmbito mais amplo, que seria aquele dos representantes da sociedade eleitos para ocupar o Poder Legislativo.

${ }^{88}$ Maiores informações podem ser obtidas em GABSCH, 2010, páginas 19 e seguintes.
} 
definitivamente o país é o Poder Executivo, com a ratificação, ato discricionário de consequências internacionais, de responsabilidade do Presidente da República. ${ }^{89}$ A Carta de 1934, assim como a de 1891, continha disposição acerca da competência privativa do Presidente para celebrar tratados, sujeitos à aceitação posterior do Poder legislativo. ${ }^{90} \mathrm{~A}$ Constituição de 1934 também inova ao atribuir à União, expressamente, o poder de celebrar tratados $\left(\operatorname{art.} 5^{\circ}, \mathrm{I}\right)^{91}$, embora, na prática, o poder de concluir tratados fosse negado aos estados desde a vigência da Carta de $1891 .^{92}$

O processo de internalização de tratados não recebeu atenção significativa dos constituintes nas Constituições brasileiras a partir da década de 1950. A primeira Constituição vigente desde o início da tramitação dos tratados aqui analisados é a Constituição de 1946. As Constituições de 1946 e $1967^{93}$ tinham dispositivos semelhantes aos adotados pela $\mathrm{CF} / 1988$; porém, esta inovou em diversos aspectos no que se refere às relações exteriores do Brasil. Ao redigir os princípios que regem as relações internacionais do país, o constituinte deixou clara sua importância para a sua condução política. Para realizar estudo minucioso a respeito do tratamento dado à política externa e ao processo de internalização de tratados nas constituições, foi feita busca das seguintes expressões em seus textos: tratado, internacion(-al, -ais), relac/ç(ões), exterior.

$\mathrm{O}$ art. 5 da Constituição de 1946 previa como competência da União "I - manter relações com os Estados estrangeiros e com eles celebrar tratados e convenções; (...)". Seria competência exclusiva do Congresso Nacional, a de "art. 66, I - resolver definitivamente sobre os tratados e convenções celebradas com os Estados estrangeiros pelo Presidente da República; (...)”. A competência do Presidente da República, segundo o art. 87, incluía manter relações com Estados estrangeiros (inciso VI) e celebrar tratados internacionais $a d$ referendum do Congresso (inciso VII). Com a Constituição de 1946, o Senado, junto com a

\footnotetext{
${ }^{89}$ GABSCH, 2010, p. 24.

${ }^{90}$ Art. 56, item 6 ${ }^{\circ}$, Constituição da República dos Estados Unidos do Brasil, de 16.07.1934. Disponível em: http://www.planalto.gov.br/ccivil_03/Constituicao/Constituicao34.htm. Acesso: 31.05.2016.

${ }^{91}$ Art $5^{\circ}$. Compete privativamente à União:

I - manter relações com os Estados estrangeiros, nomear os membros do corpo diplomático e consular, e celebrar tratados e convenções internacionais; (...)

92 BARBALHO, João. Constituição federal brasileira. Rio de janeiro: Briguiet e Cia., 1924, p. 149 e 150 . Apud GABSCH, 2010, p. 25.

93 Textos das Constituições disponíveis em: http://www.planalto.gov.br/ccivil_03/Constituicao/Constituicao46.htm; http://www.planalto.gov.br/ccivil_03/ Constituicao/Constituicao67.htm e http://www.planalto.gov.br/ccivil_03/constituicao/Constituicao Compilado.htm. Acesso: 09.02.2016.
} 
Câmara dos Deputados, participa do processo de internalização de tratados, mantendo a prerrogativa de apreciá-los em conjunto.

A Constituição de 1967, por sua vez, manteve, em certa medida, a redação de suas predecessoras no que tange aos tratados. Competia à União “art. $8^{\circ}$, I. Manter relações com Estados estrangeiros e com eles celebrar tratados e convenções; participar de organizações internacionais; (...)". O Congresso teria a competência exclusiva de "Art. 47, I. Resolver definitivamente sobre os tratados celebrados pelo Presidente da República; (...)”. A competência privativa do Presidente é retratada no art. 83, segundo o qual o chefe do Poder Executivo deverá manter relações com Estados estrangeiros (inciso VII) e celebrar tratados, convenções e atos internacionais, ad referendum do Congresso Nacional (inciso VIII).

Apesar dessa diferenciação entre espécies distintas de instrumentos internacionais, como tratados e convenções, ressalto não existir diferença, na prática, entre eles: no caso de tratados, é essencial a apreciação legislativa, independentemente da denominação do instrumento. Instrumentos internacionais que decorrem de tratado são chamados, pela praxe internacional, de "protocolos", que são, na prática, novos tratados, relacionados tematicamente, e muitas vezes decorrentes, dos primeiros. Tanto é verdade que são, de fato, novos tratados, que precisam passar por novo procedimento legislativo de internalização.

Francisco Rezek, ao tratar do que chamou de "redundância terminológica", aponta que o estudo das Constituições brasileiras a partir da fundação da República corrobora a tese de Carlos Maximiliano, que viu nesses termos a intenção de compreender todas as formas possíveis de comprometimento exterior. ${ }^{94}$ Do mesmo modo, Afonso Arinos aponta para essa incoerência, e destaca que:

\footnotetext{
"A Constituição brasileira, ao falar em tratados e convenções internacionais, empregou duas palavras para exprimir o mesmo objeto jurídico, o que é de má técnica constitucional. O que é mais grave, porém, é que não ficaria excluída a hipótese de se entender que outros atos internacionais que não viessem rotulados como convenções ou tratados ficariam dispensados da fiscalização do Legislativo." $" 95$

(grifos do autor)
}

\footnotetext{
${ }^{94}$ MAXIMILIANO, Carlos. Comentários à Constituição brasileira de 1946. Apud REZEK, Francisco. Direito Internacional Público: curso elementar, p. 84.

${ }^{95}$ ARINOS, Afonso. Estudos de direito Constitucional. Rio de Janeiro. Forense: 1957, p. 266. Apud REZEK, 2013, p. 44-45.
} 
Diferentemente das outras Cartas, a de 1967 estabelecia prazo para o envio de tratado internacional à apreciação do Congresso, algo extremamente útil para mitigar os problemas provenientes da demora nesse envio:

Art. 47. É da competência exclusiva do Congresso Nacional: (...) Parágrafo único - O Poder Executivo enviará ao Congresso Nacional até quinze dias após sua assinatura, os tratados celebrados pelo Presidente da República. (grifo nosso).

Apesar dessa feliz inovação constitucional, sabe-se que, à época de sua elaboração, não existia regime democrático no país, o que diminuía a possibilidade de cobrança, por parte do Legislativo, do cumprimento dos dispositivos constitucionais por integrantes do Poder Executivo. Ademais, permanecia a discricionariedade do Presidente para ratificar o tratado. O parágrafo único do art. 47 foi retirado pela emenda 01, de 17.10.1969. ${ }^{96}$

A Constituição atual, promulgada em 1988, estabelece:

Art. 49. É da competência exclusiva do Congresso Nacional:

I - resolver definitivamente sobre tratados, acordos ou atos internacionais que acarretem encargos ou compromissos gravosos ao patrimônio nacional; (...). (grifo nosso).

Permanece a imprecisão da expressão "resolver definitivamente", uma vez que não é o Poder Legislativo aquele que dá a "última palavra" no que se refere aos tratados internacionais; e do que seriam tratados que apresentam “(...) encargos ou compromissos gravosos ao patrimônio nacional", tampouco especificado pelo constituinte. A interpretação plausível é a de que aqueles tratados que não acarretassem "encargos ou compromissos gravosos", como os que, por exemplo, apenas apresentam o modus operandi de cumprimento de acordo previamente internalizado no país, não precisariam passar pelo crivo do Poder Legislativo. Isso deu margem ao não envio ao Congresso de alguns acordos, chamados "Acordos Executivos", o que, em determinados casos, foi considerado uma afronta às prerrogativas do Congresso Nacional; daí o interesse parlamentar - apresentado

\footnotetext{
${ }^{96} \mathrm{O}$ art. 47 passou a corresponder ao art. 44 da Constituição emendada, conforme informação obtida em: http://www.planalto.gov.br/ccivil_03/Constituicao/Emendas/Emc_anterior1988/emc01-69.htm. Acesso: 27.09.2016.
} 
nos itens sobre Propostas de Emendas Constitucionais (PEC ou PECs) e Propostas de Resolução - em alterar normas constitucionais e regimentais para detalhar sua competência.

Apesar de a Constituição não determinar, expressamente, a quem ou a que órgão compete a condução da política externa brasileira, legislação infraconstitucional estabelece que o Presidente da República exerce o papel de formulação da política exterior e que compete ao MRE auxiliá-lo. Conforme o Decreto que aprova a estrutura regimental do MRE: ${ }^{97}$

Art. $1^{\circ}$ O Ministério das Relações Exteriores, órgão da administração direta, tem como área de competência os seguintes assuntos:

I - politica internacional; (...)

Parágrafo único. Cabe ao Ministério auxiliar o Presidente da República na formulação da política exterior do Brasil, assegurar sua execução e manter relações com Estados estrangeiros, organismos e organizações internacionais.

É possível perceber que o tratamento constitucional, seja em relação à política externa nacional, seja em relação à situação específica dos tratados, não é extenso. Apesar disso, existem iniciativas parlamentares no sentido de ampliar o rol de normas nacionais que regulamentem esses temas. Segue estudo feito a esse respeito.

\subsubsection{PROPOSTAS DE EMENDAS CONSTITUCIONAIS}

Neste item, será apresentado panorama geral das Propostas de Emendas Constitucionais à Constituição de 1988, com o objetivo de alterar as competências do Congresso Nacional em relação à política externa, principalmente em relação ao processo de internalização de tratados e à consulta prévia ao Legislativo para a tomada de decisões por parte do Executivo. Com isso, a autora pretende verificar se existe envolvimento dos parlamentares, que, conforme ressaltado por parte da doutrina, não teriam interesse em temas relacionados à política externa. A possibilidade de proposição de PECs encontra-se nos artigos 60, CF; art. 201 e seguintes do RICD; e art. 354 e seguintes do RISF. Segue breve explicação do rito seguido por essas propostas.

\footnotetext{
97 Trata-se do Decreto 8.817, de 21.07.2016, que “Aprova a Estrutura Regimental e o Quadro Demonstrativo dos Cargos em Comissão e das Funções de Confiança do Ministério das Relações Exteriores, remaneja cargos em comissão e funções gratificadas e substitui cargos em comissão do Grupo Direção e Assessoramento Superior por Funções Comissionadas Técnicas do Poder Executivo Federal. Disponível em: https://www.planalto.gov.br/ccivil_03/_ato2015-2018/2016/decreto/d8817.htm. Acesso: 14.09.2016.
} 
Conforme a Constituição Federal, podem propor emendas o Presidente da República; um terço, no mínimo, dos membros da Câmara ou do Senado; e mais da metade das Assembleias Legislativas das unidades da Federação, se houver manifestação da maioria relativa de seus membros. Não pode haver emenda à Constituição durante intervenção federal, estado de defesa ou de estado de sítio (art. 60, $\S 1^{\circ}, \mathrm{CF}$ ). A proposta deve ser discutida e votada em cada uma das Casa do Congresso, em dois turnos, e será aprovada se obtiver, em ambas, três quintos dos votos dos respectivos membros. A emenda será promulgada pelas mesas da Câmara e do Senado, com o respectivo número de ordem. Caso a matéria que conste da PEC seja rejeitada ou prejudicada, não poderá ser objeto de nova proposta na mesma sessão legislativa. ${ }^{98}$ A Constituição determina, ainda, aspecto material importante para as propostas de emenda a seu texto:

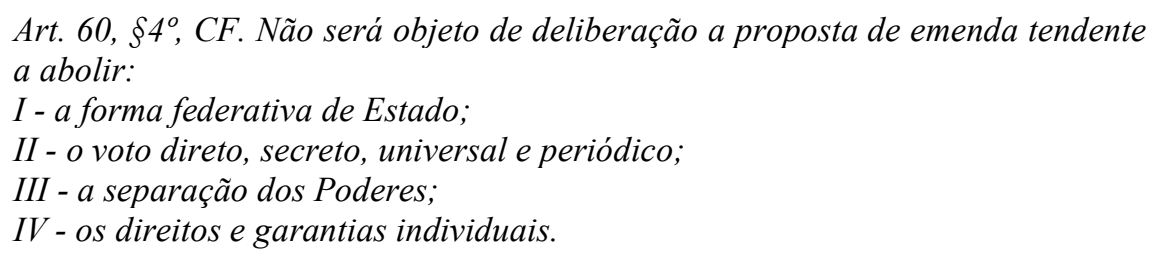

Na Câmara dos Deputados, uma vez apresentada, a PEC é analisada pela Comissão de Constituição e Justiça e de Cidadania (CCJC) quanto à sua admissibilidade. Esse exame considera a constitucionalidade, a legalidade e a técnica legislativa da proposta. Caso aprovada, a Câmara cria comissão especial para analisar o conteúdo da PEC. Essa comissão terá o prazo de 40 (quarenta) sessões do Plenário para proferir parecer. Depois disso, a PEC deve ser votada pelo Plenário da Casa em dois turnos, com intervalo de cinco sessões entre as votações. Para a aprovação, são necessários ao menos 308 votos (ou 3/5 dos Deputados) em cada uma das votações.

Uma vez aprovada na Câmara, a PEC segue para o Senado, onde é analisada primeiramente pela Comissão de Constituição, Justiça e Cidadania (do Senado Federal CCJ) e, depois, pelo Plenário, onde deve ser novamente votada, em dois turnos. Existem, a

\footnotetext{
98 A sessão legislativa ordinária é o período de atividade normal do Congresso Nacional a cada ano, especificamente de 02.02 a 17.07 e de 01.08 a 22.12. Cada quatro sessões legislativas, a contar do ano seguinte ao das eleições parlamentares, compõem uma legislatura. A sessão legislativa extraordinária compreende o trabalho realizado durante o recesso parlamentar, mediante convocação. Cada período de convocação constitui uma sessão legislativa extraordinária. Informação obtida em: http://www12.senado.leg.br/noticias/glossariolegislativo/sessao-legislativa. Acesso: 24.02.2016.
} 
partir desse momento, duas possibilidades: se o Senado aprova o texto exatamente como recebido da Câmara, a emenda é promulgada pelas Mesas da Câmara e do Senado; se o texto for alterado, voltará para a Câmara, para ser votado novamente. A proposta pode ser iniciada por qualquer uma das Casas, e vai de uma para a outra (o chamado "pingue-pongue") até ser aprovada por ambas as Casas do Congresso Nacional. ${ }^{99}$

Destaco, antes de apresentar o resultado da pesquisa empírica realizada, que, de acordo com o art. $3^{\circ}$ do Ato das Disposições Constitucionais Transitórias (ADCT), o Poder Legislativo realizaria uma revisão do texto constitucional durante os anos de 1993 e 1994. Foi proposta, à época, emenda que acrescentaria dois parágrafos ao art. $4^{\circ}, \mathrm{CF}::^{100}$

\begin{abstract}
Art. $4^{o} . \$ 1^{\circ}$ As normas gerais ou comuns de Direito Internacional Público são parte integrante do ordenamento jurídico brasileiro

$\S 2^{\circ}$ As normas emanadas dos órgãos competentes das organizações internacionais de que a República Federativa do Brasil seja parte vigoram na ordem interna, desde que expressamente estabelecido nos respectivos tratados constitutivos.
\end{abstract}

A proposta, cujo nobre objetivo foi destacar a característica vinculante das normas de Direito Internacional, foi rejeitada em plenário. Pedro Dallari observa que o texto não enfrentou a questão da hierarquia entre tratado e lei nacional, criticando a real utilidade do primeiro parágrafo, que serviria somente para reiterar o entendimento corrente acerca do tema. Apesar disso, reconhece que a expressão "normas gerais ou comuns" poderia considerar todas as fontes de Direito Internacional Público descritas no art. 38 do Estatuto da Corte Internacional de Justiça (CIJ). ${ }^{101} \mathrm{O}$ segundo parágrafo, por sua vez, teria o condão

\footnotetext{
99 Informações obtidas em: http://www2.camara.leg.br/atividade-legislativa/processolegislativo/fluxo/pec e http://www2.camara.leg.br/camaranoticias/noticias/70153.html. Acesso: 24.02.2016.

${ }^{100}$ DALLARI, 2003, p. 83-85.

${ }^{101}$ Artigo 38. 1. A Corte, cuja função é decidir de acordo com o direito internacional as controvérsias que lhe forem submetidas, aplicará:

a) as convenções internacionais, quer gerais, quer especiais. que estabeleçam regras expressamente reconhecidas pelos Estados litigantes;

b) o costume internacional, como prova de uma prática geral aceita como sendo o direito;

c) os princípios gerais de direito reconhecidos pelas Nações civilizadas;

d) sob ressalva da disposição do art. 59, as decisões judiciárias e a doutrina dos publicistas mais qualificados das diferentes Nações, como meio auxiliar para a determinação das regras de direito.

2. A presente disposição não prejudicará a faculdade da Corte de decidir uma questão ex aeque et bono, se as partes com isto concordarem.

Informação disponível em: http://www.planalto.gov.br/ccivil_03/decreto/1930-1949/d19841.htm. Acesso: 31.05.2016.
} 
de contribuir para a construção do direito comunitário. A questão da hierarquia foi, de certo modo, abrangida pela EC 45/2004.

Apesar da inovação da EC 45/2004, que incluiu na Constituição vigente regra hierárquica entre tratado e lei interna, isso ocorre, apenas, para tratados de Direitos Humanos, desde que aprovados conforme o rito prescrito: duas votações, nas duas Casas Legislativas, por três quintos de seus membros. Permaneceu, porém, uma dúvida, suscitada pela expressão do $\S 2^{\circ}$, inserido no art. $5^{\circ}$, segundo a qual os direitos e as garantias previstos na Constituição não excluiriam outros decorrentes de tratados dos quais o Brasil fosse parte. Essa expressão ensejou a formação de corrente doutrinária que preconiza o status constitucional para instrumentos de Direitos Humanos antes mesmo do surgimento da EC 45/2004. O tema foi analisado pelo Supremo Tribunal Federal em 2008, cujo plenário decidiu que os tratados sobre Direitos Humanos seriam supralegais, mas inferiores à Constituição, sendo essa condição reservada àqueles aprovados conforme o rito previsto no art. $5^{\circ}, \S 3^{\circ}, \mathrm{CF}^{102}$

Rodrigo D'Araujo Gabsch divide as propostas apresentadas no âmbito do Poder Legislativo em dois grupos. O primeiro deles consiste em iniciativas que buscam ampliar a participação dos membros do Poder Legislativo no processo de negociação de tratados. O segundo trata da regulamentação do processo de tramitação de instrumentos internacionais de Direitos Humanos, conforme o rito do art. $5^{\circ}, \S 3^{\circ}, \mathrm{CF}$.

A pesquisa apresentada a seguir foi feita nos endereços eletrônicos da Câmara dos Deputados e do Senado Federal. Os artigos utilizados para efetuar a pesquisa (arts. 49 e 84, CF) foram selecionados por conterem disposições constitucionais relacionadas à internalização de tratados e à condução da política externa brasileira. Para evitar que fossem negligenciadas PECs que objetivassem criar ou modificar outros artigos, inserindo disposições também relacionadas com a temática de política externa e internalização de tratados, optou-se, também, por realizar pesquisa textual, utilizando os termos "tratado" e “internacional”. As PECs descartadas foram-no porque (i) apesar de terem como objeto os artigos pesquisados, almejavam fazer alterações que não se relacionam com esses temas; (ii) mencionavam os artigos pesquisados, mas referentes ao ADCT - não tratavam, portanto, dos

${ }^{102}$ Conforme a decisão do Habeas Corpus 87.585, de 19.12.2005, proferida em 03.12.2008. 
artigos da Constituição; (iii) mencionavam tratados de Direitos Humanos, mas apenas com relação ao julgamento de temas correlatos por parte do Poder Judiciário.

A pesquisa no endereço do Senado Federal, realizada entre os dias 10 e 11.02.2016, teve como resultado 16 (dezesseis) PECs. ${ }^{103}$ Os resultados obtidos e as PECs selecionadas foram os seguintes:

- Pesquisa por "art. 49": 12 resultados, dos quais 4 foram selecionados, as PECs $87 / 2015 ; 100 / 2015 ; 31 / 2014$ e 35/2011. ${ }^{104}$

- Pesquisa por “artigo 49":12 resultados, dos quais 6 foram selecionados, as PECs $18 / 2003 ; 20 / 2003 ; 34 / 2003 ; 23 / 2002 ; 28 / 2001$ e $52 / 2001$. $^{105}$

- Pesquisa por "art. 84": 12 resultados, dos quais 2 foram selecionados, as PECs $100 / 2015$ e $35 / 2011 .{ }^{106}$

- Pesquisa por "artigo 84": 10 resultados, dos quais 2 foram selecionados, as PECs $18 / 2003$ e $52 / 2001 .^{107}$

- Pesquisa por "tratado": 14 resultados, dos quais 10 foram selecionados, as PECs 44/2015; 87/2015; 100/2015; 31/2014; 35/2011;34/2003; 23/2002; 8/2001; 52/2001 e $4 / 1998 .^{108}$

- Pesquisa por "internacional": 29 resultados, dos quais 16 foram selecionados, as PECs: 44/2015; 87/2015; 100/2015; 31/2014; 35/2011; 28/2006; 30/2006; 18/2003; 20/2003; 34/2003; 23/2002; 8/2001; 28/2001; 47/2001; 52/2001 e 4/1998. ${ }^{109}$

A pesquisa no endereço eletrônico da Câmara dos Deputados, realizada entre os dias 12 e 13.02.2016, teve como resultado 21 (vinte e uma) PECs. Os resultados obtidos e as PECs selecionadas foram os seguintes:

\footnotetext{
${ }^{103}$ As PECs 100/2015; 87/2015; 44/2015; 31/2014; 35/2011; 30/2006; 28/2006; 34/2003; 20/2003; 18/2003; 23/2002; 52/2001; 47/2001; 28/2001; 8/200; e 4/1998.

${ }^{104}$ Descartadas as PECS 79/2015; 86/2015; 142/2015; 46/2011; 2/2009; 53/2007; 1/2006 e 6/1992.

${ }^{105}$ Descartadas as PECs $19 / 2012 ; 73 / 2005 ; 20 / 2003 ; 12 / 1999 ; 40 / 1999$ e 38/1997.

${ }^{106}$ Descartadas as PECs 40/2015; 120/2015; 126/2015; 68/2013; 70/2013; 37/2012; 4/2011; 48/2011; 104/2011 e 64/1999.

${ }^{107}$ Descartadas as PECs $60 / 2002 ; 1 / 2002 ; 18 / 2002 ; 19 / 2002 ; 25 / 2002 ; 27 / 2002 ; 31 / 2001$ e 30/1983.

${ }^{108}$ Descartadas as PECs 61/2011; 29A/2000; 72/1984 e 75/1984.

${ }^{109}$ Descartadas as PECs 82/2015; 61/2011; 77/2011; 80/2011;29A/2000; 9/2003; 25/1999; 84/1999; 33/1995; 37/1995; 50/1995; 72/1984 (CN) e 75/1984 (CN).
} 
- Pesquisa por “art. 49": 80 resultados, dos quais 16 foram selecionados, as PECs 75/2015; 424/2014; 389/2005; 321/2004; 223/2003; 165/2003; 70/2003; 42/2003; 31/2003; 402/2001; 478/2001; 402/2001; 387/2001; 345/2001;36/1999 e 122/1999. ${ }^{110}$

- Pesquisa por “artigo 49": 17 resultados, dos quais 3 foram selecionados, as PECs 75/2015; 223/2003 e 42/2003. ${ }^{111}$

- Pesquisa por "art. 84": 126 resultados, dos quais 8 foram selecionados, as PECs 265/2013; 321/2004; 165/2003; 70/2003; 42/2003; 31/2003; 478/2001 e 345/2001. ${ }^{112}$

- Pesquisa por "artigo 84": 11 resultados, dos quais 2 foram selecionados, as PECs $165 / 2003$ e $42 / 2003 .{ }^{113}$

- Pesquisa por "tratado": 74 resultados, dos quais 11 foram selecionados, as PECs 75/2015; 424/2014; 389/2005; 321/2004; 165/2003; 70/2003; 31/2003; 478/2001; 402/2001; 122/1999 e 96/1992. ${ }^{114}$

\footnotetext{
${ }^{110}$ Foram descartadas as PECs 167/2015; PEC 164/2015; PEC 155/2015; PEC 146/2015; PEC 135/2015; PEC 120/2015; PEC 30/2015; PEC 27/2015; PEC 16/2015; PEC 339/2013; PEC 329/2013; PEC 235/2012; PEC 234/2012; PEC 171/2012; PEC 113/2011; PEC 104/2011; PEC 39/2011; PEC 33/2011; PEC 5/2011; PEC 3/2011; PEC 456/2010; PEC 451/2009; PEC 416/2009; PEC 382/2009; PEC 360/2009; PEC 341/2009; PEC 262/2008; PEC 245/2008; PEC 233/2008; PEC 71/2007; PEC 26/2007; PEC 570/2006; PEC 544/2006; PEC 531/2006; PEC 512/2006; PEC 491/2005; PEC 478/2005; PEC 463/2005; PEC 414/2005; PEC 399/2005; PEC 376/2005; PEC 319/2004; PEC 299/2004; PEC 282/2004; PEC 278/2004; PEC 275/2004; PEC 260/2004; PEC 256/2004; PEC 229/2004; PEC 222/2003; PEC 84/2003; PEC 63/2003; PEC 61/2003; PEC 36/2003; PEC 587/2002; PEC 557/2002; PEC 329/2001; PEC 305/2000; PEC 290/2000; PEC 215/2000; PEC 52/1999; PEC 603/1998 e PEC 191/1994.

${ }^{111}$ Foram descartadas as PECs 3/2011; 467/2010; 457/2010; 544/2006; 531/2006; 478/2005; 421/2001; 325/2001; 501/1997; 196/1995; 157/1995; 72/1995; 91/1992 e 25/1991.

112 Foram descartadas as PECs $173 / 2015 ; 162 / 2015 ; 140 / 2015 ; 122 / 2015 ; 120 / 2015 ; 110 / 2015 ; 97 / 2015$; 98/2015; 90/2015; 84/2015; 76/2015; 60/2015; 35/2015; 25/2015; 2/2015; 428/2014; 354/2013; 340/2013; $339 / 2013 ; 331 / 2013 ; 267 / 2013 ; 240 / 2013 ; 237 / 2013 ; 235 / 2012 ; 216 / 2012 ; 136 / 2012 ; 131 / 2011 ; 111 / 2011$; 93/2011; 84/2011; 52/2011; 45/2011; 10/2011; 503/2010; 501/2010; 467/2010; 458/2010; 456/2010; 430/2009; 425/2009; 409/2009; 407/2009; 390/2009; 3838/2009; 381/2009; 375/2009; 341/2009; 296/2008; $290 / 2008 ; 262 / 2008 ; 184 / 2007 ; 144 / 2007 ; 139 / 2007 ; 112 / 2007 ; 109 / 2007 ; 84 / 2007 ; 70 / 2007 ; 50 / 2007$; $31 / 2007 ; 30 / 2007 ; 23 / 2007 ; 21 / 2007 ; 18 / 2007 ; 16 / 2007 ; 558 / 2006 ; 531 / 2006 ; 518 / 2006 ; 516 / 2006 ; 501 / 2006$; 491/2005; 487/2005; 484/2005; 476/2005; 464/2005; 431/2005; 427/2005; 421/2005; 384/2005; 324/2004; 288/2004; 282/2004; 252/2004; 243/2004; 229/2004; 222/2003; 162/2003; 155/2003; 141/2003; 142/2003; $111 / 2003 ; 107 / 2003 ; 84 / 2003 ; 69 / 2003 ; 63 / 2003 ; 53 / 2003 ; 41 / 2003 ; 40 / 2003 ; 34 / 2003 ; 6 / 2003 ; 589 / 2002$; $587 / 2002$; 575/2002; 573/2002; 563/2002; 550/2002; 535/2002; 524/2002; 473/2001; 456/2001; 407/2001; 382/2001; 329/2001; 108/1999; 104/1999; 84/1999; 498/1997; 174/1995 e 84/1991.

${ }_{113}$ Foram descartadas as PECs $76 / 2015 ; 467 / 2010 ; 112 / 2007 ; 531 / 2006 ; 446 / 2001 ; 356 / 2001 ; 71 / 1999$; 94/1992 e 79/1991.

${ }_{114}$ Foram descartadas as PECs $143 / 2015 ; 125 / 2015 ; 116 / 2015 ; 102 / 2015 ; 10 / 2015 ; 5 / 2015 ; 390 / 2014$; $383 / 2014 ; 366 / 2013 ; 322 / 2013 ; 314 / 2013 ; 275 / 2013 ; 209 / 2012 ; 153 / 2012 ; 135 / 2012 ; 133 / 2012 ; 119 / 2011$; $108 / 2011 ; 107 / 2011 ; 53 / 2011 ; 2 / 2011 ; 519 / 2010 ; 512 / 2010 ; 455 / 2010 ; 418 / 2009 ; 404 / 2009 ; 402 / 2009$; $382 / 2009 ; 372 / 2009 ; 357 / 2009 ; 341 / 2009 ; 330 / 2009 ; 327 / 2009 ; 312 / 2008 ; 233 / 2008 ; 198 / 2007 ; 193 / 2007$;
} 
- Pesquisa por "internacional": 132 resultados, dos quais 20 foram selecionados, as PECs 75/2015; 68/2015; 424/2014; 410/2014; 206/2007; 389/2005; 321/2004; 223/2003; 165/2003; 70/2003; 42/2003; 31/2003; 478/2001; 402/2001; 387/2001; $345 / 2001 ; 203 / 2000 ; 122 / 1999 ; 36 / 1999$ e 96/1992. ${ }^{115}$

Desde 1998, ano da primeira PEC selecionada no Senado Federal, até 2015, foram propostas mais de mil PECs (1.035), conforme pesquisa feita por ano no endereço eletrônico do Senado Federal. ${ }^{116} \mathrm{O}$ rol de PECs aqui selecionado (16) é pequeno (1,3\%), se comparado à totalidade de propostas de emenda à Constituição. Por sua vez, desde 1992, ano da primeira PEC da Câmara dos Deputados selecionada nesta tese, foram propostas mais de três mil PECs, conforme pesquisa feita por ano no endereço eletrônico da Câmara dos Deputados. ${ }^{117}$ O rol de PECs aqui selecionado (21) é de $0,67 \%$ em relação ao total de PECs naquela Casa. Esse dado, por si só, não significa falta de relevância do tema, uma vez que não separamos as PECs por tema; tampouco desinteresse dos Deputados e dos Senadores em relação às atribuições de política externa. Trata-se, porém, de dado quantitativo que oferece a

$188 / 2007 ; 187 / 2007 ; 166 / 2007 ; 100 / 2007 ; 48 / 2007 ; 31 / 2007 ; 544 / 2006 ; 377 / 2005 ; 359 / 2005 ; 358 / 2005$; 324/2004; 278/2004; 252/2004; 243/2004; 237/2004; 128/2003; 111/2003; 58/2003; 43/2003; 578/2002; 549/2002; 579/1998; 549/1997; 175/1995; 195/1995 e 3/1988.

${ }^{115}$ Foram descartadas as PECs $185 / 2015$; 140/2015; 117/2015; 96/2015; 12/2015; 443/2014; 433/2014; 419/2014; 366/2013; 362/2013; 361/2013; 335/2013; 275/2013; 213/2012; 190/2012; 186/2012; 178/2012; $133 / 2012 ; 122 / 2011 ; 114 / 2011 ; 107 / 2011 ; 53 / 2011 ; 41 / 2011 ; 34 / 2011 ; 19 / 2011 ; 14 / 2011 ; 528 / 2010$; 519/2010; 511/2010; 512/2010; 477/2010; 467/2010; 439/2009; 431/2009; 425/2009; 419/2009; 409/2009; 398/2009; 394/2009; 382/2009; 369/2009; 354/2009; 353/2009; 346/2009; 341/2009; 340/2009; 327/2009; $312 / 2008$; 296/2008; 284/2008; 283/2008; 263/2008; 235/2008; 233/2008; 224/2008; 188/2007; 184/2007; $171 / 2007$; 166/2007; 115/2007; 64/2007; 47/2007; 45/2007; 31/2007; 589/2006; 556/2006; 510/2006; 475/2005; 454/2005; 412/2005; 407/2005; 405/2005; 401/2005; 392/2005; 359/2005; 337/2004; 325/2004; $314 / 2004$; 252/2004; 243/2004; 197/2003; 192/2003; 191/2003; 152/2003; 154/2003; 129/2003; 125/2003; $121 / 2003 ; 111 / 2003 ; 108 / 2003 ;$ 90/2003; 78/2003; 58/2003; 43/2003; 41/2003; 40/2003; 29/2003; 25/2003; $578 / 2002 ; 549 / 2002 ; 579 / 1998 ; 549 / 1997 ; 331 / 1996 ; 238 / 1995 ; 175 / 1995 ; 39 / 1995 ; 7 / 1995 ; 195 / 1995$; 43/1990; 21/1989 e 3/1988.

${ }^{116}$ Em 2015, foram propostas 162 PECs no Senado Federal; 56 em 2014; 79 em 2013; 71 em 2012; 126 em 2011; 36 em 2010; 56 em 2009; 49 em 2008; 104 em 2007; 52 em 2006; 74 em 2005; 62 em 2004; 96 em 2003; 34 em 2002; 57 em 2001; 46 em 2000; 97 em 1999; 48 em 1998, num total de 1.035 PECs de 1998-2015. Dados obtidos em: http://www25.senado.leg.br/. Acesso: 01.03.2016.

${ }^{117}$ Em 2015, foram propostas 185 PECs na Câmara dos Deputados; 75 em 2014; 140 em 2013; 105 em 2012; 135 em 2011; 77 em 2010; 134 em 2009; 104 em 2008; 216 em 2007; 99 em 2006; 134 em 2005; 131 em 2004; 226 em 2003; 108 em 2002; 164 em 2001; 130 em 2000; 196 em 1999; 64 em 1998; 126 em 1997; 142 em 1996; 300 em 1995; 12 em 1994; 33 em 1993; 58 em 1992, num total de 3.097 PECs de 1992-2015. Dados obtidos em: http://www.camara.leg.br/. Acesso: 01.03.2016. 
proporção dessas PECs em relação à atividade legislativa de cada uma das Casas, sendo que, proporcionalmente em relação à totalidade de PECs, o Senado tem o dobro de propostas que cuidam da temática se comparado à Câmara.

É necessário fazer, aqui, nota metodológica a respeito da pesquisa. A autora considerou, em um primeiro momento, as PECs iniciadas na Câmara dos Deputados e no Senado Federal como iniciativas distintas. A pesquisa, porém, demonstrou que algumas dessas propostas eram, na verdade, a mesma proposta que, renumerada, foi enviada de uma Casa Legislativa para a outra. ${ }^{118}$ Foram identificadas duas PECs que são, portanto, a mesma iniciativa de alteração da Constituição, que tramitaram nas diferentes Casas do Congresso Nacional. Dada a possibilidade de alteração do teor da PEC em uma ou outra Casa, porém, elas foram consideradas separadamente, uma vez que a autora analisou, apenas, suas ementas. Das PECs iniciadas no Senado Federal, apenas uma tramitou, renumerada, na Câmara dos Deputados: PEC SF 35/2011 (equivalente à PEC CD: 424/2014). Nenhuma das PECs iniciadas na Câmara dos Deputados tramitou renumerada no Senado Federal. Finalmente, algumas PECs foram apensadas às outras, por tratarem de temas semelhantes. ${ }^{119}$

Das 37 PECs analisadas (sendo 21 iniciadas na Câmara e 16 no Senado), 25 (vinte e cinco, sendo 10 do Senado e 15 da Câmara) tinham como objetivo a alteração do art. 49, CF. As PECs, tanto do Senado como da Câmara, têm como objetivo alterar a Constituição Federal nos seguintes aspectos:

(i) Altera a hierarquia de tratados internalizados em relação à legislação interna ${ }^{120}$ ou prevê a hierarquia no caso de internalização de norma jurídica emanada de órgão supranacional; ${ }^{121}$

(ii) Impossibilita que o Brasil celebre tratados com países violadores dos Direitos Humanos; ${ }^{122}$

\footnotetext{
118 Para maiores informações a respeito da numeração de iniciativas das Casas do Congresso Nacional: http://www12.senado.leg.br/noticias/materias/2012/01/31/como-funciona-a-numeracao-de-projetos-nosenado. Acesso: 14.09.2016.

${ }^{119}$ É o caso das PECs CD 122 e 36/1999; CD 223/2003 e 410/2014.

${ }^{120}$ PECs SF 4/1998; CD 96/1992; CD 321/2004.

${ }^{121}$ PEC CD 165/2003.

122 PEC SF 87/2015.
} 
(iii) Prevê submissão do Brasil a tribunal penal a que se submeta (cláusula genérica) ${ }^{123}$ ou ao Tribunal Penal Internacional (cláusula específica); ${ }^{124}$

(iv) Prevê a aprovação de chefes de missão diplomática de caráter transitório, ${ }^{125}$ de negociadores internacionais (em geral) ou de dirigentes brasileiros de pessoas jurídicas de direito internacional que exerçam atividade econômica ou prestem serviço público, ${ }^{126}$ após sabatina no Congresso Nacional ou no Senado Federal;

(v) Aumenta a competência do Senado Federal para decidir sobre tratados em detrimento do Congresso Nacional ${ }^{127}$ ou possibilita ao Congresso Nacional:

a. Criar missões diplomáticas permanentes no exterior; ${ }^{128}$

b. Propor referendo popular, no caso de tratados que possam comprometer a soberania nacional, que poderia ser de iniciativa do (i) Presidente da República; ou (ii) do CN (com votos de $1 / 3$ dos integrantes de cada Casa); ou (iii) 0,3 (três décimos) por cento do eleitorado nacional, distribuído por pelo menos 5 (cinco) estados; ${ }^{129}$

c. Apreciar tratados em geral ${ }^{130}$ e, especificamente, apreciar (c.1) aqueles tratados que representem risco à soberania nacional ${ }^{131}$ ou (c.2) aqueles nos quais a República Federativa do Brasil figure como parte, avalista ou garantidora; ${ }^{132}$

d. Apreciar, previamente, a concessão de empréstimos a governos estrangeiros, e a aquisição de bens imóveis ou instalações industriais e comerciais pelo país em território estrangeiro; ${ }^{133}$

e. Requerer a tramitação de tratados internacionais em regime de urgência, o que também pode ser feito pelo Presidente da República; ${ }^{134}$

\footnotetext{
123 PEC CD 96/1992.

124 PEC CD 203/2000.

125 PEC SF 8/2001.

${ }^{126}$ PECs SF 28/2006; SF 30/2006; SF 44/2015; CD 68/2015.

127 PEC SF $35 / 2011$.

128 PEC CD 265/2013.

${ }^{129}$ PEC CD 389/2005.

${ }^{130}$ PECs SF 34/2003; CD 36/1999.

${ }^{131}$ PEC CD 478/2001.

132 PEC SF 28/2001.

133 PEC CD 410/2004.

134 PEC CD 424/2014.
} 
(vi) Retira do Congresso Nacional a necessidade de apreciar tratados que sejam meras consequências e/ou interpretações de tratados anteriores; ${ }^{135}$

(vii) A definição precisa das expressões do art. 49, I, "resolver definitivamente sobre tratados (...)"136 e "encargos ou compromissos gravosos ao patrimônio nacional" aumentaria as competências do Congresso Nacional de emendar, ${ }^{137}$ efetuar ressalvas ${ }^{138}$ e propor cláusulas interpretativas a tratados, ${ }^{139}$ além de denunciar tratados; $;^{140}$

(viii) Estabelece prazo para a apreciação de tratados por parte do Congresso Nacional ${ }^{141}$ ou para seu envio ao Congresso Nacional e posterior ratificação pelo Executivo; ${ }^{142}$

(ix) Determina a necessidade de o Congresso Nacional acompanhar negociações do Poder Executivo ${ }^{143}$ e autorizar a celebração de $\operatorname{tratados}^{144}$ e a escolha de negociadores, ${ }^{145}$ especificamente em relação a temas de comércio internacional, propriedade intelectual, investimentos externos e barreira alfandegárias;

(x) Exige a fiscalização das contas, pelo Tribunal de Contas da União (TCU), de pessoas jurídicas de direito internacional que exerçam atividade econômica ou que prestem serviço público, de cujo capital social a União participe, direta ou indiretamente; ${ }^{146}$

(xi) Limita a declaração de guerra por parte do Brasil, além de determinar restrições para a participação em conflitos internacionais; permitida, apenas, a participação em forças de paz; ${ }^{147}$

\footnotetext{
135 PEC SF 34/2003.

${ }^{136}$ Que, de acordo com as justificativas da PEC CD 402/2001, não pode significar, apenas, rejeitar ou aprovar a totalidade do texto convencional.

${ }^{137}$ PECs SF 47/2001; SF 23/200; CD 122/1999; CD 402/2001.

138 PEC CD 122/1999.

139 PECs CD 122/1999.

140 PECs SF 23/2002; SF 31/2014; SF 87/2015; CD 122/1999; CD 321/2004; CD 75/2015.

141 PEC CD 321/2004.

142 PEC CD 321/2004.

143 PECsSF 52/2001; SF 100/2015.

144 PECs SF 18/2003; CD 345/2001; CD 31/2003; CD 70/2003; CD 223/2003.

145 PECs SF 20/2003; CD 387/2001.

146 PECs SF 28/2003; SF 30/2003; SF 44/2015.

${ }^{147}$ PEC CD 42/2003.
} 
(xii) Inclui a elaboração e a implantação da Agenda 21 (nacional e local) como competência do poder público. ${ }^{148}$

Um artigo comum em três das PECs propostas pelo Senado Federal, ${ }^{149}$ referentes à situação da hidrelétrica de Itaipu, e que tinham como objetivo alterar a Constituição nos artigos 52 (referente à competência do Senado) e 71 (referente ao controle externo, feito pelo Congresso com o auxílio do TCU), chamou a atenção da autora. Este artigo adicionava à proposta o fato de que, em até doze meses da publicação da emenda constitucional à qual as PECs se referiam, deveriam ser iniciadas "negociações para incluir nos tratados constitutivos de pessoas jurídicas de direito internacional que exerçam atividade econômica ou prestem serviço público, de cujo capital social a união participe, de forma direta ou indireta, dispositivo que permita o exercício do controle externo, conforme preceituado na Constituição" (grifo nosso). Esse dispositivo demonstra a persistência do interesse dos Senadores em um controle efetivo dessa pessoa jurídica de direito internacional público, que já existe há dez anos, uma vez que as primeiras PECs foram propostas em 2006 e a última, em 2015.

Além das propostas das PECs, descritas acima, foram consultadas as justificativas apresentadas por Deputados e por Senadores para a necessidade de alteração dos artigos constitucionais. As PECs consultadas têm como objetivo, direta ou indiretamente, ampliar o poder do Congresso na condução da política externa nacional. Os argumentos mais utilizados nas justificativas das PECs, que apresentam os motivos que levaram à proposição das mudanças constitucionais, são seguintes:

(i) Limitação do poder discricionário e do monopólio do Executivo, que tem sido o único responsável pela condução da política externa brasileira: o Congresso não pode ser mero homologador das decisões do Poder executivo, não pode tomar, apenas, decisões ex post;

(ii) Explicitar, no texto constitucional, a faculdade de o Congresso apor ressalvas, cláusulas interpretativas ou mesmo denunciar tratados tornaria incontestável essa possibilidade, que tem sido alvo de grande discussão doutrinária. Isso aumentaria a ingerência desse Poder na política externa brasileira;

\footnotetext{
148 PEC CD 206/2007.

${ }^{149}$ As PECs SF 28/2006; 30/2006 e 44/2015.
} 
(iii) Democratização da política externa brasileira, impossível sem a participação mais ativa do Legislativo, argumento que se apresenta de distintas maneiras:

a. Os membros do Legislativo, representantes legítimos (eleitos) da sociedade (diferentemente da "burocracia do Executivo", membros de Ministérios e da diplomacia nacional, segundo as PECs), têm maior sensibilidade aos interesses do povo brasileiro e, por isso, deveriam ser consultados (inclusive previamente) nos casos em que o país passe a ser obrigado internacionalmente;

b. No Parlamento, é possível efetuar debate público significativo, que tenha influência nas decisões dos dois Poderes envolvidos no ato complexo que é a internalização de tratados, o que traria maior transparência aos processos internacionais de negociação de tratados;

c. A política interna não pode ser separada da política externa;

d. A sociedade civil, e, especificamente, o empresariado nacional, poderiam ser incluídos na discussão sobre política externa brasileira, se o Legislativo fosse mais ativo nesse âmbito;

e. A necessidade de sabatina de chefes de missões transitórias, de negociadores internacionais, de representantes do país para exercer funções diretivas em instituições financeiras multilaterais e de presidentes, diretores e conselheiros brasileiros de pessoas jurídicas de Direito Internacional que exerçam atividade econômica ou que prestem serviço público (de cujo capital a União participe, direta ou indiretamente) aumentaria a ingerência do Congresso na política externa brasileira, além de fornecer tratamento isonômico a indicações de cargos de alto escalão com atribuições similares;

f. A apreciação dos objetivos das negociações internacionais - ou seja, previamente à assinatura de tratados - pelo Legislativo daria aos negociadores internacionais maior segurança em relação a seu mandato, além de uma melhor orientação a respeito dos objetivos a serem alcançados quanto à matéria negociada no âmbito internacional;

(iv) Impor prazos para a apreciação de tratados é necessário para (a) não sobrecarregar e/ou bloquear a pauta do Congresso, para que os tratados tenham procedimento expedito e, ao mesmo tempo, (b) evitar que o Executivo deixe de enviar 
os tratados ao Congresso, para as PECs que propõem um prazo para o envio dos acordos assinados ao $\mathrm{CN} ;{ }^{150}$

(v) Excetuar a apreciação, pelo Congresso, de tratados que apenas executem ou interpretem obrigações previamente estabelecidas por tratados anteriores não fere a competência congressual, e tem como objetivo reservar para a apreciação do Parlamento atos que inovem na ordem jurídica;

(vi) Para as PECs que tratam da hierarquia entre tratados e a legislação interna: necessidade de sanar, definitivamente, eventuais conflitos entre leis internas e tratados internacionais, ou entre leis internas e normas supranacionais; há preocupação particular com tratados de Direitos Humanos;

(vii) A necessidade de restringir a declaração de guerra a postura defensiva, e a participação e o apoio das forças armadas nacionais em conflitos internacionais exclusivamente em caso de defesa a ataque prévio, confeririam eficácia real aos princípios que regem as relações internacionais do Brasil, inscritos no art. $4^{\circ}$, VI e VII CF (defesa da paz e solução pacífica dos conflitos);

(viii) Particularmente para as PECs que mencionam a usina de Itaipu binacional: necessidade de controle por parte do TCU, prevista constitucionalmente;

(ix) O mecanismo de "Fast track" americano (que autoriza o presidente a negociar determinados tipos de acordos internacionais, mas não elimina a necessidade de sua apreciação pelo Congresso Nacional, ainda que com tramitação simplificada) é mencionado como prova de que a rapidez das negociações, em um mundo globalizado, não pode ser usada como pretexto para impedir a análise minuciosa desses acordos e negociações por parte do Congresso;

(x) Especificamente sobre tratados relacionados a comércio, barreiras alfandegárias e não alfandegárias, investimento externo, acordos com o Fundo Monetário Internacional (FMI) e com a Organização Mundial do Comércio (OMC), e propriedade intelectual: como as disposições desses tratados afetam diretamente o cotidiano da população, o Legislativo, seu representante, deveria ter atuação mais importante;

\footnotetext{
${ }^{150}$ A PEC SF 35/2011 tem como objetivo avocar ao Senado Federal, em caráter privativo (em detrimento do Congresso Nacional), a apreciação dos tratados internacionais.
} 
(xi) A autorização prévia do Poder legislativo de empréstimos a governos estrangeiros, além da aquisição, pelo governo brasileiro, de bens imóveis e de instalações industriais ou comerciais encravadas em território estrangeiro, tem o condão de evitar que o país “(...) seja arrastado para aventuras de natureza política, econômica ou ideológica, sem a autorização do Parlamento."151.

Das 37 (trinta e sete) PECs analisadas, apenas um terço (doze) não foi arquivado, sendo 5 (cinco) de iniciativa do Senado e 7 (sete) da Câmara. São, em geral, propostas feitas nos últimos cinco anos, com exceção das PECs CD 96/1992, a única que foi transformada em Emenda Constitucional (EC 45/2004); CD 31/2003, devolvida ao autor; e CD 223/2003, que está aguardando a criação de comissão temporária pela mesa, e à qual foi apensada a PEC CD 410/2014. Entre as PECs que permanecem em tramitação, as prioridades são:

(i) A apreciação prévia por parte do Congresso na concessão de empréstimos a governos estrangeiros e a aquisição de bens imóveis ou instalações industriais e

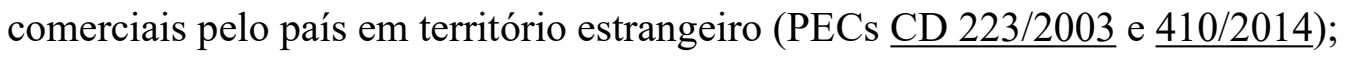

(ii) Tornar privativa do Senado a competência para decidir sobre tratados, acordos ou atos internacionais (PEC SF 35/2011, aprovada pelo Plenário e remetida à Câmara em 06.08.2014 - onde deu origem à PEC CD 424/2014);

(iii) Determinar a aprovação prévia, pelo Senado, da escolha de dirigentes brasileiros de pessoas jurídicas de direito internacional que exerçam atividade econômica ou prestem serviço público, de cujo capital social a União participe; além de exigir, expressamente, a necessidade de que os tratados internacionais que constituam essas pessoas jurídicas incluam dispositivo que garanta a fiscalização das respectivas contas nacionais pelo Tribunal de Contas da União. (PEC SF 44/2015, na CCJC desde 08.04.2015, aguardando designação do relator);

(iv) Alterar as competências do Congresso Nacional no que concerne à denúncia de tratados internacionais (PEC SF 31/2014; que se encontra na CCJC, aguardando

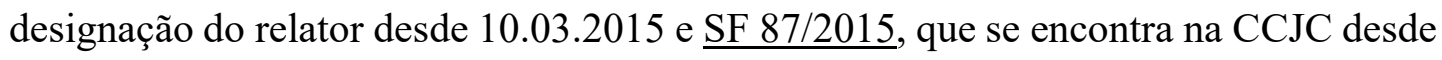
02.07.2015, aguardando designação do relator) e à negociação de tratados que versem

${ }^{151}$ Excerto da justificativa da PEC CD 410/2014. 
sobre matéria de comércio internacional (PEC SF 100/2015, na CCJC desde 15.07.2015, aguardando designação do relator).

(v) Prever a tramitação, em regime de urgência, dos tratados, acordos e atos internacionais, se requerido pelo Presidente da República ou por deliberação da Casa em que se encontrarem, na forma do regimento (PEC CD 424/2014, aguardando parecer);

(vi) Estabelecer a necessidade de sabatina prévia de representante indicado pelo país em funções diretivas de instituições financeiras multilaterais. (PEC CD 68/2015, aguardando designação de relator na CCJC); e

(vii) Dispor sobre a competência exclusiva do Congresso Nacional em matéria de tratados ( $\underline{\mathrm{PEC} \mathrm{CD} \mathrm{75/2015}}$, aguardando parecer).

A maior parte das PECs, como é possível perceber, está aguardando o prosseguimento do trâmite na CCJC. O que se observou, a partir dessa pesquisa, foram as diversas formas encontradas pelos membros do Poder Legislativo de ampliar a sua participação, não apenas no processo de internalização de tratados, mas na sua apreciação prévia e, em última análise, na própria condução da política externa brasileira. As PECs relativas à maior parte dos temas encontrados desde a elaboração da Constituição de 1988, descritos nas páginas anteriores, foram, de alguma maneira, reeditadas em propostas posteriores.

A maior participação dos membros do Poder Legislativo nos temas relativos à política externa seria, inclusive, “(...) uma das mais (grifo do autor) importantes tendências da relação entre Poderes nas democracias modernas", segundo o Senador José Fogaça, que analisou a proposta da PEC SF 52/2001 no âmbito da Comissão de Constituição, Justiça e Cidadania. Apesar de essa PEC estar circunscrita à atuação do Congresso nas negociações referentes ao comércio internacional, poderia “(...) representar uma verdadeira revolução do trato dos tratados internacionais". ${ }^{152}$

Em 2002, ao fazer uma análise de sua presidência na Câmara dos Deputados, Aécio Neves destacou, entre as realizações de sua gestão, a inauguração do que chamou de

\footnotetext{
${ }^{152}$ Segundo José T. Mascarenhas Menck, consultor legislativo da área de Direito Constitucional, Eleitoral, Municipal, Direito Administrativo, Processo Legislativo e Poder Judiciário. Prerrogativas do Congresso Nacional quanto à apreciação de atos internacionais, p. 1. Disponível em: http://www2.camara.leg.br/ documentos-e-pesquisa/publicacoes/estnottec/arquivos-pdf/pdf/303774.pdf. Acesso: 28.09.2016.
} 
"Diplomacia Parlamentar", que almejava a participação dos parlamentares nas negociações de tratados. Com isso, o Congresso brasileiro ter-se-ia distanciado de uma postura apática e ganhado posição destacada nas decisões nacionais de política externa. A Cúpula Parlamentar de Integração Continental, realizada em novembro de 2002, demonstraria a intenção dos congressistas do país em promover o debate nesse sentido. ${ }^{153}$

O processo integral de tramitação das PECs não foi analisado aqui, e, portanto, não serão apontados os motivos de rejeição das propostas. Note-se, porém, que, apesar do interesse de parte dos membros do Legislativo em uma atuação mais importante na política externa brasileira, o que pode ser percebido pela quantidade e diversidade dos temas abrangidos pelas PECs, esse interesse simplesmente não é transformado em norma constitucional. Com a exceção da PEC 96/1992, que foi aprovada na EC 45/2004, que tinha como foco principal a reforma do Poder Judiciário, nenhuma das propostas analisadas teve como resultado último uma emenda constitucional. Foge do escopo desta tese a descrição e a análise minuciosa da tramitação das PECs e dos motivos apontados por Deputados e por Senadores para a não aprovação dessas propostas, assim como a análise dos motivos políticos que culminaram nesse resultado. Entretanto, permanece a indagação a respeito das razões que podem existir para que os legisladores deixem de concretizar a avocação de maiores competências para eles mesmos em termos de política externa.

\footnotetext{
${ }^{153}$ Conforme noticiado no endereço eletrônico da Câmara dos Deputados: Aécio se despede com balanço de gestão modernizadora (16.12.2002). Informação obtida em: http://www2.camara.leg.br/camaranoticias/ noticias/25225.html. Acesso: 28.09.2016.
} 


\subsubsection{PROJETOS DE RESOLUÇÃO}

Os Projetos de Resoluções (PRC na Câmara dos Deputados, PRS no Senado Federal) são proposições que regulam matérias pertinentes à competência privativa de cada uma dessas Casas, como no caso de suas regras de funcionamento interno, presentes nos Regimentos; além de fazer propostas de prêmios ou de tomar decisões em casos concretos, como, por exemplo, de cassação de mandato de parlamentar. Com o objetivo de verificar se existe interesse em oferecer tratamento mais minucioso para a matéria de internalização de tratados no âmbito do Poder Legislativo, interesse percebido na análise a respeito de PECs, foi efetuada pesquisa no endereço eletrônico de ambas as Casas do Congresso. A busca foi feita utilizando duas palavras-chave, "internacional"154 e "tratado"; além da expressão "Direitos Humanos".

A pesquisa no endereço eletrônico da Câmara dos Deputados, realizada entre os dias 26 e 27.02.2016, teve como resultado 9 (nove) PRCs. ${ }^{155}$ Foram descartados os projetos de resoluções que (i) não tinham como objetivo alterar o procedimento de internalização de tratados; (ii) não tinham relação com a ingerência do Parlamento em política externa. Os resultados obtidos e selecionados foram os seguintes:

- Pesquisa por "internacional": 179 resultados, dos quais 9 foram selecionados, os PRCs 5/2015; 259/2014; 160/2012; 12/2011; 45/2011; 131/2008; 47/2007; 271/2005 e $204 / 2005 .^{156}$

\footnotetext{
${ }^{154}$ No endereço eletrônico da CD foi utilizada, mais especificamente, a expressão "internaciona *”, para que o termo "internacionais" também fosse incluído entre os resultados. No Senado, entretanto, foi feita pesquisa com os dois termos, separadamente, porque não era possível utilizar esse mecanismo na busca.

${ }^{155}$ Foram selecionados os PRCs 5/2015; 259/2014; 160/2012; 12/2011; 45/2011; 131/2008; 47/2007; 271/2005 e $204 / 2005$.

156 Descartados os PRCs 117/2016; 116/2016; 108/2015; PRC 107/2015; PRC 92/2015; PRC 84/2015; $75 / 2015 ; 62 / 2015 ; 59 / 2015 ; 55 / 2015 ; 54 / 2015 ; 52 / 2015 ; 39 / 2015 ; 34 / 2015 ; 21 / 2015 ; 19 / 2015 ; 10 / 2015$ 6/2015; 5/2015; 4/2015; 2/2015; 267/2014; 265/2014; 249/2014; 249/2014; 245/2014; 243/2014; 233/2013; 216/2013; 205/2013; 193/2013; 161/2012; 156/2012; 132/2012; 129/2012; 109/2012; 90/2011; 89/2011; 86/2011; 76/2011; 75/2011; 65/2011; 62/2011; 56/2011; 46/2011; 29/2011; 22/2011; 20/2011; 228/2010; 223/2010; 220/2010; 198/2009; 163/2009; 162/2009; 160/2009; 158/2009; 132/2008; 108/2007; 103/2007; 91/2007; 88/2007; 87/2007; 64/2007; 50/2007; 43/2007; 40/2007; 30/2007; 29/2007; 16/2007; 13/2007; $7 / 2007$; 2/2007; 324/2006; 301/2006; 297/2006; 294/2006; 287/2006; 281/2006; 280/2006; 261/2005; $259 / 2005$; 254/2005; 253/2005; 249/2005; 226/2005; 222/2005; 221/2005; 218/2005; 203/2005; 187/2004; $183 / 2004$; $182 / 2004$; 173/2004; 172/2004; 162/2004; 155/2004; 149/2004; 147/2004; 144/2004; 136/2004; $135 / 2004 ; 118 / 2003 ; 105 / 2003 ; 102 / 2003 ; 88 / 2003 ; 84 / 2003 ; 83 / 2003 ; 80 / 2003 ; 79 / 2003 ; 74 / 2003 ; 72 / 2003$;
} 
- Pesquisa por "tratado": 18 resultados, dos quais 7 foram selecionados, os PRCs 259/2014; 45/2011; 12/2011; 131/2008; 47/2007; 271/2005 e 204/2005. ${ }^{157}$

- Pesquisa por "direitos humanos": 65 resultados, dos quais 5 foram selecionados, os PRCs 259/2014; 12/2011; 131/2008; 271/2005 e 204/2005. ${ }^{158}$

A pesquisa no endereço eletrônico do Senado Federal, realizada no dia 28.02.2016, teve como resultado três PRSs (PRS 38/2006; 29/1008 e 35/2014). Os resultados obtidos e selecionados foram os seguintes:

- Pesquisa por "tratado": 2 resultados, dos quais ambos foram selecionados, os PRSs $38 / 2006$ e $35 / 2014$.

- Pesquisa por "internacional": 281 resultados, dos quais 3 foram selecionados, os PRSs 38/2006; 29/2008 e 35/2014. ${ }^{159}$

$68 / 2003 ; 62 / 2003 ; 60 / 2003 ; 58 / 2003 ; 49 / 2003 ; 42 / 2003 ; 41 / 2003 ; 29 / 2003 ; 27 / 2003 ; 20 / 2003 ; 10 / 2003$; 9/2003; 5/2003; 262/2002; 256/2002; 243/2002; 219/2001; 178/2001; 98/2000; 60/2000; 63/2000; 56/1999; $115 / 1996 ; 77 / 1996 ; 49 / 1995 ; 153 / 1993 ; 211 / 1989 ; 129 / 1983 ; 66 / 1983 ; 10 / 1983 ; 187 / 1978 ; 55 / 1975$ CC; 48/1968 CPI; 49/1964 CPI; 18/1963; 13/1963; 69/1960; 57/1960; 17/1959; 132/1957; 463/1953; 421/1953; 414/1953; 405/1953; 372/1953 COMDIP; 213/1952; 198/1952; 184/1952; 180/1952; 174/1952; 156/1952; $154 / 1952 ; 57 / 1951 ; 52 / 1951 ; 53 / 1951 ; 30 / 1951$ e $11 / 1947$ CEX.

157 Descartados os PRCs 50/2015; 34/2015; 196/2013; 123/2012; 79/2011; 119/2008; 107/2007; 259/2005; 235/2005; 229/2005 e 156/2004.

158 Descartados os PRCs 34/2015; 4/2015; 253/2014; 239/2014; 234/2013; 216/2013; 205/2013; 152/2012; $146 / 2012 ; 144 / 2012 ; 109 / 2012 ; 67 / 2011 ; 65 / 2011 ; 62 / 2011 ; 61 / 2011 ; 20 / 2011 ; 219 / 2010 ; 200 / 2009$; $198 / 2009 ; 163 / 2009 ; 155 / 2009 ; 152 / 2009 ; 122 / 2008 ; 18 / 2007 ; 13 / 2007 ; 307 / 2006 ; 301 / 2006 ; 280 / 2006$; $187 / 2004 ; 162 / 2004 ; 136 / 2004 ; 133 / 2004 ; 118 / 2003 ; 92 / 2003 ; 68 / 2003 ; 65 / 2003 ; 57 / 2003 ; 50 / 2003 ; 34 / 2003$; $33 / 2003 ; 14 / 2003 ; 10 / 2003 ; 3 / 2003 ; 264 / 2003 ; 244 / 2002 ; 208 / 2001 ; 118 / 1997 ; 115 / 1996 ; 86 / 1996$ CDN; $231 / 1995 ; 43 / 1991 ; 31 / 1991 ; 41 / 1988 ; 31 / 1988 ; 382 / 1985 ; 281 / 1985 ; 214 / 1984 ; 180 / 1984 ; 124 / 1983$ e $122 / 1983$.

${ }^{159}$ Descartados os PRSs 8/1947; 9/1947; 1/1949; 13/1953; 17/1953; 26/1953; 32/1953; 3/1954; 5/1954; 6/1954; $12 / 1954 ; 24 / 1954 ; 25 / 1954 ; 17 / 1956 ; 11 / 1957 ; 12 / 1957 ; 22 / 1957 ; 30 / 1957 ; 35 / 1957 ; 12 / 1958 ; 67 / 1965$; 70/1970; 71/1970 (todas anteriores ao Regimento atual do SF); 46/1971; 195/1972; 14/1975; 23/1978; 16/1979; 25/1989; 29/1989; 30/1989; 78/1989; 90/1989; 111/1989; 13/1990; 33/1990; 101/1990; 51/1991; 104/1991; $17 / 1992 ; 56 / 1992 ; 57 / 1992 ; 98 / 1992 ; 102 / 1992 ; 104 / 1992 ; 110 / 1992 ; 1 / 1993 ; 23 / 1993 ; 40 / 1993 ; 44 / 1993$; 57/1993; 59/1993; 93/1993; 94/1993; 108/1993; 121/1993; 27/1994; 31/1994; 38/1994; 39/1994; 41/1994; 44/1994; 51/1994; 54/1994; 58/1994; 81/1994; 82/1994; 83/1994; 108/1994; 12/1995; 35/1995; 76/1995; $83 / 1995 ; 93 / 1995 ; 128 / 1995 ; 136 / 1995 ; 137 / 1995 ; 11 / 1996 ; 13 / 1996 ; 62 / 1996 ; 69 / 1996 ; 75 / 1996 ; 82 / 1996$; 83/1996; 138/1996; 45/1997; 52/1997; 53/1997; 67/1997; 77/1997; 87/1997; 88/1997; 89/1997; 131/1997; $149 / 1997 ; 25 / 1998 ; 26 / 1999 ; 32 / 1999 ; 33 / 1999 ; 82 / 1999 ; 100 / 1999 ; 111 / 1999 ; 114 / 1999 ; 115 / 1999$; $118 / 1999 ; 129 / 1999 ; 133 / 1999 ; 2 / 2000 ; 3 / 2000 ; 4 / 2000 ; 10 / 2000 ; 56 / 2000 ; 61 / 2000 ; 63 / 2000 ; 83 / 2000$; $87 / 2000 ; 88 / 2000 ; 14 / 2001 ; 18 / 2001 ; 20 / 2001 ; 26 / 2001 ; 34 / 2001 ; 39 / 2001 ; 46 / 2001 ; 54 / 2001 ; 58 / 2001$; $62 / 2001 ; 64 / 2001 ; 66 / 2001 ; 72 / 2001 ; 19 / 2002 ; 21 / 2002 ; 23 / 2002 ; 24 / 2002 ; 28 / 2002 ; 36 / 2002 ; 45 / 2002$; $49 / 2002 ; 50 / 2002 ; 61 / 2002 ; 68 / 2002 ; 71 / 2002 ; 6 / 2003 ; 22 / 2003 ; 28 / 2003 ; 29 / 2003 ; 32 / 2003 ; 36 / 2003$; $40 / 2003 ; 54 / 2003 ; 55 / 2003 ; 56 / 2003 ; 12 / 2004 ; 27 / 2004 ; 33 / 2004 ; 35 / 2004 ; 40 / 2004 ; 42 / 2004 ; 44 / 2004$; 
- Pesquisa por “internacionais": 9 resultados, dos quais 3 foram selecionados, os PRSs $38 / 2006 ; 29 / 2008$ e $35 / 2014 .^{160}$

- Pesquisa por "direitos humanos": 15 resultados, dos quais 1 foi selecionado, o PRS $29 / 2008 .{ }^{161}$

Nos 9 (nove) PRCs e 3 (três) PRSs analisados, o primordial objetivo é alterar os respectivos Regimentos internos nos seguintes aspectos:

(i) Desmembrar a Comissão de Relações Exteriores e de Defesa Nacional em duas comissões separadas, pois os temas de sua competência seriam demasiadamente abrangentes; ${ }^{162}$

(ii) Necessidade de regulamentar a previsão constitucional do art. $5^{\circ}, \S 3^{\circ}, \mathrm{CF}$, que trata da internalização de tratados de Direitos Humanos no ordenamento nacional, seguindo o mesmo trâmite das propostas para emenda à Constituição; ${ }^{163}$

(iii) Conferir competência conclusiva às Comissões da Câmara e do Senado, no que se refere a diversas matérias, particularmente a apreciação de tratados de Direitos Humanos; ${ }^{164} \mathrm{e}$

(iv) Estabelecer audiências públicas regulares na CREDN com o Ministro de

Estado das Relações Exteriores. ${ }^{165}$

$15 / 2005 ; 76 / 2005 ; 78 / 2005 ; 84 / 2005 ; 85 / 2005 ; 88 / 2005 ; 89 / 2005 ; 1 / 2006 ; 2 / 2006 ; 3 / 2006 ; 4 / 2006 ; 8 / 2006$; $10 / 2006 ; 28 / 2006 ; 30 / 2006 ; 41 / 2006 ; 43 / 2006 ; 53 / 2006 ; 55 / 2006 ; 56 / 2006 ; 60 / 2006 ; 19 / 2007 ; 22 / 2007$; 45/2007; 46/2007; 74/2007; 79/2007; 85/2007; 87/2007; 89/2007; 91/2007; 1/2008; 18/2008; 20/2008; $32 / 2008 ; 34 / 2008 ; 35 / 2008 ; 36 / 2008 ; 46 / 2008 ; 48 / 2008 ; 52 / 2008 ; 57 / 2008 ; 58 / 2008 ; 60 / 2008 ; 65 / 2008$; $15 / 2009 ; 34 / 2009 ; 40 / 2009 ; 44 / 2009 ; 45 / 2009 ; 56 / 2009 ; 59 / 2009 ; 60 / 2009 ; 63 / 2009 ; 66 / 2009 ; 68 / 2009$; $77 / 2009 ; 81 / 2009 ; 82 / 2009 ; 83 / 2009 ; 85 / 2009 ; 87 / 2009 ; 91 / 2009 ; 94 / 2009 ; 4 / 2010 ; 7 / 2010 ; 15 / 2010 ; 22 / 2010$; $24 / 2010 ; 31 / 2010 ; 32 / 2010 ; 36 / 2010 ; 39 / 2010 ; 43 / 2010 ; 49 / 2010 ; 50 / 2010 ; 53 / 2010 ; 54 / 2010 ; 58 / 2010$; $63 / 2010 ; 70 / 2010 ; 7 / 2011 ; 33 / 2011 ; 47 / 2011 ; 67 / 2011 ; 68 / 2011 ; 7 / 2012 ; 12 / 2012 ; 19 / 2012 ; 26 / 2012 ; 27 / 2012$; $28 / 2012 ; 31 / 2012 ; 36 / 2012 ; 46 / 2012 ; 48 / 2012 ; 49 / 2012 ; 52 / 2012 ; 59 / 2012 ; 62 / 2012 ; 71 / 2012 ; 73 / 2012$; $77 / 2012 ; 79 / 2012 ; 82 / 2012 ; 34 / 2013 ; 50 / 2013 ; 52 / 2013 ; 53 / 2013 ; 62 / 2013 ; 85 / 2013 ; 93 / 2013 ; 97 / 2013$; 98/2013; 101/2013; 104/2013; 105/2013; 17/2014; 29/2014; 32/2014 e 42/2014. A quase totalidade das PRSs dizia respeito a autorizações para a contratação de créditos externos, com garantia da União, com o Banco Internacional para Reconstrução e Desenvolvimento (BIRD).

${ }^{160}$ Descartados os PRSs 112/1998; 31/2011; 6/2014; 21/2014; 36/2014; 5/2016, cinco dos quais tratavam da instituição de Grupos Parlamentares com outros países.

161 Descartados os PRSs 41/1979; 20/1995; 54/1998; 28/1999; 81/1999; 5/2003; 20/2003; 82/2005; 59/2007; $62 / 2008 ; 16 / 2011 ; 20 / 2011 ; 82 / 2012$ e 53/2014.

162 PRC 5/2015.

163 PRC 259/2014; 12/2011; 131/2008; 271/2005; 204/2005 e PRS 29/2008. Os autores das PRCs 259/2014 e 12/2011 mencionam a necessidade de reedição da proposta do Deputado Fernando Coruja, PRC 204/2005.

164 PRC 160/2012; 45/2011; 47/2007 e PRS 38/2006.

165 PRS 35/2014. 
Além das propostas dos PRCs e PRSs descritas acima, foram consultadas as justificativas apresentadas para a alteração dos Regimentos. Os PRs analisados têm como objetivo ampliar o poder do Congresso na condução da política externa nacional. Os argumentos mais utilizados nas justificativas são os seguintes:

(i) Ao descrever minuciosamente, nos Regimentos internos das Casas do Congresso Nacional, o procedimento para a tramitação de tratados de Direitos Humanos como Emenda Constitucional; e ao evitar que, em caso de não atingimento de quórum, o tratado seja afastado (e seja, portanto, aprovado no patamar de lei ordinária, em caso de aprovação por maioria simples - e rejeitado, apenas, caso não atinja essa maioria), é possível conceder maior segurança jurídica a esses direitos, que são de tão grande relevância para a vida de todos os brasileiros;

(ii) Ainda no que se refere à regulamentação da EC 45/2004 sobre tratados de Direitos Humanos, a intenção dos parlamentares é reforçar que a internalização como Emenda Constitucional, decisão primordialmente política, deve ser tomada pela Casa, não pode ser decorrência imediata do fato de se tratar de tratado de Direitos Humanos; ou do pedido nesse sentido por membros do Executivo; ${ }^{166}$

(iii) É preciso aprofundar o debate acerca do conceito de Direitos Humanos, e a harmonização das normas do Parlamento às disposições constitucionais auxilia o maior detalhamento no trato dessas questões, pois Deputados e Senadores, responsáveis pela constitucionalização desses tratados, devem travar discussões sérias e minuciosas a esse respeito;

(iv) É importante abreviar o procedimento de apreciação de tratados na Câmara, considerando que, no Senado, o tema é apreciado, necessariamente, apenas pela Comissão de Relações Exteriores, e não há necessidade regimental de que o seja por outras Comissões. Não é razoável que duas Casas "irmãs" tenham procedimentos discrepantes na apreciação de tratados internacionais, sendo na Câmara a tramitação

\footnotetext{
${ }^{166}$ Será possível perceber discussão acirrada nesse sentido na tramitação da Convenção sobre os Direitos das Pessoas com Deficiência, único instrumento internacional internalizado como Emenda Constitucional até o depósito desta tese.
} 
bastante mais difícil. A maior celeridade nesse processo de tramitação é meta urgente para o aprimoramento da instituição parlamentar. A concessão de poder conclusivo não impede a possibilidade de recurso ao Plenário (conforme o art. 58, $\S 2^{\circ}, \mathrm{I}, \mathrm{CF}$ ); ${ }^{167}$ (v) A previsão de que os Deputados, além do Presidente da República, possam fazer requerimento para que determinada MSC seja considerada nos termos do art. $5^{\circ}$, $\S 3^{\circ}, \mathrm{CF}$, possibilita maior ingerência na incorporação de tratados de Direitos Humanos, preocupação não apenas brasileira, mas mundial;

(vi) A necessidade de realizar audiências públicas periódicas com o Ministro das Relações Exteriores, para informar o Parlamento a respeito (a) dos tratados em negociação e (b) daqueles negociados, porém não enviados ao Congresso, é justificada com o argumento de que, apesar de a condução da política externa ser de competência do Executivo, este depende de referendo congressual, essencial em um regime democrático. Como o tratado, uma vez incorporado à ordem jurídica nacional, é, no mínimo, equivalente a lei ordinária, ele interfere na vida do cidadão. Por essas razões, é extremamente relevante manter o Congresso informado dos tratados em fase de negociação e daqueles que, terminada essa fase, ainda não foram enviados para a apreciação do Poder Legislativo.

Dos 12 (doze) Projetos de Resolução estudados, seis não foram arquivados. ${ }^{168}$ Continuam a ser analisadas, portanto, algumas das propostas de Deputados e de Senadores para a modificação dos respectivos Regimentos, com o objetivo de aumentar as atribuições das Casas do Congresso.

É possível perceber, pela exposição acima, que existe preocupação dos parlamentares em participar das decisões concernentes às obrigações do país em relação à comunidade

\footnotetext{
${ }^{167}$ Art. 58. O Congresso Nacional e suas Casas terão comissões permanentes e temporárias, constituídas na forma e com as atribuições previstas no respectivo regimento ou no ato de que resultar sua criação. (...) $\S 2^{\circ}$ Às comissões, em razão da matéria de sua competência, cabe:

I - discutir e votar projeto de lei que dispensar, na forma do regimento, a competência do Plenário, salvo se houver recurso de um décimo dos membros da Casa;

${ }^{168}$ Os PRCs 5/2015 (apensado ao PRC 87/2007, e não analisado aqui, que cria a Comissão de Defesa Nacional e está pronto para Pauta na CCJC); 259/2014 (Apensado ao PRC 12/2011); 45/2011 (apensado ao PRC 47/2007); 12/2011 (aguardando designação de relator na CCJC); 47/2007 (pronto para pauta no Plenário); e o PRS 35/2014, que está com a relatoria desde 10.11.2015 (Informação de 29.02.2016). Os PRCs 131/2008 e 271/2005 foram apensados ao PRC 204/2005. Este, por sua vez, foi arquivado em 31.01.2011. Trata-se da proposta original do deputado Fernando Coruja, mencionada por diversas PRCs posteriores.
} 
internacional, que podem ser consolidadas, no caso de internalização de tratados, apenas após referendo congressual. Ressalto, porém, que, das propostas analisadas, nenhuma foi concretizada e transformada em alteração no Regimento Interno. Entretanto, a reedição de propostas que (i) almejam uma melhor descrição do procedimento a ser adotado por parlamentares em caso de apreciação de tratados que possam ser classificados nas disposições do art. $5^{\circ}, \S 3^{\circ}, \mathrm{CF}$; e (ii) demonstram a intenção dos parlamentares em participar das discussões a respeito dos tratados negociados pelo Poder Executivo, atesta que inexiste apatia desse Poder em relação à condução da política externa nacional. 


\section{RELAÇÃO ENTRE O EXECUTIVO E O LEGISLATIVO NA INTERNALIZAÇÃO DE TRATADOS E NA ELABORAÇÃO DA POLÍTICA EXTERNA}

A leitura das manifestações de parlamentares ao longo do processo de internalização de tratados de Direitos Humanos trouxe à atenção da autora as diversas manifestações a respeito do intuito de uma maior inserção dos membros do Poder Legislativo nesse processo. Seja nos pareceres, seja nas manifestações em Plenário, congressistas demandam maior participação, inclusive durante as negociações internacionais. São feitos protestos em relação à consulta parlamentar apenas em momento posterior à assinatura do tratado, ${ }^{169} \mathrm{e} \mathrm{em}$ relação à intenção de aposição de reservas, por parte do Executivo, no mesmo momento de assinatura do tratado, o que prejudicaria a apreciação dessas reservas pelo Legislativo. ${ }^{170}$ Os parlamentares discutem, inclusive, a possibilidade de emendar o texto dos tratados internacionais, em clara demonstração de desconhecimento e de insegurança a respeito das reais possibilidades de atuação dos membros do Poder Legislativo, particularmente nos tratados multilaterais, de alteração extremamente complexa e improvável uma vez atingido o texto final. ${ }^{171}$

\subsection{LITERATURA NACIONAL E ESTRANGEIRA}

A tripartição clássica de Poderes de um Estado em Executivo, Judiciário e Legislativo tem como objetivo a supervisão de um Poder pelo outro, o chamado sistema de freios e de contrapesos, consagrado na literatura por Montesquieu na obra "O Espírito das Leis". Conforme essa teoria, os Poderes instituídos em um país devem ser capazes de atuar de duas maneiras principais. A primeira delas é a atividade fim do Poder: exercer o comando das políticas da nação, executando as leis, no caso do Executivo; julgar, no caso do Judiciário; e elaborar as leis que organizarão a sociedade, no caso do Legislativo. A segunda atividade

\footnotetext{
${ }^{169}$ Exemplificativamente, na tramitação da Convenção relativa ao Estatuto dos Refugiados.

${ }^{170} \mathrm{Na}$ discussão da Convenção Nacionalidade da Mulher Casada.

${ }^{171}$ Isso pode ser observado em diversos tratados, além dos mencionados nas últimas duas notas de rodapé. Para uma análise mais detalhada dessas manifestações, remeto o leitor ao APÊNDICE I, no qual apresento descrição detalhada de todos os instrumentos internacionais analisados.
} 
consiste em guardar a igualdade entre os três Poderes, de modo que um não se sobreponha ao outro. Os integrantes dos Poderes exercem essa atividade praticando atos que não se encontram dentre suas faculdades primeiras (executar, legislar, julgar), mas que foram incluídos em suas competências para possibilitar o controle mútuo, dentro dessa lógica dos freios e contrapesos. A necessidade de aprovação de tratados pelo Legislativo é a maneira de fiscalizar a atuação daqueles que negociam e que assinam os atos internacionais, plenipotenciários a serviço do Executivo.

A relação entre os Poderes no âmbito interno, e a interação entre a política doméstica e a externa, é objeto de estudos em diversas áreas do conhecimento, como Ciência Política, Direito e Relações Internacionais. Cada área privilegia o aspecto que melhor se coaduna com suas bases teóricas e empíricas. A intenção deste trabalho é unir a análise de fontes primárias - os relatórios elaborados e as discussões travadas no âmbito dos Poderes Executivo e Legislativo brasileiros - que poderiam ser objeto de estudos de Ciência Política ou de Direito, à análise das repercussões legislativas da interação com essas fontes, as leis elaboradas após a internalização dos tratados internacionais de Direitos Humanos. Os argumentos utilizados pelos atores na internalização de tratados servirão de base para determinar a relação entre a atuação desses Poderes em regimes de exceção ou democráticos. Isso, por sua vez, auxiliará na melhor compreensão da relação entre os Poderes no Brasil, particularmente no que se refere à temática particular dos Direitos Humanos, que ganha força internacional de maneira mais expressiva a partir da década de 1980.

A teoria do jogo de dois níveis, elaborada por Robert Putnam, é uma das principais referências da relação entre a tomada de decisões no âmbito interno e no internacional. Segundo ela, há uma necessidade de se considerar o contexto político doméstico nas decisões de cunho internacional, pois existe entrelaçamento entre as políticas nacional e internacional de determinado país, o que foi representado pela metáfora de um jogo de dois níveis. Em um dos níveis - o internacional, acontecem as negociações no âmbito externo, enquanto, no outro - o nacional, ocorrem as tentativas de garantir apoio político, que garanta o sucesso do objetivo perseguido. ${ }^{172} \mathrm{O}$ autor critica as teorias estadocêntricas, que consideram os países como os únicos atores relevantes do cenário internacional, além de entendê-los como se

\footnotetext{
${ }_{172}$ PUTNAM, Robert. "Diplomacy and Domestic Politics: The Logic of the Two-Level Games". Disponível em: http://www.scielo.br/scielo.php?script=sci_arttext\&pid=S0104-44782010000200010\&lng=pt\&nrm= iso\&tlng=pt\#back1. Acesso: 20.06.2016.
} 
fossem "bolas de bilhar", com interesses uniformes, ignorando a multiplicidade de agendas existentes dentro de um Estado.

Para Putnam, no momento em que líderes de determinado país almejam ratificar um acordo - o que, no caso do Brasil, exige apreciação parlamentar - seu comportamento nas negociações internacionais reflete e pondera, simultaneamente, os imperativos de ambos os fóruns de negociação: o nacional e o internacional. Seriam apreciadas, assim, as coalizões domésticas, as instituições e as práticas nacionais, além dos interesses e das pressões dos diversos grupos domésticos. Ademais, é preciso considerar as estratégias dos negociadores encarregados de tratativas no âmbito internacional, a repercussão das pressões internacionais no âmbito doméstico e as prioridades dos negociadores, que também buscam maximizar seus interesses no âmbito internacional. ${ }^{173}$

Assim como Putnam, Helen Milner entende que a política doméstica e a externa, e, consequentemente, as Relações Internacionais, estão intrinsecamente conectadas. O Estado define sua atuação internacional com base no contexto doméstico. Existiriam diversos atores políticos no âmbito nacional, como os dois Poderes de que aqui se trata, além de grupos de interesse que atuam no contexto internacional. ${ }^{174}$ Para a autora, assim como para Putnam, seria inevitável a interação entre os atores nacionais para definir os interesses de um Estado. Existiria, porém, uma distinção essencial entre os interesses dos políticos dos Poderes Executivo e Legislativo: enquanto os integrantes do primeiro preocupam-se com interesses de abrangência nacional e internacional, os últimos responderiam a interesses mais circunscritos. Essa é, inclusive, a razão apontada por autores brasileiros para o suposto desinteresse dos legisladores em temas referentes à política externa, temática que não traria resultados eleitorais diretos.

Milner considera, inclusive, as instituições nacionais como balizadoras dos interesses dos atores envolvidos na atuação internacional de um país. As instituições determinariam quais atores são preponderantes no processo político, e, consequentemente, quais preferências seriam determinantes ao definir uma política de Estado. ${ }^{175}$ Recusar a internalização de um tratado teria, na percepção de Milner, consequências políticas

\footnotetext{
${ }^{173}$ PUTNAM, Robert. "Diplomacy and Domestic Politics: The Logic of the Two-Level Games". Disponível em: http://www.scielo.br/scielo.php?script=sci_arttext\&pid=S0104-44782010000200010\&lng=pt\&nrm= iso\&tlng=pt\#back1. Acesso: 20.06.2016.

${ }^{174}$ MILNER, Helen. Interests, Institutions and Information. Domestic Politics e International Relations, 1997. ${ }^{175}$ MILNER, 1997.
} 
extremamente custosas para um governo, com custos domésticos e externos. Em uma negociação internacional, portanto, o plenipotenciário apenas assinaria um tratado se considerasse plausível a sua chancela nacional. A repercussão da rejeição de um acordo internacional comprovaria, para a autora, a relação necessária entre os Poderes Executivo e Legislativo na formação da política externa.

Existem, porém, casos nos quais o governo que assina um tratado não é o mesmo que o internaliza. Nesse caso, o governo que deixa de internalizar um tratado internacional poderia, a princípio, sofrer as consequências da negociação efetuada por outrem. Não existem no Brasil, atualmente, meios para exigir que um governo envie um tratado assinado ao Poder Legislativo. Seriam necessárias medidas normativas para alterar essa realidade, medidas que no Brasil, hodiernamente, consubstanciam-se nas PECs e nas propostas de alteração dos Regimentos das duas Casas legislativas.

Milner acredita que a distribuição dos Poderes influencia a ponderação a respeito das preferências dos atores envolvidos e a probabilidade de cooperação internacional, conferindo maior segurança às negociações no âmbito internacional. De modo similar, para Lisa Martin, a previsão institucional de maior participação do Legislativo nas tratativas internacionais culmina em uma cooperação mais estável entre os Poderes, e entre os próprios Estados. Estes tendem a gozar de maior credibilidade no âmbito internacional quando são efetivamente internalizados os instrumentos por eles assinados. Para a autora, se previstas pela legislação e, portanto, institucionalizadas, até mesmo discussões ardorosas entre membros do Executivo e do Legislativo tendem a favorecer, e não a impedir, as negociações internacionais. Essa interação fortalece e legitima a posição de barganha dos Estados, e aumenta a sua capacidade de cooperar com seus pares. ${ }^{176}$ É preciso, portanto, expandir a compreensão dos efeitos da política doméstica sobre a política exterior e as negociações interestatais, para que aumente a confiança entre seus atores, problemática invariavelmente presente na teoria das Relações Internacionais.

Mathew D. McCubbins e Thomas Schwartz, no artigo "Congressional oversight overlooked: police patrols versus fire alarms", ao tratar da relação entre os Poderes nos Estados Unidos, discordam da premissa de que o Congresso negligencia sua responsabilidade de supervisionar o Executivo. Para eles, aquilo que aparenta ser uma

${ }^{176}$ MARTIN, Lisa L. Democratic Commitments: Legislatures and International Cooperation. 
negligência trata-se de preferência racional por utilizar forma distinta de fiscalização. Os legisladores optariam pela fiscalização do tipo "alarme de incêndio" (fire alarm) em detrimento da fiscalização de "patrulha de polícia" (police-patrol). A distinção entre as duas remete, literalmente, aos seus títulos: a fiscalização do tipo "alarme de incêndio" é menos centralizada e envolve uma intervenção pouco ativa e direta; a fiscalização do tipo "patrulha de polícia" é centralizada, ativa e direta. Na primeira, os parlamentares optam por estruturar um sistema que possibilita aos atores domésticos a supervisão da atividade administrativa e o acionamento do Congresso quando seus interesses não são contemplados. Na segunda (patrulha de polícia), o Congresso analisa as decisões administrativas com o objetivo de encontrar e de remediar quaisquer violações dos seus objetivos, e, em virtude dessa supervisão, desencorajam violações futuras. Para os autores, a fiscalização do tipo "alarme de incêndio" é mais eficiente sob a perspectiva dos interesses dos atores da sociedade civil e dos legisladores, porque seria inviável que o Congresso efetuasse o controle sobre todos os atos do Executivo. ${ }^{177}$

Conforme Amado Cervo, em obra que trata da relação entre o Parlamento brasileiro e as relações exteriores durante o Império (1822-1889), seria possível investigar a atuação do Parlamento sob três aspectos distintos. A função primordial desempenhada pelo Parlamento seria o controle das relações internacionais por intermédio da lei, instrumento próprio do Legislativo. Nesse sentido, porém, o controle direto seria exercido, sobretudo, pelo Executivo. A segunda função desempenhada seria a de fiscalizar o desempenho dos agentes das relações exteriores, buscando verificar a adequação de suas ações ao interesse nacional. Essa função seria definida pela crítica e pelo posicionamento diante dos fatos concretos, podendo modificar o desempenho dos agentes do Executivo. Finalmente, seria possível ao Parlamento gerar teorizações, elaborar a própria doutrina a respeito das diretrizes de política externa. ${ }^{178}$ Conforme a análise de Amado Cervo, o Parlamento brasileiro exerceu, durante a Monarquia, as três funções descritas.

\footnotetext{
${ }^{177}$ MCCUBBINS, Mathew D.; SCHWARTZ, Thomas. Congressional Oversight Overlooked: Police Patrols versus Fire Alarms. Disponível em: http://www.unc.edu/ fbaum/teaching/PLSC541_Fall08/mcubbins_ schwartz 1984.pdf. Acesso: 28.06.2016.

${ }^{178}$ CERVO, Amado Luiz. O Parlamento Brasileiro e as Relações Exteriores (1826-1889), Introdução.
} 
Alguns autores que tratam da relação entre os Poderes no Brasil consideram apática a atuação do Poder Legislativo na política externa. ${ }^{179}$ A falta de interesse adviria de motivações técnicas, políticas e institucionais. ${ }^{180}$ A motivação técnica seria empecilho proveniente da dificuldade de tratar dos temas internacionais, que exigiriam grau elevado de especialização, do qual os legisladores pátrios não desfrutariam. Esse fato deve ser considerado em conjunto à excelência do MRE, o que incentivaria a delegação de poderes no que se refere à política externa. A razão política, por sua vez, parte do princípio de que a atuação em temas internacionais não leva a ganhos eleitorais diretos ou proporcionais, por sua (alegada) ínfima repercussão interna. Sob a perspectiva institucional, a atuação do Congresso seria constitucionalmente restrita nos temas afetos às relações internacionais, e restringir-se-ia à chancela dos atos do Poder Executivo. ${ }^{181} \mathrm{O}$ sistema político brasileiro concentra atribuições decisórias em relações exteriores no Poder Executivo e nas lideranças partidárias, o que desestimularia a participação individual dos congressistas. ${ }^{182}$

Outros autores, entretanto, perceberam a crescente participação do Poder Legislativo em temas relacionados à política externa. ${ }^{183}$ Alguns desses estudiosos acreditam que a atuação do Legislativo é determinada, da mesma maneira como ocorre na política doméstica,

\footnotetext{
${ }^{179}$ É possível citar, como exemplo, os trabalhos de LIMA, Instituições Democráticas e Política Exterior; LIMA \& SANTOS, O Congresso e a Política de Comércio Exterior; NEVES, O Papel do Legislativo nas Negociações do MERCOSUL e da ALCA; OLIVEIRA, Atores políticos e Parlamento brasileiro no MERCOSUL; PEREIRA, O Senado e a Formulação da Política Externa Brasileira; e SOUZA, A Agenda Internacional do Brasil: um estudo sobre a comunidade brasileira de política externa. Conforme SCHMITT, Stefanie T. A Política Externa e o Poder Legislativo: um olhar sobre a Comissão de Relações Exteriores e Defesa Nacional do Senado Federal. Dissertação de Mestrado, 2011.

${ }^{180}$ Para maiores informações a respeito do tema: FERRARI, Diogo. O Congresso Nacional e a apreciação de tratados internacionais no contexto do Presidencialismo de Coalizão.

${ }^{181}$ Segundo MAZZUOLI, Valerio. O treaty-making power na Constituição brasileira de 1988: uma análise comparativa do poder de celebrar tratados à luz da dinâmica das relações internacionais, 2001.

182 Para maiores informações: FERRARI, Diogo. O Congresso Nacional e a apreciação de tratados internacionais no contexto do Presidencialismo de Coalizão.

${ }^{183}$ Exemplificativamente: ALEXANDRE, O Congresso Brasileiro e a Política Externa: 1985-2005; Cesar \& Maia, A diplomacia congressual. Análise comparativa do papel dos Legislativos brasileiro e norte-americano na formulação da política exterior; DINIZ, O Senado Federal e a Deliberação de Atos Internacionais no Presidencialismo Brasileiro; Diniz \& Ribeiro, O papel do Congresso brasileiro em política externa: uma contribuição empírica para o debate; Fares (2005), Democratização da Política Externa Brasileira: o Papel do Legislativo; FERRARI, O Congresso Nacional e a apreciação de tratados internacionais no contexto do Presidencialismo de Coalizão; e OLIVEIRA, Partidos Políticos, Legislativo e Política Externa no Brasil: de 1995 à 2009. Conforme SCHMITT, 2011.
} 
pelas características institucionais e políticas do sistema presidencialista brasileiro. ${ }^{184}$ É possível, nesse sentido, mencionar os trabalhos de Cristina Alexandre e de Diogo Ferrari. Alexandre, ao pesquisar a capacidade de influência do Poder Legislativo na agenda de política externa brasileira, verificou que a participação parlamentar é maior naquelas tramitações em que há aposição de ressalvas, particularmente em tratados bilaterais. ${ }^{185}$ Ferrari, em sua análise, aponta que a alteração do conteúdo de tratados internacionais seria a principal maneira de o Legislativo intervir na política externa nacional, mas essa intervenção sofreria constrangimento duplo: em primeiro lugar, os parlamentares perceberiam os (altos) custos de uma renegociação; e, em segundo lugar, o Executivo, avesso ao risco, buscaria não contrariar os interesses de sua base de apoio desde o começo das negociações internacionais. ${ }^{186}$

Amâncio Oliveira, no artigo "Legislativo e Política Externa: das (in)conveniências da abdicação", ao discutir as relações entre Executivo e Legislativo no Brasil, utiliza a experiência norte-americana para demonstrar que, apesar da variação do nível de assertividade do Congresso desse país, o congresso americano teve função relevante para contrabalancear o Poder Executivo. No Brasil, porém, teriam prevalecido incentivos negativos ao incremento da atuação do Congresso em temas relativos à política externa. Esses incentivos negativos seriam relacionados, principalmente, com o modelo político e institucional brasileiro, que não atribui ao Legislativo competências significativas no âmbito da política externa. ${ }^{187}$ Ademais, haveria pouco interesse dos integrantes do Legislativo em temas internacionais, invariavelmente complexos tecnicamente, e eleitoralmente pouco rentáveis. Precisamente por isso, o Legislativo é considerado por autores como Soares e Santos, um exemplo de abdicação, ou, no melhor cenário possível, de delegação, das funções

${ }^{184}$ Como nos trabalhos de: ALEXANDRE, O Congresso Brasileiro e a Política Externa: 1985-2005; DINIZ, O Senado Federal e a Deliberação de Atos Internacionais no Presidencialismo Brasileiro; DINIZ \& RIBEIRO, O papel do Congresso brasileiro em política externa: uma contribuição empírica para o debate; FERRARI, Diogo. O Congresso Nacional e a apreciação de tratados internacionais no contexto do Presidencialismo de Coalizão; e OLIVEIRA, Partidos Políticos, Legislativo e Política Externa no Brasil: de 1995 a 2009.

${ }^{185}$ ALEXANDRE, 2006

186 FERRARI, Diogo. O Congresso Nacional e a apreciação de tratados internacionais no contexto do Presidencialismo de Coalizão.

${ }^{187}$ OLIVEIRA, Amâncio J. Legislativo e Política Externa: das (in)conveniências da abdicação, 2003, p. 3. 
de formulação e de condução da política externa nacional. ${ }^{188}$ Oliveira destaca, porém, que o poder de barganha do negociador no contexto de negociações internacionais pode ser maior quando sua atuação é constrangida pela necessidade de considerar a preferências do contexto nacional. Isso significaria que determinar a corresponsabilidade entre os Poderes aumenta a segurança do negociador nacional no âmbito internacional, por fortalecer o processo doméstico de barganha. ${ }^{189}$

Existe uma discussão, na literatura brasileira, a respeito da existência de delegação ou de abdicação, por parte do Poder Legislativo, de lidar com temas afetos à política externa. Para João Augusto Neves, "O papel de ambos poderes na formulação da política externa brasileira é mais complexo do que está estabelecido na Constituição". ${ }^{190}$ Segundo Neves, quando há convergência de interesses entre os Poderes, os congressistas delegam autoridade ao Executivo; mas, quando há divergências, pressionam os membros do governo e participam do processo decisório. ${ }^{191} \mathrm{O}$ autor trata, particularmente, das negociações para a formação da Área de Livre Comércio das Américas (ALCA), temática controversa nacional e internacionalmente, com relação à qual não teria existido convergência e, tampouco, delegação ao Executivo dos poderes de livre negociação. Isso seria comprovado por fatos como a intenção dos parlamentares de realizar plebiscito sobre a matéria, além das propostas de emendas constitucionais que institucionalizariam o controle ex-ante das tratativas realizadas pelo Executivo. Em contraposição às negociações a respeito da ALCA, havia interesse convergente entre os Poderes para a integração regional realizada no Mercosul. Para Neves, em ambas as negociações, o Poder Legislativo revelou sua preferência por uma influência legislativa sutil, mas eficiente.

A delegação de poderes pelo Legislativo ao Executivo também é defendida por Cristina Alexandre. ${ }^{192}$ Segundo ela, entre 1985 e 2005, o Congresso tentou ampliar os mecanismos que o permitem controlar o Executivo em temas relacionados à política externa. Esse controle ocorreria de duas maneiras: pela tentativa de inclusão de dispositivos na

\footnotetext{
${ }^{188}$ SOARES LIMA, Maria Regina Soares de; SANTOS, Fabiano. O Congresso e a Política de Comércio Exterior.

${ }^{189}$ OLIVEIRA, 2003, p. 4

${ }^{190}$ NEVES, João Augusto de Castro. O Papel do Legislativo nas Negociações do MERCOSUL e da ALCA, 2003. Disponível em: http://www.scielo.br/scielo.php?script=sci_arttext\&pid=S0102-85292003000100004. Acesso: 29.06.2016.

${ }^{191}$ NEVES, 2003.

192 ALEXANDRE, Cristina V. M. Disponível em: http://www.maxwell.vrac.puc-rio.br/Busca_etds. php?strSecao=resultado\&nrSeq=9572@1. Acesso: 29.06.2016.
} 
Constituição de 1988, que não foram aprovados e, portanto, não constam no texto constitucional; e pela consolidação de seu poder de formular emendas, ressalvas e cláusulas interpretativas. O Legislativo, para Alexandre, estaria aproveitando as lacunas normativas para consolidar sua participação no processo de internalização de tratados.

A professora Leany Lemos, por sua vez, constata que existe delegação, e não abdicação, na atuação do Congresso Nacional nos temas afetos à política externa. Contrariando o argumento, presente em parte da literatura nacional, de que o Congresso abdicaria de suas prerrogativas em política externa em virtude do custo político proveniente da rejeição dos acordos assinados pelo Executivo, além da falta de interesse eleitoral no tema, Lemos rejeita a tese da abdicação utilizando indicadores da atividade legislativa em questões internacionais. Dentre esses indicadores, destaca a quantidade de reuniões da CREDN, se comparada às demais Comissões parlamentares, as propostas de emendas ao orçamento, os pedidos de informação e as audiências públicas que tratam de tema afetos à atuação internacional do Brasil. ${ }^{193}$

Simone Diniz, por sua vez, adota argumentação convergente à adotada por Lemos, ao analisar a atuação dos Senadores brasileiros na discussão dos instrumentos internacionais negociados por integrantes do Poder Executivo. Apesar dos limites impostos à atuação dos parlamentares pela Constituição Federal, que os impede de emendar os instrumentos internacionais (por razões apresentadas e discutidas anteriormente nesta tese) e tampouco prevê o controle ex-ante da condução da política externa, Diniz apresenta situações pontuais nas quais houve divergência entre os Poderes em relação a determinados atos internacionais. A autora, assim, demonstra, de maneira empírica, que resta incorreta a percepção de falta de interesse dos congressistas na temática internacional. Existiria, portanto, polarização quanto à temática internacional no âmbito do Senado brasileiro, e Diniz indica o fator partidário como relevante para as decisões relacionadas à política externa brasileira. Assim como Lemos, Diniz menciona propostas de emendas à Constituição que têm como objetivo ampliar as competência dos parlamentares em relação à política externa, tema igualmente abordado nesta tese. ${ }^{194}$

\footnotetext{
${ }^{193}$ LEMOS, Leany. Brazilian Congress and Foreign Affairs: abdication or Delegation?.

${ }^{194}$ DINIZ, Simone. O Senado Federal e a Deliberação de Atos Internacionais no Presidencialismo Brasileiro.
} 
Ao analisar as votações nominais em temas relacionados à política externa em seis países latino-americanos, ${ }^{195}$ Pedro Feliú Ribeiro aponta que os resultados obtidos indicam pouca variação entre os níveis de unidade partidária dos partidos políticos nos âmbitos doméstico e internacional. Destaca, ainda, que existem níveis semelhantes de conflito interpartidário, apesar de variações significativas entre os casos estudados. Feliú concluiu pela baixa relevância da especificidade de temas de política externa para influenciar o comportamento legislativo, o que seria bastante próximo do que ocorre com as demais políticas públicas. ${ }^{196}$

Diniz e Ribeiro, por sua vez, analisam o processo de aprovação de tratados por parte do Legislativo. ${ }^{197} \mathrm{O}$ artigo, baseado em Mensagens Presidenciais que encaminham tratados para a apreciação desse Poder, entre 1988 e 2006, aponta que o modelo institucional brasileiro não restringe totalmente o processo de tomada de decisões relativo às negociações internacionais efetuadas pelo Poder Executivo. Para os atores, a análise das Mensagens possibilita identificar a existência de um espectro amplo de participação política do Legislativo. A relação entre os Poderes seria colaborativa, por meio de mecanismos institucionalmente previstos e, portanto, ao alcance do Poder Legislativo, como solicitações de urgência na votação dos projetos de decreto legislativo, por exemplo. ${ }^{198}$ Esse mecanismo teria sido utilizado em trinta por cento dos atos aprovados entre 1988 e 2006, fato que contraria a percepção da literatura de que os parlamentares não têm interesse por temas relacionados à política externa.

\footnotetext{
${ }^{195}$ Notadamente, Argentina, Brasil, Chile, México, Paraguai e Peru.

${ }^{196}$ FELIÚ, Pedro Ribeiro. Comportamiento Legislativo y Política Exterior em Latinoamérica, 2012.

197 DINIZ, Simone; RIBEIRO, Cláudio O. O Papel do Congresso Brasileiro na Política Externa: uma contribuição empírica para debate. Brazilian Political Science Review, 2008. Disponível em: http://socialsciences.scielo.org/scielo.php?pid=S1981-38212008000100006\&script=sci_arttext\&tlng=pt. Acesso: 29.06.2016.

${ }^{198} \mathrm{O}$ regime de tramitação urgente dispensa algumas exigências e formalidades regimentais, com exceção da publicação e da distribuição em avulsos ou cópias, dos pareceres das Comissões e do quórum para deliberação. O prazo das comissões é de 5 (cinco) sessões, que corre simultaneamente para todas. Existem projetos que são urgentes desde o seu início, como consequência de seu conteúdo, e esses casos estão previstos no Regimento da Câmara dos Deputados. Outros projetos passam a ser urgentes após a aprovação, em plenário, de requerimento para tanto. Informação obtida em: http://www2.camara.leg.br/atividade-legislativa/ processolegislativo/fluxo/plTramitacao/conteudoFluxo/05.html. Acesso: 29.06.2016.
} 
A atuação do Poder Legislativo na internalização de tratados, como é possível perceber, não se resume à sua aceitação ou rejeição integrais. Devido ao silêncio da legislação sobre o tema, existe discussão doutrinária a respeito da possibilidade de o Poder Legislativo emendar tratados. Os limites e os efeitos jurídicos da possibilidade de emenda a tratados internacionais pelo Legislativo foram apreciados em diversas ocasiões pela Comissão de Constituição e Justiça. Essa situação foi, igualmente, analisada por consultores jurídicos do Itamaraty. Valladão foi o primeiro, em 1962, que, inquirido sobre a possibilidade de o Congresso nacional apresentar emendas a tratado, afirmou que o Congresso poderia, além de aprovar ou de rejeitar tratados, aprová-los com emendas. ${ }^{199} \mathrm{Na}$ década de 1970, Augusto de Rezende Rocha entendeu que os membros do Poder Legislativo poderiam, apenas, aceitar ou rejeitar os tratados. ${ }^{200}$ Trindade, por sua vez, apreciou uma ressalva oferecida no decreto que aprovou o acordo de sede da Comissão Econômica para a América Latina (CEPAL); e asseverou que o Congresso deveria aprovar ou rejeitar os tratados em sua totalidade, pois, para o jurista, a rejeição parcial ou a proposta de alteração significariam a rejeição completa do instrumento internacional.

Em parecer da década de 1990, Vicente Marotta Rangel entendeu que as emendas a tratados se inserem na competência privativa do Presidente da República e, portanto, não caberia ao Legislativo emendar tratados; podendo, entretanto, sugeri-las. Acompanha, assim, o parecer de Valladão, entendendo que uma emenda sugerida pelo Congresso, proposta pelo Executivo e tida como pertinente pelas outras partes, não obriga o reexame do tratado emendado pelo Congresso. ${ }^{201}$

Em parecer de 2000, Valladão, então coordenador-geral de Direito Internacional da Secretaria de Estado das Relações Exteriores, trata da necessidade de consultar o Congresso para aprovar o Protocolo facultativo à Convenção sobre a eliminação de todas as formas de Discriminação contra a Mulher. Segundo o parecer, o Brasil é parte da Convenção à qual se

\footnotetext{
199 Segundo GABSCH, o consultor apreciava o Acordo de Comércio e Pagamentos entre o Brasil e a Tchecoslováquia, de 24.06.1960, aprovado com ressalvas pelo Decreto legislativo 17, de 15.12.1961, e promulgado pelo Decreto 51.951, de 26.04.1963. O parecer encontra-se disponível na coleção de Pareceres dos Consultores Jurídicos do Itamaraty, v. VIII (1985-1990, pp. 464-465. Ver, ainda: http://www2.camara.leg.br/legin/fed/decret/1960-1969/decreto-51951-26-abril-1963-391743-publicacaoorigi nal-1-pe.html. Acesso: 07.06.2016.

${ }^{200}$ ROCHA, Augusto de Rezende. Parecer do Consultor Jurídico do Ministério das Relações Exteriores, de 12.09.1975. In: Pareceres dos consultores jurídicos do Itamaraty, v. VII (1972-1984), p. 154.

201 RANGEL, Vicente Marotta. Parecer do Consultor Jurídico do Ministério das Relações Exteriores, de 24.09.1995. In: Pareceres dos consultores jurídicos do Itamaraty, v. IX (1990-1999), p. 87.
} 
relaciona o Protocolo, e existiria consenso quanto à conveniência da adesão. Conforme a "prática brasileira", direcionada pelos artigos 84, VIII e 49, I, CF, não seria usual submeter a intenção do Executivo de subscrever um tratado internacional à aprovação parlamentar; uma vez que caberia ao Congresso apenas referendar instrumentos internacionais previamente ajustados e assinados pelo Presidente da República. Ainda segundo o consultor, de acordo com o Direito Internacional, a negociação de tratado termina com a sua assinatura e, posteriormente, o instrumento deve ser enviado para a apreciação do Poder Legislativo nacional, que, concordando, autoriza o Poder Executivo a efetuar sua ratificação. Valladão aponta para desnecessidade de se consultar o Congresso sobre a assinatura do Protocolo Adicional. A assinatura poderia, portanto, ocorrer imediatamente, solicitando-se, após a assinatura, a aprovação do ato efetuado pelo Executivo, para sua posterior ratificação, promulgação e publicação.

Foram oferecidas opiniões a respeito do mesmo tema por Comissões do Poder Legislativo. A pedido da presidência da Câmara dos Deputados, integrantes da Comissão de Constituição e Justiça proferiram três pareceres. No primeiro deles, a Comissão de Constituição e Justiça e Cidadania, em resposta à Consulta 2/1992 da Comissão de Relações Exteriores, ${ }^{202}$ entendeu que seria necessária a edição de decreto legislativo em caso de rejeição de ato internacional. O segundo é de autoria do Deputado José Thomaz Nonô, de 1994, em resposta à Consulta 7-A/1993, no qual afirmou ser legítimo ao Congresso aprovar, inclusive parcialmente, qualquer instrumento internacional por ele apreciado, como consequência da disposição constitucional do art. 49, I. A emenda aprovada no âmbito do Poder Legislativo, entretanto, não vincularia a (ou "as", em caso de tratado multilateral) outra parte contratante. $\mathrm{O}$ direito brasileiro possibilitaria essa proposta de mudanças, que deveriam ser transformadas em reservas, no caso de tratado multilateral, ou na renegociação do tratado, em caso de acordos bilaterais. ${ }^{203}$

O último parecer é de autoria do Deputado Aloysio Nunes Ferreira. ${ }^{204}$ Nele, o Deputado destaca interpretações distintas do que seria o "poder de emendar". Em sentido amplo, considerado como a expressão da convicção do Congresso e da deliberação

\footnotetext{
202 Atual Comissão de Relações Exteriores e de Defesa Nacional.

${ }^{203}$ Parecer da Comissão de Constituição e Justiça e de Redação, aprovado em 31.08.1994, à Consulta n.7-A, de 25.06.1993, da Presidência da Câmara dos Deputados.

${ }^{204}$ Parecer da Comissão de Constituição e Justiça e de Redação, aprovado em 09.12.2004, à Consulta n. 4, de 14.05.2004, da Presidência da Câmara dos Deputados.
} 
parlamentar, o Poder Legislativo poderia, por deter a competência para resolver definitivamente sobre atos internacionais, o poder irrestrito de decidir a respeito deles. Se considerado, porém, em sentido estrito, como o poder de emendar diretamente um ato internacional, não seria possível facultar aos membros do Legislativo essa prerrogativa. Isso ocorreria como efeito (i) da natureza jurídica própria aos atos internacionais, vigentes apenas no âmbito internacional até sua ratificação pelo Presidente da República; (ii) da legitimidade dos plenipotenciários, que representam o país em suas relações exteriores; e (iii) da inexistência de competência constitucional do Legislativo para exercer funções afetas à representação internacional do Estado brasileiro. Seria, portanto, inconstitucional a apresentação de emendas ao texto de tratados; seria possível, apenas, efetuar emendas aditivas, supressivas e modificativas ao projeto de decreto legislativo, ato normativo interno, o que resultaria em aprovação condicionada e, por isso, parcial do acordo. A princípio, seria possível aditar ressalvas no âmbito do Poder Legislativo, mas não seria possível emendar os tratados, pois falta aos parlamentares a competência para representar internacionalmente os interesses do país. A Comissão de Constituição e Justiça posicionou-se da mesma maneira quando analisou a possibilidade de (i) aprovação total, (ii) rejeição total ou (iii) aprovação com ressalvas, no caso da Convenção de Viena sobre Direito dos Tratados.

As reservas, do mesmo modo que precisam da convergência entre os Poderes para serem ratificadas, não prescindem dessa convergência no momento de retiradas. Foi necessário novo referendo do Congresso Nacional, por exemplo, para a retirada das reservas à Convenção sobre a Eliminação de todas as formas de Discriminação contra as Mulheres. Essa Convenção foi aprovada pelo Decreto Legislativo 93, de 14.11.1983, com reservas aos $\operatorname{artigos} 15, \S 4^{\circ}$ e $16, \S 1^{\circ},(a),(c),(g)$ e (h), como consequência das recomendações do Poder Executivo, que as opôs no momento da assinatura. As reservas foram feitas diante da incompatibilidade da legislação interna com os dispositivos convencionais, que diferenciavam homens e mulheres quanto ao direito de fixar domicílio conjugal, além de discriminar a mulher quanto à idade mínima para o matrimônio e ao direito de dispor de seus bens quando casada. ${ }^{205}$ Esse Decreto foi revogado pelo Decreto Legislativo 26, de 22.06.1994, promulgado após a alteração do ordenamento jurídico brasileiro no que se refere ao status feminino na sociedade, proporcionada pela Constituição de 1988. No início da

${ }^{205}$ Para uma análise mais detalhada do iter desse tratado, ver APÊNDICE I. 
década de 1990, o Executivo recomendou ao Congresso a retirada dessas reservas, o que culminou em nova apreciação por parte do Poder Legislativo. Uma vez autorizado pelo Congresso, o Presidente retirou as reservas, promulgando a Convenção novamente, em 2002.

Celso Amorim, em audiência na CREDN de 29.08.2007, pede mais rapidez do Congresso Nacional no processo de aprovação de acordos internacionais, o que ajudaria as negociações externas. Segundo o chanceler, o Itamaraty seria constantemente cobrado pelos demais países da comunidade internacional a respeito da entrada em vigor de tratados assinados pelo Brasil. O Deputado Vieira da Cunha, presidente da CREDN, informa o Ministro do Projeto de resolução 47/2007 (mencionado nesta tese, ainda não arquivado) que daria caráter conclusivo às votações dessas matérias no âmbito das Comissões. O apoio dos demais parlamentares garantiria uma tramitação mais célere dos tratados. Ele pediu aos Deputados da CREDN que solicitassem o apoio das respectivas lideranças à aprovação da proposta, a fim de garantir uma tramitação mais rápida dos acordos internacionais. ${ }^{206}$

Conforme Tarciso Dal Maso Jardim, a imprecisão das normas constitucionais brasileiras a respeito do papel do Congresso Nacional em relação à celebração de tratados culmina na necessidade de imposição de condicionantes, por parte do próprio Congresso, ao Executivo nessa matéria. ${ }^{207}$ Valendo-se da experiência própria advinda da atuação profissional, o consultor apresenta diversos comentários a respeito da prática legislativa brasileira, tendo como primeiro exemplo o caso dos Acordos Executivos.

O Acordo Executivo é expressão que designa um instrumento internacional que pode ser concluído pelo chefe do Poder Executivo, independentemente da apreciação do Poder Legislativo. Seria, pela definição do termo, acordo de forma simples, concluído e posto em vigor imediatamente após sua assinatura pelas partes envolvidas. Existe, porém, certa subjetividade na apreciação do que poderia ser classificado como acordo executivo, que, a princípio, poderia ser algo inovador, ou simples subproduto de tratado vigente. Algumas propostas de alteração legislativa, como se verá adiante, têm como objetivo alterar a atuação do Poder Legislativo brasileiro na apreciação desses acordos. Apesar das longas

\footnotetext{
${ }^{206}$ Brasil. Câmara dos Deputados. Relatório de Atividades da Comissão de relações Exteriores e Defesa Nacional, $53^{\text {a }}$ Legislatura, $1^{\text {a }}$ Sessão Legislativa, ano 2007, audiência com o Ministro de Estado Celso Amorim, realizada em 29.08.2007, p. 13. Disponível em: http://www2.camara.leg.br/atividade-legislativa/comissoes/ comissoes-permanentes/credn/documentos/relatorios-de-atividades-2/relatorio-2007/ e http://www2.camara. leg.br/atividade-legislativa/comissoes/comissoes-permanentes/credn/documentos/notas-taquigraficas/NT29 082007.pdf (notas taquigráficas). Acesso: 31.05.2016.

${ }^{207}$ JARDIM, 2011.
} 
elucubrações doutrinárias a respeito, por exemplo, da necessidade de apreciação congressual dos chamados Acordos Executivos, fato é, segundo o consultor, que o Executivo Federal tem celebrado diversos acordos sem a aprovação congressual e, inclusive, sem a sua comunicação ao Congresso.

Para Hildebrando Accioly, existiria a possibilidade de concluir acordos internacionais sem a aprovação do parlamento em casos nos quais a matéria do acordo não fosse de competência exclusiva do Poder Legislativo. ${ }^{208}$ Esses acordos, segundo o autor, não dependeriam de aceite formal por parte dos membros do Poder Legislativo, e seriam, por esse motivo, denominados Acordos Executivos; não subordinados, portanto, à aprovação do Legislativo. Entrariam nessa categoria os seguintes acordos:

(i) Aqueles que tratassem de temas da competência privativa do Poder Executivo, o que Accioly apresenta como tese da razoabilidade da competência privativa;

(ii) Os concluídos por agentes com competência para fazê-lo, e que tratem de temas de interesse local ou de importância restrita;

(iii) Aqueles que apenas interpretam as cláusulas de acordos vigentes;

(iv) Os acordos que apenas complementem tratados vigentes; e

(v) Os acordos que têm como objetivo manter o status quo de determinada situação, ou que estabelecem bases para negociações futuras.

Haroldo Valladão, à época consultor do MRE, em parecer proferido ao chanceler Raul Fernandes, entendeu ser inaceitável que tratados que prescindissem de ratificação fossem imunes à apreciação congressual. Essa solução, segundo Valladão, significaria que o Direito Internacional solucionaria questão afeta à exegese constitucional, o que seria inadmissível. Mesmo escrevendo ambos os autores, Accioly e de Valladão, em época anterior à da Constituição de 1988, as ponderações são válidas ainda na época atual, o que pode ser percebido pela manutenção das discussões doutrinárias a respeito do tema. Para Mazzuoli,

\footnotetext{
208 ACCIOLY, Hildebrando. A ratificação e a promulgação dos tratados em face da Constituição Federal brasileira, in Boletim da Sociedade Brasileira de Direito Internacional. Rio de Janeiro, n. ${ }^{\text {7 }}$, jan./jun. 1948, pp. 5-11.
} 
"O maior ou menor poder que o Governo de um Estado tem para negociar e assinar atos internacionais é assunto típico do direito interno de cada País, que escapa da alçada do Direito Internacional." ${ }^{209}$

São feitas poucas condenações, expressas ou indiretas, à atuação do Executivo, o que demonstra o receio dos parlamentares de criticarem abertamente esse Poder. Por outro lado, o surgimento dessas manifestações mostra que Deputados e Senadores estão começando a discutir, mais ativamente, a sua função nesse processo. Menciono, abaixo, alguns exemplos de manifestações de parlamentares contrárias a algum aspecto da atuação do Executivo.

É possível mencionar o parecer, de 1967, de autoria do Senador Aloysio de Carvalho, que trata da emenda que o Senado pretende fazer ao Projeto proveniente da Câmara referente à Convenção sobre a Nacionalidade da Mulher Casada. Nele, o Senador destaca que, conforme o texto do art. 10 da Convenção, não restaria à outra parte signatária do tratado a possibilidade de se opor em caso de envio de contenda à apreciação da CIJ. Segundo o Senador, o Brasil apôs reserva a essa cláusula, sem que se pudesse saber qual o motivo do Executivo para tanto, em clara crítica a esse Poder.

Do mesmo modo, na discussão da Convenção 169, OIT, o Deputado Fábio Feldmann destaca que a tramitação interna da Convenção levou mais tempo do que a tramitação do tratado que institui a própria OIT. O Executivo demorou para remeter a matéria ao Legislativo, e, na Câmara, o prosseguimento também foi obstruído.

O Deputado Haroldo Lima, em voto em separado de 2002 que trata do TPI, critica abertamente a argumentação da Consultoria Jurídica do MRE. Para ele, a argumentação desse órgão, que refuta as incoerências entre o Estatuto do TPI e a Constituição, não seria convincente, particularmente no que se refere (i) à complementariedade da jurisdição do TPI, por questionar a própria legitimidade do Tribunal, que teria o condão de analisar se determinada decisão do Poder Judiciário nacional foi espúria ou não, conforme pressupõe seu Estatuto; (ii) à constitucionalidade da previsão de pena perpétua, percebendo como uma falha da diplomacia brasileira, que assinou o tratado sem considerar o direito interno.

Em parecer de 1995 sobre a Convenção Interamericana para prevenir, punir e erradicar a violência contra a Mulher (“Convenção de Belém do Pará”), a Deputada Sandra Starling ressalta que seu foco é a necessidade de o Estado adequar-se, internamente, às diretrizes

${ }^{209}$ MAZZUOLI, 2001, p. 85. 
determinadas pela Convenção. Discorda expressamente da reserva ao art. 12 da Convenção, sugerida pelo Itamaraty. Para a relatora, esse artigo apenas dispõe a respeito da participação da sociedade civil na fiscalização do cumprimento das obrigações assumidas pelos Estados signatários. Esse mecanismo seria de extrema valia, uma vez que essa fiscalização é fundamental nos sistemas democráticos. $\mathrm{O}$ artigo, ao contrário do que aponta o MRE, seria um dos mais essenciais da Convenção. Rebatendo a argumentação do Itamaraty, Starling afirma, ainda, que não há duplicação em relação à Convenção Americana de Direitos Humanos (CADH), já que o art. 12 determina que as petições serão analisadas conforme os mesmos procedimentos estabelecidos pela CADH. Não haveria, portanto, duplicação, mas harmonia entre os dois instrumentos, sendo que a Convenção de Belém do Pará define diversos direitos e deveres que não constam na CADH. Para a Deputada,

\footnotetext{
"Do nosso ponto de vista, a importância do artigo em questão é tão óbvia e insofismável, que fica a lamentável impressão de que o Ministério das Relações Exteriores quer apenas evitar constrangimentos ao Estado brasileiro, em virtude das possíveis e prováveis denúncias que surgirão com a ratificação deste instrumento." ${ }^{210}$ (grifo nosso).
}

Ressalto, ainda, parecer elaborado sobre a mesma Convenção, em 1994, pela Deputada Marta Suplicy. A Deputada menciona a Declaração de Viena, resultado da Conferência Mundial dos Direitos Humanos, que teria facilitado a discussão a respeito da violência contra as mulheres. Conforme o disposto na recomendação de Viena, a AGNU adotou, em 10.12.1993, a Declaração sobre a Violência contra a Mulher, que identifica os tipos de violência e que reconheceu, no sistema ONU, a violência baseada em gênero. A Convenção de Belém do Pará insere-se nesse contexto, e seria incoerente o MRE alegar a necessidade de fazer uma ressalva ao art. 12 , por ser disposição inédita e extremamente relevante. A Deputada ressalta sua discordância em relação aos apontamentos do MRE.

Percebe-se, pelo exposto acima, que são poucas as manifestações de expresso descontentamento com a posição do Executivo, mas são exemplos claros de discordância e de atuação parlamentar contra o disposto por esse Poder.

Existem, também, manifestações de membros do Congresso que criticam a demora do próprio Congresso na internalização dos instrumentos internacionais. Por outro lado, apesar

${ }^{210}$ DCN 17.08.1995, p. 18.592. 
de incomum, existem manifestações do Executivo que atribuem ao próprio Poder a demora no processo de internalização de determinado tratado, como ocorreu na Mensagem Presidencial relativa à CVDT, redigida pelo Ministro Celso Lafer. ${ }^{211}$

É possível perceber que não existe consenso na literatura a respeito da atuação do Poder Legislativo em temas relacionados à política externa. Parte dos autores tenta analisar essa atuação de maneira não binária, considerando uma vasta gama de possíveis graus para essa atuação, que, apesar de não ser tão intensa como a dos membros do Poder Executivo, possui nuances, e não é apática ou desinteressada. As descrições presentes no APÊNDICE I desta tese demonstram intensa participação dos membros do Poder Legislativo no processo de internalização de tratados, instrumentos que são resultado direto da atuação em política externa do Poder Executivo.

${ }^{211}$ Para a análise completa dessa tramitação, e, especificamente, para a análise da MSC 116/1992, consultar o item 31 do APÊNDICE I. 


\subsection{A INFLUENCIA DO DIREITO INTERNACIONAL NAS LEIS BRASILEIRAS E SUA RELAÇÃO COM TRATADOS DE DIREITOS HUMANOS}

As leis são uma das maneiras, encontrada pelo Legislativo nacional, de atuar em temas afetos às relações internacionais, dando maior respaldo jurídico às demandas entendidas pela comunidade internacional como relevantes, e, por isso, contempladas em tratados. Este item tem como objetivo tratar da prática legislativa que se tem estabelecido no Brasil a respeito do Direito Internacional e de sua relação com o Direito interno, além de demonstrar, de maneira não exaustiva, a relação temporal e temática entre as leis brasileiras e os tratados internacionais de Direitos Humanos analisados.

Em relação à prática legislativa brasileira, a análise dos tratados e das leis a eles relacionadas possibilitou observar algumas condutas que se tornaram um padrão na atividade parlamentar. Para evitar a exacerbação da faculdade dos integrantes do Executivo de não submeter determinados acordos à apreciação do Parlamento, estabeleceu-se a prática de inserir, nos decretos legislativos de aprovação desses acordos, a chamada cláusula de reserva de competência congressual sobre certos atos internacionais. Exemplo disso é a inserção de frase que condiciona à aprovação do Congresso os ajustes derivados de tratados por ele previamente aprovados, e que, novamente, acarretem encargos ou compromissos gravosos ao patrimônio nacional, conforme inscrito na Constituição pátria. A frase, que se tornou a regra da prática legislativa para projetos de decreto legislativo, tem redação similar à que segue:

\footnotetext{
Ficam sujeitos à aprovação do Congresso Nacional quaisquer atos que possam resultar em revisão do referido tratado, bem como quaisquer ajustes complementares que, nos termos do inciso I do art. 49 da Constituição Federal, acarretem encargos ou compromissos gravosos ao patrimônio nacional.
}

A cláusula destacada acima, segundo Jardim, “(...) denota a maior participação do Legislativo nas questões internacionais e reforça a necessidade constitucional de o Executivo submeter os tratados ao Congresso Nacional, e de lhe informar sobre os acordos a ele não remetidos." 212 Para o consultor, ademais, as denúncias aos tratados aprovados pelo

212 JARDIM, 2011, p. 284. 
Congresso deveriam, igualmente, ser submetidas à sua apreciação. O referendo congressual, ao autorizar a ratificação de um tratado, não obriga o Executivo a fazê-lo. Do mesmo modo, se o Congresso não autoriza a ratificação, fica o Executivo impossibilitado de ratificar o instrumento. Se o instrumento de aprovação congressual de tratado exigir que a denúncia lhe seja submetida, o Executivo, no momento em que aceita ratificar o tratado, deve assimilar essa condição. Apesar de não estar expressa a necessidade de submeter ao Congresso a denúncia dos tratados nos tratados aqui analisados, apresento, a seguir, qual a praxe legislativa que se tem consolidado no caso de tratados de Direitos Humanos no Brasil.

Jardim afirma que, graças à recepção constitucional dos direitos e das garantias previstos nos tratados de Direitos Humanos previstos (art. $5^{\circ}, \S 2^{\circ}, \mathrm{CF}$ ), sejam ou não aprovados pela regra do art. $5^{\circ}, \S 3^{\circ}, \mathrm{CF}$, sua eventual denúncia está, necessariamente, condicionada à apreciação prévia do Congresso Nacional. ${ }^{213}$ Os congressistas precisariam, porém, tornar clara a necessidade de submeter denúncias de tratados à sua apreciação, incluindo essa condição nos decretos legislativos que aprovem tratados.

A praxe legislativa de internalização de tratados de Direitos Humanos consolidou, a partir da década de $1990,{ }^{214}$ a inserção, com ínfima variação, da cláusula similar à exposta acima, que indica a necessidade de aprovação do Congresso Nacional de quaisquer atos que possam resultar em revisão ou em ajustes complementares do instrumento internacional aprovado, com menção expressa às modificações que acarretem encargos ou compromissos gravosos ao patrimônio nacional, nos termos do art. 49, I, CF. Dos 85 (oitenta e cinco) instrumentos que constam no processo de internalização dos tratados analisados nessa tese, quarenta e dois continham disposição similar, o que significa que $49 \%$ do total dos instrumentos analisados continham tal disposição. Considerados apenas os 67 (sessenta e sete) instrumentos posteriores a 1988 , essa proporção sobe para $63 \%$.

Os 85 decretos analisados são compostos por 44 (quarenta e quatro) Decretos Legislativos e 41 (quarenta e um) Decretos Executivos. Desses, 25 (vinte e cinco) Decretos Legislativos (56\%); e 17 (dezessete) Decretos Executivos (41\%), continham disposição

\footnotetext{
213 JARDIM, 2011, p. 285.

$214 \mathrm{O}$ primeiro caso encontrado dentre os instrumentos normativos analisados foi o Decreto Legislativo 28/1990, relativo à Convenção sobre os Direitos da Criança.
} 
semelhante. ${ }^{215}$ Apenas dois instrumentos, ambos referentes à Convenção Americana sobre Direitos Humanos, não mencionam, expressamente, o art. 49, I, CF. ${ }^{216}$

A discrepância entre o número de Decretos Executivos e Legislativos que têm essa cláusula pode ser, em parte, explicada pela existência de decretos legislativos que aprovam mais de um tratado ou Protocolo, sendo que cada protocolo é publicado, posteriormente, por um Decreto Presidencial distinto. Existem alguns casos, porém, nos quais apenas os Decretos

${ }^{215}$ Os tratados e instrumentos nacionais que contêm a referida disposição são os seguintes: (i) Convenção sobre o Estatuto dos Apátridas, Decreto Legislativo 38/1995 e Decreto Presidencial 4.246/2002; (ii) Convenção para a Redução dos Casos de Apatridia, Decreto Legislativo 274/2007 e Decreto Presidencial 8.501/2015; (iii) Declaração facultativa da Convenção internacional sobre a eliminação de todas as formas de Discriminação Racial, Decreto Legislativo 57/2002; (iv) Protocolo Facultativo ao Pacto Internacional sobre Direitos Civis e Políticos, Decreto Legislativo 311/2009; (v) Retirada das reservas à Convenção sobre a eliminação de todas as formas de discriminação contra a mulher, Decreto Presidencial 4.377/2002 e Decreto Legislativo 26/1994; (vi) Protocolo facultativo à Convenção sobre eliminação de todas as formas de discriminação contra a mulher, Decreto Legislativo 107/2002 e Decreto Presidencial 4.316/2002; (vii) Protocolo Facultativo à Convenção contra a Tortura e Outros Tratamentos ou Penas Cruéis, Desumanos ou Degradantes, Decreto Legislativo 483/2006 e Decreto Presidencial 6.085/2007; (viii) Declaração que reconhece a competência do Comitê previsto na Convenção, Decreto Legislativo 57/2006; (ix) Convenção 169 da OIT sobre Povos Indígenas e Tribais, Decreto Legislativo 143/2002 e Decreto Presidencial 5.051/2004; (x) Convenção sobre os Direitos da Criança, Decreto Legislativo 28/1990; (xi) Protocolo Facultativo à Convenção sobre os Direitos da Criança referentes à venda de criança, à prostituição infantil e à pornografia infantil, Decreto Legislativo 230/2003 e Decreto Presidencial 5.007/2004; (xii) Protocolo facultativo à Convenção sobre os direitos da criança relativos ao envolvimento de crianças em conflitos armados, Decreto Presidencial 5.006/2004; (xiii) Estatuto de Roma do Tribunal Penal Internacional, Decreto Legislativo 112/2002 e Decreto Presidencial 4.388/2002; (xiv) Acordo sobre Privilégios e Imunidades do Tribunal Penal Internacional, Decreto Legislativo 291/2011 e Decreto Presidencial 8.604/2015; (xv) Convenção das Nações Unidas contra o Crime Organizado Transnacional ("Convenção de Palermo"), Decreto Legislativo 231/2003 e Decreto Presidencial 5.015/2004; (xvi) Protocolo adicional para o Combate ao tráfico de Migrantes por via terrestre, marítima e aérea, Decreto Presidencial 5016/2004; (xvii) Protocolo para a Prevenção, Repressão e Punição do Tráfico de Pessoas, em especial Mulheres e Crianças, Decreto Presidencial 5017/2004; (xviii) Convenção Internacional sobre os Direitos das Pessoas com Deficiência e Protocolo Facultativo, Decreto Legislativo 186/2008 e Decreto Presidencial 6.949/2009; (xix) Convenção Internacional para a Proteção de Todas as Pessoas Contra o Desaparecimento Forçado, Decreto Legislativo 661/2010 e Decreto Presidencial 8.767/2016; (xx) Convenção Americana sobre Direitos Humanos, Decreto Legislativo 27/1992; (xxi) Protocolo adicional à Convenção Americana sobre Direitos Humanos em matéria de direitos econômicos, sociais e culturais e Protocolo referente à abolição da pena de morte, Decreto Legislativo 56/1995 e reconhecimento da competência obrigatória da corte interamericana de direitos humanos, Decreto Legislativo 89/1998; (xxii) Convenção Interamericana para prevenir, punir e erradicar a violência contra a mulher, Decreto Legislativo 107/1995; (xxiii) Convenção Interamericana sobre o Desaparecimento Forçado de Pessoas Decreto Legislativo 127/2011 e Decreto Presidencial 8.766/2016; (xxiv) Convenção Interamericana sobre tráfico internacional de menores Decreto Legislativo 105/1996; (xxv) Convenção Interamericana para a eliminação de todas as formas de discriminação contra as pessoas portadoras de deficiência, Decreto Legislativo 198/2001 e Decreto Presidencial 3.956/2001; (xxvi) Protocolo de Assunção sobre Compromisso com a Promoção e Proteção dos Direitos Humanos do Mercosul, Decreto Legislativo 592/2009 e Decreto Presidencial 7.225/2010; e (xxvii) Convenção de Viena sobre o Direito dos Tratados, Decreto Legislativo 496/2009 e Decreto Presidencial 7.030/2009.

${ }^{216}$ Decreto Legislativo 27/1992 e Decreto Legislativo 89/1998, este referente à solicitação de reconhecimento da competência obrigatória da Corte Interamericana de Direitos Humanos. 
Legislativos contêm o dispositivo, não sendo seguidos pelos Decretos Executivos. Como o Decreto Presidencial aprova o Legislativo, porém, a inserção da cláusula no último é suficiente para que qualquer alteração seja submetida ao Poder Legislativo.

Nesses casos, apesar de não mencionada expressamente nos tratados de direitos Humanos analisados, os parlamentares condicionaram, expressamente, em outros decretos legislativos, a denúncia dos tratados à prévia apreciação congressual, algo que pode tornarse praxe no país, com a consolidação de prática nesse sentido.

Segundo Peter Häberle, o Poder Constituinte originário, responsável por elaborar a Constituição de um Estado, não seria ilimitado, como era antigamente. O jus cogens, ou direito cogente, conjunto de normas imperativas respeitadas pela comunidade internacional, serviria como balizador para as normas internas. ${ }^{217}$ Segundo o art. 53, CVDT, seriam as normas reconhecidas pela comunidade internacional das quais não se permite qualquer derrogação, e que apenas poderiam ser modificadas por norma posterior de Direito Internacional da mesma natureza. Não existe rol exaustivo de normas de jus cogens, mas algumas normas são de tal maneira aceitas internacionalmente que se tornaram diretrizes normativas para a maioria dos legisladores nacionais. É possível mencionar, nesse sentido, o repúdio à escravidão e à tortura, veemente condenadas pela sociedade internacional. Isso demonstra a patente influência do Direito Internacional no Direito interno. Quanto ao tema, para Antonio Augusto Cançado Trindade:

\footnotetext{
Com o passar dos anos, houve um avanço, no sentido de, ao menos, distinguir entre os países em que certas normas dos instrumentos internacionais de direitos humanos passaram a ter aplicabilidade direta, e os países em que necessitavam elas ser "transformadas" em leis ou disposições de direito interno para ser aplicadas pelos tribunais e autoridades administrativas. ${ }^{218}$
}

Os Direitos Humanos receberam atenção especial do legislador pátrio, seja no âmbito constitucional, que prevê a inserção de tratados internacionais que tratem do tema como equivalentes a emendas constitucionais, seja no âmbito infraconstitucional. Exemplo disso é a Lei 12.986, de 2014, que transforma o Conselho de Defesa dos Direitos da Pessoa Humana em Conselho Nacional dos Direitos Humanos (CNDH), cujo artigo $2^{\circ}$, §1ํㅡㄹ reza:

\footnotetext{
217 Peter Häberle adota essa teoria na obra "Teoria do Estado Constitucional Cooperativo".

218 TRINDADE, Antonio Augusto Cançado. Direito Internacional e Direito Interno: sua interação na proteção dos Direitos Humanos Informação obtida em: http://www.pge.sp.gov.br/centrodeestudos/bibliotecavirtual/ instrumentos/introd.htm. Acesso: 15.06.2016.
} 
Art. $2^{\circ}$. O CNDH tem por finalidade a promoção e a defesa dos direitos humanos, mediante ações preventivas, protetivas, reparadoras e sancionadoras das condutas e situações de ameaça ou violação desses direitos.

$\S 1^{\circ}$. Constituem direitos humanos sob a proteção do CNDH os direitos e garantias fundamentais, individuais, coletivos ou sociais previstos na Constituição Federal ou nos tratados e atos internacionais celebrados pela República Federativa do Brasil. (grifo nosso).

Segundo Jorge Miranda, entre as tendências evolutivas do Direito Internacional, encontra-se a integração sistemática com o Direito interno, que culmina em relações mais cooperativas entre esses ordenamentos. ${ }^{219}$ Isso poderia ser observado não apenas na inovação constitucional do art. $4^{\circ}$, que trata das relações internacionais do Brasil, e parágrafos $3^{\circ}$ e $4^{\circ}$ do art. $5^{\circ}$; mas no Recurso Extraordinário (RE) 466.343, julgado pelo STF em 2008. Nesse RE, o Supremo, ao julgar diversas ações que envolviam a prisão civil do depositário infiel, alterou seu entendimento a respeito da hierarquia de tratados internacionais de Direitos Humanos no ordenamento brasileiro, e passou a adotar a tese da supralegalidade do Pacto de São José da Costa Rica. Por ser norma supralegal, o Pacto teria o condão de se sobrepor a lei anterior incompatível. A ementa do RE aponta:

EMENTA: PRISÃO CIVIL. Depósito. Depositário infiel. Alienação fiduciária. Decretação da medida coercitiva. Inadmissibilidade absoluta. Insubsistência da previsão constitucional e das normas subalternas. Interpretação do art. $5^{\circ}$, inc. LXVII e $\S \S 1^{\circ}, 2^{\circ}$ e $3^{\circ}$, da CF, à luz do art. $7^{\circ}, \S 7$, da Convenção Americana de Direitos Humanos (Pacto de San José da Costa Rica). Recurso improvido. Julgamento conjunto do RE $n^{\circ} 349.703$ e dos HCs no 87.585 e no 92.566. E ilícita a prisão civil de depositário infiel, qualquer que seja a modalidade do depósito. ${ }^{220}$ (grifo nosso).

A dicotomia entre as doutrinas monista e dualista permeou as discussões a respeito dos Direitos Interno e Internacional por muito tempo. Segundo os dualistas, tratar-se-iam de dois campos separados, e que não se relacionariam. Nesse sentido, o Direito Internacional teria que ser transformado em direito interno, para ter validade em determinado país. Para os monistas, integrariam uma só ordem: o Direito, portanto, seria uno. Para Antonio Augusto Cançado Trindade, no âmbito da proteção dos Direitos Humanos, o Direito Internacional e o Direito interno formariam um todo indivisível, apontando na mesma direção, com o

${ }^{219}$ MIRANDA, Jorge. Curso de Direito Internacional Público, 2009.

220 Informação obtida em: http://redir.stf.jus.br/paginadorpub/paginador.jsp?docTP=AC\&docID=595444. Acesso: 15.06.2016. 
objetivo comum de proteção da pessoa humana. Estariam, portanto, em constante interação, em benefício dos indivíduos que almejam proteger. Segundo o autor, essa diferenciação entre monistas e dualistas, que enfatiza as distinções das situações reguladas pelos dois ordenamentos, não auxilia a efetiva proteção internacional dos Direitos Humanos. ${ }^{221}$

É possível afirmar, a título de argumento, que o Brasil adota sistema dualista em relação à incorporação de tratados, pois os tratados precisam ser incorporados à ordem interna para poderem ser aplicados no país, e isso envolve, inclusive, um processo complexo, com a atuação de dois Poderes. É possível argumentar, também, pelo sistema dualista moderado. Isso ocorre pois, apesar da necessidade de os instrumentos internacionais serem incorporados ao ordenamento pátrio, eles o são mediante Decreto Presidencial. Estes, por sua vez, são atos administrativos, inferiores, portanto, às leis. Apesar disso, os tratados vigoram no país com hierarquia de lei. Poder-se-ia, ainda, argumentar, utilizando os mesmos fatos, que o Brasil é monista, pois, ao incorporar um tratado na ordem jurídica interna, apenas dá publicidade ao mesmo: o que seria incorporado, portanto, é o próprio tratado, anexo ao Decreto. Percebe-se, considerando todas as possibilidades de argumentação acima descritas, a constante e a crescente superação da discussão entre monismo e dualismo, debate que não traz, na opinião da autora, inovações significativas à ordem jurídica, tampouco à efetiva implementação de tratados.

Ainda no que se refere à influência do Direito Internacional nas leis internas, existem guias legislativos para a implementação de convenções internacionais. Esses guias são, via de regra, resultado de estudos elaborados por especialistas de diversos países, que representam tradições jurídicas diferentes, relacionados à temática do tratado. O objetivo é auxiliar os Estados em via de ratificar e de implementar os tratados, identificando requisitos legislativos e possíveis conflitos que podem surgir durante o processo de internalização. Esses guias apresentam alternativas aos Estados que se preparam para adotar legislação mais coerente com o objetivo do tratado. ${ }^{222}$ Um exemplo disso é o Guia Legislativo para a

${ }^{221}$ TRINDADE, Antonio Augusto Cançado. Direito Internacional e Direito Interno: sua interação na proteção dos Direitos Humanos Informação obtida em: http://www.pge.sp.gov.br/centrodeestudos/bibliotecavirtual/ instrumentos/introd.htm. Acesso: 15.06.2016.

${ }^{222}$ Legislative Guide for the Implementation of the United Nations Convention against Corruption. Informação obtida em: https://www.unodc.org/unodc/en/treaties/CAC/legislative-guide.html. Acesso: 08.06.2016. 
Implementação do Protocolo Adicional à Convenção das Nações Unidas contra o crime organizado transnacional. ${ }^{223}$

Existem, ademais, "leis-modelo" (ou "Model Laws"), como a Model Law against Trafficking in Persons. ${ }^{224} \mathrm{O}$ objetivo dessa lei-modelo é responder à demanda da AGNU de promover e de auxiliar nos esforços dos Estados que desejavam integrar ou implementar em seus territórios a Convenção da ONU contra o Crime Organizado Transnacional. Foi elaborada particularmente para assistir aqueles países que tinham a intenção de implementar as provisões do Protocolo dessa Convenção (Protocolo para prevenir e punir o tráfico de pessoas, particularmente mulheres e crianças). O intuito, conforme a própria lei-modelo, é facilitar a sistematização da assistência legislativa pelos órgãos responsáveis da ONU, bem como facilitar a alteração da legislação nacional e a implementação de novas leis pelos Estados. A ideia é que seja possível adaptar as disposições do modelo a qualquer tradição legal e a quaisquer condições econômica, cultural e geográfica. ${ }^{225}$

Existe influência crescente do Direito Internacional no Direito interno. Alguns tratados, inclusive, determinam que os Estados deveriam adotar legislações a respeito do tema regulado. Exemplo disso são as Convenções Interamericanas sobre o Desaparecimento Forçado e para Eliminação de todas as formas de Discriminação contra as Pessoas Portadoras de Deficiência. A primeira determina:

Artigo I. Os Estados Partes nesta Convenção comprometem-se a: (...) d. Tomar as medidas de caráter legislativo, administrativo, judicial ou de qualquer outra natureza que sejam necessárias para cumprir os compromissos assumidos nesta Convenção"

A segunda, por sua vez, reza:

Artigo III. Para alcançar os objetivos desta Convenção, os Estados Partes comprometem-se a:

1. Tomar as medidas de caráter legislativo, social, educacional, trabalhista, ou de qualquer outra natureza, que sejam necessárias para eliminar a discriminação contra as pessoas portadoras de deficiência e proporcionar a sua plena

223 Informação obtida em: https://www.unodc.org/unodc/en/treaties/CTOC/legislative-guide.html. Acesso: 08.06.2016.

${ }^{224}$ Model Law against Trafficking in Persons. Informação obtida em: https://www.unodc.org/documents/ human-trafficking/UNODC_Model_Law_on_Trafficking_in_Persons.pdf. Acesso: 08.06.2016.

${ }^{225}$ Model Law against Trafficking in Persons. Informação obtida em: https://www.unodc.org/documents/ human-trafficking/UNODC_Model_Law_on_Trafficking_in_Persons.pdf, p. 3. Acesso: 08.06.2016. 
integração à sociedade, entre as quais as medidas abaixo enumeradas, que não devem ser consideradas exclusivas: (...). (grifo nosso).

Até o depósito desta tese, o único tratado internalizado conforme o rito equivalente a emenda constitucional, foi a Convenção sobre os Direitos das Pessoas com Deficiência, que possui, assim, status constitucional.

A influência do Direito Internacional no ordenamento brasileiro pode ser percebida em dois modelos principais. Existem leis internas que mencionam expressamente os tratados, sejam ou não temporalmente próximas à elaboração ou à internalização deles. Entre as leis que não mencionam expressamente um tratado internacional como motivação, existem aquelas que são temporalmente próximas à assinatura e/ou à internalização de determinado tratado; e aquelas que, apesar da distância temporal, tratam de temática idêntica à de instrumento internacional assinado pelo Brasil. A menção dos temas tratados por instrumentos internacionais, em alguns casos, é reservada à mais alta lei do ordenamento brasileiro, a Constituição Federal, como se verá adiante.

Algumas leis mencionam tratados internacionais como motivação para sua elaboração, como é o caso da Lei 11.340, de 2006, popularmente conhecida como "Lei Maria da Penha", que cria mecanismos para coibir a violência doméstica e familiar contra a mulher. Essa Lei menciona, expressamente, o art. 226, $\S 8^{\circ}, \mathrm{CF}$, que determina que o Estado deve assegurar a assistência à família e de cada um de seus integrantes, “(...) criando mecanismos para coibir a violência no âmbito de suas relações"; além de mencionar a Convenção sobre a Eliminação de Todas as Formas de Discriminação contra as Mulheres e a Convenção Interamericana para Prevenir, Punir e Erradicar a Violência contra a Mulher.

A lei brasileira que define mecanismos para a implementação do Estatuto dos Refugiados, por sua vez, foi promulgada apenas na década de 1990 (Lei 9.474/1997), enquanto a Convenção que trata do tema é da década de 1950. Apesar dessa diferença temporal, a Lei menciona a Convenção expressamente, ao determinar que:

Art. $5^{\circ}$ O refugiado gozará de direitos e estará sujeito aos deveres dos estrangeiros no Brasil, ao disposto nesta Lei, na Convenção sobre o Estatuto dos Refugiados de 1951 e no Protocolo sobre o Estatuto dos Refugiados de 1967, cabendo-lhe a obrigação de acatar as leis, regulamentos e providências destinados à manutenção da ordem pública. (grifo nosso). 
A Convenção Internacional sobre a Eliminação de Todas as formas de Discriminação Racial, de 1965, por sua vez, é mencionada expressamente pelo art. 38, II da Lei 12.288/2010, que institui o Estatuto da Igualdade Racial, e reza:

\begin{abstract}
Art. 38, II. A implementação de politicas voltadas para a inclusão da população negra no mercado de trabalho será de responsabilidade do poder público, observando-se: (...)

II - os compromissos assumidos pelo Brasil ao ratificar a Convenção Internacional sobre a Eliminação de Todas as Formas de Discriminação Racial, de 1965" (grifo nosso)
\end{abstract}

Essa Lei cita, ainda, a Convenção 111, de 1958, da OIT, sobre a discriminação no emprego e na profissão, não analisada nesta tese. O Decreto 8.136/2013, que aprova o regulamento do Sistema Nacional de Promoção da Igualdade Racial (SINAPIR), instituído pela Lei 12.288, elenca a mesma Convenção entre seus fundamentos. ${ }^{226}$

A Lei 6.001/1973, que dispõe sobre o Estatuto do Índio, é anterior à Convenção 169 da OIT sobre Povos Indígenas e Tribais, mas posterior à Convenção 107 da OIT, sobre a proteção e integração das populações tribais e semitribais de países independentes, diretamente ligada à Convenção 169. Esta, afinal, foi o resultado de uma revisão da Convenção 107, o que está inscrito em seu preâmbulo:

\footnotetext{
“A Conferência Geral da Organização Internacional do Trabalho, (...) Após ter decidido adotar diversas propostas sobre a revisão parcial da Convenção sobre populações Indígenas e Tribais, 1957 (n. 107), Após ter decidido que essas propostas deveriam tomar a forma de uma Convenção Internacional que revise a Convenção Sobre Populações Indigenas e Tribais, 1957, adota, (...), a seguinte Convenção, (...)”.
}

O Estatuto do Índio, em seu art. 66, afirma que “O órgão de proteção ao silvícola fará divulgar e respeitar as normas da Convenção 107’'. Nota-se, ademais, clara inovação da Constituição Federal de 1988 em relação às predecessoras: enquanto estas não mencionavam os indígenas, a CF/1988 trata dessa população em artigos esparsos, como o que cuida da cultura (art. 215, particularmente o $\S 1^{\circ}$, que reza “O Estado protegerá as manifestações das culturas populares, indigenas e afro-brasileiras, e das de outros grupos participantes do processo civilizatório nacional”); e em capítulo específico (capítulo VIII - Dos Índios).

${ }^{226}$ Conforme o art. $3^{\text {o }}$, II dessa Lei. Informação obtida em: http://www.planalto.gov.br/ccivil_03/_Ato20112014/2013/Decreto/D8136.htm. Acesso: 09.06.2016. 
Historicamente, no Brasil, existem diversos exemplos de leis que têm relação temporal próxima com tratados de Direitos Humanos que cuidam da mesma temática. A Lei que define e pune o crime de Genocídio, por exemplo, é da década de 1950 (lei 2.889/1956, assinada pelo Presidente Juscelino Kubitschek e pelo Ministro Nereu Ramos), elaborada menos de dez anos após a celebração da Convenção para a prevenção e repressão do crime de Genocídio (1948). ${ }^{227}$ Ela comina para o crime de genocídio penas previstas no Código Penal brasileiro, da década de $1940 .{ }^{228}$ É possível, também, encontrar projetos de lei que se relacionam intimamente com o Direito Internacional, como aqueles que (i) dispõem sobre o crime de genocídio, além de definir crimes contra a humanidade, de guerra e contra a administração da justiça do Tribunal Penal Internacional, além de dispor sobre a cooperação com o Tribunal Penal Internacional; ${ }^{229}$ e (ii) dispõem sobre condutas que constituem crimes de violação do direito internacional humanitário, estabelece normas para a cooperação judiciária com o TPI. ${ }^{230}$

227 A Lei foi alterada pelas Leis 8.072, de 1990 e 8.930, de 1994. Informação obtida em: http://www.planalto.gov.br/ccivil_03/leis/L2889.htm. Acesso: 09.06.2016.

${ }^{228}$ Decreto-Lei 2.848 , de 07.12.1940.

229 Informação obtida em: http://www.camara.gov.br/proposicoesWeb/fichadetramitacao?id Proposicao=410747. Acesso: 09.06.2016.

230 Informação obtida em: http://www.camara.gov.br/proposicoesWeb/fichadetramitacao?id Proposicao=343615\&ord=1. Acesso: 09.06.2016. 
É possível fazer uma ligação entre a Convenção sobre o Genocídio e o Estatuto de Roma, que define os crimes de genocídio, ${ }^{231}$ contra a humanidade ${ }^{232}$ e de guerra. ${ }^{233}$ No art. 5.2 do Estatuto de Roma, destaca-se que o TPI poderá julgar o crime de agressão no momento em que seja tipificado. A lei brasileira tipifica, apenas, o crime de genocídio na lei 2.889/1956. Com exceção do genocídio, portanto, os outros crimes, tipificados pelo Estatuto de Roma, não estão definidos pelo direito brasileiro. O Judiciário brasileiro, portanto, não poderia tratar desses crimes. Adota-se, no Brasil, o princípio da legalidade estrita, uma vez que se verifica, no país, a civil law, e não a common law. Apesar de o Estatuto de Roma ter sido internalizado no Brasil, não há disposição, no direito interno, que trate de crimes de guerra e de crimes contra a humanidade, mas, apenas, do crime de genocídio.

A lei 2.889/1956 estabelece penas para a prática de genocídio, com paralelo entre o instrumento internacional e a legislação interna - o Código Penal. ${ }^{234}$ Tramita, atualmente, no Congresso Nacional, projeto de lei 4.038/2008, que “dispõe sobre o crime de genocídio, define os crimes contra a humanidade, os crimes de guerra e os crimes contra a administração da justiça do Tribunal Penal Internacional, institui normas processuais

231 Artigo $6^{\circ}$ : Crime de Genocídio: Para os efeitos do presente Estatuto, entende-se por "genocídio", qualquer um dos atos que a seguir se enumeram, praticado com intenção de destruir, no todo ou em parte, um grupo nacional, étnico, racial ou religioso, enquanto tal: a) Homicídio de membros do grupo; b) Ofensas graves à integridade física ou mental de membros do grupo; c) Sujeição intencional do grupo a condições de vida com vista a provocar a sua destruição física, total ou parcial; d) Imposição de medidas destinadas a impedir nascimentos no seio do grupo; e) Transferência, à força, de crianças do grupo para outro grupo.

${ }^{232}$ Artigo $7^{\circ}$ : Crimes contra a Humanidade

1. Para os efeitos do presente Estatuto, entende-se por "crime contra a humanidade", qualquer um dos atos seguintes, quando cometido no quadro de um ataque, generalizado ou sistemático, contra qualquer população civil, havendo conhecimento desse ataque:

a) Homicídio; b) Extermínio; c) Escravidão; d) Deportação ou transferência forçada de uma população;

e) Prisão ou outra forma de privação da liberdade física grave, em violação das normas fundamentais de direito internacional; f) Tortura; g) Agressão sexual, escravatura sexual, prostituição forçada, gravidez forçada, esterilização forçada ou qualquer outra forma de violência no campo sexual de gravidade comparável; h) Perseguição de um grupo ou coletividade que possa ser identificado, por motivos políticos, raciais, nacionais, étnicos, culturais, religiosos ou de gênero, tal como definido no parágrafo 3o, ou em função de outros critérios universalmente reconhecidos como inaceitáveis no direito internacional, relacionados com qualquer ato referido neste parágrafo ou com qualquer crime da competência do Tribunal;

i) Desaparecimento forçado de pessoas; j) Crime de apartheid; k) Outros atos desumanos de caráter semelhante, que causem intencionalmente grande sofrimento, ou afetem gravemente a integridade física ou a saúde física ou mental. (...)

${ }^{233}$ Artigo $8^{\circ}$ :Crimes de Guerra: 1. O Tribunal terá competência para julgar os crimes de guerra, em particular quando cometidos como parte integrante de um plano ou de uma política ou como parte de uma prática em larga escala desse tipo de crimes. (...)

${ }^{234}$ Lei 2.889/1956. Disponível em: http://www.planalto.gov.br/ccivil_03/leis/12889.htm. Acesso: 10.10.2014. 
específicas, dispõe sobre a cooperação com o Tribunal Penal Internacional, e dá outras providências". 235

A Convenção sobre a Nacionalidade da Mulher Casada, de 1957, por sua vez, é anterior, por alguns anos, à Lei 4.121/1962, que dispõe sobre a situação jurídica da mulher casada, mas não a menciona expressamente. A MSC referente a essa Convenção, entretanto, é de 1966, posterior, portanto, à promulgação da lei.

A Lei 8.069, que dispõe sobre o Estatuto da Criança e do Adolescente (1990), é contemporânea ao processo de internalização da Convenção sobre os Direitos da Criança, de 1989. Apesar de não a mencionar expressamente, a Lei, ao tratar da adoção internacional, cita a Convenção de Haia, de 1993, relativa à proteção das Crianças e à Cooperação em Matéria de Adoção Internacional. ${ }^{236}$

Em alguns casos, a legislação nacional se antecipou ao Direito Internacional. Esse é o caso, em alguma medida, da Convenção sobre os Direitos Políticos da Mulher. Apesar de o instrumento internacional prever diversos direitos às cidadãs, a mulher pode votar no Brasil desde a década de 1930, vinte anos antes de sua celebração. ${ }^{237}$

Apesar de não ter relação direta com a tramitação da Convenção sobre os Direitos Políticos da Mulher, e não ter sido considerado para o cômputo dos argumentos para os propósitos desta tese, farei, aqui, breve análise do PDC 1597/2005, que tem como objetivo fazer que a Convenção tenha status de Emenda Constitucional. A justificativa do projeto, de autoria do Deputado Dilmas Ramalho, aponta que, com a EC 45/2004, passou a existir a possibilidade de que tratados de Direitos Humanos equivalessem a emendas constitucionais. Decerto, segundo o Deputado, o constituinte derivado não pretendeu excluir dessa possibilidade os tratados previamente internalizados no país, o que seria inconcebível e, até mesmo, contrário ao espírito da Emenda. Para isso, bastaria que um projeto de decreto legislativo fosse aprovado seguindo os trâmites de uma Emenda Constitucional; ou seja, por

\footnotetext{
235 Informação disponível em: http://www.camara.gov.br/proposicoesWeb/fichadetramitacao?idProposicao $=410747$. Acesso: 10.10 .2014 .

236 A redação foi resultado de alteração feita em 2009, pela Lei 12.010. Art. 51. Considera-se adoção internacional aquela na qual a pessoa ou casal postulante é residente ou domiciliado fora do Brasil, conforme previsto no Artigo 2 da Convenção de Haia, de 29 de maio de 1993, Relativa à Proteção das Crianças e à Cooperação em Matéria de Adoção Internacional, aprovada pelo Decreto Legislativo no 1, de 14 de janeiro de 1999, e promulgada pelo Decreto no 3.087, de 21 de junho de 1999.

${ }^{237}$ Informação obtida em: http://www2.camara.leg.br/legin/fed/decret/1930-1939/decreto-21076-24-fevereiro1932-507583-publicacaooriginal-1-pe.html. Acesso: 09.06.2016.
} 
duas votações, nas duas Casas do Congresso, em dois turnos. Daí a intenção do Deputado e de seus pares de apresentar esse projeto.

O projeto foi devolvido ao autor, por ter sido considerado inconstitucional, nos termos do RICD, art. 137, $\S 1^{\circ}$, II, b. A justificativa é que o projeto pretenderia alterar a natureza jurídica de norma que decorre de tratado multilateral, celebrado pelo Brasil e ratificado após autorização do Congresso (Decreto Legislativo 123/1955), internalizada no ordenamento jurídico nacional pelo Decreto Presidencial 52.476/1963, que possui status de lei ordinária. A regra constitucional da EC 45/2004, que permite que seja atribuído caráter de emenda aos tratados relativos a Direitos Humanos, é aplicável, apenas, aos acordos internacionais cuja ratificação ainda não foi homologada e cujas normas ainda não ingressaram no ordenamento jurídico brasileiro. ${ }^{238} \mathrm{O}$ projeto, portanto - e infelizmente - foi arquivado.

Existem outros exemplos de antecipação da legislação nacional ao Direito Internacional. É o caso de leis brasileiras que tratam da situação da pessoa com deficiência no país: a Lei 7.853/1989 dispõe sobre o apoio às pessoas portadoras de deficiência e sua integração social, além de instituir a tutela de interesses coletivos ou difusos dessas pessoas. Essa Lei foi regulamentada pelo Decreto 3.298/1999, cuja publicação é apenas seis meses posterior à celebração do instrumento interamericano para a eliminação de todas as formas de discriminação contra as pessoas portadoras de deficiência. O tratado celebrado em âmbito internacional sobre o mesmo tema (Convenção sobre os Direitos das Pessoas com Deficiência) é posterior, de 2006. A Lei 13.146, que institui a Lei brasileira de Inclusão da Pessoa com Deficiência (Estatuto da Pessoa com Deficiência), é de 2015.

Além dos exemplos de leis que estão temporalmente próximas dos tratados internacionais que tratam do mesmo tema, existem aquelas que, apesar da distância temporal, tratam dos mesmos temas. Exemplo disso é a inovação do capítulo V do Código Penal brasileiro, intitulado "Do lenocínio e do tráfico de pessoa para fim de prostituição ou outra forma de exploração sexual", cuja redação foi dada pela Lei 12.015, de 2009. A Convenção para a repressão do tráfico de pessoas e do lenocínio, entretanto, é da década de 1950. A inovação do Código Penal brasileiro, que pune, desde 2003, a redução de alguém à condição

238 Informação obtida em: http://www.camara.gov.br/proposicoesWeb/fichadetramitacao?idProposicao =166493. Acesso: 04.03.2016. 
análoga à de escravo, ${ }^{239}$ também é bastante posterior à promulgação, no Brasil, da Convenção concernente à abolição do Trabalho Forçado, que ocorreu em 1966.

A Convenção sobre o Estatuto dos Apátridas não dispõe de legislação nacional até o momento, mas existe projeto de lei que almeja proteger indivíduos nessa condição. ${ }^{240}$ Tratase do PL 2516/2015, ${ }^{241}$ que institui a Lei de Migração, que, no artigo $1^{\circ}, \S 1^{\circ}$, IV define o apátrida como "pessoa não considerada por qualquer Estado, conforme sua legislação, como seu nacional, nos termos da Convenção sobre o Estatuto dos Apátridas, de 1954, promulgada pelo Decreto $n^{\circ} 4.246$, de 22 de maio de 2002" (grifo nosso). Essa lei, que revoga, em parte, o Estatuto do Estrangeiro (Lei 6.815/80), também faz menção às garantias provenientes de tratados, ao apontar:

\begin{abstract}
Art. $2^{\circ}$ Esta Lei não prejudica a aplicação de normas internas e internacionais especificas sobre refugiados, asilados, agentes e pessoal diplomático ou consular, funcionários de organização internacional e seus familiares.

Art. $4^{\circ}$ Ao migrante é garantida no território nacional, em condição de igualdade com os nacionais, a inviolabilidade do direito à vida, à liberdade, à igualdade, à segurança e à propriedade, bem como são assegurados:

$\S 1^{\circ}$ Os direitos e as garantias previstos nesta Lei serão exercidos em observância ao disposto na Constituição Federal, independentemente da situação migratória, observado o disposto no $\xi 4^{\circ}$ deste artigo, e não excluem outros decorrentes de convenções, tratados e acordos internacionais de que o Brasil seja parte. (grifo nosso)
\end{abstract}

Da mesma maneira, tramita, desde 2011, projeto de lei que almeja tipificar o crime de desaparecimento forçado de pessoa, tornando-o crime hediondo. ${ }^{242}$

Houve significativa movimentação, por parte da sociedade internacional, para elaborar e celebrar tratados com o objetivo de proteger os Direitos Humanos a partir da década de 1980. A combinação da conjuntura internacional de pós-Guerra Fria e do fim do regime militar no Brasil culminou na assinatura de diversos tratados por parte do governo. Exemplo disso é o início do processo de internalização, no Brasil, de tratados elaborados durante o

\footnotetext{
${ }^{239}$ Artigo 149 do Código Penal, conforme redação dada pela Lei 10.803, de 11.12.2003.

240 Informação obtida em: http://www.acnur.org/t3/portugues/noticias/noticia/governo-do-brasil-anunciaprojeto-de-lei-para-proteger-pessoas-sem-patria/. Acesso: 09.06.2016.

${ }^{241}$ Originário do PLS 288/2013, de autoria do Senador Aloysio Nunes Ferreira. Em 14.12.2016, o Projeto encontrava-se na Comissão de Relações Exteriores e Defesa Nacional (Secretaria de Apoio à Comissão de Relações Exteriores e Defesa Nacional), aguardando designação do relator.

242 O PLS 245/2011 deu origem, na Câmara, ao PL 6240/2013. Informações obtidas em: http://www25.senado.leg.br/web/atividade/materias/-/materia/100177 e http://www.camara.gov.br/ proposicoesWeb/fichadetramitacao?idProposicao=589982. Acesso: 13.06.2016.
} 
regime de exceção. Tanto os direitos civis e políticos como os econômicos, sociais e culturais, foram incluídos na Constituição Federal de 1988, momento em que ambos os Pactos tramitavam no Legislativo brasileiro; esse processo foi iniciado logo após o término da ditadura. As Constituições brasileiras de 1967 e 1946 não mencionavam direitos sociais.

A tortura também recebeu atenção da Constituição de 1988, que reza:

\begin{abstract}
Art. $5^{\circ}$ Todos são iguais perante a lei, sem distinção de qualquer natureza, garantindo-se aos brasileiros e aos estrangeiros residentes no País a inviolabilidade do direito à vida, à liberdade, à igualdade, à segurança e à propriedade, nos termos seguintes: (...)

III - ninguém será submetido a tortura nem a tratamento desumano ou degradante; (...)

XLIII - a lei considerará crimes inafiançáveis e insuscetiveis de graça ou anistia a prática da tortura, o tráfico ilícito de entorpecentes e drogas afins, o terrorismo $e$ os definidos como crimes hediondos, por eles respondendo os mandantes, os executores e os que, podendo evitá-los, se omitirem; (...). (grifo nosso).
\end{abstract}

Não existe menção à tortura nas Constituições anteriores. A lei brasileira que define a tortura (Lei 9.455/1997) foi sancionada seis anos após a promulgação da Convenção contra a Tortura no Brasil. O Decreto 6.085/2007, que promulga o Protocolo Facultativo à Convenção, por sua vez, tem um regulamento (Decreto 8.154/2013), que determina o funcionamento do Sistema Nacional de Prevenção e Combate à Tortura, a composição e o funcionamento do Comitê Nacional de Prevenção e Combate à Tortura e dispõe sobre o Mecanismo Nacional de Prevenção e Combate à Tortura. Esse Regulamento menciona, expressamente, o Protocolo como um dos fundamentos para sua elaboração.

Ainda em relação a esse tema, a discussão no Senado Federal a respeito da Convenção Interamericana para prevenir e punir tortura demonstra expressamente a influência do Direito Internacional no Direito interno. Em parecer da Comissão de Relações Exteriores, o Senador Itamar Franco ressalta que as obrigações adquiridas pela aprovação desse tratado demandam a implementação de medidas normativas no país. O Senador relator diz que, em razão da importância do tema, e para assegurar a proteção do respeito à integridade física e psicológica do ser humano, principais valores protegidos pelo tratado, apresentará ao Senado dois projetos de lei, tipificando o crime de tortura e declarando nulas as provas obtidas mediante tortura.

Após a inserção de parágrafos no artigo $5^{\circ}$ da Constituição pela Emenda Constitucional 45/2004, existe menção à submissão do Brasil a "Tribunal Penal Internacional a cuja 
criação tenha manifestado adesão." (art. $5^{\circ}, \S 4^{\circ}, \mathrm{CF}$ ). Apesar de o Estatuto de Roma do Tribunal Penal Internacional ter sido elaborado no final da década de 1990 (1998), passou a vigorar para o Brasil apenas em 2002, pouco tempo antes da aprovação dessa Emenda.

Percebe-se a influência do Direito Internacional, aqui consubstanciado em tratados de Direitos Humanos, no ordenamento jurídico interno. Em alguns casos, a influência é textual, expressa. Em outros, resultado de mudança no contexto político do país, momento de transição do regime militar para a democracia. De qualquer maneira, as coincidências temática e temporal demonstram a relação e a evolução conjuntas desses dois ordenamentos, que, apesar de emanarem de instituições e de tradições jurídicas distintas, se complementam. 


\section{PANORAMA DA POLÍTICA EXTERIOR BRASILEIRA NOS PERÍODOS ESTUDADOS}

O presente capítulo irá apresentar uma descrição das linhas gerais do cenário da política externa brasileira (PEB) a partir do primeiro governo do Presidente Getúlio Vargas (1930-1945), até o fim da ditadura militar e o começo do período democrático atual. Essa descrição tem como objetivo situar historicamente as discussões feitas durante o processo de internalização dos tratados analisados na tese. Ao compreender com maior detalhamento o contexto histórico do período, será possível perceber as nuances envolvidas nas discussões. Ao final deste capítulo, será apresentada lista com a descrição dos Ministros das Relações Exteriores responsáveis pela assinatura e pelo envio da MSC relativa a cada um dos tratados descritos no APÊNDICE I.

Ao tratar da construção da identidade brasileira, Gelson Fonseca Júnior aponta para a necessidade de se pensar a respeito da dicotomia entre a identidade de um país e a sua relação com seus pares. Apenas com a definição da identidade é possível estabelecer relações tais que a afirmem perante os outros atores do sistema internacional. Segundo Fonseca Jr., "Para países que não têm posição hegemônica, a construção da identidade internacional é necessariamente fundada no que o sistema oferece em termos de constrangimentos ideológicos". ${ }^{243}$ O Brasil, por não ser uma potência hegemônica, precisaria se adaptar a esses constrangimentos, e, dessa maneira, construiu sua relação com outros Estados. A política externa brasileira pode ser dividida em fases distintas, em relação ao papel ocupado pelo país no sistema internacional. A primeira delas, segundo Gerson Moura, é a "Autonomia na Dependência”, que vai de 1935 a 1942. A segunda, para Gelson Fonseca Jr., é a "Autonomia pela Distância", durante o período militar. Segue-se a "Autonomia pela Participação" (também segundo Gelson Fonseca Jr.) e a "Autonomia pela Diversificação" (Tullo Vigevani). ${ }^{244}$ Apresentar-se-á o contexto histórico de cada uma dessas fases.

O período da "autonomia na dependência" retrata parte do primeiro governo de Getúlio Vargas, momento de intensa industrialização, de aceleração do processo de urbanização no país e de construção da identidade nacional. Foi necessário encontrar meios de buscar o

\footnotetext{
${ }^{243}$ FONSECA JR., Gelson. A legitimidade e outras questões internacionais, 2004, p. 270.

${ }^{244}$ CEPALUNI e VIGEVANI. A política externa de Lula da Silva; CINTRA, OLIVEIRA e VIGEVANI. Política Externa no período FHC.
} 
desenvolvimento do Brasil com o auxílio de países que poderiam ser parceiros potenciais desse desenvolvimento. O governo brasileiro explorou, nesse momento histórico, a rivalidade existente entre Estados Unidos da América (EUA) e Alemanha, ambos com pretensões hegemônicas à época. Gerson Moura define o movimento de aproximação de ambas as potências, com o objetivo de obter investimentos, como "equidistância pragmática". A equidistância pragmática seria uma estratégia de barganha brasileira: ao não se mostrar claramente favorável a nenhuma das potências, o país mantinha-se em posição privilegiada, o que possibilitava obter vantagens de uma ou de outra. Vargas tentou explorar as vantagens da competição entre EUA e Alemanha para impulsionar a industrialização brasileira, o que destaca o papel da política externa como instrumento para desenvolvimento do país.

Em 1937, ocorre o golpe do Estado Novo, que subsiste até 1945. O Estado Novo pode ser caracterizado como autoritário, tecnocrático e nacionalista. Esse nacionalismo foi agregado à retórica do projeto de Estado. Com a eclosão da Segunda Guerra Mundial, não ocorre movimentação imediata do governo brasileiro para definir seu posicionamento, o que atrai o interesse das potências, que desejam garantir, de alguma forma, a opção do governo brasileiro por uma das esferas de influência possíveis.

É possível considerar, porém, que se aliar aos países do Eixo não era opção viável, pois o Brasil encontra-se no continente americano, muito longe, portanto, da Alemanha. Esta, por sua vez, não conseguiria garantir a segurança do Brasil em caso de ataque dos EUA. Eventual opção do Brasil pela neutralidade, por sua vez, preocupava os EUA, porque isso prejudicaria os interesses americanos no conflito, e o Brasil era ator importante no continente. Entretanto, à época, o Brasil valeu-se dessa insegurança do cenário mundial para garantir investimentos, o que deu sobrevida à política de equidistância pragmática. $\mathrm{O}$ governo brasileiro aproveitou a iniciativa da equidistância para tentar suprir reivindicações antigas, que se consubstanciavam principalmente nas demandas pela construção de siderúrgicas e pelo reaparelhamento das forças armadas.

Com o ingresso dos EUA na Segunda Guerra Mundial após os ataques à base de Pearl Harbor, em 1941, aumenta a pressão para que o continente americano ficasse ao lado dessa potência na guerra. Em 1942, ocorre a III Reunião de Consultas dos Ministros das Relações Exteriores das Repúblicas Americanas, no Rio de Janeiro. O objetivo dessa reunião era a aprovação unânime de rompimento imediato das relações diplomáticas e comerciais dos 
países do continente americano com os países do Eixo. Contudo, em virtude da recusa argentina e chilena, consegue-se, apenas, uma "recomendação de ruptura" com países do Eixo. $^{245}$

Logo depois, o Brasil rompe com o Eixo. Com o Acordo de Washington, o país consegue fundos para a construção da usina de Volta Redonda e para o reaparelhamento das Forças Armadas. Pode-se dizer que se trata do coroamento da equidistância pragmática. Aumenta, nesse cenário, a percepção de que o Brasil seria um aliado privilegiado dos EUA na região, o que será importante para a melhor compreensão das atitudes tomadas durante o governo Dutra.

O Brasil, único país da América Latina a enviar contingente para lutar no conflito europeu, angaria benefícios por sua participação na guerra. Além dos benefícios econômicos, o país conseguiu garantir o treinamento e a modernização de suas forças armadas, além de obter prestígio internacional e o direito de participar da ONU como membro fundador. Nesse contexto, o Brasil passa a ser responsável pelo discurso de abertura da AGNU.

O fim do Estado Novo advém como resultado de diversas mudanças conjunturais, no Brasil e no mundo. Cresce a oposição interna e o repúdio por parte das democracias na região. O Brasil deixa de ser peça estratégica no cenário da Guerra Mundial, com o famoso “trampolim para a vitória”. Os EUA, durante o governo Truman (1945-1953), passam a endurecer a política para os países da região.

Apesar de Gerson Moura tratar, especificamente, do período que vai de meados da década de 1930 até o início da década de 1940, a busca de brechas no sistema internacional por parte do Brasil é uma constante no comportamento diplomático. O Brasil, país sem “excedentes de poder", na feliz expressão de Saraiva Guerreiro, ${ }^{246}$ não possui meios para atuar de maneira mais destacada no cenário internacional, e, portanto, precisa encontrar brechas nesse sistema. Entre a década de 1950 e o golpe militar de 1964, há constante busca de autonomia, com algumas exceções pontuais.

\footnotetext{
245 Diretrizes do Estado Novo (1937 - 1945); Reunião de chanceleres do Rio de Janeiro. Informações obtidas em: http://cpdoc.fgv.br/producao/dossies/AEraVargas1/anos37-45/AGuerraNoBrasil/ReuniaoChanceleres. Acesso: 20.09.2016.

${ }^{246}$ A expressão é notoriamente atribuída a Saraiva Guerreiro, conforme consta na obra de Vasco Mariz, "Nos Bastidores da Diplomacia: memória diplomática", p. 7. Informação disponível em: http://funag.gov.br/loja/ download/1077-nos-bastidores-da-diplomacia.pdf. Acesso: 19.09.2016.
} 
O governo de Eurico Gaspar Dutra (1946-1951) começa nesse cenário. Os EUA alteram sua inserção no continente americano, aproveitando a posição de potência mundial em termos políticos, militares e econômicos. O governo Dutra, caracterizado por um contexto de instabilidade interna, alinha-se aos EUA, resultado da percepção de que o Brasil seria uma espécie de "aliado privilegiado" do país na região. É fundamental atentar à dinâmica da Guerra Fria, que pautou as relações internacionais durante toda a sua extensão. Os países tentavam enquadrar-se nessa lógica dual, ou dela distanciar-se. A diplomacia brasileira nesse período é pró-americana, conservadora e anticomunista.

O segundo governo de Getúlio Vargas (GV, 1950-1954) demonstra uma inflexão em relação ao alinhamento automático aos EUA, percebido durante o mandato de Dutra. Esse alinhamento, que ocorre em termos estratégicos e políticos, no qual o governo Dutra enquadra-se na lógica ocidental, deve ser devidamente qualificado: ele tem um caráter demandante em termos econômicos, além de ser pragmático. Conforme a lógica de Dutra, alinhando-se aos EUA, o Brasil conseguiria obter os recursos que desejava para sustentar seu desenvolvimento econômico. Em alguns momentos, o Brasil exerceu certa autonomia em relação aos EUA, o que pode ser percebido no episódio do decreto presidencial que reafirmou a soberania brasileira sobre os recursos submersos encontrados na plataforma continental. O viés pragmático continua sendo característica importante da PEB, mas acreditava-se que o alinhamento aos EUA era a forma mais pragmática de angariar os recursos almejados. No segundo governo Vargas, porém, percebe-se que esse alinhamento não havia gerado os resultados desejados.

Em um primeiro momento do segundo governo GV, há um movimento de barganha com os EUA, particularmente com o chanceler João Neves da Fontoura (1950-1953). Esse movimento consubstancia-se no apoio aos projetos estratégicos americanos em troca de ajuda para o desenvolvimento. Entretanto, há pouca margem de manobra nesse momento histórico. Não existia o contexto de tensão hegemônica explorado anteriormente por Vargas, durante a equidistância pragmática. O Brasil encontrava-se, indiscutivelmente, na órbita de influência dos EUA. Internamente, havia industrialização incipiente e momentos de crise nacional, combinada à dificuldade em conseguir recursos externos. Internacionalmente, a Guerra Fria era um grande constrangimento à liberdade de atuação dos países. 
Posteriormente, com Vicente Rao (1953-1954), ocorre o reforço da autonomia, a chamada virada nacional-desenvolvimentista. ${ }^{247}$

O governo que segue é o de Café Filho (1954-55). Seu chanceler, Raul Fernandes, havia sido chanceler durante o governo Dutra. Ocorre um retorno ao conservadorismo, com alinhamento estratégico aos EUA. Isso facilitou o relacionamento com esse país, dificultando, consequentemente, o relacionamento entre o Brasil e os demais países da América Latina.

Durante o governo de Juscelino Kubitschek (JK, 1956-1961), o contexto externo continuava a ser o de Guerra Fria, mas acelerava-se o processo de descolonização nos continentes africano e asiático. O terceiro mundismo passava a disputar espaço antes reservado à bipolaridade, e a crescente recuperação econômica da Europa Ocidental e do Japão abre espaços para atuação brasileira. Internamente, ocorre o aumento da urbanização no país, e o populismo trabalhista de Vargas é substituído pela retórica da modernização dos "50 anos em 5" de JK.

Durante o governo Kubitschek, houve associação estreita com os EUA e com o capital internacional. À medida que a associação com o capital internacional trazia resultados, o exercício da autonomia passou a ser menos intenso. O sucesso econômico inicial possibilita um compromisso político, o que gera arrefecimento dos conflitos e distanciamento do terceiro mundo e do bloco socialista, pois não era necessário buscar novas parcerias. Em um segundo momento do governo JK, porém, começam algumas dificuldades internas. O Brasil atraiu investimentos, mas não na proporção desejada. Ao avançar o processo de industrialização, são necessários investimentos maiores. Ocorre uma desaceleração do crescimento, e impõe-se um dilema entre a estabilização e o desenvolvimento. O governo opta pelo desenvolvimento.

É possível mencionar algumas alterações na conjuntura internacional do período. Além da intensificação do processo de descolonização, o que possibilitou o surgimento e o

${ }^{247}$ É possível mencionar algumas ações ligadas ao nacional-desenvolvimentismo, como a fundação da Petrobrás, da Eletrobrás, a Instrução 70 da Superintendência da Moeda e do Crédito (SUMOC), pela qual o câmbio subvencionado foi extinto e inaugurou-se um sistema de taxas múltiplas. O objetivo dessa Instrução foi tornar as exportações brasileiras mais atraentes no mercado internacional, além de diminuir a quantidade de importações, proteger a indústria e a balança comercial nacionais. A Instrução 70, apesar de ter sido incentivo substancial ao processo de substituição de importações, não impediu a manutenção da instabilidade da situação financeira do país. Além disso, ocorreu a valorização dos espaços multilaterais, como a ONU, a OEA e a CEPAL, formas de buscar autonomia. Informações sobre a Instrução 70, SUMOC disponíveis em: http://cpdoc.fgv.br/producao/dossies/AEraVargas2/artigos/EleVoltou/PoliticaCambial. Acesso: 20.09.2016. 
desenvolvimento do terceiro mundismo, ocorre, no fim da década de 1950, a criação das Comunidades Econômicas Europeias. Esse cenário possibilita uma diversificação de parcerias por parte do Brasil. As perspectivas diplomáticas brasileiras são, assim, ampliadas.

Em 1958 é lançada a Operação Pan-americana (OPA). A OPA foi uma inflexão nacionalista da condução da política externa, ao associar o desenvolvimento à segurança do Estado. O discurso seguia a lógica de que a melhor maneira de evitar "ideologias exóticas" - de viés esquerdista - no continente americano seria promover o desenvolvimento, pois a pobreza geraria subversão, e deveria ser combatida com o desenvolvimento. Esse discurso tem apelo significativo à época. A OPA buscava investimentos externos para compensar a escassez de capital interno nos países da região. A Revolução Cubana demonstra que essa percepção estaria correta. $^{248}$

Apesar de o governo brasileiro ter optado pelo desenvolvimento, ocorrem alguns “exercícios de diferenciação", conforme Fonseca Júnior. ${ }^{249}$ Para angariar empréstimos com o Fundo, o Brasil teria que adotar políticas austeras, o que não ocorreu, por ser contrário aos planos do governo. Em 1959, o governo brasileiro rompe com o FMI. O objetivo desse rompimento seria melhorar o poder de barganha do país, para que pudesse renegociar futuros empréstimos com termos mais benéficos. Outro exemplo da autonomia em relação aos EUA foi a nacionalização do petróleo, além do não envio de tropas à Coreia em 1952, apesar da renovação do acordo militar com os EUA.

A política externa do governo de Jânio Quadros (1961), por sua vez, conta com a direção do chanceler Afonso Arinos. Em artigo publicado na revista Foreign Affairs, Arinos destaca as diretrizes da PEB, o que demonstra a intenção de estruturar sua chancelaria. Um dos pontos elencados foi a necessidade de ampliar o contato com todos os países, sem excluir os socialistas; além do incremento da relação com os países europeus, africanos e asiáticos. O Brasil coloca-se como interlocutor entre os países considerados centrais e suas colônias (ou ex-colônias); assume a condição de país autônomo, não alinhado ao Movimento dos Não-Alinhados e, tampouco, interessado em formar outro bloco para proteger seus interesses. Inicia-se a formação das diretrizes da Política Externa Independente (PEI).

\footnotetext{
${ }^{248}$ Algumas interpretações historiográficas entendem que a Revolução Cubana, iniciada em 1959, teve, a princípio, caráter nacionalista. Após as tentativas de ingerência dos EUA, que culminaram na invasão da Baía dos Porcos, em 1961, teria ocorrido a virada socialista da Revolução.

${ }^{249}$ FONSECA JR., 2004, p. 271.
} 
O governo João Goulart (1961-1964) destaca os três principais chanceleres responsáveis pela PEI: San Tiago Dantas (1961-1962), Afonso Arinos (1962) e João Augusto de Araújo Castro (1963-1964). Em 1961, dá-se o reatamento das relações com a União das Repúblicas Socialistas Soviéticas (URSS). Em 1962, ocorre a crise dos mísseis, que modifica o perfil da Guerra Fria. A PEI é responsável pela diversificação de parcerias do Brasil, que tenta se afastar do conflito leste-oeste e aumentar sua autonomia. Foi uma tentativa de aumentar o mercado externo brasileiro, movimento associado ao fortalecimento da industrialização e, com isso, o desenvolvimento do país. Existe uma tentativa de formular planos de desenvolvimento de maneira autóctone, sem fórmulas importadas e inseridas sem atenção ao contexto nacional. Almeja-se a manutenção da paz baseada em uma coexistência pacífica, que pressupõe o desarmamento e o arrefecimento das tensões entre os blocos capitalista e socialista. Advoga-se, ademais, pela primazia do Direito Internacional, e pela emancipação dos territórios ainda sob intervenção estrangeira, ou colonizados.

Em 1963, Araújo Castro profere o "Discurso dos Três D's", que deveriam pautar a ordem mundial. ${ }^{250} \mathrm{O}$ chanceler é favorável ao desarmamento total, pois a escalada armamentista seria responsável pela escassez de investimentos em países que dele necessitavam, entre eles o Brasil; ao desenvolvimento e à descolonização. A PEI seria uma resposta às transformações internacionais do período, e uma política que, ao questionar a inserção internacional do Brasil, tentaria alterar sua posição perante a comunidade internacional. A PEI seria importante instrumento diplomático para o desenvolvimento do país, um dos principais interesses nacionais da época; além de clara consequência das transformações internas da sociedade brasileira. A política externa passa, assim, a ser instrumento indispensável para os projetos nacionais.

A dicotomia da Guerra Fria, porém, restringe as escolhas possíveis para a definição da identidade do Brasil no âmbito internacional. O conflito entre o leste e o oeste passa a estruturar as relações internacionais de maneira geral; e as brechas para a atuação de países como o Brasil diminuem em momento de acirramento dos conflitos, e aumentam em

\footnotetext{
${ }^{250}$ O "Discurso dos Três D's" foi proferido, originalmente, por Araújo Castro, na década de 1960, perante membros da Assembleia-Geral das Nações Unidas. Araújo Castro, um dos artífices da PEI, apontava um caminho que deveria ser sobreposto às polarizações ideológicas da Guerra Fria. Esse caminho deveria ser construído por intermédio da Descolonização, do Desenvolvimento e do Desarmamento. Conforme discurso do Ministro de Estado das Relações Exteriores, Embaixador Antonio Patriota, na cerimônia de formatura da Turma Oscar Niemeyer, do Instituto Rio Branco. Informação disponível em: http://sistemas.mre.gov.br/ kitweb/datafiles/Miami/pt-br/file/Discurso\%20de\%20formatura.pdf. Acesso: 06.09.2016.
} 
momento de distensão. A dinâmica de disputa entre leste e oeste exigia uma espécie de "lealdade" dos aliados de cada potência. A ideia da "Autonomia pela Distância" vem da percepção de que, caso o país mantivesse maior distanciamento do conflito leste-oeste, poderia aumentar sua perspectiva de atuação. A autonomia seria a expressão diplomática dessa diferença, de um Brasil que tenta se distanciar dessa dicotomia. A política externa brasileira apoia as ideias de uma nova ordem econômica internacional, e amplia sua atuação. Ocorre uma abertura universalista com o Presidente João Figueiredo.

Durante a Guerra Fria, segundo Gelson Fonseca Júnior, existiriam três modelos possíveis de inserção internacional. ${ }^{251}$ No primeiro deles, o modelo ocidental puro, haveria adesão irrestrita aos valores ocidentais. Apesar de não ocorrer alinhamento incondicional, a política externa brasileira estaria estruturada em torno dos valores ocidentais, e o Brasil identificava-se como país dentro da órbita de atuação dos EUA, tendo com este país uma aliança estratégica. O autor qualifica como governos "ocidentais puros" as presidências de Eurico Gaspar Dutra, João Fernandes Campos Café Filho e Humberto Castello Branco. 252

O modelo ocidental qualificado, por sua vez, seria uma variação na qual ocorre a adesão aos valores ocidentais, com alguns exercícios de diferenciação. Seriam exemplos desse modelo o segundo governo de Getúlio Vargas, no qual o Presidente adotou uma postura nacionalista, inclusive com a criação da Petróleo Brasileiro S.A. (Petrobrás); e o governo de Juscelino Kubitschek, com o lançamento da OPA e o rompimento com o FMI. O modelo ocidental autônomo, por sua vez, é característico da Política Externa Independente, lançada por Jânio Quadros; do pragmatismo responsável e ecumênico de Geisel e do universalismo do governo Figueiredo.

Conforme os modelos avançam do ocidental puro para o autônomo, aumenta o exercício de autonomia por parte dos governos. A PEI demonstra o aumento da diversificação de parcerias do Brasil, que passa a explorar novos eixos de atuação, aumentando a distância em relação ao conflito leste-oeste.

\footnotetext{
${ }^{251}$ Conforme modelos de inserção internacional definidos pelo autor na obra "A Legitimidade e outras questões internacionais", nas páginas 271 e seguintes.

${ }^{252}$ Apesar das discrepâncias em relação à grafia do sobrenome do Presidente Humberto de Alencar Castello Branco, adotou-se a grafia com duas letras "l", conforme consta no endereço oficial do Palácio do Planalto. Informação obtida em: http://www2.planalto.gov.br/acervo/galeria-de-presidentes. Acesso: 20.09.2016.
} 
Com o início do governo Castello Branco (1964-1967), começa o desmantelamento de alguns dos princípios da PEI. A um dos seus chanceleres, Juraci Magalhães, é atribuída a frase "o que é bom para os EUA é bom para o Brasil", o que mostra o alinhamento a este país, e marca o modelo ocidental puro do governo. ${ }^{253}$ A retórica nacionalista da PEI, associada ao nacional-desenvolvimentismo, é abandonada. Apesar dessa necessidade de marcar uma diferença em relação ao governo anterior, não são descartados todos os princípios da PEI: o país ainda precisava buscar novos parceiros para promover seu desenvolvimento. O acomodamento das relações entre EUA e URSS, e o esfriamento do conflito bipolar, abre brechas para a atuação da diplomacia brasileira. A ampliação de mercados sem distinção de sistema político é mantida no governo Castello Branco, algo defendido pela PEI. Vasco Leitão da Cunha (chanceler entre 1964-1966) defendia, nesse sentido, o "universalismo realista", atuação multilateral destacada, na qual o Brasil buscaria estabelecer relações comerciais com países independentemente de alinhamento ideológico.

Segundo Amado Cervo, o governo Castello Branco (1964-1967) foi um "passo fora da cadência". ${ }^{254} \mathrm{O}$ Brasil vinha, ao longo dos anos, constantemente afastando-se do alinhamento em relação aos EUA, buscando maior autonomia. Essa postura autônoma exacerbou-se com a PEI, e Castello Branco retoma o modelo ocidental puro. Apesar desse alinhamento ideológico, a política externa de Castello buscou um universalismo realista, importante para diferenciar seu governo do mandato de João Goulart, além de auxiliar na repressão da oposição ao regime militar.

O governo de Artur da Costa e Silva (1967-1969) é conhecido pela chamada “Diplomacia da Prosperidade”, exposta por José Magalhães Pinto, Ministro das Relações Exteriores, em seu discurso de posse. ${ }^{255}$ É feito novo cálculo em relação à política externa nacional, com mudança de rota em relação à política de Castello Branco. A autonomia e o foco no desenvolvimento são retomados. Trata-se de um momento de consolidação do regime militar, mas ainda de grande instabilidade interna. São resgatados alguns princípios

\footnotetext{
${ }^{253}$ A Era Vargas: dos anos 20 a 1945: Juraci Magalhães. Conforme Dicionário Histórico Biográfico Brasileiro pós 1930. $2^{\mathrm{a}}$ ed. Rio de Janeiro: Ed. FGV, 2001. Informações obtidas em: http://cpdoc.fgv.br/producao/dossies/AEraVargas1/biografias/juraci_magalhaes. Acesso: 20.09.2016.

${ }^{254}$ BUENO, Clodoaldo; CERVO, Amado Luiz. História da política exterior do Brasil, 2002, p. 368-373.

${ }^{255}$ BUENO; CERVO, 2002, p. 381.
} 
da PEI, como a maior autonomia nacional, e o desenvolvimento é colocado, novamente, no centro da PEB. É um período de atuação intensa em foros multilaterais.

A condução da política externa do governo de Emílio Garrastazu Médici (1969-1974), cujo chanceler foi Mário Gibson Barbosa, é conhecida como a "Diplomacia do Interesse Nacional". ${ }^{256}$ O Brasil, durante esse governo, busca atuação mais individualista no cenário internacional. Internamente, ocorria o milagre econômico, com o avanço do processo de industrialização, o que alterará as necessidades do país e de sua política externa. Externamente, ocorre o primeiro choque do petróleo (1973), com a elevação dos preços dessa commodity, em consequência da Guerra de Iom Kippur; além da desarticulação do sistema de Bretton Woods, promovido de forma unilateral pelos EUA, que rompem o padrão dólar-ouro.

Ernesto Geisel (1974-1979) teve como chanceler Azeredo da Silveira, por sua vez, o formulador do pragmatismo responsável e ecumênico. ${ }^{257}$ Pregava-se o pragmatismo como a possibilidade de fazer alianças sem restrições ideológicas, ainda presentes no contexto de Guerra Fria. Esse pragmatismo da política externa brasileira seria responsável, pelo fato de o governo manter-se capitalista, apesar de manter relações com governos que não seguissem essa orientação. Seria ecumênico, por sua vez, porque o Brasil se propunha a estabelecer relações com parceiros de todas as regiões do mundo. O contexto interno do Brasil era de arrefecimento do Milagre Econômico, e de pressão pela redemocratização, que ocorreria posteriormente, de maneira "lenta, gradual e segura". O governo Geisel tem intensa atuação multilateral, em convergência com os países do chamado "Terceiro Mundo". As relações com os EUA, por sua vez, tornam-se tensas, particularmente no que se refere aos Direitos Humanos, dada a pressão do governo de James Carter, que tenta difundi-los internacionalmente.

O governo Figueiredo (1979-1985) é conhecido pelo universalismo. Internamente, ocorrem as movimentações pelo processo de redemocratização. Ramiro Saraiva Guerreiro é o chanceler do governo, e entende que o Brasil, país sem excedentes de poder, deve valer-se de sua capacidade de influência, ou soft power, para influenciar os outros atores na comunidade internacional. Há um esforço do governo em manter a autonomia em um

\footnotetext{
${ }^{256}$ BUENO; CERVO, 2002, p. 384.

${ }^{257}$ BUENO; CERVO, 2002, p. 386.
} 
contexto internacional claramente desfavorável, de reaquecimento do conflito bipolar. Começa o exercício mais intenso da diplomacia presidencial, mantida até os dias atuais.

Com o fim da Guerra Fria, que impunha limitações ideológicas à atuação dos países, há uma necessidade crescente de repensar a política externa no novo contexto. Internacionalmente, a globalização era responsável pela crescente multilateralização, em oposição à bipolaridade. Esse período de indefinição enseja a criação de novas regras, instituições e pactos internacionais, e é possível perceber, inclusive, a proliferação de instrumentos que protegem os Direitos Humanos a partir desse momento.

Nesse momento, a conjuntura interna é de redemocratização. A “Autonomia pela Participação" é característica desse período, no qual ocorre a reavaliação das diretrizes da política externa nacional, com maior participação do governo brasileiro nos mecanismos multilaterais e reforço do aspecto universalista, com o surgimento de novas parcerias para aumentar o peso do Brasil no sistema internacional. A diplomacia nacional passa a aceitar as limitações impostas pela conjuntura internacional, com o objetivo de fortalecer a economia e a inserção internacional do país.

A "Autonomia pela Participação" demonstra uma identidade positiva, que se contrapõe à identidade negativa existente durante o regime militar. Essa nova identidade reforça a legitimidade para a ação diplomática brasileira. Ocorre, inclusive, uma atualização do célebre "Discurso dos Três D's", de Araújo Castro, em 1993. O foco da nova PEB passa a ser, segundo o chanceler Celso Amorim, o desarmamento, o desenvolvimento, que se desdobra em meio ambiente e Direitos Humanos, e a democracia. Existe necessidade de se renovar as credenciais do país, que tem como objetivo participar mais ativamente das decisões globais. Pela dimensão do Brasil, nação continental, há poucos temas que não o afetam.

A política externa do Brasil pós-redemocratização passa a ser mais propositiva, "ativa e altiva", nas palavras de Celso Amorim. O Brasil, como ator com credenciais que poderiam influenciar a construção de uma nova ordem internacional, passa a garantir sua presença em locais que, antes, eram negligenciados.

Segundo Tullo Vigevani há uma mudança de ênfase nas relações internacionais do Brasil, e o destaque é dado aos países do sul. Essa mudança contribuiria para o equilíbrio internacional, e fortaleceria as relações bilaterais e multilaterais do país, com o objetivo de aumentar o seu peso internacional. O governo brasileiro estaria cada vez mais disposto a 
participar dos debates internacionais, particularmente no que se refere aos Direitos Humanos, após a redemocratização.

O governo de José Sarney (1985-1990) é o responsável por reinserir o Brasil no sistema internacional como a nova democracia que era, tendo como foco uma "diplomacia para resultados". ${ }^{258}$ A situação dos Direitos Humanos durante a ditadura trazia significativo constrangimento para o país, e a redemocratização exigia uma mudança na atuação externa. O governo inicia o processo de adesão aos Pactos da ONU, como se verá a seguir, promovendo uma "remoção de hipoteca", segundo Seixas Corrêa: ${ }^{259}$ durante a ditadura, o Brasil não estava aberto a críticas, o que se altera na democracia. Ocorre, para Gelson Fonseca, uma "renovação das credenciais" diplomáticas brasileiras com a redemocratização, o que permitiria uma participação mais significativa das decisões no âmbito internacional. ${ }^{260}$ Com o fim dos padrões de alinhamento que vigiam à época da Guerra Fria, e por se tratar de momento de reorganização do sistema internacional, o Brasil busca uma participação internacional mais efetiva. Novamente, considerada a dimensão do país, poucos temas não o afetam, o que possibilita a interação com uma multiplicidade de atores. A atuação brasileira, reativa durante a ditadura, passa a ser cada vez mais interessada e participativa dos grandes fóruns mundiais.

A crise política que culmina no fim do governo Fernando Collor de Mello (1990-1992) deteriora, de certo modo, a imagem internacional dessa jovem democracia. Podemos afirmar, entretanto, que o protagonismo do Poder Legislativo durante o processo de impeachment fez aumentar sua capacidade de influenciar a agenda interna e internacional do país. Amplia-se o debate a respeito da política externa nacional. Itamar Franco (1992-1994) governa em ambiente desfavorável, pois o contexto político nacional demandava muita atenção, com a consequente priorização da agenda interna e a manutenção, em certa medida, da política externa do governo anterior. A atuação multilateral, porém, é intensificada nesse período, no qual o Brasil tenta renovar suas credenciais particularmente no que se refere aos temas de Direitos Humanos.

\footnotetext{
${ }^{258}$ BUENO; CERVO, 2002, p. 385.

${ }^{259}$ CORRÊA, Luis Felipe de Seixas. A política externa de José Sarney. In: ALBUQUERQUE, José Augusto Guilhon (org.) Sessenta anos de política externa brasileira (1930-1990). São Paulo: Cultura Editores Associados, 1996.

${ }^{260}$ FONSECA JR., 2004, p. 367-368.
} 
O governo de Fernando Henrique Cardoso (FHC, 1995-2002) manteve o pragmatismo na atuação da política externa brasileira. Seus chanceleres, Luiz Felipe Lampreia (19952001) e Celso Lafer (2001-2002) conseguiram construir uma PEB consistente, melhorando a imagem internacional do país, prejudicada pelas constantes mudanças de governo e de chanceler. O Brasil promove a adesão aos regimes internacionais, possibilitando a convergência entre a política externa e as tendências internacionais, inserindo-se de maneira ativa no sistema internacional. Era necessário reconstruir a imagem do país, contumaz violador dos Direitos Humanos durante décadas, notadamente durante a ditadura. A diplomacia presidencial exercida durante o governo FHC aumenta a confiança internacional no Brasil.

O governo de Luís Inácio Lula da Silva (2003-2010) também buscou ampliar a influência nacional. São inauguradas diversas embaixadas em países africanos e centroamericanos, que asseguram a presença de representantes brasileiros em locais nos quais o Brasil tem pouco, ou nenhum, histórico de atuação. O governo de Dilma Rousseff (20112016), por sua vez, manteve, em linhas gerais, a política externa de Lula, apesar do perfil mais introspectivo de atuação internacional. Valorizou os fóruns multilaterais, e inovou conceitualmente ao cunhar o termo "responsabilidade ao proteger", responsabilidade de intervir para proteger cidadãos de violações dos Direitos Humanos praticadas por seus Estados, conforme explicitado no item 1.1. JUSTIFICATIVA DA ESCOLHA E DA RELEVÂNCIA DO TEMA. Por se tratar de história extremamente recente quando do depósito desta tese, não se apreciará a política externa do atual governo Michel Temer, iniciado em 2016.

Entre a instauração do regime militar e o retorno do regime democrático ao país, os governantes brasileiros adotaram postura conservadora e defensiva em relação aos Direitos Humanos. A partir de 1985, iniciou-se processo tímido de reconhecimento da legitimidade das iniciativas multilaterais de controle das violações desses direitos. Na década de 1990, mecanismos internacionais não eram mais considerados atentatórios à soberania nacional, com o devido reconhecimento de sua legitimidade e a consolidação das instituições democráticas no país.

A política brasileira de Direitos Humanos passa a ser pautada pela transparência e pela disposição ao diálogo com organismos internacionais, além da adesão aos instrumentos relevantes que tratam do tema. Os foros multilaterais são crescentemente valorizados como 
os locais mais adequados para tratar da temática dos Direitos Humanos, o que valoriza a cooperação internacional por parte do Brasil.

\subsection{TRATADOS DE DIREITOS HUMANOS E MINISTROS DAS RELAÇÕES EXTERIORES}

Durante o processo de elaboração desta tese, foi feito esforço para separar todas as etapas referentes ao processo de internalização de tratados, conforme detalhado no Capítulo 5. Essas etapas apresentam lapsos temporais, porém não retratam o contexto histórico da época na qual foi assinado o tratado, ou enviado para a apreciação do Poder legislativo, por exemplo. O presente item tem como objetivo descrever quais os Presidentes da República, e respectivos Ministros das Relações Exteriores, responsáveis por três das principais etapas em relação ao processo de internalização de tratados, quais sejam: o momento da assinatura, a data de envio da MSC e a data de publicação do Decreto Presidencial, que finaliza o processo de internalização de tratados no âmbito interno. $\mathrm{O}$ objetivo desta apresentação, inserida, propositalmente, após o item que trata da condução da política externa brasileira, é apresentar o período histórico e o processo de internalização de tratados.

O objetivo aqui é apresentar uma descrição dos Presidentes e dos respectivos Chanceleres responsáveis pelas etapas descritas na 
Tabela 1: Ministros das Relações Exteriores do Brasil e diferentes etapas dos tratados de Direitos Humanos. Não serão apresentados os motivos pelos quais determinado governo assinou ou deixou de assinar, de enviar à apreciação do Poder Legislativo ou de internalizar determinado tratado. Isso demandaria uma apreciação não apenas da conjuntura histórica, mas dos meandros da diplomacia e da política nacionais. A tabela abaixo tem objetivo meramente informativo. 
Tabela 1: Ministros das Relações Exteriores do Brasil e diferentes etapas dos tratados de Direitos Humanos

\author{
Legenda: \\ Sublinhado: Assinatura; \\ Itálico: Envio MSC; \\ Negrito: publicação do Decreto Presidencial
}

\begin{tabular}{|c|c|c|c|c|}
\hline $\begin{array}{l}\text { MINISTRO DAS } \\
\text { RELAÇÕES EXTERIORES } \\
\end{array}$ & TRATADO & $\begin{array}{l}\text { INÍCIO DO } \\
\text { MANDATO } \\
\end{array}$ & $\begin{array}{l}\text { FIM DO } \\
\text { MANDATO } \\
\end{array}$ & Presidente \\
\hline \multicolumn{5}{|c|}{ PERÍODO DEMOCRÁTICO I: 1945-1964 } \\
\hline Pedro Leão Veloso & & 31.10 .1945 & 30.01 .1946 & José Linhares \\
\hline João Neves da Fontoura & & 31.01 .1946 & 24.07 .1946 & \multirow{3}{*}{$\begin{array}{l}\text { Eurico Gaspar } \\
\text { Dutra }\end{array}$} \\
\hline $\begin{array}{l}\text { Samuel de Sousa Leão } \\
\text { Gracie }\end{array}$ & & 25.07 .1946 & 12.12 .1946 & \\
\hline Raul Fernandes & $\frac{(1 . \text { genocídio })}{\text { (1. genocídio })}$ & 12.12 .1946 & 31.01 .1951 & \\
\hline João Neves da Fontoura & 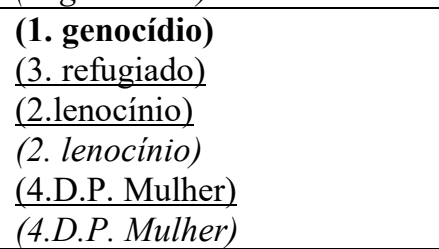 & 31.01 .1951 & 19.06.1953 & \multirow[t]{3}{*}{$\begin{array}{l}\text { Getúlio } \\
\text { Vargas }\end{array}$} \\
\hline $\begin{array}{l}\text { Mário de Pimentel } \\
\text { Brandão (interino) }\end{array}$ & & 19.06 .1953 & 02.07 .1953 & \\
\hline Vicente Rao & & 03.07 .1953 & 24.08 .1954 & \\
\hline Raul Fernandes & (5. Apátridas) & 26.08 .1954 & 11.11 .1955 & Café Filho \\
\hline \multirow{2}{*}{$\begin{array}{l}\text { José Carlos de Macedo } \\
\text { Soares }\end{array}$} & & 12.11 .1955 & 31.01 .1956 & Nereu Ramos \\
\hline & $\begin{array}{l}\text { (3.refugiado) } \\
\text { (7. } 105 \text { OIT) }\end{array}$ & 31.01 .1956 & 04.07 .1958 & \multirow[t]{3}{*}{$\begin{array}{l}\text { Juscelino } \\
\text { Kubitschek }\end{array}$} \\
\hline Negrão de Lima & & 04.07 .1958 & 30.08 .1959 & \\
\hline Horácio Lafer & $\begin{array}{l}\text { (2. lenocínio) } \\
\text { (3.refugiado) }\end{array}$ & 30.08 .1959 & 31.01 .1961 & \\
\hline $\begin{array}{l}\text { Afonso Arinos de Melo } \\
\text { Franco }\end{array}$ & & 31.01 .1961 & 25.08 .1961 & Jânio Quadros \\
\hline $\begin{array}{l}\text { Não houve nomeação para } \\
\text { o cargo durante o período }\end{array}$ & (8.Apatridia) & 25.08 .1961 & 07.09 .1961 & $\begin{array}{l}\text { Ranieri } \\
\text { Mazzilli } \\
\end{array}$ \\
\hline San Tiago Dantas & & 08.09 .1961 & 12.07 .1962 & João Goulart \\
\hline $\begin{array}{l}\text { Afonso Arinos de Melo } \\
\text { Franco }\end{array}$ & & 12.07 .1962 & 18.09 .1962 & \\
\hline \multirow[t]{2}{*}{ Hermes Lima } & & 18.09 .1962 & 24.01 .1963 & \\
\hline & & 24.01 .1963 & 18.06 .1963 & \multirow[t]{3}{*}{ João Goulart } \\
\hline Evandro Lins e Silva & & 18.06 .1963 & 22.08 .1963 & \\
\hline $\begin{array}{l}\text { João Augusto de Araújo } \\
\text { Castro }\end{array}$ & (4. Conv. D. Pol Mulher) & 22.08 .1963 & 31.03 .1964 & \\
\hline \multicolumn{5}{|c|}{ REGIME MILITAR: 1964-1985 } \\
\hline \multirow[t]{2}{*}{ Vasco Leitão da Cunha } & & 04.04 .1964 & 15.04 .1964 & $\begin{array}{l}\text { Ranieri } \\
\text { Mazzilli }\end{array}$ \\
\hline & & 15.04 .1964 & 17.01 .1966 & \multirow{2}{*}{$\begin{array}{l}\text { Castello } \\
\text { Branco }\end{array}$} \\
\hline Juraci Magalhães & $\begin{array}{l}\text { (6.Conv.Nac Mulher casada) } \\
\text { (6. Conv.Nac Mulher casada) } \\
\text { (7. Conv } 105 \text { OIT) }\end{array}$ & 17.01 .1966 & 15.03 .1967 & \\
\hline
\end{tabular}




\begin{tabular}{|c|c|c|c|c|}
\hline $\begin{array}{l}\text { MINISTRO DAS } \\
\text { RELAÇÕES EXTERIORES }\end{array}$ & TRATADO & $\begin{array}{l}\text { INÍCIO DO } \\
\text { MANDATO }\end{array}$ & $\begin{array}{l}\text { FIM DO } \\
\text { MANDATO }\end{array}$ & PRESIDENTE \\
\hline & $\frac{\text { (9.Discr racial) }}{\text { (9. Discr Racial) }}$ & & & \\
\hline \multirow[t]{2}{*}{ José de Magalhães Pinto } & $\begin{array}{l}\text { (6. Conv Nac Mulher casada) } \\
\text { (CVDT) - assinada na Ditadura, } \\
\text { internalizada na democracia }\end{array}$ & 15.03 .1967 & 31.08 .1969 & Costa e Silva \\
\hline & & 31.08 .1969 & 30.10 .1969 & $\begin{array}{l}\text { Junta } \\
\text { Governativa } \\
\text { Provisória de } \\
1969 \\
\end{array}$ \\
\hline Mário Gibson Barbosa & $\begin{array}{l}(3.1)(3.1)(\mathbf{3 . 1}) \\
\text { (9. Conv discr racial) }\end{array}$ & 31.10 .1969 & 15.03 .1974 & Emílio Médici \\
\hline Azeredo da Silveira & & 15.03 .1974 & 15.03 .1979 & Ernesto Geisel \\
\hline Ramiro Saraiva Guerreiro & $\begin{array}{l}\text { (13. Conv discr mulher) } \\
\text { (13. Conv discr mulher) } \\
\text { (13. Conv discr mulher) }\end{array}$ & 15.03 .1979 & 15.03 .1985 & $\begin{array}{l}\text { João } \\
\text { Figueiredo }\end{array}$ \\
\hline \multicolumn{5}{|c|}{ PERÍODO DEMOCRÁTICO II: 1985 - 2016} \\
\hline Olavo Setúbal & $\begin{array}{l}\text { (10. - Pacto D Civis) } \\
\text { (11- Pacto D Ec Sociais) } \\
\text { (14. Conv Tortura) } \\
\text { (22. Conv. Americana SH) } \\
\text { (23-SR - Conv Interam tortura) }\end{array}$ & 15.03 .1985 & 14.02 .1986 & \multirow[t]{2}{*}{ José Sarney } \\
\hline Abreu Sodré & $\begin{array}{l}\text { (14. Conv Tortura) } \\
\text { (16.Conv Direitos Crianças) } \\
\text { (23-SR - Conv Interam tortura) } \\
\text { (23-SR - Conv Interam } \\
\text { Tortura) }\end{array}$ & 14.02 .1986 & 15.03 .1990 & \\
\hline Francisco Rezek & $\begin{array}{l}\text { (5 - Pacto D Civis) (14. Conv } \\
\text { Tortura) } \\
(15-169 \text { OIT) } \\
\text { (16. Conv Direitos Crianças) } \\
\text { (16.Conv Direitos Crianças) }\end{array}$ & 15.03 .1990 & 13.04 .1992 & \multirow[t]{2}{*}{$\begin{array}{l}\text { Fernando } \\
\text { Collor de } \\
\text { Mello }\end{array}$} \\
\hline Celso Lafer & $\begin{array}{l}\text { (10. PIDCP) } \\
\text { (11. PIDESC) } \\
(31 . C V D T)\end{array}$ & 13.04 .1992 & 02.10 .1992 & \\
\hline $\begin{array}{l}\text { Fernando Henrique } \\
\text { Cardoso }\end{array}$ & $\begin{array}{l}\text { (5. Estatuto Apátridas) } \\
\text { (22.1. SR-Prot Conv DH D. Econ, } \\
\text { Soc e Cult) } \\
\text { (22.2. SR Prot Conv DH pena de } \\
\text { morte) } \\
\text { (22. SR Conv Americana DH) }\end{array}$ & 05.10 .1992 & 20.05 .1993 & \multirow[t]{3}{*}{ Itamar Franco } \\
\hline $\begin{array}{l}\text { Luiz Felipe Lampreia } \\
\text { (interino) }\end{array}$ & & 20.05 .1993 & 20.07 .1993 & \\
\hline Celso Amorim & 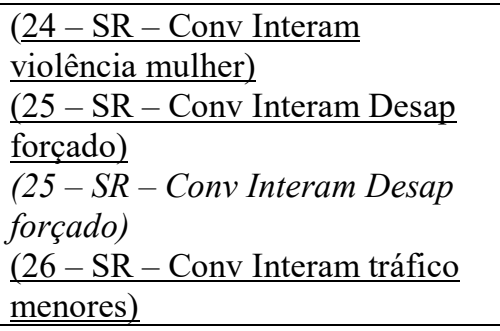 & 20.07 .1993 & 01.01 .1995 & \\
\hline Luiz Felipe Lampreia & $\begin{array}{l}\text { (12. Conv Prev cr dipl.) } \\
\text { (12. Conv prev cr dipl.) } \\
\text { (9.1. Decl. facultativa discr } \\
\text { racial) }\end{array}$ & 01.01 .1995 & 12.01 .2001 & $\begin{array}{l}\text { Fernando } \\
\text { Henrique } \\
\text { Cardoso }\end{array}$ \\
\hline
\end{tabular}




\begin{tabular}{|c|c|c|c|c|}
\hline $\begin{array}{l}\text { MINISTRO DAS } \\
\text { RELAÇÕES EXTERIORES }\end{array}$ & TRATADO & $\begin{array}{l}\text { INÍCIO DO } \\
\text { MANDATO }\end{array}$ & $\begin{array}{l}\text { FIM DO } \\
\text { MANDATO }\end{array}$ & PRESIDENTE \\
\hline & 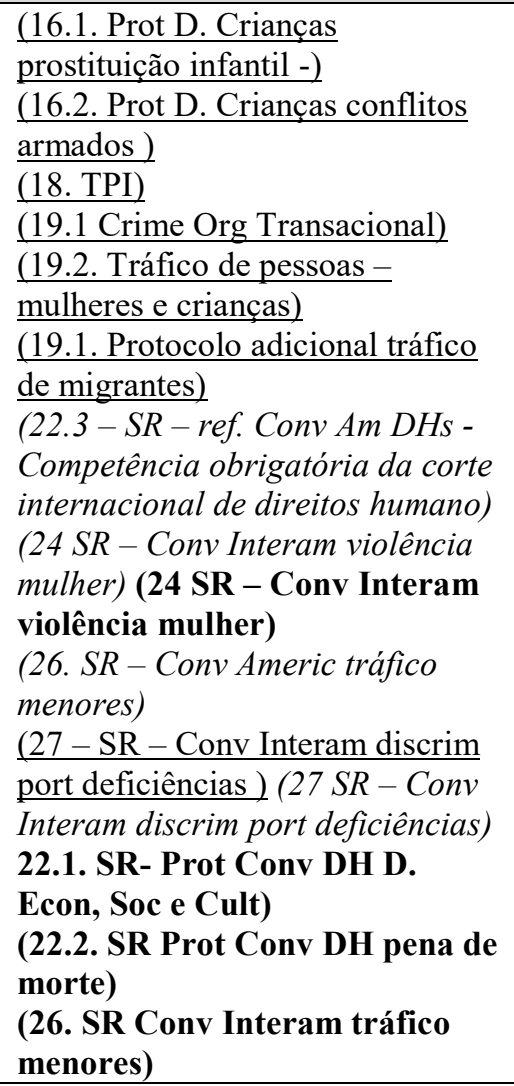 & & & \\
\hline $\begin{array}{l}\text { Luiz Felipe de Seixas } \\
\text { Corrêa (interino) }\end{array}$ & & 12.01 .2001 & 29.01 .2001 & \\
\hline Celso Lafer & $\begin{array}{l}\text { (5. Conv. Estatuto Apátridas) } \\
\text { (13.1. Retirada reservas Conv } \\
\text { Discr mulher) } \\
\text { (13.2. Protocolo Conv Discr } \\
\text { mulher) } \\
\text { (13.2. - Protocolo Conv discr } \\
\text { mulher) } \\
\text { (13.2 Protocolo Conv discr } \\
\text { mulher) (13.2 Protocolo Conv } \\
\text { discr mulher) } \\
\text { (14.2. Decl competência Comitê) } \\
\text { (16.1 Protocolo crianças } \\
\text { pornografia infantil) (16.2 } \\
\text { Protocolo crianças conflito } \\
\text { armado) } \\
\text { (18. TPI) (18.TPI) } \\
\text { (27 SR-Conv Interam discrim } \\
\text { port deficiências) } \\
\text { (8. Apatridia) } \\
\text { (19 Conv de Palermo) } \\
\text { (19.1. Protocolo Conv Palermo } \\
\text { tráfico migrantes) } \\
\text { (19.1. Protocolo Conv Palermo } \\
\text { tráfico de pessoas) }\end{array}$ & 29.01 .2001 & 01.01 .2003 & \\
\hline
\end{tabular}




\begin{tabular}{|c|c|c|c|c|}
\hline $\begin{array}{l}\text { MINISTRO DAS } \\
\text { RELAÇÕES EXTERIORES }\end{array}$ & TRATADO & $\begin{array}{l}\text { INÍCIO DO } \\
\text { MANDATO }\end{array}$ & $\begin{array}{l}\text { FIM DO } \\
\text { MANDATO }\end{array}$ & PRESIDENTE \\
\hline & $\begin{array}{l}\text { (22.3. Reconhecimento } \\
\text { competência obrigatória da } \\
\text { CIDH) }\end{array}$ & & & \\
\hline Celso Amorim & $\begin{array}{l}\text { (9.1. Decl facultativa Comitê) } \\
\text { (14.1 - Protocolo facultativo Conv } \\
\text { tortura) (14.1 Protocolo } \\
\text { facultativo Conv tortura) } \\
\text { (14.1 Protocolo facultativo Conv } \\
\text { tortura) } \\
\text { (18.1. Privilégios Imunidades TPI) } \\
\text { (18.1. Privilégios Imunidades } \\
\text { TPI) } \\
\text { (15 Conv 169 OIT) } \\
\text { (17- proteção trabalhadores } \\
\text { migrantes) } \\
\text { (16.1. Protocolo Conv Crianças } \\
\text { prost infantil) } \\
\text { (16.2. Protocolo Conv Crianças } \\
\text { conflitos armados) } \\
\text { (20-Conv pessoas deficiência) } \\
\text { (20 Conv pessoas deficiência) (20 } \\
\text { Conv pessoas deficiência) } \\
\text { (21- Desap Forçado) (21- Desap } \\
\text { Forçado) } \\
\text { (10.1. Protocolo D Civis e } \\
\text { Políticos) } \\
\text { (10.2. Segundo Protocolo D Civis } \\
\text { e Politicos) } \\
\text { (19. Convenção de Palermo) } \\
\text { (19.1. Convenção de Palermo) } \\
\text { (19.2 Convenção de Palermo) } \\
\text { (28. Protocolo Assunção } \\
\text { Mercosul) } \\
\text { (28. Protocolo Assunção } \\
\text { Mercosul) } \\
\text { (28. Protocolo Assunção } \\
\text { Mercosul) } \\
\text { (31. CVDT) }\end{array}$ & 01.01 .2003 & 31.12 .2010 & $\begin{array}{l}\text { Luís Inácio } \\
\text { Lula da Silva }\end{array}$ \\
\hline Antonio Patriota & (29-Conv Interam Racismo) & 01.01 .2011 & 26.08 .2013 & \multirow{4}{*}{$\begin{array}{l}\text { Dilma } \\
\text { Rousseff }\end{array}$} \\
\hline $\begin{array}{l}\text { Eduardo dos Santos } \\
\text { (interino) }\end{array}$ & & 26.08 .2013 & 28.08 .2013 & \\
\hline Luiz Alberto Figueiredo & & 28.08 .2013 & 01.01 .2015 & \\
\hline Mauro Vieira & $\begin{array}{l}\text { (8. Conv Apatridia) } \\
\text { (16.3. Protocolo crianças } \\
\text { comunicação) } \\
\text { (18.1 Acordo Imunidades TPI) } \\
\text { (21. Conv Internacional Desap } \\
\text { forçado) } \\
\text { (21. Conv Interamericana Desap } \\
\text { forcado) }\end{array}$ & 01.01 .2015 & 12.05 .2016 & \\
\hline José Serra & & 12.05 .2016 & --- & Michel Temer \\
\hline
\end{tabular}

Fonte: elaboração própria 


\section{A TRAMITAÇÃO DE TRATADOS DE DIREITOS HUMANOS NO BRASIL: ASPECTOS TEMPORAIS E ARGUMENTOS UTILIZADOS NA DITADURA E NOS PERÍODOS DEMOCRÁTICOS}

As principais perguntas que se deseja responder neste capítulo são: existem diferenças temporais significativas no processo de internalização de tratados entre aqueles que tramitaram durante a ditadura militar e a democracia brasileiras? O regime político interfere na quantidade de argumentos proferidos pelos membros do Poder Executivo e do Legislativo (dividido em Câmara dos Deputados e Senado Federal) brasileiros? Isso pode ser provado ou refutado pelo tempo de tramitação ou pela quantidade de argumentos utilizados pelos membros dos Poderes? Os dados coletados sustentam essa discrepância?

Conforme a hipótese da autora, a tramitação de tratados, na ditadura, deveria ser mais rápida, porque o Executivo apenas assinaria tratados cuja internalização realmente seria de seu interesse, e deveria ser, ainda, considerada a desnecessidade de discussão com os membros do Poder Legislativo. Além disso, e por essa razão, seriam proferidos menos argumentos.

A descrição minuciosa dos argumentos utilizados por parlamentares e por membros do Poder Executivo em todas as manifestações às quais a autora teve acesso encontra-se no APÊNDICE I desta tese. Serão discutidos, no item 5.3, os aspectos mais importantes dos resultados obtidos nessa análise.

Destacarei aspectos relevantes das estatísticas apresentadas a seguir, tanto no que se refere à totalidade dos tratados considerados, representando a situação dos tratados de Direitos Humanos internalizados pelo Brasil como um todo, quanto no que se refere à especificidade temporal dos tratados internalizados durante períodos de democracia ou de exceção no Brasil. A análise do conjunto dos tratados é importante para uma percepção generalizada do tempo que cada etapa de seu processo de internalização leva, além de desmistificar o suposto desinteresse dos membros do Poder Legislativo em reação a questões internacionais no geral, e de Direitos Humanos, em particular.

Foram realizadas estatísticas que destacam os tratados internalizados durante a ditadura e a democracia. Essa separação possibilita comparar, tanto no quesito "tempo de 
internalização" como no quesito "quantidade de argumentos", se o regime faz diferença no que se refere à internalização de tratados de Direitos Humanos. A hipótese é que sim, o regime faz diferença. Teoricamente (e de acordo com a lógica do sistema ditatorial), haveria menos discussão entre os parlamentares (e, portanto, os argumentos seriam menos abundantes). Justamente por haver menos discussão, a internalização seria mais célere. Verificaremos a veracidade dessa suposição.

\subsection{METODOLOGIA}

A primeira etapa da pesquisa empírica referente a este capítulo consistiu em definir quais seriam os tratados de Direitos Humanos a serem considerados. Em um segundo momento, foi necessário verificar os documentos presentes na tramitação desses tratados, obtendo todos aqueles disponíveis, e, em seguida, encontrar as datas referentes a cada etapa da tramitação. Posteriormente, foram selecionados os argumentos utilizados em cada etapa da tramitação, conforme a classificação determinada pela autora.

Essa classificação separou os argumentos em cinco temas: Política Externa; Política Brasileira (interna); Direito Internacional; Direito Brasileiro (interno) e Direitos Humanos. O objetivo dessa parte da pesquisa foi descobrir se existiam diferenças entre as razões apresentadas pelos integrantes do Poder Executivo e Legislativo para a internalização dos tratados, e se existem discrepâncias desse processo entre tratados que tramitaram durante a democracia e a ditadura. Foi necessário identificar as razões enunciadas pelo Executivo para a aprovação de determinado tratado, e as razões oferecidas pelo Legislativo para a aprovação ou para a inclusão de ressalva a determinado tratado. Ademais, foi preciso ressaltar se os membros do Legislativo analisavam, de fato, o mérito do tratado em pauta. Para isso, foram lidos todos os documentos encontrados, e feita uma paráfrase de todo o conteúdo lido, disponível para consulta no APÊNDICE I.

Durante a análise, surgiram dificuldades e necessidades inesperadas em relação ao desmembramento das etapas de tramitação e à classificação de argumentos. Isso será evidenciado nesta Metodologia e nas respectivas seções desta tese que apresentam os dados empíricos obtidos. Para apresentar de maneira mais detalhada as etapas que culminaram nesta tese, o presente item será separado em seções. 


\subsubsection{SELEÇÃO DE TRATADOS DE DIREITOS HUMANOS}

Para analisar a atuação dos Poderes Executivo e Legislativo na apreciação dos tratados internacionais, foi feita a identificação dos atos internacionais de Direitos Humanos assinados pelo Brasil, em vigor no país ou em tramitação. Essa identificação teve como fontes:

(i) $\mathrm{O}$ endereço eletrônico da $\mathrm{ONU}$, organização depositária de parte significativa dos tratados internacionais, com base no tema dos tratados ${ }^{261}$ e na busca do país (Brasil) como signatário; ${ }^{262}$

(ii) $\mathrm{O}$ endereço eletrônico da Organização dos Estados Americanos (OEA), depositária dos tratados assinados em seu âmbito;

(iii) $\mathrm{O}$ endereço eletrônico da Divisão de Atos Internacionais do Ministério das Relações Exteriores do Brasil (DAI);

(iv) Coletânea de legislação de Direito Internacional; ${ }^{263}$

(v) Coletânea elaborada pelo Ministério Público Federal do Brasil (MPF), na qual foram compilados os tratados internacionais de Direitos Humanos dos sistemas global e interamericano incorporados ao direito brasileiro, lançada em $2015 .^{264}$

A base de dados primordial em relação à definição de tratados como propriamente de Direitos Humanos foi o endereço eletrônico da ONU. Assim, foram descartados tratados

\footnotetext{
${ }^{261}$ Foi feita busca por tema no endereço eletrônico da ONU, com base nos capítulos da Carta da Organização, nos seguintes títulos: CHAPTER I Charter of the United Nations and Statute of the International Court of Justice; CHAPTER III Privileges and Immunities, Diplomatic and Consular Relations, etc; CHAPTER IV Human Rights; CHAPTER V Refugees and Stateless Persons; CHAPTER VII Traffic in Persons; CHAPTER IX Health; CHAPTER XIV Educational and Cultural Matters; CHAPTER XV Declaration of Death of Missing Persons; CHAPTER XVI Status of Women; CHAPTER XVIII Penal Matters; CHAPTER XXIII Law of Treaties; CHAPTER XXIX Miscellaneous. Informação disponível em: https://treaties.un.org/pages/ParticipationStatus.aspx. Acesso: 07.02.2016.

262 Informação disponível em: https://treaties.un.org/pages/TreatyParticipantSearch.aspx?tab=UN; http://tbinternet.ohchr.org/_layouts/TreatyBodyExternal/Treaty.aspx?CountryID=24\&Lang=EN. Acesso: 07.02.2016.

${ }^{263}$ Legislação de Direito Internacional. Coleção Saraiva de Legislação. $8^{\mathrm{a}}$ Ed., 2015.

${ }^{264}$ BRASIL. Ministério Público Federal. Secretaria de Cooperação Internacional. Tratados em direitos humanos: Sistema internacional de proteção aos direitos humanos / Secretaria de Cooperação Internacional Brasília: MPF, 2015, 4 volumes.
} 
que, apesar de classificados como de Direitos Humanos em outras coletâneas e endereços eletrônicos utilizados como base para a seleção dos tratados, tratavam de subdivisões muito específicas da definição do tema. Como exemplo, menciono as Convenções da Organização das Nações Unidas para a Educação, a Ciência e a Cultura (UNESCO), que protegem diversos aspectos do patrimônio cultural e, apesar de poderem ser consideradas cartas de Direitos Humanos, não são mencionadas pela ONU no rol de instrumentos internacionais relevantes para a sua proteção; ou a Convenção sobre a prestação de Alimentos no Estrangeiro (Convenção de Nova Iorque, de 1956), que trata mais de aspectos de Direito Civil do que de Direitos Humanos. ${ }^{265}$ A Declaração Universal dos Direitos Humanos (DUDH, 1948) consta em uma das coletâneas consultadas, mas não é um tratado, e, por isso, não se submete a processo de internalização. Foram, do mesmo modo, descartados tratados anteriores à fundação da ONU, que fogem do escopo deste trabalho, como a Convenção relativa à Escravidão (1926) e seu protocolo.

Considerou-se, conforme mencionado acima, o Estatuto do Tribunal Penal Internacional como instrumento de Direitos Humanos. O Estatuto do TPI tipifica condutas como crimes passíveis de sanção, evitando a constituição de tribunais ad hoc, como os que se formaram após a Segunda Guerra Mundial, nos quais a necessidade de leis anteriores às condutas consideradas criminosas foi desconsiderada. Será analisada, também, a Convenção de Viena sobre Direito dos Tratados (CVDT - 1969), por sua relevância para a formalização jurídica de tratados internacionais.

Os tratados de Direitos Humanos selecionados após essa busca foram separados em sistema global, regional e "tratado relevante para o sistema internacional", e são os seguintes:

\footnotetext{
265 Também foram descartados os seguintes tratados: Convenção Internacional para Repressão do Tráfico de Mulheres e Crianças (1921); Convenção relativa à Escravidão (1926) combinada com seu protocolo e a Convenção Suplementar sobre a Escravidão, do Tráfico de Escravos e das Instituições e Práticas Similares à Escravidão (1957); Protocolo de Emenda da Convenção Internacional para a Repressão do Tráfico de Mulheres e Crianças e da Convenção para a Repressão do Tráfico de Mulheres Maiores (1947); Convenção Interamericana sobre Concessão dos Direitos Políticos à Mulher (1948) e Convenção Interamericana sobre Concessão dos Direitos Civis à Mulher (1948), Carta da OEA (1948), anteriores à fundação da ONU; e Convenção relativa à luta contra a Discriminação no campo do Ensino (1960); Convenção da UNESCO sobre as Medidas a serem Adotadas para Proibir e impedir a Importação, Exportação e Transportação e Transferência de Propriedade Ilícitas dos Bens Culturais (1970); Convenção UNESCO relativa à Proteção do Patrimônio Mundial, Cultural e Natural (1972); Convenção sobre os Aspectos Civis do Sequestro Internacional de Crianças (“Convenção de Haia”) (1980); Convenção Interamericana sobre Obrigação Alimentar (1989); Convenção Relativa à Proteção das Crianças e à Cooperação em Matéria de Adoção Internacional (1993); Convenção UNESCO para a Salvaguarda do Patrimônio Cultural Imaterial (2003) e Convenção UNESCO sobre a Proteção e Promoção da Diversidade das Expressões Culturais (2005).
} 


\section{A. SISTEMA GLOBAL:}

1. Convenção para a prevenção e a repressão do crime de genocídio (1948);

2. Convenção para a repressão do tráfico de pessoas e do Lenocínio (1950);

3. Convenção relativa ao Estatuto dos Refugiados (1951);

3.1. Protocolo sobre o Estatuto dos Refugiados (1967);

4. Convenção sobre os Direitos Políticos da Mulher (1953);

5. Convenção sobre o Estatuto dos Apátridas (1954);

6. Convenção sobre a Nacionalidade da Mulher Casada (1957);

7. Convenção concernente à abolição do trabalho forçado (Convenção 105, OIT) (1957);

8. Convenção para a Redução dos Casos de Apatridia (1961);

9. Convenção internacional sobre a eliminação de todas as formas de discriminação racial (1966);

9.1. Declaração facultativa da Convenção;

10. Pacto Internacional sobre Direitos Civis e Políticos (1966);

10.1. Protocolo Facultativo ao Pacto Internacional sobre Direitos Civis e Políticos (1966);

10.2. Segundo Protocolo Facultativo ao Pacto Internacional sobre Direitos Civis e Políticos, com vistas à Abolição da Pena de Morte (1989);

11. Pacto Internacional sobre Direitos Econômicos, Sociais e Culturais (1966);

12. Convenção sobre a Prevenção e Punição de Crimes Contra Pessoas que gozam de Proteção Internacional, incluindo agentes diplomáticos (1973);

13. Convenção sobre a eliminação de todas as formas de discriminação contra a mulher (1979);

13.1. Retirada das reservas à Convenção;

13.2. Protocolo facultativo à Convenção sobre eliminação de todas as formas de discriminação contra a mulher (1999);

14. Convenção contra a tortura e outros tratamentos ou penas cruéis, desumanos ou degradantes (1984);

14.1. Protocolo Facultativo à Convenção contra a Tortura e Outros Tratamentos ou Penas Cruéis, Desumanos ou Degradantes (2002);

14.2. Declaração que reconhece a competência do Comitê previsto na Convenção; 
15. Convenção 169 da OIT sobre Povos Indígenas e Tribais (1989);

16. Convenção sobre os Direitos da Criança (1989);

16.1. Protocolo Facultativo à Convenção sobre os Direitos da Criança referentes à venda de criança, à prostituição infantil e à pornografia infantil (2000);

16.2. Protocolo facultativo à Convenção sobre os direitos da criança relativos ao envolvimento de crianças em conflitos armados (2000);

16.3. Protocolo facultativo à Convenção sobre os Direitos da Criança sobre procedimentos de comunicação (2011);

17. Convenção Internacional sobre a Proteção dos Direitos de todos os Trabalhadores Migrantes e dos Membros das suas Famílias (1990);

18. Estatuto de Roma do Tribunal Penal Internacional (1998);

18.1. Acordo sobre Privilégios e Imunidades do Tribunal Penal Internacional (2002);

19. Convenção das Nações Unidas contra o Crime Organizado Transnacional (“Convenção de Palermo") (2000);

19.1. Protocolo adicional para o Combate ao tráfico de Migrantes por via terrestre, marítima e aérea (2000);

19.2. Protocolo para a Prevenção, Repressão e Punição do Tráfico de Pessoas, em especial Mulheres e Crianças (2000);

20. Convenção sobre os Direitos das Pessoas com Deficiência e de seu Protocolo Facultativo (2006);

21. Convenção Internacional para a Proteção de Todas as Pessoas Contra o Desaparecimento Forçado (2006);

\section{B. SISTEMA REGIONAL INTERAMERICANO:}

22. Convenção Americana sobre Direitos Humanos (1969);

22.1. Protocolo adicional à Convenção Americana sobre Direitos Humanos em matéria de direitos econômicos, sociais e culturais (1988);

22.2. Protocolo referente à abolição da pena de morte (1990);

22.3. Reconhecimento da Competência obrigatória da Corte Interamericana de Direitos Humanos;

23. Convenção Interamericana para prevenir e punir tortura (1985); 
24. Convenção Interamericana para prevenir, punir e erradicar a violência contra a mulher (1994);

25. Convenção Interamericana sobre o Desaparecimento Forçado de Pessoas (1994);

26. Convenção Interamericana sobre tráfico internacional de menores (1994);

27. Convenção Interamericana para a eliminação de todas as formas de discriminação contra as pessoas portadoras de deficiência (1999);

28. Protocolo de Assunção sobre Compromisso com a Promoção e Proteção dos Direitos Humanos do Mercosul (2005);

29. Convenção Interamericana contra o Racismo, a Discriminação Racial e formas correlatas de intolerância (2013);

30. Convenção Interamericana contra toda forma de discriminação e intolerância (2013);

\section{TRATADO RELEVANTE PARA O SISTEMA INTERNACIONAL}

31. Convenção de Viena sobre o Direito dos Tratados (1969)

A seleção dos tratados determinou quais instrumentos internacionais integrariam a pesquisa empírica realizada nesta tese. Após a seleção do material referente à tramitação, porém, percebeu-se que nem todos os tratados tinham completado a tramitação interna no âmbito do Poder Legislativo brasileiro. A opção da autora foi descartar, na contagem final, os argumentos dos tratados cuja tramitação não foi finalizada. Apenas foram incluídos na tese aqueles que, no mínimo, foram aprovados por Decreto Legislativo (DLG) e, portanto, tiveram a discussão no âmbito do Poder Legislativo encerrada, mesmo que não tenham sido promulgados por Decreto Presidencial. Apesar de não terem os argumentos contabilizados para fins da tese, os argumentos foram analisados, para que, no momento em que passarem a integrar o ordenamento jurídico nacional, possam ser considerados por pesquisas futuras.

\subsubsection{INTERVALOS REFERENTES ÀS ETAPAS DE TRAMITAÇÃO DOS TRATADOS}

Com base nos tratados mencionados acima, foram identificadas as etapas referentes a cada um deles, processo que se inicia, no âmbito internacional, com a assinatura do plenipotenciário brasileiro e, no âmbito nacional, com a elaboração da Mensagem do Poder 
Executivo. Esse levantamento foi feito no endereço eletrônico e no Sistema de Informações Legislativas (SILEG) da Câmara dos Deputados, e na base de dados do endereço eletrônico do Senado Federal.

A autora verificou todos os intervalos de tempo entre a celebração dos tratados selecionados, a assinatura/acessão/adesão ${ }^{266}$ pelo Brasil e a promulgação do Decreto Presidencial, que faz da obrigação assumida em âmbito internacional uma obrigação para cidadão brasileiro, ao dar publicidade ao ato internacional no território do país. Foram verificados os lapsos temporais de cada uma das etapas relativas a cada tratado para, posteriormente, analisar quais são os tratados que, uma vez celebrados no âmbito internacional, mais demoraram para serem assinados por plenipotenciário brasileiro. A definição de um intervalo de tempo como "elevado" será feita mediante a comparação entre os intervalos de tramitação dos tratados analisados. A etapa seguinte verificará o lapso temporal do processo interno de tramitação, e analisará quais os motivos para a demora nas tramitações. Serão consideradas as características do regime em curso durante a tramitação dos tratados.

Os intervalos referentes à internalização de tratados foram calculados com base em informações relativas às datas relevantes para esse processo no âmbito nacional e internacional. As datas internacionais foram obtidas no endereço eletrônico das organizações depositárias dos tratados, e nos instrumentos normativos referentes aos mesmos elaborados no Brasil. Inicialmente, foram considerados alguns marcos para o processo de internalização, como a data de celebração do tratado, sua assinatura pelo plenipotenciário brasileiro, a data de elaboração da Mensagem presidencial, do Decreto Legislativo e do Decreto Presidencial.

\footnotetext{
266 É necessário diferenciar, formalmente, os termos Assinatura, Acessão e Adesão. A acessão é uma formalidade diplomática relacionada a tratados internacionais, pela qual o Estado interessado torna-se parte de determinado tratado, previamente negociado e assinado por outros Estados, aceitando as obrigações (direitos e deveres) previstas pelo instrumento. A acessão normalmente ocorre após a entrada em vigor do tratado em questão. As condições para a acessão a um tratado estão, normalmente, descritas no mesmo. Na ausência de disposições do tipo, a acessão apenas ocorrerá caso os Estados em negociação acordarem nesse sentido, conforme artigos 2 (1) (b) e 15, CVDT. A adesão de determinado Estado a um tratado, por sua vez, implica a aceitação, por parte desse Estado, do conteúdo do tratado, ressalvada a previsão de possibilidade de efetuar reservas. Ao aderir a um tratado, o Estado aceita a oportunidade de tornar-se parte integrante de um documento negociado e assinado por outros. A adesão ocorre apenas após a entrada em vigor do tratado em questão. A assinatura sujeita a ratificação, aceitação ou aprovação, não vincula juridicamente o Estado; entretanto, expressa a intenção desse Estado de continuar a seguir os procedimentos necessários para concluir a tramitação do tratado. Cria-se uma obrigação de boa-fé, e de abstenção da prática de atos que seriam contrários ao objeto e à finalidade do tratado. Conforme artigos 10 e 18, CVDT. Fonte: https://treaties.un.org/pages/Overview.aspx?path=overview/glossary/page1_en.xml. Acesso: 24.11.2015.
} 
Posteriormente, porém, a autora percebeu que algumas datas, não consideradas nesse primeiro momento, traziam informações relevantes sobre o período de tramitação dos projetos relativos aos atos internacionais nas Casas do Congresso Nacional e no Executivo. Para refinar as informações obtidas no primeiro momento, foram incluídas na análise novas datas, que possibilitariam uma apreciação mais detalhada do processo. Nesse segundo momento, foram incluídas na Tabela 2: Cálculo das médias de cada etapa de tramitação dos tratados internacionais analisados, que analisou os intervalos temporais, informações relativas às datas de envio da Mensagem ao Poder Legislativo, da transformação da Mensagem em Projeto de Decreto Legislativo (PDC - da Câmara dos Deputados do Brasil) e de seu envio ao Senado, entre outras.

É necessário fazer uma nota metodológica a respeito dos tratados que tramitaram durante o período em que se realizou a Assembleia Nacional Constituinte, cujos trabalhos culminaram na promulgação da Constituição Federal de 1988. Como bem apontado pelo professor Pedro Dallari, na banca de defesa desta tese, em 17.04.2017, existiu uma norma que estabelecu a suspensão parcial dos trabalhos do Congresso durante o funcionamento da Constituinte. Isso significa, portanto, que o Congresso apenas voltaria a funcionar alguns anos depois. Esse fato, porém, não foi considerado nos dados obtidos, o que deve ser feito com atenção em esforços futuros de pesquisa.

\subsubsection{CONTAGEM DE ARGUMENTOS DOS DOCUMENTOS ANALISADOS}

Para analisar a atuação dos Poderes no processo de internalização de tratados, foram consultados, inicialmente, todos os documentos disponíveis na tramitação dos tratados nos endereços eletrônicos da Câmara dos Deputados e do Senado Federal. As Mensagens Presidenciais, que informam ao Legislativo os motivos pelos quais o Executivo optou pela assinatura de um tratado, foram os primeiros documentos apreciados. Além dos relatórios das Comissões (exemplificativamente, mas não restrita às de Relações Exteriores e Defesa Nacional; de Direitos Humanos e Legislação Participativa; de Constituição, Justiça e Cidadania), foram analisados pareceres jurídicos e o material elaborado pelos integrantes dos Poderes a respeito da internalização dos tratados.

A análise e a paráfrase das manifestações de cada documento analisado encontram-se no APÊNDICE I. Os argumentos proferidos por parlamentares e por membros do Executivo 
foram separados, conforme mencionado na introdução, em argumentos de (i) Política Externa (PEB); (ii) Política Brasileira (interna) (PBR); (iii) Direito Internacional (DIN); (iv) Direito Brasileiro (interno) (DBR) e (v) Direitos Humanos (DH). ${ }^{267}$

Após uma primeira análise do material relativo aos tratados, a autora notou a necessidade de separar os argumentos em favoráveis e contrários à internalização. Isso enriqueceu o estudo, e possibilitou separar os temas dos argumentos utilizados nos pareceres e nos outros documentos analisados. Além disso, foram separados argumentos que não eram contrários à totalidade do tratado (a grande maioria deles), mas, apenas, a dispositivo específico do instrumento internacional.

A autora percebeu, ademais, que existem informações que vão além da separação dos argumentos entre aqueles contrários e a favoráveis à internalização dos tratados. Nas Mensagens presidenciais, cuja quase totalidade foi redigida pelo Ministro das Relações Exteriores, como o objetivo é encaminhar o tratado à apreciação do Poder Legislativo, não há de se falar, salvo raríssimas exceções, em argumentos contrários aos tratados.

Em um segundo momento da pesquisa, após analisar as manifestações mais comuns presentes nos PDCs e PDSs, a autora deparou-se com a menção, em algumas tramitações, a pareceres dos consultores jurídicos do Itamaraty. A consultoria jurídica do Itamaraty, órgão setorial da Advocacia-Geral da União, além de prestar consultoria ao Ministério em questões jurídicas, estabelece a interpretação da Constituição, das leis internas, dos tratados internacionais e dos demais atos normativos a serem considerados pelo MRE, sempre que não houver orientação a respeito do Advogado Geral da União. ${ }^{268}$

Foi possível acessar os pareceres disponíveis na obra Pareceres dos Consultores Jurídicos do Itamaraty, de IX volumes; analisados a partir do volume IV (1946-1951), em razão do corte temporal desta tese. Foram selecionados, então, os pareceres que apreciaram os tratados analisados, inserindo os argumentos utilizados neste trabalho como "Parecer do MRE” ou "Outras Manifestações (do Poder Executivo)". Além de analisar pareceres relativos a tratados de Direitos Humanos aqui estudados, realizei um estudo de pareceres que tratavam de questões mais gerais de Direito Internacional, o que foi importante para o capítulo que trata da relação entre o Poder Legislativo e o Poder Executivo. Os pareceres da

267 O critério para a categorização dos argumentos pode ser encontrado no item 5.3.ARGUMENTOS UTILIZADOS NA DITADURA E NOS PERÍODOS DEMOCRÁTICOS.

${ }^{268}$ Conforme disposição do art. $7^{\circ}$, I e II, Decreto 8.817, de 21.07.2016. 
Consultoria Jurídica do Ministério das Relações Exteriores (CJ/MRE) não são, apenas, um repositório de doutrina jurídica, mas peças utilizadas pelo aparato estatal para pensar a respeito da aplicação do Direito Internacional no âmbito interno. Percebe-se, assim, a relevância do pensamento jurídico aplicado ao caso concreto, pelos integrantes do poder público que realmente participam da processualística de elaboração e de incorporação de tratados ao direito brasileiro. Foram descartados os pareceres a respeito dos projetos de convenções, uma vez que a apreciação de um projeto de convenção não poderia ser equiparado à apreciação do seu texto final, o que deixaria a análise sem parâmetro coerente. ${ }^{269}$ É possível encontrar as principais informações a respeito desses pareceres nos itens 2.4. DENÚNCIA, 3.1. LITERATURA NACIONAL E ESTRANGEIRA e APÊNDICE I.

$\mathrm{Na}$ maioria dos pareceres elaborados por membros do Poder Legislativo, os argumentos também são favoráveis: não há, salvo raras exceções, ponderações por parte dos Deputados ou dos Senadores, não são apresentados argumentos favoráveis e contrários a determinado tratado. Nos casos em que há argumentos contrários, porém, a autora deparouse com a necessidade de distinguir aqueles argumentos contrários à totalidade da Convenção - nos casos, portanto, dos pareceres que tinham como objetivo evitar a internalização do tratado - daqueles argumentos contrários apenas a um artigo do tratado - nos casos de aposição de ressalva por parte do Poder Legislativo, portanto. Optou-se por considerar, conjuntamente, no cômputo dos argumentos favoráveis e contrários, todos os argumentos contrários, inclusive aqueles contrários apenas a parte do tratado. A descrição minuciosa dos argumentos contrários a um artigo pode ser encontrada no APÊNDICE I desta tese, que os apresenta em sua totalidade.

\footnotetext{
269 Foram, assim, descartados os pareceres dos seguintes consultores: Haroldo Valladão (i) Projeto de Convenção da Comissão de Codificação do Direito Internacional da ONU. O projeto de Código de Direito Internacional Público de Epitácio Pessoa 1910, e a Convenção Pan-americana sobre Tratados, de Havana, 1928 - Textos a serem afastados ou emendados e (ii) Projeto de Convenção Interamericana de Direitos Humanos. Antonio Augusto Cançado Trindade (i) Projeto de Protocolo Adicional à Convenção Americana de Direitos Humanos em Matéria de Direitos Econômicos, Sociais e Culturais: Elementos para a Tomada de Posição do Brasil; e (ii) Novos Elementos para a Tomada de Posição do Brasil em Relação ao Projeto de Protocolo Adicional à Convenção Americana de Direitos Humanos em Matéria de Direitos Econômicos, Sociais e Culturais. Vicente Marotta Rangel: (i) Exame do projeto de Declaração sobre Desaparecimentos Forçados ou Involuntários. O problema da extradição de nacionais. Identificação de autoridades internacionais. Definição do crime de desaparecimento forçado ou involuntário; e (ii) Projeto de Convenção Interamericana sobre Desaparecimento Forçado de Pessoas. A questão do asilo político. Remissões a outros instrumentos. As Regras Mínimas para o Tratamento de Prisioneiros. Conveniência de Protocolos Adicionais à Convenção Americana sobre Direitos Humanos.
} 
No Legislativo, existem discrepâncias entre o entendimento das Comissões que apreciam a relação entre tratado internacional e a legislação interna. Existem inúmeros motivos para a discordância entre membros de um Poder e entre membros de Poderes distintos. A descrição do APÊNDICE I, que apresenta os argumentos de maneira detalhada, mostra essas discordâncias, e a tese aprofundará o estudo dessa questão e dos outros temas descritos para esclarecer a tramitação e as razões utilizadas pelos Poderes para a internalização de tratados no ordenamento interno, sejam elas de política externa ou interna, de Direito Internacional ou de Direito interno ou, finalmente, de Direitos Humanos.

$\mathrm{O}$ acesso às audiências públicas, que também poderiam trazer argumentos importantes a serem considerados no processo de internalização de tratados, foi ferramenta de pesquisa sugerida pelas professoras Leany Lemos e Suely de Araújo. Em janeiro de 2016, a autora realizou viagem de pesquisa para Brasília, na qual visitou os arquivos históricos da Câmara dos Deputados e do Senado Federal. O objetivo dessa visita foi ter acesso (i) principalmente no caso do Senado Federal, aos documentos que não se encontravam disponíveis no endereço eletrônico da Casa, particularmente aos pareceres sobre PDSs; (ii) principalmente na Câmara dos Deputados, às audiências públicas que não estavam disponíveis no endereço eletrônico da Casa; (iii) aos dossiês dos PDCs (Câmara) e dos PDSs (Senado) referentes aos Tratados analisados nesta tese, para verificar se existiam documentos que não estavam disponíveis no endereço eletrônico das casas do Legislativo, e que, portanto, não tinham sido previamente considerados.

Sobre a possibilidade de utilizar as audiências públicas como material de pesquisa, verificou-se que elas constam no material de apenas um tratado, como será mencionado mais detalhadamente adiante. ${ }^{270}$ Foram realizadas, nos últimos anos, diversas audiências públicas para tratar, por exemplo, da situação dos Direitos Humanos no Brasil, especificamente em relação a determinadas minorias, como mulheres, crianças e pessoas portadoras de deficiências. A pesquisa inicial teve como objetivo selecionar aquelas que trataram, apenas, do processo de internalização dos tratados aqui estudados. Foi feita busca in loco nos

\footnotetext{
${ }^{270}$ Constam nos arquivos da Câmara e do Senado audiências públicas relativas ao processo de internalização de um único instrumento internacional analisado nesta Tese, o Protocolo Facultativo à Convenção sobre a Eliminação de todas as formas de Discriminação contra a Mulher.
} 
arquivos da Câmara dos Deputados e do Senado Federal das audiências públicas das Comissões de Defesa das Pessoas com Deficiência; Comissão de Direitos Humanos e Minorias; Comissão de Constituição e Justiça e de Cidadania (CCJC) ${ }^{271}$ e de Constituição, Justiça e Cidadania (do Senado Federal - CCJ) e Comissão de Relações Exteriores e de Defesa Nacional.

A apresentação minuciosa da maior parte das audiências encontradas, contudo, não seria condizente com o escopo da tese. Isso porque estas, importante ferramenta da democracia brasileira, ao possibilitar a participação da sociedade civil em discussões no âmbito dos Poderes, não apresentam argumentos de membros do Legislativo ou do Executivo relativos à internalização dos tratados a que se referem, com apenas uma exceção, ${ }^{272}$ devidamente considerada. Em geral, as audiências referentes a tratados de Direitos Humanos tratam de sua implementação, e da necessidade de o Poder Público fazer políticas nesse sentido, e não de sua incorporação ao ordenamento jurídico pátrio. Os argumentos presentes na audiência pública efetuada para discutir a internalização da Convenção sobre a eliminação de todas as formas de Discriminação contra a Mulher foram contabilizados como manifestações em plenário, da CD ou do SF.

No caso da única audiência considerada, as manifestações dos membros do Executivo e do Legislativo foram consideradas separadamente das manifestações em documentos oficiais. $\mathrm{O}$ motivo disso é a maior liberdade das manifestações em audiências em relação às manifestações em MSC (para membros do Executivo) ou em pareceres dos membros do Legislativo.

O processo de internalização de alguns instrumentos tramitou em conjunto internamente, como é o caso de tratados e protocolos a eles correlatos, e, portanto, a mesma MSC é referente a instrumentos distintos. Para não contar os argumentos em duplicidade, os documentos referentes a esses tratados foram contabilizados apenas uma vez. ${ }^{273}$ Esses casos

\footnotetext{
${ }^{271}$ Antiga Comissão de Constituição e Justiça e Redação da Câmara dos Deputados.

272 Referente à Convenção sobre a eliminação de todas as formas de Discriminação contra a Mulher.

${ }^{273}$ São os seguintes instrumentos: Itens 10 e 11: Pacto Internacional sobre Direitos Civis e Políticos e Pacto Internacional sobre Direitos Econômicos, sociais e culturais; Itens 10.1 e 10.2: Protocolo Facultativo ao Pacto Internacional sobre Direitos Civis e Políticos (16.12.1966) e Segundo Protocolo Facultativo ao Pacto Internacional sobre Direitos Civis e Políticos, com vistas à Abolição da Pena de Morte (15.12.1989); Itens 16.1 e 16.2: Protocolo Facultativo à Convenção sobre os Direitos da Criança referentes à venda de criança, à
} 
constam no Apêndice II, que apresenta tabela referente aos dados agregados dos argumentos utilizados pelos membros dos Poderes Executivo e Legislativo.

Dos tratados selecionados, não foram objeto de MSC, até a entrega desta tese, as Convenções Interamericanas contra o Racismo, a Discriminação Racial e formas correlatas de intolerância e contra toda forma de discriminação e intolerância. Por esse motivo, não há de se falar em argumentos proferidos na tramitação desses instrumentos.

Em relação às discussões em plenário a respeito dos tratados, foram utilizadas aquelas publicadas nos Diários oficiais, seja do Congresso Nacional, da Câmara dos Deputados ou do Senado Federal. As discussões em plenário ocorreram na tramitação de poucos tratados, uma vez que, na maioria dos casos, houve aprovação unânime dos pareceres apresentados.

\subsection{ASPECTOS TEMPORAIS: ANÁLISE DO TEMPO DE TRAMITAÇÃO}

Para determinar, de maneira minuciosa, os intervalos entre as etapas de internalização de tratados, foram reunidos dados a respeito de cada uma dessas etapas. Com isso, a autora pretendeu não apenas determinar quanto tempo (em dias) determinado tratado leva para ser encaminhado pelo Executivo ao Legislativo, e durante quanto tempo tramita no âmbito desses Poderes, mas obter dados exatos em relação a cada etapa da tramitação dentro das Casas legislativas. Com essas informações, foi possível determinar o lapso temporal que cada instrumento levou para tramitar no âmbito da Câmara, do Senado e do Poder Executivo. Foram coletados dados relativos aos seguintes intervalos, apresentados com maior detalhe no Apêndice IV (TABELAS REFERENTES AOS ATOS INTERNACIONAIS E INTERNOS ANALISADOS) desta tese.

1. Entre a data de celebração do tratado e a data de sua assinatura pelo Brasil;

2. Entre a assinatura pelo Brasil e a elaboração da MSC;

3. Entre a elaboração da MSC e seu envio ao Poder Legislativo;

4. Entre o envio da MSC ao Poder Legislativo e sua transformação em PDC;

prostituição infantil e à pornografia infantil Protocolo facultativo à Convenção sobre os direitos da criança relativos ao envolvimento de crianças em conflitos armados; Itens 19, 19.1 e 19.2: Convenção das Nações Unidas contra o Crime Organizado Transnacional; Protocolo adicional para o Combate ao tráfico de Migrantes por via terrestre, marítima e aérea e Protocolo para a Prevenção, Repressão e Punição do Tráfico de Pessoas, em especial Mulheres e Crianças; e Itens 22.1 e 22.2.: Protocolo adicional à Convenção Americana sobre Direitos Humanos em matéria de direitos econômicos, sociais e culturais e Protocolo referente à abolição da pena de morte. 
5. Entre o envio da MSC e o envio do PDC ao Senado;

6. Entre o envio do PDC ao Senado e a promulgação do Decreto Legislativo;

7. Entre o Decreto Legislativo e a ratificação

8. Entre a ratificação e o Decreto Presidencial

9. Entre o Decreto Legislativo e o Decreto Presidencial

10. Entre a assinatura pelo Brasil e a ratificação

11. Entre a MSC e o Decreto Presidencial

Cada um desses dados auxilia a compreender, de maneira mais detalhada, o processo de internalização dos tratados de Direitos Humanos no Brasil. Os intervalos de (1) a (4) e (6) a (9) ocorrem em sequência, e os intervalos (5), (10) e (11) agregam etapas distintas da tramitação de tratados. O intervalo (1) revela a intenção, ao menos aparente, do Poder Executivo de se vincular a tratado. Digo "ao menos aparente" pois existem casos nos quais a assinatura ocorre na mesma data ou pouco tempo depois da celebração internacional do tratado, mas a elaboração da MSC, que demonstra a intenção do Executivo de enviar o instrumento à apreciação do Legislativo, tarda alguns anos.

O intervalo (2) demonstra a distância temporal entre a assinatura de um tratado e a data de elaboração da MSC. Esse intervalo possibilita verificar quanto tempo o Executivo levou para enviar o tratado à apreciação do Poder Legislativo. A MSC é o primeiro ato interno relacionado com a tramitação de um tratado, e configura a vontade de o Executivo efetivamente levar o instrumento internacional à apreciação do Legislativo. Nos casos em que houve acessão ou adesão ao tratado, não se considerou esse intervalo, pois se trata de caso no qual o Executivo optou por iniciar o processo de aprovação interna previamente à assinatura do tratado, ocorrendo adesão ou acessão ao tratado somente após o término do processo de internalização. Nesses casos, esse intervalo consta como zero; caso contrário, seria negativo, o que não faz sentido quando se trata de intervalos temporais.

O intervalo (3), por sua vez, indica o tempo entre a elaboração da MSC, geralmente por parte do Ministro das Relações Exteriores, e seu envio ao Poder Legislativo. A elaboração da MSC demonstra o interesse do Poder Executivo em enviar a matéria ao Poder Legislativo, o que pode ser comprovado pela brevidade, na maior parte dos casos, desse intervalo. O intervalo (4), por sua vez, mostra o tempo para a apreciação, pela Câmara dos Deputados, única e exclusivamente da Mensagem Presidencial que encaminha a essa Casa o texto do tratado. Com a superação dessa etapa, a Câmara começa a apreciar o PDC, a 
primeira parte desse processo complexo de internalização de tratados, que se inicia, por analogia, nessa Casa.

O intervalo (5) mostra o tempo de tramitação do tratado na Câmara dos Deputados. ${ }^{274}$ O PDC, a partir do momento em que é recebido pelo Senado Federal, é transformado em PDS. O intervalo (6) mostra o tempo de tramitação do tratado no Senado Federal. O intervalo (7) mostra quanto tempo, após a publicação do Decreto Legislativo, o Executivo demorou para ratificar o instrumento internacional, ato exclusivo desse Poder.

O intervalo (8) demonstra o tempo que se passou entre a ratificação (ato internacional) e a promulgação do Decreto Presidencial (ato interno que confere publicidade ao tratado). $\mathrm{O}$ intervalo (9) revela quanto tempo o Executivo levou para promulgar o Decreto Presidencial, que dá publicidade ao tratado em território brasileiro, após a edição do Decreto Legislativo.

O intervalo (10), entre a assinatura do tratado e a sua ratificação, apresenta a totalidade do processo de comprometimento com determinado tratado no âmbito internacional, que apenas se perfaz após o término do processo de internalização do tratado no âmbito do Poder Legislativo. Esse processo inicia-se no momento em que o plenipotenciário demonstra à comunidade internacional sua intenção de se comprometer com um tratado, com a assinatura, e termina no momento em que esse processo é finalizado, com a ratificação. ${ }^{275} \mathrm{O}$ intervalo (11), finalmente, ao apontar o lapso temporal entre a MSC e o Decreto Presidencial, mostra a totalidade do tempo de tramitação interna (nacional) do tratado.

Com base nesses dados, foram elaboradas estatísticas que auxiliaram a determinar não somente as médias gerais, relacionadas à totalidade dos tratados, e as médias quando separados em grupos conforme o regime no qual tramitaram; mas a determinar aqueles instrumentos cujos intervalos de tempo foram os mais discrepantes. Esses dados serão analisados, em um segundo momento, em conjunto com aqueles relativos aos argumentos proferidos pelos parlamentares durante o processo de internalização. Foram elaborados os seguintes cálculos em relação ao aspecto temporal dos tratados:

\footnotetext{
${ }^{274}$ Em alguns casos, o Projeto de Decreto voltou à apreciação da Câmara, após sua apreciação do Senado. Como existem poucos exemplos disso dentre os instrumentos estudados, manteve-se esse intervalo como demonstrativo do temo de tramitação do tratado na Câmara.

${ }^{275}$ Destaco que o Decreto Presidencial, responsável pela promulgação do Decreto Legislativo no âmbito interno, é, na maior parte dos casos analisados nesta tese, posterior à ratificação. Deste modo, a ratificação, derradeiro ato de caráter internacional para a vinculação de um país a determinado tratado, não é o último ato relacionado ao tratado, pois falta, com poucas exceções, a promulgação do Decreto Presidencial.
} 
(i) Média: foram analisados 48 (quarenta e oito) instrumentos no total, mas não constam todas as datas analisadas em todos eles; por isso, o número $(\mathrm{N})$ que divide a soma dos dias, para chegarmos à média, é diferente em cada coluna;

(ii) Mediana: foi necessário calcular a mediana dos tratados considerados em conjunto pois, como a quantidade de dias dos intervalos acima mencionados é extremamente discrepante em alguns casos, a média poderia ficar distorcida.

Esses cálculos foram feitos para verificar quais tratados demoraram mais em cada etapa de internalização; para encontrar, posteriormente, motivos para essa demora. Os motivos serão investigados dentro dos argumentos utilizados pelo Poder Executivo e Poder Legislativo, descritos com maior detalhe no Apêndice III (TABELA DOS ARGUMENTOS UTILIZADOS PELOS MEMBROS DOS PODERES EXECUTIVO E LEGISLATIVO). Espera-se que, nos tratados que levam muito tempo em cada etapa, os argumentos utilizados sejam, no mínimo, mais numerosos em relação aos outros tratados, e, potencialmente, discrepantes entre si. Isso foi observado em um segundo momento da pesquisa, que consta no item 5.3.

É essencial destacar que faltam algumas das datas relacionadas a determinados tratados. ${ }^{276}$ Essas informações ou não foram encontradas, ou não existem, principalmente pelos motivos a seguir:

(i) Assinatura:

a. Nos casos em que o dado existe: o Brasil não assinou o tratado até a data de entrega desta tese;

b. Não aplicação: é o caso de (i) Declarações que precisam ser feitas voluntariamente pelos países, e que não comportam assinatura propriamente dita; (ii) Convenções da OIT, que não são assinadas pelos Estados membros, pois a Organização considera, apenas, a data de ratificação;

(ii) Vigor Internacional:

a. $\quad$ O tratado não está em vigor internacionalmente;

\footnotetext{
${ }^{276}$ Os pontos (“.”) destacados na tabela de estatísticas referem-se a dados inexistentes ou não encontrados em relação a determinado tratado.
} 
b. Não cabimento: trata-se de declaração que deve ser feita pelo país, e o vigor relaciona-se, especificamente, ao país que efetuou a declaração relacionada a determinado tratado;

(iii) Ratificação:

a. $\quad$ Não é o caso de ratificação (nas Declarações);

b. $\quad$ O tratado não foi ratificado;

c. Não consta a data de ratificação pelo Brasil em nenhum documento normativo interno, e tampouco nos endereços eletrônicos das organizações internacionais depositárias;

(iv) Tramitação legislativa: quando não consta data em algum dos espaços referentes à tramitação legislativa, isso significa que determinada etapa (ou etapas) não foi cumprida pelo Executivo (nos casos de Mensagem Presidencial e de Decreto Presidencial) ou por alguma das Casas do Poder Legislativo.

Apresento, a seguir, tabela referente ao cálculo das médias de cada etapa de tramitação dos tratados internacionais analisados.

Tabela 2: Cálculo das médias de cada etapa de tramitação dos tratados internacionais analisados 


\begin{tabular}{|c|c|c|c|c|c|c|c|c|c|c|c|}
\hline Tratado ou Protocolo & $\begin{array}{c}\text { (1) Data do } \\
\text { Tratado } x \\
\text { Assinatura (dias) }\end{array}$ & $\begin{array}{l}\text { (2) Assinatura } \\
\text { x Data da } \\
\text { MSC }\end{array}$ & $\begin{array}{l}\text { (3) Mensagem x } \\
\text { Envio (Poder } \\
\text { Executivo) }\end{array}$ & $\begin{array}{l}\text { (4) Envio MSC x } \\
\text { Transformação } \\
\text { em PDC }\end{array}$ & $\begin{array}{l}\text { (5) Tempo de } \\
\text { tramitação na } \\
\text { Câmara (envio } \\
\text { da MSC x envio } \\
\text { PDC ao Senado) }\end{array}$ & $\begin{array}{c}\text { (6) Tempo de } \\
\text { tramitação no Senado } \\
\text { (envio PDC ao } \\
\text { Senado x Decreto } \\
\text { Legislativo) }\end{array}$ & $\begin{array}{c}\text { (7) Decreto } \\
\text { Legislativo } \\
\mathbf{x} \\
\text { Ratificação }\end{array}$ & $\begin{array}{l}\text { (8) Ratificação x } \\
\text { Decreto Executivo }\end{array}$ & $\begin{array}{l}\text { (9) Decreto } \\
\text { Legislativo } x \\
\text { Decreto } \\
\text { Executivo }\end{array}$ & $\begin{array}{l}\text { (10) Te mpo de } \\
\text { tramitação } \\
\text { internacional: } \\
\text { Assinatura x } \\
\text { Ratificaçãa }\end{array}$ & $\begin{array}{c}\text { (11) Tempo de } \\
\text { tramitação } \\
\text { interna: MSC x } \\
\text { Decreto } \\
\text { Executivo }\end{array}$ \\
\hline 1. Convenção para a prevenção e a repressão do crime de genocídio & 2 & 268 & 12 & 314 & 419 & 152 & 370 & 21 & 391 & 1221 & 974 \\
\hline 2. Convenção para a repressão do tráfico de pessoas e do Lenocínio & 563 & 130 & 2 & 2316 & 1359 & 950 & 93 & 391 & 484 & 2534 & 2795 \\
\hline 3. Convenç̃o relativa ao Estatuto dos Refugiados & 353 & 1841 & 29 & 624 & 716 & 328 & 132 & 73 & 205 & 3046 & 1278 \\
\hline 3.1. Protocolo sobre o Estatuto dos Refugiados & 1893 & & 36 & 29 & 32 & 3 & 251 & 0 & 251 & 122 & 322 \\
\hline 4. Convenção sobre os Direitos Políticos da Mulher & 51 & 23 & 6 & 12 & 809 & 75 & 2823 & 30 & 2853 & 3736 & 3743 \\
\hline 5. Convenção sobre o Estatuto dos Apátridas & 0 & 14042 & 29 & 56 & 440 & 288 & 496 & 2108 & 2604 & 15295 & 3361 \\
\hline 6. Convenção sobre a Nacionalidade da Mulher Casada & 3443 & 72 & 48 & 57 & 188 & 392 & 162 & 104 & 266 & 862 & 894 \\
\hline $\begin{array}{l}\text { 7. Convenção concernente à abolição do trabalho forçado (Convenção 105, } \\
\text { OIT) }\end{array}$ & $\cdot$ & & 5 & 2226 & 2345 & 184 & 49 & 391 & 440 & 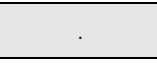 & 2974 \\
\hline 8. Convencão para a Redução dos Casos de Apatridia & 0 & 14474 & 8 & 624 & 2134 & 220 & 21 & 2854 & 2875 & 16857 & 5237 \\
\hline $\begin{array}{l}\text { 9. Convenção internacional sobre a eliminação de todas as formas de } \\
\text { discriminação racial }\end{array}$ & 0 & 218 & 43 & 57 & 148 & 62 & 280 & 621 & 901 & 751 & 1154 \\
\hline 9.1. Declaração facultativa que reconhece a competência do Comitê & & & 14 & 196 & 392 & 191 & & & 412 & & 1009 \\
\hline 10. Pacto Internacional sobre Direitos Civis e Políticos & 9170 & & 6 & 174 & 572 & 1633 & 134 & 73 & 207 & 91 & 2418 \\
\hline 10.1. Protocolo Facultativo ao Pacto Internacional sobre Direitos Civis e Pol & 15624 & & 81 & 155 & 898 & 369 & & & &. & \\
\hline $\begin{array}{l}\text { 10.2. Segundo Protocolo Facultativo ao Pacto Internacional sobre Direitos } \\
\text { Civis e Politicos, com vistas à Abolicão da Pena de Morte }\end{array}$ & 7224 & & 81 & 155 & 898 & 369 & & & $\cdot$ & . & \\
\hline 11. Pacto Internacional sobre os Direitos Econômicos, Sociais e Culturais & 9170 & & 6 & 174 & 572 & 1633 & 43 & 164 & 207 & 0 & 2418 \\
\hline $\begin{array}{l}\text { 12. Convenção sobre a Prevenção e Punição de Crimes Contra Pessoas que } \\
\text { Gozam de Proteção Internacional, incluindo agentes diplomáticos }\end{array}$ & 9306 & & 6 & 239 & 414 & 112 & 68 & 99 & 167 & 0 & 699 \\
\hline $\begin{array}{l}\text { 13. Convenção sobre a eliminação de todas as formas de discriminação } \\
\text { contra a mulher }\end{array}$ & 469 & 464 & 18 & 15 & 337 & 139 & 79 & 48 & 127 & 1037 & 621 \\
\hline 13.1. Retirada das reservas à Convenção & & & 22 & 274 & 351 & 14 & & & 3005 & 1007 & 3392 \\
\hline $\begin{array}{l}\text { 13.2. Protocolo facultativo à Convenção sobre eliminação de todas as } \\
\text { formas de discriminacăoo contra a mulher }\end{array}$ & 524 & 34 & 9 & 175 & 240 & 167 & 54 & 0 & 54 & 504 & 470 \\
\hline $\begin{array}{l}\text { 14. Convenção contra a tortura e outros tratamentos ou penas cruéis, } \\
\text { desumanos ou degradantes }\end{array}$ & 287 & 248 & 5 & 183 & 385 & 700 & 128 & 505 & 633 & 1466 & 1723 \\
\hline $\begin{array}{l}\text { 14.1. Protocolo Facultativo à Convenção contra a Tortura e Outros } \\
\text { Tratamentos ou Penas Cruéis, Desumanos ou Degradantes }\end{array}$ & 299 & 192 & 57 & 153 & 893 & 22 & 22 & 98 & 120 & 1186 & 1092 \\
\hline $\begin{array}{l}\text { 14.2. Declaração que reconhece a competência do Comitê previsto na } \\
\text { Convenção }\end{array}$ & . & & 9 & 188 & 1258 & 125 & & & $\cdot$ & . & \\
\hline 15. Convenção 169 da OIT sobre Povos Indígenas e Tribais & & & 18 & 617 & 771 & 3221 & 35 & 634 & 669 & & 4679 \\
\hline 16. Convenção sobre os Direitos da Criança & 67 & 110 & 15 & 69 & 103 & 3 & 10 & 58 & 68 & 241 & 189 \\
\hline $\begin{array}{l}\text { 16.1. Protocolo Facultativo à Convenção sobre os Direitos da Criança } \\
\text { referentes à venda de criança, à prostituição infantil eà pornografia infantil }\end{array}$ & 104 & 369 & 15 & 518 & 532 & 79 & 243 & 41 & 284 & 1238 & 910 \\
\hline $\begin{array}{l}\text { 16.2. Protocolo facultativo à Convenção sobre os direitos da criança } \\
\text { relativos ao envolvimento de crianças em conflitos armados }\end{array}$ & 104 & 369 & 15 & 518 & 532 & 79 & 243 & 41 & 284 & 1238 & 910 \\
\hline $\begin{array}{l}\text { 16.3. Protocolo facultativo à Convenção sobre os Direitos da Criança sobre } \\
\text { procedimentos de comunicaçăo }\end{array}$ & 71 & 1072 & 112 & 204 & . & . & 0 & 0 & . & . & . \\
\hline $\begin{array}{l}\text { 17. Convenção Internacional sobre a Proteção dos Direitos de Todos os } \\
\text { Trabalhadores Migrantes e dos Membros das suas Familias }\end{array}$ & $\cdot$ & & 227 & $\cdot$ & . & $\cdot$ & 0 & 0 & $\cdot$ & $\cdot$ & \\
\hline 18. Estatuto de Roma do Tribunal Penal Internacional & 570 & 535 & 76 & 177 & 196 & 43 & 14 & 97 & 111 & 864 & 426 \\
\hline $\begin{array}{l}\text { 18.1. Acordo sobre Privilégios e Imunidades do Tribunal Penal } \\
\text { Internacional }\end{array}$ & 615 & 1512 & 612 & 160 & 447 & 113 & 81 & 1467 & 1548 & 2765 & 2720 \\
\hline $\begin{array}{l}\text { 19. Convenção das Nações Unidas contra o Crime Organizado } \\
\text { Transnacional ("Convenção de Palermo") }\end{array}$ & 27 & 350 & 64 & 392 & 406 & 78 & 245 & 43 & 288 & 1143 & 836 \\
\hline $\begin{array}{l}\text { 19.1. Protocolo adicional para o Combate ao tráfico de Migrantes por via } \\
\text { terrestre, marítima e aérea }\end{array}$ & 27 & 350 & 64 & 392 & 406 & 78 & 245 & 43 & 288 & 1143 & 836 \\
\hline $\begin{array}{l}\text { 19.2. Protocolo para a Prevenção, Repressão e Punição do Tráfico de } \\
\text { Pessoas, em especial Mulheres e Crianças }\end{array}$ & 27 & 350 & 64 & 392 & 406 & 78 & 245 & 43 & 288 & 1143 & 836 \\
\hline $\begin{array}{l}\text { 20. Convenção sobre os Direitos das Pessoas com Deficiência e de seu } \\
\text { Protocolo Facultativo }\end{array}$ & 107 & 118 & 62 & 230 & 245 & 42 & 23 & 389 & 412 & 490 & 761 \\
\hline $\begin{array}{l}\text { 21. Convenção Internacional para a Proteção de Todas as Pessoas Contra o } \\
\text { Desaparecimento Forçado }\end{array}$ & 48 & 268 & 581 & 174 & 307 & 147 & 89 & 1990 & 2079 & & \\
\hline
\end{tabular}




\begin{tabular}{|c|c|c|c|c|c|c|c|c|c|c|c|}
\hline Tratado ou Protocolo & $\begin{array}{c}\text { (1) Data do } \\
\text { Tratado x } \\
\text { Assinatura (dias) }\end{array}$ & $\begin{array}{l}\text { (2) Assinatura } \\
\text { x Data da } \\
\text { MSC }\end{array}$ & $\begin{array}{l}\text { (3) Mensagem x } \\
\text { Envio (Poder } \\
\text { Executivo) }\end{array}$ & $\begin{array}{l}\text { (4) Envio MSC x } \\
\text { Transformação } \\
\text { em PDC }\end{array}$ & $\begin{array}{l}\text { (5) Tempo de } \\
\text { tramitação na } \\
\text { Câmara (envio } \\
\text { da MSC x envio } \\
\text { PDC ao Senado) }\end{array}$ & $\begin{array}{l}\text { (6) Tempo de } \\
\text { tramitação no Senado } \\
\text { (envio PDC ao } \\
\text { Senado x Decreto } \\
\text { Legislativo) }\end{array}$ & $\begin{array}{c}\text { (7) Decreto } \\
\text { Legislativo } \\
\mathbf{x} \\
\text { Ratificação }\end{array}$ & $\begin{array}{l}\text { (8) Ratificação x } \\
\text { Decreto Executivo }\end{array}$ & $\begin{array}{l}\text { (9) Decreto } \\
\text { Legislativo } x \\
\text { Decreto } \\
\text { Executivo }\end{array}$ & $\begin{array}{l}\text { (10) Tempo de } \\
\text { tramitação } \\
\text { internacional: } \\
\text { Assinaturax } \\
\text { Ratificação }\end{array}$ & $\begin{array}{c}\text { (11) Tempo de } \\
\text { tramitação } \\
\text { interna: MSC x } \\
\text { Decreto } \\
\text { Executivo }\end{array}$ \\
\hline $\begin{array}{l}\text { 22.1. Protocolo adicional à Convenção Americana sobre Direitos Humanos } \\
\text { em matéria de direitos econômicos, sociais e culturais }\end{array}$ & 2834 & . & 6 & 216 & 461 & 413 & & & 1716 & . & 2596 \\
\hline 22.2. Protocolo referente à abolição da pena de morte & 1460 & 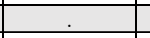 & 6 & 216 & 461 & 413 & 482 & 744 & 1226 & 798 & 2106 \\
\hline $\begin{array}{l}\text { 22.3. Reconhecimento da Competência obrigatória da Corte Interamericana } \\
\text { de Direitos Humanos }\end{array}$ & 10610 & $\cdot$ & 4 & 36 & 41 & 45 & & & 1436 & . & 1526 \\
\hline 23. Convenção Interamericana para prevenir e punir tortura & 46 & 138 & 2 & 173 & 725 & 358 & 50 & 112 & 162 & 1273 & 1247 \\
\hline $\begin{array}{l}\text { 24. Convencnão Interamericana para prevenir, punir e erradicar a violência } \\
\text { contra a mulher }\end{array}$ & 89 & 132 & 3 & 118 & 216 & 8 & 77 & 259 & 336 & 436 & 563 \\
\hline 25. Convenção Interamericana sobre o Desaparecimento Forçado de Pessoas & 1 & 187 & 11 & 143 & 4905 & 1043 & 840 & 1020 & 1860 & 6986 & 7819 \\
\hline 26. Convenção Interamericana sobre tráfico internacional de menores & 0 & 304 & 3 & 111 & 566 & 84 & 251 & 408 & 659 & 1208 & 1312 \\
\hline $\begin{array}{l}\text { 27. Convenção Interamericana para a eliminação de todas as formas de } \\
\text { discriminação contra as pessoas portadoras de deficiência }\end{array}$ & 0 & 118 & 18 & 159 & 501 & 99 & 34 & 83 & 117 & 770 & 735 \\
\hline $\begin{array}{l}\text { 28. Protocolo de Assunção sobre Compromisso com a Promoção e Proteção } \\
\text { dos Direitos Humanos do Mercosul }\end{array}$ & 0 & 448 & 32 & 523 & 977 & 72 & 189 & 119 & 308 & 1718 & 1389 \\
\hline $\begin{array}{l}\text { 29. Convenção Interamericana contra o Racismo, a Discriminação Racial e } \\
\text { formas correlatas de intolerância }\end{array}$ & 61 & . & . & . & . & . & & . & . & . & 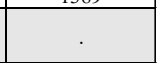 \\
\hline $\begin{array}{l}\text { 30. Convenção Interamericana contra toda forma de discriminação e } \\
\text { intolerância }\end{array}$ & 61 & . & & & & . & & & . & . & \\
\hline 31. Convenção de Viena sobre o Direito dos Tratados & 0 & 8364 & 6 & 224 & \begin{tabular}{l|l}
6238 & 1 \\
\end{tabular} & 57 & 70 & 80 & 150 & 14735 & 6451 \\
\hline Soma & 83632 & 47100 & 2578 & 14332 & 36604 & 15690 & 8793 & 15293 & 30655 & $\begin{array}{r}88307 \\
\end{array}$ & 81100 \\
\hline Média: 48 instrumentos no total & 1991 & 1570 & 56 & 318 & 832 & $\begin{array}{r}357 \\
\end{array}$ & 225 & 392 & 748 & 2523 & 1978 \\
\hline Mediana: ( $\mathrm{n}=48$ para os que têm todas as datas). & $96,5(89+104 / 2)$ & 286 & 15 & 177 & 461 & $132(125+139 / 2)$ & 93 & 98,5 & 284 & 1.143 & 1.278 \\
\hline$N=$ & 42 & 30 & 46 & 45 & 44 & 44 & 39 & 39 & 41 & 35 & 41 \\
\hline
\end{tabular}

Fonte: elaboração própria 
A separação dos tratados em grupos foi feita em duas etapas. Em um primeiro momento, observou-se a data inicial de tramitação dos tratados no Brasil, a partir da data da MSC, para separá-los em três grupos: (i) aqueles cuja tramitação foi iniciada durante a democracia anterior a 1964, (ii) durante o regime militar e (iii) após o seu término. Foram feitas estatísticas iniciais relativas a esses dados, que possibilitaram uma análise global do intervalo de tempo relativo a cada etapa da tramitação. Alguns tratados, porém, tinham etapas de tramitação em regimes diferentes, o que indicou um problema na categorização inicialmente estabelecida, ${ }^{277}$ fazendo-se necessário corrigir a distorção que ocorreria caso se considerasse o intervalo inteiro como pertencendo a um regime apenas.

Para superar o erro que adviria da categorização dos tratados considerando apenas a data de início da tramitação em âmbito nacional, foi necessário desmembrar as etapas de tramitação. Ao considerar intervalos menores, foi possível verificar quantos dias determinado instrumento tramitou em cada regime. A partir desses números, delimitou-se quanto tempo cada um levou para ser assinado ou ratificado em cada regime. Por essa razão, um tratado pode integrar mais de um grupo, e os dados relativos ao tempo de tramitação serão considerados em conformidade com o regime vigente à época da tramitação. Com isso, foi possível chegar a conclusões que consideram as mudanças de regime.

A quase totalidade dos processos de internalização analisados foi iniciada (com a elaboração da MSC) e finalizada no mesmo regime, com apenas uma exceção: a Convenção concernente à abolição do trabalho forçado (Convenção 105, OIT), cujo intervalo entre o envio da MSC à Câmara e a transformação da MSC em PDC perpassa dois regimes. As informações relativas a esse tratado encontram-se, portanto, em dois grupos diferentes.

A "Média Geral” considera a totalidade dos tratados, não os separando por regime. Os regimes e os tratados que tramitaram durante o período foram separados em três grupos. $\mathrm{O}$ Grupo 1 considera aqueles celebrados e/ou assinados entre 1945 e 1964 (G1), o Grupo 2 considera os tratados entre 1964 e 1985 (G2), e o Grupo 3, aqueles a partir de 1985 (G3). Isso é importante para verificar, com exatidão, cada um dos intervalos de tempo analisados, imprescindível para uma média fiel à tramitação em cada um dos regimes.

Em alguns casos, o número (“N”) da amostra geral é diferente (sempre menor) da soma dos "N's" dos grupos. Isso ocorre porque existem tratados cujas etapas de tramitação são consideradas mais de uma vez, em grupos diferentes. Por esse motivo, a soma dos tratados nos grupos pode ser maior do que o " $\mathrm{N}$ " da amostra geral.

\footnotetext{
${ }^{277}$ Notadamente, os intervalos (1) Data do Tratado x Assinatura, (2) Assinatura x Data da MSC, (10) Assinatura x Ratificação, e (11) Data da MSC x Decreto Presidencial.
} 
Temos, portanto, os seguintes valores para cada etapa dos tratados, expostos em dias:

1. Entre a data do tratado e a assinatura pelo Brasil:

1.1. Média geral: 1.991 dias

\subsubsection{Para tratados entre 1945-1964: 509 dias $(\mathrm{N}=7)$}

1.1.1.1. Para tratados assinados durante o regime: $162(\mathrm{~N}=6)$

1.1.1.2. Para tratados não assinados durante o regime: $2.295(\mathrm{~N}=1)$

1.1.2. Para tratados entre 1964-1985: 3.216 dias $(\mathrm{N}=12)$

1.1.2.1. Para tratados assinados durante o regime: 642 dias $(\mathrm{N}=5)$

1.1.2.2. Para tratados não assinados durante o regime: $5.054(\mathrm{~N}=7)$

1.1.3. Para tratados a partir de 1985: 1.338 dias $(\mathrm{N}=31)$

1.2. Mediana: 96,5 dias

1.3. Número de tratados acima da Média Geral: 9 (21\%)

1.4. "N" da amostra geral: 42

Existe aspecto importante que se deve abordar em relação aos dados desse intervalo: o cálculo dos dias que se passaram entre a celebração internacional ("data do tratado") e a assinatura foi feito considerando o intervalo de tempo entre essas duas datas. Os tratados foram, em um primeiro momento, separados em grupos conforme a data do início de sua internalização, com a elaboração da MSC. Entretanto, em virtude da data de celebração, alguns tratados foram elaborados e assinados em períodos históricos diferentes, o que culminou em períodos extremamente longos de tempo entre a celebração internacional e a assinatura pelo Brasil. Inicialmente, porém, na divisão inicial, o regime responsável pela assinatura do tratado era "penalizado" pela demora do regime anterior. ${ }^{278}$ Como consequência da demora do regime anterior (democrático ou ditatorial) em assinar um tratado, o regime que efetivamente o assinou passava a ser responsabilizado por todos os dias que se passaram entre a celebração e a assinatura, mesmo não sendo o regime vigente à época. Conclui que o regime posterior não poderia ser responsabilizado pela inação do

\footnotetext{
${ }^{278}$ O termo "penalizado" foi utilizado porque, na percepção da autora, a demora de um regime em assinar um tratado de Direitos Humanos prejudica sua imagem no âmbito internacional, considerando o cenário de Estados Democráticos de Direito convivendo em comunidade. É indiscutível, porém, que não se trata de percepção unânime, daí as aspas.
} 
governo que o precedeu. Apesar da importância de apresentar os dados gerais, não se pode considerá-los sem atentar à separação feita entre os grupos.

As médias por período demonstram que o regime democrático entre 1945 e 1964 teve o menor delta temporal entre a data de celebração de um tratado e a sua assinatura pelo Brasil. O período da ditadura, considerados todos os tratados, foi responsável pela maior média; e o período democrático que a seguiu culminou em diminuição do tempo de assinatura de tratados relativos aos Direitos Humanos. No primeiro período analisado (19451964), os tratados levaram uma média de 509 dias para serem assinados. Durante a ditadura, a média foi de 3.216 dias; e, no período democrático que se seguiu, de 1.338 dias.

A média inicial de dias para a assinatura de tratados durante a ditadura considerou todos os dias que se passaram desde a celebração (internacional) do tratado e sua assinatura por parte do plenipotenciário brasileiro. Entretanto, ressalto que, dos 12 (doze) tratados considerados para essa estatística, apenas 5 (cinco) foram, efetivamente, assinados durante o período. ${ }^{279} \mathrm{O}$ restante foi, simplesmente, ignorado pelo regime, e assinado apenas durante a democracia. Considerados somente os tratados que contaram com a atenção do regime, a média de tempo para a assinatura foi de 642 dias, ou $48 \%$ do intervalo de tempo médio para a assinatura de um tratado durante o período democrático atual. Os outros acordos, relacionados aos Direitos Humanos básicos dos cidadãos e à sua proteção contra a tortura, não foram assinados pelo Brasil à época, fato que ocorreu, apenas, na democracia. ${ }^{280}$ Os dias que se passaram entre a instauração do regime democrático pós-1985 e a assinatura do tratado foram devidamente contabilizados no G3.

Esse cálculo diferencia os tratados com os quais o regime verdadeiramente lidou - ou seja, aqueles nos quais os Poderes Executivo e Legislativo se imiscuíram para sua internalização - dos tratados ignorados pelo regime. Isso apresenta uma noção mais precisa do intervalo de tempo que um regime precisou para internalizar algum tratado, agregando informações à primeira estatística elaborada. Esta, ao considerar, também, os tratados

\footnotetext{
${ }^{279}$ A Convenção de Viena sobre o Direito dos Tratados, a Convenção internacional sobre a eliminação de todas as formas de discriminação racial, a Convenção sobre a eliminação de todas as formas de discriminação contra a mulher, a Convenção sobre a Nacionalidade da Mulher Casada e o Protocolo sobre o Estatuto dos Refugiados. ${ }^{280}$ São os seguintes tratados: Pactos Internacionais sobre Direitos Civis e Políticos e Direitos Econômicos, Sociais e Culturais, Protocolo Facultativo ao Pacto Internacional sobre Direitos Civis e Políticos, Convenção sobre a Prevenção e Punição de Crimes contra pessoas que gozam de proteção internacional, incluindo agentes diplomáticos, Convenção contra a tortura e outros tratamentos ou penas cruéis, desumanos ou degradantes e a Convenção Americana sobre Direitos Humanos.
} 
ignorados pelos regimes, aumenta o valor real do intervalo de tramitação, sem discriminar o motivo para esse aumento, que corresponde ao conjunto de tratados desprezados.

Considerando a estatística que diferencia os tratados assinados durante o regime daqueles não assinados, é possível afirmar que o período democrático entre 1945-1964 foi responsável pelo menor intervalo (162 dias) entre a data do tratado e a assinatura pelo Brasil. Segue-se o período da ditadura (com 642 dias), e o período democrático atual (1.338 dias).

Destaco que a ditadura terminou em 15.03.1985, o que impossibilita saber se os tratados que não foram assinados durante o regime militar seriam assinados posteriormente, caso tivesse se prolongado. Essa questão, porém, não é passível de solução.

Segue tabela que demonstra como foram calculados os intervalos de tempo dos tratados celebrados e assinados, pelo Brasil, em regimes diferentes. A mesma lógica foi utilizada para calcular outros intervalos que perpassaram regimes distintos.

\section{Tabela 3: Datas do tratado e assinatura, na Ditadura e na Democracia: dados e cálculo dos intervalos}

\begin{tabular}{|l|c|c|}
\hline Tratado ou Protocolo & Data do Tratado & (A) \\
& $\begin{array}{c}\text { Assinatura, Acessão ou adesão } \\
\text { (D) }\end{array}$ & $26 / 07 / 1966$ \\
\hline 6. Convenção sobre a Nacionalidade da Mulher Casada & $20 / 02 / 1957$ & N/A \\
\hline 7. Convenção concernente à abolição do trabalho forçado (Convenção 105, OIT) & $25 / 06 / 1957$ & $24 / 01 / 1992$ \\
\hline 10. Pacto Internacional sobre Direitos Civis e Políticos & $16 / 12 / 1966$ & $25 / 09 / 2009$ \\
\hline 10.1. Protocolo Facultativo ao Pacto Internacional sobre Direitos Civis e Políticos & $16 / 12 / 1966$ & $24 / 01 / 1992$ \\
\hline 11. Pacto Internacional sobre Direitos Econômicos, Sociais e Culturais & $16 / 12 / 1966$ & $07 / 06 / 1999$ \\
\hline $\begin{array}{l}\text { 12. Convenção sobre a Prevenção e Punição de Crimes Contra Pessoas que Gozam } \\
\text { de Proteção Internacional, incluindo agentes diplomáticos }\end{array}$ & $14 / 12 / 1973$ & $23 / 09 / 1985$ \\
\hline $\begin{array}{l}\text { 14. Convenção contra a tortura e outros tratamentos ou penas cruéis, desumanos ou } \\
\text { degradantes }\end{array}$ & $10 / 12 / 1984$ & $07 / 09 / 1992$ \\
\hline 22. Convenção Americana sobre Direitos Humanos & $22 / 11 / 1969$ & $10 / 12 / 1998$ \\
\hline $\begin{array}{l}\text { 22.3. Reconhecimento da Competência obrigatória da Corte Interamericana de } \\
\text { Direitos Humanos }\end{array}$ & $22 / 11 / 1969$ & \\
\hline
\end{tabular}

\begin{tabular}{|c|c|c|c|c|c|c|c|}
\hline Tratado ou Protocolo & $\begin{array}{l}\text { (1) Data do Tratado x Assinatura (A) } \\
\text { (1) }=\text { (D) - (A) }\end{array}$ & $\begin{array}{c}\text { G1 (B) } \\
\text { 30/03/1964 }\end{array}$ & $\begin{array}{c}\text { G2 (C) } \\
31 / 03 / 1964\end{array}$ & $\begin{array}{c}\text { G3 (D) } \\
15 / 03 / 1985\end{array}$ & $\begin{array}{c}\text { Tempo no G1 } \\
(\%)(\mathrm{F}) \\
(\mathrm{F})=(\mathrm{B}):(\mathrm{A})\end{array}$ & $\begin{array}{c}\text { Tempo no G2 } \\
(\%)(\mathbf{G}) \\
(\mathbf{G})=(\mathbf{C}):(\mathbf{A})\end{array}$ & $\begin{array}{c}\text { Tempo no G3 } \\
\text { (\%) (H) } \\
(\text { H) }=\text { (D) : (A) }\end{array}$ \\
\hline 6. Convenção sobre a Nacionalidade da Mulher Casada & 3443 & 2595 & 847 & & $75 \%$ & $25 \%$ & \\
\hline 7. Convenção concernente à abolição do trabalho forçado (Convenção 105, OIT) & N/A & & & & & & \\
\hline 10.1. Protocolo Facultativo ao Pacto Internacional sobre Direitos Civis e Politicos & 15624 & 0 & 6664 & 8960 & 0 & $43 \%$ & $57 \%$ \\
\hline 11. Pacto Internacional sobre Direitos Econômicos, Sociais e Culturais & 9170 & 0 & 6664 & 2506 & 0 & $73 \%$ & $27 \%$ \\
\hline $\begin{array}{l}\text { 12. Convenção sobre a Prevenção e Punição de Crimes Contra Pessoas que Gozam } \\
\text { de Proteção Internacional, incluindo agentes diplomáticos }\end{array}$ & 9306 & 0 & 4109 & 5197 & 0 & $44 \%$ & $56 \%$ \\
\hline $\begin{array}{l}\text { 22.3. Reconhecimento da Competência obrigatória da Corte Interamericana de } \\
\text { Direitos Humanos }\end{array}$ & 10610 & 0 & 5592 & 5018 & & $53 \%$ & $47 \%$ \\
\hline
\end{tabular}

Fonte: elaboração própria ${ }^{281}$

${ }^{281}$ Faz-se necessário elaborar uma nota de rodapé a respeito da data que consta na coluna referente ao G2 (C) - 31.03.1964, para evitar a falta de compreensão da tabela. Essa é a a data de início da ditadura, o que, a 
É possível perceber, pela análise dos dados acima apresentados, que, do intervalo total de dias entre a data do tratado e a assinatura da Convenção sobre a nacionalidade da Mulher Casada (item 6), de 3443 dias, 75\% (2.595 dias) estiveram no regime democrático, enquanto 25\% (847 dias) se passaram na ditadura militar.

Em relação aos Pactos Internacionais sobre Direitos Civis e Políticos e sobre os Direitos Econômicos, Sociais e Culturais, além do Protocolo ao primeiro, todos celebrados na mesma data, nenhum foi assinado pelo plenipotenciário brasileiro durante a ditadura. No caso dos Pactos, dos 9.170 dias de intervalo entre a data do tratado e a assinatura, 73\% (6.664 dias) passaram-se durante a ditadura, e 27\% (2.506 dias) na democracia. ${ }^{282} \mathrm{O}$ Protocolo Facultativo ao primeiro Pacto demorou 15.624 dias para ser assinado, dos quais 43\% (6.664 dias) se passaram durante a ditadura, e 57\% (8.960 dias), durante a democracia.

A Convenção sobre a Prevenção e Punição de crimes contra pessoas que gozam de proteção internacional, incluindo agentes diplomáticos, levou 9.306 dias para ser assinada, dos quais $44 \%$ na ditadura (4.109 dias) e 56\% na democracia (5197 dias).

A Convenção contra a tortura e outros tratamentos ou penas cruéis, desumanos ou degradantes, celebrada ao final do período ditatorial no Brasil, demorou 287 dias para ser assinada, 33\% dos quais durante a ditadura (95 dias), e 67\% (192 dias) durante a democracia. A Convenção Americana sobre Direitos Humanos, por sua vez, levou 8.325 dias para ser assinada, dos quais 67\% durante a ditadura (5.592 dias) e 33\% (2.733 dias) durante o período democrático.

Apesar de não se tratar de um tratado propriamente dito, o reconhecimento da competência obrigatória da Corte Interamericana de Direitos Humanos pelo Brasil levou 10.610 dias. Deles, 53\% (5.592 dias) se passaram na ditadura e 47\% (5.018 dias), na democracia. A data que consta na tabela (10.12.1998) é a de promulgação do Decreto Legislativo 89, que

\footnotetext{
princípio, pode parecer um erro - já que, na coluna anterior, consta a data de término do regime democrático que precedeu o regime militar. Essa data, entretanto, está correta: como o objetivo desta tabela foi calcular a quantidade de dias do período em questão no regime militar (neste caso, o intervalo de tempo entre a data do tratado e a assinatura), contou-se a quantidade de dias que se passaram desde o início do regime militar. Do mesmo modo, no caso da democracia pós-regime. No caso do período democrático anterior, contou-se o intervalo entre a data do tratado - todas posteriores a 1945 - e o momento de assinatura. Esse esclarecimento pareceu necessário à autora, em virtude das dúvidas apresentadas durante a defesa desta tese, em 17.04.2017. ${ }^{282}$ Os tratados tramitaram em conjunto, daí os mesmos intervalos de tempo referentes ao seu processo de internalização.
} 


\begin{abstract}
"aprova a solicitação de reconhecimento da competência obrigatória da Corte Interamericana de Direitos Humanos em todos os casos relativos à interpretação ou aplicação da Convenção Americana de Direitos Humanos para fatos ocorridos a partir do reconhecimento, de acordo com o previsto no parágrafo primeiro do art. 62 daquele instrumento internacional.".
\end{abstract}

2. Entre a assinatura e a data da MSC:

2.1.Média geral: 1.570 dias

\title{
2.1.1. Para tratados entre 1945-1964: 1.113 dias $(\mathrm{N}=6)$
}

2.1.1.1. Para tratados cuja MSC foi enviada durante o regime: 566 $(\mathrm{N}=4)$

2.1.1.2. Para tratados cuja MSC não foi enviada durante o regime: $2.207(\mathrm{~N}=2)$

2.1.2. Para tratados entre 1964-1985: 3.640 dias $(\mathrm{N}=6)$

2.1.2.1. Para tratados cuja MSC foi enviada durante o regime: 251 dias $(\mathrm{N}=3)$

2.1.2.2. Para tratados cuja MSC não foi enviada durante o regime: $7.028(\mathrm{~N}=3)^{283}$

2.1.3. Para tratados a partir de 1985: $:^{284} 774$ dias $(\mathrm{N}=24)$

2.2. Mediana: 286

2.3. Número de tratados acima da Média: 4 (13\%)

2.4. "N" da amostra: 30

O intervalo compreendido entre a assinatura de determinado tratado e a data da MSC respectiva demonstra o interesse do Poder Executivo em enviar à apreciação do Legislativo nacional o tratado assinado. A análise desse intervalo demonstra que a ditadura foi

\footnotetext{
${ }^{283}$ Nesses casos, o tratado foi assinado pelo regime anterior. O único tratado estudado assinado pela ditadura e não internalizado pelo regime militar foi a Convenção de Viena sobre Direito dos Tratados.

${ }^{284}$ Os dados referentes a mensagens presidenciais do G3 não foram segregados em "tratados cuja MSC foi enviada durante o regime" e "não enviada durante o regime" porque os únicos tratados que não foram objeto de MSC, até a entrega desta tese (a Convenção Interamericana contra o Racismo, a Discriminação Racial e formas correlatas de intolerância e a Convenção Interamericana contra toda forma de discriminação e intolerância), não foram considerados nas estatísticas temporais, porque a tramitação interna não se iniciou. De qualquer modo, pressupõe-se que o regime democrático será responsável por internalizar esses tratados, ambos de 2013, a menos que se instaure nova ditadura no país.
} 
responsável pelo menor tempo (251 dias), seguida pela democracia pré-1964 (566 dias) e pelo período democrático atual (774 dias).

3. Entre a data de elaboração da MSC e seu envio ao Poder Legislativo:

3.1.Média geral: 56 dias

3.1.1. Para tratados entre 1945-1964: 11 dias $(\mathrm{N}=5)$

3.1.2. Para tratados entre 1964-1985: 36 dias $(\mathrm{N}=4)$

3.1.3. Para tratados a partir de 1985: 64 dias $(\mathrm{N}=37)$

3.2. Mediana: 15 dias

3.3. Número de tratados acima da média: $12(26 \%)$

3.4. "N" da amostra: 46

A democracia pré-1964 foi responsável pelo menor intervalo de tempo, em média, entre a data de elaboração da MSC e seu envio ao Poder Legislativo (11 dias), seguida pela ditadura (36 dias) e pela democracia pós-1985 (64 dias).

4. Entre o envio da MSC ao Poder Legislativo e sua transformação em PDC:

4.1. Média geral: 318 dias

4.1.1. Para tratados entre 1945-1964: 1.080 dias $(\mathrm{N}=5)$

4.1.2. Para tratados entre 1964-1985: 50 dias $(\mathrm{N}=5)$

4.1.3. Para tratados a partir de 1985: 241 dias $(\mathrm{N}=36)$

4.2.Mediana: 177 dias

4.3.Número de tratados acima da média: $11(24 \%)$

4.4."N" da amostra: 45

O tempo para a primeira apreciação da MSC é menor durante a ditadura: são 50 dias, contra 241 para tratados do G3 e 1.080 para tratados do G1.

5. Entre o envio da MSC e o envio do PDC ao Senado:

5.1. Média geral: 832 dias

5.1.1. Para tratados entre 1945-1964: 1.087 dias $(\mathrm{N}=5)$

5.1.2. Para tratados entre 1964-1985: 183 dias $(\mathrm{N}=5)$ 
5.1.3. Para tratados a partir de 1985: 864 dias $(\mathrm{N}=35)$

5.2. Mediana: 461 dias

5.3. Número de tratados acima da média: $11(25 \%)$

5.4. "N" da amostra: 44

Esse intervalo é de extrema relevância, pois demonstra o tempo de tramitação do PDC na Câmara dos Deputados, que culmina no envio do projeto ao Senado. A média geral nesse item é de 832 dias. O menor valor foi obtido na ditadura (183 dias), seguido pelos 864 dias que os PDCs levaram, em média, para tramitar no pós-1985, e 1.087 dias entre 1945 e 1964.

6. Entre o envio do PDC ao Senado e a promulgação do Decreto Legislativo:

6.1.Média geral: 357 dias

6.1.1. Para tratados entre 1945-1964: 376 dias $(\mathrm{N}=4)$

6.1.2. Para tratados entre 1964-1985: 156 dias $(\mathrm{N}=5)$

6.1.3. Para tratados a partir de 1985: 383 dias $(\mathrm{N}=35)$

6.2. Mediana: 132 dias

6.3. Número de tratados acima da média: 13 (29\%)

6.4. "N" da amostra: 44

O tempo de tramitação no Senado Federal também é menor durante a ditadura: 156 dias, menos da metade do tempo para a tramitação, nessa mesma Casa, durante a democracia 1945-1964 (376 dias) e 1985-hoje (383 dias).

7. Entre o Decreto Legislativo e a ratificação

7.1.Média Geral: 225 dias

7.1.1. Para tratados entre 1945-1964: 655 dias $(\mathrm{N}=6)$

7.1.2. Para tratados entre 1964-1985: 164 dias $(\mathrm{N}=5)$

7.1.3. Para tratados a partir de 1985: 163 dias $(\mathrm{N}=28)$

7.2.Mediana: 93

7.3.Número de tratados acima da média: 13 (33\%)

7.4."N" da amostra: 39 
8. Entre a ratificação e o Decreto Presidencial

8.1.Média Geral: 392 dias

8.1.1. Para tratados entre 1945-1964: 685 dias $(\mathrm{N}=6)$

8.1.2. Para tratados entre 1964-1985: 233 dias $(\mathrm{N}=5)$

8.1.3. Para tratados a partir de 1985: 486 dias $(\mathrm{N}=28)$

8.2. Mediana: 98 dias

8.3.Número de tratados acima da média: $10(25 \%)$

8.4. "N" da amostra: 39

9. Entre o Decreto Legislativo e o Decreto Presidencial:

9.1.Média geral: 748 dias

9.1.1. Para tratados entre 1945-1964: 983 dias $(\mathrm{N}=4)$

9.1.2. Para tratados entre 1964-1985: 397 dias $(\mathrm{N}=5)$

9.1.3. Para tratados a partir de 1985: 773 dias $(\mathrm{N}=32)$

9.2. Mediana: 284 dias

9.3. Número de tratados acima da média: $11(27 \%)$

9.4."N" da amostra: 41

Esse intervalo engloba os dois anteriores (7) e (8). Novamente, é menor, na ditadura, o intervalo de tempo entre o Decreto Legislativo e o Executivo (397 dias); se comparado aos 773 dias do período democrático atual e aos 983 dias do período entre 1945-1964.

10. Entre a assinatura pelo Brasil e a ratificação: ${ }^{285}$

10.1.Média geral: 2.523 dias

10.1.1. Para tratados entre 1945-1964: 2.492 dias $(\mathrm{N}=6)$

10.1.1.1. Para tratados ratificados durante o regime: $2.634(\mathrm{~N}=4)$

10.1.1.2. Para tratados não ratificados durante o regime: $2.207(\mathrm{~N}=2)$

\footnotetext{
${ }^{285}$ Nos casos em que o intervalo de tempo nas tabelas é igual a zero, trata-se da data da acessão ou adesão (e não da assinatura), ou de tratado que teve consulta ao Legislativo antes da assinatura por parte do plenipotenciário brasileiro.
} 


\subsubsection{Para tratados entre 1964-1985: 3.408 dias $(\mathrm{N}=7)$}

10.1.2.1. Para tratados ratificados durante o regime: $693(\mathrm{~N}=4)$

10.1.2.2. Para tratados não ratificados durante o regime: $7.028(\mathrm{~N}=3)$

10.1.3. Para tratados a partir de 1985: 1.833 dias $(\mathrm{N}=27)^{286}$

10.2.Mediana: 1.143 dias

10.3. Número de tratados acima da Média: $8(23 \%)$

10.4. "N" da amostra: 35

Esse intervalo mostra a totalidade de tempo para o Brasil cumprir a etapa internacional relacionada aos tratados. Trata-se da quantidade de tempo necessária para o país completar o processo de vinculação jurídica, demonstrando a seus pares, no âmbito internacional, que está disposto a cumprir as determinações de um acordo.

A razão para a necessidade de separar os dados entre tratados ratificados e não ratificados pelo regime adveio, novamente, do interesse em separar aqueles que foram, simplesmente, ignorados pelo regime, e não ratificados durante toda a sua extensão; daqueles que tiveram o seu procedimento de internalização iniciado. As médias relativas aos tratados não ratificados pela ditadura são maiores do que as relativas aos tratados ratificados, porque os primeiros foram desconsiderados, o que pode ser comprovado pelo fato de a MSC de todos eles ter sido elaborada na democracia. Isso possibilita uma análise que considera o tempo efetivo de tramitação, e não, apenas, o tempo em que determinado tratado ficou completamente esquecido, sem atenção por parte dos Poderes nacionais.

Considerando esse cenário, a ditadura foi responsável pelo menor intervalo de tempo entre a assinatura de um tratado e sua ratificação (693 dias), sendo os períodos democráticos responsáveis, respectivamente, por uma demora de 2.634 e 1.833 dias.

No G1, apenas um tratado (Convenção concernente à abolição do trabalho forçado Convenção 105, OIT) tramitou entre a democracia anterior ao regime de 1964 e a ditadura. Porém, como não consta a data de assinatura do tratado (pelas razões apontadas acima, relacionadas ao iter das Convenções da OIT), este não foi considerado para essa estatística e, portanto, não houve distorção nos valores apresentados. No G2, apenas um tratado (Convenção sobre a Nacionalidade da Mulher Casada) tramitou entre a democracia anterior

${ }^{286}$ Todos os tratados assinados no G3 foram ratificados nesse período. 
ao regime de 1964 e a ditadura. A totalidade de tempo entre sua assinatura (26.07.1966) e ratificação (04.12.1968), porém, deu-se integralmente durante o período ditatorial, portanto, tampouco houve distorções.

\section{Entre a MSC e o Decreto Presidencial:}

11.1. Média geral: 1.978 dias

11.1.1. Para tratados entre 1945-1964: 2.186 dias $(\mathrm{N}=5)$

11.1.1.1.Tratados com Decreto Presidencial elaborado durante o regime: $2.198(\mathrm{~N}=4)$

11.1.1.2. Tratados com Decreto Presidencial não elaborado durante o regime: $2.138(\mathrm{~N}=1)$

11.1.2. Para tratados entre 1964-1985: 765 dias $(\mathrm{N}=5)^{287}$

11.1.3. Para tratados a partir de 1985: 2.073 dias $(\mathrm{N}=32)$

11.2. Mediana: 1.278

11.3. Número de tratados acima da Média: 16 (39\%)

11.4. "N" da amostra: 41.

Antes de reunir todos os dados a respeito da tramitação dos tratados, a autora imaginava que o intervalo de tramitação interna (intervalo 11) seria, necessariamente, mais curto do que o intervalo de tramitação internacional (intervalo 10). Isso porque, no entendimento da autora, a tramitação internacional apenas poderia ser encerrada após a publicação do Decreto Presidencial no Brasil, fato que possibilitaria a ratificação do tratado. Isso, porém, não ocorre. Na verdade, o instrumento de ratificação é depositado após a publicação do Decreto Legislativo; antes, portanto, do Decreto Presidencial. Apesar de o processo de internalização não ter sido finalizado, o que ocorre, apenas, com a publicação do Decreto Presidencial, o Brasil obriga-se internacionalmente com a ratificação. Daí a possibilidade de a tramitação interna ser, na prática, mais extensa do que a internacional.

Esse intervalo mostra a totalidade do tempo de tramitação interna de um tratado, que se perfaz no momento em que a ele é dada publicidade, com o Decreto Presidencial. Esse

\footnotetext{
287 Todos os tratados que tiveram a MSC elaborada durante o período da ditadura militar tiveram o Decreto Presidencial publicado durante esse regime.
} 
intervalo é, novamente, menor na ditadura (765 dias), seguido pelo período democrático atual (2.073 dias), e pela democracia de 1945-1964 (2.198 dias).

\subsubsection{CONSIDERAÇÕES A RESPEITO DOS DADOS OBTIDOS}

A primeira preocupação ao lidar com os dados obtidos foi determinar o que poderia ser considerado "rápido" em termos de internalização de tratados. Seria insuficiente fazer uma média do tempo total entre a assinatura e a ratificação e, por isso, optou-se por dividir os intervalos temporais em etapas menores. A partir dessas informações, foi possível determinar a "demora", ou não, de cada processo de internalização.

Em busca de dados referentes ao tempo para a internalização de tratados, Gabsch apresenta dado estatístico, baseado nos acordos bilaterais sujeitos à apreciação legislativa, celebrados entre 2004 e 2006: a demora média entre a assinatura e a ratificação é de 2 anos e 9 meses; o que seria “(...) evidentemente excessivo". ${ }^{288}$ Se compararmos os dados obtidos por Gabsch com aqueles obtidos na presente pesquisa, verifica-se que, se os tratados de Direitos Humanos ratificados pela ditadura levaram uma média de quase dois anos para cumprir essa etapa, na democracia atual eles levam uma média de 5 (cinco) anos.

O tempo de apreciação pelo Poder Legislativo, por sua vez, é obtido somando o período de tramitação dos tratados na Câmara e no Senado. A média de tempo na ditadura é de pouco mais de 11 meses; quase três anos e meio no pós-1985 e quatro anos entre 19451964. Gabsch informa, ainda, que, em média, 2 (dois) anos do período de apreciação dos tratados por ele analisados devem-se à fase de exame pelo Legislativo, o que é muito se comparado aos dados obtidos durante o regime ditatorial; e menos da metade do tempo de tramitação dos tratados nas democracias brasileiras.

Segundo Gabsch, o Poder Executivo teria demorado uma média de 9 meses para enviar o tratado para a apreciação do Legislativo, após sua conclusão. Novamente, ressalto que a ditadura foi responsável pelo menor tempo (menos de 8 meses e meio), seguida pela democracia pré-1964 (um ano e meio) e pelo período democrático hodierno (seis anos).

Os dados descritos acima confirmam a hipótese da autora, de que os intervalos de tramitação de tratados considerados foram, realmente, menores durante a ditadura. Apesar

${ }^{288}$ GABSCH, 2010, p. 14. 
de a democracia pré-1964 ser responsável pelo menor intervalo de tempo entre (i) a data de celebração do tratado e a assinatura pelo Brasil, e (ii) a data de elaboração da MSC e seu envio ao Poder Legislativo, o primeiro intervalo apenas mostra a intenção do governo brasileiro de cumprir o tratado internacional, demonstração política, não juridicamente vinculante; que, muitas vezes, não é seguida de atuação concreta por parte do governo. $\mathrm{O}$ segundo intervalo, por sua vez, é insignificante em termos proporcionais (se comparado com a totalidade de tempo de tramitação dos acordos) e práticos, pois sua média varia entre 11 dias (média entre 1945-1964) e 64 dias (média pós-1985).

A título de informação, ao considerar o conjunto dos regimes políticos, Janina Onuki também comprovou que as democracias são responsáveis por um maior tempo médio de adesão do que as autocracias, além de uma maior variância, no que se refere, particularmente aos regimes internacionais de segurança. ${ }^{289}$ Segundo a autora,

\footnotetext{
Em que pese uma maior propensão dos regimes democráticos em aderir aos regimes de segurança, existe um percentual bastante elevado de regimes autoritários que optam pela adesão às regras multilaterais. Esses resultados são igualmente contra intuitivos na medida em que não se espera dos autocratas autorestrição dos seus graus de liberdades na elaboração de políticas de defesa e segurança. (grifo nosso $)^{290}$
}

A autora, além de considerar o regime político vigente nos países, também atentou à democracia no âmbito internacional, ou seja, a "quão democrático" estaria o sistema internacional no momento de celebração de determinado tratado. Exemplificativamente, poder-se-ia dizer que o regime internacional de segurança não era democrático durante o período histórico da Guerra Fria. Quanto mais pacífico e democrático o sistema internacional, maiores seriam os incentivos para os países aderirem a tratados que restringissem a sua liberdade de ação, particularmente se considerada a liberdade de agir em relação a armamento, que é o tema de estudo da autora.

Durante a ditadura, os tratados que não eram de interesse do regime simplesmente não eram assinados. Aqueles que eram assinados não tinham oposição no Congresso, por motivos óbvios de restrição de liberdades, e, consequentemente, sua tramitação foi mais expedita. Com exceção da CVDT, que, assinada pelo regime militar, teve sua tramitação

\footnotetext{
289 ONUKI, Janina, p. 29.

${ }^{290}$ ONUKI, Janina, p. 33.
} 
interna iniciada apenas durante a democracia, o restante dos tratados celebrados internacionalmente durante a ditadura, e que não eram interessantes para o regime, não foram assinados. Apenas aqueles relegados ao esquecimento, desconsiderados pela ditadura, tiveram tempos maiores de tramitação. Considerou-se, para o cômputo das estatísticas, a totalidade de dias que se passaram até o fim do regime, que durou duas décadas.

Comparando os dados relativos aos tratados individualmente, é possível perceber que alguns instrumentos analisados levaram mais tempo do que a média para cada uma das etapas consideradas, quatro vezes ou mais. ${ }^{291}$ Esses tratados são os seguintes:

A. Sete vezes:

i. Convenção para a Redução dos Casos de Apatridia (item 8);

ii. Convenção Interamericana sobre o Desaparecimento Forçado de Pessoas (item 25);

B. Seis vezes:

i. Convenção sobre o Estatuto dos Apátridas (item 5);

C. Cinco vezes:

i. Convenção para a repressão do tráfico de pessoas e do Lenocínio (item 2);

ii. Convenção sobre os Direitos Políticos da Mulher (item 4);

iii. Acordo sobre Privilégios e Imunidades do Tribunal Penal Internacional (item 18.1);

iv. Protocolo referente à abolição da pena de morte (item 22.2);

D. Quatro vezes:

i. Protocolo Facultativo ao Pacto Internacional sobre Direitos Civis e Políticos e Segundo Protocolo Facultativo ao Pacto Internacional sobre Direitos Civis e Políticos, com vistas à Abolição da Pena de Morte (tramitaram em conjunto - itens 10.1 e 10.2);

ii. Convenção 169 da OIT sobre Povos Indígenas e Tribais (item 15);

${ }^{291}$ O termo "vezes", aqui, refere-se à frequência em que isso aconteceu para cada um dos tratados em cada intervalo de tempo analisado (de 1 a 11). A quantidade de vezes (quatro) foi escolhida por demonstrar que o instrumento em pauta demorou mais do que a média em mais de um terço dos intervalos, o que é significativo. 
iii. Convenção Internacional para a Proteção de Todas as Pessoas Contra o Desaparecimento Forçado (item 21);

iv. Convenção Americana sobre Direitos Humanos e protocolo adicional à Convenção Americana sobre Direitos Humanos em matéria de direitos econômicos, sociais e culturais (itens 22 e 22.1);

v. Convenção de Viena sobre o Direito dos Tratados (item 31);

A hipótese da autora é que, para os tratados que levaram mais tempo do que a média para tramitar, em três ou mais etapas distintas, tenha ocorrido discussão mais intensa. Ademais, a intenção desta tese é verificar se houve maior discrepância entre a quantidade de argumentos utilizados pelos membros dos Poderes (Executivo e Legislativo) nesses casos.

Em relação ao tempo de tramitação em cada etapa, foi possível notar que alguns dos tratados extrapolaram em muitas vezes a média de tempo em cada etapa de tramitação nas Casas Legislativas, ou no Poder Executivo. Foram escolhidas as etapas que a autora considerou as mais relevantes para a tramitação dos tratados, pelos motivos mencionados abaixo. É possível mencionar os seguintes exemplos de tratados que levaram mais de três vezes a média do tempo de cada etapa:

(i) Tempo entre a assinatura do tratado e a data da MSC: demonstra o interesse do Executivo em enviar o tratado para a apreciação do Poder Legislativo. Na maior parte dos casos, esse intervalo temporal não é muito extenso, mas, em casos excepcionais, chega a algumas décadas:

- Convenção sobre o Estatuto dos Apátridas (item 5): o tratado foi assinado em 1954, e a MSC é de 1993. O Executivo levou mais de 38 anos para enviar o tratado ao Legislativo;

- Convenção para a Redução dos casos de Apatridia (item 8): o tratado foi assinado em 1961, e a MSC é de 2001. O Executivo levou quase 40 anos para enviar o tratado à apreciação do Legislativo;

- Convenção de Viena sobre o Direito dos Tratados (item 31): o tratado foi assinado em 1969, e a MSC é de 1992. O Executivo levou quase 23 anos para enviar o tratado à apreciação do Legislativo; 
(ii) Tempo de tramitação na Câmara:

- Convenção Interamericana sobre o Desaparecimento Forçado de Pessoas (item 25): tramitou por mais de 13 anos;

- Convenção de Viena sobre o Direito dos Tratados (item 31): tramitou por 17 anos;

(iii) Tempo de tramitação no Senado:

- Pacto Internacional sobre Direitos Civis e Políticos e Pacto Internacional sobre Direitos Econômicos, sociais e culturais (itens 10 e 11): tramitaram em conjunto por 4 anos e meio;

- Convenção 169 da OIT sobre Povos Indígenas e Tribais (item 15): tramitou por quase 9 anos.

(iv) Tempo total de tramitação internacional; período entre a assinatura do tratado e sua ratificação:

- Convenção sobre o Estatuto dos Apátridas (item 5): quase 42 anos de tramitação;

- Convenção para a redução dos casos de Apatridia (item 8): mais de 46 anos de tramitação;

- Convenção de Viena sobre o Direito dos Tratados (item 31): passaram-se mais de 40 anos para que se completasse a tramitação internacional desse instrumento.

(v) Tempo total de tramitação interna: tempo entre a MSC e o Decreto Presidencial - Convenção Interamericana sobre o Desaparecimento Forçado de Pessoas (item 25): tramitou durante quase 21 anos e meio.

- Convenção de Viena sobre o Direito dos Tratados (item 31): tramitou por mais de 17 anos e meio;

Analisados conjuntamente, os dados acima apresentados culminam em um grupo de cinco tratados que, simultaneamente, tiveram tempo de tramitação maior do que a média em 
três ou mais etapas da tramitação, e que levaram três vezes mais do que a média de tempo em uma ou mais etapas de tramitação. Esses tratados são os seguintes:

1. Convenção sobre o Estatuto dos Apátridas (item 5);

2. Convenção para a Redução dos Casos de Apatridia (item 8);

3. Convenção 169 da OIT sobre Povos Indígenas e Tribais (item 15);

4. Convenção Interamericana sobre o Desaparecimento Forçado de Pessoas (item 25);

5. Convenção de Viena sobre o Direito dos Tratados (item 31);

Todos esses tratados tiveram a MSC elaborada durante o regime democrático atual, e, portanto, tramitaram no Legislativo integralmente durante a democracia. Nesse grupo, é possível encontrar tratados sobre temas afetos à soberania estatal, como as convenções sobre apatridia e sobre povos indígenas e tribais; instrumentos que se relacionam, também, com o tema de autodeterminação, responsáveis por intensa discussão a respeito das fronteiras nacionais. A relação com outros Estados também é intensamente regulamentada na Convenção de Viena sobre Direito dos Tratados. Por fim, o desaparecimento forçado de pessoas, tema particularmente problemático durante a ditadura militar, também ensejou tempo prolongado para os debates parlamentares.

Desses tratados, apenas dois (a Convenção 169 da OIT e a Convenção Interamericana sobre o Desaparecimento Forçado) não tramitaram em regimes diferentes, pelo simples fato de que ambos são posteriores ao retorno da democracia no Brasil. Ambos, porém, foram objeto de intensa discussão entre os Poderes, e levaram mais de 15 (quinze) anos entre a celebração e a ratificação.

Em ordem de magnitude, o maior empecilho, em termos temporais, para a internalização de tratados de Direitos Humanos, considerada as médias gerais apresentadas acima (nos itens 1 a 11), é o Poder Executivo. Em média, o tempo entre a assinatura de um tratado e a elaboração da MSC para a apreciação do Legislativo é de 1.570 dias (mais de 4 anos), retratada no intervalo (2). A demora no âmbito do Executivo ainda ocorre entre a data do tratado e a sua assinatura, com uma média de 1.991 dias de intervalo (1). Ademais, o Poder Executivo demora uma média de 748 dias, ou mais de 2 (dois) anos, para publicar o Decreto Presidencial, norma que segue o Decreto Legislativo e que dá publicidade ao tratado 
no âmbito nacional. Apenas a promulgação do Decreto Presidencial possibilita a exigibilidade interna do tratado. Não existe, reitero, exigência legal para que o Executivo envie a Mensagem para a apreciação do Legislativo em prazo determinado após sua assinatura. Resta, portanto, a possibilidade de pressionar politicamente os integrantes desse Poder, ou de alterar a legislação, para que se imponha prazo para o processo de internalização de tratados. As PECs e as propostas de alteração de regimento (vide itens 2.5.1.1. PROPOSTAS DE EMENDAS CONSTITUCIONAIS e 2.5.1.2. PROJETOS DE RESOLUÇÃO) integram as iniciativas nesse sentido.

Dentro do Poder Legislativo, a Casa que leva mais tempo para apreciar os tratados analisados nesta tese é a Câmara: 832 dias em média ( 2 anos e 2 meses). No Senado, os tratados analisados tramitaram durante uma média de 357 dias, ou menos de um ano.

Alguns itens apresentados acima devem ser atribuídos à atuação dos Poderes em conjunto, por retratarem a totalidade de tempo que leva determinado tratado a tramitar, seja no âmbito internacional (item 10), seja no âmbito interno (item 11). A média de tempo para se concretizar a tramitação interna dos tratados de Direitos Humanos analisados nesta tese é de 1.978 dias. A média entre a assinatura de um tratado e sua ratificação, por sua vez, é de 2.523 dias, ou quase 7 (sete) anos.

Existem alguns casos nos quais o Brasil aderiu com consulta prévia ao Legislativo, o que pode ser percebido, inclusive, se compararmos a data da acessão/adesão à data da elaboração ou do envio da MSC. Na adesão, diferente do que ocorre na assinatura, o país compromete-se ao tratado depois do período estabelecido para assinaturas. Nesses casos, foram desconsideradas as datas para fins de estatística, pois não seria possível considerar uma data negativa, que seria o resultado de MSC anterior à assinatura de um tratado. Os seguintes instrumentos tiveram consulta ao Legislativo anteriormente ao compromisso internacional por parte do Brasil:

- 3.1. Protocolo sobre o Estatuto dos Refugiados;

- 10. Pacto Internacional sobre Direitos Civis e Políticos;

- 10.1. Protocolo Facultativo ao Pacto Internacional sobre Direitos Civis e Políticos;

- 10.2. Segundo Protocolo Facultativo ao Pacto Internacional sobre Direitos Civis e Políticos, com vistas à Abolição da Pena de Morte;

- 11. Pacto Internacional sobre Direitos Econômicos, sociais e culturais; 
• 12. Convenção sobre a Prevenção e Punição de Crimes Contra Pessoas que Gozam de Proteção Internacional, incluindo agentes diplomáticos

- 13. Convenção sobre a eliminação de todas as formas de discriminação contra a mulher (consta na tramitação que foi assinada ad referendum do Congresso Nacional, apesar de as datas expressas no Apêndice IV, que apresenta a TABELAS REFERENTES AOS ATOS INTERNACIONAIS E INTERNOS ANALISADOS contradizerem essa informação);

- 17. Convenção Internacional sobre a Proteção dos Direitos de Todos os Trabalhadores Migrantes e dos Membros das suas Famílias, de 18.12.1990, entrou em vigor internacional em 01.07.2003. Essa Convenção ainda não foi assinada pelo Brasil, tendo sido, primeiramente, enviada para a apreciação do Congresso. Foi enviada ao Congresso Nacional por intermédio da Mensagem Presidencial 696, de 2010. Seu processo de aprovação ainda não começou a tramitar na Câmara dos Deputados. Os argumentos utilizados para a internalização da Convenção, portanto, não foram contabilizados para fins dessa tese;

- 22. Convenção Americana sobre Direitos Humanos;

- 22.1. Protocolo adicional à Convenção Americana sobre Direitos Humanos em matéria de direitos econômicos, sociais e culturais;

- 22.2. Protocolo referente à abolição da pena de morte.

Com a exceção do Protocolo sobre o Estatuto dos Refugiados, que tramitou integralmente durante a ditadura, os outros tratados apresentados tiveram sua tramitação legislativa durante a democracia. Desses, 4 (quatro) foram celebrados internacionalmente durante a ditadura, e assinados apenas durante o período democrático. ${ }^{292}$ Quanto ao tempo de tramitação, esperava-se que os tratados que tramitaram durante a democracia tivessem

292 São eles: o Pacto Internacional sobre Direitos Civis e Políticos, o Protocolo Facultativo ao Pacto Internacional sobre Direitos Civis e Políticos, o Pacto Internacional sobre Direitos Econômicos, Sociais e Culturais e a Convenção Americana sobre Direitos Humanos. 
tido tempo de tramitação mais longo, como consequência da maior discussão entre os parlamentares, do que aqueles que tramitaram durante a ditadura. ${ }^{293}$

Existem casos nos quais o texto convencional foi submetido à apreciação de ramos do próprio Poder Executivo, antes do seu envio ao Legislativo. Um exemplo disso é a Convenção para a Repressão do Tráfico de Pessoas e do Lenocínio, submetida à apreciação do Ministério da Justiça e Negócios Interiores, que exarou parecer favorável à sua aplicação no país, conforme a MSC 41/1952. ${ }^{294}$

Foi possível perceber, pela análise desse conjunto, que existem nuances entre os diversos tratados de Direitos Humanos. A hipótese inicial da autora era de que não existiriam empecilhos para a internalização de tratados com essa temática, por motivos simples: o custo político de internalizá-los seria baixo no Brasil, e o custo de barrar a sua internalização seria significativo no âmbito doméstico e no internacional. Percebe-se, porém, que determinadas matérias, particularmente as apontadas acima, enfrentam dificuldades.

O próximo item deste capítulo trata dos argumentos utilizados em cada um dos tratados analisados. Em um primeiro momento, serão apresentados dados relativos a cada um dos grupos. Verificarei, posteriormente, se nos cinco tratados que fugiram da média temporal sob dois critérios distintos, ${ }^{295}$ há mais discussão (maior quantidade de argumentos) no âmbito do Legislativo e do Executivo. Serão analisados, no item 5.4. TRATADOS INTERNALIZADOS COM RESERVAS E COM DECLARAÇÕES INTERPRETATIVAS, se esses tratados levaram mais tempo para tramitar, e se foram proferidos mais argumentos pelos integrantes dos Poderes Executivo e Legislativo, conforme esperado pela hipótese da autora.

\footnotetext{
${ }^{293}$ São eles: Protocolo sobre o Estatuto dos Refugiados (item 3.1); Convenção sobre a Nacionalidade da Mulher Casada (item 6); Convenção 105, OIT (item 7); Convenção internacional sobre a eliminação de todas as formas de discriminação racial (item 9); Convenção sobre a eliminação de todas as formas de discriminação contra a mulher (item 13).

${ }^{294}$ Para uma descrição detalhada da tramitação dessa Convenção, consultar o APÊNDICE I, item 2.

295 Os tratados são: 1. Convenção sobre o Estatuto dos Apátridas (item 5); 2. Convenção para a Redução dos Casos de Apatridia (item 8); 3. Convenção 169 da OIT sobre Povos Indígenas e Tribais (item 15); 4. Convenção Interamericana sobre o Desaparecimento Forçado de Pessoas (item 25); 5. Convenção de Viena sobre o Direito dos Tratados (item 31).
} 


\subsection{ARGUMENTOS UTILIZADOS NA DITADURA E NOS PERÍODOS DEMOCRÁTICOS}

Finalizada a análise dos dados temporais, foi necessário aliá-la aos dados relativos aos argumentos utilizados na tramitação. A hipótese inicial da autora é que os parlamentares, na discussão dos tratados que tramitaram durante a ditadura, além de demorarem menos tempo para cumprir todas as etapas (hipótese confirmada pelos dados temporais obtidos), proferem menos argumentos (numericamente) do que para aqueles que tramitaram durante o regime democrático. Além disso, na ditadura não haveria argumentos contrários aos tratados, seja à sua integralidade, seja a um artigo específico. Os tratados mais "polêmicos" ensejariam maior discussão e, portanto, um maior número de argumentos no total.

A análise dos argumentos proferidos por integrantes dos Poderes Executivo e Legislativo configura o segundo aspecto mais relevante desta tese. Em um primeiro momento, a autora teve a inclinação de testar a hipótese de que, nas democracias, seriam apresentados mais argumentos internacionalistas - particularmente no regime democrático atual, como consequência da maior difusão de temas relacionados com a comunidade internacional e, portanto, com o Direito Internacional - enquanto a ditadura apresentaria argumentos mais voltado para o âmbito interno. Entretanto, as ditaduras, assim como as democracias, podem ter viés mais nacionalista ou mais internacionalista. É possível ter governantes nacionalistas e internacionalistas em ambos os regimes: uma ditadura pode ser nacionalista ou profundamente internacionalista, principalmente no caso daquelas que se voltam contra "inimigo interno"; e uma democracia pode ser internacionalista ou extremamente nacionalista - este último caso pode ocorrer, por exemplo, quando seus governantes, democraticamente eleitos e seguindo os anseios da população, instauram medidas que impedem o ingresso de estrangeiros no país. $\mathrm{O}$ objetivo deste item, portanto, é descobrir em qual regime, se na ditadura ou na democracia, são proferidos mais argumentos em geral, e, em particular, mais argumentos relacionados ao âmbito internacional (PEB e DIN) e ao âmbito interno, ao direito e à política nacional.

Existiriam, ademais, diferenças entre os argumentos proferidos pelos Poderes: o Executivo, mais cosmopolita, proferiria argumentos mais ligados aos âmbitos externo/internacional; e o Legislativo, com interesses mais locais, teria maior foco em 
argumentos de Direito Interno e de Política Brasileira. Dentro das Casas do Poder Legislativo, a hipótese inicial é de que a Câmara dos Deputados teria foco mais em argumentos internos do que internacionais, diferentemente do que ocorreria com o Senado, Casa de abrangência mais ampla. Como foi afirmado em diversos momentos desta tese, o Executivo está, invariavelmente, preocupado com o jogo de dois níveis, e, consequentemente, atua em contextos mais abrangentes do que o Legislativo. Quanto mais abrangente for a instituição, maior o seu campo de atuação, a amplitude de sua tomada de decisões, e o rol de políticas às quais deve atentar. Almeja-se verificar se os dados comprovam, ou não, a percepção do paroquialismo do legislador, que consta em parte da literatura consultada.

Faço uma ressalva em relação à quantidade de argumentos. As manifestações dos membros do Poder Executivo são menos numerosas do que as manifestações do Legislativo. Isso se dá porque, no processo de internalização de tratados, o Executivo manifesta-se, primordialmente, na MSC, e, eventualmente, em pareceres dos Consultores Jurídicos do Itamaraty, sendo outras manifestações menos frequentes. Além disso, destaco a exiguidade das Mensagens, que, muitas vezes, não preenchem uma página do Diário Oficial no qual são publicadas. Muitas não constroem argumentação que tente convencer os membros do Poder Legislativo a internalizar o instrumento internacional, apenas encaminham o tratado para apreciação, sem maiores detalhes a respeito de sua matéria ou de seu teor. Os congressistas, por sua vez, manifestam-se nos pareceres das diversas Comissões, tanto na Câmara como no Senado. Assim, o Executivo conta, invariavelmente, com menos argumentos, em número, do que o Legislativo; o que não significa que as manifestações do Executivo tenham menos argumentos, em média, do que as manifestações do Legislativo.

Uma das dificuldades metodológicas que se apresentou durante o trabalho foi a de separar argumentos relativos a Direito interno e Direito Internacional, de um lado, e a Política Interna e Externa, de outro. Foram classificados como de Direito interno os argumentos que mencionavam normas nacionais (Constituição, Códigos, leis, decretos, regimentos, entre outros), e como de Direito Internacional menções a tratados e a outros instrumentos internacionais (a DUDH, por exemplo, que, mesmo não sendo um tratado, é documento importante para a efetivação dos Direitos Humanos no âmbito internacional).

Paralelamente às menções a normas (internas ou não), está a classificação de determinado argumento como de política nacional ou de política externa. Argumentos 
relacionados à tradição diplomática brasileira, ou à relação entre o Brasil e a comunidade internacional, foram classificados como de política externa; argumentos sobre os benefícios que determinado tratado traria à população brasileira, o foram como de política interna. Exemplifico a distinção entre direito interno e política interna: um discurso sobre os benefícios de determinado tratado aos trabalhadores brasileiros foi classificado como de política interna; caso fosse mencionada a Consolidação das Leis do Trabalho (CLT), seria um argumento de direito interno. ${ }^{296}$

Apesar da patente relação entre política e direito, foi necessário separar argumentos jurídicos e estritamente normativos daqueles que não o são. Com isso, a autora teve como objetivo verificar a especificidade da argumentação utilizada pelos legisladores pátrios, que, diferentemente da maior parte dos que assinam os acordos internacionais (plenipotenciários como diplomatas e Ministros de Estado), foram eleitos pela população para exercer o cargo que ocupam, e, por isso, são particularmente responsáveis (accountable) pelas consequências de seus atos. Constitucionalmente, afinal, são eles os responsáveis por "resolver definitivamente sobre tratados, acordos ou atos internacionais que acarretem encargos ou compromissos gravosos ao patrimônio nacional; (...)”; por mais abrangente, e imprecisa, que seja essa determinação.

Inicialmente, os argumentos foram separados, apenas, entre argumento do Executivo e do Legislativo. Em um segundo momento da pesquisa, optou-se por separar as manifestações dos membros do Poder Legislativo entre Câmara e Senado. A hipótese é de que o Senado utiliza mais argumentos relacionados ao Direito Internacional e a Política Externa (ou seja, mais próximo do Executivo) do que a Câmara dos Deputados, cujos integrantes são mais ligados aos interesses de seus eleitores, o que é corroborado por parte da doutrina consultada.

Em relação à análise dos argumentos proferidos nas fontes primárias que retratam a tramitação de tratados no Brasil, foram destacados os argumentos "a favor" e "contra" a internalização dos tratados e de um artigo em específico do tratado. Essa informação demonstra que há poucos argumentos contrários à internalização de instrumentos de Direitos Humanos.

\footnotetext{
296 Utilizou-se como exemplo a Convenção Internacional sobre a proteção dos Direitos de todos os trabalhadores migrantes e membros de suas famílias.
} 
Os tratados descritos no APÊNDICE I foram apresentados cronologicamente, conforme a data de celebração dos tratados. Apesar disso, apresento outra classificação, conforme a data da Mensagem Presidencial, que marca o início da tramitação interna do tratado. São elencados, a seguir, aqueles cuja tramitação ${ }^{297}$ ocorreu durante o período democrático anterior a 1964 (primeiro grupo: 1945-1964); durante o regime militar (segundo grupo: 1964-1985) e após o fim da ditadura (terceiro grupo: 1985 em diante). A quase totalidade dos tratados teve a tramitação iniciada e completada em um mesmo período. A única exceção, neste caso, é a Convenção concernente à abolição do Trabalho Forçado, cuja tramitação foi iniciada em 1958, mas que tramitou no Legislativo integralmente durante a ditadura militar. ${ }^{298}$ Neste caso, os argumentos foram separados, para fins de cálculo estatístico, por período: os argumentos do Poder Executivo na MSC, proferidos entre 1958 e 1964, foram contabilizados no primeiro grupo; os proferidos entre 1964 e 1985 foram contabilizados no segundo grupo.

\section{(i) Entre 1945 e 1964:}

\section{Sistema Global:}

1. Convenção para a prevenção e a repressão do crime de Genocídio (MSC: 17.09.1949; Decreto Presidencial: 06.05.1952);

2. Convenção para a repressão do tráfico de pessoas e do Lenocínio (MSC: 12.02.1952; Decreto Presidencial: 08.10.1959);

3. Convenção relativa ao Estatuto dos Refugiados (MSC: 30.07.1957; Decreto Presidencial: 28.01.1961);

4. Convenção sobre os Direitos Políticos da Mulher (MSC: 13.06.1953; Decreto Presidencial: 12.09.1963);

7. Convenção concernente à abolição do Trabalho Forçado (Convenção 105, OIT) (MSC: 23.05.1958; Decreto Presidencial: 14.07.1966) ${ }^{299}$;

(ii) Entre 1964 e 1985:

\section{Sistema Global:}

\footnotetext{
${ }^{297}$ São aqueles tratados cuja MSC foi redigida e cujo Decreto Presidencial foi publicado no mesmo período. O "período" é definido como o intervalo de tempo compreendido desde a formação da ONU até 1964; entre 1964 e 1985 e a partir de 1985.

${ }^{298}$ A Convenção de Viena sobre Direito dos Tratados, apesar de ter sido assinada durante a ditadura, apenas começou a tramitar internamente após a redemocratização do Brasil e, por isso, encontra-se no terceiro grupo. ${ }^{299}$ Conforme explicação acima, os argumentos referentes a esse tratado serão contabilizados considerando as datas nas quais foram proferidos. Apenas a MSC foi elaborada antes de 1964 e, portanto, apenas os seus argumentos integrarão o cálculo estatístico do G1.
} 
3.1. Protocolo sobre o Estatuto dos Refugiados (MSC: 20.09.1971; Decreto Presidencial: 07.08.1972);

6. Convenção sobre a Nacionalidade da Mulher Casada (MSC: 06.10.1966; Decreto Presidencial: 18.03.1969);

7. Convenção concernente à abolição do Trabalho Forçado (Convenção 105, OIT) (MSC: 23.05.1958; Decreto Presidencial: 14.07.1966); ${ }^{300}$

9. Convenção internacional sobre a eliminação de todas as formas de Discriminação Racial (MSC: 11.10.1966; Decreto Presidencial: 08.12.1969);

13. Convenção sobre a eliminação de todas as formas de Discriminação contra a Mulher (MSC: 08.07.1982; Decreto Presidencial: 20.03.1984);

(iii) A partir de 1985:

\section{Sistema Global:}

5. Convenção sobre o Estatuto dos Apátridas (MSC: 09.03.1993; Decreto Presidencial: 22.05.2002);

8. Convenção para a Redução dos casos de Apatridia (MSC: 16.04.2001; Decreto Presidencial: 18.08.2015);

9.1. Declaração facultativa que reconhece a competência do Comitê relativo à Convenção Internacional sobre a eliminação de todas as formas de discriminação racial (MSC: 06.09.2000; Decreto Presidencial: 12.06.2003);

10. Pacto Internacional sobre Direitos Civis e Políticos (MSC: 22.11.1985; Decreto Presidencial: 06.07.1992);

10.1. Protocolo Facultativo ao Pacto Internacional sobre Direitos Civis e Políticos (MSC: 07.10.2005; Decreto Presidencial: não promulgado);

10.2. Segundo Protocolo Facultativo ao Pacto Internacional sobre Direitos Civis e Políticos, com vistas à Abolição da Pena de Morte (MSC: 07.10.2005; Decreto Presidencial: não promulgado);

11. Pacto Internacional sobre Direitos Econômicos, Sociais e Culturais (MSC: 22.11.1985; Decreto Presidencial: 06.07.1992);

12. Convenção sobre a Prevenção e Punição de Crimes Contra Pessoas que Gozam de Proteção Internacional, incluindo agentes diplomáticos (MSC: 15.10.1997; Decreto Presidencial: 14.09.1999);

13.1. Retirada das reservas à Convenção sobre a eliminação de todas as formas de Discriminação contra a mulher (MSC: 31.05.1993; Decreto Presidencial: 13.09.2002);

13.2. Protocolo facultativo à Convenção sobre eliminação de todas as formas de Discriminação contra a Mulher (MSC: 16.04.2001; Decreto Presidencial: 30.07.2002);

14. Convenção contra a Tortura e outros tratamentos ou penas cruéis, desumanos ou degradantes (MSC: 29.05.1986; Decreto Presidencial: 15.02.1991);

14.1. Protocolo Facultativo à Convenção contra a Tortura e outros tratamentos ou penas cruéis, desumanos ou degradantes (MSC: 22.04.2004; Decreto Presidencial: 19.04.2007);

14.2. Declaração que reconhece a competência do Comitê previsto na Convenção (MSC: 25.06.2002; Decreto Presidencial: não promulgado);

300 Vide nota acima. 
15. Convenção 169 da OIT sobre Povos Indígenas e Tribais (MSC: 28.06.1991; Decreto Presidencial: 19.04.2004);

16. Convenção sobre os Direitos da Criança (MSC: 16.05.1990; Decreto Presidencial: 21.11.1990);

16.1. Protocolo Facultativo à Convenção sobre os Direitos da Criança referentes à venda de criança, à prostituição infantil e à pornografia infantil (MSC: 10.09.2001; Decreto Presidencial: 08.03.2004);

16.2. Protocolo facultativo à Convenção sobre os Direitos da Criança relativos ao envolvimento de crianças em conflitos armados (MSC: 10.09.2001; Decreto Presidencial: 08.03.2004);

16.3. Protocolo facultativo à Convenção sobre os Direitos da Criança sobre procedimentos de comunicação (MSC: 04.02.2015); ${ }^{301}$

17. Convenção Internacional sobre a Proteção dos Direitos de todos os Trabalhadores Migrantes e dos membros das suas famílias (MSC: 30.04.2010; Decreto Presidencial: não promulgado); ${ }^{302}$

18. Estatuto de Roma do Tribunal Penal Internacional (MSC: 26.07.2001; Decreto Presidencial: 25.09.2002);

18.1. Acordo sobre Privilégios e Imunidades do Tribunal Penal Internacional (MSC: 07.07.2008; Decreto Presidencial: 18.12.2005);

19. Convenção das Nações Unidas contra o Crime Organizado Transnacional ("Convenção de Palermo") (MSC: 27.11.2001; Decreto Presidencial: 12.03.2004);

19.1. Protocolo adicional para o Combate ao tráfico de Migrantes por via terrestre, marítima e aérea (MSC: 27.11.2001; Decreto Presidencial: 12.03.2004);

19.2. Protocolo para a Prevenção, Repressão e Punição do Tráfico de Pessoas, em especial Mulheres e Crianças (MSC: 27.11.2001; Decreto Presidencial: 12.03.2004);

20. Convenção sobre os Direitos das Pessoas com Deficiência e de seu Protocolo Facultativo (MSC: 26.07.2007; Decreto Presidencial: 25.08.2009);

21. Convenção Internacional para a Proteção de Todas as Pessoas Contra o Desaparecimento Forçado (MSC: 01.11.2007; Decreto Presidencial: 11.05.2016);

\section{Sistema Regional:}

22. Convenção Americana sobre Direitos Humanos (MSC: 29.10.1985; Decreto Presidencial: 06.11.1992);

22.1. Protocolo adicional à Convenção Americana sobre Direitos Humanos em matéria de Direitos Econômicos, Sociais e Culturais (MSC: 20.11.1992; Decreto Presidencial: 30.12.1999);

22.2. Protocolo referente à Abolição da Pena de Morte (MSC: 20.11.1992; Decreto Presidencial: 27.08.1998);

\footnotetext{
${ }^{301}$ A tramitação deste instrumento não foi finalizada e, portanto, seus argumentos não foram contabilizados para os fins desta tese, apesar de estarem descritos no APÊNDICE I.

${ }^{302} \mathrm{~A}$ tramitação deste instrumento não foi finalizada e, portanto, seus argumentos não foram contabilizados para os fins desta tese, apesar de estarem descritos no APÊNDICE I.
} 
22.3. Reconhecimento da Competência obrigatória da Corte Interamericana de Direitos Humanos (MSC: 04.09.1998; Decreto Presidencial: 08.11.2002);

23. Convenção Interamericana para prevenir e punir tortura (MSC: 11.06.1986; Decreto Presidencial: 09.11.1989);

24. Convenção Interamericana para prevenir, punir e erradicar a violência contra a mulher (MSC: 16.01.1995; Decreto Presidencial: 01.08.1996);

25. Convenção Interamericana sobre o Desaparecimento Forçado de Pessoas (MSC: 14.12.1994; Decreto Presidencial: 11.05.2016);

26. Convenção Interamericana sobre tráfico internacional de menores (MSC: 16.01.1995; Decreto Presidencial: 20.08.1998);

27. Convenção Interamericana para a eliminação de todas as formas de discriminação contra as pessoas portadoras de deficiência (MSC: 04.10.1999; Decreto Presidencial: 08.10.2001);

28. Protocolo de Assunção sobre Compromisso com a Promoção e Proteção dos Direitos Humanos do Mercosul (MSC: 11.09.2006; Decreto Presidencial: 01.07.2010);

\section{Instrumentos sobre tratados}

31. Convenção de Viena sobre o Direito dos Tratados (MSC: 16.04.1992; Decreto Presidencial: 14.12.2009).

O processo de internalização da maior parte dos instrumentos ocorreu integralmente durante um de três períodos destacados da história brasileira recente: o regime democrático que existiu entre a criação da ONU e o ano de 1964; durante o regime militar ou durante a democracia que o seguiu (a partir de 1985). Alguns tratados (4 de 48 instrumentos analisados) foram assinados e tiveram seu processo de internalização iniciado ${ }^{303}$ ou finalizado ${ }^{304} \mathrm{em}$ regimes diferentes. Esse é o caso dos seguintes tratados:

(a) Convenção sobre o Estatuto dos Apátridas, assinada em 1954 e apenas encaminhada para a apreciação do Poder Legislativo na década de 1990, ou seja, após o término do regime militar;

(b) Convenção para a redução dos casos de Apatridia, assinada em 1961, antes, portanto, da ditadura no Brasil, cuja MSC é de 2001;

(c) Convenção concernente à abolição do Trabalho Forçado, elaborada antes da ditadura, que teve seu processo de internalização iniciado em 1958 e finalizado durante o regime militar;

\footnotetext{
${ }^{303}$ Esse início é contado a partir da elaboração da MSC.

${ }^{304}$ Com a publicação do Decreto Presidencial.
} 
(d) Convenção de Viena sobre Direito dos Tratados, assinada durante a ditadura (1969), e cujo processo de internalização apenas foi iniciado durante o período democrático (1992). Sua tramitação levou mais de 17 anos.

Desses, três coincidem com aquele grupo de cinco tratados ${ }^{305}$ que, simultaneamente, tiveram tempo de tramitação maior do que a média em três ou mais etapas da tramitação, e que levaram mais do que a média de tempo em uma ou mais etapas de tramitação: a Convenção de Viena sobre o Direito dos Tratados, a Convenção para a Redução dos Casos de Apatridia e a Convenção sobre o Estatuto dos Apátridas.

Como é possível perceber, a vasta maioria dos tratados analisados foi elaborada após o regime militar no Brasil, período em que os Direitos Humanos começaram a ganhar cada vez mais atenção da comunidade internacional. Existem, porém, tratados que, embora celebrados internacionalmente durante o período do regime militar, apenas foram assinados pelo Brasil com a instauração da democracia no país. São eles:

(i) A intenção de efetuar a Declaração facultativa que reconhece a competência do Comitê relativo à Convenção internacional sobre a eliminação de todas as formas de discriminação racial, presente no texto da Convenção de 1966, apenas foi levada a cabo nos anos 2000;

(ii) Os Pactos Internacionais sobre Direitos Civis e Políticos e de Direitos Econômicos, sociais e culturais (ambos de 1966, com MSC de 1985);

(iii) O Protocolo Facultativo ao Pacto Internacional sobre Direitos Civis e Políticos, de 1966, tem MSC de 2005;

(iv) A Convenção sobre a Prevenção e Punição de crimes contra pessoas que gozam de proteção internacional, incluindo agentes diplomáticos (1973, com MSC referente de 1997 e adesão em 1999);

(v) A Convenção contra a Tortura e outros tratamentos ou penas cruéis, desumanos ou degradantes foi celebrada nos momentos finais da ditadura no Brasil (1984), sua assinatura ocorreu em setembro de 1985 e a MSC é de 1986. O mesmo ocorre com a Declaração que reconhece a competência do Comitê previsto na Convenção (MSC de 2002);

${ }^{305}$ Apontado no item 5.2.1. CONSIDERAÇÕES A RESPEITO DOS DADOS OBTIDOS. 
(vi) A Convenção Americana sobre Direitos Humanos (de 1969), com MSC de 1985 e assinada em 1992. Do mesmo modo, o reconhecimento da competência obrigatória da Corte Interamericana de Direitos Humanos, que apenas começou a tramitar no Congresso Nacional em 1998 (data da MSC).

Dos 9 (nove) tratados multilaterais relacionados à temática dos Direitos Humanos celebrados pela comunidade internacional durante o período da ditadura, o Brasil não assinou 6 (seis). Um deles - a Convenção contra a tortura e outros tratamentos ou penas cruéis, desumanos ou degradantes - foi celebrado nos estertores do regime militar, e sua temática estava diretamente relacionada com as denúncias, posteriormente comprovadas, de tortura que ocorreram durante o regime no Brasil.

Foi necessário calcular a média de argumentos utilizados durante a democracia e a ditadura, para, posteriormente, compará-las. Será apresentada a média dos argumentos proferidos nas tramitações que ocorreram durante o período de democracia pré-1964; durante a ditadura militar (1964-1985) e durante o período democrático pós-1985. Esse cálculo teve como objetivo verificar se a média de argumentos utilizados por manifestação durante a democracia seria maior do que a média de argumentos na Ditadura (resultado esperado).

Os dados obtidos serão apresentados em duas etapas: primeiramente, são apresentados os dados relativos aos tratados considerados em conjunto, sem separação de regime. Isso é importante para uma perspectiva ampla a respeito da quantidade média de argumentos utilizados em cada etapa da tramitação, e por cada um dos Poderes. Em seguida, são apresentados os dados relativos aos tratados separados por regime. Estes, combinados aos dados relativos ao tempo de tramitação dos tratados, serão utilizados para chegar a conclusões a respeito da tramitação dos tratados nos diferentes regimes.

As estatísticas dos tratados considerados em conjunto serão separadas por Poder e por manifestação. Foram destacadas em negrito as maiores médias dentre os grupos. A primeira delas, que inicia o processo de internalização, refere-se aos dados relativos à Mensagem Presidencial. 


\section{MANIFESTAÇÕES DO PODER EXECUTIVO:}

1. MSC

1.1. Quantidade total de argumentos proferidos: 218

i.G1: 26

ii.G2: 17

iii.G3: 175

1.1.1. Argumentos a favor: $211(97 \%)$

1.1.2. Argumentos contra: 7 (3\%)

1.2. Média geral de argumentos por MSC: 5,7

1.2.1. G1: 5,2

1.2.2. G2: 4,3

1.2.3. G3: 6

1.3. Porcentagem de tipo de argumento por MSC:

1.3.1. DIN: $16 \%$
1.3.1.1.
G1: $\mathbf{2 3 \%}$
1.3.1.2.
G2: $18 \%$
1.3.1.3.
G3: $14 \%$

1.3.2. DBR: $16 \%$
1.3.2.1.
G1: $\mathbf{4 2 \%}$
1.3.2.2.
G2: $24 \%$
1.3.2.3.
G3: $11 \%$

1.3.3. PBR: $25 \%$
1.3.3.1.
G1: $15 \%$
1.3.3.2.
G2: $12 \%$
1.3.3.3.
G3: $27 \%$

1.3.4. PEB: $\mathbf{3 6} \%$
1.3.4.1.
G1: $19 \%$
1.3.4.2.
G2: $\mathbf{4 1} \%$
1.3.4.3.
G3: $38 \%$

1.3.5. DH: $8 \%$
1.3.5.1.
G1: $0 \%$
1.3.5.2.
G2: $6 \%$
1.3.5.3.
G3: $9 \%$

1.4. $\mathrm{N}=38$.

1.4.1. $\mathrm{G} 1, \mathrm{~N}=5$

1.4.2. $\mathrm{G} 2, \mathrm{~N}=4$

1.4.3. $\mathrm{G} 3, \mathrm{~N}=29$

Tabela 4: Argumentos presentes nas Mensagens Presidenciais (em \%)

\begin{tabular}{|l|l|l|l|l|}
\hline ARGUMENTOS NAS MSC (EM \%) & MSCS CONSIDERADAS EM CONJUNTO & G1 & G2 & G3 \\
\hline DIN & 16 & 23 & 18 & 14 \\
\hline DBR & 16 & $\mathbf{4 2}$ & 24 & 11 \\
\hline PBR & 25 & 15 & 12 & 27 \\
\hline PEB & $\mathbf{3 6}$ & 19 & $\mathbf{4 1}$ & $\mathbf{3 8}$ \\
\hline DH & 8 & 0 & 6 & 9 \\
\hline TOTAL & 100 & 100 & 100 & 100 \\
\hline
\end{tabular}

Fonte: elaboração própria 
As Mensagens do Executivo têm como foco principal a PEB, na ditadura e no regime democrático atual. Entre as médias gerais, a maior média dentro das MSCs é de argumentos de PEB (36\%). Essa lógica é seguida pelas MSCs do G2 e do G3. No G1, por sua vez, o DBR é mencionado em 42\% dos argumentos das MSCs. Apenas no período entre 1945 e 1964, portanto, o maior número de argumentos foi de direito interno.

A média de argumentos por manifestação é de 5,7 por MSC, valor que é maior do que o observado no G1 $(5,2)$ e no G2 $(4,3)$, e menor do que o observado no G3 $(6,0)$. Esse dado corrobora a hipótese da autora, de que a ditadura possuiria menor número de argumentos proferidos do que a democracia.

\section{Parecer do MRE}

2.1. Quantidade total de argumentos proferidos: 92
i. $\mathrm{G} 1: 12$
ii. G2: 5
iii. G3: 75

2.1.1. Argumentos a favor: $83(90 \%)$

2.1.2. Argumentos contra: $9(10 \%)$

2.2. Média de argumentos por Parecer do MRE: 8
2.2.1. G1: 12
2.2.2. G2: 5

2.2.3. G3: 7,5

2.3. Porcentagem de tipo de argumento por Parecer do MRE:

2.3.1. DIN: $14 \%$
2.3.1.1.
G1: $8 \%$
2.3.1.2.
G2: $\mathbf{2 0} \%$
2.3.1.3.
G3: $15 \%$

2.3.2. DBR: $\mathbf{2 9} \%$
2.3.2.1.
G1: $8 \%$
2.3.2.2.
G2: $20 \%$
2.3.2.3.
G3: $\mathbf{3 3} \%$

2.3.3. PBR: 29\%

2.3.3.1. G1: $\mathbf{5 8} \%$

2.3.3.2. G2: $20 \%$

2.3.3.3. G3: $25 \%$

2.3.4. PEB: $26 \%$

2.3.4.1. G1: $25 \%$

2.3.4.2. G2: $\mathbf{4 0} \%$

2.3.4.3. G3: $25 \%$

2.3.5. DH: $1 \%$

2.3.5.1. G1: $0 \%$

2.3.5.2. G2: $0 \%$

2.3.5.3. G3: $1 \%$

2.4. $\mathrm{N}=12$ 
2.4.1. $\mathrm{G} 1, \mathrm{~N}=1$

2.4.2. $\mathrm{G} 2, \mathrm{~N}=1$

2.4.3. G3, $\mathrm{N}=10$

No caso dos pareceres do MRE, também é possível perceber que os períodos democráticos são responsáveis pelo maior número de argumentos proferidos, em média, por manifestação.

\section{Outras manifestações}

3.1. Quantidade total de argumentos proferidos: 41

i. G1: 0 (zero)

ii. $\mathrm{G} 2: 7$

iii. G3: 34

3.1.1. Argumentos a favor: $40(98 \%)$

3.1.2. Argumentos contra: $1(2 \%)$

3.2. Média de argumentos por manifestação: 8,2

3.2.1. G1: 0 (zero)

3.2.2. G2: 7

3.2.3. G3: 8,5

3.3. Porcentagem de tipo de argumento por manifestação:

3.3.1. DIN: $20 \%$

3.3.1.1. G1: 0 (zero)

3.3.1.2. G2: $14 \%$

3.3.1.3. G3: $\mathbf{2 1} \%$

3.3.2. DBR: $15 \%$

3.3.2.1. G1: 0 (zero)

3.3.2.2. G2: $\mathbf{2 9} \%$

3.3.2.3. G3: $12 \%$

3.3.3. PBR: $32 \%$

3.3.3.1. G1: 0 (zero)

3.3.3.2. G2: $29 \%$

3.3.3.3. G3: 32\%

3.3.4. PEB: $27 \%$

3.3.4.1. G1: 0 (zero)

3.3.4.2. G2: $29 \%$

3.3.4.3. G3: $26 \%$

3.3.5. DH: $7 \%$

3.3.5.1. G1: 0 (zero)

3.3.5.2. G2: 0 (zero)

3.3.5.3. G3: $9 \%$

3.4. $\mathrm{N}=5$.

3.4.1. $\mathrm{G} 1, \mathrm{~N}=0$

3.4.2. $\mathrm{G} 2, \mathrm{~N}=1$

3.4.3. G3, $\mathrm{N}=4$ 
Aqui, novamente, a democracia tem, em média, mais argumentos proferidos, por manifestação, do que a ditadura. ${ }^{306}$

\section{MANIFESTAÇÕES DO PODER LEGISLATIVO:}

\section{Câmara dos Deputados}

\section{Pareceres}

1.1. Quantidade total de argumentos proferidos: 346

i. G1: 42

ii. $\mathrm{G} 2: 27$

iii. G3: 277

1.1.1. Argumentos a favor: $143(92 \%)$

1.1.2. Argumentos contra: $16(8 \%)$

1.2. Média de argumentos por Parecer: 3,5

1.2.1. G1: 3,8

1.2.2. G2: 2,1

1.2.3. G3: 3,7

1.3. Porcentagem de tipo de argumento por Parecer:

1.3.1. DIN: $17 \%$
1.3.1.1.
G1: $14 \%$
1.3.1.2.
G2: $19 \%$
1.3.1.3.
G3: $17 \%$

1.3.2. DBR: $25 \%$
1.3.2.1.
G1: $\mathbf{3 8} \%$
1.3.2.2.
G2: $26 \%$
1.3.2.3.
G3: $23 \%$

\subsubsection{PBR: $\mathbf{2 8} \%$}

1.3.3.1. G1: $19 \%$

1.3.3.2. G2: $\mathbf{3 0} \%$

1.3.3.3. G3: $29 \%$

1.3.4. PEB: $20 \%$
1.3.4.1.
G1: $21 \%$
1.3.4.2.
G2: $22 \%$
1.3.4.3.
G3: $19 \%$

1.3.5. DH: $10 \%$
1.3.5.1.
G1: $7 \%$
1.3.5.2.
G2: $4 \%$
1.3.5.3.
G3: 11\%

1.4. $\mathrm{N}=98$.
1.4.1.1.
$\mathrm{G} 1, \mathrm{~N}=11$
1.4.1.2.
$\mathrm{G} 2, \mathrm{~N}=13$
1.4.1.3.
G3, N=74

\footnotetext{
306 No item "outras manifestações", encontram-se descritos os argumentos utilizados por membros do Executivo que não puderam ser incluídos nos itens anteriores, como manifestações em audiências públicas ou pareceres, por exemplo.
} 
Aqui, novamente, a média de argumentos proferidos durante a ditadura é menor do que a média de argumentos proferidos durante a democracia. A média, contudo, foi afetada pelo fato de que muitos pareceres não possuem qualquer argumento, apenas enunciam que o projeto de decreto legislativo foi aprovado pela Comissão que o apreciou, sem dar motivos para isso. Por esse motivo, apesar de todos os Pareceres serem apresentados nas tabelas que mostram os argumentos proferidos (APÊNDICE III), muitos deles, apesar de contarem para o número final $(\mathrm{N})$, simplesmente não contém argumentos. A descrição detalhada desses pareceres pode ser encontrada no APÊNDICE I. Nos regimes democráticos, foram utilizados mais argumentos relativos a DBR ( $38 \%$ no G1) e PBR ( $29 \%$ no G3); e na ditadura foram utilizados mais argumentos de PBR (30\%). 


\section{Voto em Separado}

2.1. Quantidade total de argumentos proferidos: 21

i. G1: 0 (zero)

ii. G2: 8

iii. G3: 13

2.1.1. Argumentos a favor: $16(76 \%)$

2.1.2. Argumentos contra: 5 (24\%)

2.2. Média de argumentos por Voto em separado: 5,3

2.2.1. G1: 0 (zero)

2.2.2. G2: 4

2.2.3. G3: 6,5

2.3. Porcentagem de tipo de argumento por Voto em separado:

2.3.1. DIN: $10 \%$
2.3.1.1. G1: 0 (zero)

2.3.1.2. G2: $\mathbf{1 3} \%$

2.3.1.3. G3: $8 \%$

2.3.2. DBR: $19 \%$

2.3.2.1. G1: 0 (zero)

2.3.2.2. G2: $13 \%$

2.3.2.3. G3: $23 \%$

2.3.3. PBR: $\mathbf{2 4} \%$

2.3.3.1. G1: 0 (zero)

2.3.3.2. $\mathrm{G} 2: \mathbf{6 3} \%$

2.3.3.3. G3: 0 (zero)

2.3.4. PEB: $24 \%$

2.3.4.1. G1: 0 (zero)

2.3.4.2. G2: $13 \%$

2.3.4.3. G3: $\mathbf{3 1} \%$

2.3.5. DH: $0 \%$

2.3.5.1. G1: 0 (zero)

2.3.5.2. G2: 0 (zero)

2.3.5.3. G3: 0 (zero)

2.4. $\mathrm{N}=4$

2.4.1. $\mathrm{G} 1, \mathrm{~N}=0$ (zero)

2.4.2. $\mathrm{G} 2, \mathrm{~N}=2$

2.4.3. G3, $\mathrm{N}=2$

Aqui, novamente, a média de argumentos proferidos na ditadura é menor do que na democracia. Na democracia pré-1964, não houve voto em separado.

\section{Manifestações em Plenário}

3.1.Quantidade total de argumentos proferidos: 92

i. G1: 0 (zero)

ii. G2: 0 (zero)

iii. G3: 92 
3.1.1. Argumentos a favor: $85(92 \%)$

3.1.2. Argumentos contra: $7(8 \%)$

3.2. Média de argumentos por manifestação: 18,4

3.3. Porcentagem de tipo de argumento por manifestação:

3.3.1. DIN: $8 \%$

3.3.2. DBR: $12 \%$

3.3.3. PBR: 53\%

3.3.4. PEB: $12 \%$

3.3.5. DH: $15 \%$

\section{4. $\mathrm{N}=5$}

No item "Manifestações em Plenário" constam todas as manifestações presentes na Ata publicada no Diário Oficial da União, ou disponível nos arquivos da Câmara e/ou do Senado. Contabilizei, nesse item, como "manifestação" as sessões nas quais foram discutidas os tratados em plenário; sendo que todas as manifestações feitas em plenário de cada sessão foram contabilizadas como uma sessão. ${ }^{307}$ Justamente por isso, a quantidade de argumentos é mais numerosa. Apenas o G3 apresenta manifestações em plenário e, por isso, não há comparação com os outros regimes.

\section{Senado Federal}

\section{Pareceres}

1.1. Quantidade total de argumentos proferidos: 202

i. $\mathrm{G} 1: 25$

ii. $\mathrm{G} 2: 31$

iii. G3: 146

1.1.1. Argumentos a favor: $166(82 \%)$

1.1.2. Argumentos contra: $15(7 \%)$

1.2. Média de argumentos por parecer: 3,5

1.2.1. G1: 2,5

1.2.2. G2: 2,6

1.2.3. G3: 4,2

1.3. Porcentagem de tipo de argumento por parecer:

1.3.1. DIN: $17 \%$
1.3.1.1.
G1: $16 \%$
1.3.1.2.
$\mathrm{G} 2: 10 \%$
1.3.1.3.
G3: $19 \%$

1.3.2. DBR: $29 \%$
1.3.2.1.
$\mathrm{G} 1: 32 \%$
1.3.2.2.
G2: $19 \%$

${ }^{307}$ As sessões constam, na tabela de argumentos do APÊNDICE III, como CD PLEN, para a Câmara, e SF PLEN, para o Senado. 
1.3.2.3. G3: $30 \%$

1.3.3. PBR: $25 \%$
1.3.3.1.
G1: $20 \%$
1.3.3.2.
G2: $\mathbf{3 5 \%}$
1.3.3.3.
G3: $24 \%$

1.3.4. PEB: $20 \%$

1.3.4.1. G1: $28 \%$

1.3.4.2. G2: $19 \%$

1.3.4.3. G3: $19 \%$

1.3.5. DH: $8 \%$

1.3.5.1. G1: $4 \%$

1.3.5.2. G2: $\mathbf{1 6} \%$

1.3.5.3. G3: $8 \%$

1.4. $\mathrm{N}=57$

1.4.1. $\mathrm{G} 1, \mathrm{~N}=10$

1.4.2. $\mathrm{G} 2, \mathrm{~N}=12$

1.4.3. $\mathrm{G} 3, \mathrm{~N}=35$

Na democracia atual, são proferidos mais argumentos do que no período democrático pré-1964 e do que durante a ditadura (ambos com quantidade de pareceres e média de argumentos por parecer semelhantes). No G1 e no G3, são utilizados mais argumentos de DBR (32\% e 30\%, respectivamente). Na ditadura, são utilizados mais argumentos de PBR nos pareceres do Senado (35\%).

\section{Voto em Separado}

2.1. Quantidade total de argumentos proferidos: 12

2.1.1. Argumentos a favor: $12(100 \%)$

2.1.2. Argumentos contra: $0(0 \%)$

2.2. Média de argumentos por Voto em separado: 6

2.3. Porcentagem de tipo de argumento por Voto em separado:
2.3.1. DIN: $8 \%$
2.3.2. DBR: $17 \%$
2.3.3. PBR: $\mathbf{3 3} \%$
2.3.4. PEB: $17 \%$
2.3.5. DH: $8 \%$

2.4. $\mathrm{N}=2$.

Apenas o G3 apresenta votos em separado e, por isso, não há comparação com os outros regimes. A quantidade de argumentos dos votos em separado do G3, entretanto, é maior do que a média de argumentos dos pareceres proferidos. Os votos em separado são redigidos por Senadores que não concordam com um parecer exarado, o que se coaduna com 
o fato de conterem argumentação mais abundante do que os pareceres que almejam contestar. Foram proferidos, apenas, dois votos em separado, ambos referentes ao processo de internalização da Convenção 169 da OIT, sobre povos indígenas e tribais.

\section{Manifestações em Plenário}

3.1. Quantidade total de argumentos proferidos: 51

i. $\mathrm{G} 1: 14$

ii. G2: 0 (zero)

iii. G3: 37

3.1.1. Argumentos a favor: $51(100 \%)$

3.1.2. Argumentos contra: $0(0 \%)$

3.2. Média de argumentos por manifestação: 8,5

3.2.1. G1: 14

3.2.2. G3: 7,4

3.3. Porcentagem de tipo de argumento por manifestação:

3.3.1. DIN: $6 \%$
3.1.1.1.
G1: 0 (zero)
3.1.1.2.
G2: 0 (zero)
3.1.1.3.
$\mathrm{G} 3: 8 \%$

3.3.2. DBR: $18 \%$

3.3.2.1. G1:7\%

3.3.2.2. G2: 0 (zero)

3.3.2.3. G3: $22 \%$

3.3.3. PBR: 53\%

3.3.3.1. G1: $43 \%$

3.3.3.2. G2: 0 (zero)

3.3.3.3. G3: $57 \%$

3.3.4. PEB: $18 \%$

3.3.4.1. G1: $\mathbf{4 3} \%$

3.3.4.2. G2: 0 (zero)

3.3.4.3. G3: $8 \%$

3.3.5. DH: $6 \%$

3.3.5.1. G1: $7 \%$

3.3.5.2. G2: 0 (zero)

3.3.5.3. G3: $5 \%$

3.4. $\mathrm{N}=6$.

3.4.1. $\mathrm{G} 1, \mathrm{~N}=1$

3.4.2. G2, $\mathrm{N}=0$ (zero)

3.4.3. $\mathrm{G} 3, \mathrm{~N}=5$

Assim como no caso da Câmara, as "manifestações em plenário" são diversas manifestações, de parlamentares diferentes, agrupadas em um item que as consolida. 


\subsubsection{CONSIDERAÇÕES A RESPEITO DOS DADOS OBTIDOS}

Essa primeira apreciação dos dados obtidos e apresentados acima terá como foco os três itens considerados principais para a tramitação de tratados no Brasil, demonstrativos da atuação dos Poderes nesse processo: o envio do tratado para a apreciação do Legislativo, seguido pela sua apreciação pelas duas Casas, que configuram as principais etapas para a internalização de um tratado internacional. São de extrema relevância, portanto, os dados relativos aos argumentos apresentados na Mensagem e nos pareceres dos membros da Câmara e do Senado. O total de argumentos utilizados pelo Poder Executivo em suas manifestações foi de 351. O total de argumentos pelo Legislativo foi de 724, sendo 459 proferidos por Deputados (63\%) e 265 (37\%) proferidos por Senadores.

As Mensagens do Executivo, como era a percepção inicial da autora, têm como foco principal a PEB, tanto durante a ditadura como regime democrático atual. A média de argumentos por MSC é de 5,7, sendo a ditadura responsável pela menor média, o que comprova a hipótese, de que a ditadura possui menor número de argumentos proferidos do que a democracia.

A média de argumentos proferidos durante a ditadura por Deputados também é menor do que a média de argumentos proferidos durante a democracia. Nos regimes democráticos, foram utilizados mais argumentos relativos a DBR (G1) e PBR (G3); na ditadura, por sua vez, foram utilizados mais argumentos de PBR.

No que se refere ao Senado, na democracia (após 1985), são proferidos mais argumentos do que no período democrático pré-1964 e do que durante a ditadura. No G1 e no G3, foram utilizados mais argumentos de DBR; e na ditadura, de PBR nos pareceres do Senado.

Além de atentar à quantidade de argumentos proferida por grupo de tratados, é importante verificar se, dentre os tratados analisados, há relação entre o tempo de tramitação e o número de argumentos proferidos. Iniciarei a análise com o grupo de cinco tratados que demorou mais do que a média em etapas distintas de tramitação, e que, em cada etapa, extrapolou o tempo médio de tramitação. Dentre esses tratados, apenas dois tiveram o total de argumentos proferidos acima da média, de 28 argumentos por tratado: a Convenção 169 da OIT (item 15, com 79 argumentos) e a CVDT (item 31, com 29 argumentos).

Os tratados com mais do que a média de argumentos total por tratado são os seguintes: 
Tabela 5: Tratados com mais argumentos do que a média

\begin{tabular}{|l|c|}
\hline \multicolumn{1}{|c|}{ TRATADO } & $\begin{array}{c}\text { No ARGUMENTOS } \\
\text { (TOTAL) }\end{array}$ \\
\hline 3. Convenção relativa ao Estatuto dos Refugiados & 54 \\
\hline 6. Convenção sobre a Nacionalidade da Mulher Casada & 29 \\
\hline $\begin{array}{l}\text { 10. Pacto Internacional sobre Direitos Civis e Políticos e 11. Pacto } \\
\text { Internacional sobre os Direitos Econômicos, Sociais e Culturais }\end{array}$ & 42 \\
\hline $\begin{array}{l}\text { 10.1. e 10.2. Protocolo Facultativo ao Pacto Internacional sobre Direitos } \\
\text { Civis e Políticos e Segundo Protocolo Facultativo ao Pacto Internacional } \\
\text { sobre Direitos Civis e Políticos, com vistas à Abolição da Pena de Morte }\end{array}$ & 37 \\
\hline $\begin{array}{l}\text { 13.2. Protocolo facultativo à Convenção sobre eliminação de todas as formas } \\
\text { de discriminação contra a mulher }\end{array}$ & 70 \\
\hline $\begin{array}{l}\text { 14.1. Protocolo Facultativo à Convenção contra a Tortura e Outros } \\
\text { Tratamentos ou Penas Cruéis, Desumanos ou Degradantes }\end{array}$ & 45 \\
\hline $\begin{array}{l}\text { 14.2. Declaração que reconhece a competência do Comitê previsto na } \\
\text { Convenção contra a tortura e outros tratamentos ou penas cruéis, desumanos } \\
\text { ou degradantes }\end{array}$ & 37 \\
\hline 15. Convenção 169 da OIT sobre Povos Indígenas e Tribais & 79 \\
\hline 18. Estatuto de Roma do Tribunal Penal Internacional & 73 \\
\hline $\begin{array}{l}\text { 20. Convenção sobre os Direitos das Pessoas com Deficiência e de seu } \\
\text { Protocolo Facultativo }\end{array}$ & 62 \\
\hline 22. Convenção Americana sobre Direitos Humanos & 59 \\
\hline $\begin{array}{l}\text { 27. Convenção Interamericana para a eliminação de todas as formas de } \\
\text { discriminação contra as pessoas portadoras de deficiência }\end{array}$ & 31 \\
\hline 31. Convenção de Viena sobre o Direito dos Tratados & 29 \\
\hline
\end{tabular}

Fonte: elaboração própria

Desses tratados, seis encontram-se entre aqueles cuja MSC apresentou mais do que o dobro de argumentos do que a média geral: ${ }^{308}$

i.Pacto Internacional sobre Direitos Civis e Políticos (item 10);

ii.Protocolo Facultativo ao Pacto Internacional sobre Direitos Civis e Políticos (item $10.1)$

iii.Segundo Protocolo Facultativo ao Pacto Internacional sobre Direitos Civis e Políticos, com vistas à Abolição da Pena de Morte (item 10.2)

iv.Pacto Internacional sobre Direitos Econômicos, Sociais e Culturais (item 11);

v.Estatuto de Roma do Tribunal Penal Internacional (item 18);

vi. Convenção Americana sobre Direitos Humanos (item 22).

${ }^{308}$ Foi utilizada, como base para esse cálculo, a média geral, e não a média de argumentos dos tratados separados em grupos. No caso das MSCs, esses números variam entre 4,3 (G2) e 6 (G3). 
Uma das questões que se desejou responder é se a quantidade de argumentos proferidos pelos parlamentares e por membros do Executivo, que indicam maior ou menor discussão a respeito do tema, influenciam o tempo de envio do tratado para a apreciação, e a tramitação do tratado. Para obter dados a respeito, foi feito um cálculo de correlação entre esses valores. Existe uma correlação de 34,8\% entre a quantidade de argumentos na MSC e a quantidade de dias entre a assinatura de um tratado e a data da MSC. É maior a correlação entre a quantidade de argumentos da MSC e o tempo entre a data do tratado e a sua assinatura, de 46,4\%. Ambos os intervalos de tempo foram considerados importantes e pertinentes para a comparação com a quantidade de argumentos da MSC, pois não há de se falar em "tempo de tramitação no Executivo", diferentemente do que ocorre com o Legislativo. O tempo de apreciação do tratado exclusivamente pelo Executivo é, justamente, aquele que se passa entre a elaboração internacional (celebração) do tratado e sua assinatura pelo Brasil, entre esta e o envio da MSC, e entre a data do Decreto Legislativo e a ratificação e posterior promulgação do Decreto Presidencial.

Dos dez tratados com mais argumentos proferidos pelo Executivo na MSC, ${ }^{309}$ apenas um (a Convenção 105 da OIT, sobre a abolição do trabalho forçado, com 79 argumentos) tramitou durante a ditadura. Daqueles com mais argumentos proferidos pelos Deputados, nenhum tramitou durante a ditadura. ${ }^{310}$ Entre os tratados com mais argumentos proferidos

\footnotetext{
${ }^{309}$ São eles: Convenção relativa ao Estatuto dos Refugiados (item 3), com 19 argumentos; Convenção sobre o Estatuto dos Apátridas (item 5), com 11; Convenção concernente à abolição do trabalho forçado (Convenção 105, OIT - item 7), com 11; Pacto Internacional sobre Direitos Civis e Políticos (item 10 e 11), com 29; Protocolo Facultativo ao Pacto Internacional sobre Direitos Civis e Políticos e Segundo Protocolo Facultativo ao Pacto Internacional sobre Direitos Civis e Políticos, com vistas à Abolição da Pena de Morte (itens 10.1 e 102.2), com 12; Protocolo facultativo à Convenção sobre eliminação de todas as formas de discriminação contra a mulher (item 13.2), com 27; Declaração que reconhece a competência do Comitê previsto na Convenção (item 14.2), com 11; Estatuto de Roma do Tribunal Penal Internacional (item 18), com 38; Convenção Americana sobre Direitos Humanos (item 22), com 33; e a aceitação da Competência obrigatória da corte internacional de direitos humanos (item 22.3), com 21. As tramitações entre parênteses ocorreram em conjunto.

310 São eles: Convenção relativa ao Estatuto dos Refugiados (item 3), com 19 argumentos; Protocolo Facultativo ao Pacto Internacional sobre Direitos Civis e Políticos e Segundo Protocolo Facultativo ao Pacto Internacional sobre Direitos Civis e Políticos, com vistas à Abolição da Pena de Morte (itens 10.1. e 10.2.), com 17; Protocolo facultativo à Convenção sobre eliminação de todas as formas de discriminação contra a mulher (item 13.2), com 38; Protocolo Facultativo à Convenção contra a Tortura e Outros Tratamentos ou Penas Cruéis, Desumanos ou Degradantes (item 14.1), com 35; Declaração que reconhece a competência do Comitê previsto na Convenção (item 14.2), com 21; Estatuto de Roma do Tribunal Penal Internacional (item 18), com 29; Convenção sobre os Direitos das Pessoas com Deficiência e de seu Protocolo Facultativo (item 20), com 38; Convenção Americana sobre Direitos Humanos (item 22), com 18; Convenção Interamericana
} 
durante a tramitação no Senado, apenas dois tramitaram durante a ditadura (a Convenção sobre a Nacionalidade da Mulher Casada - item 6, com 15 argumentos e a Convenção internacional sobre a eliminação de todas as formas de discriminação racial - item 9, com 9). ${ }^{311}$ Isso demonstra que, conforme era esperado, a quantidade de argumentos proferidos pelos Poderes durante a ditadura foi realmente menor.

Há coincidência entre os tratados que demoraram mais tempo do que a média para tramitar interna e internacionalmente. Com exceção da Convenção relativa ao Estatuto dos Refugiados, todos os tratados que levaram mais tempo para tramitar internamente também foram responsáveis por elevar a média relativa à etapa internacional. ${ }^{312}$ Dos 16 (dezesseis) tratados que demoraram mais tempo do que a média para tramitar internamente, quatro tiveram mais do que a média de argumentos totais. ${ }^{313}$ Apenas um deles (a Convenção 105

para a eliminação de todas as formas de discriminação contra as pessoas portadoras de deficiência (item 27), com 24; Convenção de Viena sobre o Direito dos Tratados (item 31), com 18.

311 Convenção para a prevenção e a repressão do crime de genocídio (item 1), com 14 argumentos; Convenção para a repressão do tráfico de pessoas e do Lenocínio (item 2), com 8; Convenção relativa ao Estatuto dos Refugiados (item 3), com 16; Convenção sobre a Nacionalidade da Mulher Casada (item 6), com 15; Convenção para a Redução dos Casos de Apatridia (item 8), com 8; Convenção internacional sobre a eliminação de todas as formas de discriminação racial (item 9), com 9; Pacto Internacional sobre Direitos Civis e Políticos e Pacto Internacional sobre Direitos Econômicos, Sociais e Culturais (itens 10 e 11), com 8; Protocolo Facultativo ao Pacto Internacional sobre Direitos Civis e Políticos e Segundo Protocolo Facultativo ao Pacto Internacional sobre Direitos Civis e Políticos, com vistas à Abolição da Pena de Morte (itens 10.1 e 10.2), com 8; Convenção 169 da OIT sobre Povos Indígenas e Tribais (item 15), com 61; Convenção sobre os Direitos das Pessoas com Deficiência e de seu Protocolo Facultativo (item 20), com 17; Convenção Americana sobre Direitos Humanos (item 22), com 8. Aqui, foram retratados 13 (treze) instrumentos no total, pois cinco tratados tinham um total de oito argumentos proferidos, e optou-se por não estabelecer um critério de eliminação entre eles.

${ }^{312} \mathrm{O}$ "tempo de tramitação internacional” é o intervalo entre a assinatura e a ratificação. Foram eles: Convenção para a repressão do tráfico de pessoas e do Lenocínio; Convenção relativa ao Estatuto dos Refugiados; Convenção sobre os Direitos Políticos da Mulher; Convenção sobre o Estatuto dos Apátridas; Convenção para a Redução dos Casos de Apatridia; Acordo sobre Privilégios e Imunidades do Tribunal Penal Internacional; Convenção Interamericana sobre o Desaparecimento Forçado de Pessoas; e Convenção de Viena sobre o Direito dos Tratados.

313 Os dezesseis tratados são: Convenção para a repressão do tráfico de pessoas e do Lenocínio; Convenção sobre os Direitos Políticos da Mulher; Convenção sobre o Estatuto dos Apátridas; Convenção concernente à a abolição do trabalho forçado (Convenção 105, OIT); Convenção para a Redução dos Casos de Apatridia; Pacto Internacional dos Direitos Econômicos, sociais e culturais; Retirada das reservas à Convenção sobre a eliminação de todas as formas de discriminação contra a mulher; Acordo sobre Privilégios e Imunidades do Tribunal Penal Internacional; Convenção Internacional para a Proteção de Todas as Pessoas Contra o Desaparecimento Forçado ; Protocolo adicional à Convenção Americana sobre Direitos Humanos em matéria de direitos econômicos, sociais e culturais; Protocolo referente à abolição da pena de morte; e Convenção Interamericana sobre o desaparecimento forçado de pessoas. Os tratados que apresentaram mais do que a média de argumentos, no total, são: Pacto Internacional sobre Direitos Civis e Políticos; Convenção 169 da OIT sobre Povos Indígenas e Tribais; Convenção Americana sobre Direitos Humanos; e Convenção de Viena sobre o Direito dos Tratados. 
da OIT, sobre a abolição do trabalho forçado) tramitou durante a ditadura. Ressalto, porém, que a maior parte desses tratados foi elaborada após a ditadura.

Em média, cada tramitação apresentou 25 argumentos. Nos tratados com reserva, esse número foi de 32,6 , enquanto nos que levaram mais tempo do que a média para tramitar, em três ou mais etapas distintas, a média foi de 26,6 argumentos. Esperava-se que o número de argumentos nos tratados nos quais fossem apostas reservas fosse maior, o que efetivamente ocorreu, e demonstra uma discussão mais intensa nessas tramitações.

Ao atentarmos aos números relacionados à Câmara dos Deputados, especificamente à relação entre os argumentos proferidos em pareceres e o tempo de tramitação do tratado na Câmara, essa correlação é relativamente baixa (17,3\%); enquanto é significativamente mais alta a correlação entre a quantidade de argumentos nos pareceres dos Senadores e o tempo de tramitação no Senado, de 61,8\%. Comparados os intervalos maiores, como tempo de tramitação interna e internacional, com o total de argumentos proferidos na tramitação de determinado tratado, a correlação é de menos de $1 \%$. Considerando o baixo nível de correlação, podemos afirmar que a influência dos argumentos no tempo de tramitação é restrita à relação entre as Casas do Congresso e a quantidade de argumentos proferidos nos pareceres. No caso do Executivo, a relação entre as datas relativas ao tratado e os argumentos da MSC é maior no caso do intervalo entre a data do tratado e a assinatura pelo plenipotenciário brasileiro.

Tabela 6: Correlações para todos os tratados analisados

\begin{tabular}{|c|c|c|}
\hline \multicolumn{3}{|c|}{ CORRELAÇÕES (PARA TODOS OS TRATADOS ANALISADOS) } \\
\hline ARGUMENTO & TEMPO & CORRELAÇÃO \\
\hline MENSAGEM & ASSINATURA X DATA DA MSC & $34,8 \%$ \\
\hline MENSAGEM & DATA DO TRATADO X ASSINATURA & $46,4 \%$ \\
\hline PARECERES & TEMPO DE TRAMITAÇÃO NA CÂMARA & $17,3 \%$ \\
\hline PARECERES & TEMPO DE TRAMITAÇÃO NO SENADO & $61,8 \%$ \\
\hline
\end{tabular}

Fonte: elaboração própria

Tabela 7: Correlações para tratados com Reservas

\begin{tabular}{|c|c|c|}
\hline \multicolumn{3}{|c|}{ CORRELAÇÕES (PARA TRATADOS COM RESERVAS) } \\
\hline ARGUMENTO & TEMPO & CORRELAÇÃO \\
\hline MENSAGEM & ASSINATURA X DATA DA MSC & $29,6 \%$ \\
\hline MENSAGEM & DATA DO TRATADO X ASSINATURA & $40,2 \%$ \\
\hline PARECERES & TEMPO DE TRAMITAÇÃO NA CÂMARA & $37,6 \%$ \\
\hline PARECERES & TEMPO DE TRAMITAÇÃO NO SENADO & $41,3 \%$ \\
\hline
\end{tabular}

Fonte: elaboração própria 
Apesar de ser um contrassenso, a correlação entre essas informações é ainda mais baixa para tratados aos quais foram apostas reservas, com exceção da correlação entre tempo de tramitação na Câmara e quantidade de argumentos proferidos nos pareceres exarados nessa Casa. Isso porque se pressupõe que a discussão parlamentar seria mais intensa durante a tramitação desses tratados, o que não foi comprovado pelos dados obtidos.

Os gráficos abaixo demonstram a relação entre a quantidade de argumentos proferidos por Deputados e por Senadores e o tempo de tramitação para cada tratado, e demonstram a relação do tempo de tramitação de tratados, em dias, e o número de argumentos nos pareceres da Câmara e do Senado. Cada ponto nos dois gráficos seguintes refere-se a um instrumento internacional, e relaciona a quantidade de dias para sua tramitação em cada Casa legislativa e a quantidade de argumentos proferidos nessa Casa. Os dados detalhados referentes a cada um dos tratados podem ser consultados nos Apêndices II a IV.

\section{Figura 2: Tramitação de tratados na Câmara dos Deputados}

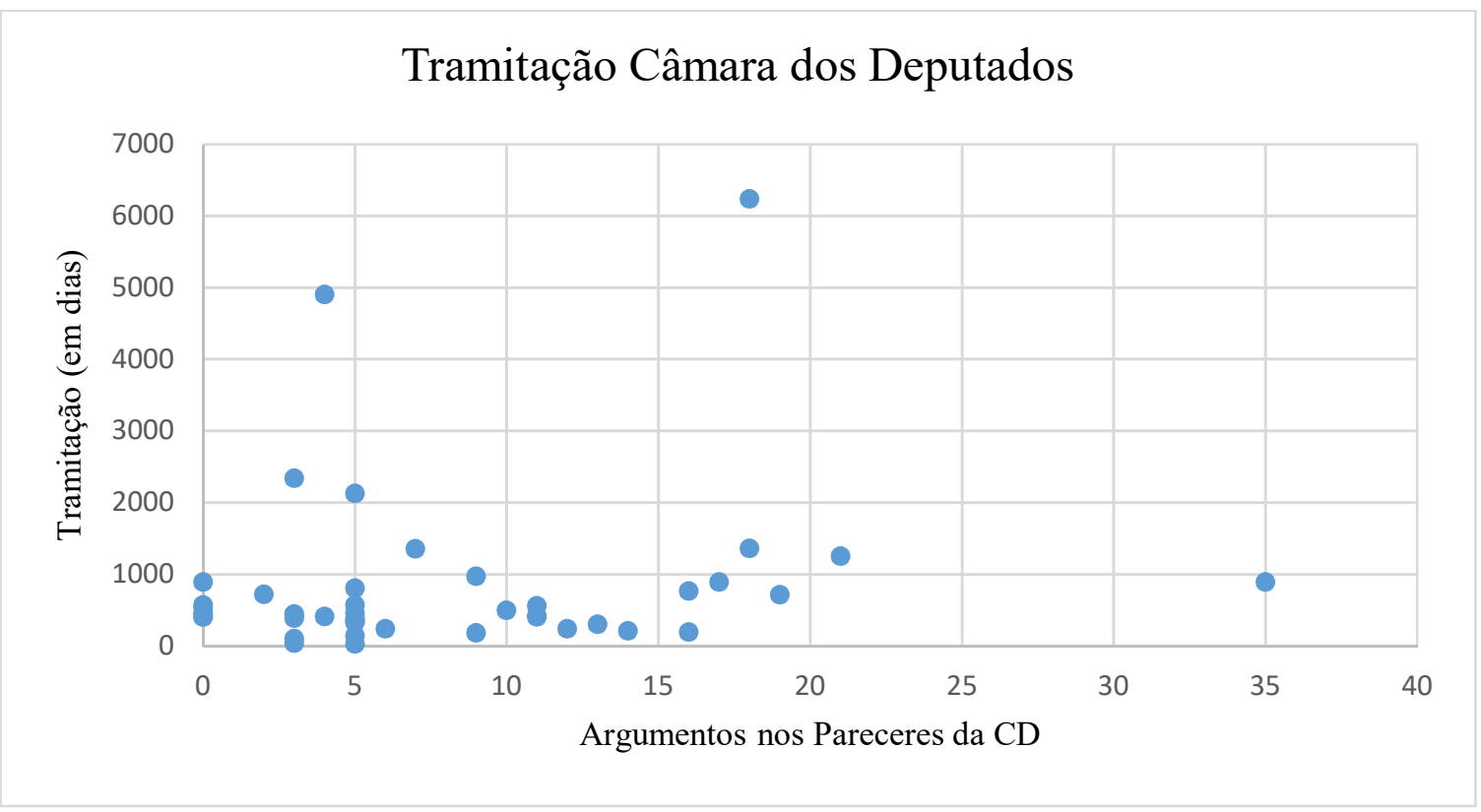


Figura 3: Tramitação de tratados no Senado Federal

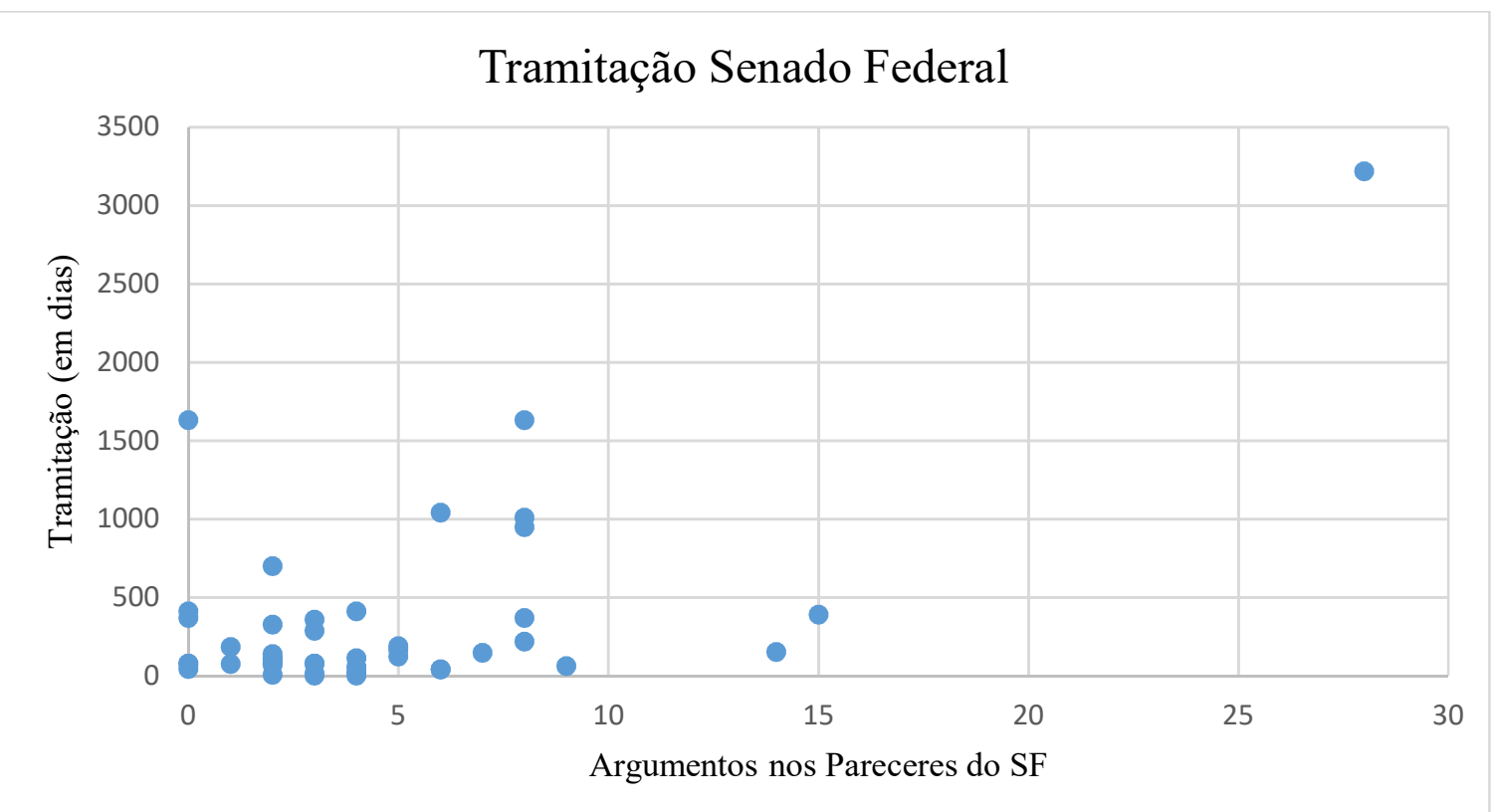

Se compararmos os tratados com reserva àqueles que demoraram mais tempo para tramitar em quatro ou mais etapas, a correlação é maior em quase todos os itens, exceto entre a quantidade de argumentos nos pareceres da Câmara e o tempo de tramitação na Câmara (para os tratados com reserva), conforme a tabela abaixo:

Tabela 8: Correlações em tratados que demoraram mais do que a média para tramitar em diversas etapas da tramitação

\begin{tabular}{|c|c|c|}
\hline \multicolumn{3}{|c|}{ CORRELAÇÕES (TRATADOS QUE DEMORARAM MAIS DO QUE A MÉDIA PARA TRAMITAR } \\
EM DIVERSAS ETAPAS - CF. P. 161 E SS)
\end{tabular}

Percebe-se que apenas a relação entre (i) a quantidade de argumentos das MSCs e o intervalo entre a data do tratado e sua assinatura, por um lado; e (ii) a quantidade de argumentos proferidos nos pareceres dos Senadores e o tempo de tramitação no Senado, por outro, ultrapassam os $50 \%$. O último dado chega a $90 \%$, valor significativo. 


\subsection{TRATADOS INTERNALIZADOS COM RESERVAS E COM DECLARAÇÕES INTERPRETATIVAS}

A aprovação com reservas ocorreu em apenas 8 (oito) dos tratados analisados. Alguns instrumentos receberam, além de reservas, declarações interpretativas. A maior parte das reservas e das declarações interpretativas foi sugerida pelo Poder Executivo, em sua primeira manifestação, a MSC. Segue breve descrição dos tratados que foram objeto de reservas e de declarações interpretativas, que esclarecem aos outros signatários a interpretação do governo brasileiro de suas disposições. A descrição detalhada da tramitação desses instrumentos pode ser encontrada no APÊNDICE I.

A Convenção relativa ao Estatuto dos Refugiados foi promulgada com reservas aos artigos 15 e 17. As restrições à Convenção foram sugeridas pela MSC (1957). Ambos os artigos tratam da relação entre os refugiados e o mercado de trabalho brasileiro, sendo o primeiro intitulado "Direitos de Associação" e o segundo "Profissões Assalariadas". Em 1972, quando da acessão do Brasil ao Protocolo sobre o Estatuto dos Refugiados (1967), o governo retirou as reservas. Além das reservas, consta a seguinte declaração interpretativa feita pelo Brasil no endereço eletrônico da ONU:

\footnotetext{
"Refugees will be granted the same treatment accorded to nationals of foreign countries in general, with the exception of the preferential treatment extended to nationals of Portugal through the Friendship and Consultation Treaty of 1953 and Article 199 of the Brazilian Constitutional Amendment No.1, of 1969."
}

À Convenção sobre a Nacionalidade da Mulher Casada foi feita reserva, aposta pelo Executivo no momento de assinatura do tratado (1966), ao artigo da Convenção que trata da submissão de contendas entre os signatários à jurisdição da CIJ:

\footnotetext{
Artigo 10: Toda questão que surja entre dois ou mais contratantes sobre a interpretação ou a aplicação da presente Convenção, que não seja resolvida por meio de negociações, será submetida à Corte Internacional de Justiça, para que esta a resolva, a petição de qualquer das partes em conflito, salvo que as partes interessadas concordem em um outro modo de solucioná-la.
}

A Convenção para a Redução dos Casos de Apatridia, por sua vez, foi assinada com reserva ao art. $8, \S 3^{\circ}$, a, ii: 


\begin{abstract}
Artigo 8:
1. Os Estados Contratantes não privarão uma pessoa de sua nacionalidade se essa privação vier a convertê-la em apátrida. (...)

3. Não obstante o disposto no parágrafo 1 deste Artigo, os Estados Contratantes poderão conservar o direito de privar uma pessoa de sua nacionalidade se, no momento da assinatura, ratificação ou adesão, especificarem que se reservam tal direito por um ou mais dos seguintes motivos, sempre que estes estejam previstos em sua legislação nacional naquele momento:

a) quando, em condições incompatíveis com o dever de lealdade ao Estado Contratante, a pessoa: (...)

ii) tiver se conduzido de maneira gravemente prejudicial aos interesses vitais do Estado;

(grifo nosso)
\end{abstract}

Consta, inclusive, uma declaração no endereço eletrônico da ONU, que diz que, com relação ao artigo mencionado acima, o Brasil reserva o direito de privar a pessoa de sua nacionalidade quando ela se portar de maneira seriamente prejudicial aos interesses vitais do país. No endereço eletrônico da ONU, entretanto, consta a informação de que o instrumento de acessão depositado pelo Brasil não especificou essa restrição ao art. 8 (3). ${ }^{314}$ A reserva foi sugerida pela MSC, elaborada por Celso Lafer (2001), e aposta em virtude da disposição constitucional do art. $12, \S 4^{\circ}$, I, segundo a qual "Será declarada a perda da nacionalidade do brasileiro que: I - tiver cancelada sua naturalização, por sentença judicial, em virtude de atividade nociva ao interesse nacional; (...)". A reserva reitera a necessidade de que o país mantenha o direito especificado na disposição constitucional; que, como é possível perceber, aplica-se apenas aos brasileiros naturalizados.

O Segundo protocolo facultativo ao Pacto Internacional sobre Direitos Civis e Políticos, com vistas à abolição da pena de morte, teve reserva ao seu art. 2, sugerida pela MSC (2005):

Artigo 2:

1. Não é admitida qualquer reserva ao presente Protocolo, exceto a reserva formulada no momento da ratificação ou adesão que preveja a aplicação da pena de morte em tempo de guerra em virtude de condenação por infração penal de natureza militar de gravidade extrema cometida em tempo de guerra.

2. O Estado que formular tal reserva transmitirá ao Secretário-Geral das Nações Unidas, no momento da ratificação ou adesão, as disposições pertinentes da respectiva legislação nacional aplicável em tempo de guerra.

3. O Estado Parte que haja formulado tal reserva notificará o Secretário-Geral das Nações Unidas de declaração e do fim do estado de guerra no seu território. (grifo nosso)

314 Informação obtida em: https://treaties.un.org/pages/ViewDetails.aspx?src=TREATY\&mtdsg_no=V-4\& chapter $=5 \&$ lang=en. Acesso: 08.03.2016. 
A Convenção sobre a prevenção e punição de crimes contra pessoas que gozam de proteção internacional, incluindo agentes diplomáticos, teve reserva ao art. $13, \S 2^{\circ}$, igualmente sugerida pela MSC (1997):

\begin{abstract}
Artigo 13:
1. Toda controvérsia entre dois ou mais Estados Partes, relativa à interpretação ou aplicação da presente Convenção, caso não seja resolvida pela via de negociação, deverá, por solicitação de uma das Partes, ser submetida à arbitragem. Se, dentro de seis meses a partir da data de solicitação da arbitragem, as Partes não chegarem a um acordo quanto à forma da arbitragem, qualquer das Partes poderá submeter a controvérsia à Corte Internacional de Justiça, mediante solicitação, em conformidade com o Estatuto da Corte.

2. Todo Estado Parte poderá, por ocasião da assinatura ou ratificação da presente Convenção, ou de sua adesão a ela, declarar que não se considera obrigado pelos dispositivos do parágrafo 1 do presente Artigo. Os demais Estados Partes não estarão obrigados pelos referidos dispositivos com respeito a qualquer Estado Parte que tenha formulado semelhante reserva.

3. Todo Estado Parte que tiver formulado a reserva prevista no parágrafo 2 do presente Artigo, poderá suspendê-la, a qualquer momento, mediante notificação dirigida ao Secretário-Geral das Nações Unidas.
\end{abstract}

A Convenção sobre a Eliminação de todas as formas de Discriminação contra a Mulher apresenta reservas aos seus artigos $15, \S 4^{\circ}$, e $16, \S 1^{\circ}$, alíneas (a), (c), (g) e (h), posteriormente retiradas, e ao art. 29.2. As reservas feitas em relação à Convenção eram - à exceção à reserva feita ao art. 29(2) - relativas à situação da mulher no ordenamento pátrio. O Código Civil de 1916 guardava disposições que mantinham a mulher em posição subalterna e hipossuficiente em relação ao homem. Com a mudança do Código Civil (CC), em 2002, essas reservas deixaram de fazer sentido, em virtude da evolução do ordenamento brasileiro. Persiste, entretanto, reserva em relação ao mecanismo de solução de controvérsias da Convenção.

Foi aposta reserva, também, ao Protocolo referente à abolição da Pena de Morte à Convenção Americana sobre Direitos Humanos, nos termos do artigo 2.1 desse Protocolo. $\mathrm{O}$ artigo assegura aos Estados o direito de aplicar a pena de morte em tempo de guerra, de acordo com o Direito Internacional, por delitos graves de caráter militar.

Artigo 2:

1. Não é admitida qualquer reserva ao presente Protocolo, exceto a reserva formulada no momento da ratificação ou adesão que preveja a aplicação da pena de morte em tempo de guerra em virtude de condenação por infração penal de natureza militar de gravidade extrema cometida em tempo de guerra. 
2. O Estado que formular tal reserva transmitirá ao Secretário-Geral das Nações Unidas, no momento da ratificação ou adesão, as disposições pertinentes da respectiva legislação nacional aplicável em tempo de guerra.

3. O Estado Parte que haja formulado tal reserva notificará o Secretário-Geral das Nações Unidas de declaração e do fim do estado de guerra no seu território. (grifo nosso)

A MSC, de 1985, também sugere que o Brasil declarasse que os dispositivos do tratado que tratam das inspeções não incluiriam o direito automático de visitas ou de inspeções in loco da CIDH, visitas estas que dependeriam, portanto, da concordância expressa do país. Essa interpretação não foi efetuada, o que demonstra a discordância dos integrantes do Legislativo nesse sentido.

A Convenção de Viena sobre o Direito dos Tratados foi assinada com reserva aos Artigos 25 e 66. A MSC não faz menção à necessidade de fazer reserva em relação a esses dispositivos. $\mathrm{O}$ art. 25 trata da possibilidade de aplicação provisória de tratados:

Artigo 25: Aplicação Provisória

1. Um tratado ou uma parte do tratado aplica-se provisoriamente enquanto não entra em vigor, se:

a) O próprio tratado assim dispuser; ou

b) Os Estados negociadores assim acordarem por outra forma.

2. A não ser que o tratado disponha ou os Estados negociadores acordem de outra forma, a aplicação provisória de um tratado ou parte de um tratado, em relação a um Estado, termina se esse Estado notificar aos outros Estados, entre os quais o tratado é aplicado provisoriamente, sua intenção de não se tornar parte no tratado.

O outro artigo ao qual se fez ressalva trata da regulamentação do processo de solução judicial, de arbitragem e de conciliação:

Artigo 66: Processo de Solução Judicial, de Arbitragem e de Conciliação Se, nos termos do parágrafo 3 do artigo 65, nenhuma solução foi alcançada, nos 12 meses seguintes à data na qual a objeção foi formulada, o seguinte processo será adotado:

a) Qualquer parte na controvérsia sobre a aplicação ou a interpretação dos artigos 53 ou 64 poderá, mediante pedido escrito, submetê-la à decisão da Corte Internacional de Justiça, salvo se as partes decidirem, de comum acordo, submeter a controvérsia a arbitragem;

b) Qualquer parte na controvérsia sobre a aplicação ou a interpretação de qualquer um dos outros artigos da Parte V da presente Convenção poderá iniciar o processo previsto no Anexo à Convenção, mediante pedido nesse sentido ao Secretário-Geral das Nações Unidas. 
A discordância em relação ao art. 66 provém de sua rigidez, uma vez que qualquer das partes de uma controvérsia sobre a aplicação ou a interpretação de um tratado poderia submetê-la à Corte Internacional de Justiça, supletivamente e de comum acordo, à arbitragem ou à Comissão de Conciliação descrita no anexo da Convenção. Esse empecilho existia no momento da elaboração da CVDT, e, por isso, foi criada a "cláusula facultativa de jurisdição obrigatória", presente no art. 36(6) do Estatuto da CIJ, ${ }^{315}$ à qual o Brasil tampouco se vinculou.

Em alguns tratados, apesar de haver discussão a respeito da elaboração de reservas, as mesmas não foram efetivadas. Trata-se do caso da Convenção 169 da OIT sobre Povos Indígenas e Tribais (1989), na qual também foi feita proposta de elaboração de declaração interpretativa, não levada a cabo; da Convenção Interamericana sobre o Desaparecimento Forçado de Pessoas e da Convenção Interamericana para prevenir, punir e erradicar a Violência contra a Mulher, na qual a reserva foi sugerida pela MSC. Nesse caso, à época da aprovação do texto da Convenção, durante a reunião de especialistas da OEA, a delegação brasileira fez restrição em relação ao art. 12, referente à apresentação de petições à CIDH sobre denúncias ou queixas de violações por signatários da Convenção. O Brasil, assim como outros países, advogou sua supressão, pois não seria essencial aos objetivos da Convenção, além de ser uma duplicação de dispositivo presente na Convenção Interamericana de Direitos Humanos. A reserva ao art. 12 deveria ser reiterada quando da ratificação, o que não ocorreu como consequência de sua não aprovação pelo Legislativo.

Além das mencionadas acima, foram feitas algumas declarações interpretativas. Estas têm como objetivo resguardar o país de interpretações possíveis a artigo que, na sua percepção, pode ser interpretado de maneiras distintas. O país, dessa maneira, antecipa eventuais problemas que julga que podem ocorrer, e determina qual é a sua percepção a respeito do texto do tratado. Conforme apontado previamente, há uma linha tênue entre as declarações interpretativas e as reservas, estas com um custo político maior do que as primeiras. Justamente por isso, é possível tentar burlar o sistema, fazendo declarações interpretativas que são verdadeiras reservas. Exemplificativamente, em relação ao Estatuto

\footnotetext{
315 Artigo 36:

1. A competência do Tribunal abrange todas as questões que as partes lhe submetam, bem como todos os assuntos especialmente previstos na Carta das Nações Unidas ou em tratados e convenções em vigor. (...) 6. da jurisdição obrigatória do Tribunal Internacional de Justiça, pelo período em que ainda devem vigorar e em conformidade com os seus termos.
} 
do TPI, que não aceita reservas, alguns parlamentares sugerem a adoção de declarações interpretativas, o que não foi acatado.

Em nota sobre o Protocolo Facultativo relativo ao envolvimento de Crianças em Conflitos Armados, apesar de o Decreto que o promulgou ter afirmando que esse Protocolo seria “(...) executado e cumprido tão inteiramente como nele se contém”;"316 a autora encontrou, no endereço eletrônico da ONU, texto que trata de declarações interpretativas em relação a esse Protocolo. Não consta, porém, discussão a respeito do tema em parte alguma da tramitação do Protocolo no Poder Legislativo. Segue, para conhecimento, o teor da declaração interpretativa, no idioma original (conforme a ONU) e em tradução livre.

\begin{abstract}
"With regard to article 3, paragraph 2, of the Optional Protocol to the Convention on the Rights of the Child on the involvement of children in armed conflict, the Brazilian Government declares that, according to article 143 of the Federal Constitution, military service is compulsory, as set forth by law. The Constitution also provides that it is within the competence of the Armed Forces, according to the law, to assign an alternative service to those who, in times of peace, after being enlisted, claim imperative of conscience. Women and clergymen are exempt from compulsory military service in times of peace, but are subject to other duties assigned by law.
\end{abstract}

According to the Military Service Act (Law no 4.375, of 17 August 1964), the obligation to military service, in times of peace, begins the $1 \mathrm{st}$ January of the year the citizen becomes 18 years old (article 5). Pursuant to the Regulation of the Military Service (Decree n. 57.654, of 20 January 1966), citizens may freely present themselves to voluntary military service provided they have the minimum age of 16 years (article 41, paragraph 1 and article 49, paragraph 4).

However, their acceptance to voluntary military service is only possible from the 1 st January of the year they become 17 years old (article 127). The acceptance of voluntaries to Military Service requires special authorization from the Armed Forces (Military Service Act, article 27).

Pursuant to the Regulation of the Military Service, the civil incapacity to act, to the purposes of military service, ends on the date the citizen
Com relação ao artigo 3, parágrafo 2, do Protocolo Facultativo à Convenção sobre os Direitos da Criança relativo ao envolvimento de crianças em conflitos armados, o governo brasileiro declara que, de acordo com o artigo 143 da Constituicão Federal, o servico militar é obrigatório, conforme estabelecido por lei. A Constituição também estabelece que é da competência das Forças Armadas, de acordo com a lei, atribuir serviço alternativo aos que, em tempo de paz, depois de alistados, alegar imperativo de consciência. Mulheres e eclesiásticos ficam isentos do serviço militar obrigatório em tempo de paz, mas estão sujeitos a outras funções atribuídas por lei.

De acordo com a Lei do Serviço Militar (Lei 4.375, de 17.08.1964), a obrigação de serviço militar, em tempo de paz, começa em 01 de janeiro do ano em que o cidadão faz 18 anos de idade (artigo $5^{\circ}$ ). De acordo com o Regulamento do Serviço Militar (Decreto 57.654, de 20.01.1966), os cidadãos podem apresentar-se livremente ao serviço militar voluntário, desde que tenham a idade mínima de 16 anos (artigo 41, parágrafo $1^{\circ}$ e artigo 49, parágrafo 4).

No entanto, a aceitação para o serviço militar voluntário só é possível a partir de $1^{\circ}$ de janeiro do ano em que completam 17 anos de idade (artigo 127). A aceitação de voluntários ao serviço militar exige autorização especial das Forças Armadas (Lei do Serviço Militar, artigo 27).

De acordo com o Regulamento do Serviço Militar, a incapacidade civil para agir, para fins de serviço militar, termina na data em que o cidadão completa

${ }^{316}$ Decreto Presidencial 5.006/2004. 
becomes 17 years old. Voluntaries who, upon the act of incorporation or enrollment to the military service, have not yet completed 17 years old, must present written consent from parents or guardians (article 239)."
17 anos. Voluntários que, no ato de incorporação ou inscrição para o serviço militar, não tenham ainda completado 17 anos de idade, devem apresentar autorização por escrito dos pais ou responsáveis (art. 239)."

No Decreto que promulga a Convenção Americana Sobre Direitos Humanos (Pacto de São José da Costa Rica) consta declaração interpretativa relativa aos artigos 43 e 48.d., segundo a qual o governo brasileiro entende que esses artigos “(...) não incluem o direito automático de visitas e inspeções in loco da Comissão Interamericana de Direitos Humanos, as quais dependerão da anuência expressa do Estado". 


\subsubsection{DISCUSSÃO DOS RESULTADOS EMPÍRICOS}

Existem algumas reservas que se repetem nos instrumentos analisados. Foram feitas restrições quanto à submissão de conflitos a organismo internacional, além de reservas sobre o processo de solução de controvérsias determinado pelo tratado. ${ }^{317}$

Existem reservas que se relacionam diretamente ao ordenamento jurídico brasileiro. A mais notória delas é a que se refere à possibilidade de aplicação da pena de morte no país. A reserva ao Segundo protocolo facultativo ao PIDCP refere-se a essa possibilidade. No mesmo sentido é a reserva feita ao Protocolo referente à abolição da pena de morte à Convenção Americana sobre Direitos Humanos. Outras, como a feita à Convenção para a redução dos casos de apatridia e à Convenção dos refugiados, referem-se a aspectos pontuais do direito brasileiro, como a possibilidade de o país privar indivíduo de sua nacionalidade, caso tiver agido de maneira prejudicial aos interesses do país, no primeiro caso; e restrições relativas ao mercado de trabalho brasileiro e à relação preferencial entre os brasileiros e os portugueses.

Apenas a reserva ao art. 25, CVDT, é um exemplo de restrição que se relaciona com a possibilidade de aplicação provisória de tratado, tema de extrema relevância para fins desta tese. A aplicação provisória de tratado não é possível no Brasil, considerando o processo de internalização desse tipo de instrumento, sendo, portanto, incompatível com a Constituição brasileira. Para que um compromisso internacional seja incluído no ordenamento pátrio, é mister cumprir o procedimento de internalização. O direito brasileiro, salvo no caso dos Acordos Executivos, ${ }^{318}$ não admite a aplicação provisória de tratado.

Quase todas as reservas foram sugeridas pelo Poder Executivo, na Mensagem Presidencial ou no momento de assinatura do tratado. Existem, porém, casos nos quais, apesar da sugestão da MSC, a mesma não foi acatada pelos parlamentares.

\footnotetext{
317 Isso ocorreu nos seguintes instrumentos: (i) Convenção sobre a Nacionalidade da mulher casada, particularmente quanto à submissão de conflitos decorrentes do tratado à CIJ; (ii) Convenção sobre a prevenção e punição de crimes contra pessoas que gozam de proteção internacional (iii) Convenção sobre a Eliminação de todas as formas de Discriminação contra a Mulher e (iv) CVDT.

${ }^{318}$ Acordos Executivos não pressupõem análise legislativa, pois não inovam no ordenamento, (i) oferecendo interpretação para tratados vigentes; (ii) trazendo complementos necessários de um tratado vigente ou (iii) tendo como objetivo deixar as coisas como estão - os chamados "acordos modus vivendi". Conforme o voto do relator da matéria, DCD 28.10.1995, p. 7.955, col. 2.
} 


\section{CONCLUSÕES}

Os resultados obtidos nesta tese demonstram e destacam a relevância das instituições políticas domésticas para a compreensão do processo de internalização de tratados no ordenamento jurídico brasileiro, a relação do país com os tratados que integram o regime internacional dos Direitos Humanos e o comportamento dos governos democráticos e ditatorial existentes no Brasil desde a fundação da Organização das Nações Unidas. Os dados permitem pensar a respeito de determinadas premissas utilizadas pela literatura das Relações Internacionais, sem, no entanto, pretensão de apresentar as explicações causais para as conclusões obtidas.

Estas Conclusões estão divididas em duas partes, relacionadas aos dois objetivos principais de investigação desta tese, quais sejam, a atuação dos parlamentares no processo de internalização de tratados no Brasil e a influência do regime político no processo de internalização de tratados.

As conclusões relativas ao primeiro objetivo demonstram que é possível afirmar que os membros do Poder Legislativo não são apáticos em relação aos temas internacionais, em particular ao processo de incorporação de instrumentos internacionais de Direitos Humanos ao ordenamento jurídico brasileiro. Além de apresentar os dados obtidos, destaco perspectivas e elaboro sugestões para a maior participação dos parlamentares nesse processo, com o objetivo de estabelecer um procedimento mais célere e dinâmico.

Nas conclusões relativas ao segundo objetivo, apresento considerações a respeito do tempo de tramitação e dos argumentos proferidos, nos diferentes regimes, por parlamentares e por membros do Poder Executivo. A base empírica é composta pelos documentos presentes na tramitação interna dos tratados analisados. A intenção foi fazer um panorama da situação atual da tramitação de tratados de Direitos Humanos no Brasil, e das diferenças observadas durante os processos na ditadura e na democracia, estabelecendo uma ligação entre três pontos distintos: a teoria da relação entre o Executivo e o Legislativo, o comportamento de distintos regimes frente aos tratados internacionais de Direitos Humanos, e a prática brasileira.

Existem gradações e diferenças na apreciação dos tratados que protegem os Direitos Humanos. A percepção de parte da literatura, de que o Legislativo seria apático em temas de 
âmbito internacional, pois seriam insignificantes os eventuais empecilhos para a internalização de tratados de Direitos Humanos, em razão do baixo custo político de internalizá-los e do alto custo de barrar sua internalização, não foi comprovada. Determinadas matérias, relacionadas com temas mais sensíveis da política nacional, enfrentam maiores dificuldades. Esse foi o caso do grupo de cinco tratados, apresentado no item 5.2.1. CONSIDERAÇÕES A RESPEITO DOS DADOS OBTIDOS, ${ }^{319}$ cujos temas, intimamente relacionados à soberania estatal, ensejaram períodos de tramitação prolongados. Percebeu-se, pela análise desse grupo de instrumentos, que existem nuances entre os tratados de Direitos Humanos.

Faz-se necessário, aqui, ponderar a respeito da literatura que trata da influência dos regimes políticos na adesão a tratados internacionais de Direitos Humanos. A literatura que apresenta estudos empíricos que tentam demonstrar, ou refutar, a percepção liberal, particularmente dos autores que tratam da Paz Democrática, geralmente compara dados relativos a democracias - recentes ou estabelecidas - e ditaduras, mas não as diferenças existentes em um mesmo país em períodos históricos e regimes distintos. Andrew Moravcsik, ao dizer que os dados por ele encontrados coadunam-se com a teoria liberal, ${ }^{320}$ por ter observado o fortalecimento dos países com o regime internacional de Direitos Humanos durante e após a redemocratização, na América Latina e na Europa Central, não considera o comprometimento desses países a tratados durante o período ditatorial que os governou. $^{321}$

Apesar de entender que a aplicação da teoria da Paz Democrática ao presente estudo não é direta, os dados obtidos demonstram que houve adesão a tratados de Direitos Humanos nos três momentos históricos distintos vividos pelo Brasil, de democracia (pré-1964), ditadura e, novamente, de democracia (pós-1985). Os períodos democráticos poderiam ser considerados, dependendo da perspectiva adotada, períodos de transição, de democracia

\footnotetext{
319 São eles: Convenção sobre o Estatuto dos Apátridas (item 5); Convenção para a Redução dos Casos de Apatridia (item 8); Convenção 169 da OIT sobre Povos Indígenas e Tribais (item 15); Convenção Interamericana sobre o Desaparecimento Forçado de Pessoas (item 25); Convenção de Viena sobre o Direito dos Tratados (item 31).

${ }^{320}$ Que afirma que as novas democracias adeririam mais aos regimes de Direitos Humanos, se comparadas às acima mencionadas democracias estabelecidas ou às ditaduras.

${ }^{321}$ MORAVCSIK, 2000, p. 245.
} 
recente ou consolidada, mas não entrarei no mérito dessa distinção. ${ }^{322}$ Sob a perspectiva liberal, comprovada histórica e empiricamente, o maior apoio aos regimes de Direitos Humanos seria proveniente de democracias recentes e/ou instáveis, e não de democracias estabelecidas, que apoiariam apenas compromissos opcionais ou retóricos; e a oposição viria de ditaduras ou de regimes de transição incompleta, desinteressados nesse tipo de restrição e em qualquer desafio à ordem doméstica não democrática. ${ }^{323}$ Isso não foi observado nos dados obtidos, principalmente no que se refere ao tempo de tramitação de tratados, conforme será reiterado adiante. Apesar de a quantidade de tratados celebrada internacionalmente ser significativamente diferente nas três épocas, não se pode dizer que o regime militar deixou de assinar todos os tratados de Direitos Humanos do período. Tampouco foi o regime democrático responsável pela aprovação mais célere dos tratados, como poder-se-ia esperar. Deste modo, a relação entre regimes distintos em um mesmo país pode ser uma alternativa de agenda de pesquisa futura, para oferecer maior substrato empírico à teoria da Paz Democrática.

Foi confirmada a hipótese, aventada no início da pesquisa, de que a tramitação de tratados seria mais rápida na ditadura, regime no qual os integrantes do Executivo brasileiro apenas assinaram tratados que pretendiam internalizar. ${ }^{324}$ Excetuando dois intervalos, a ditadura foi responsável pelos menores deltas temporais - menores intervalos de tempo, se comparados os mesmos intervalos de tempo entre os processos de internalização na ditadura e a democracia - para o perfazimento da internalização. O tempo de tramitação dos tratados foi menor na Câmara e no Senado durante o regime militar, o que culminou em períodos também menores para a tramitação nacional e internacional dos tratados. Apesar de esta tese não ter como objetivo encontrar razões para a velocidade da adesão do regime de exceção

\footnotetext{
${ }^{322}$ A definição de democracias recentes, democracias estabelecidas e de governos de transição ou ditaduras de MORAVCSIK (2000) apenas se aplica aos países europeus, em virtude da circunscrição da análise do autor. HATHAWAY (2007) menciona o Brasil no rol de países considerados "semidemocráticos" ou "democráticos com relatos de violações dos Direitos Humanos", sem especificar em qual categoria o país poderia ser enquadrado. Deste modo, considero, aqui, o período histórico anterior a 1964 como democrático, o período entre 1964-1985 como ditatorial, e o período posterior como um período de transição, que culmina em uma democracia recente e, hoje, estabelecida. Destaco, de antemão, que seria possível alegar que o período que se seguiu ao primeiro governo de Getúlio Vargas (1930-1945), após a queda do Estado Novo (1937-1945) poderia, também, ser considerado um momento de transição, por ser posterior a uma ditadura. Essa discussão, entretanto, não é essencial para os fins a que se propõe esta tese, e destaco que o primeiro tratado analisado aqui data de 1948, ano no qual o Brasil era, institucionalmente, um país democrático.

${ }^{323}$ MORAVCSIK, 2000, p. 229 e 230.

${ }^{324}$ A única exceção é a CVDT, assinada durante a ditadura e apenas internalizada após o retorno à democracia.
} 
aos tratados de Direitos Humanos, trata-se de campo interessante para futuros estudos, apesar de a literatura consultada oferecer algumas respostas a esse respeito. Além disso, e também pelas próprias características do sistema ditatorial, foi menor a quantidade de argumentos proferidos.

Andrew Moravcsik acredita que existe uma motivação de dois níveis para o comprometimento estatal aos regimes de Direitos Humanos, que comprometeria o Estado nos âmbitos nacional e internacional, "trancando" os governantes futuros e fortalecendo a credibilidade das instituições estatais. Segundo ele, a teoria liberal sugere três condições para esse comprometimento: (i) o medo de insegurança política nacional; (ii) o apoio, por consenso estrangeiro, da posição adotada pelo governo e (iii) a possibilidade de a cooperação internacional induzir atores domésticos a apoiar a manutenção das políticas domésticas. Para o autor, no momento em que governos autocráticos cooperam para aumentar a sua credibilidade doméstica, comprometendo-se a tratados de Direitos Humanos, surge uma espécie de "imagem espelhada" ("mirror image") de instituições de Direitos Humanos. Segundo Stephen David, líderes fracos e ilegítimos de países em desenvolvimento muitas vezes percebem os inimigos internos como mais perigosos do que os inimigos externos, e, portanto, podem escolher alianças internacionais para enfraquecer os oponentes domésticos. $^{325}$

Na ditadura, os tratados que não eram interessantes para o regime simplesmente não eram assinados. Os tratados assinados não enfrentavam oposição no Congresso, o que culminava em uma apreciação mais veloz. Sendo assim, nos casos em que existiu baixo conflito de interesses entre a temática do tratado e o governo, a internalização foi rápida. Quando existiu conflito, os tratados foram, simplesmente, ignorados.

Se, por um lado, a demora na apreciação dos instrumentos poderia demonstrar a efetiva discussão a respeito dos temas de Direito Humanos na democracia brasileira, o excesso de tempo para ponderar a respeito de determinado tratado não significa, necessariamente, apreciação mais detalhada e criteriosa do texto convencional, ou de sua relação com a tradição jurídica, os interesses políticos e o contexto nacionais. Na prática, a maior demora no processo de internalização de tratados não culmina em argumentos mais minuciosos ou

${ }^{325}$ DAVID, Stephen R. Explaining Third-World Alignment, 1991. Apud MORAVCSIK, 2000, p. 247. 
em uma apreciação mais detalhista da matéria do tratado, apenas prejudica e prolonga o prazo da sua incorporação ao ordenamento jurídico nacional.

A esse fato soma-se a falta de obrigatoriedade, em virtude da inexistência de lei nesse sentido, de pronta consulta aos membros do Poder Legislativo após a assinatura. Apesar das iniciativas parlamentares no sentido de se estabelecer consulta prévia ao Legislativo, anterior, portanto, à assinatura de um tratado, acredito que uma mudança nesse sentido poderia ter o efeito inverso, de prolongar esse já demorado processo. Apesar disso, poderia, por outro lado, tornar o processo mais legítimo, pois o Legislativo seria consultado antes de qualquer atitude no âmbito internacional (assinatura) por parte do Executivo.

Se a rapidez na apreciação legislativa pode significar coesão entre os interesses dos Poderes, pode também expressar indiferença. Principalmente a partir da redemocratização, discursos contrários aos Direitos Humanos seriam percebidos como prejudiciais aos interesses do Estado Democrático de Direito e do cidadão brasileiro. Nesse contexto, não se pode falar em um grupo de legisladores abertamente contrário aos Direitos Humanos protegidos pelos tratados analisados no âmbito do Legislativo, e isso pode ser observado nas manifestações dos parlamentares. Nesse trabalho, não se pretende solucionar essa questão, que exigiria apreciar a dinâmica política de bastidores desse iter. Apesar disso, a leitura dos pareceres e de todas as manifestações formais presentes nos dossiês das Casas do Congresso Nacional nas quais os tratados tramitaram possibilitou concluir que, salvo exceções pontuais, a apreciação de tratados pelo Legislativo não apresenta construção contundente de argumentos, que pese os aspectos negativos e positivos da recepção de um tratado no Brasil. Menções à "tradição diplomática brasileira" ou à "bondade de espírito do nosso povo" são abundantes, mas dizem pouco.

Apesar de algumas manifestações fugirem a esse padrão, particularmente aquelas redigidas por consultores jurídicos do Itamaraty, grande parte dos pareceres apenas cita alguns motivos para que se perfaça a internalização, sem dar maior atenção ao teor do tratado. O relatório a respeito do tema de que trata o instrumento internacional é, muitas vezes, cópia exata do parecer do relator, sem qualquer preocupação interpretativa. Os membros do Poder Legislativo têm responsabilidades perante seus eleitores, e raramente são contrários à matéria de tratado de Direitos Humanos. Isso poderia ser usado como pretexto para a pronta apreciação da matéria, o que, como foi possível perceber na análise dos intervalos temporais, não ocorre. Infelizmente, os intervalos maiores de tempo na apreciação 
de tratados na democracia não são acompanhados por uma discussão mais informada, apesar da maior quantidade de argumentos proferidos.

O maior óbice, sob a perspectiva temporal, para o processo de internalização, é o Poder Executivo. No âmbito do Poder Legislativo, a Câmara dos Deputados é responsável, em média, por quase $70 \%$ do tempo de tramitação. A falta de obrigatoriedade e a inexistência de prazo determinado para a comunicação entre os Poderes são as grandes responsáveis pela inação de ambos.

Esta tese verificou a efetiva discrepância entre os intervalos de tramitação de tratados de Direitos Humanos, no Brasil, durante a democracia e a ditadura. À análise dos intervalos de tempo agregou-se a apreciação dos argumentos proferidos, durante esse processo, por integrantes dos Poderes Executivo e Legislativo brasileiros. A hipótese inicial, confirmada pela pesquisa, é de que os intervalos, durante o regime ditatorial, seriam menores, em comparação aos da democracia. Nos períodos de exceção, a discussão entre os membros dos Poderes Executivo e Legislativo, e entre os parlamentares, não seria particularmente necessária. Na democracia, a possibilidade de manifestar interesses discrepantes ensejaria maiores intervalos temporais para cada etapa analisada.

As Mensagens do Executivo, em conformidade com a hipótese inicial, têm a política externa nacional como eixo principal, durante a ditadura e a democracia atual. Durante a ditadura, a quantidade média de argumentos proferidos por Deputados é inferior à quantidade média de argumentos proferidos durante a democracia. Nos regimes democráticos, foram usados mais argumentos relativos a DBR (G1) e PBR (G3); enquanto no regime militar foram utilizados mais argumentos de PBR.

Os membros do Poder Legislativo, particularmente da Câmara dos Deputados, tendem a tratar, primordialmente, de questões relacionadas às consequências internas, políticas ou jurídicas, do processo de internalização de tratados, em detrimento das questões externas. Os pareceres dos Senadores também enfatizam questões relacionadas ao direito e à política brasileira. As mensagens elaboradas por membros do Poder Executivo, como se afirmou acima, estão mais focadas em questões de política externa. 


\section{PERSPECTIVAS, RECOMENDAÇÕES E PROPOSTAS}

Um dos maiores desafios relacionado ao tema em pauta foi, após e mediante a análise das fontes primárias, reunir e conceber possibilidades práticas que dessem à tese aspecto propositivo. Existem diversas propostas, nos âmbitos teórico-doutrinário e prático, mediante PECs e resoluções, para acelerar o processo de tramitação de tratados no Brasil. O objetivo parcial destas Conclusões é reunir as propostas que parecem mais adequadas ou factíveis, apresentadas por parlamentares, por estudiosos e pela autora; além das práticas consolidadas por responsáveis pela atividade legislativa. Em linhas gerais, são mencionadas propostas que tratam da velocidade na apreciação de tratados; do controle legislativo dos atos do Executivo; da qualidade da argumentação e da transparência do processo de internalização.

Estabelecer prazos para as distintas etapas de tramitação de tratados no âmbito interno parece maneira factível e direta para agilizar esse processo. Determinar um prazo, por exemplo, para o envio de MSCs para a apreciação do Poder Legislativo, uma vez assinado determinado tratado, é medida que pode ser aprovada pelos integrantes desse Poder, e que permitiria ingerência direta no processo que, iniciado na negociação dos termos de um tratado, é finalizado na sua ratificação. Apesar de o Poder Executivo ser responsável pelos atos que marcam o início e o término do processo de comprometimento internacional em relação aos tratados, a participação do Poder Legislativo é imprescindível para a conclusão desse procedimento. Uma vez assinado um tratado, o país compromete-se, no âmbito internacional, a não frustrar seus objetivos. Nada mais lógico, portanto, que esse objetivo seja, prontamente, levado a cabo. É inevitável, entretanto, observar que as iniciativas legislativas nesse sentido existem, e não são aprovadas pois falta interesse político, fato que foge do escopo desta tese, mas que pode ser investigado por estudos futuros.

A determinação legislativa de prazo seria interessante, ademais, para que o presidente da República, por intermédio do MRE, cuja estrutura institucional contém divisão específica para atos internacionais, enviasse à apreciação do Poder Legislativo todos aqueles tratados que, embora assinados, ainda não foram encaminhados.

É possível, também, encaminhar requerimento de informações ao MRE, solicitando a descrição de todos os acordos celebrados pelo Executivo e não submetidos à apreciação do Congresso. Este, devidamente informado, poderia requerer que determinados instrumentos 
fossem submetidos à sua aprovação, sempre que julgasse necessário. Isso poderia ser feito por intermédio de indicação legislativa, ${ }^{326}$ conforme disposição do Regimento da Casa. ${ }^{327}$

A necessidade de referendo do Congresso para a aprovação de denúncias aos tratados por ele apreciados pode ser prevista, explicitamente, nos decretos legislativos de aprovação dos próprios tratados; assim como ocorre na praxe legislativa atual em relação às eventuais modificações futuras nos textos dos tratados, conforme demonstrado nesta tese. Se, por um lado, o referendo parlamentar autoriza, mas não obriga, a ratificação de um tratado; por outro, se o Congresso deixa de autorizar a ratificação, o Executivo está impedido de levá-la a cabo. Disso decorre que, caso conste no decreto legislativo exigência de que a denúncia ao tratado seja submetida à apreciação parlamentar, o Poder Executivo, ao ratificar o tratado, deverá aceitar essa condição. Isso possibilita a apreciação de quaisquer denúncias sem a necessidade de alterações legislativas - que, apesar de apresentadas por diversos parlamentares, não têm sido bem-sucedidas nesse sentido, por motivos que fogem do escopo desta tese. ${ }^{328}$

É possível verificar, com a promulgação da Constituição de 1988, a evolução do tratamento legislativo dos tratados internacionais. A prática legislativa no caso dos tratados analisados consolidou a inserção, nos decretos legislativos que aprovam tratados, de cláusula que submete à aprovação, por parte do Congresso Nacional, de quaisquer atos que possam culminar em revisão ou em complementação dos tratados, bem como daqueles que tenham como objetivo estabelecer-lhe ajustes complementares, que acarretem encargos ou compromissos gravosos ao patrimônio nacional - é citado expressamente, na maior parte dos casos, o art. 49, I, CF. A inserção dessa cláusula é prova da preocupação dos parlamentares em temas afetos à inserção internacional do país, fortalecendo a premissa, inscrita na Constituição, referente à participação do Poder Legislativo na internalização de tratados. Além disso, demonstra como o Legislativo conseguiu, com o auxílio de decretos

\footnotetext{
${ }^{326}$ Sugestão apresentada por Tarciso dal Maso Jardim, 2011, p. 292.

${ }^{327}$ Art. 113, I, RICD. Indicação é a proposição através da qual o deputado.

I - sugere a outro Poder a adoção de providência, a realização de ato administrativo ou de gestão, ou o envio de projeto sobre a matéria de sua iniciativa exclusiva; (...).

${ }^{328}$ É o caso das PECs e das propostas de resolução, que, apesar de propostas por Deputados e Senadores, não foram bem sucedidas. Saber o motivo político e institucional por trás disso não é o intuito da tese.
} 
que aprovam os tratados, alterar a sua relação com o Executivo, mesmo sem instituir ou modificar qualquer lei.

Especialmente em relação aos tratados de Direitos Humanos, deveria existir sistema particular para a tramitação daqueles a serem aprovados conforme o rito estabelecido pelo art. $5^{\circ}, \S 3^{\circ}, C F{ }^{329}$ Apesar da possibilidade de aprovação desses tratados mediante decreto legislativo, as normas referentes a essa classe de instrumentos normativos não preveem a aprovação por quórum qualificado, de três quintos, em dois turnos, em ambas as Casas do Congresso; requisito do artigo supra mencionado, e tampouco discriminam rito especial para essa aprovação. Nos artigos 109, II, RICD e 213, II, RISF não existe previsão à possibilidade de modificar o status constitucional de outros tratados que, porventura, sejam aprovados por esse rito especial.

Nos itens desta tese que trataram das propostas de emendas constitucionais e dos projetos de resolução, tanto da Câmara como do Senado, foram destacadas as principais demandas dos membros do Poder Legislativo no sentido de aumentar a sua participação no processo de internalização e de denúncia de tratados e na elaboração da política externa nacional, por meios diversos. Os parlamentares demonstram a intenção, ademais, de esclarecer o significado da expressão do constituinte que confere ao Congresso a responsabilidade de "resolver definitivamente sobre tratados". A intenção de determinar prazos para que os membros do Legislativo tenham ciência dos instrumentos assinados pelo Executivo, sejam ou não considerados Acordos Executivos; além de definir prazos para a atuação do próprio Legislativo, demonstra que esse Poder não se exime da responsabilidade que tem nesse processo complexo, antes, durante e depois de seu término.

É necessário fazer comentário a respeito da transparência do processo de internalização de tratados perante a sociedade civil. Deveria haver uma maneira mais simples de acompanhar essa tramitação, tanto na Câmara como no Senado. O endereço eletrônico da Câmara dos Deputados é muito mais completo, em termos de quantidade de documentos disponíveis, do que o do Senado Federal. O endereço eletrônico da Divisão de Atos Internacionais do MRE - incumbida da guarda dos tratados que obriguem internacionalmente o Estado, além de manter registros de atos internacionais dos quais,

\footnotetext{
${ }^{329}$ Sugestão apresentada por Tarciso dal Maso Jardim, em "Condicionantes impostas pelo congresso nacional ao executivo federal em matéria de celebração de tratados”, p. 293.
} 
mesmo o Brasil não sendo parte, tenha participado de sua negociação - encontra-se em manutenção, ao menos, desde 2013, ano no qual a autora ingressou no programa de doutorado, sendo ferramenta de busca incompleta e, por isso, inútil.

A definição precisa da hierarquia normativa existente entre leis nacionais e tratados também é problema recorrente, objeto, inclusive, de demandas perante o Poder Judiciário, que Deputados e Senadores tentam solucionar. Nesse tema, os tratados de Direitos Humanos recebem especial atenção.

Limitar a discricionariedade, exercida por membros do Executivo, na condução da política externa brasileira, é uma das prioridades do Congresso, conforme as justificativas dos parlamentares em suas propostas de alteração legislativa. Os projetos de resolução, que têm como objetivo alterar as normas internas das Casas, também demonstram a intenção de detalhar o comportamento legislativo em relação à apreciação de tratados.

O Poder Legislativo não é, e não pode ser, mero espectador da atuação do Executivo, por dividirem a competência constitucional da vinculação do país a tratados. A maior participação do Legislativo, inclusive conferindo aos parlamentares maior acesso ao teor do processo de negociação internacional, é maneira clara e eficiente de democratizar a política externa nacional. Isso se percebe, inclusive, pela intenção dos parlamentares de estabelecer audiências públicas regulares com o Ministro das Relações Exteriores.

Os Direitos Humanos não são todos iguais. Existem nuances entre os distintos temas a que se referem os tratados analisados. Isso pode ser percebido, inclusive, pela não assinatura de determinados tratados, elaborados e celebrados internacionalmente, durante a ditadura; principalmente aqueles que garantiam aos cidadãos direitos muito amplos (como os Pactos Internacionais de 1966).

Na maioria dos documentos analisados, os argumentos são favoráveis à internalização. Com raras exceções, particularmente em pareceres elaborados por consultores do Itamaraty, ${ }^{330}$ não há ponderação ou sopesamento de argumentos. Poucos relatores proferem argumentos a favor e contra determinado tratado, analisando, simultaneamente, seus prós e contras. É necessário um esforço parlamentar e dos integrantes do Poder Executivo de melhorar a qualidade do debate.

\footnotetext{
${ }^{330}$ Ver, nesse sentido, o Parecer CJ/MRE, elaborado por Antônio Paulo Cachapuz de Medeiros, no qual faz a análise da internalização do Tratado de Roma do Tribunal Penal Internacional (APÊNDICE I, item 18).
} 
Verifica-se que o regime político vigente no Brasil efetivamente influenciou o processo de internalização de tratados de Direitos Humanos. Ao analisar as convergências e as divergências entre os Poderes nos diferentes regimes, e estabelecer um padrão de comportamento, a autora verificou que os membros do Poder Legislativo não são apáticos nesse processo, o que é realçado pelas iniciativas institucionais de alteração da regulamentação desse processo, como a propositura de Emendas Constitucionais ou Regimentais pelos parlamentares brasileiros. As iniciativas parlamentares, entretanto, não bastam para uma apreciação célere dos instrumentos internacionais que têm o intuito de aprimorar o ordenamento jurídico nacional e, como consequência disso, a própria proteção dos Direitos Humanos no Brasil. A influência de instrumentos internacionais na legislação brasileira demonstra, novamente, a disposição de Deputados e de Senadores em utilizar o Direito Internacional como meio de aprimorar a legislação que protege os Direitos Humanos. Percebe-se, assim, que existem nuances entre as diversas classes de direitos protegidos pelos tratados analisados, e que o Direito Internacional influencia o Direito interno, justamente como consequência da atuação parlamentar nesse sentido. 


\section{BIBLIOGRAFIA}

- $\quad$ ACCIOLY, Hildebrando. A conclusão de atos internacionais no Brasil. In: Revista Forense. Rio de Janeiro: v.155, a.51, set-out. 1954.

- $\quad$ ACCIOLY, Hildebrando. A ratificação e a promulgação dos tratados em face da Constituição Federal brasileira. In: Boletim da Sociedade Brasileira de Direito Internacional. Rio de Janeiro: a.IV, n.7, jan-jun. 1948 .

- ACCIOLY, Hildebrando. Ainda o problema da ratificação dos tratados, em face da Constituição Federal. In: Boletim da Sociedade Brasileira de Direito Internacional. Rio de Janeiro: n.13-14, jan-dez., 1951.

- ACCIOLY, Hildebrando; SILVA, G.E. do Nascimento; CASELLA, Paulo Borba. Manual de Direito Internacional Público. São Paulo: Ed. Saraiva, 2008.

- $\quad$ ALBUQUERQUE, José Augusto Guilhon (org.) Sessenta anos de política externa brasileira (1930-1990). São Paulo: Cultura Editores Associados, 1996.

- $\quad$ ALCÂNTARA, Lúcio. Os Parlamentos e as relações internacionais. Revista Brasileira de Política Internacional, v.44, n.1, p. 13-21, jan./jun. 2001.

- ALEXANDRE, Cristina V. Machado. O congresso brasileiro e a política externa. Dissertação (Mestrado em Relações Internacionais), Rio de Janeiro: Instituto de Relações Internacionais - Pontifícia Universidade Católica, Rio de Janeiro, 2006.

- $\quad$ ALMEIDA, P. R. de. Relações Internacionais e Política Externa do Brasil. Porto Alegre: Ed. UFRGS, 2004.

- $\quad$ AMIN, Aleph H. C.; COSTA, Marcela Ferreira. A promulgação da Convenção de Viena sobre Direito dos Tratados pelo Brasil e suas implicações no direito interno. Trabalho publicado nos Anais do XIX Encontro Nacional do CONPEDI realizado em Fortaleza - CE nos dias 09, 10, 11 e 12 de Junho de 2010.

- $\quad$ AMORIM NETO, O.; SCHIAVON, J. A. Instituciones políticas internas y la política exterior de Instituciones políticas internas y la política exterior de Brasil y México. In: MENA, A. O.; AMORIM NETO, O.; CASTRO, R. F. de (Ed.). Brasil y México: encuentros y desencuentros. México: Instituto Matías Romero, Secretaría de Relaciones Exteriores, 2005. p. 167-200.

- $\quad$ ASSANO, Camila. Comportamento dos Estados em instituições internacionais: padrões de votação na Comissão de Direitos Humanos da ONU (1995-2005). Dissertação de mestrado defendida na Faculdade de Filosofia, Letras e Ciências Humanas da Universidade de São Paulo (Ciência Política). São Paulo: 2008.

- $\quad$ BARBOSA, A. J. O Parlamento e a política externa brasileira (1961-1967). Brasília, 2000. 340 p. Tese (Doutorado em História) - Departamento de História, UnB.

- $\quad$ BARBOSA, S. A. O Poder de celebrar tratados no direito positivo brasileiro. Revista de Informação Legislativa, v.41, n.162, p. 353-362, abr./jun. 2004.

- $\quad$ BARROS, A. de S. C. A formulação e implementação da Política Externa Brasileira: o Itamaraty e os Novos Atores. In: MUÑOZ, H.; TULCHIN, J. S. (Orgs.). A América Latina e a Política Mundial. São Paulo: Convívio, 1986. p. 29-42.

- $\quad$ BAYEFSKY, Anne F. The UN Human Rights treaty system: universality at the crossroads. Disponível em: http://www.bayefsky.com/report/finalreport.pdf. Acesso: 30.01.2017. 
- $\quad$ BEVILAQUA, C. Celebração de Tratados e Convenções e o que dispõe a respeito a Constituição Federal. In: Pareceres dos Consultores Jurídicos do Itamaraty, v. 2, 1913-1934. Brasília: Senado Federal, 1962. p. 345-346.

- $\quad$ BRANT, Leonardo N. C. O Brasil e os novos desafios do Direito Internacional. Rio de Janeiro: Forense, 2004.

- $\quad$ BRASIL. Câmara dos Deputados. Centro de Documentação e Informação. Sistema de Informações Legislativas - SILEG. Base de Dados.

- $\quad$ BRASIL. Constituição da República Federativa do Brasil de 1988 (CF). Disponível em www.planalto.gov.br.

- $\quad$ BRASIL. Ministério das Relações Exteriores (MRE), Pareceres dos Consultores Jurídicos do Itamaraty. Org. e prefácio de Antônio Paulo Cachapuz de Medeiros. Ed. Fundação Alexandre de Gusmão. Brasília: Senado Federal, 9 volumes.

- $\quad$ BRASIL. Ministério das Relações Exteriores: Atos Internacionais - Prática Diplomática Brasileira - Manual De Procedimentos. Brasília, 2008. Disponível em: http://sistemas.mre.gov.br/kitweb/datafiles/IRBr/pt-br/file/CAD/LXI\%20CAD/Direito/

MANUAL\%20de\%20procedimentos\%20-\%20atos\%20internacionais.pdf

- $\quad$ BRASIL. Ministério das Relações Exteriores: dai-mre.serpro.gov.br.

- $\quad$ BRASIL. Ministério Público Federal. Secretaria de Cooperação Internacional. Tratados em direitos humanos: Sistema internacional de proteção aos direitos humanos / Secretaria de Cooperação Internacional - Brasília: MPF, 2015.

- $\quad$ BRASIL. Senado Federal. Regimento Interno (RISF): disponível em: www.senado.gov.br.

- BROWNLIE, Ian. Princípios de Direito Internacional Público. Lisboa: Calouste Gulbenkian, 1997.

- $\quad$ BRUSCO, D. E. Histórico das Comissões Permanentes da Câmara dos Deputados 18232004: síntese histórica. Brasília: Câmara dos Deputados, Coordenação de Publicações, 2006.

- $\quad$ BUENO, Clodoaldo; CERVO, Amado Luiz. História da política exterior do Brasil. Brasília: Ed. UnB, 2002.

- CACHAPUZ DE MEDEIROS, Antônio Paulo. Desafios do Direito Internacional Contemporâneo. Fundação Alexandre de Gusmão, 2007.

- $\quad$ CACHAPUZ DE MEDEIROS, Antônio Paulo. O poder de celebrar tratados. Porto Alegre: Sérgio Antonio Fabris, 1995.

- CÂMARA, José Sette. A conclusão dos tratados internacionais e o direito constitucional brasileiro. In: Boletim da Sociedade Brasileira de Direito Internacional. Brasília: n.69-71, 19871989.

- $\quad$ CAMPELLO, Daniela; LEMOS, Leany. The non-ratification of bilateral investment treaties in Brazil: a story of conflict in a land of cooperation. Review of International Political Economy (Print), v. 22, p. 1-32, 2015.

- $\quad$ CANÇADO TRINDADE, A. A. O direito internacional em um mundo em transformação. Rio de Janeiro: Ed. Renovar, 2003.

- CANÇADO TRINDADE, A. A. A proteção Internacional dos direitos humanos e o Brasil (1948-1997): as primeiras cinco décadas. 2a ed., Brasília: Edições Humanidades, 2000.

- CANOTILHO, J. J. Gomes. "Brancosos" e Interconstitucinalidade - Itinerários dos Discursos sobre a historicidade constitucional. $2^{\mathrm{a}}$ Ed., Coimbra: Almedina, 2008. 
- CASSEB, Paulo Adib. Processo Legislativo: atuação das comissões permanentes e temporárias. São Paulo: Ed. Revista dos Tribunais, 2008.

- C CELli JÚNIOR, Umberto. A Constituição, o Parlamento e a Política Externa Brasileira. Direito e Política, São Paulo, v. 1, p. 83-87, 2004.

- $\quad$ CERVO, Amado Luiz. Inserção Internacional: formação dos conceitos brasileiros. São Paulo: Ed. Saraiva, 2008.

- $\quad$ CERVO, Amado Luiz. O Parlamento Brasileiro e as Relações Exteriores (1826-1889). Brasília: Ed. UnB, 1981.

- $\quad$ CESAR, S. E. M. Congresso Nacional e a Política Externa Brasileira. Brasília, 2002. 118 p. Dissertação (Mestrado em Relações Internacionais) - Departamento de Relações Internacionais, UnB.

- $\quad$ CHEIBUB, Z. B. Diplomacia, Diplomatas e Política Externa: aspectos do processo de institucionalização do Itamaraty. Dissertação (Mestrado em Ciência Política) - Departamento de Ciência Política, IUPERJ. Rio de Janeiro, 1984.

- $\quad$ CINTRA, R. Política Externa no Senado: fortalecimento ou risco? Colunas de RelNet, n.12, jul./dez. 2005. Disponível em: http://www.relnet.com.br.

- $\quad$ COELHO, Fábio A. Processo Legislativo. São Paulo: Ed. Juares de Oliveira, 2007.

- CORREA, Renato S. F. Lex América: Os tratados e o Legislativo no Mercosul. E-Legis, Revista Eletrônica do Programa de Pós-Graduação - Centro de Formação, Treinamento e Aperfeiçoamento da Câmara dos Deputados n.05, p. 48 - 65, 2 semestre de 2010.

- DAL MASO, Tarsio. Condicionantes impostas pelo Congresso Nacional ao Executivo Federal em matéria de celebração de tratados. In: MENEGUIN, Fernando B. Agenda legislativa para o desenvolvimento nacional. Brasília: Senado Federal, Consultoria Legislativa, 2010.

- $\quad$ DALLARI, Dalmo de Abreu. Elementos de Teoria Geral do Estado. 16a ed., São Paulo: Ed. Saraiva, 1991.

- DALLARI, Pedro Bohomoletz de Abreu. Constituição e Tratados Internacionais. São Paulo: Ed. Saraiva: 2003.

- $\quad$ DAVID, René. Os grandes Sistemas do Direito Contemporâneo. $4^{\mathrm{a}}$ ed., São Paulo: Ed. Martins Fontes, 2002.

- $\quad$ DINIZ, Simone. Atos Internacionais e Atuação do Legislativo. Teoria \& Pesquisa, v. XVIII, p. 27-59. 2009.

- $\quad$ DINIZ, Simone. O Senado Federal e a deliberação de atos internacionais no presidencialismo brasileiro. Revista Brasileira de Ciências Sociais (Impresso), v. 27, p. 169-184. 2012.

- $\quad$ DINIZ, Simone. Processo Legislativo e o Sistema de Comissões. Revista do Legislativo, Belo Horizonte, v. 26, n.26, p. 59-78. 1999.

- $\quad$ DINIZ, Simone; RIBEIRO, Cláudio Oliveira. The role of the Brazilian congress in foreign policy: an empirical contribution to the debate. Brazilian Political Science Review, vol.3. 2008.

- $\quad$ EVANS, P. Building an Integrative Approach to International and Domestic Politics: reflections and projections. In: EVANS, P. B.; JACOBSON, H. K.; PUTNAM, R. (Orgs.). DoubleEdged Diplomacy: International bargaining and domestic politics. New York: Columbia University Press, 1992. p. 397-430. 
- $\quad$ FELIÚ, P. R. Comportamento Legislativo e Política Externa na América Latina. Tese (Doutorado em Ciência Política) - Departamento de Ciência Política, Universidade de São Paulo. São Paulo, 2012.

- $\quad$ FELIÚ, P. R.; AMORIM, C. Congresso Nacional e MERCOSUL: o caso da Aprovação da Entrada da Venezuela. Meridiano 47 (UnB), v. 12, p. 11-17. 2011.

- $\quad$ FELIÚ, P. R.; MIRANDA, R. Congresso Nacional e Política Externa. O caso do envio de tropas ao Haiti: Argentina, Brasil e Chile. Política Hoje (UFPE Impresso), v. 20, p. 310-342. 2011.

- $\quad$ FERREIRA FILHO, Manoel Gonçalves. Do processo legislativo. São Paulo: Ed. Saraiva, 2007.

- FERREIRA, Marcelo Costa. O Congresso Nacional brasileiro na política externa do Mercosul e no debate da ALCA - 1998-2003. Tese de doutorado defendida na Faculdade de Ciências Sociais da Pontifícia Universidade católica, São Paulo: 2005.

- $\quad$ FERREIRA, Marcelo Costa. O Congresso Nacional e política externa da integração: um controverso debate acadêmico. Revista ponto-e-vírgula, 5: 202-214, 2009.

- $\quad$ FERRARI, Diogo A. O Congresso Nacional e apreciação de tratados internacionais entre 1999 e 2006. Cadernos Adenauer XII (2011), n 2. O Congresso e o presidencialismo de coalizão. Rio de Janeiro: Fundação Konrad Adenauer, p. 83-97, setembro 2011.

- $\quad$ FIGUEIRA, Ariane C. Roder. Processo Decisório em Política Externa no Brasil. Tese de doutorado defendida na Faculdade de Filosofia, Letras e Ciências Humanas, Departamento de Ciência Política da Universidade de São Paulo. São Paulo: 2009.

- $\quad$ FIGUEIREDO, A. C. Instituições e Política no Controle do Executivo. Revista Dados: Rio de Janeiro, v.44, n.4, p. 689-727, 2001.

- $\quad$ FIGUEIREDO, A. C.; LIMONGI, F. Executivo e Legislativo na nova ordem constitucional. Rio de Janeiro: Ed. FGV, 1999.

- $\quad$ FILHO, Manoel G. Ferreira. Direito Constitucional Comparado: O Poder Constituinte. São Paulo: Bushatsky, 1974.

- $\quad$ FILHO, Manoel G. Ferreira. Estado de direito e constituição. São Paulo: Ed. Saraiva, 1988.

- $\quad$ FONSECA, Gelson. A legitimidade e outras questões internacionais - poder e ética entre as nações. $2^{\mathrm{a}}$ ed,. São Paulo: Paz e Terra, 2004.

- $\quad$ FRAGA, Mirtô. O conflito entre tratado internacional e norma de direito interno: estudo analítico da situação do tratado na ordem jurídica brasileira. Rio de Janeiro: Ed. Forense, 1997.

- $\quad$ FRANÇA, Cassio Luiz de; BADIN, Michelle Ratton S. A inserção internacional do Poder Executivo Federal brasileiro. Analises e propostas, n. 40. Agosto, 2010.

- $\quad$ FREIRE, Maria Raquel (coord.). Política Externa: as relações internacionais em mudança. $2^{a}$ ed., Imprensa da Universidade de Coimbra: Coimbra, 2015.

- $\quad$ GABSCH, Rodrigo D'Araujo. Aprovação de tratados internacionais pelo Brasil: possíveis opções para acelerar o seu processo. Brasília: FUNAG, 2010.

- GARCIA, Márcio Pereira Pinto. A terminação de tratado e o Poder Legislativo à vista do Direito Internacional, do Direito Comparado e do Direito Constitucional Internacional Brasileiro. Rio de Janeiro: Renovar, 2011.

- $\quad$ GRILlo, V. T. de A. O Congresso e a Política Externa Brasileira: o poder visto por ele mesmo. Santa Catarina, 1991. 229 p. Tese (Doutorado em Direito) - Departamento de Direito, UFSC. 
- $\quad$ GUERREIRO, R. S. O Itamaraty e o Congresso Nacional. Brasília: Senado Federal, Centro Gráfico, 1985.

- $\quad$ HARDT, Matheus S. Os determinantes que influenciam na adesão aos regimes internacionais de Direitos Humanos. 2014. 52 f. Dissertação (mestrado em Relações Internacionais). Instituto de Relações Internacionais da Universidade de São Paulo. São Paulo, 2014.

- HATHAWAY, Oona A. Why Do Countries Commit to Human Rights Treaties? Journal of Conflict Resolution. Volume 51, n. 4, p. 588-621, agosto, 2007.

- JARDIM, Tarciso Dal Maso. Condicionantes impostas pelo Congresso Nacional ao Executivo Federal em matéria de celebração de tratados. Agenda legislativa para o desenvolvimento nacional. cap. 13. Brasília: Núcleo de Estudos e Pesquisas do Senado Federal, 2011. Disponível em: http://www2.senado.leg.br/ bdsf/item/id/243243.

- JONES, M. P. Legislator Behavior and Executive-Legislative Relations in Latin America. Latin American Research Review, v. 37, n. 3, p. 176-188, 2002.

- $\quad$ KRASNER, Stephen D. "Causas estruturais e Consequências dos regimes Internacionais: regimes como variáveis interveniente", artigo publicado originalmente sob o título "Structural Causes and Regime Consequences: Regimes as Intervening Variables". Tradução de Dalton Guimarães, Feliciano Guimarães e Gustavo Biscaia de Lacerda. Rev. Sociol. Polít., Curitiba, v. 20, n. 42, p. 93-110, jun. 2012.

- $\quad$ LEMOS, Leany. Tese de Doutorado: Controle legislativo em democracias presidencialistas: Brasil e EUA em perspectiva comparada. Ano de obtenção: 2006. Orientador: Maria das Graças Rua. Universidade de Brasília, UNB, Brasil.

- $\quad$ LIMA, J. de C. O Direito Internacional e o Poder Legislativo na condução da política externa. Revista de Informação Legislativa, v.42, n.166, p. 165-180, abr./jun. 2005.

- $\quad$ LIMA, Maria Regina Soares de. O Legislativo e a Política Externa. In: REBELO, A.; FERNANDES, L.; CARDIM, C. H. (Orgs.). Seminário Política Externa do Brasil para o Século XXI. $2^{\mathrm{a}}$ ed. Brasília: Câmara dos Deputados, Coordenação de Publicações, 2004. p. 41-51.

- $\quad$ LIMA, Maria Regina Soares de; SANTOS, Fabiano. O Congresso e a Política de Comércio Exterior. Revista Lua Nova de Cultura e Política, n.52. 2001.

- $\quad$ LYNCH, Christian. Tratado, Governo e Congresso - a referenda de tratados e a possibilidade de sua alteração legislativa no direito público brasileiro. Revista de Informação Legislativa. Brasília a.46 n.181 jan./mar. 2009

- $\quad$ MAIA, C. C. M.; CESAR, S. E. M. A Diplomacia congressual: análise comparativa dos Legislativos brasileiro e norte-americano na formulação da política exterior. Revista de Informação Legislativa, v.41, n.163, p. 363-388, jul./set. 2004.

- MARIZ, Vasco. Nos bastidores da diplomacia: memórias diplomáticas. Brasília: FUNAG, 2013.

- $\quad$ MARTIN, Lisa L. Democratic Commitments: Legislatures and International Cooperation. Princeton University Press: 2000.

- $\quad$ MARTINS, Ives Gandra. Eficácia provisória e definitiva dos tratados internacionais. Disponível em: http://www.saraivajur.com.br/menuesquerdo/doutrinaArtigosDetalhe. aspx? Doutrina $=10$.

- $\quad$ MAZZUOLI, Valerio de O. O Poder Legislativo e os tratados internacionais: o treaty making power na Constituição brasileira de 1988. Revista de Informação Legislativa, v.38, n.150, p. 27-53, abr.jun. 2001. 
- $\quad$ MAZZUOLI, Valerio de O. O treaty-making power na Constituição brasileira de 1988: uma análise comparativa do poder de celebrar tratados à luz da dinâmica das relações internacionais. Revista Brasileira de Política Internacional, 44 (2): 82-108 [2001]. Disponível em: http://www.scielo.br/scielo.php?script=sci_arttext\&pid=S0034-73292001000200005. Acesso: 20.06.2016.

- $\quad$ MEDEIROS, A. P. C. O Poder de Celebrar Tratados: competência dos Poderes constituídos para a celebração de tratados, à luz do Direito Internacional, do Direito Comparado e do Direito Constitucional Brasileiro. Porto Alegre: Fabris, 1995.

- $\quad$ MEDEIROS, A. P. C. O Poder Legislativo e os Tratados Internacionais. Porto Alegre: L\&PM/Instituto dos Advogados do Rio Grande do Sul, 1983.

- MILNER, Helen V. Interests, Institutions, and Information: Domestic Politics and International Relations. Princeton University Press: 1997.

- $\quad$ MORAVCSIK, Andrew. The Origins of Human Rights Regimes: Democratic Delegation in Postwar Europe. International Organization 54, 2, Primavera, 2000, pp. 217-252.

- $\quad$ NEIVA, Pedro; VILELA, Elaine. Temas e regiões nas políticas externas de Lula e Fernando Henrique: comparação do discurso dos dois presidentes. Revista Brasileira de Política Internacional (Impresso), v. 54, p. 70-96. 2011.

- $\quad$ NEVES, J. A. de C. O papel do Legislativo nas Negociações do Mercosul e da ALCA. Contexto Internacional, v.25, n.1, p. 103-138, jan./jun. 2003.

- $\quad$ NEVES, J. A. de C. Participação do Poder Legislativo na Política Externa Brasileira: o caso do Mercosul. Rio de Janeiro, 2002. 75 p. Dissertação (Mestrado em Ciência Política) - Departamento de Ciência Política, IUPERJ.

- OLIVEIRA, Amâncio J. Legislativo e Política Externa: Das (in)conveniências da abdicação. In: Working Papers CAENI, n 3, 2003.

- OLIVEIRA, Amâncio J. Legislativo e Política Exterior no Brasil: Partidos Políticos e Interesses Organizados. Livre-docência. Instituto de Relações Internacionais da Universidade de São Paulo. São Paulo: 2010.

- $\quad$ OLIVEIRA, Amâncio J.; ONUKI, Janina. Política comercial e Legislativo: a atuação do empresariado brasileiro. In MANCUSO, Wagner Pralon; LEOPOLDI, M. Antonieta; IGLECIAS, Wagner (org.). Estado, Empresariado e Desenvolvimento no Brasil: novas teorias, novas trajetórias. São Paulo: Ed. de Cultura, 2010.

- $\quad$ OLIVEIRA, Amâncio J.; ONUKI, Janina. Eleições, Partidos Políticos e Política Externa no Brasil. Revista Política Hoje, Vol. 19, n. 1, p. 144-185: 2010.

- OLIVEIRA, Rodrigo R. de. O Congresso Nacional e a Política Externa brasileira. Posicionamento dos senadores frente às negociações para a formação da ALCA (1994-2005). Dissertação defendida na Faculdade de História da Universidade de Brasília. Biblioteca Digital da Câmara dos Deputados. Brasília: 2011.

ONUKI, Janina. O elo entre regimes politicos domésticos e adesão a regimes internacionais. 42 p. São Paulo: Centro de Estudos das Negociações Internacionais, Universidade de São Paulo, maio, 2013.

- Organização das Nações Unidas. United Nations Treaty Collection. Disponível em: http://treaties.un.org/. 
- $\quad$ PANNUNZIO, Eduardo. A judicialização das relações internacionais no Brasil em face do princípio constitucional da prevalência dos direitos humanos. Tese apresentada na Faculdade de Direito da Universidade de São Paulo. São Paulo: 2012.

- Pareceres dos Consultores Jurídicos do Itamaraty. Org: Antônio Paulo Cachapuz de Medeiros. Brasília: Fundação Alexandre de Gusmão.

- $\quad$ PEREIRA, Carlos; MUELLER, Bernardo. Comportamento estratégico em Presidencialismo de Coalizão: As Relações entre Executivo e Legislativo na Elaboração do Orçamento Brasileiro. Dados, vol. 45, n 2, p. 265-301, 2002.

- PINHEIRO, L. Os véus da transparência: política externa e democracia no Brasil. In: REBELO, A.; FERNANDES, L.; CARDIM, C. H. (Orgs.). Seminário Política Externa do Brasil para o Século XXI. $2^{a}$ ed. Brasília: Câmara dos Deputados, Coordenação de Publicações, 2004. p. 53-73. 2004.

PINHEIRO, L. Política Externa Brasileira, 1889-2002. Rio de Janeiro: Jorge Zahar Ed.,

- $\quad$ PINHEIRO, L. Traídos pelo Desejo: um Ensaio sobre a Teoria e a Prática da Política Externa Brasileira Contemporânea. Contexto Internacional, v.22, n.2, p. 305-335, jul./dez. 2000.

- PIOVESAN, Flávia. Direitos Humanos e o Direito Constitucional Internacional. São Paulo: Saraiva, 2006.

- $\quad$ PIOVESAN, Flávia. Temas de Direitos Humanos. São Paulo: Max Limonad, 1998.

- $\quad$ PIRES, Norma da Silva V. A atuação do Congresso Nacional na celebração de tratados internacionais: Legislatura 1999-2002. Biblioteca Digital da Câmara dos Deputados. Brasília; 2003.

- $\quad$ PUTNAM, R. Diplomacy and Domestic Politics: the logic of two-level games. International Organization, v.42, n.3, p. 427-461, 1988.

- $\quad$ QUOC DINH, Nguyen, DAILLER, Patrick, PELLET, Alain. Direito Internacional Público. Lisboa: Calouste Gulbekian, 1999.

- $\quad$ RAMOS, André Carvalho. Teoria Geral dos Direitos Humanos na Ordem Internacional. Rio de Janeiro: Renovar, 2005.

- $\quad$ RANGEL, Vicente M. Direito e Relações Internacionais. Rio de Janeiro, 2002.

- $\quad$ RANGEL, Vicente M. Emenda dos Tratados Internacionais. Parecer 029 do Consultor Jurídico do Ministério das Relações Exteriores, de 24 de setembro de 1991.

- $\quad$ REALE, Miguel. Teoria do Direito e do Estado. São Paulo: Ed. Martins, 1970.

- $\quad$ REZEK, Francisco. Direito dos Tratados. Rio de Janeiro: Ed. Forense, 1984.

- $\quad$ REZEK, Francisco. Direito Internacional Público: curso elementar. São Paulo: Ed. Saraiva. $14^{\mathrm{a}}$ ed., 2013.

- $\quad$ REZEK, Francisco. Parlamento e tratados internacionais: o modelo constitucional do Brasil. Revista de Direitos Fundamentais e Democracia, Curitiba, v. 14, n. 14, p. 40-72, julho/dezembro de 2013.

- $\quad$ RIBEIRO, Silvia. A participação do Legislativo no processo de celebração dos tratados. Revista de Informação Legislativa. Brasília a. 43 n. 170 abr./jun. 2006

- $\quad$ RIZEK JÚNIOR, Rubens N. O processo de consolidação e organização legislativa. 2009. Tese (Doutorado em Direito do Estado) - Faculdade de Direito, Universidade de São Paulo. São Paulo: 2009. Disponível em: http://www.teses.usp.br/teses/disponiveis/2/2134/tde-26052010$160859 \%$. 
- $\quad$ RODAS, João Grandino. Os acordos em forma simplificada. In: Revista da Faculdade de Direito da Universidade de São Paulo, v.68, n.1, 1973.

- $\quad$ RODRIGUES, Thaís de Camargo. O Tráfico internacional de pessoas para fim de exploração sexual e a questão do consentimento. 204 p. Dissertação (mestrado). Faculdade de Direito da Universidade de São Paulo. Orientador: Vicente Greco Filho.

- $\quad$ ROSENAU, J. (editor). Domestic sources of foreign policy. Free Press. Nova Iorque: 1967.

- $\quad$ SANTOS, F. O Poder Legislativo no Presidencialismo de Coalizão. Belo Horizonte: Ed. UFMG; Rio de Janeiro: IUPERJ, 2003.

- $\quad$ SCHMITT, Stefanie Tomé. A política externa e o Poder Legislativo: um olhar sobre a Comissão de Relações Exteriores e Defesa Nacional do Senado Federal. 2011. Dissertação (Mestrado em Ciência Política) - Faculdade de Filosofia, Letras e Ciências Humanas, Universidade de São Paulo, São Paulo, 2011. Disponível em: http://www.teses.usp.br/teses/disponiveis/8/8131/tde12062012-165231. Acesso: 18.05.2016.

- $\quad$ SHAW, Malcom N. International Law. Cambridge University Press, 4a ed., 1997.

- $\quad$ SILVA, Elaini; SPECIE, Priscila; VITALE, Denise. Atual arranjo institucional da política externa brasileira. Texto para discussão n.1489. Instituto de Pesquisa Econômica aplicada, IPEA. Brasília: maio, 2010.

- $\quad$ SOARES, Clemente de Lima Baena. O processo legislativo e a aprovação de acordos internacionais assinados pelo Brasil. Monografia do $48^{\circ}$ Curso de Altos Estudos do Instituto Rio Branco do Ministério das Relações Exteriores, 2005.

- $\quad$ SOARES, Guido F. Silva. Curso de Direito internacional público. São Paulo: Ed. Atlas S.A, 2002

TRINDADE, Antônio Augusto Cançado. A questão da aprovação pelo Legislativo de Atos Internacionais. In: MEDEIROS, A. P. C. (Org.). Pareceres dos consultores jurídicos do Itamaraty, vol. 8. Brasília: Senado Federal, 2004. p. 518-523.

- TRINDADE, Antônio Augusto Cançado. Proteção internacional dos direitos humanos no Brasil. $2^{\mathrm{a}}$ ed. Brasília: Ed. UnB, 2000.

- $\quad$ VREELAND, James R. Political Institutions and Human Rights: Why Dictatorships Enter into the United Nations Convention against Torture. International Organization, Vol. 62, No. 1 (Winter, 2008), pp. 65-101.

- WALDRON, Jeremy. The core of the case against Judicial review. 115 Yale Law Journal 1346 (2006). Disponível em: http://yalelawjournal.org/the-yale-law-journal/ content-pages/the-coreof-the-case-against-judicial-review/.

- WALTZ, K. International Politics is not Foreign Policy. Security Studies, v.6, n.1, p. 54-57, 1996. 


\section{APÊNDICE I \\ ANÁLISE TEXTUAL DA TRAMITAÇÃO DOS TRATADOS SELECIONADOS}




\section{SUMÁRIO}

1. ANÁLISE: CONVENÇÃO PARA A PREVENÇÃO E A REPRESSÃO DO CRIME DE GENOCÍDIO

STATUS NA ONU

MENSAGEM DO PODER EXECUTIVO (MSC 450/1949).... 251

PARECER DA COMISSÃO DE DIPLOMACIA (CD), VARGAS NETO, 1949...253

PARECER DA COMISSÃO DE DIPLOMACIA (CD), JOÃO HENRIQUE, 1950.254

PARECER DA COMISSÃO DE CONSTITUIÇÃO E JUSTIÇA (CD), AFONSO

ARINOS, 1950 254

PARECER DA COMISSÃO DE CONSTITUIÇÃO E JUSTIÇA (n.93 - SF),

FERREIRA DE SOUZA, 1951 255

PARECER DA COMISSÃO DE RELAÇÕES EXTERIORES (n.94 - SF), ARTHUR SANTOS, 1951 256

2. ANÁLISE: CONVENÇÃO PARA A REPRESSÃO DO TRÁFICO DE PESSOAS E DO LENOCÍNIO 258

STATUS NA ONU 258

MENSAGEM DO PODER EXECUTIVO (MSC 41/1952) 258

PARECER DA COMISSÃO DE DIPLOMACIA (CD), ALCIDES CARNEIRO, 1953

PARECER DE OSVALDO TRIGUEIRO (CD), 1955 259

PARECER DA COMISSÃO DE CONSTITUIÇÃO E JUSTIÇA (CD), LOURIVAL

DE ALMEIDA 260

PARECER 193 (CN), RUI PALMEIRA, 1958. 260

PARECER DA COMISSÃO DE CONSTITUIÇÃO E JUSTIÇA (n.104 - SF), LOURIVAL FONTES, 1958. 261

PARECER DA COMISSÃO DE RELAÇÕES EXTERIORES (n. 105 - SF), JOÃO VILLASBOAS, 1958 261

3. ANÁLISE: CONVENÇÃO RELATIVA AO ESTATUTO DOS REFUGIADOS 262 3.1. ANÁLISE: PROTOCOLO SOBRE O ESTATUTO DOS REFUGIADOS277

4. ANÁliSE: CONVENÇÃO SOBRE OS DIREITOS POLÍTICOS DA MULHER 281

MENSAGEM DO PODER EXECUTIVO (MSC 247/1953) 281

PARECER DA COMISSÃO DE DIPLOMACIA (CD), OSVALDO TRIGUEIRO, 1953 282

PARECER DA COMISSÃO DE CONSTITUIÇÃO E JUSTIÇA (CD), NESTOR DUARTE, 1955. 282

PARECER DA COMISSÃO DE RELAÇÕES EXTERIORES (n. 1182 - SF), JOÃO

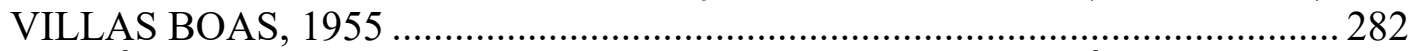

5. ANÁLISE: CONVENÇÃO SOBRE O ESTATUTO DOS APÁTRIDAS ........283 STATUS NA ONU 283 MENSAGEM DO PODER EXECUTIVO (MSC 171/1993). 284 PARECER DA COMISSÃO DE CONSTITUIÇÃO E JUSTIÇA E DE REDAÇÃO (CD), RUBEM MEDINA, 1993...... 286

PARECER DA COMISSÃO DE RELAÇÕES EXTERIORES E DEFESA NACIONAL (n. 84 - SF), PEDRO SIMON, 1995 ….......................................... 286 PARECER DA COMISSÃO DE RELAÇÕES EXTERIORES (SF), JARBAS PASSARINHO, 1994 286

6. ANÁLISE: CONVENÇÃO SOBRE A NACIONALIDADE DA MULHER CASADA 288 
MENSAGEM DO PODER EXECUTIVO (MSC 149/1966) ............................. 289

PARECER COMISSÃO DE RELAÇÕES EXTERIORES (CD), LUIZ FRANSCICO, 1967 289

PARECER DA COMISSÃO DE CONSTITUIÇÃO E JUSTIÇA (CD), NELSON CARNEIRO, 1967. 290

VOTOS EM SEPARADO, DJALMA MARINHO E PEDROSO HORTA .......... 291

EMENDA DO SENADO AO PROJETO DA CÂMARA DOS DEPUTADOS, 1967 291

PARECER DA COMISSÃO DE RELAÇÕES EXTERIORES (n. 470 - SF), JOSÉ

LEITE, 1967 292

PARECER DA COMISSÃO DE CONSTITUIÇÃO E JUSTIÇA (n. 471 - SF),

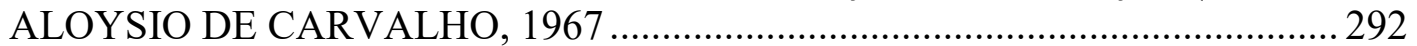

PARECER DA COMISSÃO DE LEGISLAÇÃO SOCIAL (n. 472 - SF), JÚLIO LEITE, 1967 293

PARECER DA COMISSÃO DE REDAÇÃO (n. 659 - SF), BEZERRA NETO, 1967 294

PARECER DA COMISSÃO DE RELAÇÕES EXTERIORES (CD) A RESPEITO DA EMENDA DO SENADO AO PDC 306/1967 294

PARECER DA COMISSÃO DE CONSTITUIÇÃO E JUSTIÇA (CD), WILSON MARTINS, 1967 295

7. ANÁLISE: CONVENÇÃO CONCERNENTE À ABOLIÇÃO DO TRABALHO

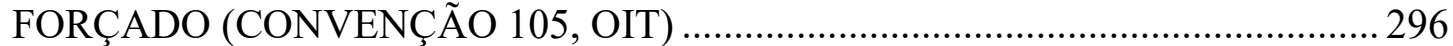

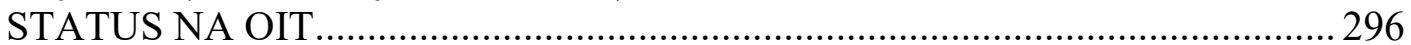

PARECER DA COMISSÃO PERMANENTE DE DIREITO SOCIAL DO MINISTÉRIO DO TRABALHO E PREVIDÊNCIA SOCIAL (n. 7), EVARISTO DE

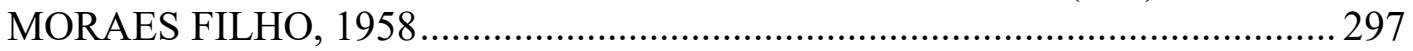

MENSAGEM DO PODER EXECUTIVO (MSC 143/1958) …............................2 297

PARECER DA COMISSÃO DE CONSTITUIÇÃO E JUSTIÇA (CD), NELSON

CARNEIRO, 1964. 298

PARECER DA COMISSÃO DE RELAÇÕES EXTERIORES (CD), EWALDO PINTO, 1964 298

PARECER DA COMISSÃO DE LEGISLAÇÃO SOCIAL (CD), GEREMIAS FONTES, 1964 298

PARECER DA COMISSÃO DE CONSTITUIÇÃO E JUSTIÇA (n. 350 - SF), JEFFERSON DE AGUIAR, 1964 299

MANIFESTAÇÃO DO MINISTÉRIO DAS RELAÇÕES EXTERIORES, VASCO LEITÃO DA CUNHA, 1965. 299 PARECER DO MINISTÉRIO DA JUSTIÇA E ASSUNTOS INTERIORES, ALOÍSIO ADJUCTO SILVEIRA,1965. 299 PARECER DA COMISSÃO DE RELAÇÕES EXTERIORES (n. 351 - SF), ANTONIO CARLOS, 1965 300 PARECER DA COMISSÃO DE LEGISLAÇÃO SOCIAL (n. 352 - SF), VIVALDO LIMA, 1965 300

8. ANÁLISE: CONVENÇÃO PARA A REDUÇÃO DOS CASOS DE APATRIDIA 301

STATUS NA ONU 302 
PARECER DE BRUNO FERRAZ COUTINHO, CONSULTORIA JURÍDICA DA SECRETARIA DE ESTADO DAS RELAÇÕES EXTERIORES, SEM DATA. 302 MENSAGEM DO PODER EXECUTIVO (MSC 370/2001). 303

PARECER COMISSÃO DE RELAÇÕES EXTERIORES E DE DEFESA NACIONAL (CD), JOSÉ LOURENÇO, 2002 305

PARECER COMISSÃO DE CONSTITUIÇÃO E JUSTIÇA E DE REDAÇÃO (CD), ALOYSIO NUNES FERREIRA, 2003. 305

PARECER DA COMISSÃO DE CONSTITUIÇÃO E JUSTIÇA E DE REDAÇÃO (CD), CARLOS SAMPAIO, 2003 306 PARECER DA COMISSÃO DE RELAÇÕES EXTERIORES E DEFESA NACIONAL (SF), ROMEU TUMA, 2007. 306 9. ANÁLISE: CONVENÇÃO INTERNACIONAL SOBRE A ELIMINAÇÃO DE TODAS AS FORMAS DE DISCRIMINAÇÃO RACIAL 308

9.1. PROJETOS DA CÂMARA E DO SENADO PARA A APROVAÇÃO DE DECLARAÇÃO FACULTATIVA À CONVENÇÃO. 312 MENSAGEM DO PODER EXECUTIVO (MSC 1309/2000) 313 PARECER DO CONSULTOR JURÍDICO DA SECRETARIA DE ESTADO DAS RELAÇÕES EXTERIORES, ANTONIO CACHAPUZ DE MEDEIROS, 2000314 PARECER DA COMISSÃO DE RELAÇÕES EXTERIORES E DE DEFSA NACIONAL (CD), FERNANDO GABEIRA, 2001 314 RELATÓRIO COMISSÃO DE CONSTITUIÇÃO E JUSTIÇA E DE REDAÇÃO (CD), REGINALDO GERMANO, 2001 315 PARECER DA COMISSÃO DE RELAÇÕES EXTERIORES E DEFESA NACIONAL (n. 81 - SF), GERALDO CÂNDIDO, 2002. 315

10. ANÁLISE: PACTO INTERNACIONAL SOBRE DIREITOS CIVIS E POLÍTICOS E 316

11. ANÁLISE: PACTO INTERNACIONAL SOBRE DIREITOS ECONÔMICOS, SOCIAIS E CULTURAIS 316

PARECER DO CONSULTOR JURÍDICO DO ITAMARATY, HAROLDO VALLADÃO, SOBRE A ASSINATURA DOS PACTOS, 1968 317 10.1. ANÁLISE: PROTOCOLO FACULTATIVO AO PACTO INTERNACIONAL SOBRE DIREITOS CIVIS E POLÍTICOS, E SEGUNDO PROTOCOLO FACULTATIVO AO PACTO INTERNACIONAL SOBRE DIREITOS CIVIS E POLÍTICOS, COM VISTAS À ABOLIÇÃO DA PENA DE MORTE .... 324 PARECER DA COMISSÃO DE CONSTITUIÇÃO E JUSTIÇA E DE CIDADANIA (CD), BOSCO COSTA, 2006 327 PARECER DA COMISSÃO DE DIREITOS HUMANOS E MINORIAS (CD), LUIZ COUTO, 2006 328 PARECER COMISSÃO DE RELAÇÕES EXTERIORES E DEFESA NACIONAL (SF), ANTONIO CARLOS VALADARES, 2009. 329

12. ANÁLISE: CONVENÇÃO SOBRE A PREVENÇÃO E PUNIÇÃO DE CRIMES CONTRA PESSOAS QUE GOZAM DE PROTEÇÃO INTERNACIONAL, INCLUINDO AGENTES DIPLOMÁTICOS. 331 STATUS NA ONU.

PARECER DA CONSULTORIA JURÍDICA DO ITAMARATY, ANTONIO AUGUSTO CANÇADO TRINDADE, 1988 
PARECER DA COMISSÃO DE RELAÇÕES EXTERIORES E DE DEFESA NACIONAL (CD), AROLDO CEDRAZ, 1998 334

PARECER DO RELATOR DESIGNADO PELA MESA - EM SUBSTITUIÇÃO À COMISSÃO DE CONSTITUIÇÃO E JUSTIÇA E DE REDAÇÃO (CD), ALOYSIO NUNES FERREIRA, 1998 334

PARECER DA COMISSÃO DE RELAÇÕES EXTERIORES E DE DEFESA NACIONAL (n. 117 - SF), AGRIPINO MAIA, 1999 334

13. ANÁLISE: CONVENÇÃO SOBRE A ELIMINAÇÃO DE TODAS AS FORMAS DE DISCRIMINAÇÃO CONTRA A MULHER 336

PARECER DA COMISSÃO DE COMISSÃO DE RELAÇÕES EXTERIORES (CD), DIOGO NOMURA, 1982 340

PARECER DA COMISSÃO DE COMISSÃO DE CONSTITUIÇÃO E JUSTIÇA (CD), GOMES DA SILVA, 1982. 340

PARECER DA COMISSÃO DE RELAÇÕES EXTERIORES (n. 911 - SF), OCTAVIO CARDOSO, 1983 341

PARECER DA COMISSÃO DE CONSTITUIÇÃO E JUSTIÇA (n.912 - SF), HERVIIDIO NUNES, 1983 341

13.1. RETIRADA DAS RESERVAS À CONVENÇÃO ................................ 342

13.2. PROTOCOLO FACULTATIVO À CONVENÇÃO SOBRE A ELIMINAÇÃO DE TODAS AS FORMAS DE DISCRIMINAÇÃO CONTRA A MULHER 346

DISCUSSÃO EM PLENÁRIO, JUNHO DE 2002 E AUDIÊNCIA PÚBLICA.. 353

14. ANÁLISE: CONVENÇÃO CONTRA A TORTURA E OUTROS TRATAMENTOS OU PENAS CRUÉIS, DESUMANOS OU DEGRADANTES 359

14.1. ANÁLISE: PROTOCOLO FACULTATIVO À CONVENÇÃO. 363

14.2. DECLARAÇÃO FACULTATIVA DO ARTIGO 22 DA CONVENÇÃO. 369 15. ANÁLISE: CONVENÇÃO 169 DA ORGANIZAÇÃO INTERNACIONAL DO TRABALHO SOBRE POVOS INDÍGENAS E TRIBAIS 374 MENSAGEM DO PODER EXECUTIVO (MSC 327/1991) …............................. 375 PARECER DA COMISSÃO DE RELAÇÕES EXTERIORES (CD), LUIZ GUSHIKEN, 1993. 375

PARECER DA COMISSÃO DE DEFESA DO CONSUMIDOR, MEIO AMBIENTE E MINORIAS (CD), FÁBIO FELDMANN, 1993 377 PARECER DA COMISSÃO DE CONSTITUIÇÃO E JUSTIÇA (CD), ÁTILA LINS, 1993 378

PARECER DA COMISSÃO DE RELAÇÕES EXTERIORES E DEFESA NACIONAL (n. 603 - SF), JARBAS PASSARINHO, 1994 .............................. 378 PARECER DA COMISSÃO DE CONSTITUIÇÃO E JUSTIÇA (n. 604 - SF), ROMERO JUCÁ, 1995 380 PARECER DA COMISSÃO DE RELAÇÕES EXTERIORES E DEFESA NACIONAL (SF), BERNARDO CABRAL, 1999. 380 VOTO EM SEPARADO, SENADORA BENEDITA DA SILVA, 1997 .............. 381 VOTO EM SEPARADO, ARTUR DA TÁVOLA, MENCIONADO PELOS PARECERES DOS SENADORES TIÃO VIANA E ROMEU TUMA................. 382 PARECER DA COMISSÃO DE RELAÇÕES EXTERIORES (n. 1.315 - SF), TIÃO VIANA, 1999 384 
PARECER DA COMISSÃO DE CONSTITUIÇÃO, JUSTIÇA E CIDADANIA (n.

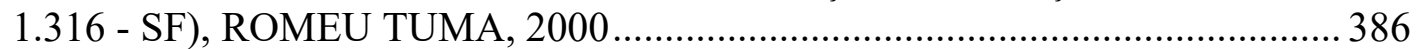

DISCUSSẪ EM PLENÁRIO, DSF 20.06.2002 ……………............................. 387

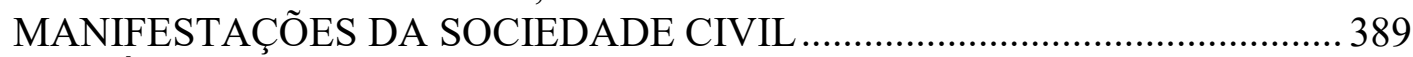

16. ANÁLISE: CONVENÇÃO SOBRE O DIREITO DAS CRIANÇAS ….............390

16.1. e 16.2. ANÁLISE: PROTOCOLOS FACULTATIVOS À CONVENÇÃO 393

17. ANÁLISE: CONVENÇÃO INTERNACIONAL SOBRE A PROTEÇÃO DOS DIREITOS DE TODOS OS TRABALHADORES MIGRANTES E DOS MEMBROS

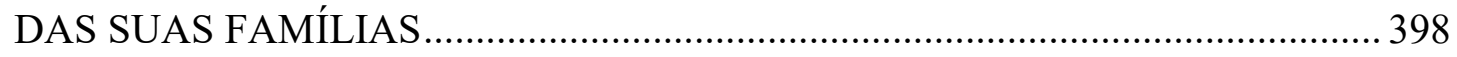

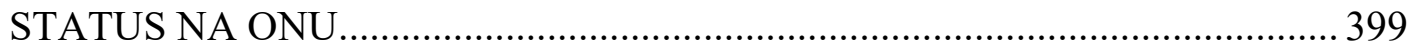

MENSAGEM DO PODER EXECUTIVO (MSC 696/2010) ………………….... 399

REQUERIMENTO DA COMISSÃO DE RELAÇÕES EXTERIORES E DE DEFESA

NACIONAL (n. 1826 - CD), CARLOS ALBERTO LERÉIA, 2011 .................... 400

ATOS DA PRESIDÊNCIA DA CÂMARA DOS DEPUTADOS ........................... 401

18. ANÁLISE: TRATADO DE ROMA DO TRIBUNAL PENAL INTERNACIONAL 402

18.1. ACORDO DE IMUNIDADES E PRIVILÉGIOS DO TPI ..................... 414 19. ANÁLISE: CONVENÇÃO DAS NAÇÕES UNIDAS CONTRA O CRIME

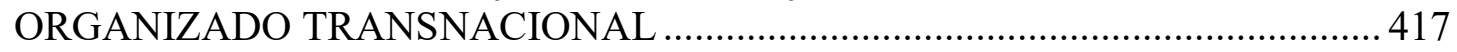

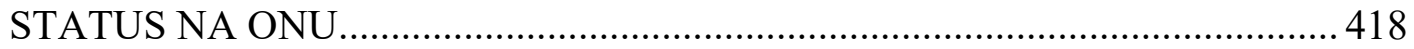

MENSAGEM DO PODER EXECUTIVO (MSC 48/2002) ……………………... 418

REQUERIMENTO DE URGÊNCIA.................................................................419

PARECER DO RELATOR DESIGNADO PELA MESA EM SUBSTITUIÇÃO À COMISSÃO DE RELAÇÕES EXTERIORES E DE DEFESA NACIONAL ..... 419

PARECER DA COMISSÃO DE RELAÇÕES EXTERIORES (n. 484 - SF), PATRÍCIA SABOYA GOMES, 2003 ..............................................................4 420

MANIFESTAÇÃO EM PLENÁRIO NO SENADO FEDERAL ........................... 420

20. ANÁLISE: CONVENÇÃO SOBRE OS DIREITOS DAS PESSOAS COM

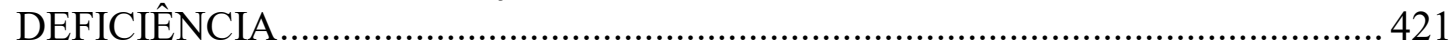

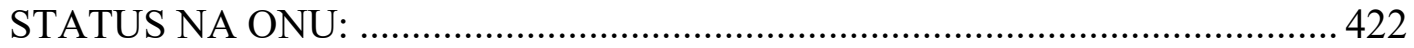

MENSAGEM DO PODER EXECUTIVO (MSC 711/2007) …………………. 422

MANIFESTO AO CONGRESSO NACIONAL DO CONSELHO NACIONAL DOS

DIREITOS DA PESSOA PORTADORA DE DEFICIÊNCIA, 10.08.2007 ........ 423

REQUERIMENTO DE URGÊNCIA, CD, 09.05.2008 ……............................... 423

DISCUSSÃO EM PRIMEIRO TURNO NA CÂMARA DOS DEPUTADOS:

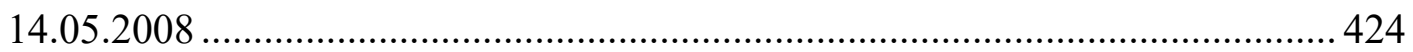

PARECER DA COMISSÃO ESPECIAL (CD) SOBRE A MSC 711/2007, EDUARDO

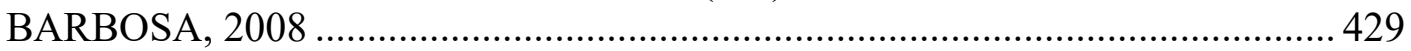

DISCUSSÃO EM SEGUNDO TURNO NA CÂMARA DOS DEPUTADOS:

29.05.2008 431

DECLARAÇÃO DE VOTO DOS DEPUTADOS GUSTAVO FRUET E BRUNO ARAÚJO, DCD 29.05.2008 ……………………………………………... 431

PARECER DA COMISSÃO DE RELAÇÕES EXTERIORES E DE DEFESA NACIONAL (n. 587 - SF), EDUARDO AZEREDO, 2008.

DISCUSSÃO EM PRIMEIRO TURNO NO SENADO FEDERAL: DSF 03.07.2008

REQUERIMENTO n. 854 (SF) - DISPENSA DE INTERSTÍCIO 434 
DISCUSSÃO EM SEGUNDO TURNO NO SENADO FEDERAL: DSF 03.07.2008 434

21. ANÁLISE: CONVENÇÃO INTERNACIONAL PARA A PROTEÇÃO DE TODAS AS PESSOAS CONTRA O DESAPARECIMENTO FORÇADO ........................... 435

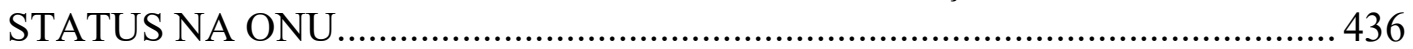

MENSAGEM PRESIDENCIAL ................................................................... 436

PARECER DA COMISSÃO DE DIREITOS HUMANOS E MINORIAS (CD),

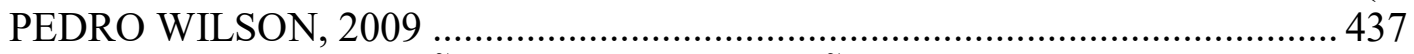

PARECER DA COMSSÃO DE CONSTITUIÇÃO E JUSTIÇA E DE CIDADANIA (CD), LUIZ COUTO, 2009 437

PARECER DA COMISSÃO DE RELAÇÕES EXTERIORES E DE DEFESA NACIONAL (CD), ÍRIS DE ARAÚJO, 2009 438

PARECER DA COMISSÃO DE RELAÇÕES EXTERIORES E DEFESA NACIONAL (n. 1322 - SF), PAULO PAIM, 2010 438

22. ANÁLISE: CONVENÇÃO AMERICANA SOBRE DIREITOS HUMANOS PACTO DE SÃO JOSÉ DA COSTA RICA 440

22.1. e 22.2. PROTOCOLOS ADICIONAIS À CONVENÇÃO AMERICANA SOBRE DIREITOS HUMANOS: (I) PROTOCOLO EM MATÉRIA DE DIREITOS ECONÔMICOS, SOCIAIS E CULTURAIS - PROTOCOLO DE SÃO SALVADOR E (II) PROTOCOLO REFERENTE À ABOLIÇÃO DA PENA DE MORTE ........ 452 22.2. ANÁLISE: DECLARAÇÃO SOBRE A COMPETÊNCIA OBRIGATÓRIA DA CORTE INTERNACIONAL DE DIREITOS HUMANOS ...........................458 23. ANÁLISE: CONVENÇÃO INTERAMERICANA PARA PREVENIR E PUNIR TORTURA. 463

STATUS NA OEA 463

MENSAGEM DO PODER EXECUTIVO (MSC 235/1986) 463

PARECER DA COMISSÃO DE RELAÇÕES EXTERIORES (CD), JOSÉ TAVARES, 1988 464 PARECER DA COMISSÃO DE RELAÇÕES EXTERIORES (CD), AMAURY MÜLLER, 1986. 464

PARECER DA COMISSÃO DE RELAÇÕES EXTERIORES (n. 17 - SF), ITAMAR FRANCO, 1989 464

24. ANÁLISE: CONVENÇÃO INTERAMERICANA PARA PREVENIR, PUNIR E ERRADICAR A VIOLENNCIA CONTRA A MULHER. 466

STATUS NA OEA 466

MENSAGEM DO PODER EXECUTIVO (MSC 95/1995) 466

PARECER DA COMISSÃO DE RELAÇÕES EXTERIORES (CD), SANDRA STARLING, 1995 467

PARECER DA COMISSÃO DE CONSTITUIÇÃO E JUSTIÇA E DE REDAÇÃO (CD), RÉGIS DE OLIVEIRA, 1995 469 PARECER DA COMISSÃO DE SEGURIDADE SOCIAL E FAMÍLIA (CD),

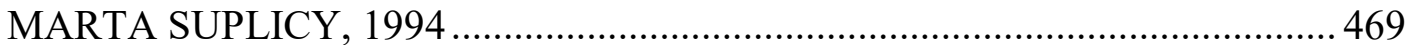
REQUERIMENTOS DE URGÊNCIA 470 PARECER DA COMISSÃO DE RELAÇÕES EXTERIROES E DEFESA NACIONAL (SF), BENEDITA DA SILVA, 1995. 470 25. ANÁLISE: CONVENÇÃO INTERAMERICANA SOBRE DESAPARECIMENTO FORÇADO DE PESSOAS 472 


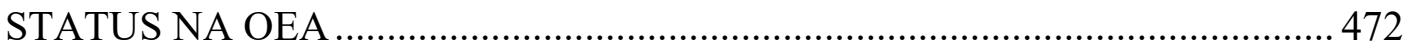

MENSAGEM DO PODER EXECUTIVO (MSC 1.204/1994) …........................ 472

PARECER DA COMISSÃO DE RELAÇÕES EXTERIORES (CD), HAROLDO

LIMA, 1995 473

PARECER DA COMISSÃO DE CONSTITUIÇÃO E JUSTIÇA E DE REDAÇÃO

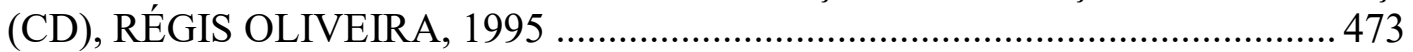

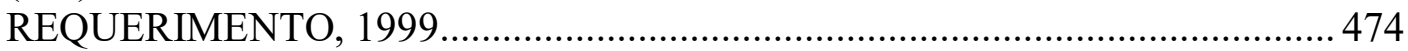

PARECER DA COMISSÃO DE RELAÇÕES EXTERIORES E DEFESA

NACIONAL (SF), ROMEU TUMA, 2009 474

PARECER DA COMISSÃO DE RELAÇÕES EXTERIORES E DEFESA

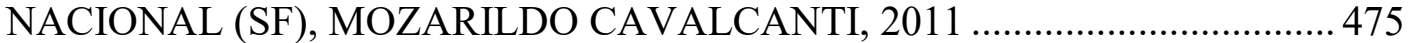

DISCUSSÃO, PLENÁRIO DO SENADO FEDERAL ....................................... 476

26. ANÁLISE: CONVENÇÃO INTERAMERICANA SOBRE TRÁFICO

INTERNACIONAL DE MENORES............................................................... 477

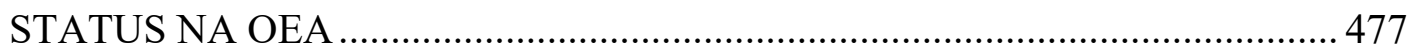

MENSAGEM DO PODER EXECUTIVO (MSC 94/1995) …............................4 478

PARECER DA COMISSÃO DE RELAÇÕES EXTERIORES (CD), RENAN KURTZ,

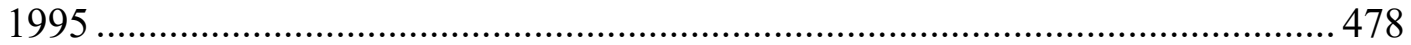

PARECER DA COMISSÃO DE SEGURIDADE SOCIAL E FAMÍLIA (CD), RITA

CAMATA, 1995 479

PARECER DA COMISSÃO DE CONSTITUIÇÃO E JUSTIÇA E DE REDAÇÃO, (CD), RÉGIS DE OLIVEIRA, 1995 480

PARECER DA COMISSÃO DE CONSTITUIÇÃO E JUSTIÇA SOBRE EMENDA OFERECIDA EM PLENÁRIO AO PDC 90/1995, NELSON TRAD (AUTOR) E HÉLIO BICUDO (RELATOR). 480

COMISSÃO DE RELAÇÕES EXTERIORES, RELATÓRIO A RESPEITO DA

EMENDA OFERECIDA, MÁRIO CAVALAZZI, 1996 481

PARECER DA COMISSÃO DE RELAÇÕES EXTERIORES E DEFESA

NACIONAL (n. 547 - SF), PEDRO SIMON, 1996 482

27. ANÁLISE: CONVENÇÃO INTERAMERICANA PARA A ELIMINAÇÃO DE TODAS AS FORMAS DE DISCRIMINAÇÃO CONTRA AS PESSOAS PORTADORAS DE DEFICIÊNCIA ............................................................. 483

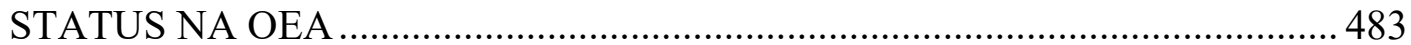

MENSAGEM DO PODER EXECUTIVO (MSC 1.545/1999) …......................... 483

PARECER DA COMISSÃO DE RELAÇÕES EXTERIORES E DEFESA

NACIONAL (CD), CLÓVIS VOLPI, 2000 484

PARECER DA COMISSÃO DE SEGURIDADE SOCIAL E FAMÍLIA (CD),

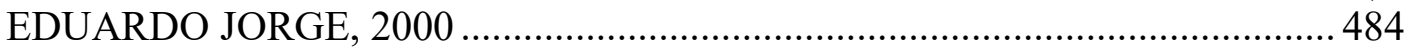

PARECER DA COMISSÃO DE CONSTITUIÇÃO E JUSTIÇA E DE REDAÇÃO

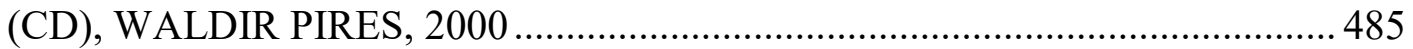
DISCUSSÃO EM PLENÁRIO NA CÂMARA DOS DEPUTADOS, DCD 22.02.2001 486

PARECER DA COMISSÃO DE RELAÇÕES EXTERIORES E DEFESA NACIONAL (n. 484 - SF), ROMEU TUMA, 2001 487

DISCUSSÃO EM PLENÁRIO, DSF 13.06.2001 488

28. ANÁLISE: PROTOCOLO DE ASSUNÇÃO SOBRE COMPROMISSO COM A PROMOÇÃO E PROTEÇÃO DOS DIREITOS HUMANOS DO MERCOSUL ... 489 
STATUS NO MERCOSUL 489

MENSAGEM DO PODER EXECUTIVO (MSC 897/2006).... 490

PARECER DA COMISSÃO PARLAMENTAR CONJUNTA DO MERCOSUL REPRESENTAÇÃO BRASILEIRA, 2008 490

PARECER DA COMISSÃO DE RELAÇÕES EXTERIORES E DEFESA NACIONAL (CD), ANTONIO CARLOS MENDES THAME, 2008 490

PARECER DA COMISSÃO DE DIREITOS HUMANOS E MINORIAS (CD), GERALDO THADEU, 2008. 491

PARECER DA COMISSÃO DE CONSTITUIÇÃO E JUSTIÇA E DE CIDADANIA (CD), CEZAR SCHIRMER, 2008

PARECER DA COMISSÃO DE RELAÇÕES EXTERIORES E DEFESA

NACIONAL (n. 1.301 - SF), EFRAIM MORAIS, 2009 491

29. CONVENÇÃO INTERAMERICANA CONTRA O RACISMO, A DISCRIMINAÇÃO RACIAL E FORMAS CORRELATAS DE INTOLERÂNCIA493 30. CONVENÇÃO INTERAMERICANA CONTRA TODA FORMA DE DISCRIMINAÇÃO E INTOLERÂNCIA 493

31. ANÁLISE: CONVENÇÃO DE VIENA SOBRE DIREITO DOS TRATADOS494

STATUS NA ONU 495

MENSAGEM DO PODER EXECUTIVO (MSC 116/1992) 495

CONSULTA 7-A, PRESIDÊNCIA DA CÂMARA, 1993 496

PARECER DA COMISSÃO DE RELAÇÕES EXTERIORES (CD), ANTONIO CARLOS MENDES THAME, 1992 497

PARECER DA COMISSÃO DE CONSTITUÇÃO E JUSTIÇA E DE REDAÇÃO (CD), JESUS TAJRA, 1993 499

PARECER DA COMISSÃO DE CONSTITUIÇÃO, JUSTIÇA E REDAÇÃO (CD), JOSÉ THOMAZ NONÔ, 1993 499

PARECER DA COMISSÃO DE CONSTITUIÇÃO E JUSTIÇA E DE REDAÇÃO (CD), EDINHO ARAÚJO, 1995 501

PARECER REFORMULADO DA COMISSÃO DE CONSTITUIÇÃO E JUSTIÇA E DE REDAÇÃO (CD), EDINHO ARAÚJO, 1995 501

DECLARAÇ̃̃O DE VOTO DO DEPUTADO RÉGIS DE OLIVEIRA, 1995 ... 502 DECLARAÇÃO DE VOTO DO DEPUTADO VICENTE ARRUDA, 1995 .......504 PARECER DA COMISSÃO DE RELAÇÕES EXTERIORES (CD), PEDRO VALADARES, 1995 504

PARECER COMISSÃO DE RELAÇÕES EXTERIORES E DEFESA NACIONAL (n. 1.026 - SF), CRISTOVAM BUARQUE, 2009 506 


\section{ANÁlise: CONVENÇÃo PARA A PREVENÇÃo E A REPRESSÃo do CRIME DE GENOCÍDIO}

A Convenção para a prevenção e a repressão do crime de Genocídio, de 09.12.1948, entrou em vigor internacional 12.01.1951, de acordo com as disposições do artigo XIII. Essa Convenção foi assinada pelo plenipotenciário brasileiro em 11.12.1948, e ratificada em 15.04.1952, entrando em vigor para o Brasil em 15.07.1952 (art. XIII.3). Foi enviada ao Congresso Nacional por intermédio da Mensagem Presidencial 450, de 05.09.1950. Seu processo de aprovação tramitou na Câmara dos Deputados como Projeto de Lei 633, de autoria da Comissão de Diplomacia (COMDIP), e no Senado Federal como Projeto de Decreto Legislativo 36, de 13.11.1950. ${ }^{1}$ Foi aprovada pelo Decreto Legislativo 02, de 11.04.1951, e promulgada pelo Decreto Presidencial 30.822, de 06.05.1952.

A Convenção é instrumento paradigmático na história do Direito Internacional Público, por ser o primeiro tratado de Direitos Humanos adotado pela AGNU, no contexto do pós II Guerra Mundial. Seu foco é a proteção de minorias nacionais, raciais, étnicas e religiosas contra ameaças à sua integridade e existência. A Convenção também destaca a função da justiça internacional criminal e a necessidade de responsabilização (“accountability") na proteção e na promoção dos Direitos Humanos. ${ }^{2}$

\section{STATUS NA ONU}

https://treaties.un.org/Pages/ViewDetails.aspx?src=UNTSONLINE\&tabid=2\&mtdsg_no $=\mathrm{IV}-1 \&$ chapter $=4 \&$ lang=en\#Participants

\section{MENSAGEM DO PODER EXECUTIVO (MSC 450/1949)}

A Mensagem do Poder Executivo concernente ao envio da Convenção data de 05.09.1950 (MSC 450/1949), assinada pelo Ministro das Relações Exteriores, senhor Raul

\footnotetext{
${ }^{1}$ No caso desta Convenção, o Senado envia à Câmara a Mensagem Presidencial, conforme explicitado no Parecer da Comissão de Constituição e Justiça, de 20.07.1950.

${ }^{2}$ Informação disponível em: http://legal.un.org/avl/ha/cppcg/cppcg.html. Acesso: 01.03.2016.
} 
Fernandes,${ }^{3}$ foi enviada pelo Presidente Eurico Gaspar Dutra ao Congresso em 17.09.1950. O Ministro destaca que, na Convenção, as partes contratantes assumem o compromisso de prevenir e de punir o genocídio, qualificando-o como crime contra o Direito Internacional. Segundo Fernandes, a Convenção não apresentaria incompatibilidade com a legislação brasileira, acrescentando que poderia ser identificada com o homicídio qualificado, se adotada interpretação mais ampla do art. 121, $\S 2^{\circ}$, I e III do Código Penal (CP) (DBR - F). ${ }^{4}$ Ainda segundo o Ministro, o objeto da Convenção encontraria sustentação na Constituição nacional (Constituição de 1946) (DBR - F), que assegura a liberdade religiosa (art.141, $\S 7^{\circ}$ e $\left.8^{\circ}\right)^{5}$ e condena o preconceito racial, vedando sua propaganda (art.141, $\left.\S 5^{\circ}\right){ }^{6} \mathrm{~A}$ Constituição, ademais, vedava a distinção de salário para o mesmo trabalho, por motivo de nacionalidade (art.157, II). ${ }^{7}$ O Ministro justifica, ainda, a aplicabilidade da Convenção no âmbito nacional, pois o Código Penal brasileiro sujeita à lei nacional os crimes cometidos no exterior que, por tratado ou convenção, o Brasil obrigou-se a reprimir $\left(\operatorname{art} .5^{\circ}\right.$, II, a). ${ }^{8}$

\footnotetext{
${ }^{3}$ Raul Fernandes foi chanceler do Presidente Eurico Gaspar Dutra de 12.12 .1946 a 31.01.1951. Seria chanceler novamente, de 26.08.1954 a 11.11.1955, do Presidente Café Filho.

${ }^{4}$ Art. 121. Matar alguém: (...) Homicídio qualificado

$\S 2^{\circ}$ Se o homicídio é cometido:

I - mediante paga ou promessa de recompensa, ou por outro motivo torpe;

III - com emprego de veneno, fogo, explosivo, asfixia, tortura ou outro meio insidioso ou cruel, ou de que possa resultar perigo comum;

${ }^{5}$ Art. 141 - A Constituição assegura aos brasileiros e aos estrangeiros residentes no País a inviolabilidade dos direitos concernentes à vida, à liberdade, a segurança individual e à propriedade, nos termos seguintes:

$\S 7^{\circ}$ - É inviolável a liberdade de consciência e de crença e assegurado o livre exercício dos cultos religiosos, salvo o dos que contrariem a ordem pública ou os bons costumes. As associações religiosas adquirirão personalidade jurídica na forma da lei civil.

$\S 8^{\circ}$ - Por motivo de convicção religiosa, filosófica ou política, ninguém será privado de nenhum dos seus direitos, salvo se a invocar para se eximir de obrigação, encargo ou serviço impostos pela lei aos brasileiros em geral, ou recusar os que ela estabelecer em substituição daqueles deveres, a fim de atender escusa de consciência.

${ }^{6}$ Art. 141 - A Constituição assegura aos brasileiros e aos estrangeiros residentes no País a inviolabilidade dos direitos concernentes à vida, à liberdade, a segurança individual e à propriedade, nos termos seguintes:

$\S 5^{\circ}$ - É livre a manifestação do pensamento, sem que dependa de censura, salvo quanto a espetáculos e diversões públicas, respondendo cada um, nos casos e na forma que a lei preceituar pelos abusos que cometer. Não é permitido o anonimato. É assegurado o direito de resposta. A publicação de livros e periódicos não dependerá de licença do Poder Público. Não será, porém, tolerada propaganda de guerra, de processos violentos para subverter a ordem política e social, ou de preconceitos de raça ou de classe.

${ }^{7}$ Art. 157 - A legislação do trabalho e a da previdência social obedecerão nos seguintes preceitos, além de outros que visem a melhoria da condição dos trabalhadores:

II - proibição de diferença de salário para um mesmo trabalho por motivo de idade, sexo, nacionalidade ou estado civil;

${ }^{8}$ Art. $5^{\circ}$ Ficam sujeitos à lei brasileira, embora cometidos no estrangeiro:

II - os crimes:
} 
Conforme o exposto, o Ministro aponta que o tratado merece a aprovação por parte do Legislativo, conforme o disposto no art.66, I, da Constituição de $1946 .{ }^{9}$

Foram utilizados, na MSC 450/1949, basicamente argumentos de direito interno para a aprovação do tratado em pauta. Como foram mencionadas, apenas, duas normas, contabilizou-se como dois argumentos de Direito Brasileiro.

\section{PARECER DA COMISSÃO DE DIPLOMACIA (CD), VARGAS NETO, 1949}

[Câmara - Parecer 1]

O parecer de Vargas Neto, de 06.10.1949, é relativo, particularmente, ao crime de genocídio, e se inicia com uma menção ao apelo grego ao Brasil, em virtude do "plano de genocídio, praticado sistematicamente por grupos guerrilheiros, em atos de violência armada" no país, que faria parte de um plano dos países da esfera de influência da União das Repúblicas Socialistas Soviéticas (URSS) (PEB - F). É necessário lembrar que se trata de momento histórico de início da Guerra Fria.

No presente momento de evolução do cenário internacional, diz o relator, não é simples construir mecanismo eficiente de repressão dos crimes contra a humanidade que, praticados em tempo de guerra, continuam sendo cometidos em momentos de paz (PEB F). A Convenção, porém, seria instrumento pioneiro nesse sentido, ao declarar o genocídio um crime contra a humanidade e fazer as partes contratantes assumirem um compromisso de tomar medidas legislativas necessárias para estabelecer sanções penais eficazes nesse sentido (DIN - F).

O relator aponta para o surgimento da tipificação do genocídio como crime em virtude de uma criação acadêmica, do professor Raphael Lemkin, consultor da ONU. ${ }^{10}$ Segundo o relator, o genocídio é um crime que, coletivo, congrega diversos crimes individuais, e que seu rechaço deve ser feito em virtude de sua perversidade e monstruosidade. Diz, ainda, que "a dificuldade em aplicar as sanções não reside nas dúvidas para caracterizar os crimes [de genocídio], mas na força dos criminosos". O relator, até esse ponto, utiliza, basicamente,

a) que, por tratado ou convenção, o Brasil se obrigou a reprimir;

9 Art. 66 - É da competência exclusiva do Congresso Nacional:

I - resolver definitivamente sobre os tratados e convenções celebradas com os Estados estrangeiros pelo Presidente da República; (...)

${ }^{10}$ O termo "genocídio" foi usado, pela primeira vez, por Raphael Lemkin, no livro "Axis Rule in Occupied Europe", publicado em 1944. Informação obtida em: http://legal.un.org/avl/ha/cppcg/cppcg.html. Acesso: 02.03.2016. 
argumentos relacionados aos Direitos Humanos e à matéria do tratado para justificar a assinatura do Tratado (DH - Genocídio - F).

O Deputado encerra seu argumento apontando que, como parlamentar e cidadão, esperava que a ONU lograsse manter o equilíbrio entre os direitos e as liberdades que visava a garantir, inclusive o "direito humano e divino de não ter medo que integra a mais profunda e a mais soberana das liberdades" (DH - F).

O parecer é aprovado sem debates.

\section{PARECER DA COMISSÃO DE DIPLOMACIA (CD), JOÃO HENRIQUE, 1950}

[Câmara - Parecer 2]

O Parecer da Comissão de Diplomacia foi elaborado por João Henrique, e data de 31.03.1950. Conforme o relator, o Brasil, por intermédio de seu representante (Gilberto Amado), ${ }^{11}$ foi parte relevante na discussão e na aceitação da "tese contrária ao genocídio" (PEB - F). Segundo ele, essa tese não só estaria de acordo com as leis nacionais (a Constituição e o Código Penal, particularmente (DBR - F), mas também com as “tradições brasileiras, com o espirito cristão de nossa gente e a tolerância humana de nosso povo" (PBR - F). Segundo o relator, a ratificação do tratado estaria em conformidade com os "sentimentos nacionais" (PBR - F).

Assim, o relator encerra sua argumentação pedindo a aprovação da Convenção. $\mathrm{O}$ parecer é aprovado sem debates.

\section{PARECER DA COMISSÃO DE CONSTITUIÇÃO E JUSTIÇA (CD), AFONSO ARINOS, 1950}

[Câmara - Parecer 3]

O relator, de 20.07.1950, Afonso Arinos, ${ }^{12}$ aponta ter o Senado enviado à Câmara, conforme disposição do art. 67.3 da Constituição, a Mensagem Presidencial. Após descrever o processo de elaboração da Convenção no âmbito da ONU, destaca que não é possível negar

\footnotetext{
${ }^{11}$ Gilberto Amado foi jornalista e diplomata, além de Deputado Federal pelo Sergipe entre 1915-1917 e 1921 1926; Senador pelo SE entre 1927-1930, embaixador do Brasil no Chile entre 1936-1937 e na Itália entre 19391942. Informação obtida em: http://cpdoc.fgv.br/sites/default/files/verbetes/primeirarepublica/AMADO,\%20Gilberto.pdf. Acesso: 02.03.2016.

12 Afonso Arinos seria, no futuro, o chanceler dos governos de Jânio Quadros (31.01.1961 a 25.08.1961) e de João Goulart (12.07.1962 a 18.09.1962).
} 
a oportunidade da definição do extermínio de grupos humanos, seja por motivos de raça, seja por motivos de religião ou de ideologia, considerando as "barbaridades de que ainda é pródiga a história contemporânea" (PEB - F). Aponta, enfim, para a constitucionalidade do projeto (DBR - F), anteriormente aprovado pela Comissão de Diplomacia.

O parecer é aprovado sem debates.

\section{PARECER DA COMISSÃO DE CONSTITUIÇÃO E JUSTIÇA (n.93 - SF), FERREIRA DE SOUZA, 1951}

[Senado - Parecer 1]

Após breve relato a respeito da Convenção, o Senador Ferreira de Souza, em parecer de 19.12.1950, aponta que o genocídio passaria, com a inovação deste instrumento internacional, a ser mais um crime definido pelo Direito Penal Internacional, como “(...) manifestação da inadaptabilidade social que interessa a todos os homens" (DIN - F). Não seria viável, para o Senador, confiar a tipificação desse crime aos legisladores nacionais, pois o tema, por sua natureza, apenas poderia ser enfrentado por leis de âmbito mais abrangente, "resultante de entendimentos entre os Estados soberanos" (PEB - F). O genocídio não é mero perigo interno, mas atenta contra o de mais alto existe no gênero humano, exteriorizando a periculosidade de grupos e de governos nacionais (PEB - F). Os homens, e todas as raças, têm o direito de conviver juntos na terra, e a pretensão de eliminar determinados grupos não é possível (DH - genocídio - F).

A Convenção seria um marco da etapa atual (daquele momento histórico) do Direito Internacional, com o escopo moderno de não restringir a disciplina às relações interestatais, mas ampliá-la para as nações, os homens e as raças. ${ }^{13}$ No caso particular do Brasil, a

\footnotetext{
${ }^{13}$ Um breve comentário a respeito da noção de raça, que, apesar de fugir ao escopo principal desta tese, é relevante. O Supremo Tribunal Federal brasileiro decidiu, no Habeas Corpus 82.424, no qual se discutia a possibilidade de aplicação do termo "raça", a publicação de indivíduo (Siegfried Ellwanger) que fora condenado pelo crime de antissemitismo; além de publicar, vender e distribuir material antissemita. $\mathrm{O}$ art. $5^{\circ}$, XLII, CF determina: "a prática do racismo constitui crime inafiançável e imprescritível". Os impetrantes, baseados na presunção de que judeus não podem ser considerados uma raça, alegaram que o delito de discriminação antissemita pelo qual Ellwanger fora condenado, não teria conotação racial. O Supremo decidiu em sentido contrário, alegando que "A construção da definição jurídico-constitucional do termo "racismo" requer a conjugação de fatores e circunstâncias históricas, políticas e sociais que regeram a sua formação e aplicação. $O$ crime de racismo constitui um atentado contra os princípios nos quais se erige e se organiza a sociedade humana, baseada na respeitabilidade e dignidade do ser humano e de sua pacifica convivência".
} 
Convenção traduz o sentimento de "amor ao semelhante e de caridade cristã que nos legaram os antepassados" (PBR - F). O Brasil, prossegue, não conheceria o racismo nem a eliminação de grupos humanos, tampouco admitindo o ódio racial - como ocorreria nos países da Europa (PBR - F). O embaixador Gilberto Amado, representante brasileiro na AGNU, foi um dos primeiros a pugnar pela necessidade de celebração da Convenção (PEB $-\mathrm{F})$.

A Convenção, deste modo, seria totalmente compatível com a Constituição Federal (DBR - F) e, por isso, deveria ser aprovada. O parecer é aprovado sem debates.

\section{PARECER DA COMISSÃO DE RELAÇÕES EXTERIORES (n.94 - SF), ARTHUR SANTOS, 1951}

[Senado - Parecer 2]

O Senador Arthur Santos, em parecer de 18.01.1951, aponta que, após ser apreciada na Câmara dos Deputados, a Mensagem Presidencial foi aprovada e votado projeto de decreto legislativo que aprovasse a Convenção.

O relator faz breve histórico da Convenção e apontou que as nações latino-americanas estavam na vanguarda da ideia de combater o genocídio, algo que se coaduna com os princípios de justiça internacional que informam sua organização política (PEB - F). Entre os principais defensores que repudiaram o genocídio, estavam os embaixadores Raul Fernandes, João Carlos Muniz e Gilberto Amado (PEB - F). Apesar da relevância da lei nacional para punir o genocídio, apenas a lei internacional poderia criar sanções jurídicas para proscrever esse delito (DIN - F).

A Convenção acrescentaria, ademais, a tipificação de genocídio aos crimes sujeitos, à época, à condenação internacional, quais sejam: o tráfego de brancas, o comércio de entorpecentes, a pirataria, a circulação de livros e de publicações obscenas e a falsificação de moedas (DIN - F).

Apesar de não ter sido previsto o estabelecimento de uma "Corte Penal Internacional", que ocorreria, apenas, em 1998, com a celebração do Estatuto de Roma, os compromissos

\footnotetext{
Isso parece particularmente relevante quando se apresenta a Convenção de genocídio, celebrada poucos anos depois dos crimes contra a humanidade cometidos no curso da II Guerra Mundial. Informações obtidas em: http://www2.stf.jus.br/portalStfInternacional/cms/verConte udo.php? sigla=portalStfJurisprudencia_pt_br\&idConteudo $=185077 \&$ modo $=$ cms. Aceso: 02.03.2016.
} 
estabelecidos pela Convenção, somados à atribuição da Corte de Haia para analisar a possibilidade de sua aplicação e a Carta da ONU, seriam subsídios relevantes para preservar os valores básicos da humanidade (DIN - F).

O Brasil, por suas "tradições cristãs", "formação moral de respeito à dignidade da pessoa humana" e por seu respeito ao Direito Internacional (PBR - F), não poderia deixar de ratificar esse instrumento internacional, "expressão de seus sentimentos e de sua vontade soberana" (PEB - F).

O parecer é aprovado sem debates. 


\section{ANÁliSE: CONVENÇÃo PARA A REPRESSÃo dO TRÁFICO DE PESSOAS E DO LENOCÍNIO}

A Convenção para a Repressão do Tráfico de Pessoas e do Lenocínio, de 21.03.1950, entrou em vigor internacional em 25.07.1951, conforme disposições de seu art. 24. Assinada pelo Brasil em 05.10.1951, teve seu instrumento de ratificação depositado em 12.09.1958. Foi enviada ao Congresso Nacional por intermédio da Mensagem Presidencial 41, de 1952. Seu processo de aprovação tramitou na Câmara dos Deputados como Projeto de Decreto Legislativo 29, de 1955, e no Senado Federal como Projeto de Decreto Legislativo 58, de 1955. Aprovada pelo Decreto Legislativo 6, de 1958 e promulgada pelo Decreto Presidencial 46.981, de 08.10.1959.

A Convenção começou a ser elaborada à época da Sociedade das Nações, na década de 1930, mas o início da II Guerra Mundial interrompeu os trabalhos para sua celebração, retomados no final da década de 1940. Nela, os Estados signatários concordam em criminalizar diversas categorias de incitação à prostituição, auxiliar a reabilitação de prostitutas e fiscalizar o tráfico de pessoas para fins de prostituição, além de assegurar a repatriação de estrangeiros. O protocolo final da Convenção adiciona que nada em seu texto deverá prejudicar qualquer legislação que assegure condições mais severas do que aquelas descritas no texto convencional. ${ }^{14}$

\section{STATUS NA ONU}

https://treaties.un.org/Pages/ViewDetails.aspx?src=IND\&mtdsg_no=VII-11a\&chapter $=7 \&$ lang $=$ en

\section{MENSAGEM DO PODER EXECUTIVO (MSC 41/1952)}

A Mensagem 41, de 12.02.1952, foi encaminhada ao Congresso pelo Presidente Getúlio Vargas em 14.02.1952, e assinada por seu chanceler, João Neves da Fontoura. Segundo o chanceler, encontram-se consolidadas na Convenção as principais disposições dos tratados internacionais que tratam do assunto (DIN - F), sendo que a Convenção inova

\footnotetext{
${ }^{14}$ Informações obtidas em: http://legal.un.org/avl/ha/uncstpepo/uncstpepo.html. Acesso: 02.03.2016. 
ao trazer a experiência no âmbito internacional para combater, de maneira agressiva, o combate à prostituição e ao tráfico de pessoas. Informa que a Convenção foi anteriormente submetida à apreciação do Ministério da Justiça e Negócios Interiores, que deu parecer favorável à sua aplicação no país (PBR - F), por não contrariar a legislação nacional (DBR - F). A prescrição da Convenção, que prevê a punição de quem favoreça a prostituição, seja praticando atos de aliciamento, seja "desencaminhando" alguém nesse sentido, é menos rigorosa do que a lei brasileira, que não apenas pune o aliciador, mas quem impede alguém de abandonar a atividade (DBR - F). Aponta, igualmente, que a prescrição da Convenção, que estatui a punição de quem fornece imóvel para a realização desta atividade, é inédita na legislação penal brasileira (DBR - F), e fornecerá às autoridades locais uma nova arma contra a prostituição (PBR - F).

A Convenção seria, igualmente, consistente com nossas prescrições constitucionais (DBR - F), ao equiparar estrangeiros e nacionais em caso de reparação do dano sofrido, e ao permitir que estrangeiro seja parte civil, por motivo de qualquer das infrações descritas, quando a legislação nacional reconhecer tal direito ao ofendido. Esse princípio (igualdade jurídica) é consagrado na Constituição (neste caso, a Carta de 1946).

A Convenção também estaria de acordo com as disposições sobre extradição e cartas rogatórias, por reconhecer aos Estados o direito de não extraditar seus nacionais (DBR - F). O Tratado de extradição celebrado entre Brasil e Uruguai, de 1948, possui disposição semelhante (DIN - F).

O chanceler aponta para a necessidade de aprovação da Convenção pelo Congresso.

\section{PARECER DA COMISSÃO DE DIPLOMACIA (CD), ALCIDES CARNEIRO, 1953} [Câmara - Parecer 1]

O parecer, de Alcides Carneiro, data de 11.12.1953. Explica o trâmite da Convenção até o momento, mencionando, entre outras coisas, que o Ministro da Justiça opinou favoravelmente à aceitação das disposições da Convenção pelo Brasil, que não contrariariam as normas constitucionais, nem a legislação penal em vigor (DBR - F). ${ }^{15}$ Sem apresentar argumentos novos, o parecer é pela aprovação do projeto de Decreto Legislativo.

\footnotetext{
${ }^{15} \mathrm{O}$ argumento foi mantido neste parecer pois a autora não teve acesso à manifestação do Ministro da Justiça mencionada.
} 
O parecer foi aprovado sem discussão.

\section{PARECER DE OSVALDO TRIGUEIRO (CD), 1955}

[Câmara - Parecer 2]

Osvaldo Trigueiro foi Deputado e embaixador do Brasil na Indonésia. ${ }^{16}$ À época em que exercia esta função, deu o parecer, de 01.09.1955. Segundo o diplomata, não há que se objetar à aprovação legislativa do ato em relação às disposições constitucionais, por coerência com os artigos 87, VII ${ }^{17}$ e 66 , I, da Constituição (DBR - F). ${ }^{18}$ A execução das obrigações previstas na Convenção, ademais, pode ser feita sem conflito com a legislação nacional e sem violar as competências do Congresso (DBR - F). Apesar de a lei brasileira ser mais severa do que o disposto na convenção (DBR - F), esta determina, em seu Protocolo Final, que nenhum de seus dispositivos pode ser interpretado em detrimento da legislação nacional sobre o tema que preveja sanções mais rigorosas (DIN - F). A Convenção, ademais, determina a repressão a atos que não estão previstos na lei nacional (DBR - F).

O parecer é favorável à aprovação da Convenção.

\section{PARECER DA COMISSÃO DE CONSTITUIÇÃO E JUSTIÇA (CD), LOURIVAL DE ALMEIDA}

[Câmara - Parecer 3]

O parecer de Lourival de Almeida, de junho de 1955, diz nada adicionar ao de Trigueiro, e apenas aprova o decreto, em virtude da constitucionalidade da MSC 41/1952 (DBR - F). O parecer foi aprovado sem discussão.

\section{PARECER 193 (CN), RUI PALMEIRA, 1958}

O Parecer de Rui Palmeira apenas aprova a Convenção e publica o decreto legislativo correspondente.

\footnotetext{
${ }^{16}$ Informação obtida em: http://www.fgv.br/cpdoc/acervo/dicionarios/verbete-biografico/osvaldo-trigueirode-albuquerque-melo. Acesso: 02.03.2016.

17 Art. 87 - Compete privativamente ao Presidente da República:

VII - celebrar tratados e convenções internacionais ad referendum do Congresso Nacional;

${ }^{18}$ Art. 66 - É da competência exclusiva do Congresso Nacional:

I - resolver definitivamente sobre os tratados e convenções celebradas com os Estados estrangeiros pelo Presidente da República;
} 
PARECER DA COMISSÃO DE CONSTITUIÇÃO E JUSTIÇA (n.104 - SF), LOURIVAL FONTES, 1958

[Senado - Parecer 1]

Segundo o relator deste parecer, de 03.01.1955, a Convenção trata de consolidar os principais dispositivos existentes nos acordos internacionais vigentes, com o objetivo de combater de maneira enérgica o tráfico de pessoas e a prostituição. Algumas das sanções existentes na Convenção não integram o direito nacional, particularmente as leis penais brasileiras, e serão, por isso, uma inovação com repercussões decisivas no combate à prostituição no país (PBR - F). Existem diversas disposições igualmente interessantes, todas em conformidade com a lei pátria a respeito da matéria (DBR - F).

O parecer é, assim, pela aprovação do Projeto, em conformidade com a Constituição (DBR - F) e conveniente para o país (PBR - F).

\section{PARECER DA COMISSÃO DE RELAÇÕES EXTERIORES (n. 105 - SF), JOÃO VILLASBOAS, 1958}

[Senado - Parecer 2]

O parecer do Senador João Villas Boas, de 23.04.1958, reitera o fato, mencionado em pareceres anteriores, de que a lei brasileira é mais severa do que a Convenção (DBR - F), em alguns aspectos, mas que isso não é um problema per se, uma vez que o Protocolo Final da Convenção permite a aplicação de leis nacionais mais severas (DIN - F). A Convenção, inclusive, preencheu lacunas na legislação nacional, por ter sido aprovada lei cominando penas para determinados delitos (DBR - F), claramente influenciada pela Convenção. As demais cláusulas estariam em consonância com a legislação nacional vigente (DBR - F) e, por isso, o parecer é pela aprovação da Convenção.

O parecer foi aprovado sem discussão. 


\section{ANÁLISE: CONVENÇÃO RELATIVA AO ESTATUTO DOS REFUGIADOS}

A Convenção relativa ao Estatuto dos Refugiados, de 28.07.1951, entrou em vigor internacional em 22.04.1954, conforme disposição de seu art.43. Essa Convenção foi assinada pelo plenipotenciário brasileiro em 15.07.1952, ratificada em 16.11.1960, e promulgada pelo Decreto Presidencial 50.215, de 28.01.1961, com reserva aos artigos 15 e 17. Foi enviada ao Congresso Nacional por intermédio da Mensagem Presidencial 355, de 30.07.1957. Seu processo de aprovação tramitou na Câmara dos Deputados como Projeto de Decreto Legislativo 07, de 14.05.1959, e no Senado Federal como Projeto de Decreto Legislativo 09, de 1959.

A Convenção é o documento central do regime internacional de proteção aos refugiados. No contexto de pós II Guerra Mundial, refugiados e pessoas deslocadas internamente eram foco importante da comunidade internacional, algo notado pelos órgãos da ONU, particularmente pela AGNU. Mesmo com a fundação de uma agência especializada, a Organização Internacional para os Refugiados, que funcionou entre 1946 e 1952, era difícil e dispendioso manter esse auxílio, envolvido na dinâmica da Guerra Fria. Foi necessário substitua-la por uma agência inicialmente temporária, e complementar a nova instituição com um tratado a respeito da situação dos refugiados. ${ }^{19}$

O tratado foi assinado com reservas. Em 07.04.1972, quando da acessão do Brasil ao Protocolo sobre o Estatuto dos Refugiados, de 31.01.1967, o governo retirou suas reservas aos artigos 15 e 17, parágrafos 1 e 3, de sua aplicação da Convenção. No endereço eletrônico da ONU, consta a seguinte declaração feita pelo Brasil:

\footnotetext{
"Refugees will be granted the same treatment accorded to nationals of foreign countries in general, with the exception of the preferential treatment extended to nationals of Portugal through the Friendship and Consultation Treaty of 1953 and Article 199 of the Brazilian Constitutional Amendment No.1, of 1969."
}

A emenda constitucional 01, de 17.10.1969, editou o texto da Constituição Federal de 1967, e foi assinada por Augusto H. Rademaker Grünewald, Aurélio de Lyra Tavares e Márcio de Souza e Mello, a chamada "Junta Governativa Provisória", triunvirato de militares

\footnotetext{
${ }^{19}$ Informação disponível em: http://legal.un.org/avl/ha/prsr/prsr.html. Acesso: 03.03.2016. 
que governou por dois meses (agosto-outubro, 1969) entre os mandatos dos Presidentes Artur da Costa e Silva e Emílio Garrastazu Médici. Segundo o artigo mencionado acima:

Art. 199. Respeitado o disposto no parágrafo único do artigo 145 , as pessoas naturais de nacionalidade portuguêsa não sofrerão qualquer restrição em virtude da condição de nascimento, se admitida a reciprocidade em favor de brasileiros. ${ }^{20}$

O Decreto 50.215, de 28.01.1961, assinado por Juscelino Kubitschek e por Horácio Lafer, promulgou a Convenção e fez reserva aos seus artigos 15 e 17, além de uma declaração interpretativa, dizendo que para os efeitos da Convenção, com relação ao Brasil, se aplique o disposto na Seção B.1 (a), do seu Artigo $1^{\text {*}}$ :

B.1) Para os fins da presente Convenção, as palavras "acontecimentos ocorridos antes de $1^{\circ}$ de janeiro de 1951", do art. $1^{\circ}$, seção A, poderão ser compreendidos no sentido de

a) "acontecimentos ocorridos antes de $1^{\circ}$ de janeiro de 1951 na Europa"; ou

b) "acontecimentos ocorridos antes de $1^{\circ}$ de janeiro de 1951 na Europa ou alhures";

e cada Estado Contratante fará, no momento da assinatura, da ratificação ou da adesão, uma declaração precisando o alcance que pretende dar a essa expressão do ponto de vista das obrigações assumidas por ele em virtude da presente Convenção. (grifo nosso).

Esse Decreto foi alterado pelo Decreto 98.602, de 19.12.1989, assinado por José Sarney e Roberto Costa de Abreu Sodré, que determina que a declaração acima passe a seguir o disposto na Seção B.1 (b), do artigo $1^{\circ}$. Por sua vez, o decreto 99.757, de 03.12.1990, retifica o Decreto 98.602, afirmando que o Brasil, ao efetuar o depósito na ONU, em 07.04.1972, da adesão ao Protocolo de 1967 sobre o Estatuto dos Refugiados, retirou as reservas aos Artigos 15 e 17 da Convenção de 1951, o que não foi expressamente mencionado pelo Decreto 98.602/1989. O Decreto 98.602/1989 estabelece que a Convenção seja executada e cumprida integralmente, e que, para os efeitos da mesma, se aplicará no Brasil o disposto na Seção B.1 (b) do Artigo $1^{\circ}$. O Decreto é assinado por Fernando Collor e pelo Ministro Francisco Rezek.

\footnotetext{
${ }^{20} \mathrm{O}$ artigo 145 trata dos requisitos de nacionalidade para brasileiros natos e naturalizados. Informação obtida em: http://www.planalto.gov.br/ccivil_03/Constituicao/Emendas/Emc_anterior1988/emc01-69.htm. Acesso: 03.03.2016.
} 


\section{STATUS NA ONU}

Convenção: https://treaties.un.org/Pages/ViewDetailsII.aspx?\&src=UNTSONLINE\& mtdsg_no $=\mathrm{V} \sim 2 \&$ chapter $=5 \&$ Temp $=$ mtdsg2\&lang=en\#Participants

Protocolo: https://reaties.un.org/Pages/ViewDetails.aspx?src=UNTSONLINE\& tabid $=2 \&$ mtdsg no $=V-5 \&$ chapter $=5 \&$ lang $=$ en\#Participants

\section{MENSAGEM DO PODER EXECUTIVO (MSC 355/1957)}

A Mensagem do Ministro das Relações Exteriores, o senhor José Carlos de Macedo Soares (MSC 355, de 30.07.1957), foi enviada pelo Presidente da República, Juscelino Kubitschek, ao Congresso Nacional, em 28.08.1957. Destaca a importância da Convenção como instrumento de proteção contra a xenofobia no âmbito mundial, tendo sido a medida mais concreta efetivada pela ONU até o momento, reiterando os objetivos da Declaração dos Direitos do Homem de 1948 (DIN - F). A Convenção seria digna de nota sob três aspectos distintos:

(i) É aplicável a número significativo de refugiados, sem precedentes na história da humanidade;

(ii) Estabelece para esses refugiados um conjunto mínimo de direitos; e

(iii) Prevê a criação de um órgão da ONU para zelar pelo cumprimento de suas disposições.

O Ministro aponta que a Convenção foi resultado de esforços humanitários em prol da proteção dos refugiados no âmbito do Direito Internacional, que, apesar de protegidos por convenções assinadas posteriormente à Primeira Guerra Mundial, ainda não tinham recebido suficiente atenção. Para Soares, o diferencial da Convenção seria a extensa variedade de pessoas beneficiadas por ela: todos que não tenham proteção de outro órgão da $\mathrm{ONU}$, além do Alto Comissariado para Refugiados (DIN - F).

Foram excluídos do resguardo da Convenção os refugiados que tenham:

(i) Cometido crimes contra a paz, crimes de guerra ou contra a humanidade;

(ii) Cometido crime grave de direito comum fora do país de refúgio, antes de serem admitidos como refugiados; e

(iii) Sido considerados culpados da prática de atos contrários aos fins e princípios da ONU. 
O Ministro destaca que a Convenção é de extrema relevância para o Brasil, uma vez que, no âmbito nacional, não havia a figura jurídica de refugiado; à época, equiparado a estrangeiro (PBR - F). A Convenção ainda possibilita que os Estados decidam entre duas definições possíveis de "Refugiado", declarando sua preferência no momento da assinatura ou do depósito do instrumento de ratificação. A opção brasileira foi pela interpretação restritiva, de que seriam refugiados apenas as vítimas dos acontecimentos que ocorreram na Europa antes de janeiro de 1951, conforme apresentado no Decreto Presidencial 50.215/1961 (PEB - F).

A Convenção também prevê que as partes contratantes deverão conceder aos refugiados o mesmo tratamento conferido aos estrangeiros em geral, exceto em caso de existência de dispositivos mais favoráveis. Como, à época, no Brasil, a figura jurídica do refugiado não existia, a ratificação do Estatuto restringiria os direitos garantidos no país aos deslocados e refugiados (DBR - F).

A previsão convencional de que o estatuto pessoal do refugiado seguirá a lei domiciliar ou, caso não possuísse domicílio, a lei do local de residência, em virtude de sua similaridade em relação às disposições da Lei de Introdução ao Código Civil, facilitaria a aplicação da Convenção no Brasil (DBR - F).

Após descrever diversos aspectos da Convenção, o Ministro destaca a possiblidade, prevista por ela, de apor reservas aos seus artigos (art.42), exceto aos que proíbem a discriminação contra refugiados em razão de sua raça, religião, ou aos que limitam o direito de os refugiados praticarem sua religião ou terem acesso aos tribunais do Estado; o que facilita a sua assinatura da maior quantidade possível de países (PEB - F).

\section{PARECER DA COMISSÃO DE CONSTITUIÇÃO E JUSTIÇA (CD), JOAQUIM DUVAL, 1957}

[Câmara - Parecer 1]

O Parecer, de 20.11.1957, é de autoria de Joaquim Duval. Após descrição da Convenção, o relator aponta que à Comissão compete examinar se há conflito com a Constituição, o que não ocorre (DBR - F). Destaca, porém, que, com o objetivo de colaborar 
com a Comissão de Relações Exteriores, sugere a oposição de reservas aos artigos $15^{21} \mathrm{e}$ $17,{ }^{22}$ que tratam dos direitos de associação e das profissões assalariadas, e outorgam aos refugiados "o tratamento mais favorável concedido aos nacionais de um país estrangeiro, nas mesmas circunstâncias" (grifo nosso). Para o relator, as disposições desses artigos divergem das disposições que constam nos artigos 13, 18, 19, 21 e 22, que concedem aos refugiados (em relação a propriedade de móveis e imóveis, profissões não assalariadas, profissões liberais, alojamento e educação pública) tratamento tão favorável quanto o concedido aos estrangeiros em geral, nas mesmas circunstâncias. No seu entendimento, as disposições dos artigos 15 e 17 confeririam aos refugiados mais vantagens do que as outorgadas aos demais estrangeiros radicados no Brasil, muitos deles há muito mais tempo $(\mathrm{PBR}-\mathrm{C})$.

Os refugiados ficariam, assim, equiparados aos portugueses, que têm proteção especial pela Constituição pátria (DBR - C). Os laços históricos e culturais existentes entre Brasil e Portugal (PBR - C), acrescidos aos privilégios legais internos (art. 129, IV, CF (DBR) - C) $)^{23}$ e externos (Tratado de Amizade e Consulta entre Brasil e Portugal) (DIN - C) a eles concedidos, seriam motivos suficientes para apresentar ressalvas em relação a essa parte do tratado, o que não o invalidaria em absoluto.

\footnotetext{
${ }^{21}$ Artigo 15: Direitos de associação

Os Estados Contratantes concederão aos refugiados que residem regularmente em seu território, no que concerne às associações sem fins políticos nem lucrativos e aos sindicatos profissionais, o tratamento mais favorável concedido aos nacionais de um país estrangeiro, nas mesmas circunstâncias.

${ }^{22}$ Artigo 17: Profissões assalariadas

1. Os Estados Contratantes darão a todo refugiado que resida regularmente no seu território o tratamento mais favorável dado, nas mesmas circunstâncias, aos nacionais de um país estrangeiro no que concerne ao exercício de uma atividade profissional assalariada.

2. Em qualquer caso, as medidas restritivas impostas aos estrangeiros ou ao emprego de estrangeiros para a proteção do mercado nacional do trabalho não serão aplicáveis aos refugiados que já estavam dispensados na data da entrada em vigor desta Convenção pelo Estado Contratante interessado, ou que preencham uma das seguintes condições: (grifo nosso)

a) contar três anos de residência no país; b) ter por cônjuge uma pessoa que possua a nacionalidade do país de residência. Um refugiado não poderá invocar o benefício desta disposição no caso de haver abandonado o cônjuge; c) ter um ou vários filhos que possuam a nacionalidade do país de residência.

3. Os Estados Contratantes considerarão com benevolência a adoção de medidas tendentes a assimilar os direitos de todos os refugiados no que concerne ao exercício das profissões assalariadas aos dos seus nacionais, e em particular para os refugiados que entraram no seu território em virtude de um programa de recrutamento de mão-de-obra ou de um plano de imigração.

${ }^{23}$ Art. 129 - São brasileiros: (...) IV - os naturalizados pela forma que a lei estabelecer, exigidas aos portugueses apenas residência no País por um ano ininterrupto, idoneidade moral e sanidade física.
} 
O relator menciona, inclusive, que sua interpretação tem o respaldo das conferências internacionais que discutiram o tema, como a Conferência de Genebra, de 28.07.1951, que examinou a Convenção:

\footnotetext{
“(...) 2. Os Estados deveriam dispensar aos refugiados o mesmo tratamento que aos procedentes de países estrangeiros, (...)

6. As prescrições atinentes a estrangeiros em geral, em matéria de segurança nacional, deveriam ser aplicáveis aos refugiados" (DIN - F)
}

Corroboram com o argumento, igualmente, as conclusões da $46^{\mathrm{a}}$ Conferência da União Interparlamentar, realizada em 1957, que cuidou da questão dos refugiados. A recomendação para o cumprimento da Convenção seria conceder aos refugiados o mesmo tratamento outorgado aos demais estrangeiros. Não haveria, entretanto, recomendação para que fossem tratados de maneira equivalente a estrangeiros beneficiados com uma "cláusula da nação mais favorecida" (DIN - C).

Deste modo, conclui o relatório com a necessidade de que a Comissão de Relações Exteriores examine o caso com patriotismo (PBR - C) e em face da nossa política internacional e migratória. (PEB - C)

O parecer foi aprovado por unanimidade.

\section{PARECER DA COMISSÃO DE RELAÇÕES EXTERIORES (CD), MENDES DE MORAES, 1959}

[Câmara - Parecer 2]

O parecer da CRE, elaborado por Mendes de Morais em 14.05.1959, menciona o parecer da Comissão de Constituição e Justiça, que desejou restringir o Estatuto no que se refere ao tratamento aos refugiados em relação aos tratamento dispendido aos portugueses; que, por questões de tradição, gozam de privilégios no Brasil, conforme disposição constitucional. ${ }^{24}$ A CRE concorda com as sugestões da CCJ, de ressalvas aos artigos 15 e 17 do Estatuto, ${ }^{25}$ ainda mais porque feitas em relação ao mérito e às consequências deste (PBR - C) - e não em relação à constitucionalidade do projeto, que é da alçada da própria CRE.

\footnotetext{
${ }^{24}$ Apesar de, à época, estar vigente a Constituição de 1946, a Constituição atual, de 1988, também confere privilégios aos portugueses, no art. $12, \S 1^{\circ}$.

${ }^{25}$ O relator coloca, sabiamente, aspas quando fala em "reservas", provavelmente por saber que as reservas são apostas pelo Poder executivo, e que cabe ao legislativo, tão somente, apor ressalvas a tratados - que podem ser transformadas em reservas pelo Executivo.
} 
Segundo o Deputado, o assunto “(...) vem se arrastando (...)” na Câmara e nas Comissões desde 1957, sendo necessária sua rápida conclusão (PBR - F).

O relator destaca que a internalização do tratado corresponderia a:

\begin{abstract}
“(...) uma etapa a mais, no terreno da cooperação Internacional pelo Brasil, vem consolidar cada vêz mais a situação do nosso país no conceito Internacional como um alto cultor do Direito Internacional, além do aspecto político e humano que é essa grande e útil iniciativa." (p.62, Diário do Congresso Nacional, 10.06.1959) (PEB - F)
\end{abstract}

O parecer é pela aprovação, ainda que tardia, da Convenção (PBR - F). Foi aprovado por unanimidade.

\title{
PROJETO DE LEI, MENOTTI DEL PICCHIA, SEM DATA
}

[Câmara - Parecer 3]

Incluo, neste momento, parecer, assinado por Menotti del Picchia, inserido ao final da tramitação deste PDC. Não consta, porém, data nem a Comissão relacionada ao Parecer. Os argumentos mencionados, de qualquer modo, serão aqui considerados. Segundo o Parecer, a Convenção tem como objetivo solucionar uma das questões humanas mais dramáticas, decorrente das guerras no âmbito internacional ( $\mathrm{DH}$ - refugiados - F). $\mathrm{O}$ instrumento é condizente com o texto da DUDH (DIN - F). O Brasil, exercendo a faculdade que a Convenção concede, optou pela definição restritiva do conceito de refugiado (PEB - F). No país, a figura do refugiado não é prevista em lei, sendo equiparada ao estrangeiro (DBR - F), vindo o Estatuto em boa hora, por prever que o estatuto pessoal do refugiado deverá seguir a lei domiciliar ou do país de residência. O Código Civil pátrio facilita, inclusive, a aplicação dos princípios definidos no tratado em território nacional (DBR - F). O parecer é, assim, pela aprovação do tratado, além de apresentar um projeto de lei que o complementa.

Não consta aprovação expressa do parecer.

\section{PARECER COMISSÃO DE CONSTITUIÇÃO E JUSTIÇA (n. 615 - SF), MILTON CAMPOS, 1959}

[Senado - Parecer 1]

O parecer, de 23.09.1959, menciona as manifestações anteriores provenientes da Câmara dos Deputados, particularmente de Joaquim Duval, acerca da Convenção, e aponta 
que o projeto veio ao Senado após aprovação naquela Casa. O Senador nada acrescenta ao parecer da CCJ da Câmara, e diz que a CRE manifestar-se-á a respeito do mérito.

PARECER DA COMISSÃO DE RELAÇÕES EXTERIORES (n. 616 - SF), MOURA ANDRADE

[Senado - Parecer 2]

Após menção ao conteúdo da Convenção e à sua tramitação interna, o autor do parecer de 31.10.1959, Senador Moura Andrade, destaca a concordância com o parecer da CCJ/CD, do Deputado Joaquim Duval, em relação a necessidade de aposição de reservas aos artigos 15 e 17, mas adiciona que os artigos 15 e 17 deveriam ser excluídos, pelo Brasil, da Convenção a que aderirá (PEB - C). O Senador faz uma sugestão em relação ao texto do Projeto analisado, que, ao invés de dizer que "aprova a participação do Brasil na Convenção" deveria dizer que aprova a própria Convenção, já que a Constituição (no art.66, I), ao determinar que cabe ao Congresso resolver definitivamente sobre tratados, define que cabe ao Legislativo decidir sobre o próprio instrumento, além de corrigir alguns outros aspectos do texto do Projeto, emendando-o (DBR - C).

\section{SENADO FEDERAL: DISCUSSÃO ÚNICA ACERCA DO PROJETO DE DECRETO LEGISLATIVO 9, DE 1959}

[SF PLEN]

Foi documentada discussão a respeito do Projeto 9/1959, publicada no Diário do Congresso Nacional de 27.10.1959. Nela, o Senador Cunha Mello, ao discursar na data do $14^{\circ}$ aniversário da ONU, diz que os Estados modernos estão no caminho de inscrever em suas Cartas Magnas os direitos e as garantias dos indivíduos, o que foi feito por nossa Constituição, em seu art. 141, ao tratar de nacionais e estrangeiros (DBR - F). O Senador presta homenagem à ONU e à elaboração de um Estatuto Universal dos Direitos do Homem, e fala da necessidade de se estabelecerem princípios para legar às gerações futuras em todo o mundo. Dentro dessas preocupações foi assinada a Convenção, que resguarda os direitos dos refugiados, tema que vem sendo tratado não apenas pela ONU, mas pelo órgão especializado no tema (PEB - F). Trata-se de um problema político e humano, e não é 
suficiente “considera-lo com o coração, mas auxiliá-lo com o bolso" (PEB - F). ${ }^{26}$ É possível fazer um paralelo entre o drama dos refugiados e o dos nordestinos, mas há diferença no tratamento jurídico que damos a eles, posto que o estatuto jurídico do status de refugiado deve dar à sua situação, bem como à dos apátridas, solução política e humana (PBR - F). A Convenção deve ser considerada no espírito hospitaleiro do Brasil (PBR - F). Para que possam ser protegidos, é essencial a assistência e a proteção internacionais, sendo que o Brasil, percebendo a natureza iminentemente política da situação dos refugiados, tem acolhido esses indivíduos (PEB - F). Deste modo, o país tem agido em conformidade com a tradição de hospitalidade e de vida em harmonia no âmbito internacional (PBR - F). Trabalhamos, em conjunto com a ONU, pela paz universal e pela liberdade e justiça, social e econômica (PEB - F).

Segue a esse discurso uma explanação do Senador Moura Andrade e uma discussão a respeito da tramitação de emenda de substância ou de redação ao PDS 9/1959. Optou-se por não documentar essa discussão, uma vez que não trata da matéria do tratado, e sim de minúcia regimental a respeito da tramitação das reservas feitas e mencionadas anteriormente.

Adiciono, aqui, manifestação de Moura Andrade, a respeito da mesma temática tratada no item acima. ${ }^{27}$ Segundo o Senador, a disposição constitucional mais benéfica em relação aos portugueses é posterior à apreciação da Convenção pela Câmara, e, justamente por isso, os Deputados deveriam ter deliberado pela exclusão, e não pela mera reserva em relação aos artigos 15 e 17. Apesar de os Deputados falarem em "exclusão", a Convenção não menciona essa terminologia, falando, em seu art. 42, apenas em "reservas", aspecto mencionado pelo Senador. Assim, para evitar a interpretação errônea de "exclusão de artigos" como sinônima de "reservas", o Senador propôs a mudança de redação. Segundo o Senador, se o Plenário entendesse procedente sua argumentação, isso contribuiria para o prestígio brasileiro na Convenção, na qual o Brasil atuou de maneira enérgica (PEB - F). O Senador faz longa descrição da situação deplorável dos refugiados (DH - refugiados - F), dizendo que o Brasil deveria demonstrar sua convicção na formulação de solução jurídica tão significativa para todas as democracias no mundo (PEB - F).

\footnotetext{
${ }^{26}$ Diário do Congresso Nacional, seção II, 27.10.1959, p.2563.

${ }^{27}$ Parecer da Comissão de Relações Exteriores (n. 616 - SF), Moura Andrade.
} 
Foi, em seguida, dada a palavra ao Senador Cunha Mello, que, além de parabenizar Moura Andrade pela boa técnica legislativa, menciona a péssima situação dos refugiados, e menciona o fato de que se passaram dez anos da data da Mensagem Presidencial, sem que tenha sido aprovada e, em seguida, faz uma crítica à tramitação de tratados no Brasil. Segundo o Senador, o Poder Executivo, apesar de ter completa liberdade para enviar delegados às reuniões internacionais, não tem competência constitucional para aceitar compromissos (PBR - F). O Senador faz, aqui, uma reclamação a respeito de o Congresso ser consultado apenas posteriormente à celebração de tratados (PBR - F). O Senador apoia Moura Andrade, no sentido de considerar a emenda como sendo, apenas, de redação, e finaliza seu discurso dizendo que a emenda em nada altera o sentimento brasileiro, reservado à solução do problema dos refugiados e dos apátridas (PBR - F).

A discussão sobre a emenda proposta pelo Senador dá ensejo a outra comunicação, de 27.10.1959, de autoria de Filinto Müller, vice-presidente do Senado Federal. Segundo ele, na sessão de 23.10.1959, ao ser anunciada a votação de requerimento de dispensa de interstício para a matéria, ${ }^{28}$ o Senador Afonso Arinos teria prestado um esclarecimento a respeito do tema, sobre a emenda de substância, e não de redação, proposta por Moura Andrade (descrita acima), e que a aprovação do projeto por parte do Senado não impediria sua devolução à Câmara para apreciação. O Senador Moura Andrade, autor da emenda, por sua vez, disse ser a emenda apenas de redação, no que foi apoiado pelo Senador Cunha Melo. Diante da divergência, a Mesa do Senado solicitou parecer da CCJ-SF a respeito, conforme disposição do art. $232, \S 2^{\circ}$ do Regimento Interno da Casa. ${ }^{29}$

\section{PARECER COMISSÃO DE CONSTITUIÇÃO E JUSTIÇA (n. 676 - SF), MILTON CAMPOS, 1959}

[Senado - Parecer 3]

O parecer do Senador Milton Campos, de 04.11.1959, trata, basicamente, da emenda proposta pelo Senador Moura Andrade, apontando que, efetivamente, o Congresso não apoia

\footnotetext{
${ }^{28}$ O Requerimento 387, de Ruy Carneiro, publicado no DCN de 24.10.1959, seção II: requer a dispensa do interstício e prévia distribuição de avulsos para o PDS 9/1959, que aprova a participação do Brasil na Convenção, para que figure na Ordem do Dia da sessão seguinte. Segundo o requerimento, a aprovação do projeto pelo Senado não impediria sua devolução à Câmara dos Deputados, para apreciação. O requerimento foi aprovado.

29 Aqui, não foram selecionados ou categorizados os argumentos por se tratar de discussão a respeito dos trâmites internos da casa, e não da matéria do tratado.
} 
a participação do país em determinada Convenção, mas a própria Convenção, algo que está bastante claro na Constituição Federal. Sobre a polêmica entre a reserva versus a exclusão dos artigos convencionais, sendo a primeira passível de retirada a qualquer tempo, para o Senador a intenção da Câmara teria sido a de efetuar reservas. De qualquer maneira, o Senador acredita que o ideal seria o reexame do caso pela Câmara, para que não houvessem dúvidas a respeito. ${ }^{30}$

PARECER DA CÂMARA DE REDAÇÃO (n. 737 - SF), PADRE CALAZANS, 1959 [Senado - Parecer 4]

No parecer, de 17.11.1959, é apresentada a redação final do que viria a ser o Decreto Legislativo 11, de 07.07.1960, que ficou assim:

\footnotetext{
Art. $1^{\circ}$ É aprovada a Convenção de 25 de julho de 1851, relativa ao Estatuto dos Refugiados, assinada pelo Brasil, a 15 de julho de 1952, com exclusão dos artigos 15 e 17. (grifo nosso).
}

Ou seja: a sugestão de Moura Andrade, de trocar o termo "aprovar a participação do Brasil na Convenção (...)" por "aprovar a Convenção" foi considerada; assim como a exclusão da menção ao art. 42 da Convenção - que trata de reserva, e não da exclusão de artigos.

\section{PARECER DA COMISSÃO DE RELAÇÕES EXTERIORES (SF), MENDES DE MORAES,1960}

[Senado - Parecer 5]

O parecer de Mendes de Moraes, de 05.02.1960, retoma a discussão a respeito das emendas, e não trata da matéria do tratado. Sugere que a Comissão aprove a sugestão de emenda feita pelo Senado, o que foi feito por unanimidade.

\section{PARECER DA CJ/MRE, ANTONIO AUGUSTO CANÇADO TRINDADE, 1986}

[Executivo - Parecer MRE]

\footnotetext{
${ }^{30}$ Aqui, novamente, não se documentaram os argumentos, por se tratar de discussão a respeito de minúcias da redação do PDS, matéria mencionada anteriormente.
} 
O parecer, de 19.05.1986, é de autoria do jurista Antonio Augusto Cançado Trindade. Trata, em suma, dos aspectos jurídicos da proteção dos refugiados e da questão do levantamento, por parte do Brasil, da reserva geográfica contida na Convenção. A presente descrição ater-se-á aos argumentos do parecerista em relação ao levantamento da reservas geográfica (parte IV do parecer), uma vez que a Convenção tinha, à época da elaboração do parecer, sido internalizada pelo Brasil, e sua internalização, portanto, não foi objeto dessa análise. $^{31}$

O parecer apresenta, inicialmente, minucioso estudo a respeito da situação do refugiado nacional e internacionalmente, com dados e descrições normativas, além das distinções entre os estatutos, que não se confundem, do asilo e do refúgio; além dos distintos tipos de refugiado, conforme a Convenção, o Alto Comissariado das Nações Unidas para Refugiados (ACNUR) ou o direito interno dos países.

Cançado Trindade prossegue, apresentando a questão do levantamento das reservas temporal e geográfica da Convenção. Pela primeira delas, o reconhecimento da condição de refugiado estava delimitado por acontecimentos ocorridos antes de 01.01.1951; e, pela segunda, restringia-se a definição de refugiado para aqueles indivíduos provenientes da Europa. O Protocolo de 1967, analisado a seguir, superou a restrição temporal, e tinha sido internalizado no ordenamento brasileiro na década de 1970 - ou seja, muito anos antes da elaboração do parecer. A segunda restrição, portanto, permanecia em vigor para o Brasil, ressaltando o consultor que a grande maioria dos países signatários teriam revogado a restrição geográfica anteriormente.

Por ser o Brasil parte da Convenção e de seu protocolo, não existiria preocupação quanto à reserva temporal, abolida pelo próprio protocolo. $\mathrm{O}$ consultor apresenta argumentos favoráveis e contrários à reserva. Apesar dos argumentos - contrários ao levantamento da reserva - de que a Convenção voltar-se-ia para a questão específica da Europa, e, por isso, não deveria ser aplicada em nenhuma outra circunstância, é possível verificar esforço internacional significativo para estender essa proteção aos ditos "novos" refugiados, existindo, inclusive, interação significativa entre os âmbitos nacional e internacional, este

\footnotetext{
${ }^{31}$ Retomo, brevemente, o histórico da tramitação deste tratado. Como foi possível perceber pela análise acima descrita, o Brasil, ao ratificar a Convenção, optou por aplicar a restrição, de caráter geográfico, pela qual o reconhecimento da condição de refugiado estava vinculado a acontecimentos no continente europeu antes da data limite estipulada pela Convenção. Essa reserva restringiu a aplicação do tratado no Brasil aos refugiados de origem europeia.
} 
desdobrando-se em convencional e consuetudinário. A cláusula geográfica, sob a análise da realidade da época e dos esforços na redução do número de indivíduos desprotegidos, vítimas de eventos ocasionados pelo homem, é completamente anacrônica, e sua manutenção, prova de percepção ultrapassada da realidade internacional (PEB - F).

Tampouco prosperaria o argumento de que o levantamento da cláusula de reserva geográfica levaria a pressões futuras sobre o país, não só pelo ACNUR, órgão supervisor da Convenção, como pelos países - principalmente fronteiriços - recipientes de grandes fluxos de refugiados, que tentariam dividir esse ônus com o Brasil. Os defensores desse argumento lembram que alguns desses países não assinaram a Convenção; ao que Trindade responde que um país, mesmo não signatário, pode estabelecer sistemática interna estruturada para lidar com os fluxos de refugiados em seu território. O problema dos refugiados é algo real, fático, independe da existência de instrumentos internacionais. Não existe país cujo governo não se preocupe com o possível influxo em massa de refugiados; e uma estrutura normativa propriamente estabelecida nos âmbitos nacional e internacional servirá para auxiliar os Estados na solução dos problemas. (PEB - F).

Outro argumento rebatido no parecer é o que prevê grande impacto, no mercado de trabalho interno, do ingresso de refugiados no país. Para o jurista, "seria irrealista, se não irrisório, pretender que as cifras recentes e atuais de refugiados em trânsito no Brasil poderiam contribuir para agravar os nossos problemas sociais; a culpa não está nas estrelas." 32 (PBR - F). Apresenta, ainda, dados da Divisão das Nações Unidas do Itamaraty, que registrou o número médio anual de refugiados em trânsito no território brasileiro como de, apenas, 201.

De qualquer modo, seria legítima a preocupação governamental a respeito da preservação das boas condições do mercado de trabalho. Essa preocupação, porém, não pode ser desmedida: o consultor remete à manifestação da Divisão de Imigração, unidade competente do Itamaraty para tratar do assunto em pauta, que informa não ter fundamentos a alegação de que o mercado de trabalho nacional seria invadido por refugiados, em caso de retirada da reserva geográfica, até porque o Estado que assinou a Convenção não se obriga a reconhecer um refugiado como tal, mesmo em caso de reconhecimento por parte do ACNUR. Ainda de acordo com o órgão, a quantidade de estrangeiros que se encontram em

\footnotetext{
${ }^{32}$ Pareceres dos Consultores Jurídicos do Itamaraty, vol. VII, p. 304.
} 
território nacional clandestinamente é muito superior à de refugiados (PBR - F). Não há, reitera, decisão que vincule as autoridades estatais ao reconhecimento da condição de refugiado, existindo, sempre, uma relação de diálogo entre o ACNUR e os órgãos nacionais responsáveis. (PBR - F)

Seria necessário que o levantamento da reserva geográfica fosse acompanhado por medidas no âmbito interno (PBR - F). O Estatuto do Estrangeiro (Lei 6.815/1980) (DBR F) é omisso a respeito do refúgio, o que poderia ser solucionado. O consultor dá sugestões a respeito das inovações que poderiam ser feitas, já que o projeto de revisão do Estatuto do Estrangeiro, de 1986, não demonstra o espírito humanitário que rege o tema e, tampouco, soluciona a questão da delimitação jurídica do refugiado (PBR - F).

O levantamento da reserva geográfica por parte do Brasil não traria encargos adicionais insuportáveis, posto que as obrigações se encontram inseridas na Convenção, que o país integra há décadas. As preocupações - principalmente as administrativas - em relação ao trato dos refugiados fazem parte do cotidiano dos órgãos responsáveis do Departamento de Polícia Federal, que se comunica diretamente com o ACNUR. (PBR - F) O consultor segue:

"Por que então não regularizar a matéria, mediante a aplicação integral da
Convenção de 1951 e medidas no âmbito do direito interno (com o
estabelecimento de um procedimento - cf. supra), de modo a deixá-la regida pela
tão desejável clareza das normas jurídicas?". ${ }^{33}$

O tema relaciona-se com os desenvolvimentos da posição do país em relação aos tratados humanitários, temática esta desenvolvida em outro parecer do mesmo autor, por ele mencionado, analisado no item 22 deste capítulo, referente à ANÁLISE: CONVENÇÃO AMERICANA SOBRE DIREITOS HUMANOS - PACTO DE SÃO JOSÉ DA COSTA RICA. Não irei repetir os motivos apresentados pelo consultor. Segundo ele, a decisão recente de aderir à Convenção Americana de Direitos Humanos e aos Pactos de 1966 (PIDCP e PIDESC) (DIN - F) pode ser considerada argumento adicional em favor do levantamento da cláusula geográfica da Convenção relativa ao Estatuto dos Refugiados, mormente pelas disposições desses Pactos, que preveem, por exemplo, que os Estados

${ }^{33}$ Pareceres dos Consultores Jurídicos do Itamaraty, vol. VII, p. 307. 
signatários comprometem-se a assegurar os Direitos descritos no Pacto a "todos os indivíduos dentro de seu território e sujeitos a sua jurisdição, (...) sem distinção de qualquer tipo, tal como (...) opinião política ou outra, origem nacional ou social (...)”. ${ }^{34} \mathrm{O}$ autor menciona diversos outros artigos do Pacto e da Convenção Americana nesse sentido, sendo que estes instrumentos iriam além da Convenção de 1951, em relação a algumas obrigações assumidas pelos Estados (PEB - F).

Para Cançado Trindade, manter a reserva geográfica seria, além de anacrônico, incompreensível (PBR - F).

${ }^{34}$ PIDCP, art. 2.1. 


\subsection{ANÁLISE: PROTOCOLO SOBRE O ESTATUTO DOS REFUGIADOS}

O Protocolo sobre o Estatuto dos Refugiados foi concluído em 31.01.1967, e entrou em vigor internacional em 04.10.1967, conforme seu artigo VIII. O Brasil assinou o protocolo em 07.04.1972, e depositou, na mesma data, instrumento de adesão junto ao Secretariado da ONU. Foi enviado ao Congresso Nacional por intermédio da Mensagem Presidencial 410, de 1971. O Protocolo tramitou na Câmara dos Deputados como PDC 53/1971, e no Senado como PDS 43/1971, e foi aprovado pelo Decreto Legislativo 93, de 30.11.1971. Foi promulgado pelo Decreto Presidencial 70.946, de 07.08.1972. O referido protocolo entrou em vigor, para o Brasil, em 07.04.1972.

As origens do protocolo remontam à necessidade de adaptar as disposições da Convenção, limitadas a uma realidade histórica particular, à nova proporção do trabalho exercido pelo ACNUR. Com o Protocolo, os Estados concordaram em aplicar dispositivos relevantes da Convenção, sem, necessariamente, tornar-se parte do tratado. Apesar de muitos referirem-se ao protocolo como uma espécie de emenda à convenção, ele é instrumento independente, pelo qual os signatários concordam em aplicar os artigos 2 a 24 da Convenção. ${ }^{35}$

\section{STATUS NA ONU}

https://treaties.un.org/pages/ViewDetails.aspx?src=TREATY\&mtdsg_no=V-

$5 \&$ chapter $=5 \&$ lang $=$ en

\section{MENSAGEM DO PODER EXECUTIVO}

A Mensagem 410/1971, de 20.09.1971, foi enviada pelo Presidente Emílio Garrastazu Médici ao Congresso em 26.10.1971. Essa MSC submeteu à apreciação do Congresso o texto do Protocolo sobre o Estatuto dos Refugiados, solicitando não apenas que o Brasil o internalizasse, mas que retirasse as reservas feitas aos artigos 15 e 17 , parágrafos $1^{\circ}$ e $3^{\circ}$, da Convenção relativa ao Estatuto dos Refugiados.

\footnotetext{
${ }^{35}$ Informações obtidas em: http://legal.un.org/avl/ha/prsr/prsr.html. Acesso: 04.03.2016. 
O Ministro das Relações Exteriores, Mário Gibson Barboza, inicia a análise do Protocolo afirmando que a questão dos refugiados ocasiona problemas de ordem humanitária, financeira e jurídica aos países que os recebem. Diferentemente do que ocorreria com os estrangeiros, que poderiam gozar da proteção do país de sua nacionalidade ou residência, o refugiado não goza de proteção diplomática, sendo, assim, um estrangeiro em qualquer país ( $\mathrm{DH}$ - refugiados F). Liga das Nações e ONU tentaram mitigar o problema, o que culminou na Convenção relativa ao Estatuto dos Refugiados, um código de direitos mínimos concedidos a esses indivíduos (DIN - F).

O Brasil ter-se-ia mantido "fiel à sua tradição humanitária" 36 (PEB - F) ao assinar a Convenção. Esta subsume, em seu $\operatorname{art.} 1^{\circ}$, a condição de refugiado às vítimas dos acontecimentos ocorridos antes de 01.01.1951, que, estando fora do país de que seriam nacionais ou no qual teriam estabelecido residência, não pudessem valer-se da proteção desse país; ou voltar para o país de residência - caso não possuísse nacionalidade. Com o surgimento, após essa data, de conflitos que culminaram no aparecimento de novos refugiados, desejou-se ampliar essa definição. O Protocolo, portanto, suprime da definição de refugiado o aspecto temporal. Tampouco há restrições geográficas com relação à proveniência dos refugiados.

Conforme as reservas à Convenção apostas pelo Brasil, este indicou que (i) a Convenção apenas seria aplicada aos refugiados em virtude dos acontecimentos ocorridos na Europa e (ii) não concederia aos refugiados o tratamento de nação mais favorecida no que tange ao direito de associação sem fins políticos ou de exercício de atividade assalariada em virtude do tratamento privilegiado dado aos portugueses no Brasil. O Ministro aponta que seria possível retirar as reservas aos artigos 15 e $17, \S 1^{\circ}$, substituindo-as por uma declaração interpretativa que determinasse que o tratamento preferencial concedido aos portugueses, em virtude do Tratado de Amizade e Consulta (DIN - F), bem como do art.199 da Emenda Constitucional 01, de 1969 (DBR - F), não deveriam ser considerados para fins de aplicação desses artigos da Convenção. Ou seja, os refugiados gozarão do mesmo tratamento dispensado aos estrangeiros em geral.

${ }^{36}$ DCN 26.11.1971, p. 7.195. 
A reserva ao art.17, $\S 2^{\circ}$, deveria, para o Ministro, ser mantida, por ser contrária ao art.353 da CLT, ${ }^{37}$ (DBR - C) que exige 10 (dez) anos de residência para a assimilação do estrangeiro ao Brasil, para fins de apuração do critério de proporcionalidade de $2 / 3$ de brasileiros, na mesma empresa, enquanto o parágrafo referido da Convenção exige, apenas, três anos. Em relação à reserva feita ao art. $17, \S 3^{\circ}$, poderia ser retirada, por se tratar de mera recomendação.

Quanto à delimitação geográfica da proveniência dos refugiados, pondera que a maior parte dos acontecimentos que ocasionaram o aparecimento de refugiados, após 01.01.1951, ocorreram tanto na Europa como em outros locais, o que possibilitaria a ampliação do âmbito da Convenção por parte do Brasil (PEB - F). Essa percepção seria compartilhada pelo Itamaraty, pelo Ministério do Trabalho e Previdência Social e pelo Ministério da Justiça $(\mathrm{PBR}-\mathrm{F}){ }^{38}$

\section{PARECER DA COMISSÃO DE RELAÇÕES EXTERIORES (CD), MARCELO LINHARES, 1971}

[Câmara - Parecer 1]

É apresentado o Parecer da Comissão de Relações Exteriores, de 24.11.1971, elaborado pelo Deputado Marcelo Linhares. Para o relator, o Estatuto dos refugiados seria um exercício louvável e novo, sob a perspectiva internacional, por oferecer proteção a quantidade significativa de indivíduos, antes sem qualquer resguardo no sistema internacional (DIN - F)

Opinou pela aceitação do teor da MSC 410/1971, pela conveniência de se ampliar os benefícios outorgados aos refugiados após 1951 a todos os novos refugiados que surgissem

\footnotetext{
${ }^{37}$ A Consolidação das Leis Trabalhistas foi publicada em 1943, pelo Presidente Getúlio Vargas. Segue, a título de comparação, a dicção do art.353 vigente à época da presente análise, e a redação atual, dada em 1979:

Art. 353. Equiparam-se aos brasileiros para os fins-deste capítulo e ressalvado- exercício-de profissẽes reservadas aos brasileiros natos ou aos brasileiros em geral, os estrangeiros que, residindo no país há mais de dez anos, tenham cônjuge ou filho brasileiro.

Art. 353 - Equiparam-se aos brasileiros, para os fins deste Capítulo, ressalvado o exercício de profissões reservadas aos brasileiros natos ou aos brasileiros em geral, os estrangeiros que, residindo no País há mais de dez anos, tenham cônjuge ou filho brasileiro, e os portugueses. (Redação dada pela Lei $\mathrm{n}^{\circ} 6.651$, de 23.5.1979)

38 Alguns dos pareceres mencionam manifestação do Ministério do Trabalho e Previdência Social e pelo Ministério da Justiça. A autora, apesar de ter recebido, diretamente dos Arquivos Históricos da CD e do SF, os dossiês do PDC e PDS referente ao Protocolo, não teve acesso a essas manifestações.
} 
(PEB - F). Para o relator, o alargamento das disposições da Convenção foi recomendado pelo ACNUR, aprovado pela Resolução/AGNU 2.198/1966 (DIN - F).

O PDC 53/1971, a que se refere o Parecer, além de aprovar o texto do Protocolo, autoriza a retirada das reservas aos artigos 15 e $17, \S 1^{\circ}$ e $3^{\circ}$, da Convenção dos Refugiados. O relator concordou com a retirada das reservas aos artigos 15 e $17, \S 1^{\circ}$ e $3^{\circ}$, e favorável à manutenção da reserva ao $\S 2^{\circ}$ do art.17, conforme descrito pelo Ministro na MSC 410/1971 (PBR - F).

PARECER dA COMISSÃo de CONSTITUIÇÃo E JUSTIÇA (CD), ÉlCio ÁLVARES, 1971

[Câmara - Parecer 2]

O parecer, de 24.11.1971, aprova na íntegra o protocolo, e opina por sua constitucionalidade (DBR - F) e juridicidade, concordando com o Parecer do Deputado Marcelo Linhares.

\section{PARECER COMISSÃO DE RELAÇÕES EXTERIORES (n. 678 - SF), SALDANHA DERZI, $1971^{39}$}

[Senado - Parecer 1]

O parecer, de 29.11.1971, após mencionar o histórico da tramitação do PDS 43/1971, aponta que a matéria é de alto interesse humanitário ( $\mathrm{DH}$ - refugiados - F), e coerente com a tradição nacional de sensibilidade aos "problemas e angústias" que assolam o país (PEB F). Apesar de, à época da elaboração da Convenção, imaginar-se que não surgiriam mais refugiados, após a sua celebração, essa presunção estava equivocada, e tragédias humanitárias voltaram a ocorrer $(\mathrm{DH}$ - refugiados - F). Considerando sua aprovação em todas as instâncias nacionais (PBR - F), o Senador opina pela aprovação do PDS.

\footnotetext{
${ }^{39}$ Foi elaborado, em 30.11.1971, novo parecer da Comissão de Redação do SF (Parecer n. 689), por Filinto Müller. O Parecer apenas aprova a redação final do PDS 43/1971.
} 


\section{ANÁLISE: CONVENÇÃO SOBRE OS DIREITOS POLÍTICOS DA MULHER}

A Convenção sobre os Direitos Políticos da Mulher, de 31.03.1953, entrou em vigor internacional em 07.07.1954, de acordo com as disposições de seu artigo art. VI. Essa Convenção foi assinada pelo plenipotenciário brasileiro em 21.05.1953 e ratificada em 13.08.1963, entrando em vigor para o Brasil em 11.11.1963 (art. V). Foi enviada ao Congresso Nacional pela Mensagem Presidencial 247, de 1953. Seu processo de aprovação tramitou na Câmara dos Deputados como Projeto de Decreto Legislativo 17, de 1955, e no Senado Federal como Projeto de Decreto Legislativo 49, de 1955. Foi aprovada pelo Decreto Legislativo 123, de 20.11.1955, e promulgada pelo Decreto Presidencial 52.476, de 12.09.1963.

A Convenção foi o primeiro instrumento de Direito Internacional que reconheceu e passou a proteger os direitos políticos femininos. A Comissão que a elaborou teve como foco, em um primeiro momento, estabelecer padrões que modificassem a situação de discriminação legal sofrida pelas mulheres; além de pregar uma conscientização global a respeito do tema. A codificação dos direitos das mulheres precisou ser informada por dados concretos, pela Comissão que avaliou as condições globais das mulheres, país por país. O sistema ONU para mulheres tem a Convenção como base para seu funcionamento. ${ }^{40}$

\section{MENSAGEM DO PODER EXECUTIVO (MSC 247/1953)}

A MSC 247, de 13.06.1953, foi enviada ao Congresso Nacional pelo Presidente Getúlio Vargas em 19.06.1953, e assinada pelo Ministro João Neves da Fontoura. Segundo o Ministro, os primeiros artigos da Convenção, que concedem à mulher o direito de voto ativo e passivo, estariam implicitamente contidos na Carta da ONU (DIN - F). Menciona Convenção Interamericana que concede às mulheres esse mesmo direito (DIN - F).

Conforme discurso da Delegação do Brasil à VII Sessão da AGNU, a Constituição assegura às mulheres os direitos protegidos pela Convenção (DBR -F) e, por isso, a

\footnotetext{
${ }^{40}$ Informação obtida em: http://www.unwomen.org/en/csw/brief-history. Acesso: 04.03.2016. 
delegação sentia-se tranquila em subscrevê-la (PEB - F). O Ministro aponta, então, para a necessidade de sua aprovação pelo Legislativo.

PARECER dA COMISSÃO DE DIPLOMACIA (CD), OSVALdO TRIGUEIRO, 1953

[Câmara - Parecer 1]

O parecer, de 02.09.1953, é de autoria de Osvaldo Trigueiro. Após breve explanação a respeito da Convenção, aponta que o Brasil foi um dos 17 países que celebraram a Convenção sem ressalvas (PEB - F), e que a nossa Constituição garante os direitos previstos pela Convenção (DBR - F). As previsões do tratado tampouco são contrárias à legislação nacional (DBR - F).

Celebrá-la seria conveniente para que seu exemplo tenha influência na universalização de normas jurídicas a ser seguidas por todas as nações civilizadas (PEB - F). O parecer foi aprovado por unanimidade.

\section{PARECER DA COMISSÃO DE CONSTITUIÇÃO E JUSTIÇA (CD), NESTOR DUARTE, 1955}

[Câmara - Parecer 2]

O parecer, de 12.07.1955, é de autoria do Deputado Nestor Duarte. Após breve explicação sobre a Convenção, informa que suas disposições estão consagradas na Constituição pátria, confirmando seus princípios (DBR - F).

A Comissão, portanto, opina pela aprovação do projeto. O parecer foi aprovado por unanimidade.

PARECER DA COMISSÃO DE RELAÇÕES EXTERIORES (n. 1182 - SF), JOÃO VILLAS BOAS, 1955

[Senado - Parecer 1]

O parecer, de 19.10.1955, é de autoria de João Villas Boas, e apenas diz que a Convenção não inova na legislação pátria (DBR). O parecer é pela aprovação do projeto, e foi aprovado por unanimidade. 


\section{ANÁLISE: CONVENÇÃO SOBRE O ESTATUTO DOS APÁTRIDAS}

A Convenção Sobre o Estatuto dos Apátridas, de 28.09.1954, entrou em vigor internacional em 06.06.1960, de acordo com as disposições de seu artigo 39. A Convenção foi assinada pelo plenipotenciário brasileiro em 28.09.1954, e ratificada em 13.08.1996, entrando em vigor para o Brasil em 13.11.1996 (art. 39, $2^{\circ}$ ). Foi enviada ao Congresso Nacional por intermédio da Mensagem Presidencial 171, de 07.04.1993. Seu processo de aprovação tramitou na Câmara dos Deputados como Projeto de Decreto Legislativo 285, de 1993, e no Senado Federal como Projeto de Decreto Legislativo 56, de 1994. Foi aprovada pelo Decreto Legislativo 38, de 05.04.1995, e promulgada pelo Decreto Presidencial 4.246, de 22.05.2002.

O histórico do Estatuto remonta à década de 1920, no pós I Guerra Mundial, quando não havia clara distinção entre apátridas e refugiados. Ambos eram considerados pessoas sem a proteção de seu governo de origem, ou sem a proteção de qualquer outro governo. Questões relativas a nacionalidade, seja de múltiplas nacionalidades ou de perda da original, eram percebidas como de responsabilidade dos governos, mas a Liga das Nações começou a envidar esforços para auxiliar os indivíduos em situação de perigo. Após a II Guerra Mundial, questões como essa voltaram à agenda internacional, e os membros da recémcriada ONU fizeram significativo esforço para lidar com refugiados e apátridas, em documentos distintos. Era necessário melhorar a situação das pessoas sem Estado, e eliminar a apatridia. ${ }^{41}$ A Convenção foi elaborada para que aos apátridas fossem garantidos seus direitos, definindo-os como aqueles que não são reconhecidos como nacionais pela lei de nenhum Estado. ${ }^{42}$

\section{STATUS NA ONU}

https://treaties.un.org/Pages/ViewDetailsII.aspx?src=TREATY\&mtdsg_no=V-

$3 \&$ chapter $=5 \&$ Temp $=m t d s g 2 \&$ lang $=e n$

\footnotetext{
${ }^{41}$ Informação obtida em: http://legal.un.org/avl/ha/cssp/cssp.html. Acesso: 05.03.2016.

${ }^{42}$ Informação obtida em: http://www.unhcr.org/pages/4a2535c3d.html. Acesso: 08.03.2016. 


\section{MENSAGEM DO PODER EXECUTIVO (MSC 171/1993)}

A MSC 171, de 09.03.1993, foi enviada ao Congresso pelo Presidente Itamar Franco em 07.04.1993, e assinada por seu Ministro de Relações Exteriores, senhor Fernando Henrique Cardoso. Após breve histórico dos trabalhos preparatórios e da própria Convenção, o Ministro destaca que a mesma não foi imediatamente submetida à apreciação do Congresso quando assinada, apesar do parecer favorável, redigido à época pelo então consultor jurídico do MRE, embaixador Hildebrando Accioly. O tema, de acordo com o parecer, está intimamente ligado à situação dos refugiados, Convenção assinada pelo Brasil, devidamente aprovada e ratificada no início da década de 1960. Segundo Accioly, a Convenção, de tema extremamente relevante, é complexa, por abranger não somente apátridas que o são em virtude da legislação de seus Estados de origem, mas daqueles que abandonaram sua nacionalidade de maneira voluntária, em consequência de eventos políticos que aconteceram em seus países. Os primeiros seriam apátridas de jure, os últimos, de facto. A Convenção, no entanto, é aplicável, apenas, aos últimos.

Para o Ministro, as disposições da Convenção estão em conformidade com a legislação brasileira (DBR - F). Particularmente a respeito do princípio da reciprocidade, que abrange matérias como isenções fiscais, dispensa de vistos, cláusula da nação mais favorecida, entre outras, diz que possui aplicação mais restrita no âmbito legislativo, compreendido com o decorrente de normas internas e consistente com a concessão a estrangeiro de direitos outorgados aos nacionais por norma do país do qual ele é original. Essa classe de reciprocidade, apesar de existir em outras nações (menciona o Código Civil francês), é muito mais generosa no Brasil, onde o Código Civil prevê que "A lei não distingue entre nacionais e estrangeiros quanto á aquisição e ao gozo dos direitos civis" ${ }^{43}$

Particularmente a respeito da disposição convencional que determina a criação de título de viagem para que o apátrida possa sair do território do Estado que o acolheu, FHC recorda que, desde fins da década de 1920, é possível conceder passaporte a indivíduo sem

\footnotetext{
${ }^{43} \mathrm{O}$ artigo mencionado é o $3^{\circ}$ do Código Civil de 1916, vigente à época (Lei 3.071/1916). O Novo Código Civil (Lei 10.406/2002) não possui disposição semelhante, conforme quadro comparativo publicado pelo Senado Federal (Informação obtida em: http://www2.senado.leg.br/bdsf/bitstream/handle/id/70309/704509 .pdf? sequence=2. Acesso: 05.03.2016). A Constituição de 1988, porém, assegura, em seu art. $5^{\circ}$, que "Todos são iguais perante a lei, sem distinção de qualquer natureza, garantindo-se aos brasileiros e aos estrangeiros residentes no País a inviolabilidade do direito à vida, à liberdade, à igualdade, à segurança e à propriedade, nos termos seguintes: (..)".
} 
nacionalidade no Brasil (PBR - F). A partir de 1934, somente no Brasil, eles passaram a receber o "passaporte para estrangeiro", somente para uma viagem ao exterior, cessando seus efeitos uma vez atingido o local de destino; o que significa que não era documento hábil para retornar ao país. Na década de 1940, essa restrição foi diminuída, passando a ser possível o retorno desse indivíduo ao Brasil, respeitados alguns requisitos. Desde o "Estatuto do Estrangeiro", de 1969, (DBR - F) o termo "apátrida" passou a ser usado corretamente, e sua situação, à época da elaboração da mensagem, era idêntica à de qualquer estrangeiro registrado como permanente, podendo retornar independentemente de visto, desde que o fizesse dentro de dois anos da data que se ausentasse do país.

O Ministro aponta que a Convenção deve ser aprovada sem dúvidas, e uma de suas vantagens seria integrar à nossa nacionalidade pessoas que podem ser úteis para o Brasil (PBR - F). A Convenção tem como objetivo assegurar aos apátridas, indivíduos com a sina de não contar com a assistência dos próprios países (DH - apátridas - F), a situação de estrangeiro. Em casos como o da assistência social, assegura aos apátridas tratamento igual ao concedido aos nacionais, sendo, no Brasil, o objetivo primordial da seguridade social, a universalidade da cobertura (art. 194, § único, I) (DBR - F). ${ }^{44}$

O Brasil integra o protocolo anexo à Convenção Universal para a proteção do direito de autor, relacionado à proteção de apátridas e de refugiados, desde 1952 (versão original de Genebra) e, hodiernamente, desde a versão de Paris, da década de 1970 (DIN - F).

A Constituição Federal, no caput do art. $5^{\circ}$, posiciona brasileiros e estrangeiros residentes no país em situação de igualdade (DBR - F). O fato de um indivíduo não ter pátria não pode ser considerado uma desculpa para não lhe prover os Direitos Humanos concedidos aos que gozam de proteção estatal (PBR - F) (DH - apátrida - F). É necessário combater a apatridia.

Passaram 42 anos entre a assinatura, que ocorreu antes do regime militar, e a ratificação desse tratado, com a volta da democracia. O Executivo demorou 39 anos para enviar a MSC ao Congresso. (PBR - F)

\footnotetext{
${ }^{44}$ Art. 194. A seguridade social compreende um conjunto integrado de ações de iniciativa dos Poderes Públicos e da sociedade, destinadas a assegurar os direitos relativos à saúde, à previdência e à assistência social. Parágrafo único. Compete ao Poder Público, nos termos da lei, organizar a seguridade social, com base nos seguintes objetivos: I - universalidade da cobertura e do atendimento;
} 


\section{PARECER DA COMISSÃO DE CONSTITUIÇÃO E JUSTIÇA E DE REDAÇÃo (CD), RUBEM MEDINA, 1993}

[Câmara - Parecer 1]

O parecer, de 06.10.1993, descreve a tramitação da Convenção e menciona que a Comissão de Relações Exteriores, após aprovar a MSC 171/1993, fez proposta, no projeto de decreto legislativo, para que fossem sujeitos ao Congresso quaisquer atos que impliquem revisão da Convenção, ou que acarretem encargos ou compromissos gravosos, nos termos do art. 49, I, CF. Segundo o relator, não haveria inconstitucionalidade no projeto, (DBR - F) e, quando ao mérito, seria recomendável ratificar a Convenção, que possui louváveis propósitos humanitários ( $\mathrm{DH}$ - apátridas - F). A Convenção tenta solucionar, de modo que parece satisfatório, a questão da apatridia (PEB - F).

\section{PARECER DA COMISSÃO DE RELAÇÕES EXTERIORES E DEFESA NACIONAL (n. 84 - SF), PEDRO SIMON, 1995}

[Senado - Parecer 1]

O parecer é de 21.03.1995, e menciona parecer anterior, de autoria de Jarbas Passarinho, transcrevendo literalmente o parecer desse que, à época, já era ex-Senador. A seguir, o parecer de Jarbas Passarinho. ${ }^{45}$

\section{PARECER DA COMISSÃO DE RELAÇÕES EXTERIORES (SF), JARBAS PASSARINHO, 1994}

[Senado - Parecer 2]

O parecer é de 24.11.1994, e seu autor, Jarbas Passarinho, foi favorável à assinatura da Convenção. Após mencionar a tramitação do projeto até chegar à sua apreciação, inclusive parecer da década de 1950, de autoria de Hildebrando Accioly, descreve os aspectos fundamentais da Convenção. O Senador destaca que a matéria precisa de regulamentação jurídica de âmbito universal, para que não mais existam apátridas, sujeitos à desigualdade impostas por certas legislações nacionais (DH - apátridas - F). O Brasil

\footnotetext{
${ }^{45}$ A autora não teve acesso direto a esse parecer, mas, como foi transcrito na íntegra por Pedro Simon, foi aqui analisado.
} 
deveria aderir a esse texto de tão alto caráter humanitário, (PEB - F) que não colide com a legislação constitucional ou a ela inferior (DBR - F). 


\title{
6. ANÁliSE: CONVENÇÃO SOBRE A NACIONALIDADE DA MULHER CASADA
}

A Convenção sobre a Nacionalidade da Mulher Casada, de 20.03.2957, entrou em vigor internacional em 11.08.1958, de acordo com as disposições de seu artigo 6. Essa Convenção foi assinada pelo plenipotenciário brasileiro em 26.07.1966 e ratificada em 04.12.1968, entrando em vigor para o Brasil em 04.03.1969 (art. 5, $\S 2^{\circ}$ ). Foi enviada ao Congresso Nacional pela Mensagem Presidencial 149, de 06.10.1966. Seu processo de aprovação tramitou na Câmara dos Deputados como Projeto de Decreto Legislativo 306, de 1967, e no Senado Federal como Projeto de Decreto Legislativo 27, de 1967. Foi aprovada pelo Decreto Legislativo 27, de 25.06.1968, e promulgada pelo Decreto Presidencial 64.216, de 18.03.1969.

Antes da celebração da Convenção, não existia legislação que protegesse o direito das mulheres casadas de manter ou de renunciar à sua nacionalidade da mesma maneira permitida aos indivíduos do sexo masculino. Diversos grupos de apoio aos direitos das mulheres passaram a reivindicar a necessidade de proteção legal aos direitos de cidadania das mulheres casadas com homens nacionais de outros países. A Convenção foi o resultado de um esforço da comunidade internacional para garantir maior segurança jurídica às mulheres, ao estabelecer que nem a dissolução do casamento nem a mudança da nacionalidade do marido durante o casamento alterariam a sua nacionalidade. Trata-se da necessária separação jurídica entre a nacionalidade dos cônjuges. ${ }^{46}$

Foi feita reserva ao artigo 10 da Convenção. O artigo em pauta reza:

\begin{abstract}
Artigo 10: Toda questão que surja entre dois ou mais contratantes sobre a interpretação ou a aplicação da presente Convenção, que não seja resolvida por meio de negociações, será submetida à Corte Internacional de Justiça, para que esta a resolva, a petição de qualquer das partes em conflito, salvo que as partes interessadas concordem em um outro modo de solucioná-la.
\end{abstract}

Houve, porém, discussão intensa entre a Câmara e o Senado a respeito da reserva feita pelo Executivo. Ao ser debatida a reserva na Comissão de Relações Exteriores da Câmara, dois Deputados, Pedro Horta e José Carlos Guerra, manifestaram-se contra a inclusão da

\footnotetext{
46 Informações obtidas em: https://treaties.un.org/doc/Treaties/1958/08/19580811\%200134\%20AM/Ch_XVI_2p.pdf. Acesso: 06.03.2016.
} 
reserva no texto do Decreto. Apesar disso, a redação foi aprovada com a menção à reserva pela Comissão de Constituição e Justiça. Encaminhado para o Senado, este o emendou, excluindo a expressão, tida como contrária à Constituição pelo Senados Aloísio Carvalho. Uma vez emendado o projeto, este retornou à Câmara, para apreciação da emenda elaborada pelo Senador José Leite. ${ }^{47}$ Foi elaborado novo parecer, da lavra do Deputado Wilson Martins, da Comissão de Constituição e Justiça da Câmara, favorável à emenda, segundo o qual não haveria necessidade nem legitimidade do Congresso para repetir a reserva feita pelo Executivo de maneira explícita.

\section{STATUS NA ONU}

https://treaties.un.org/pages/ViewDetailsIII.aspx?src=TREATY\&mtdsg_no=XVI$2 \&$ chapter $=16 \&$ Temp $=$ mtdsg $3 \&$ lang $=$ en\#EndDec

\section{MENSAGEM DO PODER EXECUTIVO (MSC 149/1966)}

A Mensagem 749, de 06.10.1966, assinada pelo Ministro Juracy Magalhães, foi enviada ao Congresso pelo Presidente Humberto de Alencar Castello Branco em 23.11.1966. O Ministro faz breve menção a alguns artigos da Convenção, e assinala que a legislação nacional tradicionalmente acolhe o princípio da livre escolha em relação à aquisição da nacionalidade, possibilitando a concessão da naturalização nos casos em que o naturalizando tem cônjuge brasileiro (DBR - F).

O Ministro destaca que a Convenção foi celebrada com reserva ao artigo 10, relativo à jurisdição compulsória da Corte Internacional de Justiça (CIJ). O artigo torna obrigatória a competência da Corte, a pedido de qualquer das partes envolvidas na disputa, e, por essa razão, fazer a reserva foi considerado conveniente (PEB - C).

\section{PARECER COMISSÃO DE RELAÇÕES EXTERIORES (CD), LUIZ FRANSCICO, 1967 \\ [Câmara - Parecer 1]}

\footnotetext{
${ }^{47}$ Conforme o parecer 550, de 1967, do Senado Federal.
} 
O parecer, elaborado pelo Deputado Luiz Francisco, em 18.01.1967, após breve relatório a respeito da Convenção, declara não ter objeções à sua aprovação, por seguir as diretrizes da DUDH (DIN - F). A Convenção também se coaduna com a legislação brasileira, que concede à mulher livre escolha para adquirir a nacionalidade do cônjuge, permitindo a naturalização de estrangeiro casado com brasileiro (DBR - F).

\section{PARECER DA COMISSÃO DE CONSTITUIÇÃO E JUSTIÇA (CD), NELSON CARNEIRO, 1967}

[Câmara - Parecer 2]

O parecer, de 17.04.1967, é de autoria do Deputado Nelson Carneiro e aprova a Convenção, concordando com a reserva ao art.10. Segundo o Deputado, as condições entre homens e mulheres devem ser iguais em todos os sentidos, “(...) e será proclamada, em outra Convenção, quando os homens abandonarem a pretensão de uma falsa superioridade, que os fatos desmentem a cada momento (DH - nacionalidade da mulher casada - F). Segundo o Deputado, é necessário repudiar legislações que desconsideram o reconhecimento de decisões judiciais relativas ao status matrimonial, e os estadistas precisam se empenhar nesse sentido (PEB - F).

O Deputado chama atenção para o fato de a Convenção, adotada em 1957, apenas tenha sido assinada pelo Brasil quase dez anos depois (PEB - F); e, uma vez assinada, tenha levado 120 dias para que se iniciasse sua apreciação pelo Congresso (PBR - F). Acrescenta que isso demonstra o quão injustificável era o Projeto de Constituição, enviado ao Congresso, segundo o qual "os tratados se consideram aprovados se o Congresso Nacional não resolver o contrário, dentro de cento e vinte dias a contar de seu recebimento" (PBR F). O Deputado congratula seus pares por ter ficado o texto constitucional (referente à Constituição de 1967) assim:

Art. 47 - É da competência exclusiva do Congresso Nacional:

I - resolver definitivamente sobre os tratados celebrados pelo Presidente da República; (...)

Parágrafo único: O Poder Executivo enviará ao Congresso Nacional, até quinze dias após sua assinatura, os tratados celebrados pelo Presidente da República" (DBR - F). 


\section{VOTOS EM SEPARADO, DJALMA MARINHO E PEDROSO HORTA}

[Câmara - Vt Sep 1]

Ainda na CCJ, foram explicitados os votos dos senhores Djalma Marinho e Pedroso Horta, de 18.04.1967, que têm interpretação distinta do art. 47, I, CF/1967, apontado pelo relator. Os Deputados mencionam o art. 83, VIII, CF/1967, que dispõe a respeito da competência privativa do Presidente para celebrar tratados ad referendum, ou seja, para a aprovação, do Congresso (DBR - F). Disso resulta que o chefe do Poder Executivo é o responsável por negociar o tratado e celebrá-lo, cabendo ao Congresso aprová-lo ou não, sem a possibilidade de emendá-lo. Esse foi o papel do Congresso durante toda a tradição constitucional brasileira, desde o Império. (PBR - F) O Executivo age como parte do tratado que é, gestor da política externa do país. (PEB - F)

Assim, os Deputados acreditam que o Decreto Legislativo em pauta não deve conter a reserva ao art. 10 da Convenção, que é ato exclusivo do Poder Executivo.

\section{EMENDA DO SENADO AO PROJETO DA CÂMARA DOS DEPUTADOS, 1967}

Destaco aqui que, apesar da manutenção da menção à reserva na redação final no PDC 306-A, que tramitou na Câmara dos Deputados, a redação final do PDC 306-D, elaborada após o recebimento da emenda do Senado, e o Decreto Legislativo 27, de 25.06.1968, promulgado pela presidência do Senado Federal, que aprova a Convenção, não fazem menção à reserva ao artigo 10.

Isso se deu em virtude da Emenda proposta pela Comissão de Relações Exteriores do Senado, assinada pelo Presidente da Casa, Senador Auro Moura Andrade, em 12.10.1967, ao Projeto de Decreto que tramitou na Câmara dos Deputados. Nela, propõe-se que seja suprimida a expressão "com reserva quanto ao artigo X" e seja acrescentada a expressão "nos termos em que foi assinado pelo Governo da União". 48

\footnotetext{
48 Sobre o "Governo da União": a pessoa jurídica de Direito Internacional Público, responsável por assinar tratados, é a República Federativa do Brasil, e não a União. A União representa a República no âmbito interno.
} 
PARECER DA COMISSÃO DE RELAÇÕES EXTERIORES (n. 470 - SF), JOSÉ LEITE, 1967

[Senado - Parecer 1]

O parecer, de 13.06.1967, de autoria de José Leite, após relatar a tramitação do projeto na Câmara, apenas oferece um substitutivo à redação original, que retira a menção à reserva e acrescenta ao texto que aprova a Convenção a expressão “(...) nos termos em que foi assinado pelo Poder Executivo". O Senador não faz nenhuma argumentação, tampouco explica quaisquer motivos.

PARECER dA COMISSÃo de CONSTITUIÇÃO E JUSTIÇA (n. 471 - SF), ALOYSIO DE CARVALHO, 1967

[Senado - Parecer 2]

O parecer, de 21.06.1967, de autoria do Senador Aloysio de Carvalho, trata da emenda que o Senado pretende fazer ao Projeto proveniente da Câmara. O Senador destaca que, conforme o texto do art. 10 da Convenção, não restaria à outra parte a possibilidade de se opor em caso de envio de uma contenda à apreciação da CIJ. O Brasil fez reserva a essa cláusula, sem que se possa saber qual o motivo do Executivo para tanto (PBR - F). Aponta, porém, a menção à reserva na MSC, segundo a qual o artigo pressupõe a jurisdição compulsória da CIJ, sendo a Corte, portanto, o principal recurso a ser utilizado pelas partes em situação de conflito. Caso a outra parte não concordasse em recorrer à Corte, haveria decisão à revelia, ou seja, ouvida apenas uma das partes, ou, em casos extremos, a denúncia do tratado pela parte discordante.

Assim, opina o Senador pela prudência da decisão do governo brasileiro (PEB - F), mesmo que, em um tratado como o que se tem em pauta, o apelo à CIJ seja uma maneira de prestigiar a Corte como "organismo supranacional” (DIN - F), apto a dirimir controvérsias, particularmente aquelas que podem estar no âmbito de aplicação da Convenção sobre a Nacionalidade da Mulher Casada (PEB - F).

Para o Senador, se o Congresso concorda com a "ressalva" apresentada pelo Poder Executivo, bastaria aprovar o tratado nos termos em que foi assinado por este Poder (PBR C). Para embasar seu entendimento, cita doutrina de autoria do embaixador Rubens Ferreira de Melo, na obra "Dicionário de Direito Internacional Público" (1962), que trata de reservas a tratados. A Convenção em pauta permite a aposição de reservas, com exceção de alguns 
artigos, que constituem aspectos principais do tratado. As reservas apostas pelo governo brasileiro, portanto, não dependeriam de confirmação explícita por parte do Poder Legislativo (PBR - F). Esse comportamento seria destoante com a Constituição, (DBR - F) que especifica as atribuições particulares a cada Poder.

Assim, opina pela coerência legislativa da Emenda Substitutiva da CRE-SF, que exclui a referência à reserva ao artigo 10, e inclui a expressão "nos termos em que [a Convenção] foi assinada pelo Poder Executivo" (PBR - C). O Senador destaca, ainda, que seria melhor dizer "Governo da República”, pois se, dentro do país, é o Poder Executivo, auxiliado pelos Ministros de Estado, o responsável por celebrar tratados, convenções e atos internacionais (conforme os artigos 74 a 83, VIII, CF) (DBR - F); no âmbito internacional é o Estado, representado por seu governo, quem assina o ato (PEB - F).

A Emenda é plenamente constitucional, assim como o é a assinatura da Convenção, louvável orientação para o direito nacional (PBR - F).

\section{PARECER DA COMISSÃO DE LEGISLAÇÃO SOCIAL (n. 472 - SF), JÚLIO LEITE, 1967}

[Senado - Parecer 3]

O parecer, de 22.06.1967, de autoria do Senador Júlio Leite, após relatório acerca da tramitação do PDC, aponta que a Convenção é uma conquista da ONU em relação ao reconhecimento universal dos Direitos Humanos, independentemente de raça, de sexo, de crença ou de convicção política $(\mathrm{DH}-\mathrm{ONU}-\mathrm{F})$. Destaca que é louvável a previsão da Convenção de que o casamento entre nacionais e estrangeiros, a dissolução do vínculo matrimonial ou a modificação de nacionalidade do marido não poderão, ipso facto, alterar a nacionalidade da esposa (DH - mulher - F). Nela, as partes contratantes também estabeleceram processo especial e privilegiado de naturalização, por intermédio do qual a mulher de um nacional pode adquirir a nacionalidade do marido de maneira facilitada, ressalvados interesses de segurança nacional ou de ordem pública.

A Convenção estaria em perfeita consonância com o direito brasileiro (DBR - F), particularmente com o princípio da liberdade de escolha para a aquisição de nacionalidade, facilitando sua aquisição em caso de cônjuge brasileiro. Seria interessante a adesão do Brasil a esse instrumento, por assegurar a proteção à mulher brasileira casada com nacionais de Estados signatários (PBR - F). 
O relator, entretanto, não se manifesta a respeito da reserva, e diz que essa questão será melhor apreciada pela CRE-SF.

PARECER DA COMISSÃO DE REDAÇÃO (n. 659 - SF), BEZERRA NETO, 1967 [Senado - Parecer 4]

O parecer, do Senador Bezerra Neto, de 03.10.1967, aprecia o PDS 27/1967, que aprova a Convenção. O parecer refere-se, apenas, à emenda proposta pelo Senador Aloysio de Carvalho, no que adiciona a expressão "nos termos em que [o tratado] foi assinado pelo Governo da União" e suprime a menção à reserva. O Senador aponta o lapso da Comissão, que desconsiderou a adição mencionada, e corrige-o.

\section{PARECER DA COMISSÃO DE RELAÇÕES EXTERIORES (CD) A RESPEITO DA EMENDA DO SENADO AO PDC 306/1967}

[Câmara - Parecer 3]

O relatório, de 07.11.1967, é de autoria do Deputado Gilberto Azevedo, e faz uma recapitulação da tramitação do PDC 306/1967. No parecer, diz que, de fato - e isso estaria claro para todos os parlamentares - o artigo 10 da Convenção faz menção à jurisdição compulsória da CIJ.

Artigo 10: Toda questão que surja entre dois ou mais contratantes sobre a interpretação ou a aplicação da presente Convenção, que não seja resolvida por meio de negociações, será submetida ã Corte Internacional de Justiça, para que esta a resolva, a petição de qualquer das partes em conflito, salvo que as partes interessadas concordem em um outro modo de solucioná-la.

Não haveria nenhuma disposição imperativa nesse artigo, apenas exemplificativo: a Convenção admite que, caso surja uma contenda entre duas ou mais partes, que não seja resolvida por negociação, poderá ser submetida à apreciação da CIJ, por pedido de qualquer das partes envolvidas no conflito. O artigo, porém, determina uma exceção: salvo se as partes interessadas convenham solucionar o conflito de outro modo (DIN - F).

O Deputado, portanto, apoia a emenda proposta pelo Senado Federal. 
PARECER DA COMISSÃO DE CONSTITUIÇÃO E JUSTIÇA (CD), WILSON MARTINS, 1967

[Câmara - Parecer 4]

O parecer, de 08.11.1967, aprecia a emenda acima mencionada, proposta pelo Senado. O parecer é favorável à emenda, e o Congresso deve, a partir desse momento, manifestar sua concordância com a "ressalva" feita, no tempo devido, pelo Brasil. 


\section{ANÁLISE: CONVENÇÃO CONCERNENTE À ABOLIÇÃO DO TRABALHO FORÇADO (CONVENÇÃO 105, OIT)}

A Convenção concernente à abolição do Trabalho Forçado, ou Convenção 105 da OIT, de 25.06.1957, entrou em vigor internacional em 17.01.1959, de acordo com as disposições de seu artigo $4^{\circ}$. Essa Convenção foi ratificada em 18.06.1965, entrando em vigor para o Brasil em 18.06.1966 (art. 4 ${ }^{\circ} \S 3^{\circ}$ ). Foi enviada ao Congresso Nacional pela Mensagem Presidencial 143, de 1958. Seu processo de aprovação tramitou na Câmara dos Deputados como Projeto de Decreto Legislativo 164, de 1964; e no Senado Federal como Projeto de Decreto Legislativo 113, de 1964. Foi aprovada pelo Decreto Legislativo 20, de 30.04.1965, ${ }^{49}$ e promulgada pelo Decreto Presidencial 58.822, de 14.07.1966.

$\mathrm{O}$ assunto da Convenção, o trabalho forçado, foi o primeiro tema tratado no âmbito internacional, primeiramente pelo Congresso de Viena, em 1815, e depois pela Liga das Nações (LDN), após o término da I Guerra Mundial. Na década de 1930, a OIT abordou a situação na Convenção 29, sobre o uso de trabalho compulsório, definido como todo tipo de trabalho ou de serviço feito por indivíduo sob ameaça de penalidade, e para o qual essa pessoa não se tenha oferecido voluntariamente. A Convenção também requer que a utilização forçada de mão de obra seja considerada ilegal nos países signatários. Em acréscimo à Convenção 29, a Convenção 105 proíbe o trabalho compulsório como meio de coerção política, educação ou punição pela manifestação de posicionamento político ou ideologias opostas àquelas do sistema político, social ou econômico vigentes. ${ }^{50}$

É, no mínimo, curioso o fato de essas disposições terem sido internalizadas durante a ditadura no Brasil.

\section{STATUS NA OIT}

http://www.ilo.org/dyn/normlex/en/f?p=1000:11300:0::NO:11300:P11300_INSTRUME NT_ID:312250

\footnotetext{
${ }^{49}$ Este Decreto aprovou as seguintes Convenções adotadas pela Conferência-Geral da OIT, que tramitaram em conjunto na Câmara dos Deputados e no Senado Federal: 21, 22, 91, 93, 94, 97, 103, 104, 105, 106 e 107. O Decreto expressamente rejeita a Convenção 90, OIT, relativa ao Trabalho Noturno de Menores na Indústria (1948).

50 Informações obtidas em: http://www.oit.org.br/sites/all/forced labour/oit/convencoes/convencoes.php e http://www.ilo.org/century/history/iloandyou/WCMS_189599/lang--en/index.htm. Acesso: 07.03.2016.
} 
PARECER DA COMISSÃO PERMANENTE DE DIREITO SOCIAL DO MINISTÉRIO DO TRABALHO E PREVIDÊNCIA SOCIAL (n. 7), EVARISTO DE MORAES FILHO, 1958

[Executivo - outras manif]

O parecer, de 23.01.1958, é de autoria de Evaristo de Moraes Filho. Após apresentar histórico da Convenção, resultado do esforço de outros instrumentos internacionais que a antecederam, aponta que esse tratado foi o resultado de um esforço dos participantes da $40^{\mathrm{a}}$ Conferência Internacional do Trabalho, ao adotarem propostas novas relativas à abolição de formas de trabalho forçado ou obrigatório, uma violação dos direitos do homem, conforme definição da Carta da ONU e da DUDH (DIN - F).

Quanto aos dois aspectos principais do tratado - a forma adotada pelo instrumento e a abolição de todas as formas de trabalho forçado - destaca que a intenção da delegação brasileira foi adotar uma convenção que condenasse todas as modalidades de trabalho forçado (PEB - F). Diferentemente de uma simples recomendação, o tratado vincula juridicamente os países que o ratificam, e o Brasil teria muito a lucrar com a ratificação desse tratado, por ter envidado esforços em seus trabalhos preparatórios (PEB - F).

Em relação ao mérito da Convenção, o Brasil não deveria ter receios em internalizála. Não se adota, no país, nenhuma modalidade de trabalho forçado, rejeitado pela legislação $(\mathrm{DBR}-\mathrm{F})^{51}$ e pela prática brasileira $(\mathrm{PBR}-\mathrm{F})$.

Não existiriam, assim, obstáculos materiais ou formais para a ratificação da Convenção 105, uma vez que seu texto não entraria em conflito com os "hábitos da gente brasileira" nem com a prática do trabalho na indústria, no comércio e na agricultura existente no país (PBR - F), tampouco com a legislação nacional. Moraes Filho, então, dá o seu parecer no sentido de o Presidente enviar a Convenção para a apreciação do Poder Legislativo, pedindo, encarecidamente, sua pronta ratificação.

\section{MENSAGEM DO PODER EXECUTIVO (MSC 143/1958)}

A Mensagem 143, de 23.05.1958, foi assinada pelo Ministro José Carlos de Macedo Soares, e enviada ao Poder Legislativo pelo Presidente Juscelino Kubitschek em 28.05.1958.

${ }^{51}$ Menciona a Constituição Federal, o Código Penal e a CLT. 
A Mensagem encaminha à apreciação do Congresso diversas Convenções da OIT, entre as quais a Convenção 105, aqui analisada. Segundo o Ministro, tanto a forma jurídica da Convenção, uma vitória para o Brasil (PEB - F), como seu mérito, em nada prejudicam os hábitos brasileiros, tampouco as práticas trabalhistas existentes no país (PBR - F) ou a legislação nacional (DBR - F), voltada para a proteção do ser humano em todas as suas manifestações de liberdade e de livre expressão (DH - F). A necessidade de ratificação da Convenção é ainda mais patente ao considerar que representa a proibição de um dos tipos possíveis de concorrência desleal na competição internacional por mercado (PEB - F).

Os países signatários comprometeram-se a submetê-la à apreciação dos órgãos nacionais competentes, e, assim, o Ministro aponta para a necessidade de submetê-la ao Congresso.

\section{PARECER DA COMISSÃO DE CONSTITUIÇÃO E JUSTIÇA (CD), NELSON CARNEIRO, 1964}

[Câmara - Parecer 1]

No parecer, de 03.06.1964, de autoria de Nelson Carneiro, o Deputado reitera os pontos da MSC 143/1958, e acrescenta que a Convenção não fere os hábitos brasileiros, as práticas de trabalho existentes no país (PBR - F) e, tampouco, a legislação nacional voltada para a proteção do ser humano em todas as manifestações de liberdade e de livre expressão de sua personalidade (DBR - F). A ratificação faz-se ainda mais conveniente se considerado o fato de que representa a proscrição de uma das possíveis formas de concorrência desleal na competição internacional por mercados (PEB - F).

\section{PARECER DA COMISSÃO DE RELAÇÕES EXTERIORES (CD), EWALDO PINTO, 1964}

[Câmara - Parecer 2]

O parecer, de 01.07.1964, é de autoria do Deputado Ewaldo Pinto. Nele, o Deputado apenas aprova a Convenção 105, sem análise do texto.

\section{PARECER DA COMISSÃO DE LEGISLAÇÃO SOCIAL (CD), GEREMIAS FONTES, 1964 \\ [Câmara - Parecer 3]}


O parecer, de autoria do Deputado Geremias Fontes, é de 26.08.1964. Após mencionar como se deu a tramitação da Convenção, e transcrever alguns de seus artigos, diz ser favorável à sua ratificação.

PARECER DA COMISSÃo de CONSTITUIÇÃO E JUSTIÇA (n. 350 - SF), JEFFERSON DE AGUIAR, 1964

[Senado - Parecer 1]

O parecer, de 12.11.1964, é de autoria do Senador Jefferson Aguiar. Nele, o Senador trata das diversas Convenções aprovadas pelo PDS 113/1964, e aponta que o Congresso não deveria se pronunciar antes de audiência dos Ministérios do Trabalho e Previdência Social e das Relações Exteriores, para manifestarem-se a respeito de todas as convenções apreciadas pelo PDS, e do Ministérios da Justiça e da Agricultura, especificamente, sobre a Convenção 105 .

Em parecer de mesmo número, de 09.04.1965, o Senador refere-se a esse parecer, mas não acrescenta nada em relação à Convenção 105.

\section{MANIFESTAÇÃO DO MINISTÉRIO DAS RELAÇÕES EXTERIORES, VASCO LEITÃO DA CUNHA, 1965}

[Executivo - parecer MRE]

O parecer, de autoria do senhor Ministro das Relações Exteriores, senhor Vasco Leitão da Cunha, de 09.02.1965, trata de todas as convenções aprovadas pelo PDS. A respeito da Convenção 105, não haveria o que se opor: o Ministro não apresenta nenhum motivo particular para justificar sua posição. Não tratarei, aqui, dos argumentos referentes às outras Convenções, que não são aqui analisadas.

\section{PARECER DO MINISTÉRIO DA JUSTIÇA E ASSUNTOS INTERIORES, ALOÍSIO ADJUCTO SILVEIRA,1965}

[Executivo - outras manif]

O parecer, de 15.02.1965, é de autoria de Aloísio Adjucto Silveira, da Consultoria Jurídica. O parecer apenas endossa as conclusões do parecer do Deputado Nelson Carneiro, apontando, apenas, pela constitucionalidade do projeto (DBR - F). 
PARECER DA COMISSÃO DE RELAÇÕES EXTERIORES (n. 351 - SF), ANTONIO CARLOS, 1965

[Senado - Parecer 2]

O parecer, de 11.11.1965, é da autoria do Senador Antonio Carlos. Após descrever brevemente cada uma das Convenções a serem aprovadas, o Senador diz ser favorável ao projeto, que seria condizente com a legislação nacional (DBR - F).

PARECER DA COMISSÃO DE LEGISLAÇÃO SOCIAL (n. 352 - SF), VIVALDO LIMA, 1965

[Senado - Parecer 3]

O parecer, de 24.11.1965, é de autoria do Senador Vivaldo Lima. Segundo ele, não haveria nenhuma contraindicação na aprovação das Convenções, não apresentando, porém, argumentos para corroborar sua posição. 


\section{ANÁlise: CONVENÇão PARA A REDUÇão DOS CASOS DE APATRIDIA}

A Convenção para a redução de casos de Apatridia, de 30.08.1961, entrou em vigor internacional em 13.12.1975, de acordo com as disposições de seu artigo 18. Foi assinada pelo plenipotenciário brasileiro em 30.08.1961, e a acessão ocorreu em 25.10.2007, entrando em vigor para o Brasil em 23.01.2008. Foi enviada ao Congresso pela Mensagem Presidencial 370, de 2001. Seu processo de aprovação tramitou na Câmara dos Deputados como Projeto de Decreto Legislativo 2.999, de 2003, e no Senado Federal como Projeto de Decreto Legislativo 26, de 2007. Foi aprovada pelo Decreto Legislativo 274, de 2007, e promulgada pelo Decreto Presidencial 8.501, de 18.08.2015.

A Convenção tem como objetivo prevenir e reduzir a apatridia, ou situação de apátrida, aquele sem Estado, heimatlos. Estabelece estrutura internacional que assegura os direitos de todos os seres humanos à nacionalidade, demandando aos Estados que estabeleçam medidas protetivas em suas legislações nacionais para prevenir a apatridia no nascimento, e desse momento em diante. Quiçá, a determinação mais relevante desse instrumento seja a previsão de que crianças devem adquirir a nacionalidade do país em que nasceram, se não possuírem o direito legal de adquirir qualquer outra. A Convenção estabelece um conjunto de salvaguardas para prevenir a apatridia como consequência de perda ou de renúncia de nacionalidade, além de casos de sucessão de Estado. O tratado estabelece rol limitado de situações nas quais os Estados podem privar indivíduos de sua nacionalidade. ${ }^{52}$

A Convenção foi assinada com reserva ao art. $8, \S 3$, a, ii, como será relatado adiante..$^{53}$

\footnotetext{
${ }^{52}$ Informações obtidas em: http://www.unhcr.org/pages/4a2535c3d.html. Acesso: 08.03.2016.

53 Declaração que consta no endereço eletrônico da ONU: "On 10 December 2009, the Secretary-General received from the Government of Brazil, the following communication: "In reference to the instrument of accession relating to the Convention on the Reduction of Statelessness, concluded in New York on 30 August 1961, the Government of the Federative Republic of Brazil declares that, in accordance with Article 8, paragraph 3, sub-paragraph "a", item "ii" of the Convention, the Federative Republic of Brazil retains the right to deprive a person of his nationality when he conducts himself in a manner seriously prejudicial to the vital interests of the Brazilian State.

The Secretary-General also wishes to communicate the following information received by the Government of Brazil on 18 December 2009 (Original: English):

"The National Congress of Brazil approved the text of the Convention on the Reduction of Statelessness by means of Legislative Decree n. 274, of 4 October 2007. In accordance with Legislative Decree n. 274/2007,
} 


\section{STATUS NA ONU}

https://treaties.un.org/pages/ViewDetails.aspx?src=TREATY\&mtdsg_no=V$4 \&$ chapter $=5 \&$ lang $=$ en

\section{PARECER DE BRUNO FERRAZ COUTINHO, CONSULTORIA JURÍDICA DA SECRETARIA DE ESTADO DAS RELAÇÕES EXTERIORES, SEM DATA}

[Executivo - Parecer MRE]

Trata-se de parecer emitido pela Consultoria Jurídica da Secretaria de Estado das Relações Exteriores, da lavra do então Terceiro Secretário, Bruno Ferraz Coutinho, aprovado em 01.10.1998, pelo Consultor Jurídico do Ministério, Antônio Paulo Cachapuz de Medeiros. Seus argumentos serão incluídos no trabalho como argumentos do Poder Executivo, apesar de não serem de elaboração do Ministro das Relações Exteriores. O parecer explica a situação dos apátridas, o instituto jurídico desses indivíduos e experiências anteriores para protegê-los juridicamente. A legislação brasileira, particularmente a Constituição, é uma das mais abrangentes em termos de nacionalidade, admitindo tanto o jus soli quanto o jus sanguinis. Não haveria, portanto, conflito entre a Convenção e o ordenamento jurídico pátrio (DBR - F).

Existiriam, porém, pontos sensíveis. O primeiro deles relaciona-se com o art. 1, que estende o direito de jus soli a qualquer indivíduo que, de outro modo, poderia ser considerado apátrida. Conforme a Constituição, existe uma exceção à regra de jus soli, que se dá em caso de nascimento no Brasil de filho de pais estrangeiros a serviço de seu país. ${ }^{54}$ Isso se dá em virtude da excepcional proteção diplomática de que gozam esses indivíduos. Poderia ser um caso de incompatibilidade entre a Convenção e a Constituição, mas isso advém da distinção, no Brasil, entre brasileiros natos e naturalizados. A Convenção não menciona a figura do nacional nato, diferenciando-o do naturalizado. Como o direito que se pretende assegurar

the text of the Convention is approved expressly with the restriction allowed for in article 8 (3) (a) (ii) of the Convention, so that the Federative Republic of Brazil retains the right to deprive a person of his nationality when he conducts himself in a manner seriously prejudicial to the vital interests of the Brazilian State." In this regard, it is noted that the instrument of accession to the Convention deposited by Brazil with the SecretaryGeneral on 25 October 2007 did not specify the above restriction, in accordance with article 8 (3) of the Convention. Informação obtida em: https://treaties.un.org/pages/ViewDetails. aspx? src=TREATY\&mtdsg_no=V-4\&chapter=5\&lang=en. Acesso: 08.03.2016.

${ }^{54}$ Conforme o art. 12. I, a, CF, que reza: Art. 12. São brasileiros: I - natos: a) os nascidos na República Federativa do Brasil, ainda que de pais estrangeiros, desde que estes não estejam a serviço de seu país; (...). 
pela Convenção é, justamente, o de naturalização, nada impediria que o Brasil se obrigasse a conceder a naturalização aos que, mesmo sendo filhos de estrangeiros a serviço de seu país, corressem o risco de ficar em situação de apatridia se não fosse a concessão brasileira. Essa solução não contrariaria a Constituição pátria (DBR - F).

O segundo aspecto relaciona-se ao art. 3 da Convenção:

Art. 3: Para o fim de se determinarem as obrigações dos Estados Contratantes nos termos da presente Convenção, o nascimento a bordo de um navio ou uma aeronave será considerado como ocorrido no território do Estado de cuja bandeira for o navio ou no território do Estado em que a aeronave estiver matriculada, conforme o caso.

O artigo é conflitante com a Constituição, que determina serem brasileiros natos todos os nascidos na República Federativa do Brasil, exceto no caso do art. 12, I, a, CF, pois determina que nascidos em navio ou em aeronave, mesmo que no território do Brasil, não seriam brasileiros, mas nacionais do país cuja bandeira o navio ostenta, ou de onde for registrada a aeronave. Apesar dessa aparente discrepância, Coutinho aponta que somente seria aplicada essa norma em caso de brasileiros em território estrangeiro, uma vez que estrangeiros em território brasileiro não correm o risco de se tornarem apátridas, conforme disposição constitucional (DBR - F).

A Convenção, ademais, permite o estabelecimento de reservas. Entretanto, o autor do parecer entende não serem necessárias. De qualquer modo, destaca a disposição do art. $8^{\circ}$, 3: no caso do Brasil, a retenção de direitos deve compreender a disposição do art. $8^{\circ}, 3$, a ii, que prevê a possibilidade de cancelamento da naturalização por conduta prejudicial aos interesses vitais do Estado (DBR - F). A Mensagem 370/2001 tratará da discussão a respeito desse disposto convencional.

\section{MENSAGEM DO PODER EXECUTIVO (MSC 370/2001)}

A Mensagem 370, de 16.04.2001, foi elaborada pelo Ministro das Relações Exteriores, senhor Celso Lafer, e encaminhada pelo Presidente Fernando Henrique Cardoso ao Congresso em 24.04.2001. Segundo o Ministro, o Brasil teve atuação de destaque nas Conferências da ONU preparatórias da Convenção, com a atuação do Embaixador Gilberto Amado (PEB - F). A Convenção está inserida em contexto histórico de conscientização 
internacional para os contingentes populacionais sem nacionalidade, percebendo-se que, para o exercício pleno dos direitos previstos na DUDH, era essencial que todos tivessem garantida sua nacionalidade (DIN - F) ${ }^{55} \mathrm{~A}$ assinatura da Convenção sobre o Estatuto dos Apátridas, de 1954, (DIN - F) foi importante, mas não suficiente para lidar com o problema, sendo necessário dar um passo adiante e tomar medidas mais assertivas para solucionar o problema da apatridia, que culminou na elaboração da presente Convenção.

Após descrição minuciosa da Convenção, o Ministro aponta a previsão do art. 8, 3, a, ii:

\begin{abstract}
Artigo 8.1. Os Estados Contratantes não privarão uma pessoa de sua nacionalidade se essa privação vier a convertê-la em apátrida.

3. Não obstante o disposto no parágrafo 1 deste Artigo, os Estados Contratantes poderão conservar o direito de privar uma pessoa de sua nacionalidade se, no momento da assinatura, ratificação ou adesão, especificarem que se reservam tal direito por um ou mais dos seguintes motivos, sempre que estes estejam previstos em sua legislação nacional naquele momento:

a) quando, em condições incompatíveis com o dever de lealdade ao Estado Contratante, a pessoa: (...)

(ii) tiver se conduzido de maneira gravemente prejudicial aos interesses vitais do Estado;
\end{abstract}

Considerando a disposição constitucional do art. $12, \S 4^{\circ}, I^{56}$ reitera a necessidade de que o país reserve o direito especificado na disposição constitucional (DBR - C).

Lafer destaca, ainda, que o Brasil assinou o Estatuto dos Apátridas em 28.09.1954, e sua aprovação pelo Poder Legislativo ocorreu em 05.04.1995, sendo o instrumento de ratificação depositado em 30.04.1996, no primeiro mandato de FHC. A adesão à Convenção fortalece o compromisso assumido pelo Brasil quando da assinatura do Estatuto, e reforça o compromisso com a proteção dos Direitos Humanos (PEB - F).

\footnotetext{
${ }^{55}$ Apesar de não se tratar de documento de Direito Internacional em sentido estrito - ou seja, não ser um tratado e, portanto, não passar pelo rito de internalização comum aos tratados - a autora optou por classificar a DUDH como menção a instrumento de Direito Internacional, em virtude de sua relevância normativa para esse sistema, e de se tratar de documento paradigmático para a proteção dos Direitos Humanos desde a metade do século $\mathrm{XX}$.

${ }^{56}$ Artigo $12, \S 4^{\circ}$. Será declarada a perda da nacionalidade do brasileiro que:

I - tiver cancelada sua naturalização, por sentença judicial, em virtude de atividade nociva ao interesse nacional; (...)
} 


\section{PARECER COMISSÃO DE RELAÇÕES EXTERIORES E DE DEFESA NACIONAL (CD), JOSÉ LOURENÇO, 2002}

[Câmara - Parecer 1]

O parecer, de autoria do Deputado José Lourenço, após relatório sobre o teor da MSC 370/2001, aponta que a celebração do instrumento foi há quarenta anos, no período do pós II Guerra Mundial, momento de rearranjo do cenário político europeu. Retoma o argumento utilizado na Mensagem, de que, para a completa proteção dos direitos previstos na DUDH (DIN - F), é necessário que todos tenham proteção estatal (DH - F). Aponta para o ineditismo da Convenção, que contém em seus dispositivos hipóteses fáticas de configuração da apatridia, para que, uma vez verificada essa situação, seja possível determinar, conforme o caso concreto, a qual Estado caberá outorgar a respectiva nacionalidade ao indivíduo sem pátria.

O Deputado faz a mesma ressalva em relação à necessidade de especificar a reserva do direito de privar indivíduo de sua nacionalidade, consoante a combinação do art. $8^{\circ}, 3$, a, ii da Convenção e do art. 12, §4 $4^{\circ}, \mathrm{I}, \mathrm{CF}$ (DBR - C). Ademais, ressalta a assinatura do Estatuto dos Apátridas em 1954 e sua aprovação legislativa em 1995, e que a adesão à Convenção apenas complementaria e fortaleceria os compromissos assumidos pelo país no sentido de reforçar o compromisso com os Direitos Humanos (PEB - F).

\section{PARECER COMISSÃO DE CONSTITUIÇÃO E JUSTIÇA E DE REDAÇÃO (CD), ALOYSIO NUNES FERREIRA, 2003}

[Câmara - Parecer 2]

O parecer, de 2003, é de autoria do Deputado Aloysio Nunes Ferreira, que, após breve relatório, menciona que a competência regimental da CCJR, conforme o art. 32, III de seu Regimento Interno, é analisar os aspectos constitucionais, legais, jurídicos, regimentais e de técnica legislativa de projetos submetidos à apreciação da Câmara ou de suas Comissões, bem como o mérito daqueles projetos que tratem de temas como nacionalidade e cidadania. Menciona, também, as atribuições constitucionais reservadas ao Presidente da república (art. 84, VIII) e ao Congresso Nacional (art. 49, I) (DBR - F). 
O relator aponta que cabe reparo ao parágrafo único do art. $1^{\circ}$ do projeto apresentado, para que sua redação seja aprimorada. ${ }^{57}$ Quanto ao mérito da Convenção, o parecer é favorável, e não apresenta qualquer argumento nesse sentido.

\section{PARECER DA COMISSÃO DE CONSTITUIÇÃO E JUSTIÇA E DE REDAÇÃo (CD), CARLOS SAMPAIO, 2003}

[Câmara - Parecer 3]

O parecer, de 2003, é de autoria do Deputado Carlos Sampaio. Relatório e análise da Convenção são exatamente iguais ao apresentado pelo Deputado Aloysio Nunes. Por isso, o segundo não será considerado neste trabalho.

\section{PARECER DA COMISSÃO DE RELAÇÕES EXTERIORES E DEFESA NACIONAL (SF), ROMEU TUMA, 2007}

[Senado - Parecer 1]

O autor para o parecer seria o Senador Eduardo Suplicy, mas o relatório foi elaborado pelo relator ad hoc, Romeu Tuma. O Senador aponta que a existência de mecanismos inovadores de participação do indivíduo, como sujeito de direitos, não retira a necessidade de vínculo entre pessoa e Estado, do qual decorre a proteção de direitos essenciais (DH apátridas - F). No contexto internacional, a personalidade jurídica do Estado é preeminente, e é por intermédio dele que as reivindicações dos cidadãos são conduzidas (DIN - F). Destaca o fato de que mesmo sistemas regionais de proteção dos Direitos Humanos e mecanismos como o TPI reconhecem a jurisdição internacional como complementar à nacional - e, por isso, exigem o esgotamento dos recursos internos para que as demandas lhe sejam encaminhadas (DIN - F).

A situação atípica da apatridia, atentatória aos direitos mais básicos do homem, previstos pela DUDH (DIN - F), deve ser combatida. O Brasil é signatário de diversos tratados que a reconhecem como situação de intolerável vulnerabilidade da condição humana (DIN - F), sendo o país tradicional militante nas causas humanitárias e na defesa

\footnotetext{
${ }^{57}$ Para conhecimento do leitor, a redação ficaria da seguinte maneira: "Parágrafo único. Nos termos do inciso I, do art. 49, da Constituição Federal, ficam sujeitos à aprovação do Congresso Nacional quaisquer atos que possam resultar em revisão da referida Convenção, assim como quaisquer ajustes complementares que acarretem encargos ou compromissos gravosos ao patrimônio nacional.
} 
internacional dos Direitos Humanos, (PEB - F) o que está consignado na Constituição pátria (DBR - F). Faz crítica ao Legislativo, que "chega tardiamente à análise do texto da Convenção em tela" (PBR - F). Aprovar a Convenção é oportuno para dar maior coerência ao rol de instrumentos multilaterais a respeito do tema. (PEB - F) 


\section{ANÁLISE: CONVENÇÃO INTERNACIONAL SOBRE A ELIMINAÇÃO DE TODAS AS FORMAS DE DISCRIMINAÇÃO RACIAL}

A Convenção Internacional sobre a Eliminação de todas as formas de Discriminação Racial, de 07.03.1966, entrou em vigor internacional em 04.01.1969, conforme seu artigo 19, 30 dias após o depósito do $27^{\circ}$ instrumento de ratificação ou acessão. Essa Convenção foi assinada pelo plenipotenciário brasileiro em 07.03.1966, e ratificada em 27.03.1968. Foi enviada ao Congresso pela Mensagem Presidencial 748, de 1966. Seu processo de aprovação tramitou na Câmara dos Deputados como Projeto de Decreto Legislativo 305, de 1967, e no Senado Federal como Projeto de Decreto Legislativo 20/1967. A Convenção foi aprovada pelo Decreto Legislativo 23, de 21.06.1967, e promulgada pelo Decreto Presidencial 65.810, de 08.12.1969.

Posteriormente, foi enviada a MSC 895/2001, para solicitar a aprovação para fazer a Declaração Facultativa presente no art. 14 da Convenção, reconhecendo a competência do Comitê Internacional para a Eliminação da Discriminação Racial para receber e analisar denúncias de violação dos direitos humanos previstos na Convenção. A atribuição dessa competência ao Comitê passou a ter efeito após o depósito da décima declaração nesse sentido, em 03.12.1982, conforme o art. 14, $\S 1^{\circ}$ da Convenção. A Mensagem tramitou pela Câmara dos Deputados como PDC 895/2001; e no Senado Federal como PDS 369/2002. O Congresso Nacional aprovou a solicitação por meio do Decreto Legislativo 57, de 26.04.2002, promulgado pelo Decreto Presidencial 4.738, de 12.06.2003. A Declaração foi depositada junto à Secretaria Geral da ONU em 17.06.2002.

O histórico da elaboração da Convenção remonta ao início da década de 1960, quando a Subcomissão sobre a prevenção da discriminação e a proteção de minorias, ao examinar os dados relacionados às manifestações de antissemitismo e outras formas de preconceito racial e de intolerância religiosa, propôs iniciativas mais enérgicas para combater essas atitudes. A Convenção condena a discriminação racial, persegue todos os meios necessários e apropriados para uma política que elimine a discriminação racial em todas as suas formas. A Convenção estabelece um Comitê para a eliminação da discriminação racial, que deve se 
reportar anualmente à AGNU a respeito de medidas adotadas pelos Estados signatários para efetivar a Convenção, e que pode lidar com conflitos existentes entre esses Estados. ${ }^{58}$ STATUS NA ONU

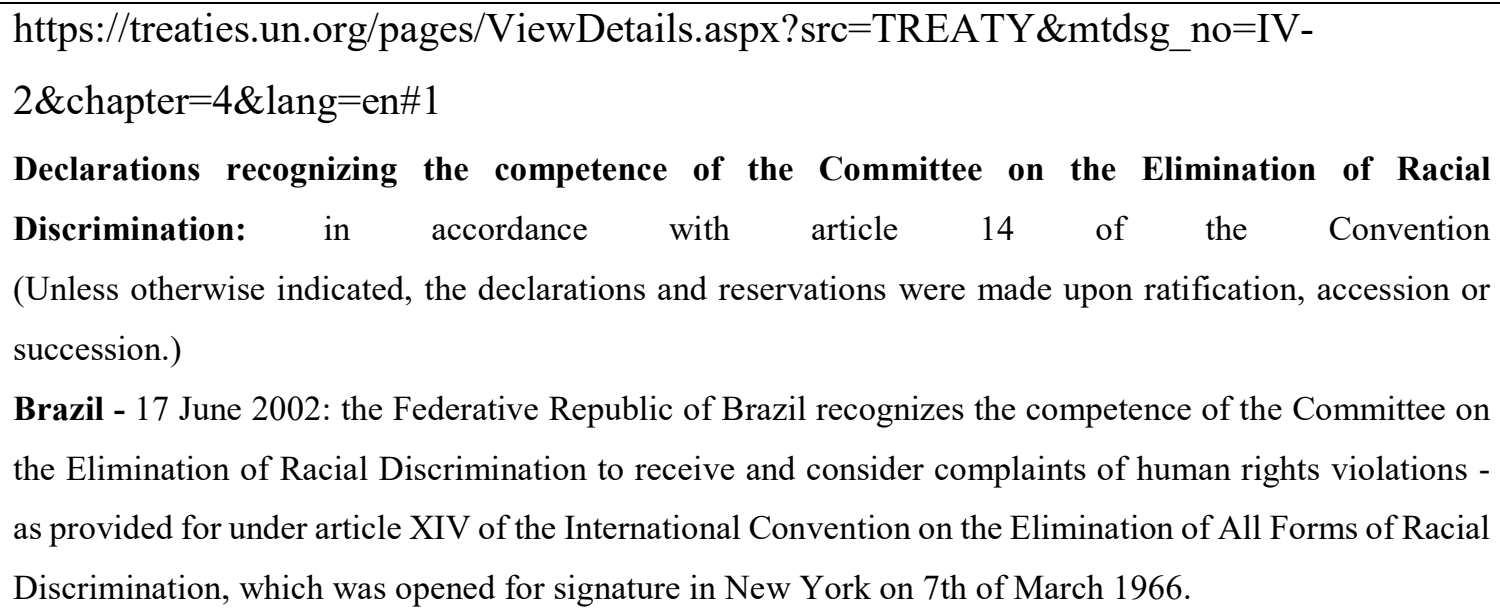

Brazil - 17 June 2002: the Federative Republic of Brazil recognizes the competence of the Committee on the Elimination of Racial Discrimination to receive and consider complaints of human rights violations as provided for under article XIV of the International Convention on the Elimination of All Forms of Racial Discrimination, which was opened for signature in New York on 7th of March 1966.

\section{MENSAGEM DO PODER EXECUTIVO (MSC 748/1966)}

A Mensagem 748, de 11.10.1966, foi redigida pelo Ministro das Relações Exteriores, Juracy Magalhães, e enviada pelo Presidente Castello Branco ao Congresso Nacional em 23.11.1966.

O Ministro destaca diversos aspectos da Convenção, que viria "ao encontro da tradicional política brasileira de igualdade racial" (PBR - F). ${ }^{59}$ Sua ratificação seria uma evidência da sinceridade e da boa-fé dos Estados em relação à defesa dos Direitos Humanos, particularmente do Brasil, o primeiro país a assinar o instrumento (PEB - F).

O Brasil, ao assinar a Convenção, não depositou a declaração facultativa prevista no art.14. O país não reconhecia, nesse primeiro momento, a competência para receber e para analisar denúncias a respeito de violações dos direitos humanos do Comitê sobre a Eliminação da Discriminação Racial.

\footnotetext{
${ }^{58}$ Informações obtidas em: http://legal.un.org/avl/ha/cerd/cerd.html. Acesso: 09.03.2016.

${ }^{59}$ DCN 23.01.1967, p. 292, col. 1.
} 


\section{PARECER DA COMISSÃO DE RELAÇÕES EXTERIORES (CD), LUIZ FRANCISCO, 1967}

[Câmara - Parecer 1]

O parecer, elaborado pelo Deputado Luiz Francisco, de 19.01.1967, após relato sobre a Convenção, aponta para o repúdio tradicional do nosso país à discriminação racial (PBR F), não poupando esforços para defender políticas não segregacionistas no contexto internacional (PEB - F). O parecer é, pois, pela aprovação do Projeto.

\section{PARECER COMISSÃO DE CONSTITUIÇÃO E JUSTIÇA (CD), YUKISHIGUE TAMURA, 1967}

[Câmara - Parecer 2]

Conforme o parecer da CCJ, nas palavras do relator Yukishigue Tamura, de 11.04.1967, a Convenção obedece às normas seguidas pela ONU, em defesa dos Direitos Humanos e das liberdades individuais (DIN - F). Os membros da ONU, gozando dessa posição privilegiada, estabeleceram a conduta que deveria ser tomada para proteger esses direitos e, nesse sentido, foi criado um Comitê pela Convenção. O projeto de decreto legislativo apresentado não teria nenhum conflito com as normas institucionais vigentes à época, e não haveria nada que afetasse a sua juridicidade (DBR - F).

A aprovação da Convenção seria, para o relator, "mais um passo para a completa extinção do segregacionismo racial em nosso país" (PBR - F). ${ }^{60}$

\section{MANIFESTAÇÃO CD, DAYL DE ALMEIDA, 1967}

[Câmara - Vt Sep 1]

Logo após o relatório da CCJ, no momento de encaminhamento do projeto à votação, manifestou-se o Deputado Dayl de Almeida. Segundo o Deputado, “O Brasil tem tradições etimológicas que nos permitem aprovar o presente Decreto Legislativo em consonância com os rumos da nossa evolução social." (PBR - F). ${ }^{61}$ Ele continua, dizendo que "O caldeirão de todas as raças no melting-pot brasileiro, no dizer de Roquete Pinto, nos transformou na maior democracia racial dos últimos séculos." ${ }^{62}$ (PBR - F).

\footnotetext{
${ }^{60}$ DCN 12.04.1967, p. 1.232, col. 2.

${ }^{61}$ DCN 12.04.1967, p. 1.232, col. 3.

${ }^{62}$ DCN 12.04.1967, p. 1.232, col. 3.
} 
Menciona a principal obra de Gilberto Freyre (Casa-Grande \& Senzala), que retrata a miscigenação racial; e Oliveira Viana, autor que mostra que os preconceitos de raça no Brasil teriam dado lugar aos preconceitos de classe. Para o Deputado, por se tratar de um problema sociológico, o racismo no Brasil seria apenas pedagogicamente atenuado por leis e por convenções (PBR - F). Seria necessário reformular a mentalidade dos povos.

Para ele, qualquer legislação contrária às disposições da DUDH seria um retrocesso às disposições desse instrumento internacional (DIN - F). Termina a sua manifestação louvando a miscigenação social brasileira, a "paz interna" entre as raças no país (PBR - F), e o fato de que é necessário reconhece, cristãmente, que "todos os homens são filhos de Deus, irmãos de Jesus Cristo herdeiro do Céu".

\section{PARECER DA COMISSÃO DE RELAÇÕES EXTERIORES (n. 352 - SF), MÁRIO MARTINS, 1967}

[Senado - Parecer 1]

Conforme o parecer do Senador Mário Martins, de 24.05.1967, apesar de não inovar os princípios contidos na Carta da $\mathrm{ONU}$, ela reiterou as disposições que tratam da defesa dos Direitos Humanos e das liberdades fundamentais, não admitindo discriminação em razão de raça, de sexo ou de crença religiosa (DIN - F). Segundo o relator, o Brasil é conhecido como país que nunca ficou indiferente às discriminações raciais existentes no mundo (PEB - F), por ser um modelo de miscigenação racial (PBR - F). É um dos poucos Estados que possui uma lei específica a respeito da matéria, conhecida como Lei Afonso Arinos (DBR - F). ${ }^{63}$

Aponta que somente com o apoio do Brasil na ONU foi possível a aprovação de medidas, por parte do governo da África do Sul, para sanar as injustiças político-raciais que ocorreram durante o regime de apartheid (PEB - F). O parecer é, assim, pela aprovação da Convenção.

\footnotetext{
${ }^{63}$ Trata-se da Lei 1.390, de 03.07.1951, que inclui entre as contravenções penais a prática de atos resultantes de preconceitos de raça ou de cor. Foi promulgada pelo Presidente Getúlio Vargas. Informação obtida em: http://www2.camara.leg.br/legin/fed/lei/1950-1959/lei-1390-3-julho-1951-361802-normaatualizada-pl.pdf. Acesso: 09.03.2016.
} 
PARECER DA COMISSÃO DE EDUCAÇÃO E CULTURA (n. 353 - SF), ÁLVARO MAIA, 1967

[Senado - Parecer 2]

O parecer de Álvaro Maia, de 11.05.1967, após descrição da Convenção, aponta que se baseia em diversos instrumentos internacionais que a precederam, como a "Declaração sobre a Outorga de Independência aos países e povos coloniais" (14.12.1960), e a "Declaração sobre a erradicação de todas as formas de discriminação étnica" (20.11.1963), além do "Acordo sobre Discriminação no emprego e na ocupação" (1958), da OIT e da Convenção contra Discriminação no Ensino (1960), da UNESCO. (DIN - F)

Segundo o Senador, toda forma de discriminação racial é atentatória à liberdade humana (DH - discriminação - F). O Estado, protetor dos cidadãos, deve assegurar a eles o gozo de seus direitos (PBR - F). Não existiria maior atentado ao progresso de uma sociedade democrática do que as práticas e os processos discriminatórios que decorrem das distinções étnicas, que historicamente alimentaram o ódio nas sociedades (PBR - F).

O parecer é pela aprovação do projeto.

\subsection{PROJETOS DA CÂMARA E DO SENADO PARA A APROVAÇÃO DE DECLARAÇÃO FACULTATIVA À CONVENÇÃO}

Em razão do seu íntimo relacionamento com a Convenção acima descrita, segue a descrição do trâmite dos projetos da Câmara e do Senado Federal que apreciam a solicitação de que o Brasil faça a declaração facultativa, prevista no art. 14 da Convenção, ${ }^{64}$

\footnotetext{
${ }^{64}$ Artigo 14

1. Todo o Estado parte poderá declarar e qualquer momento que reconhece a competência do Comitê para receber e examinar comunicações de indivíduos sob sua jurisdição que se consideram vítimas de uma violação pelo referido Estado Parte de qualquer um dos direitos enunciados na presente Convenção. 0 Comitê não receberá qualquer comunicação de um Estado Parte que não houver feito tal declaração.

2. Qualquer Estado parte que fizer uma declaração de conformidade com o parágrafo do presente artigo, poderá criar ou designar um órgão dentro de sua ordem jurídica nacional, que terá competência para receber e examinar as petições de pessoas ou grupos de pessoas sob sua jurisdição que alegarem ser
} 
reconhecendo a competência do Comitê Internacional para a Eliminação da Discriminação Racial para receber e analisar denúncias de violação de Direitos Humanos nela previstos.

\section{MENSAGEM DO PODER EXECUTIVO (MSC 1309/2000)}

A Mensagem 1309, de 06.09.2000, assinada pelo Ministro Luiz Felipe Lampreia, foi encaminhada ao Congresso Nacional pelo Presidente Fernando Henrique Cardoso, em 20.09.2000. Na Mensagem, o Ministro informa o Congresso a respeito da tramitação da Convenção durante a década de 1960, e destaca que o Brasil, à época, não realizou a declaração facultativa para receber e analisar as denúncias a respeito de violações dos Direitos Humanos. Após descrever as competências do Comitê, elencadas no art. 15 da Convenção, afirma que o sistema, pioneiro, trata de relevante precedente para que sejam estabelecidos mecanismos semelhantes em outras áreas de defesa e de promoção dos Direitos Humanos na ONU, reconhecidos pelo Brasil (PEB - F).

Segundo ele, o reconhecimento do Comitê tem sido pedido manifestado por distintas partes da sociedade nacional, e a atuação do governo nesse sentido seria resposta apropriada para essas expectativas (PBR - F), principalmente no momento que antecipa a realização da III Conferência Mundial contra o Racismo, a discriminação racial, a xenofobia e a intolerância correlata, que se realizou na África do Sul, em 2001. Esse gesto demonstraria o compromisso internacional, assumido pelo Brasil, com a defesa dos Direitos Humanos (PEB - F). Aponta, ainda, para a concordância do Secretário de Estado dos Direitos Humanos com o reconhecimento da competência do Comitê de que trata a Convenção, e propõe o depósito do instrumento de declaração facultativa.

vítimas de uma violação de qualquer um dos direitos enunciados na presente Convenção e que esgotaram os outros recursos locais disponíveis. (...)

6. a) O Comitê levará, a título confidencial, qualquer comunicação que Ihe tenha sido endereçada, ao conhecimento do Estado Parte que, pretensamente houver violado qualquer das disposições desta Convenção, mas a identidade da pessoa ou dos grupos de pessoas não poderá ser revelada sem o consentimento expresso da referida pessoa ou grupos de pessoas. O Comitê não receberá comunicações anônimas.

b) Nos três meses seguintes, o referido Estado submeterá, por escrito ao Comitê, as explicações ou recomendações que esclarecem a questão e indicará as medidas corretivas que por acaso houver adotado. (...) 


\section{PARECER DO CONSULTOR JURÍDICO DA SECRETARIA DE ESTADO DAS RELAÇÕES EXTERIORES, ANTONIO CACHAPUZ DE MEDEIROS, 2000}

[Executivo - Parecer MRE]

O parecer n. 45, de 04.09.2000, solicitado ao consultor jurídico do Itamaraty, Antônio Paulo Cachapuz de Medeiros, pelo Subsecretário-geral de assuntos políticos, explicita que o reconhecimento da competência do Comitê Internacional para a eliminação da discriminação racial é uma opção voluntária dos Estados signatários da Convenção. No momento em que o Poder Legislativo brasileiro concordou em ratificar a Convenção, conferiu ao Poder Executivo a prerrogativa de reconhecer a competência obrigatória do Comitê a qualquer momento (PBR - não pode ser considerado direito, é discussão política - F). Segundo o parecer, portanto, trata-se de faculdade do Presidente da República, como chefe do Poder Executivo, dar execução à Convenção, tratado devidamente aprovado pelo Congresso Nacional.

Destaca, entretanto, que em caso análogo, ${ }^{65}$ apesar de ter sido exarado parecer semelhante, opinando pela desnecessidade da submissão do ato de reconhecimento ao Congresso, o governo da época optou por pedir a autorização do Legislativo (PBR - F).

\section{PARECER DA COMISSÃO DE RELAÇÕES EXTERIORES E DE DEFSA NACIONAL (CD), FERNANDO GABEIRA, 2001}

[Câmara - Parecer 1]

O parecer, de 14.02.2001, é de autoria do Deputado Fernando Gabeira, faz breve relatório no qual relata o histórico da Convenção e da declaração facultativa. Para ele, ao reconhecer a possibilidade prevista no art. 14 da Convenção, o Brasil concede mais um instrumento de proteção dos direitos de todos os seus cidadãos (PBR - F). Ademais, os procedimentos previstos para que o indivíduo, que não teve seus direitos protegidos pelo Estado, tenha acesso ao Comitê são de praxe no âmbito da proteção aos Direitos Humanos, e confere significativa responsabilidade aos órgãos nacionais de defesa desses direitos (PBR

\footnotetext{
65 Parecer sobre o reconhecimento da competência obrigatória da Corte Interamericana de Direitos Humanos, conforme disposição do art. 62 do Pacto de São José da Costa Rica.
} 
- F), pois estes se sujeitarão ao controle da sociedade internacional, por meio do Comitê (PEB - F).

O parecer é, portanto, favorável à aprovação da declaração facultativa.

\section{RELATÓRIO COMISSÃO DE CONSTITUIÇÃO E JUSTIÇA E DE REDAÇÃo (CD), REGINALDO GERMANO, 2001}

[Câmara - Parecer 2]

O Relatório do Deputado Reginaldo Germano, de 2001 (sem data exata), tem como objeto a aprovação do Projeto de Decreto Legislativo 895/2001, referente à solicitação de fazer a declaração facultativa, prevista no art. 14 da Convenção.

O relator apresenta o exposto na MSC 1309/200 e no Parecer 45/2000 da Consultoria Jurídica da Secretaria de Estado das Relações Exteriores, ambos apresentados acima, além do parecer do Deputado Fernando Gabeira.

O relator vota pela inexistência de empecilho para que se aprove o projeto de Decreto Legislativo 895/2001, para a elaboração da declaração facultativa prevista no art. 14 da Convenção.

\section{PARECER DA COMISSÃO DE RELAÇÕES EXTERIORES E DEFESA} NACIONAL (n. 81 - SF), GERALDO CÂNDIDO, 2002

[Senado - Parecer 1]

O parecer, de autoria do Senador Geraldo Cândido, de 26.02.2002, aponta ser a declaração facultativa conveniente e oportuna aos interesses nacionais (PBR - F), em virtude da relevância do comprometimento do Brasil com a proteção internacional dos Direitos Humanos (PEB - F). O Senador, assim como fez o consultor jurídico do Itamaraty, mencionou a declaração facultativa do Pacto de São José da Costa Rica (DIN - F), apontando que não há dúvidas de que cabe ao Congresso dar a opinião última no que se refere à permissão ao Executivo para incorporar obrigações internacionais ao ordenamento jurídico interno (PBR - F).

O voto do Senador é pela conveniência do projeto, que em nada destoa da legislação nacional (DBR - F). 


\section{ANÁlise: PACTO INTERNACIONAL SOBRE DIREITOS CIVIS E POLÍTICOS E}

\section{ANÁLISE: PACTO INTERNACIONAL SOBRE DIREITOS ECONÔMICOS, SOCIAIS E CULTURAIS}

O Pacto Internacional sobre Direitos Civis e Políticos (PIDCP), de 16.12.1966, entrou em vigor internacional em 23.03.1976, conforme as disposições do seu art. 49. A acessão do Brasil a esse Pacto ocorreu em 24.01.1992, e ratificação em 24.04.1992, entrando em vigor para o Brasil na mesma data (art. 49, $\S 2^{\circ}$ ). Foi enviado ao Congresso Nacional por meio da Mensagem Presidencial 620, de 1985. Seu processo de aprovação tramitou na Câmara dos Deputados como Projeto de Decreto Legislativo 131, de 1986, e no Senado Federal como Projeto de Decreto Legislativo 4, de 1987. Foi aprovado pelo Decreto Legislativo 226, de 12.12.1991, e promulgado pelo Decreto Presidencial 592, de 06.07.1992.

O Pacto Internacional sobre Direitos Econômicos, Sociais e Culturais (PIDESC), de 16.12.1966, está em vigor internacional desde 03.01.2976, e seguiu a mesma tramitação interna que o PIDCP. O Brasil acedeu ao tratado em 24.01.1992, que foi promulgado pelo Decreto Presidencial 591, de 06.07.1992.

A história de ambos os Pactos está intimamente ligada, o que é possível perceber pela sua tramitação interna. Ambos foram celebrados na mesma data, no contexto do pós II Guerra Mundial, quando a comunidade internacional entrou em consenso a respeito da necessidade de evitar novas catástrofes mundiais, colocando o ser humano sob sua tutela. Demonstrou-se que governos nacionais podiam ser ineficientes para combater calamidades em escala mundial, ou, inclusive, ser perpetradores dessas catástrofes. Era necessário proteger seres humanos de seus governos, e uma Organização Internacional, a ONU, foi criada para garantir essa proteção.

Durante a Conferência de São Francisco, diversos países reivindicaram a inclusão, na Carta da ONU, de disposições mais minuciosas acerca dos Direitos Humanos. Em um primeiro momento, foi elaborada a DUDH, e, quase duas décadas depois, foram celebrados os Pactos, juridicamente vinculantes para seus signatários, diferentemente da Declaração, e que detalharam os direitos dos quais a humanidade deveria gozar. Em um contexto de Guerra Fria, sendo difícil atingir consenso a respeito da inserção desses direitos em documento 
único ou em dois tratados separadamente, optou-se pela segunda opção, o que possibilitou a adesão de diversos países, que, com raras exceções, assinam ambos os tratados.

A separação entre os Pactos é percebida, particularmente, sob a perspectiva estatal. Se o PIDCP trata dos Direitos Humanos ditos “tradicionais”, presentes em documentos como a Declaração francesa dos Direitos do Homem e do Cidadão (1789/1791), e dependentes, de certo modo, de "obrigação de não fazer" do Estado, ou uma abstenção, o PEDESC garante direitos que dependem de uma ação estatal. Conforme as prescrições do PIDCP, o Estado não deve, por exemplo, deter seus cidadãos de maneira arbitrária, tampouco julgá-los sem garantir o contraditório e a ampla defesa, ou restringir a liberdade de expressão. A estrutura dos direitos econômicos, sociais e culturais, por sua vez, depende de atuação assertiva do Estado, de uma obrigação de fazer, de prover a educação, a saúde e outras garantias para os cidadãos. É claro que se pode criticar essa distinção, posto que a realização de eleições ou o devido processo legal não prescindem de atuação estatal, mas foi o modo encontrado pelos países para garantir a assinatura de, ao menos, um dos Pactos pelos países que, em caso de documento único, não adeririam ao tratado. ${ }^{66}$

\section{STATUS NA ONU:}

PIDCP:https://treaties.un.org/pages/viewdetails.aspx chapter $=4 \& s r c=$ treaty\&mtdsg_no $=$ iv-4\&lang=en

PIDESC:https://treaties.un.org/Pages/ViewDetails.aspx?src=TREATY\&mtdsg no=IV$3 \&$ chapter $=4 \&$ lang $=$ en

\section{PARECER DO CONSULTOR JURÍDICO DO ITAMARATY, HAROLDO VALLADÃO, SOBRE A ASSINATURA DOS PACTOS, 1968}

O parecer, de 31.10.1968, é de autoria do professor Haroldo Valladão, e responde ao questionamento do Ministro das Relações Exteriores a respeito da assinatura, pelo Brasil, dos dois Pactos aqui analisados, bem como do protocolo adicional ao PIDCP. Segundo Valladão, a Secretaria-Geral Adjunta para Organismos Internacionais opinou pela assinatura dos Pactos, opondo-se à assinatura do protocolo, ressaltando a previsão do direito de petição

66 Informações obtidas em: http://legal.un.org/avl/ha/iccpr/iccpr.html e http://legal.un.org/avl/ha/icescr/ icescr.html. Aceso: 10.03.2016. 
individual contra Estados-membro que o tenham assinado, em virtude de violações dos Direitos Humanos. Ainda de acordo com a Secretaria-Geral, a matéria de que trata o protocolo opcional estava, originalmente, incluída no PIDCP, e o Brasil tentou, ativamente, mantê-la em instrumento separado e opcional. A competência do Comitê de Direitos do Homem não pressupõe decisões obrigatórias para os Estados signatários, mas, de qualquer modo, entendeu que o Brasil não deveria fazer parte desse tratado, que admitiria a intervenção, mesmo que limitada, de órgão internacional em sua soberania. A Secretaria entendeu, portanto, que o Brasil deveria assinar os Pactos, mas sem fazer a declaração unilateral de reconhecimento da competência do Comitê nem, tampouco, assinar o Protocolo Opcional.

O consultor concorda com a assinatura dos Pactos, que seriam compatíveis com o direito brasileiro (DBR - F). Sobre o Protocolo Opcional, “(...) a tendência universal é no sentido que ali ficou expresso, e, como jurista, parece-me plenamente aceitável" (PEB - F) ${ }^{67}$ Entretanto, pondera, o tema teria conotações políticas que explicariam a perspectiva da Secretaria. O ideal seria a manifestação do Ministério da Justiça, no qual funciona a Comissão Nacional dos Direitos Humanos, presidida pelo respectivo Ministro. ${ }^{68}$

\section{DISCURSO DO PRESIDENTE JOSÉ SARNEY NA ABERTURA DA 40} ASSEMBLEIA GERAL DA ORGANIZAÇÃO DAS NAÇÕES UNIDAS

[Executivo - outras Manif.]

Apesar de não existir regra escrita nesse sentido, existe uma tradição, que remonta aos primeiros anos de trabalho da ONU, de plenipotenciário do Brasil, muitas vezes o Presidente da República, ter o privilégio de fazer o pronunciamento inicial dos trabalhos da AGNU.

\footnotetext{
${ }^{67}$ Pareceres dos Consultores Jurídicos do Itamaraty, vol. VI, p. 267.

${ }^{68}$ São mencionados, no Parecer de Antonio Augusto Cançado Trindade à Convenção Americana de Direitos Humanos - Pacto de São José da Costa Rica, outros dois pareceres elaborados pelo Poder Executivo, relativos aos Pactos de 1966: parecer, de junho de 1970, da Consultoria Jurídica do Ministério da Justiça, e parecer, de março de 1971, do Ministério do Trabalho e Previdência Social. A autora, entretanto, não teve acesso a esses pareceres, que não se encontravam nem no dossiê do PCD nem do PDS, obtidos, respectivamente, nos arquivos da Câmara dos Deputados e do Senado Federal. Serão mencionados no item 22 deste capítulo, entretanto, os argumentos apresentados no Parecer de Cançado Trindade a respeito dos Pactos. Remeto o leitor, portanto, a esse item.
} 
Essa tradição teve início na segunda AGNU, na qual discursou o então Ministro das Relações Exteriores, senhor Oswaldo Aranha. O motivo apontado por alguns para a concessão dessa benesse ao Brasil é o contexto da Guerra Fria e a necessidade de evitar tensões entre as superpotências, uma vez que o Brasil era considerado neutro. Apesar de não ser confirmada por dispositivo expresso, essa tradição nos é relevante aqui pois, em um desses pronunciamentos, o Presidente do Brasil, senhor José Sarney, mencionou a necessidade de assinatura dos Pactos que aqui se analisam. O discurso, proferido em Nova Iorque, a 23.09.1985, logo após o término do regime militar no país,${ }^{69}$ servirá de material para a presente tese, apenas no que se refere à assinatura dos Pactos. Vamos a ele.

O Presidente aponta para o fato de os Direitos Humanos, e, particularmente, a DUDH (DIN - F), serem os pilares para o convívio entre nações díspares. Ao tratar dos Direitos Humanos, Sarney aponta a decisão de aderir aos Pactos mencionados acima (PEB - F), além da adesão à Convenção contra a Tortura e outros Tratamentos ou Penas Cruéis, Desumanos ou Degradantes (DIN - F). Com essa atitude, o Brasil daria um passo em direção à afirmação democrática do país (PBR - F), reiterando, perante seus cidadãos e a sociedade internacional (PEB - F), o compromisso com os princípios descritos pela Carta da ONU (DIN - F), e com a promoção da dignidade do ser humano (DH - F).

\section{MENSAGEM DO PODER EXECUTIVO (MSC 620/1985)}

A Mensagem do Poder Executivo (MSC 620, de 28.11.1985) foi enviada ao Congresso Nacional em 13.02.1986, pelo Presidente da República, José Sarney, e seguida de exposição de motivos elaborada pelo Ministro das Relações Exteriores, senhor Olavo Setúbal. Essa Mensagem submeteu à apreciação do Congresso os textos do Pacto Internacional sobre Direitos Civis e Políticos e do Pacto Internacional sobre Direitos Econômicos, Sociais e Culturais, juntamente com o Protocolo Facultativo relativo ao último.

Em breve descrição dos Pactos, o Presidente aponta que ambos apresentam, com maior nitidez, aspectos previstos na DUDH (DIN - F). Se, porém, o PIDCP envolve a necessidade de omissão estatal, por descrever direitos relativos à liberdade do indivíduo -

\footnotetext{
${ }^{69} \mathrm{O}$ discurso faz menção à ditadura, ao dizer, por exemplo, que "O Brasil acaba de sair de uma longa noite", ou que " $O$ instrumento de nossa viagem do autoritarismo para a democracia foi a capacidade de conciliar $e$ de entender, sem violência e sem traumatismos".
} 
exemplificativamente, o Estado compromete-se a não perseguir seus cidadãos por motivos de raça, religião; e não os torturar - o PIDESC pressupõe a atuação do Estado, que, dependendo de seus recursos, poderá proteger de maneira mais ou menos eficiente os direitos de seus cidadãos. Deste modo, os direitos descritos pelo último Pacto possuem característica programática, devendo os Estados signatários assumir a obrigação de adotar, progressivamente, medidas que assegurem o gozo desses direitos. Para o Presidente, os Pactos constituem, somados à DUDH, os instrumentos de Direito Internacional Público mais importantes no âmbito dos Direitos Humanos (DIN - F).

Após explicar o teor dos Pactos, o Presidente passa aos motivos pelos quais o Brasil deveria internalizá-los. Essas razões seriam diversas:

(i) A ativa participação brasileira na elaboração dos Pactos; (PEB - F)

(ii) A votação favorável à Resolução 2.200/1966 da AGNU, pela qual os Pactos foram adotados e abertos à assinatura; (PEB - F)

(iii) $\mathrm{O}$ fato de, à época, ambos os Pactos contarem com aproximadamente 80 (oitenta) signatários, ${ }^{70}$ pertencentes a distintos sistemas de organização jurídica, social e econômica, o que demonstraria sua universalidade; (PEB - F)

(iv) A adesão seria uma demonstração do processo de modificação interna do Brasil, no qual, buscando reorganizar-se "social, econômica e politicamente", ${ }^{71}$ estaria inaugurando uma nova fase de sua história (PBR - F);

(v) A adesão aos Pactos teria excelente repercussão, interna (PBR - F) e externamente (PEB - F), constituindo uma garantia da proteção dos Direitos Humanos no país $(\mathrm{DH}-\mathrm{F})$;

(vi) A assinatura de tratados de Direitos Humanos ou a adesão a eles integraria a tradição jurídica (PBR - F) e diplomática do Brasil; (PEB - F) e

(vii) A adesão estaria em concordância com a evolução do Direito Internacional, que reconhece cada vez mais a cooperação internacional em questões relativas aos Direitos Humanos, tendo o Brasil assinado diversos tratados nesse sentido, como a Convenção relativa ao Estatuto dos Refugiados, a Convenção Internacional sobre a

\footnotetext{
${ }^{70}$ Atualmente, o PIDCP conta com 168 Estados partes, enquanto o PIDESC conta com 164. Informações obtidas em: https://treaties.un.org/Pages/ViewDetails.aspx?src=TREATY\&mtdsg_no=IV-3\&chapter=4\& lang=en e https://treaties.un.org/pages/viewdetails.aspx?chapter $=4 \& s r c=$ treaty\&mtdsg_no=iv-4\&lang=en. Acesso: 10.03.2016.

${ }^{71}$ DCN 04.03.1986, p. 25, col. 2.
} 
Eliminação de todas as formas de discriminação racial e a Convenção Internacional sobre a Eliminação de todas as formas de discriminação contra a Mulher (DIN - F).

O Presidente segue apontando que, no âmbito da proteção internacional dos Direitos Humanos, os Estados são responsáveis por contrair as obrigações que desejam, por serem soberanos (PEB - F). A sociedade brasileira estaria em desenvolvimento, e teria patentes desigualdades (PBR - F). O fato de o Brasil aderir aos Pactos, que contêm mecanismos de supervisão internacional a respeito de suas implementações, deveria ser acompanhado da intenção de aceitar o debate a respeito de eventual descumprimento dos Pactos (PEB - F).

Ao tratar do modo como deve ser feita a adesão aos Pactos, o Presidente aponta que, em um primeiro momento, seria melhor não efetivar a declaração prevista no art. 41 do PIDCP, ${ }^{72}$ relativa à aceitação da competência do Comitê de Direitos Humanos (previsto no art.28, PIDCP) para receber e examinar queixas dos Estados Partes sobre violações do Pacto por outro Estado parte. Na justificativa, aponta para o fato de esse mecanismo ainda não ter utilidade comprovada, e tampouco ter alcançado número significativo de adesões (PEB - F). O Presidente trata de modo semelhante o Protocolo Facultativo do PIDCP, que dispõe sobre a possibilidade de apresentar petições individuais em casos de violação dos direitos previstos no Pacto. A possibilidade de recurso individual a órgãos internacionais seria algo inovador, cuja compatibilidade com o direito brasileiro deveria ser verificada (DBR - F). A declaração deveria ser feita, portanto, em momento posterior.

\section{EXPOSIÇÃO DE MOTIVOS DE 22.11.1985, DO MRE}

[Executivo - Mensagem]

Segue-se ao relatório do Presidente uma explanação elaborada pelo Ministro das Relações Exteriores, Olavo Setúbal. O Ministro aponta para a tradição jurídico-diplomática brasileira (PEB - F), que sempre deu importância aos tratados relativos aos direitos humanos, "de cunho eminentemente ético e humanitário" (DH - F). ${ }^{73}$ Prova disso seria a assinatura,

\footnotetext{
72 Artigo 41.1. Com base no presente Artigo, todo Estado Parte do presente Pacto poderá declarar, a qualquer momento, que reconhece a competência do Comitê para receber e examinar as comunicações em que um Estado Parte alegue que outro Estado Parte não vem cumprindo as obrigações que lhe impõe o presente Pacto. As referidas comunicações só serão recebidas e examinadas nos termos do presente artigo no caso de serem apresentadas por um Estado Parte que houver feito uma declaração em que reconheça, com relação a si próprio, a competência do Comitê. O Comitê não receberá comunicação alguma relativa a um Estado Parte que não houver feito uma declaração dessa natureza. As comunicações recebidas em virtude do presente artigo estarão sujeitas ao procedimento que se segue: (...)

${ }^{73}$ DCN 04.03.1986, p. 25, col. 3.
} 
por parte do Brasil, de diversos tratados de Direitos Humanos, enunciados pelo Ministro (DIN - F).

PARECER DA COMISSÃO DE RELAÇÕES EXTERIORES (CD), MIGUEL ARRAES, 1986

[Câmara - Parecer 1]

Em 21.05.1986, o Deputado Miguel Arraes proferiu parecer acerca do Projeto de Decreto Legislativo 131/1996, sobre a aprovação dos textos dos Pactos Internacionais, ambos aprovados, juntamente com o Protocolo facultativo do PIDESC. Após descrição dos Pactos, aponta para o fato de que ambos são resultado de um esforço da ONU de “(...) internacionalizar normas e princípios do direito, com o objetivo de proporcionar maior aproximação dos povos" (DIN - F). ${ }^{74}$ Segundo ele, essa intenção da ONU, que, antes se limitava aos direitos individuais, ampliou-se para os problemas de ordem econômica, social e cultural.

O país signatário dos Pactos deveria adotar medidas que assegurassem o pleno gozo dos direitos neles previstos (PBR - F). Ambos preveem mecanismos que permitem que a sua aplicação pelos Estados signatários seja supervisionada e fiscalizada (PEB - F). Nesse contexto, o Deputado menciona que o Presidente, na MSC 620/1985, sugere que não fosse feita a declaração do art. 41, PIDCP; e, do mesmo modo, que não fosse aceita a possibilidade de petições individuais, prevista no Protocolo Facultativo do PIDESC, que dispõe sobre a apresentação de petições individuais por violações dos direitos lá reconhecidos. A esse respeito, afirma:

\footnotetext{
"Embora admitindo o caráter facultativo da adesão, por qualquer Estado Parte, ao Pacto, no nosso entender, ao não reconhecer a competência do Comitê de Direitos Humanos, prevista no art. 41 do Pacto Internacional sobre Direitos Civis e Políticos, bem como ao não aderir ao Protocolo Facultativo relativo ao Pacto sobre Direitos Civis e Políticos, os referidos Pactos perderão, em grande parte, a sua razão de ser; tornar-se-ão simples declaração de boas intenç̃̃es. (PEB F). (grifo nosso).
}

Por essas razões, vota pela plena aprovação dos textos dos Pactos e do Protocolo facultativo sobre Direitos Econômicos, Sociais e Culturais, sem ressalvas.

\footnotetext{
${ }^{74}$ Diário do Congresso Nacional, 28.04.1987, p. 28, col. 2.
} 


\section{PARECER DA COMISSÃO DE CONSTITUIÇÃO E JUSTIÇA (CD), NILSON GIBSON, 1986}

[Câmara - Parecer 2]

O parecer, de autoria do Deputado Nilson Gibson, data de 26.11.1986. Nele, o relator aponta que a Constituição Federal determina que cabe à União manter relações com Estados estrangeiros e celebrar tratados, bem como participar de organismos internacionais (art. $8^{\circ}$, I). Compete, igualmente, ao Congresso resolver, definitivamente, a respeito da matéria, por intermédio de Decreto Legislativo (artigos 44, I e 46, VI). A iniciativa de apresentação pode, portanto, ser de Comissão da Câmara. ${ }^{75} \mathrm{O}$ parecer é pela constitucionalidade, juridicidade e boa técnica legislativa do Projeto (DBR - F).

\section{PARECER DA COMISSÃO DE CONSTITUIÇÃO, JUSTIÇA E CIDADANIA (n. 460} - SF), VALMIR CAMPELO, 1991

[Senado - Parecer 1]

O parecer, de 09.10.1991, de autoria do Senador Valmir Campelo. Segundo ele, os tratados aprovados pelo projeto são relevantes instrumentos jurídicos internacionais de proteção dos Direitos Humanos, e equiparam-se à DUDH em relevância (DIN - F). O Brasil, por ter participado ativamente dos trabalhos preparatórios da fase de elaboração dos tratados, além de ter votado favoravelmente à Resolução da AGNU 2200/1966, pela qual os Pactos foram adotados, deve continuar a cumprir a sua tradição jurídica e diplomática (PEB - F), que registra a adesão a diversos instrumentos internacionais de proteção dos Direitos Humanos, mencionados nominalmente pelo Senador (DIN - F).

Particularmente em relação ao PIDESC, aponta que seu artigo 25 é de significativa atualidade, consideradas as críticas que o Brasil vem sofrendo em relação às questões de preservação ambiental (PEB - F).

Constitucionalmente, não haveria qualquer problema em internalizar os Pactos (DBR - F), sendo que ambos foram aprovados na Câmara, pela CRE e CCJ, recebendo também parecer pela aprovação, proferido em plenário pelo Deputado Walmor de Luca, em virtude

75 Aqui, a Constituição citada é a de 1967, com as emendas realizadas pela Emenda Constitucional 1, de 17.10.1969. 
da desativação das comissões técnicas durante os trabalhos da Constituinte, que se realizavam à época. Com isso, o projeto foi encaminhado ao Senado, onde se verificou que não constava do processado o texto do Protocolo Facultativo, o que foi posteriormente corrigido.

Ao examinar os novos dispositivos constitucionais relacionados a tratados, o Senador destaca que, como ocorria na Constituição anterior, continua integrando a competência do Presidente a celebração de acordos internacionais, assim como segue sendo o Congresso responsável por examiná-los, para sua posterior ratificação pelo Executivo (DBR - F) ${ }^{76} \mathrm{~A}$ $\mathrm{CF} / 1988$, entretanto, inova ao contemplar, de maneira expressa, os direitos decorrentes dos tratados de que o Brasil faça parte, conferindo-lhes tratamento especial (DBR - F).

O parecer é pela aprovação do Projeto.

\section{PARECER DA COMISSÃO DE RELAÇÕES EXTERIORES E DEFESA NACIONAL (n. 461 - SF), JOSÉ FOGAÇA, 1991}

[Senado - Parecer 2]

O parecer, de 13.11.1991, é de autoria do Senador José Fogaça. Após rever a tramitação interna dos Pactos, diz que é pela aprovação do Projeto, por serem os Pactos importantes instrumentos de Direito Internacional, dos quais o Brasil, nação moderna e democrática, não pode prescindir (PBR - F).

\subsection{ANÁlISE: PROTOCOLO FACULTATIVO AO PACTO INTERNACIONAL SOBRE DIREITOS CIVIS E POLÍTICOS, E SEGUNDO PROTOCOLO FACULTATIVO AO PACTO INTERNACIONAL SOBRE DIREITOS CIVIS E POLÍTICOS, COM VISTAS À ABOLIÇÃO DA PENA DE MORTE}

Serão analisados, nesse item, o Protocolo Facultativo ao Pacto Internacional sobre Direitos Civis e Políticos, de 16.12.1966, que entrou em vigor internacionalmente em 23.03.1976 (art. 9); e o Segundo Protocolo Facultativo ao PIDCP, com vistas à Abolição da Pena de Morte, de 15.12.1989, em vigor internacional desde 11.07.1991 (art. 8.1). A acessão do Brasil a ambos os protocolos ocorreu em 25.09.2009, tendo o país formulado reserva ao

\footnotetext{
${ }^{76}$ É importante, aqui, ressaltar que se trata de momento de mudança da Constituição nacional.
} 
art. 2 do Segundo Protocolo, e ambos foram apreciados pela MSC 924/2005. O processo de aprovação tramitou na Câmara dos Deputados como Projeto de Decreto Legislativo 2.253, de 2006, e no Senado Federal como Projeto de Decreto Legislativo 139, de 2008. Foram aprovados pelo Decreto Legislativo 311, de 16.06.2009. Ambos os Protocolo entraram em vigor para o Brasil em 24.12.2009. Até o momento de entrega desta tese, não ocorreu a promulgação.

O Protocolo ao Pacto (chamá-lo-emos de "Primeiro Protocolo") tem o objetivo de estabelecer mecanismo individual de denúncias, que serão analisadas pelo Comitê de Direitos Humanos. O Segundo Protocolo opcional tem como objetivo vincular os seus signatários à abolição da pena de morte dentro de suas fronteiras, apesar de facultar a possibilidade de fazer reservas quando se tratar de tempo de guerra ou de crimes cometidos durante esse estado. ${ }^{77}$

A matéria foi encaminhada ao Senado em 12.06.2008, por meio do ofício 302/08/PSGSE. Em 16.06.2009, foi transformada no Decreto Legislativo 311. Destaco, porém, que não houve promulgação do Decreto Presidencial referente a esses tratados até a entrega desta tese.

\section{STATUS NA ONU}

Primeiro Protocolo Opcional:

https://treaties.un.org/Pages/ViewDetails.aspx?src=IND\&mtdsg_no=IV-

$5 \&$ chapter $=4 \&$ lang $=$ en

Segundo Protocolo Opcional - pena de morte:

https://treaties.un.org/Pages/ViewDetails.aspx?src=IND\&mtdsg_no=IV-

$12 \&$ chapter $=4 \&$ lang $=$ en

\section{MENSAGEM DO PODER EXECUTIVO (MSC 924/2005)}

A MSC 924, de 07.10.2005, assinada por Samuel Pinheiro Guimarães Neto, foi enviada pelo Presidente Luís Inácio Lula da Silva para o Congresso em 27.12.2005. Segundo o Embaixador, referindo-se ao PIDCP, o Brasil apenas pôde aderir a esse instrumento após o retorno à democracia (PBR - F), quando houve condições suficientes para a integração do

\footnotetext{
77 Informações obtidas em: https://www.amnesty.org/download/Documents/ACT5023052015 ENGLISH.PDF. Acesso: 11.03.2016. 
país aos mecanismos internacionais de Direitos Humanos (PEB - F). Apesar de ter aderido ao Pacto, o país não o fez em relação aos Protocolos, adesão esta recomendada por integrantes do Comitê de Direitos Humanos da ONU após examinar o Relatório Inicial do Brasil, em 1996. Tendo como base a política nacional referente aos Direitos Humanos, orientada para uma maior integração aos mecanismos internacionais de proteção, Guimarães recomenda a adesão aos Protocolos, após a autorização do Congresso (PBR - F).

O Primeiro Protocolo está em plena harmonia com o reconhecimento, por parte do Brasil, da legitimidade da preocupação de todos os países em relação aos Direitos Humanos (PEB - F), e do interesse em proteger as possíveis vítimas, que teriam um mecanismo adicional de salvaguarda contra violações. O país, inclusive, reconhece a competência para exame de petições individuais por órgãos internacionais de suma relevância nesse campo, como o Comitê para a Eliminação da Discriminação Racial e o Comitê para a Eliminação da Discriminação contra as Mulheres, ambos previstos em tratados assinados (DIN - F). Reconhecer a competência descrita no Primeiro Protocolo significaria aprofundar essa vertente da nossa política de Direitos Humanos (PEB - F).

A subsidiariedade do órgão internacional em relação às instituições brasileiras é garantida pelo Protocolo, pois existe a previsão de esgotamento dos recursos internos como condição sine qua non de admissão das petições. Seria conveniente, porém, resguardar o princípio da irretroatividade dos efeitos do tratado, o que pode ser feito com declaração interpretativa, dizendo que o Protocolo apenas produzirá efeitos sobre fatos, atos ou omissões e sobre decisões relativas a acontecimentos ocorridos após a entrada em vigor para o Brasil (PEB - F).

A adesão ao Segundo Protocolo, por sua vez, é igualmente compatível com a Constituição (DBR - F), e com as posições internacionalmente defendidas pelo país em relação aos Direitos Humanos (PEB - F). Apesar da previsão de abolição da pena de morte, resta a possibilidade de apor reserva que resguarde ao país a opção de aplicar a pena capital em caso de guerra, por infração penal de cunho militar e gravidade extrema, o que é coerente com as disposições constitucionais (art. $5^{\circ}$, XLVII, a). Assim, é necessário fazer essa reserva.

O país aderiu, em 1998, ao Protocolo à Convenção Americana sobre Direitos Humanos relativo à abolição da Pena de Morte (DIN - F), que possui dispositivos semelhantes aos do Segundo Protocolo. Além disso, apoia, em diversos órgãos da ONU, a abolição dessa pena e a moratória em sua aplicação por parte dos países que a mantém (PEB - F). A pena de 
morte não é aqui aplicada desde 1855 , nem nos casos das exceções autorizadas pela Carta magna (PBR - F).

A Mensagem propõe, portanto, a adesão aos Protocolos.

PARECER DA COMISSÃO DE RELAÇÕES EXTERIORES E DE DEFESA NACIONAL (CD), LUIZ CARLOS HAULY, 2006

[Câmara - Parecer 1]

No parecer, de autoria do Deputado Luiz Carlos Hauly, de 21.05.2006, após resumir os principais pontos dos Protocolos, o relator faz um apanhado das informações presentes na MSC 924/2005, descrita acima, e acrescenta, concordando com o Embaixador Guimarães, que não é do feitio de governantes de regimes ditatoriais assinar tratados que resguardem os Direitos Humanos; e que, no início da década de 1990, o Brasil estava começando a estabelecer sua democracia (PBR - F). Porém, decorreram quase quinze anos entre a assinatura do Pacto e de seus Protocolos, e quase dez desde a recomendação de sua assinatura por parte da ONU (PEB - F). Caberia, portanto, ao Poder Legislativo aprovar, o mais rapidamente possível, os Protocolos (PBR - F). O Deputado reitera a necessidade de apor reserva ao art. $2^{\circ}$ do Segundo Protocolo, em conformidade com a disposição constitucional supracitada (DBR - C).

O parecer é, pois, pela aprovação dos Protocolos. ${ }^{78}$

\section{PARECER DA COMISSÃO DE CONSTITUIÇÃO E JUSTIÇA E DE CIDADANIA (CD), BOSCO COSTA, 2006}

[Câmara - Parecer 2]

O parecer, de 04.09.2006, de autoria do Deputado Bosco Costa, aponta que a proposta atende aos requisitos constitucionais formais, particularmente sobre a competência da União de manter relações com outros Estados (art. 21, I, CF) e seu exercício privativo pelo

\footnotetext{
${ }^{78}$ O parecer da Comissão, de 24.05.2006, que aprova o texto do Projeto de parecer do Deputado Hauly, informa que a MSC 924/2005 foi aprovada acatando o parecer do relator e contra o voto do Deputado Jair Bolsonaro. A autora, porém, não teve acesso a essa manifestação, que não se encontrava na tramitação do Projeto nos dossiês da Câmara dos Deputados, tampouco no Senado Federal.
} 
Presidente da República (art. 49, I e art. 84, VIII, CF). A proposta também se coaduna materialmente com as disposições constitucionais, particularmente com os princípios que regem as Relações Internacionais do Brasil (art. $4^{\mathrm{o}}$, I, II, V e IX, CF).$^{79}$ (DBR - F) O parecer é, pois, pela aprovação do Projeto, sob o aspecto jurídico.

Em relação ao mérito do Primeiro Protocolo, a adesão do país é coerente com a política adotada pelo Brasil em suas relações exteriores (PEB - F), por admitir a competência de relevantes órgãos internacionais de Direitos Humanos, tanto no âmbito global como no regional. Como exemplo, menciona Comissão e a Corte Interamericanas de Direitos Humanos, o Comitê para a Eliminação da Discriminação racial e o Comitê para a Eliminação da Discriminação contra as Mulheres (DIN - F). A aprovação da competência do Comitê previsto no Protocolo, portanto, seria um avanço na política brasileira de defesa dos Direitos Humanos, além de reconhecer o ser humano como sujeito de Direito Internacional (PEB F).

A respeito do Segundo protocolo, aponta para a única reserva cabível, e que deve ser formulada, a respeito da aplicação da pena de morte em caso de guerra, conforme prescrição constitucional (DBR - C). Ressalta, ainda, o fato de a pena de morte não ter sido aplicada no Brasil desde 1855, uma vez que essa pena não diminui a prática de crimes e, além disso, faz do erro judiciário algo sem volta (PBR - F). Destaca, ainda, a adesão ao Protocolo à Convenção Americana sobre Direitos Humanos relativo à Abolição da Pena de morte, com normas semelhantes (DIN - F).

O parecer é, portanto, pela aprovação do Projeto de Decreto Legislativo.

\section{PARECER DA COMISSÃO DE DIREITOS HUMANOS E MINORIAS (CD), LUIZ COUTO, 2006}

[Câmara - Parecer 3]

Segundo o parecer, de 08.11.2006, de autoria do Deputado Luiz Couto, o texto do Primeiro Protocolo tem o mérito de se coadunar com a política seguida pelo Brasil em suas relações exteriores, defendendo internacionalmente os Direitos Humanos (PEB - F). Nesse

\footnotetext{
${ }^{79}$ Art. $4^{\text {o }}$ A República Federativa do Brasil rege-se nas suas relações internacionais pelos seguintes princípios: I - independência nacional; II - prevalência dos direitos humanos; III - autodeterminação dos povos; (...) V - igualdade entre os Estados; (...) IX - cooperação entre os povos para o progresso da humanidade.
} 
sentido, afirma que o país reconhece a competência de instâncias internacionais de proteção, como Comitê para a Eliminação da Discriminação Racial, o Comitê para a Eliminação da Discriminação contra Mulheres e a Corte Interamericana de Direitos Humanos (DIN - F). Essa aprovação configura avanço da política externa em direção ao reconhecimento do ser humano, em determinadas situações, como sujeito de Direito Internacional (PEB - F).

O Segundo Protocolo, por sua vez, admite reserva à disposição acerca da pena de morte, como ressaltado à exaustão pelos pareceres anteriores, para que se harmonize com as disposições constitucionais (DBR - C). Menciona, assim como fez o parecer acima, que desde 1855 essa pena não é aplicada no país (PBR - F), e que o Brasil é signatário de outros tratados semelhantes (DIN - F).

\section{PARECER COMISSÃO DE RELAÇÕES EXTERIORES E DEFESA NACIONAL (SF), ANTONIO CARLOS VALADARES, 2009}

[Senado - Parecer 1]

O parecer, de 21.05.2009, é de autoria do Senador Antonio Carlos Valadares, relator

ad hoc. ${ }^{80}$ Segundo o Senador, houve demora injustificada da apreciação congressual dos Protocolos, existindo, há muito tempo, concordância política e jurídica em prol da adesão (PBR - F). Mesmo considerando que a prática brasileira não contradiga os Protocolos (PBR - F), é conveniente e oportuna a adesão a tratados que promovam os Direitos Humanos, para reiterar os compromissos nacionais com sua proteção, além de dar exemplo aos regimes que a eles não aderem (PEB - F).

As previsões do Primeiro Protocolo são coerentes com o animus da EC 45/2004, particularmente no que se refere à possibilidade de recorrer ao Comitê de Direitos Humanos em casos de demora injustificada, e sempre que esgotados os recursos internos (DBR - F). A adesão ainda reitera, no sistema ONU, a aceitação do Brasil da legitimidade do Direito Internacional à justiça e à aplicação dos Direitos Humanos, (PEB - F) cujo marco foi a competência obrigatória da Corte Interamericana de Diretos Humanos, a que o Brasil se obrigou (DIN - F). A possibilidade de se exigir, em âmbito internacional, normas convencionais, é a essência da jurisdição constitucional internacional, reconhecida pelo ordenamento jurídico pátrio (DBR - F).

${ }^{80} \mathrm{O}$ relator do Parecer seria, originalmente, o Senador Cristovam Buarque. 
O Segundo Protocolo, por sua vez, é coerente com as normas constitucionais e com as cláusulas pétreas de nossa Constituição (DBR - F), principalmente em virtude da permissão de reserva ao art. $2^{\circ}$ de seu texto.

O parecer é pela aprovação do Projeto. 


\section{ANÁliSE: CONVENÇÃo SOBRE A PREVENÇÃo E PUNIÇÃO DE CRIMES CONTRA PESSOAS QUE GOZAM DE PROTEÇÃO INTERNACIONAL, INCLUINDO AGENTES DIPLOMÁTICOS}

A Convenção sobre a Prevenção e Punição de Crimes contra pessoas que gozam de proteção internacional, incluindo Agentes Diplomáticos, de 14.12.1973, entrou em vigor internacional em 20.02.1977, de acordo com as disposições de seu artigo 17.1. O Brasil acedeu a essa Convenção em 07.06.1999, entrando em vigor para o país na mesma data. Foi enviada ao Congresso Nacional por intermédio da Mensagem Presidencial 1213, de 1997. Seu processo de aprovação tramitou na Câmara dos Deputados como Projeto de Decreto Legislativo 696, de 1998, e no Senado Federal como Projeto de Decreto Legislativo 147, de 1998. Foi aprovada pelo Decreto Legislativo 25, de 31.03.1999, e promulgada pelo Decreto Presidencial 3.167, de 14.09.1999, com reserva ao art. 13, $\S 2^{\circ}$.

A Convenção integra o setor de tratados das Nações Unidas, negociados no âmbito de suas agências, em um esforço contra o terrorismo, particularmente relacionada com a codificação no campo das relações diplomáticas, da qual é exemplo a Convenção de Viena sobre Relações Consulares, e aos ataques a membros de corpos diplomáticos durante a década de 1960. Durante os trabalhos preparatórios, houve significativa dificuldade em lidar com a questão dos movimentos de libertação nacional, empecilho solucionado pela previsão de que a Convenção não prejudicaria a busca dos povos pela autodeterminação e pela independência. Conforme a principal provisão da Convenção, o indivíduo que, alegadamente, cometeu ataque sério contra diplomatas e outras pessoas protegidas internacionalmente deve ser extraditado ou ter seu caso submetido às autoridades para processamento. O objetivo é abranger todos aqueles que possam ser protegidos, de maneira específica, pelo Direito Internacional, dispositivo intimamente ligado com a Convenção de Viena sobre relações diplomáticas. ${ }^{81}$

\section{STATUS NA ONU}

https://treaties.un.org/Pages/ViewDetails.aspx?src=IND\&mtdsg_no=XVIII7\&chapter $=18$ \&lang=en

${ }^{81}$ Informações obtidas em: http://legal.un.org/avl/ha/cppcipp/cppcipp.html. Acesso: 13.03.2016. 331 


\section{PARECER DA CONSULTORIA JURÍDICA DO ITAMARATY, ANTONIO AUGUSTO CANÇADO TRINDADE, 1988}

O parecer, de 27.05.1988, foi elaborado pelo jurista Antonio Augusto Cançado Trindade, e trata de dois tratados: (i) a Convenção sobre a Prevenção e Punição de Crimes Contra Pessoas que Gozam de Proteção Internacional, incluindo agentes diplomáticos; e (ii) a Convenção Internacional contra a Tomada de Reféns (1980). Serão considerados, apenas, os argumentos relativos ao primeiro instrumento, pois o outro não será analisado nesta tese. ${ }^{82}$

Em virtude do ínfimo progresso logrado, nos anos anteriores, a respeito das questões referentes ao terrorismo, e diante da dificuldade de um tratamento abrangente do tema, o Brasil tem favorecido abordar o tema por etapas, partindo de áreas nas quais existe consenso, buscando um combate mais eficaz, mesmo que restrito, às diversas manifestações do fenômeno (PEB - F). Ampliar as discussões nas áreas em que existe concordância evita o impasse ao qual poderíamos chegar se optássemos por uma discussão ampla do tema.

A Convenção não seria tratado do tipo rígido, o que seria possível comprovar pela remissão expressa à lei nacional em algumas de suas cláusulas. Ela resguarda, ademais, o instituto do asilo, e estabelece obrigações para os Estados signatários, entre as quais a de fazê-los incluir alguns delitos entre os casos de extradição em todos os tratados de extradição que vierem a celebrar entre si; e de incluir delitos específicos em suas legislações internas. Obrigações semelhantes encontram-se em outros instrumentos internacionais aos quais o Brasil aderiu, o que facilita a análise da viabilidade jurídica da adesão do Brasil à Convenção $(\mathrm{DIN}-\mathrm{F}),{ }^{83}$ coerente com a posição do país a respeito do tema nos últimos anos (PEB - F). As disposições a respeito da solução de controvérsias, ademais, são idênticas na Convenção e em outros instrumentos internacionais assinados pelo Brasil (DIN - F), sendo, porém, possível efetuar reservas, caso o setor competente do MRE acredite ser necessário.

\footnotetext{
${ }^{82} \mathrm{O}$ pedido de parecer menciona um terceiro instrumento, a Convenção para Prevenir e Punir os atos de Terrorismo configurados em delitos contra as pessoas e a extorsão conexa, quanto tiverem eles transcendência internacional (1971). Entretanto, o consultor informa que se pronunciara, em parecer de 18.09.1987, a respeito do tema, e remete a esse parecer para sua apreciação do tratado.

${ }^{83}$ São mencionadas a Convenção para a Repressão ao Apoderamento Ilícito de Aeronaves de Haia (1970); Convenção para Repressão aos Atos Ilícitos contra a Segurança da Aviação Civil de Montreal (1971).
} 
Após fazer diversas considerações a respeito da Convenção, pondera que seu parecer se limita a apreciar o aspecto jurídico da Convenção, pois a decisão a respeito da efetiva adesão é um juízo de vontade ou de conveniência, a respeito do qual não caberia opinar.

\section{MENSAGEM DO PODER EXECUTIVO (MSC 1.213/1997)}

A Mensagem 1.213, de 15.10.1997, é assinada pelo Ministro de Estado da Justiça, senhor Íris Resende Machado, e pelo Ministro de Estado das Relações Exteriores, Felipe Lampreia; e foi enviada ao Congresso em 21.10.1997 pelo Presidente Fernando Henrique Cardoso. A Mensagem descreve a Convenção, além dos motivos para sua elaboração nesse momento histórico, no qual ocorreram diversos ataques a agentes diplomáticos e a outros indivíduos que gozam de proteção internacional.

De acordo com a Mensagem, seria importante que o Brasil fizesse reserva ao art. 13, $\S 2^{\circ}$ da Convenção, relativo à solução de controvérsias, já que a Convenção faculta a possibilidade de apor reservas e de optar por um regime obrigatório ou facultativo no que se refere à arbitragem e à jurisdição da CIJ. Assim, o Brasil asseguraria que eventuais disputas relativas à interpretação ou à aplicação do tratado seriam apenas submetidas à arbitragem ou à Corte mediante consentimento de ambos os envolvidos no caso concreto (PEB - F).

Justamente por não existir tratado relativo ao combate do terrorismo em todas as possíveis manifestações, a evolução do Direito Internacional nessa seara ocorre mediante o preenchimento de falhas existentes na ordem jurídica internacional. Nesse sentido, a Convenção tem função de extrema relevância (DIN - F). A adesão a esse instrumento, além de justificada em virtude da importância da matéria, está inserida em um contexto de “(...) atualização e (de) fortalecimento dos compromissos internacionais do Brasil no combate ao terrorismo internacional" (PEB - F). ${ }^{84}$

Os Ministros, então, ressaltam o envio da Convenção para a apreciação do Congresso anteriormente à adesão ao tratado (PBR - F).

\footnotetext{
${ }^{84}$ DCD 25.10.1997, p.34.137, col. 1.
} 


\section{PARECER DA COMISSÃO DE RELAÇÕES EXTERIORES E DE DEFESA NACIONAL (CD), AROLDO CEDRAZ, 1998}

[Câmara - Parecer 1]

O parecer, de 17.06.1998, é de autoria de Aroldo Cedraz. Nele, o Deputado faz descrição histórica do contexto de terrorismo no qual foi celebrada a Convenção, praticado por grupos dentro dos Estados, além de alguns casos de terrorismo estatal. Após descrição dos principais artigos da Convenção, o Deputado detém-se no art. 13, relativo à solução de controvérsias, que possibilita reserva ao seu conteúdo, conforme mencionado anteriormente. Segundo o Deputado, o Brasil, historicamente, não se submete à jurisdição obrigatória da CIJ, utilizando meios diplomáticos de solução de controvérsias e obtendo, geralmente, sucesso nesse sentido; e recorrendo à arbitragem somente em situações inevitáveis (PBR C).

A postura do país perante situações controversas é a de defender a própria soberania, no que se refere à decisão acerca do direito aplicável (PEB - C). Desse modo, não se admite submeter o Brasil à obrigação compulsória de acatar determinada jurisdição, o que não deve ser percebido como descrédito em relação a esses órgãos, mas preferência pelos meios diplomáticos, em virtude da tradição e da eficiência da diplomacia nacional (PEB - C). Assim, o Deputado aponta para a necessidade e se fazer a reserva prevista no art. $13, \S 2^{\circ}$ da Convenção.

PARECER DO RELATOR DESIGNADO PELA MESA - EM SUBSTITUIÇÃO À COMISSÃO dE CONSTITUIÇÃO E JUSTIÇA E DE REDAÇÃO (CD), ALOYSIO NUNES FERREIRA, 1998

[Câmara - Parecer 2]

O parecer, de 03.12.1998, diz que o projeto é irrepreensível sob a perspectiva constitucional e da juridicidade e da boa técnica legislativa (DBR - F). O parecer é pela aprovação do projeto.

PARECER DA COMISSÃO DE RELAÇÕES EXTERIORES E DE DEFESA NACIONAL (n. 117 - SF), AGRIPINO MAIA, 1999

[Senado - Parecer 1] 
O parecer, de 15.03.1999, foi elaborado pelo Deputado Agripino Maia. O Deputado descreve a tramitação do projeto para a aprovação da Convenção no Brasil, e aponta para a relevância de sua aprovação interna, por sua importância permanecer inalterada, mesmo tendo sua assinatura ocorrido há mais de vinte anos.

Para o relator, a Convenção é conveniente e oportuna aos interesses nacionais, (PBR F) atendendo aos requisitos da juridicidade e da constitucionalidade (DBR - F). Por essas razões, o parecer é pela aprovação da Convenção. 


\section{ANÁliSE: CONVENÇÃO SOBRE A ELIMINAÇÃO DE TODAS AS FORMAS DE DISCRIMINAÇÃO CONTRA A MULHER}

A Convenção sobre a eliminação de todas as formas de discriminação contra a Mulher (CEDAW), de 18.12.1979, entrou em vigor internacional em 03.09.1981, conforme disposição do seu art. 27(1). Essa Convenção foi assinada pelo plenipotenciário brasileiro em 31.03.1981, ratificada em 01.02.1984, e promulgada pelo Decreto Presidencial 89.460 de 20.03.1984. Foi enviada ao Congresso Nacional pela Mensagem Presidencial 320, de 08.07.1982. Seu processo de aprovação tramitou na Câmara dos Deputados como Projeto de Decreto Legislativo 141, de 1982, e no Senado Federal como Projeto de Decreto Legislativo 13, de 1983. O Projeto foi enviado ao Senado em 28.06.1983, e transformou-se no Decreto Legislativo 93, de 14.11.1983.

A Convenção, tida um dos principais instrumentos internacionais relacionados com os direitos das mulheres, define a discriminação contra a mulher e estabelece uma agenda para que ações nacionais acabem com essa discriminação. O tratado provê uma base para estabelecer a igualdade entre homens e mulheres mediante o igual acesso a oportunidades nos âmbitos público e privado, assim como na educação, na saúde e na empregabilidade. Os signatários concordam em fazer o necessário, inclusive em termos legislativos, para que as mulheres possam gozar de seus direitos e de suas liberdades fundamentais. ${ }^{85}$

O Congresso Nacional aprovou a Convenção pelo Decreto Legislativo 93/1983, com reservas aos seus artigos 15, $\S 4^{\circ}$, e 16, $\S 1^{\circ}$, alíneas (a), (c), (g) e (h). O Decreto Legislativo 26, de 22.06.1994, por sua vez, revogou o Decreto 93/1983, aprovando a Convenção, inclusive os artigos previamente citados. O Brasil retirou as reservas mencionadas em 20.12.1994. O Decreto Presidencial 4.377, de 13.09.2002, revogou o Decreto 89.460, de 20.03.1984, que havia promulgado a Convenção, e dispôs que a mesma seria executada e cumprida integralmente, com reserva facultada em seu art. $29, \S 2^{\circ}{ }^{86}$ A análise dessa tramitação será feita neste item.

\footnotetext{
${ }^{85}$ Informações obtidas em: http://www.un.org/womenwatch/daw/cedaw/. Acesso: 14.03.2016.

${ }^{86}$ Artigo 29
} 


\section{STATUS NA ONU}

https://treaties.un.org/pages/ViewDetails.aspx?src=IND\&mtdsg_no=IV-

$8 \&$ chapter $=4 \&$ lang $=$ en\#EndDec

MENSAGEM DO PODER EXECUTIVO (MSC 320/1982)

A Mensagem que o Ministro das Relações Exteriores, Ramiro Saraiva Guerreiro, encaminhou ao Presidente João Baptista Figueiredo, data de 08.07.1982, e foi enviada ao Congresso Nacional em 26.07.1982. O Ministro descreve o contexto no qual a Convenção foi elaborada, apontando que se refere à promoção dos Direitos Humanos e da proteção das liberdades fundamentais sem distinção de raça, sexo, idioma ou crença religiosa. Seria uma etapa adicional aos instrumentos previamente aprovados no âmbito da ONU e de suas agências especializadas, com o intuito de promover a igualdade de direitos entre homens e mulheres. Nesse sentido, o Ministro destaca a Declaração sobre a eliminação da Discriminação contra a Mulher, de 1967, e a Resolução 2058 (LXIII), aprovada pelo ECOSOC, que trata da necessidade da elaboração de uma convenção internacional a respeito do tema (DIN - F).

O Ministro destaca os esforços, no âmbito da política externa brasileira, em relação ao apoio à intensificação da defesa dos direitos das mulheres e à chamada "Década da Mulher", que teria como o objetivo "promover a igualdade de direitos entre homens e mulheres, assegurar a plena integração da mulher no esforço de desenvolvimento dos países e

1. Qualquer controvérsia entre dois ou mais Estados-Partes relativa à interpretação ou aplicação desta Convenção e que não for resolvida por negociações será, a pedido de qualquer das Partes na controvérsia, submetida a arbitragem. Se no prazo de seis meses a partir da data do pedido de arbitragem as Partes não acordarem sobre a forma da arbitragem, qualquer das Partes poderá submeter a controvérsia à Corte Internacional de Justiça mediante pedido em conformidade com o Estatuto da Corte.

2. Qualquer Estado-Parte, no momento da assinatura ou ratificação desta Convenção ou de adesão a ela, poderá declarar que não se considera obrigado pelo parágrafo anterior. Os demais Estados-Partes não estarão obrigados pelo parágrafo anterior perante nenhum Estado-Parte que tenha formulado essa reserva.

3. Qualquer Estado-Parte que tenha formulado a reserva prevista no parágrafo anterior poderá retirá-la em qualquer momento por meio de notificação ao Secretário-Geral das Nações Unidas. 
intensificar sua contribuição para o fortalecimento da paz entre as nações" nos foros regionais e mundiais $(\mathrm{PEB}-\mathrm{F}){ }^{87}$

O Brasil absteve-se quando da votação da Resolução 34/180 da AGNU, de 18.12.1979, que adotou o texto da Convenção. O Ministro explica que a delegação brasileira apontou para determinados aspectos do texto que poderiam ser aperfeiçoados. A abstenção não excluía a possibilidade de eventual adesão ou a elaboração de reservas ao tratado (PEB - F).

Após a submissão da Convenção a setores do Itamaraty e dos Ministérios da Justiça, Trabalho e Assistência e Previdência Social, foram determinadas reservas à Convenção, compatíveis com o seu art. 28(2) ${ }^{88}$ Foram feitas reservas aos artigos $15, \S 4,{ }^{89}$ e $16, \S 1^{\circ}$, alíneas (a), (c), (g) e (h), ${ }^{90}$ em virtude de incompatibilidades com a legislação interna (DBR - C). As incompatibilidades seriam as seguintes:

\begin{tabular}{|l|l|}
\hline $\begin{array}{l}\text { ARTIGO DA } \\
\text { CONVENÇ̃̃O }\end{array}$ & NORMA INTERNA \\
\hline $\begin{array}{l}\text { Artigo 15, } \\
\S 4\end{array}$ & $\begin{array}{l}\text { Art. 7, } \text { 7, LICC: }{ }^{91} \\
\text { Art. 7 } 7^{\circ} \text { A lei do país em que domiciliada a pessoa determina as regras sobre o } \\
\text { começo e o fim da personalidade, o nome, a capacidade e os direitos de família. } \\
\text { §7 Salvo o caso de abandono, o domicílio do chefe da família estende-se ao } \\
\text { outro cônjuge e aos filhos não emancipados, e o do tutor ou curador aos } \\
\text { incapazes sob sua guarda. }\end{array}$ \\
\hline
\end{tabular}

${ }^{87}$ DCN 06.08.1982, p. 6.066, col. 2.

${ }^{88}$ Artigo 28.1. O Secretário Geral das Nações Unidas receberá e enviará a todos os Estados o texto das reservas feitas pelos Estados no momento da ratificação ou adesão.

2. Não será permitido uma reserva incompatível com o objeto e o propósito desta Convenção.

${ }^{89}$ Artigo 15.4. Os Estados-partes concederão ao homem e à mulher os mesmos direitos no que respeita à legislação relativa ao direito das pessoas, à liberdade de movimento e à liberdade de escolha de residência e domicílio.

${ }^{90}$ Artigo 16.1. Os Estados-partes adotarão todas as medidas adequadas para eliminar a discriminação contra a mulher em todos os assuntos relativos ao casamento e às relações familiares e, em particular, com base na igualdade entre homens e mulheres, assegurarão:

a) o mesmo direito de contrair matrimônio;

c) os mesmos direitos e responsabilidades durante o casamento e por ocasião de sua dissolução;

g) os mesmos direitos pessoais como marido e mulher, inclusive o direito de escolher sobrenome, profissão e ocupação;

h) os mesmos direitos a ambos os cônjuges em matéria de propriedade, aquisição, gestão, administração, gozo e disposição dos bens, tanto a título gratuito quanto a título oneroso.

${ }^{91}$ A LICC é de 1942. Apesar de leis posteriores e a LINDB terem modificado algumas de suas disposições, esse artigo ainda é vigente. 


\begin{tabular}{|c|c|}
\hline $\begin{array}{l}\text { ARTIGO DA } \\
\text { CONVENCÃO }\end{array}$ & NORMA INTERNA \\
\hline & 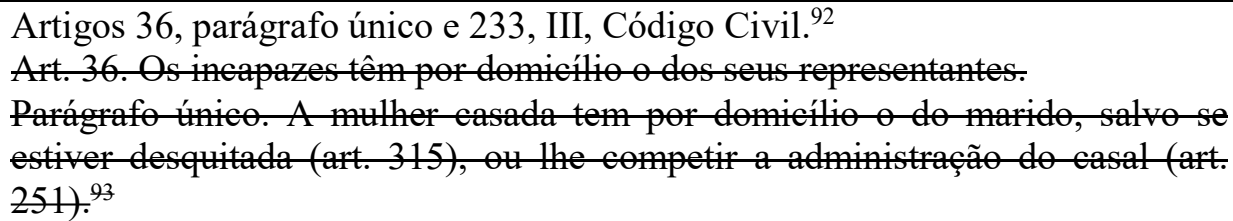 \\
\hline $16, \S 1^{\circ},(a)$ & $\begin{array}{l}\text { Art.183, XII, CC } \\
\text { Art. 183. Não podem casar (arts. } 207 \text { e } 209 \text { ): } \\
\text { XII. As mulheres menores de dezesseis anos es homens menores de dezoito. }{ }^{94}\end{array}$ \\
\hline $16, \S 1^{\mathrm{o}},(\mathrm{c})$ & 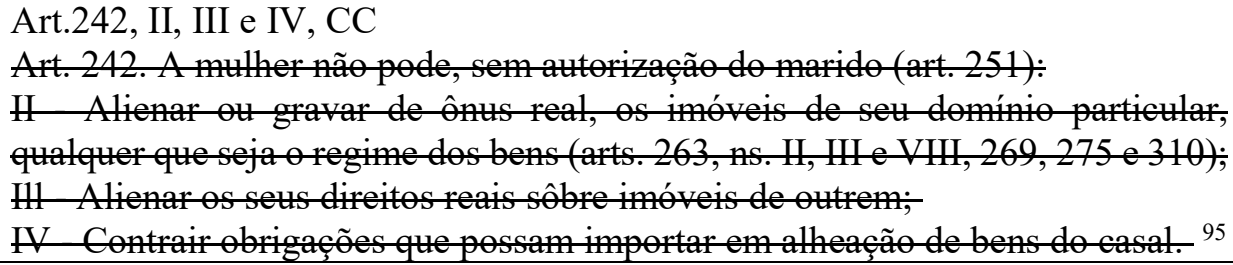 \\
\hline $16, \S 1^{\circ},(\mathrm{g})$ & $\begin{array}{l}\text { Art. } 240, \text { CC } \\
\text { Art. } 240 \text {. A mulher assume, pelo casamento, com os apelidos do marido, a } \\
\text { 324). }{ }^{96}\end{array}$ \\
\hline $16, \S 1^{\circ},(\mathrm{h})$ & $\begin{array}{l}\text { Art.233, II, CC } \\
\text { Art. } 233 \text {. O marido é o chefe da sociedade conjugal. } \\
\text { Compete-1he: } \\
\text { H. A administração dos bens comuns e dos particulares da mulher, que ao maride } \\
\text { competir administrar em virtude do regime matrimenial adaptado, ou do pacte } \\
\left.\text { antenupcial (arts. } 178, \& 9^{\circ}, \mathrm{n}^{\circ} \mathrm{I}, \mathrm{c}, 274,289, \mathrm{n}^{\circ} \mathrm{I}, \mathrm{e} 311\right){ }^{97}\end{array}$ \\
\hline
\end{tabular}

Uma vez que a Convenção foi amplamente aceita pelos membros da ONU, o representante permanente do Brasil junto à Organização foi autorizado a assiná-la, ad referendum do Congresso Nacional. (PEB - F). Nesse momento, foram feitas as reservas mencionadas, além da reserva ao art. 29.2, relativa ao mecanismo de solução de controvérsias.

${ }^{92}$ O Código Civil mencionado nesse momento é o de 1916, que não se encontra em vigor desde 2002, em virtude da entrada em vigor do novo Código Civil. Entretanto, existem, no novo Código, dispositivos semelhantes àqueles do CC/1916. Essa comparação foi possível graças a documento publicado pelo Senado Federal em 2003, com a comparação entre esses dois instrumentos normativos. Informação obtida em: http://www2.senado.leg.br/bdsf/bitstream/handle/id/70309/704509.pdf? sequence=2. Acesso: 30.10.2014.

${ }^{93}$ Não há, no Código Civil de 2002, dispositivo que faça previsão desse tipo a respeito da mulher casada. O dispositivo que, hoje, trata do domicílio do incapaz é o art.76.

${ }^{94}$ Não há, no Código Civil de 2002, dispositivo que faça previsão desse tipo específico a respeito dos impeditivos para matrimônio, que estão consubstanciados no art.1.521.

${ }^{95}$ Não há, no Código Civil de 2002, dispositivo que faça previsão desse tipo. Não há dispositivo correspondente no Código Civil atual.

${ }^{96}$ Não há, no Código Civil de 2002, dispositivo que faça previsão desse tipo. Não há dispositivo correspondente no Código Civil atual.

${ }^{97}$ Não há, no Código Civil de 2002, dispositivo que faça previsão desse tipo. Não há dispositivo correspondente no Código Civil atual. 


\section{PARECER DA COMISSÃO DE COMISSÃO DE RELAÇÕES EXTERIORES (CD), DIOGO NOMURA, 1982}

[Câmara - Parecer 1]

O Parecer da CRE, de autoria do Deputado Diogo Nomura, de 11.08.1982, foi publicado no Diário do Congresso Nacional, em 01.06.1983. Após relato acerca do teor da Mensagem Presidencial, o relator destaca alguns trechos da Convenção, que tem como primordial objetivo promover uma política que elimine a discriminação contra a mulher, por meio de alguns compromissos assumidos pelos signatários, mencionando diversos artigos da Convenção.

Para o Deputado, é clara sua conveniência para o Governo brasileiro, por tratar de tema caro ao país, a valorização de uma força de trabalho, concedendo a essa parcela da população o merecido destaque (PBR - F). Ressalta, ainda, que a Constituição Federal (à época, de 1967) prevê a igualdade de direitos entre homens e mulheres, em seu art. $150, \S 1^{\text {o.98 }}$ (DBR - F)

\footnotetext{
Art. 150 - A Constituição assegura aos brasileiros e aos estrangeiros residentes no País a inviolabilidade dos direitos concernentes à vida, à liberdade, à segurança e à propriedade, nos termos seguintes:

$\S 1^{\circ}$ - Todos são iguais perante a lei, sem distinção, de sexo, raça, trabalho, credo religioso e conviç̧ões políticas. O preconceito de raça será punido pela lei.
}

Conclui que, para evitar deslizes na conduta brasileira em relação aos problemas das mulheres (PBR - F), e com o objetivo de intensificar as relações entre o Brasil e os demais países signatários da Convenção - para que, inclusive, exista cooperação na resolução de questões relativas ao tema (PEB - F) - seu parecer é pela aprovação da Convenção.

\section{PARECER dA COMISSÃO DE COMISSÃO DE CONSTITUIÇÃO E JUSTIÇA (CD), GOMES DA SILVA, 1982.}

[Câmara - Parecer 2]

\footnotetext{
${ }^{98}$ Apesar de o Parecer mencionar o art. 153, parágrafo $1^{\circ}$, o artigo com a redação explicitada no parecer é, na verdade, o art.150, $\S 1^{\circ}$, da Constituição de 1967.
} 
O parecer, elaborado pelo Deputado Gomes da Silva, em 13.09.1982, apenas aponta que o Projeto de Decreto Legislativo 141/1982, "além de não ofensivo a qualquer princípio jurídico, encontra-se elaborado de forma irretocável". Vota, então, favoravelmente, "Por sua constitucionalidade, juridicidade e técnica legislativa" (DBR - F). ${ }^{99}$

\section{PARECER DA COMISSÃO DE RELAÇÕES EXTERIORES (n. 911 - SF), OCTAVIO CARDOSO, 1983}

[Senado - Parecer 1]

O parecer, de 14.09.1983, é de autoria do Senador Octavio Cardoso, e descreve a tramitação do Projeto até sua chegada ao Senado. No que se refere à competência da Comissão, o relator aponta que não há nada para repreender na Convenção, nos termos do Projeto de Decreto Legislativo 13/1983. O Senador não dá quaisquer motivos para sua decisão.

PARECER DA COMISSÃO DE CONSTITUIÇÃO E JUSTIÇA (n.912 - SF), HERVÍDIO NUNES, 1983

[Senado - Parecer 2]

No parecer, de 19.10.1983, o Senador, após apresentar a Convenção, ressalta que ela valoriza uma das mais relevantes forças de trabalho do país (PBR - F), completamente merecedora do destaque que lhe é consignado pela Constituição Federal, no art. 153, $\S 1^{\circ}$, que trata da igualdade de todos perante a lei, sem distinção de sexo (DBR - F). O parecer é pela aprovação da Convenção, nos termos do projeto de decreto legislativo. ${ }^{100}$

\section{PARECER DA CONSULTORIA JURÍDICA DO ITAMARATY, ANTONIO AUGUSTO CANÇADO TRINDADE, 1986}

[Executivo, Parecer MRE]

\footnotetext{
${ }^{99}$ DCN 01.06.1983, p. 4.331.

${ }^{100}$ O Parecer 972, de 03.11.1983, da Comissão de redação, de autoria da Senadora Íris Célia, aprova a redação final do projeto. Publicado no DCN (Seção II) de 04.11.1983.
} 
O parecer, de 11.07.1986, é de autoria do professor Antonio Augusto Cançado Trindade. Nele, é apreciada a necessidade de harmonização entre a Convenção e a legislação interna a respeito da discriminação contra a mulher, além do levantamento das reservas feitas à Convenção. ${ }^{101}$ Segundo o consultor, as reservas formuladas pelo Brasil ao art. 15.4 e ao art. 16 são alvo constante de críticas dos países ocidentais na ONU, por serem incompatíveis com o objeto e com o propósito da Convenção, o que contrariaria seu art. 28.2. A reserva ao art. 29.2, referente à solução pacífica de controvérsias internacionais, reitera posição adotada e mantida pelo Brasil nos últimos anos - menciona, inclusive, parecer próprio a respeito do tema (PEB - F). ${ }^{102}$

O consultor aponta a permanência da incompatibilidade dos artigos da Convenção com diversos dispositivos do direito interno (DBR - C). Em virtude da manutenção dessas incompatibilidades, ressalta que não seria cabível retirar as reservas feitas pelo Brasil, o que poderia ser feito, apenas, mediante prévia - e necessária - modificação da legislação nacional, para compatibilizá-la com a Convenção. Lembra do envio, para a aprovação do Congresso Nacional, dos dois Pactos de Direitos Humanos de 1966, sendo que o PIDCP proíbe a discriminação com base no sexo (DIN - F). Seria, portanto, ideal modificar a legislação nacional, para que pudesse estar em harmonia com as obrigações internacionais contraídas pelo país (PEB - F). No âmbito da proteção dos Direitos Humanos, é imprescindível assegurar a interação entre o Direito internacional e o interno (PBR - F).

\subsection{RETIRADA DAS RESERVAS À CONVENÇÃO}

\section{MENSAGEM DO PODER EXECUTIVO (MSC 345/1993)}

A Mensagem, de 31.05.1993, redigida pelo Ministro interino Luiz Felipe Lampreia, foi encaminhada ao Congresso em 22.06.1993, pelo Presidente da República, Itamar Franco, com a indicação de que fosse submetida à apreciação dos parlamentares o levantamento das reservas apostas pelo governo aos artigos $15, \S 4^{\circ}$, e $16, \S 1^{\circ}$, alíneas (a), (c), (g) e (h) da

\footnotetext{
${ }^{101}$ Relembro o leitor, rapidamente, que o Brasil ratificou a Convenção com reservas ao artigo 15.4 e ao artigo 16.1 (a), (c), (g) e (h), em virtude do conflito com a legislação interna; e ao art. 29.2, que trata da solução pacífica de controvérsias internacionais.

${ }^{102}$ Cláusulas sobre Solução Pacífica de Controvérsias em Acordos internacionais (com Atenção Especial à Prática do Brasil), de 28.10.1985.
} 
Convenção. O Ministro Lampreia apresenta o histórico dessa Mensagem, qual seja, a assinatura e a promulgação da Convenção. Segundo o Ministro, o Brasil “(...) tem reafirmado sua disposição de cumprir integralmente suas obrigações, no campo da promoção e proteção dos direitos humanos, ai incluidos os direitos da mulher." (PBR - F). O governo brasileiro, ademais, estaria empenhado em construir um país no qual fossem respeitados a democracia, a justiça social e a pessoa humana, seus direitos e liberdades fundamentais (PBR - F). Além dessa defesa dos Direitos Humanos no âmbito interno, o Brasil manifesta seu apoio à proteção dos Direitos Humanos internacionalmente, em foros multilaterais (PEB - F). A mulher é relevante para o desenvolvimento do país (DH mulheres $-F$ ), que tem atuado para responder às expectativas da sociedade civil (PBR - F). Tratar-se-ia de momento adequado para implementar a Convenção em sua totalidade, retirando as reservas, eliminando a discriminação em relação às mulheres e contribuindo para a melhoria de seus direitos no país (PBR - F).

A retirada das reservas teria significativa importância política, pois, à época, ocorreram diversos encontros paradigmáticos internacionais, no âmbito da ONU, para tratar de temas globais (PEB - F). Exemplo disso foi a Conferência Mundial dos Direitos Humanos (Viena, 1993), a Conferência Mundial de População (Cairo, 1994) e a Conferência Internacional da Mulher (Pequim, 1995).

O Ministro aponta, ainda, que teriam sido superados os obstáculos jurídicos à aceitação dos artigos aos quais foram apostas reservas. Os artigos $5^{\circ}, \mathrm{I}^{103}$ e $226, \S 5^{\mathrm{o}},{ }^{104} \mathrm{CF}$, teriam esse condão (DBR - F). Considera, além da inovação constitucional, o fato de que o Brasil aderiu, em 1992, aos dois Pactos de Direitos Humanos da ONU (DIN - F).

\section{PARECER DA COMISSÃO DE RELAÇÕES EXTERIORES (CD), ZILA BEZERRA, 1994}

[Câmara - Parecer 1]

\footnotetext{
${ }^{103}$ Art. $5^{\circ}$ Todos são iguais perante a lei, sem distinção de qualquer natureza, garantindo-se aos brasileiros e aos estrangeiros residentes no País a inviolabilidade do direito à vida, à liberdade, à igualdade, à segurança e à propriedade, nos termos seguintes:

I - homens e mulheres são iguais em direitos e obrigações, nos termos desta Constituição; (...)

${ }^{104}$ Art. 226. A família, base da sociedade, tem especial proteção do Estado.

$\S 5^{\circ}$ Os direitos e deveres referentes à sociedade conjugal são exercidos igualmente pelo homem e pela mulher.
} 
Em 23.03.1994, a Deputada Zila Bezerra proferiu parecer a respeito da MSC 345/1993. Após relatório acerca do pedido de levantamento de reservas, objeto da Mensagem, a Deputada afirma que, embora as reservas fossem válidas à época que foram elaboradas, por serem contrárias à ordem jurídica nacional vigente; os obstáculos legislativos que as justificavam foram superados, principalmente após a promulgação da Constituição de 1988 (DBR - F).

O parecer foi acatado, unanimemente, pela Comissão.

\section{PARECER COMISSÃO DE SEGURIDADE SOCIAL E FAMÍlIA (CD), RITA CAMATA, 1994}

[Câmara - Parecer 2]

A Deputada Rita Camata proferiu, em 17.05.1994, parecer a respeito do PDC 407/1994. Após relato acerca da tramitação da Convenção, e da intenção do Poder Executivo de levantar as reservas, diz que esse instrumento é de extrema relevância para a proteção dos direitos das mulheres, batalha que vêm travando desde as últimas décadas do século XIX, e que ainda não terminou ( $\mathrm{DH}$ - mulheres - F). A igualdade legal é etapa essencial para superar a discriminação social das mulheres, algo que o direito interno, com a Constituição de 1988, fez em tempos recentes (DBR - F).

O PDC em pauta seria instrumento importante para reafirmar novo posicionamento do Brasil nas relações internacionais, como país coerente com a democracia estampada em sua Carta Magna (PEB - F). No âmbito nacional, a adesão irrestrita à Convenção contribuiria para retirar a legislação anacrônica e discriminatória que existe no país, consubstanciando a necessária igualdade entre homens e mulheres (PBR - F).

O parecer foi aprovado por unanimidade.

\section{PARECER DA COMISSÃO DE SEGURIDADE SOCIAL E FAMÍlIA (CD), NELSON TRAD, 1994}

[Câmara - Parecer 3]

No parecer, sem data específica, o Deputado Nelson Trad diz, apenas, que o projeto é de alta relevância, e de perfeita técnica legislativa, opinando por sua aprovação. 
PARECER dA COMISSÃo de CONSTITUIÇÃO, JUSTIÇA E CIDADANIA (SF), JUTAHY MAGALHÃES, 1994

[Senado - Parecer 1]

O parecer, de 15.06.1994, é de autoria do Senador Jutahy Magalhães. Após relato sobre da tramitação do tratado, o Senador diz que a preocupação do governo brasileiro, veiculada no país (PBR - F) e no exterior (PEB - F), é garantir a proteção efetiva dos direitos das mulheres. As reservas feitas à Convenção, não se justificam, em virtude das mudanças constitucionais (DBR - F). O parecer é, portanto, pela aprovação do PDS.

O parecer foi aprovado por unanimidade.

\section{MANIFESTAÇÃO DO SENADOR NELSON CARNEIRO}

O Senador Nelson Carneiro manifestou-se quando da votação do relatório acima analisado. Segundo o Senador, é necessário aprovar a Convenção sem reservas, pois a luta em prol dos direitos das mulheres culminou no texto da Constituição de 1988, que expressamente acaba com as diferenças entre homens e mulheres no Brasil (DBR - F). 


\subsection{PROTOCOLO FACULTATIVO À CONVENÇÃO SOBRE A ELIMINAÇÃO DE TODAS AS FORMAS DE DISCRIMINAÇÃO CONTRA A MULHER}

O Protocolo Facultativo à Convenção sobre a Eliminação de Todas as Formas de Discriminação contra a Mulher foi adotado pela AGNU em 06.10.1999, assinado pelo governo brasileiro em 13.03.2001 e promulgado pelo Decreto Presidencial 4.316, de 30.07.2002. Seu processo de aprovação tramitou na Câmara dos Deputados como Projeto de Decreto Legislativo 1.357, de 2001, e no Senado Federal como Projeto de Decreto Legislativo 01, de 2002. A matéria foi encaminhada ao Senado Federal em 12.12.2001. O Congresso Nacional aprovou o texto do Protocolo Facultativo à Convenção sobre a Eliminação de Todas as Formas de Discriminação contra a Mulher, por meio do Decreto Legislativo 107, de 06.06.2002. O Protocolo entrou em vigor, para o Brasil, em 28.09.2002, nos termos de seu art. $16, \S 2^{\circ}$.

O Protocolo trata do reconhecimento, por parte dos Estados membros da Convenção, da competência do Comitê da Convenção sobre a eliminação de todas as formas de Discriminação contra a Mulher; e prevê mecanismo por meio do qual as denúncias sobre casos de discriminação contra a mulher podem ser apresentadas individualmente ao Comitê.

\section{STATUS NA ONU}

https://treaties.un.org/Pages/ViewDetails.aspx?src=IND\&mtdsg_no=IV-8b\&chapter $=4$ \&lang $=$ en

\section{MENSAGEM DO PODER EXECUTIVO (MSC 374/2001)}

A Mensagem, de 16.04.2001, foi enviada ao Congresso pelo Presidente Fernando Henrique Cardoso, em 25.04.2001, e redigida pelo Ministro das Relações Exteriores, o senhor Celso Lafer. Segundo a Mensagem, o Protocolo seria instrumento importante para fortalecer a Convenção e renovar o compromisso do governo brasileiro em relação à promoção e à proteção dos direitos das mulheres (PEB - F). 


\section{PARECER DA SECRETARIA DE ESTADO DAS RELAÇÕES EXTERIORES, HAROLDO TEIXEIRA VALLADÃO JÚNIOR, 2000}

[Executivo - Parecer MRE]

Na MSC 374/2001 é encaminhado ao Congresso parecer elaborado por Haroldo Teixeira Valladão Filho, coordenador-geral de Direito Internacional, de 23.11.2000, que trata da necessidade de consultar o Congresso Nacional para a aprovação do Protocolo em pauta. Segundo o parecer, o Brasil é parte da Convenção à qual se relaciona o Protocolo, e, referindo-se à assinatura do Protocolo, "parece existir consenso interno quanto à conveniência da medida", tanto por parte da sociedade civil como dos Poderes Legislativo e Executivo (PBR - F). O Protocolo, em seu art. 15.1(e), pode ser assinado por qualquer país que se tenha vinculado à Convenção, como é o caso do Brasil.

Conforme o parecer, segundo a "prática brasileira", direcionada pelos artigos 84 , VIII e 49, I, CF, não seria usual submeter a intenção do Poder Executivo de subscrever um tratado internacional à aprovação do Congresso; uma vez que caberia ao Congresso apenas referendar instrumentos internacionais previamente ajustados e assinados pelo Presidente da República (DBR - F).

Ressalta, ainda, que, de acordo com o Direito Internacional, a negociação do tratado termina com a sua assinatura e, após a assinatura, o instrumento em pauta deve ser enviado para a apreciação do Poder Legislativo nacional, que, concordando, autoriza o Poder Executivo a efetuar o depósito do instrumento de ratificação (DIN - F). O parecer aponta para desnecessidade de se consultar o Congresso sobre a assinatura do Protocolo Adicional. A assinatura, segundo Valladão, poderia ocorrer imediatamente, solicitando-se, posteriormente, a aprovação do ato efetuado pelo Executivo, para prosseguir à sua ratificação, promulgação e publicação (PBR - F).

\section{PARECER COMISSÃO DE RELAÇÕES EXTERIORES E DE DEFESA NACIONAL (CD), ELCIONE BARBALHO, 2001}

[Câmara - Parecer 1]

O relatório, de 27.09.2001, é de autoria da Deputada Elcione Barbalho. Após descrição do Protocolo e dos trâmites para a proteção dos direitos das mulheres por ele previstos, a Deputada profere seu voto pela aprovação. 
Segundo a relatora, a normatização dos Direitos Humanos vem crescendo desde 1948, com a elaboração da DUDH (DIN - F). Mecanismos internacionais para a verificação da efetividade da proteção dos Direitos Humanos nos Estados também têm sido adotados, uma vez que os governantes dos Estados percebem, cada vez mais, que não é suficiente declarar direitos, deve haver uma maneira eficaz para monitorar sua proteção (PBR - F).

Reconhecer os direitos das mulheres integra o movimento mundial de afirmação dos Direitos Humanos, o que pode ser verificado pela vigência da Convenção e de seu Protocolo (DIN - F). Para a Deputada, o Brasil deve aderir ao Protocolo para "consolidar o compromisso do país com a garantia dos direitos da mulher e com a promoção da igualdade entre homens e mulheres" (PEB - F). A situação nacional, assim como a realidade internacional em diversos países, seria de persistência das discrepâncias entre homens e mulheres; estas, hipossuficiente em relação ao homem em seu posicionamento na sociedade (PBR - F).

As disposições do Tratado seriam "condizentes com os compromissos internacionais que o Brasil tem assumido no campo dos direitos humanos, sendo semelhantes às normas a que o país está obrigado em função do reconhecimento da jurisdição da Corte Interamericana de Direitos Humanos" (PEB - F). O recurso aos trâmites internos é preservado pelo Protocolo, o que possibilita que o país tente corrigir eventuais infringências aos direitos das mulheres, evitando, deste modo, que efetivamente ocorra uma comunicação contra o país frente ao Comitê, conforme previsto no Protocolo (PBR - F).

A Deputada destaca que a aprovação “(...) atende aos anseios das mulheres brasileiras ao conferir mais um instrumento para que estas possam lutar pela garantia de seus direitos e pela igualdade de condições com os homens" (PBR - F). Assim, vota por sua aprovação.

\section{PARECER COMISSÃo DE SEGURIDAdE SOCIAL E FAMÍliA (CD), TETÉ BEZERRA, 2001}

[Câmara - Parecer 2]

O parecer, de 28.11.2001, foi elaborado pela Deputada Teté Bezerra. Após descrição do Protocolo e de sua tramitação, a relatora analisa o mérito da proposição. Segundo ela, a Carta da ONU e a DUDH reafirmam a igualdade entre homens e mulheres, além de proclamar que todos os seres humanos nascem livres e sem distinções (DIN - F). A Convenção, da qual o Protocolo faz parte, tem como objetivo eliminar a discriminação contra 
as mulheres em todas as suas formas e, para isso, instituiu o Comitê cuja competência deve ser reconhecida pelos Estados signatários por intermédio do Protocolo.

Quanto ao mérito do projeto, deveria ser aprovado por permitir a erradicação de violações aos direitos fundamentais das mulheres, para que todas as atrocidades que sofrem não se perpetuem ( $\mathrm{DH}$ - mulheres - F).

\section{PARECER DA COMISSÃO DE SEGURIDADE SOCIAL E FAMÍLIA (CD), LAURA CARNEIRO, 2001}

[Câmara - Parecer 3]

O Parecer, de autoria da Deputada Laura Carneiro, data de 13.12.2001. Após relato acerca do Protocolo, aponta que este recebeu parecer favorável e foi aprovado por unanimidade da Comissão de Relações Exteriores e Defesa Nacional.

Após mencionar a importância da DUDH e da Convenção (DIN - F), afirma que a instituição do Comitê por parte do Protocolo "constitui uma forma eficaz de combater as violações aos direitos das mulheres, restabelecendo a sua dignidade" (DH - mulher - F). A proposta deveria, portanto, ser aprovada para que fossem erradicadas as violações aos direitos fundamentais das mulheres, para que sejam evitados os abusos aos seus direitos, como ocorre em diversos países.

\section{DIÁRIO DA CÂMARA DOS DEPUTADOS, 13.12.2001 [CD PLEN]}

No Diário da Câmara dos Deputados publicado em 13.12.2001, é relatada uma discussão entre o presidente da Câmara, Aécio Neves, e a Deputada Zulaiê Cobra, que afirma que, como se trata de uma questão relativa aos direitos das mulheres, seria mais adequado que a relatora pela Comissão de Constituição e Justiça e de Redação fosse uma mulher. O presidente tinha, antes disso, concedido a palavra ao Deputado Jaime Martins. Aécio Neves diz que "A Presidência apenas quis que o Deputado Jaime Martins pudesse ter oportunidade para mostrar seu cavalheirismo e ceder a V. Exa a relatoria. Mais uma homenagem à mulher.".

Após conceder a palavra à deputada Zulaiê Cobra, ela informa que a Comissão de Constituição e Justiça e de Redação se manifestou pela constitucionalidade e pela juridicidade do projeto (DBR - F), um avanço do Brasil junto à ONU (PEB - F). 
A Deputada Iara Bernardi aponta que o projeto teria sido o resultado da articulação da bancada feminista com as entidades feministas que atuam na Câmara dos Deputados (PBR - F). O projeto seria um marco para o Brasil, uma vez que as mulheres que não têm suas reivindicações atendidas pelo Judiciário brasileiro, em relação à violência contra as mulheres, terão a faculdade de recorrer aos mecanismos previstos pelo Tratado (DIN - F).

A Deputada Jandira Feghali também reitera a importância do Protocolo, uma vez que, de acordo com dados de instituto latino americano (não menciona o nome), uma mulher é agredida a cada quatro minutos no Brasil (PBR - F).

\section{PARECER DA COMISSÃO DE RELAÇÕES EXTERIORES E DEFESA NACIONAL (n. 277 - SF), EMÍLIA FERNANDES, 2002}

[Senado - Parecer 1]

No parecer, de 16.04.2002, a Senadora Emília Fernandes faz relatório da tramitação e, especificamente, do projeto que aprova o Protocolo - diferentemente do que ocorre em geral nos outros pareceres, que geralmente têm como foco o mérito. Segundo a Senadora, a quantidade de tratados que têm como objetivo assegurar os Direitos Humanos tem crescido nas últimas décadas, sendo as mulheres um grupo que recebe particular atenção. A erradicação de todas as formas de discriminação contra as mulheres tem sido uma prioridade no âmbito internacional. Em diversos países, porém, não foram atingidas as metas estabelecidas pela IV Conferência Mundial sobre a Mulher, realizada em Pequim, 1995 (DH - mulher - F). Inspirada por essas constatações, a Plataforma de Ação do relatório de Pequim recomenda que as reformulações por ela propostas sejam incluídas em um documento para a monitoração efetiva dos direitos das mulheres, o que culminou no Comitê de que trata o Protocolo facultativo.

A aprovação do Protocolo pelo Brasil reafirma o compromisso assumido pelo país para a promoção e a proteção dos direitos das mulheres como parte inseparável dos Direitos Humanos universais. (PEB - F) A Senadora destaca que a adesão do país é coerente com os compromissos internacionais assumidos no âmbito dos Direitos Humanos, e com o reconhecimento da jurisdição de organismos internacionais sobre fatos que tenham ocorrido em território nacional (PEB - F). A internalização do instrumento seria coerente com os interesses nacionais (PBR - F), a nossa Constituição e legislação interna (DBR - F). 


\section{MANIFESTAÇÃO CNBB, 2002}

Apesar de não se tratar de manifestação de nenhum dos Poderes da República e, portanto, não ser considerada neste trabalho para fins de argumentação, destaco a existência de manifestação da Conferência Nacional dos Bispos do Brasil (CNBB), em relação ao PDS 1/2002. A manifestação, de abril de 2002, destaca a "ameaça" silenciosa que se apresenta pela ratificação do Protocolo facultativo à CEDAW. A preocupação dos Bispos é o fato de que o texto da Convenção, apesar de não falar abertamente sobre as “ 'uniões' homossexuais" e o aborto, tem defendido este último abertamente, em particular a sua legalização em diversos países. Para a CNBB, a ratificação do Protocolo daria enormes poderes ao Comitê, que poderia realizar "inquisições", sendo que o Brasil ver-se-ia obrigado a cumprir as recomendações do Comitê, restando completamente subordinado à sua ingerência - externa - sobre os assuntos internos. A ratificação seria verdadeiro "cavalo de Tróia" para o Brasil. E afirma: "se há verdadeiras discriminações injustas contra a mulher em nossa nação, cabe aos nossos legítimos representantes eliminá-las.". Finalmente, a manifestação apela que os membros do Legislativo neguem o prosseguimento do projeto, afirmando que "Deus saberá recompensar os Senadores pelo atendimento a este pedido".

A manifestação é assinada por 71 Bispos do Brasil. ${ }^{105}$

\section{DISCUSSÕES EM PLENÁRIO NA CÂMARA DOS DEPUTADOS, ABRIL DE 2002} [CD PLEN]

É elaborado requerimento (Requerimento 225/2002), de autoria do Senador Tião Viana, para o adiamento da discussão a respeito do PDS 1/2002, em virtude da comunicação recebida da $\mathrm{CNBB}$.

Na discussão em plenário de 25.04.2002, a Senadora Emília Fernandes, umas das relatoras do projeto, manifesta sua surpresa com o fato de que o Protocolo havia sido recebido, discutido e tido o parecer aprovado pela Comissão de Relações Exteriores. A Casa, portanto, conheceu do assunto (PBR - F). A Senadora menciona o recebimento da

\footnotetext{
${ }^{105}$ Em 2015, o Brasil tem um total de 479 Bispos, sendo 312 ativos e 167 eméritos. Apesar de não possuir os dados relativos ao ano de 2012, percebe-se que a assinatura de 71 Bispos é número significativo em relação à quantidade de Bispos ativos do Brasil à época. Informação obtida em: http://servico.cnbb.org.br/carteira/index/painel-episcopado. Acesso: 15.03.2016.
} 
manifestação da CNBB pedindo o adiamento da votação, e diz-se admirada com o recebimento desse pedido apenas após a prolongada tramitação do Protocolo na Casa. O tratado, importante para os Direitos Humanos, é instrumento de caráter procedimental, não cria novos direitos, tampouco estabelece diretrizes que devam ser adotadas pelo país (DH mulher - F). Destaca os equívocos cometidos pela manifestação da $\mathrm{CNBB}$, que trata o Protocolo como instrumento ameaçador da soberania brasileira. E acrescenta que a Presidência da República apoia a internalização do tratado, como pode ser percebido pela sua assinatura (PEB - F). O tratado não define, mas faz recomendações aos países, e reitera que o Brasil é signatário do Protocolo e da CEDAW, apesar de não ter internalizado o primeiro instrumento naquele momento. Para a Senadora, “O país vai avançar ou retroceder quando o Congresso Nacional e a sua legislação assim o entender" (PBR - F). ${ }^{106}$ A Senadora lamenta que a Casa adie a votação de matéria apoiada pelo Presidente, pelas ONGs e por todos os Deputados que aprovaram o relatório na Comissão de Constituição, Justiça e de Redação e na Comissão de Família e Seguridade (PBR - F). Os argumentos da manifestação da CNBB, portanto, não se sustentariam. Apesar disso, a Senadora aponta que se trata de oportunidade de discutir mais intensamente a situação, quiçá realizando audiência pública para isso.

Para o Senador Roberto Freire, por sua vez, o que a manifestação da CNBB pretende não é apenas adiar a discussão, mas a rejeição do tratado por parte do Senado. Para ele, o Protocolo insere-se no contexto de esforço da ONU para a consolidação dos Direitos Humanos, particularmente dos direitos das mulheres, algo de fundamental importância no século XXI (DH - mulher - F). A presença do Brasil nesse tratado é fundamental para a democracia nacional (PBR - F). Freire demonstra preocupação quanto à interferência da Igreja no Brasil: seria necessário respeitar a laicidade da República (PBR - F).

A Senadora Marina Silva, por sua vez, destaca que a CNBB apenas pede que a situação seja discutida com maior cautela. Apesar de concordar que o Protocolo apresenta relevantes direitos para as mulheres, o tema é delicado e, por existir no país um regime democrático, deve estar aberto a discussões (PBR - F). O debate aprofundado é ainda mais justificável se considerado o fato de a Câmara dos Deputados ter tido um ano para discutir a matéria, e não seria justo que os Senadores fossem tratados como indivíduos sem opiniões (PBR - F).

${ }^{106}$ DSF 26.04.2002, col. 2., grifo nosso. 
Marina Silva é favorável ao requerimento, apesar de entender a importância da Convenção e do Protocolo para os direitos das mulheres.

O Requerimento de adiamento da votação foi aprovado.

\section{DISCUSSÃO EM PLENÁRIO, JUNHO DE 2002 E AUDIÊNCIA PÚBLICA ${ }^{107}$ [CD PLEN]}

Na sessão de 06.06.2002, a Relatora, Senadora Emília Fernandes, fala da audiência pública, realizada entre 25.04.2002 e 05.06.2002, para discutir o tema, com a presença de integrantes do Poder Executivo - Ministro Hildebrando Tadeu Nascimento Valadares, representante do MRE, do Poder Legislativo, acadêmicos, membros da sociedade civil e da Igreja Católica. ${ }^{108}$ Teria sido unânime o entendimento a respeito da necessidade de se aprovar o Protocolo, documento instrumental que não cria direitos substantivos para as mulheres, fortalecendo a Convenção, que o Brasil integra desde a década de 1980. A CNBB, inclusive, representada por D. Aloysio Penna, reconheceu a falha da comunicação enviada ao Legislativo, que não representaria a posição da presidência da instituição. As notas

\footnotetext{
${ }^{107}$ Apesar de, conforme a Senadora Emília Fernandes, não se tratar propriamente de audiência pública, mas de “(...) uma reunião, a convite desta Senadora, relatora do projeto, mediante a qual quero agregar dados, inclusive, para ir ao Plenário fazer a defesa da matéria” (DSF 06.06.2002, col. 1), utilizei a denominação "Audiência Pública" no título, por falta de denominação mais específica, e por se tratar de reunião feita nos moldes das audiências públicas.

108 É mencionada a presença e a participação de: Ministro Hildebrando Tadeu Nascimento Valadares, Diretor-Geral do Departamento de Direitos Humanos e Temas Sociais do MRE; Dra Solange Bentes Jurema, Secretária Nacional dos Direitos da Mulher; D. Aloysio José Leal Penna, Arcebispo de Botucatu e responsável pela Pastoral da Família, que veio autorizado e representando a CNBB; Dra Silvia Pimentel, Coordenadora Nacional do Comitê Latino-Americano e do Caribe para a Defesa dos Direitos da Mulher (CLADEM/Brasil); Dra Flávia Piovesan, Procuradora do Estado de São Paulo e professora de Direitos Humanos da Pontifícia Universidade Católica de São Paulo. Secundariamente, são mencionados Pe. Ernane Pinheiro, assessor da CNBB; Valéria Pandjiarjiam, do Comitê Latino-americano de Defesa dos Direitos Humanos; Regina Bitencourt e Adriana Rodrigues Martins, ambas da Divisão de Temas Sociais do MRE; Magalho da Silva, da DAI-MRE; Marlene Libardone, Diretora Executiva da Agende; Ella Castilho, Subprocuradora-Geral da República; Sueli Aparecida Bilato, do gabinete do Senador Tião Viana, do Partido dos Trabalhadores do Acre; e professora Deputada Esther Grossi, Presidente da Comissão de Educação da Câmara dos Deputados. Também estavam presentes Diane Isabel Dias, representante do Cfemea; Vereador José Caixeta, Presidente da Câmara Municipal de Anápolis, Goiás; Srạ Marta Avancini, do Estado de São Paulo; Sra Elisabeth Oliveira Barreiros, do Fórum de Mulheres do Distrito Federal; Padre Luís Carlos da Cruz, do Pró-Vida de Anápolis, Goiás; Srạs Maria da Piedade Lopes, Neli Pimenta de Souza, Marilene Cunha Santos e Cícera Soares dos Santos também do Pró-Vida de Anápolis.
} 
taquigráficas da Audiência foram incluídas no pronunciamento da Senadora, mas não serão abordadas em sua totalidade, por fugirem de seu escopo da tese.

Serão, apenas, consideradas como manifestação do Poder Executivo as manifestações do Ministro Hildebrando Tadeu Nascimento Valadares e de Solange Bentes Jurema, Secretária Nacional dos Direitos da Mulher e Presidente Nacional do Conselho Nacional dos Direitos da Mulher; e como manifestações do Poder legislativo, as da Senadora Marina Silva e das Deputadas Iara Bernardi, e Luiza Erundina, integrantes da Bancada Feminina do Congresso Nacional, que inclui a aprovação do Protocolo como um de seus projetos prioritários. $^{109}$

Em sua primeira manifestação, além de explicar o procedimento de internalização do Protocolo e o porquê da convocação da audiência pública, a Senadora Emília Fernandes reitera que o Protocolo é, como outros tratados internacionais firmados pelo Brasil, instrumento que contempla procedimentos de denúncias, como o Protocolo Facultativo ao Pacto Internacional de Direitos Civis e Políticos; Convenção sobre a Eliminação de todas as Formas de Discriminação Racial em seu art. 14; e a Convenção contra a Tortura, por exemplo, em seu art. 22 (DIN - F). Ressalta, ainda, a recente promulgação, à época, do Decreto Legislativo 57/2002, que aprovou a solicitação de o Brasil fazer a declaração facultativa prevista no art. 14 da Convenção Internacional sobre a Eliminação de todas as Formas de Discriminação Racial, para receber e analisar denúncias relativas a violações de Direitos Humanos por ela previstos (DBR - F).

[Executivo - outras manif.]

O senhor Hildebrando Tadeu Nascimento Valadares discursa em nome do Poder Executivo, como ele mesmo aponta no início de sua manifestação. O Embaixador discorre a respeito do histórico foco da ONU em promover a igualdade de gênero, e na criação, na década de 1940, da Comissão sobre a Situação da Mulher, órgão especial competente para tratar do tema. Esse órgão promove conferências mundiais a respeito da questão da mulher, algo essencial para a conscientização. A Convenção e o seu Protocolo são essenciais para promover a igualdade de gêneros no mundo (PEB - F). O movimento fortaleceu-se e culminou na elaboração da Convenção sobre a Eliminação de Todas as Formas de

${ }^{109}$ Foram descartadas, pelas razões supra mencionadas, as manifestações de D. Aloysio José Leal Penna; Dr ${ }^{\mathrm{a}}$ Silvia Pimentel e Dr ${ }^{\mathrm{a}}$ Flávia Piovesan. 
Discriminação contra a Mulher, na década de 1970. Destaca a assinatura, pelo Brasil, da Convenção, assinada com reservas relativas à igualdade entre homens e mulheres perante a lei, e a discriminação contra mulheres em relação ao instituto do casamento e à família; reservas que, posteriormente, foram retiradas, em virtude dos dispositivos da nova Constituição de 1988 (DBR - F). A Convenção prevê um comitê de peritos, eleitos pelos Estados signatários, para acompanhar a implementação da CEDAW, além de examinar os relatórios nacionais quadrienais. O Brasil, segundo o diplomata, possui significativa dívida institucional em termos de política externa, por não ter apresentado relatório nacional até aquele momento $(\mathrm{PEB}-\mathrm{F})$. O relatório, que seria encaminhado à $\mathrm{ONU}$ dentro de alguns meses, sanando essa dívida, teria sido elaborado, em grande medida, pela sociedade civil, movimentos femininos atuantes na sociedade brasileira, o que teria sido de grande valia para o MRE (PBR - F). Valadares explica minuciosamente o teor do Protocolo, e afirma que, assim como ocorreu com o Relator Especial da ONU sobre tortura, que veio ao Brasil e deu seu parecer e suas recomendações, o Estado acredita que a relação com plenipotenciários da ONU é interação positiva para a maior defesa dos Direitos Humanos no país (PBR - F). Para o Poder Executivo, o sistema criado pelo Protocolo é um estímulo adicional à implementação dos objetivos da Convenção, porque prevê um mecanismo de petição para esse tratado. Destaca, ainda, que a Convenção Interamericana para Prevenir e Punir a Violência contra a Mulher, de 1984, ratificada sem reservas pelo Brasil, tem mecanismo semelhante (DIN - F). Os membros do Poder Executivo acreditam que o reconhecimento da competência do Comitê com a ratificação do Protocolo responde às expectativas da nossa sociedade (PBR F) e será relevante gesto, que vai reforçar internacionalmente o compromisso do Brasil com a defesa e a promoção dos direitos da mulher (PEB - F), principalmente desde a redemocratização e a elaboração da $\mathrm{CF} / 1988$. A ratificação do Protocolo estaria em plena harmonia com a política externa brasileira, pelo respeito, defesa e promoção dos Direitos Humanos (PEB - F). Essa política coaduna-se não apenas com a dimensão dos direitos civis e políticos, mas com os direitos econômicos, culturais e sociais, implementadas pelo Brasil desde a redemocratização e a adoção da Constituição de 1988 (PBR - F).

[Executivo - outras Manif.]

Segue-se à manifestação do Embaixador a ponderação da Dra. Solange Bentes Jurema, Secretária Nacional dos Direitos da Mulher, que fala em nome dessa Secretaria e do Conselho Nacional dos Direitos da Mulher. Após descrever a Convenção e o Protocolo, a 355 
Secretária diz que este promove o acesso à Justiça para as mulheres em âmbito internacional $(\mathrm{DH}$ - mulher - F). O Protocolo seria um catalisador de mudanças no ordenamento e nas práticas nacionais, pois motivaria os governos a assegurarem a implementação da Convenção no âmbito nacional, em virtude da possibilidade de avaliação internacional, o que também aumentará a consciência pública a respeito do tema das mulheres. (PBR - F) O governo brasileiro vem realizando esforços, nacional (PBR - F) e internacionalmente (PEB - F), para promover os Direitos Humanos em todas as suas manifestações, civil, política, econômica, social e cultural. Os avanços na proteção dos Direitos Humanos foram significativos, particularmente com a adoção da CF/1988 (DBR - F), que demonstra a preocupação com eles e reflete o debate do qual participou a sociedade civil (PBR - F). No Âmbito externo, o Brasil é signatário dos principais tratados multilaterais, regionais ou não, de proteção aos Direitos Humanos (PEB - F). A Secretária menciona diversos deles (DIN F). ${ }^{110} \mathrm{O}$ impulso que esses tratados deram ao movimento de mulheres fez surgir, no Brasil, iniciativas para a redução das desigualdades entre gêneros, e entre etnias, e são mencionados programas de ação afirmativa em âmbito ministerial (PBR - F). ${ }^{111}$ As brasileiras, que podem contar com os mecanismos de proteção presentes na Convenção de Belém do Pará, no âmbito regional (DIN - F), precisam ter o direito de recorrer ao Comitê da CEDAW, no âmbito multilateral mais abrangente, o que só será possível com a ratificação do Protocolo (PBR F). Segundo a Secretária, tanto a Secretaria como o Conselho Nacional dos Direitos da

\footnotetext{
${ }^{110}$ Convenção Sobre a Eliminação da Discriminação Contra a Mulher, de 1979; a Declaração de Direitos Humanos, de Viena; e os documentos referidos, inclusive, pelo Sr. Ministro Tadeu Valadares: a Declaração de Direitos Humanos, em 1993; a Conferência Sobre a População e o Desenvolvimento, do Cairo, em 1994; a Convenção Interamericana para Prevenir, Punir e Erradicar a Violência contra a Mulher, em 1994; e a Declaração e a Plataforma de Ação de Pequim, em 1995.

${ }^{111}$ O Ministério de Desenvolvimento Agrário estabeleceu programa de cotas que destinou, inicialmente, $30 \%$ de todos os recursos para mulheres assentadas e para quem tem unidades de agricultura familiar. Esses recursos englobam financiamentos do Programa Nacional de Fortalecimento da Agricultura Familiar, Banco da Terra, capacitação e assistência técnica. As mulheres terão direito a 30\% dos R\$4 bilhões que o Governo oferece em financiamentos para a reforma agrária todos os anos. O Ministério da Justiça, por sua vez, instituiu programa de ações afirmativas, cujo principal objetivo é incorporar, no Ministério, conjunto de medidas previstas no Programa Nacional de Direitos Humanos, especificamente as referências à promoção e proteção dos direitos dos afrodescendentes, das mulheres e dos portadores de deficiência física. Foi também estabelecido que deveria ser observado, no Ministério da Justiça, no preenchimento de cargos de Direção e de Assessoramento Superior, até o final de 2002, metas de participação de afrodescendentes, de mulheres e de portadores de deficiência física.
} 
Mulher acreditam que a ratificação do Protocolo expressa o compromisso do Governo, no contexto internacional, com a promoção dos Direitos Humanos das mulheres, sinalizando sua posição no combate a todas as formas de discriminação (PEB - F).

Seguiu-se o pronunciamento da Deputada Luíza Erundina, que agradece a presença de todos, inclusive a dos representantes da CNBB, e congratula a Senadora Emília Fernandes pela iniciativa.

A Deputada Iara Bernardi, por sua vez, pede uma manifestação da CNBB que deixe clara a posição da organização em relação ao tratado. ${ }^{112}$ A Deputada reitera a necessidade de o Protocolo ajudar o país na aprovação de legislação que aprimore o respeito aos direitos das mulheres (PBR - F).

A Senadora Marina Silva destaca que o pedido da Deputada Iara é desnecessário, uma vez que a manifestação do clérigo é tida como manifestação oficial da CNBB, sem que haja necessidade de carta formal nesse sentido. Ademais, a Senadora aponta para o aspecto do Protocolo que suscitou a discussão que culminou na realização da Audiência Pública: a questão do direito à vida e ao aborto. Apesar de a Senadora ser, pessoal e abertamente, contra o aborto, cita o art. $5^{\circ}, \mathrm{VI}, \mathrm{CF}$, que determina a inviolabilidade do direito à liberdade de consciência (DBR - C), e possibilitaria, em sua percepção, a discussão a respeito do tema. A Câmara levou mais de um ano para realizar as discussões a respeito do tema, e o Senado teria os mesmos direitos (PBR - C).

Na discussão em Plenário do dia 05.06.2002, o Senador Mauro Miranda ressalta a aprovação do Projeto de Lei 10.455, sancionado pelo Presidente, que se refere à discriminação contra a mulher e à violência sofrida pela mulher no lar (DBR - F). Reitera o fato de que o Protocolo deve ser tratado com cuidado, em virtude da manifestação recebida pelos Bispos, mesmo tendo sido rechaçada pela $\mathrm{CNBB}$ durante a reunião anterior, fato

\footnotetext{
${ }^{112}$ Isso porque, em sua manifestação, o representante da CNBB destacou que a carta recebida pelos membros do Legislativo, assinada por diversos Bispos brasileiros, não correspondia à posição oficial da Presidência da instituição, que apoiava a internalização do Protocolo.
} 
reiterado por documento enviado pela $\mathrm{CNBB}$, de autoria do próprio Dom Aloysio José Leal Penna. ${ }^{113}$

A Senadora Heloísa Helena destaca que a discussão já foi feita na Casa em momentos anteriores, e, após recapitular a tramitação do Protocolo, afirma que, apesar de ser contrária ao aborto, o Protocolo disso não trata. E diz que o Protocolo possibilita às mulheres no Brasil uma discussão séria sobre seus direitos, além de disporem de instâncias internacionais para que sejam respeitados (PBR - F).

O Senador Carlos do Patrocínio, o primeiro autor do requerimento para adiar a discussão do Projeto, reitera a necessidade de mais tempo para a discussão do tema do Protocolo.

O Senador Roberto Freire aponta que o Protocolo reitera a posição do Brasil perante os foros internacionais, um defensor do combate à discriminação contra a mulher no mundo, e o país deve dar esse exemplo (PEB - F).

O Senador Artur da Távola diz que o governo brasileiro se fez representar no Protocolo (PEB - F), com sua assinatura, e que a sua apreciação não deve ser, novamente, postergada.

A Senadora Emília Fernandes afirma que o país quer colocar-se à frente das questões relevantes no âmbito internacional, o que seria possibilitado pelo Protocolo (PEB - F) O Governo brasileiro pede a aprovação do Protocolo, assim como a Câmara dos Deputados, que já o aprovou, sendo um retrocesso que o Senado não o faça (PBR - F).

O Requerimento foi votado e rejeitado, com os votos contrários dos Senadores Mauro Miranda, Iris Rezende, Maguito Vilela, Carlos Patrocínio, Pedro Simon, Álvaro Dias, Jonas Pinheiro e Osmar Dias.

\footnotetext{
${ }^{113}$ No documento, o clérigo diz que: "Gostaria de esclarecer que há dois documentos. O primeiro é uma carta" - referindo-se à carta que motivou a discussão a respeito do Protocolo - "que foi assinada por representantes regionais da CNBB. Tenho a dizer, a bem da verdade, que foi entregue, juntamente com essa carta, que tem apenas uma folha, um outro documento que não é, absolutamente, oficial na CNBB e que não representa o pensamento da CNBB".
} 


\section{ANÁliSE: CONVENÇÃO CONTRA A TORTURA E OUTROS TRATAMENTOS OU PENAS CRUÉIS, DESUMANOS OU DEGRADANTES}

A Convenção contra a tortura e outros tratamentos ou penas cruéis, desumanos ou degradantes, de 10.12.1984, entrou em vigor internacional em 26.06.1987, de acordo com as disposições de seu artigo 27.1. Essa Convenção foi assinada pelo plenipotenciário brasileiro em 23.09.1985, e ratificada em 28.09.1989, na forma do art. 27.2; entrando em vigor para o Brasil em 28 de outubro de 1989, na forma de seu art. 27.2. Foi enviada ao Congresso Nacional pelo Presidente José Sarney em 03.06.1986 pela Mensagem Presidencial 192, de 29.05.1986. Seu processo de aprovação tramitou na Câmara dos Deputados como Projeto de Decreto Legislativo 153, de 1986, e a matéria foi enviada ao Senado Federal em 23.06.1987, onde tramitou como Projeto de Decreto Legislativo 2, de 1987. Foi aprovada pelo Decreto Legislativo 4, de 23.05.1989, e promulgada pelo Decreto Presidencial 40, de 15.02.1991.

A Convenção foi o resultado de esforços que se seguiram à conhecida "Declaração sobre a Tortura", ${ }^{114}$ com a qual os representantes de membros da ONU iniciaram esforços para combater a utilização da tortura. Depois dessa Declaração, outras foram adotadas, e, finalmente, iniciados os trabalhos para a elaboração da Convenção. Diversos temas controversos foram discutidos, particularmente a definição de tortura, que, para muitos, seria de difícil especificação; a questão da jurisdição estatal ou universal em relação a esse crime, sendo aceita esta última, e a efetividade da implementação internacional da Convenção, o que culminou na formação de um Comitê para supervisionar o sistema. ${ }^{115}$

O Presidente José Sarney, no discurso analisado no item 10, também expressa a intenção de aderir a essa Convenção. Para evitar a repetição dos argumentos, remeto o leitor à descrição referente ao Pacto Internacional sobre os Direitos Civis e Políticos.

\section{STATUS NA ONU:}

https://treaties.un.org/Pages/ViewDetails.aspx?src=IND\&mtdsg_no=IV-9\&chapter=4\&lang=en Declarations made under articles 21 and 22 (Declarations recognizing the Competence of the Committee against Torture)

\footnotetext{
114 Resolução 3451 (XXX), adotada pela AGNU em 09.12.1975.

115 Informações obtidas em: http://legal.un.org/avl/ha/catcidtp/catcidtp.html. Acesso: 16.03.2016. 
Brazil 26 June 2006: "the Federative Republic of Brazil recognizes the competence of the Committee against Torture to receive and consider denunciations of violations of the provisions of the Convention against Torture and Other Cruel, Inhuman or Degrading Treatment or Punishment, adopted in New York on December 10, 1984, as permitted by Article 22 of the Convention."

\section{MENSAGEM DO PODER EXECUTIVO (MSC 195/1986)}

A Mensagem do Poder Executivo 195, de 29.05.1986, é de autoria do Ministro das Relações Exteriores, Roberto de Abreu Sodré, e foi encaminhada pelo Presidente José Sarney ao Congresso Nacional em 03.06.1986. O primeiro ponto apontado por Sodré é o fato de o governo Sarney ter "um compromisso efetivo com a causa da promoção e proteção dos direitos humanos" (PBR - F). ${ }^{116}$ Essa seria a causa da assinatura, por parte do Brasil, de diversos tratados internacionais relativos aos Direitos Humanos, mencionados expressamente pelo Ministro (DIN - F) ${ }^{117}$ - fato que ressaltado pelo Presidente Sarney em seu discurso durante a abertura da $40^{\mathrm{a}} \mathrm{AGNU}$, mencionado acima.

Ainda de acordo com o Ministro, a opção por assinar o Tratado se enquadraria na "tradição jurídico diplomática brasileira", ${ }^{118}$ que concede grande relevância aos tratados de direitos humanos, de natureza particularmente humanitária e ética (PEB - F). Esse fato seria ilustrado por ser o Brasil signatário de diversos tratados humanitários.

\section{PARECER dA COMISSÃo de RELAÇÕES EXTERIORES (CD), FLÁVIO BIERRENBACH, 1986}

[Câmara - Parecer 1]

O Parecer da Comissão de Relações Exteriores foi elaborado pelo Deputado Flávio Bierrenbach, em 03.12.1986. O voto do relator afirma que o texto da Convenção retoma os passos, ao longo da história da humanidade, em direção à afirmação dos Direitos Humanos perante a "prepotência dos Estados". O relator aponta para os diversos casos de violações

\footnotetext{
${ }^{116}$ DCN 28.04.1987, p.1.345, col. 1.

${ }^{117}$ Foram mencionados os seguintes tratados: Pactos da ONU sobre Direitos Humanos, Convenção Americana de Direitos Humanos, Convenção relativa ao Estatuto dos Refugiados, Convenção Internacional sobre a Eliminação de todas as formas de Discriminação Racial e Convenção Internacional sobre a Eliminação de todas as formas de Discriminação contra a Mulher.

${ }^{118}$ DCN 28.04.1987, p.1.345, col. 2.
} 
aos Direitos Humanos, remotos e recentes, "especialmente durante o regime autoritário que dominou nossa Nação por mais de duas décadas" (PBR - F). ${ }^{119}$

Conclui que é relevante que a AGNU faça que seus membros ratifiquem a Convenção, por se tratar de um avanço na luta pela afirmação dos Direitos Humanos, bem como no avanço “(...) na consciência moral e jurídica da humanidade” (DH - F). ${ }^{120} \mathrm{O}$ voto é pela aprovação da Convenção.

\section{PARECER DE RUY NEDEL (CD), 1987}

[Câmara - Parecer 2]

Trata-se de parecer de Ruy Nedel, na qualidade de relator apontado pela Mesa da Câmara dos Deputados, para apreciar o Projeto de Decreto Legislativo 153/1986, que aprova o texto da Convenção. Para o Deputado, o texto da Convenção relaciona-se com questões afetas à moral e à dignidade do ser humano (DH - tortura - F). Não queremos que episódios de tortura voltem a ocorrer na história brasileira (PBR - F). Essa legislação internacional é essencial para evitar acontecimentos como esse e para a punição de torturadores. A Convenção traz orientações para que "o humanismo faça parte da nossa sociedade até nos momentos de crise" (PBR - F). ${ }^{121}$

[CD PLEN]

Segue-se à leitura do Parecer as manifestações de Deputados. O primeiro deles é José Genoíno. Segundo ele, a aprovação da Convenção é decisão histórica, e deveria ter sido assinada pelo governo há mais tempo (PBR - F). Genoíno ressalta que a questão da tortura está contemplada no texto da Comissão da Soberania e dos Direitos e Garantias do Homem e da Mulher (PBR - F). A aprovação da Convenção tem relevância histórica para um país como o Brasil, que vem de um período no qual a tortura era prática de governo (PBR - F).

O Deputado Amaury Müller, por sua vez, registra a satisfação do se partido (o Partido Democrático Trabalhista) com a aprovação da Convenção. Ressalta, concordando com Genoíno, que se trata de decisão histórica, instrumento relevante para evitar que a violência promovida por um Estado autoritários volte a ocorrer (PBR - F).

\footnotetext{
${ }^{119}$ DCN 28.04.1987, p.1.344, col. 3.

${ }^{120}$ DCN 28.04.1987, p.1.344, col. 3.

${ }^{121}$ DCN 19.06.1987, p. 2.057, col. 3.
} 
O Deputado Walmor de Luca, por sua vez, reitera o repúdio à tortura realizada pelo governo brasileiro na ditadura, ressaltando que o governo deveria ter assinado a Convenção em momento anterior (PBR - F).

O Deputado Edmilson Valentim também acredita que a aprovação da Convenção é fundamental no momento histórico vivido pelo Brasil (PBR - F).

Segue a manifestação do Deputado Oswaldo Lima Filho, que aponta o momento histórico de luta contra os métodos cruéis e desumanos (DH - F). Aqueles que conviveram com mais de duas décadas de ditadura militar no país devem ser solidários com a aprovação desse texto (PBR - F).

O Deputado Ottomar Pinto também manifesta seu apoio à Convenção, o que engrandeceria a Câmara (PBR - F). Segue a manifestação do Deputado Benedicto Monteiro, que propõe a promulgação do Decreto Legislativo em sessão solene, por se sobrepor, inclusive, aos trabalhos de muitos Constituintes - era o momento de elaboração da Constituição de 1988 - empenhados em incluir na nova Carta dispositivo que impeça a tortura no país (PBR - F). A Convenção, diz ele, seria um instrumento supranacional e suprapartidário, para que cidadãos do mundo inteiro fossem resguardados da tortura $(\mathrm{DH}-$ tortura - F).

O projeto é aprovado por unanimidade.

\section{PARECER DA COMISSÃO DE RELAÇÕES EXTERIORES (n. 16 - SF), ALBANO FRANCO, 1989}

[Senado - Parecer 1]

O parecer, de 23.05.1989, após relatório a respeito da tramitação da MSC na Câmara e do teor da Convenção, particularmente sobre o reconhecimento da competência do Comitê para examinar comunicações relativas a tortura ocorrida nos Estados signatários. Para o Senador, é extremamente urgente complementar o ordenamento nacional, incorporando a ele a Convenção (DBR - F), que, assim como outros documentos da ONU, reconhece os direitos iguais e inalienáveis de todo ser humanos como “(...) fundamento da liberdade, da justiça e da paz no mundo" (DH - F). 


\subsection{ANÁLISE: PROTOCOLO FACULTATIVO À CONVENÇÃO}

O Protocolo Facultativo à Convenção contra a Tortura e Outros Tratamentos ou Penas Cruéis, Desumanos ou Degradantes, de 18.12.2002, entrou em vigor internacional em 22.06.2006. Esse Protocolo foi assinado pelo plenipotenciário brasileiro em 13.10.2003, e ratificado em 11.01.2007, entrando em vigor para o Brasil em 11.02.2007. O Protocolo foi enviado ao Congresso pelo Executivo pela MSC 335/2004, aprovado pelo Decreto Legislativo 483, de 20.12.2006, e promulgado pelo Decreto Presidencial 6.085, de 19.04.2007. O Brasil depositou o instrumento de ratificação do Protocolo junto ao Secretário-Geral da ONU em 11.01.2007.

O Protocolo estabeleceu um sistema de visitas regulares, por parte de Comitê internacional e de órgãos dos próprios países a locais de detenção, para prevenir a tortura e outros tratamentos considerados cruéis e degradantes. Um comitê subsidiário foi estabelecido para dar suporte institucional ao Comitê, além de apoiar os Estados signatários e as instituições nacionais para exercer funções similares no âmbito nacional. No Comitê, foi estabelecido um grupo de trabalho para examinar as comunicações individuais recebidas sob a égide do art. 22 da Convenção, cuja tramitação pode ser encontrada a seguir. Esse grupo examina os requisitos de admissibilidade e o mérito da comunicação, elaborando recomendações para o Comitê. ${ }^{122}$

\section{STATUS NA ONU}

https://treaties.un.org/Pages/ViewDetails.aspx?src=IND\&mtdsg_no=IV-9b\&chapter $=4 \&$ lang $=$ en

\section{MENSAGEM DO PODER EXECUTIVO (MSC 335/2004)}

A Mensagem, elaborada pelo Ministro Celso Amorim, de 22.04.2004, foi enviada ao Congresso Nacional pelo Presidente Luís Inácio Lula da Silva em 18.08.2004. Segundo o Ministro, o Brasil apoiou as negociações a respeito do Protocolo de maneira ativa, sendo copatrocinador dos projetos de resolução da Comissão de Direitos Humanos e da AGNU

${ }^{122}$ Informações obtidas em: http://legal.un.org/avl/ha/catcidtp/catcidtp.html. Acesso: 16.03.2016. 
que culminaram na aprovação do texto final do Protocolo (PEB - F). De acordo com o Ministro, a legislação de alguns estados brasileiros permite que sejam realizadas visitas não anunciadas de representantes de órgãos públicos e da sociedade civil com o objetivo de reprimir a prática da tortura (PBR - F). A Secretaria Especial de Direitos Humanos criou, no âmbito do Conselho de Defesa dos Direitos da Pessoa Humana, o Grupo Móvel de Combate à Tortura, que visita locais de detenção e elabora sugestões para a prevenção e punição desse crime, o que se coaduna com as normas previstas pelo Protocolo (PBR - F).

A ratificação do Protocolo por parte do Brasil não apenas fortalece as ações do governo e da sociedade que têm o objetivo de promover o cumprimento da Convenção (PBR - F), além dos dispositivos constitucionais e infraconstitucionais que proíbem a prática (DBR F); mas também aumenta a transparência do país quanto ao tema no âmbito internacional $(\mathrm{PEB}-\mathrm{F})$, intensificando a proteção às potenciais vítimas de tortura.

\section{PARECER DA COMISSÃO DE RELAÇÕES EXTERIORES E DEFESA NACIONAL (CD), ZULAIÊ COBRA, 2004}

[Câmara - Parecer 1]

O parecer, de 10.11.2004, é de autoria da Deputada Zulaiê Cobra, e faz breve explicação dos termos do Protocolo. A Deputada menciona, no início de seu voto, a celebração do PIDESC e do PIDCP, sendo que este último consagra, entre outros, o direito à vida e a proibição da tortura e de outros tratamentos cruéis, além da criação do Comitê de Direitos Humanos no âmbito da ONU (DIN - F). Após apresentar a definição de tortura, e a sua diferença entre o tratamento desumano ou cruel, a relatora aponta que, na legislação brasileira, a matéria encontra-se disciplinada por normas de Direito Internacional Público internalizadas e, portanto, inseridas no direito nacional. Menciona, expressamente, instrumentos de Direito Internacional ratificados pelo Brasil (DIN - F), ${ }^{123}$ além de legislação nacional referente ao tema (DBR - F). ${ }^{124}$

A relatora aponta a menção, na MSC 335/2004, ao apoio brasileiro nos trabalhos que culminaram na assinatura do Protocolo, mecanismo adicional à Convenção, que possibilita

\footnotetext{
${ }^{123}$ A Convenção das Nações Unidas contra a tortura e outros Tratamentos ou Penas Cruéis, Desumanos ou Degradantes e a Convenção Interamericana para Prevenir e Punir a Tortura.

${ }^{124}$ A Deputada menciona (i) o art. 5, III, CF; (ii) art. 61, II, “d” e art. 121, §2º III do Código Penal, referente ao homicídio qualificado em virtude de tortura, que difere do crime de tortura em si; e (iii) Lei 9.455, de 07.04.1997, que dispõe sobre crimes hediondos.
} 
seu cumprimento de maneira mais adequado, sendo a Convenção acolhida pelo direito brasileiro (DBR - F). Existiria, ademais, relevância diplomática na ratificação do Protocolo, justamente no momento em que a prática de tortura é tão noticiada, em virtude de legislação estadunidense que possibilitará ao país enviar suspeitos de terrorismo para serem interrogados e, possivelmente, torturados em outros países (PEB - F). A Deputada cita, ainda, o TPI, que define, em seu estatuto, a tortura como modalidade de crime de guerra (DIN - F), e que perpetradores podem ser presos por autoridades em Estados signatários do TPI, como o Brasil.

O Protocolo poderia servir, inclusive, no âmbito interno, fortalecendo ações governamentais e da sociedade civil para seu cumprimento (PBR - F), servindo para aumentar a transparência do país em relação ao tema no contexto internacional (PEB - F).

O voto é, pois, pela aprovação do Protocolo.

\section{PARECER DA COMISSÃO DE SEGURANÇA PÚBLICA E COMBATE AO CRIME ORGANIZADO (CD), ANTONIO BISCAIA, 2005}

[Câmara - Parecer 2]

O parecer, de 22.06.2005, é de autoria do Deputado Antonio Carlos Biscaia, e destaca as visitas de observadores internacionais ao país com a aquiescência do Governo Federal, uma decisão política importante tanto no âmbito interno (PBR - F) como no internacional (PEB - F). ${ }^{125} \mathrm{O}$ informe de Nigel Rodley, relator especial sobre a Tortura da Comissão de Direitos Humanos da ONU, descreveu condições subumanas encontradas nas prisões brasileiras, nas quais a tortura seria método habitual para obter informações de indivíduos sob custódia estatal. Aponta que o sistema carcerário brasileiro não se modificou desde o relatório da $\mathrm{ONU}$, o que demonstra o menosprezo pela vida humana por parte dos integrantes das forças de segurança (PBR - F).

Apesar de essas visitas internacionais não servirem apenas para trazer à tona o conhecimento a respeito dessas questões, amplamente noticiadas por ONGs e imprensa nacionais, as visitas ampliam a percepção das irregularidades na situação dos Direitos

\footnotetext{
${ }^{125}$ Ocorreram visitas de observadores internacionais que trabalharam na avaliação da situação do Brasil com relação à tortura (relator especial sobre a Tortura da Comissão de Direitos Humanos da ONU); venda de crianças, prostituição e pornografia infantis, violência contra a mulher, racismo, discriminação racial, xenofobia e intolerâncias correlatas e Direitos Humanos e resíduos tóxicos.
} 
Humanos no Brasil (PBR - F). A restauração da democracia no país possibilitou o conhecimento de diversos testemunhos de tortura no país, e isso fortalece a vontade de combater essa realidade (PBR - F).

A discussão a respeito de eventual ameaça à soberania nacional, decorrente do mandato de representante estrangeiro para monitorar a situação dos Direitos Humanos no país, foge da competência da Comissão, competindo à Comissão de Constituição e Justiça e de Cidadania (PBR - F). Entretanto, o Deputado lembra que a Constituição, com as modificações inseridas pela EC 45/2004, confere status constitucional aos tratados sobre Direitos Humanos internalizados com quórum de Emenda Constitucional, além de reconhecer, expressamente, a jurisdição de tribunal penal internacional ao qual o país tenha aderido (DBR - F). Esses dispositivos, somados aos princípios que regem as Relações Internacionais, presentes no art. $4^{\mathrm{o}}$, II e IX, CF (DBR - F), deixam claro o fato de que a proteção dos Direitos Humanos é de extrema relevância para o país (PBR - F), e pode ser operada, inclusive, por ações multinacionais (PEB - F).

O parecer é pela aprovação do Protocolo.

\section{PARECER DA COMISSÃO DE DIREITOS HUMANOS E MINORIAS (CD), CHICO} ALENCAR, 2005

[Câmara - Parecer 3]

O parecer, de 03.08.2005, é de autoria do Deputado Chico Alencar. Após relato acerca do Protocolo, o relator retoma a iniciativa brasileira nas negociações internacionais do protocolo (PEB - F). Destaca que, apesar da limitação de publicidade das recomendações do Subcomitê, que apreciará a situação dos estabelecimentos prisionais nos Estados signatários, esse trabalho será valioso para que as autoridades competentes possam tomar medidas eficazes para combater a tortura (PBR - F). Essas informações, ademais, podem ser usadas para planejar ações estatais que aperfeiçoem as políticas criminais.

O Brasil possui, de antemão, mecanismo previsto pelo Protocolo, cuja atribuição é conhecer e acompanhar denúncias de crimes de tortura no país, o chamado Grupo Móvel de combate à tortura, vinculado à Comissão Especial do Conselho de Defesa dos Direitos da Pessoa Humana (PBR - F), o que demonstra a harmonia da legislação nacional com o Protocolo (DBR - F). 
O país é signatário de diversos tratados de defesa e de proteção dos Direitos Humanos, particularmente aplicáveis aos encarcerados (DIN - F) ${ }^{126}$ No direito nacional, a CF/1988 considera crime inafiançável a prática de tortura, além de insuscetível de graça ou de anistia. A Lei 9.455/1997 tipifica o crime, cuja pena é de reclusão de dois a oito anos (DBR - F). Apesar da existência de normas nesse sentido, estas não foram suficientes para impedir a prática no país, que continua sendo rotineira (PBR - F).

O parecer é pela aprovação do Protocolo.

\section{PARECER DA COMISSÃO DE CONSTITUIÇÃO E JUSTIÇA E CIDADANIA (CD), LUIZ EDUARDO GREENHALGH, 2005}

[Câmara - Parecer 4]

O parecer, de 09.08.2005, é de autoria do Deputado Luiz Eduardo Greenhalgh. Após minuciosa apresentação do Protocolo e de sua tramitação interna, o Deputado menciona artigos do Regimento da Casa (art. 32, IV, "a", "c" e "e"), apontando que compete à Comissão manifestar-se a respeito dos aspectos constitucionais, legais, jurídicos, regimentais e de técnica legislativa de projetos submetidos à apreciação da Câmara, além de poder manifestar-se a respeito do mérito da questão (DBR - F).

No que concerne à incorporação do Protocolo, o Deputado afirma que o Brasil, Estado Democrático de Direito - conforme o art. $1^{\circ}$, III, CF (DBR - F), tem a dignidade da pessoa humana como um dos seus fundamentos, e essa dignidade é plenamente respeitada pela proposição em análise. Menciona, ainda, os princípios que regem as Relações Internacionais do Brasil, que constam no art. $4^{\circ}, \mathrm{CF}$, além de mencionar incisos do art. $5^{\circ}$ que tratam dos Direitos Humanos assegurados pela Constituição (DBR - F). O rol de direitos fundamentais descritos, ressalta, não é exaustivo, uma vez que o art. $5^{\circ}, \S$ único determina que não excluem outros direitos decorrentes “(...) do regime e dos princípios por ela (a Constituição) adotados, ou dos tratados internacionais em que a República Federativa do Brasil seja parte" (DBR - F).

\footnotetext{
${ }^{126}$ O Deputado menciona os seguintes instrumentos: PIDCP, Convenção contra a Tortura e outros Tratamentos ou Penas Cruéis, Desumanas ou Degradantes e a Convenção Americana sobre Direitos Humanos.
} 
Não haveria, portanto, vício constitucional, formal ou material, que impedisse a incorporação do Protocolo ao ordenamento interno. Existem, inclusive, na legislação nacional, leis que tratam da questão em pauta (DBR - F). ${ }^{127} \mathrm{O}$ Brasil, ademais, incorporou ao seu ordenamento tratados em que assume o compromisso de combater a tortura e outros tratamentos ou penas cruéis (DIN - F). ${ }^{128}$ Menciona, ainda, o Conselho de Defesa dos Direitos da Pessoa Humana como órgão que poderia cumprir as funções designadas pelo Protocolo (PBR - F), descrevendo suas competências, estabelecidas em lei.

O relator conclui, assim, pela juridicidade e pela legalidade do protocolo, cuja internalização fortalece o direito interno, que propicia ambiente adequado à sua implementação (DBR - F). No que se refere à técnica legislativa, o Projeto não merece correção.

Quanto ao mérito, apresenta as conclusões do relatório exarado pelo Comitê contra a tortura da ONU em 18.05.2001, a respeito da situação da prática de tortura no país. O relatório apresenta os aspectos positivos e os que inspiram preocupação em relação ao tema no país, além de recomendações. Entre as recomendações do Comitê, está a que sugere que o Brasil assegure a interpretação da Lei contra a Tortura em conformidade com o art. $1^{\circ}$ da Convenção.

O Deputado aponta que o país avançou significativamente no combate à tortura, mas há muito a ser feito (PBR - F). O governo elaborou o relatório, entregue à ONU em conjunto com a sociedade civil. É necessário utilizar esse documento para deter o avanço e criar mecanismos que culminem em medidas mais efetivas para eliminar a cultura de tortura e de maus-tratos no país (PBR - F).

O parecer é pela aprovação do Projeto de Decreto Legislativo.

\section{PARECER do PLENÁRIO, EM SUBSTITUIÇÃo À CREDNA (SF - 1290-A), MARCELO CRIVELLA, 2006}

[Senado - Parecer 1]

\footnotetext{
127 O Deputado menciona a Lei de Execuções Penal (Lei 7.210/1984); Lei 4.898, que descreve hipóteses de abuso de autoridade; o próprio Código Penal brasileiro (Decreto Lei 2.848/1940); Lei 9.455/1997, que define o crime de tortura; e a Lei 8.072/1990, a Lei dos Crimes Hediondos.

${ }^{128} \mathrm{O}$ relator menciona instrumentos internacionais, bem como os instrumentos internos que os internalizaram: (i) Convenção Interamericana para Prevenir e Punir a Tortura, Decreto 98.386/1989; (ii) Convenção contra a Tortura e outros tratamentos ou Penas cruéis, desumanos ou degradantes, Decreto 40/1991; (iii) Convenção Americana sobre Direitos Humanos - Pacto de São José da Costa Rica, Decreto 678/1992.
} 
O parecer, de 2006, é de autoria do Senador Marcelo Crivella, que descreve a tramitação do Projeto que aprecia o Protocolo na Câmara, até seu texto chegar ao Senado. Para o Senador, o Protocolo fortalece as ações governamentais e da sociedade brasileira par promover o cumprimento da Convenção (PBR - F), além das normas constitucionais que proíbem a prática (DBR - F). Ademais, aumenta a transparência do país no contexto internacional, fortalecendo os mecanismos de proteção às potenciais vítimas desse tipo de abuso (PEB - F). O relator aponta para o fato de que a legislação de alguns estados brasileiros tem dispositivos que permitem a realização de visitas não anunciadas por parte de representantes de órgãos públicos e por membros da sociedade civil, para coibir a tortura e outros maus-tratos (DBR - F).

O parecer é pela aprovação do PDS 478/2006.

\section{REQUERIMENTO DE URGÊNCIA, 2006}

O requerimento, publicado no DSF de 20.12.2006, col. 2, pede a urgência, nos termos do art. 336 do Regimento Interno, para o PDS 478/2006. O requerimento é aprovado.

\subsection{DECLARAÇÃO FACULTATIVA DO ARTIGO 22 DA CONVENÇÃO}

Trata-se de declaração, prevista no art. 22 da Convenção das Nações Unidas contra a Tortura e outros Tratamentos ou Penas Cruéis, Desumanos ou Degradantes, reconhecendo a competência do Comitê contra a Tortura para receber e analisar denúncias de violações dos dispositivos da Convenção. A Declaração facultativa do art. 22 da Convenção foi objeto da Mensagem 579, de 25.06.2002, enviada pelo Presidente Fernando Henrique Cardoso ao Congresso em 04.07.2002. A Mensagem foi transformada no PDC 3003/2003 em 08.01.2003. A matéria foi enviada ao Senado Federal em 13.12.2005, transformando-se no PDS 32/2006. Foi aprovada pelo Decreto Legislativo 57, de 2006. Não foi, até o momento de depósito desta tese, promulgado Decreto Presidencial referente a essa Declaração.

\section{MEMORANDO DO CONSULTOR JURÍDICO DO ITAMARATY, 2002}

[Executivo - Parecer MRE] 
O Parecer, de 21.06.2002, é de autoria de Patrick Petiot, à época Segundo Secretário da careira diplomática. Conforme o parecer, há uma tendência do Direito Internacional em reconhecer o indivíduo como sujeito de DIN, particularmente no âmbito dos Direitos Humanos. Isso é admitido pela Comissão Interamericana de Direitos Humanos, instituída pela Convenção Americana sobre Direitos Humanos, à qual o Brasil aderiu (DIN - F). Igualmente, o Comitê Internacional para a Eliminação da Discriminação racial, criado pela Convenção Internacional sobre a Eliminação de Todas as Formas de Discriminação Racial (DIN - F), da qual o Brasil também é parte; tendo sido aprovado pelo Congresso, em abril de 2002 - ano de redação do Parecer - o pedido do governo brasileiro para aceitar a competência do Comitê (PBR - F). Do mesmo modo, o Comitê sobre a Eliminação da Discriminação contra a Mulher, estabelecido pela Convenção sobre a Eliminação de todas as formas de Discriminação contra a Mulher, de 1979, da qual o Brasil é parte, admite, em seu Protocolo Facultativo, de 1999, também assinado pelo Brasil (DIN - F) e aprovado pelo Poder Legislativo em 2002 (PBR - F), o mecanismo de queixas individuais.

As iniciativas mencionadas estão de acordo com o posicionamento progressivo do indivíduo como sujeito de Direito Internacional, além do fortalecimento da proteção internacional dos Direitos Humanos, com o qual o Brasil está comprometido nos termos da sua Constituição (DBR - F). Portanto, não haveria obstáculo jurídico para que o país fizesse o reconhecimento previsto no art. 22, sendo recomendável pedir a autorização do Congresso (PBR - F), considerando os antecedentes mencionados.

O consultor jurídico substituto, Haroldo Valladão, acrescenta ao Parecer o fato de que a XXXII Assembleia Geral da OEA, ocorrida entre 02 e 04.06.2002, aprovou a resolução 1.895, de 04.06.2002, intitulada "Estudo sobre o Acesso das Pessoas à Corte Interamericana de Direitos Humanos", que proclama que “o Direito Internacional dos Direitos Humanos tem como característica intrínseca o fato de que a pessoa é sujeito de Direito Internacional" (DIN - F).

\section{MENSAGEM DO PODER EXECUTIVO (MSC 579/2002)}

A Mensagem, de 25.06.2002, foi enviada ao Congresso Nacional pelo Presidente da República, senhor Fernando Henrique Cardoso, em 04.07.2002, e assinada pelo Ministro das Relações Exteriores, Celso Lafer. Nela, o Ministro aponta que, quando da assinatura da 
Convenção, o Brasil não depositou a Declaração facultativa do artigo 22, que reconhece a competência do Comitê contra a Tortura para receber e analisar petições individuais. Após explicar minuciosamente as competências do Comitê, ressalta que seu reconhecimento aperfeiçoaria a atuação do Brasil em Direitos Humanos (PBR - F), e coaduna-se com as manifestações de ONGs de credibilidade nacional e internacional; assim como é coerente com as recomendações elaboradas pelo Relator Especial sobre a Tortura, Nigel Rodley, em sua visita ao Brasil. Essa decisão reforçaria internacionalmente o compromisso do Brasil, e, particularmente, do governo FHC, com a defesa e a promoção dos Direitos Humanos, e com a inserção do país no contexto internacional relativo ao tema (PEB - F).

O Secretário de Estado de Direitos Humanos, consultado, concorda com o reconhecimento do Comitê (PBR - F). O Ministro recomenda, ainda, a consulta ao Congresso Nacional para tanto.

\section{PARECER DA COMISSÃO dE CONSTITUIÇÃO E JUSTIÇA E DE REDAÇÃO (CD), JOSÉ MENTOR, 2002}

[Câmara - Parecer 1]

O parecer, de 28.10.2002, é de autoria do Deputado José Mentor. Segundo o Deputado, caberia à Comissão apreciar o PDC quanto à sua constitucionalidade, juridicidade, técnica legislativa e, quanto ao mérito, pronunciar-se em relação ao direito constitucional de não ser submetido a tortura ou a tratamento desumano ou degradante (art. 32, III, "a" e "d", RICD) (DBR - F). Segundo o Deputado, foram atendidos os requisitos constitucionais (DBR - F), e a Declaração não importa perda de soberania nacional (PBR - F). A proposta, inclusive, leva maior efetividade às normas constitucionais, tanto àquela que prega a prevalência dos Direitos Humanos nas Relações Internacionais do país (art. $4^{\mathrm{o}}$, II), como àquela que define ser direito fundamental a proteção contra a tortura (art. 5\%, III) (DBR - F).

Com relação ao mérito, entende que a Declaração seria um avanço no trato dos Direitos Humanos, por considerar que, muitas vezes, o Estado é responsável pelos maus-tratos (PBR - F). O reconhecimento do Comitê viria ao encontro de diversas medidas semelhantes no âmbito internacional (PEB - F), dentre as quais a instalação do TPI (DIN - F).

O parecer é pela aprovação da Declaração. 


\section{PARECER DA COMISSÃO DE RELAÇÕES EXTERIORES E DE DEFESA NACIONAL (CD), MILTON TEMER, 2002}

[Câmara - Parecer 2]

O parecer, de 11.12.2002, é de autoria do Deputado Milton Temer. Segundo o Deputado, a Convenção é um dos principais instrumentos jurídicos de Direito Internacional, que, assim como outros instrumentos relativos aos Direitos Humanos, ${ }^{129}$ (DIN - F) tem órgãos que fiscalizam o seu cumprimento pelos signatários. Esclarece a natureza facultativa do art. 22 da Convenção, e assinala que, apesar de ser opcional, efetuar a declaração seria fundamental para o cumprimento de suas cláusulas, uma vez que o Estado não seria um bom fiscal de si mesmo, precisando da sociedade civil ou de outros grupos organizados para efetuar denúncias em instância internacionais contra aquele Estado que desrespeite os Direitos Humanos (PEB - F). O Brasil, infelizmente, recusava-se a realizar esse tipo de declaração no passado próximo, justificando com a existência de suposta perda de soberania que adviria do reconhecimento desses mecanismos, o que não deve prosperar, pela previsão de esgotamento dos mecanismos internos pela Convenção (PBR - F).

Ele critica, ainda, o fato de que esse zelo pela soberania não era aplicado a acordos econômicos assinados na última década (PEB - F), os quais, inclusive, permitem que o investidor estrangeiro recorra à arbitragem sem antes passar pelo crivo do Judiciário nacional, flagrante desrespeito aos princípios basilares do Direito Internacional. O governo brasileiro no poder até 2002 teria, portanto, critérios diferentes para situações similares, o que não é aceitável (PBR - F). A situação alterou-se com a retirada da reserva aposta pelo Executivo quando da assinatura da Convenção de Belém do Pará, que impedia denúncias por parte da sociedade civil contra o Brasil, em caso de descumprimento da Convenção (PBR - F). Depois, o país emitiu a declaração facultativa, prevista na Convenção Interamericana de Diretos Humanos, reconhecendo as sentenças da Corte Interamericana de Direitos Humanos (PBR - F). Em abril de 2002, o Congresso aprovou o pedido do governo de reconhecer a competência do Comitê Internacional sobre a Eliminação de todas as formas de Discriminação Racial (PBR - F). Os membros do Poder Legislativo também aprovaram o Protocolo Facultativo que reconheceu a competência do Comitê sobre a Eliminação da

\footnotetext{
${ }^{129}$ O Deputado menciona a Convenção Internacional sobre a Eliminação de Todas as Formas de Discriminação Racial e a Convenção sobre a Eliminação de Todas as Formas de Discriminação contra a Mulher.
} 
Discriminação contra a Mulher, estabelecido pela Convenção sobre o mesmo tema, para receber denúncias individuais (PBR - F). O Brasil também ratificou o Estatuto do TPI. (DIN - F)

Deste modo, aprovar a declaração contida no art. 22 insere-se nesse contexto recente de reconhecimento de comitês e de cortes internacionais como instâncias legítimas para receber e para examinar denúncias de indivíduos contra ações, ou omissões, dos Estados (PEB - F). As iniciativas mencionadas são coerentes com o esforço internacional de alçar o indivíduo à condição de sujeito de DIN, fortalecendo o sistema de proteção dos Direitos Humanos (DH - F). Essa declaração aumenta o protagonismo do país no âmbito da defesa internacional dos Direitos Humanos (PEB - F), além de assegurar a sua soberania (PEB - F).

O parecer é, assim, pela aprovação da solicitação.

\section{PARECER DA COMISSÃO DE RELAÇÕES EXTERIORES E DEFESA NACIONAL (n. 277 - SF), ROMEU TUMA, 2006}

[Senado - Parecer 1]

O parecer n. 277, de 23.05.2006, é de autoria do Senador Romeu Tuma, relator ad hoc para o Senador José Jorge. Após relatório, o Senador aponta que a Declaração é um ato internacional de particular interesse para o Brasil, oportuno e conveniente aos interesses nacionais (PBR - F). O país tem buscado realizar o mandamento constitucional de se comprometer com o "humanitarismo jurídico internacional" (PEB - F). Não seria comprometida a jurisdição estatal para julgar violações ocorridas internamente, uma vez que a Convenção traz jurisdição complementar à nacional (PBR - F).

Não existe motivos para o Brasil, cuja Constituição garante os direitos de sua população (DBR - F), reflexo da cultura de seu povo (PBR - F), rejeitar instrumentos internacionais que complementam essa tutela. O parecer é pela aprovação da Declaração. 


\section{ANÁLISE: CONVENÇÃO 169 DA ORGANIZAÇÃO INTERNACIONAL DO TRABALHO SOBRE POVOS INDÍGENAS E TRIBAIS}

A Convenção 169 da OIT sobre Povos Indígenas e Tribais, de 27.06.1989, entrou em vigor internacional em 05.09.1991. Essa Convenção foi ratificada em 25.07.2002, entrando em vigor para o Brasil em 25.07.2003 (art. 38.3). Foi enviada ao Congresso Nacional por intermédio da Mensagem Presidencial 367, de 28.06.1991, e enviada ao Congresso em 16.07.1991. Seu processo de aprovação tramitou na Câmara dos Deputados como Projeto de Decreto Legislativo 237, de 1993. Foi enviada ao Senado Federal em 25.08.1993, onde tramitou como Projeto de Decreto Legislativo 34, de 1993. Foi aprovada pelo Decreto Legislativo 143, de 20.06.2002, e promulgada pelo Decreto Presidencial 5.051, de 19.04.2004.

A Convenção é o único instrumento internacional em vigor que trata de povos indígenas e tribais, povos que têm culturas, modos de vida e costumes próprios. O desrespeito histórico em relação a esses povos provocou conflitos em diversas partes do mundo; e os integrantes da OIT, desde a década de 1920, demonstraram preocupação com esses acontecimentos. $\mathrm{O}$ trabalho dessa Organização tem dois aspectos principais: a adoção e a supervisão das normas, bem como a assistência aos povos indígenas e tribais nos países signatários. Hodiernamente, a comunidade internacional tem aceitado que as culturas dessas populações são valiosos e devem ser respeitados e protegidos, possibilitando a participação desses povos na tomada de decisões dos países nos quais se encontram. ${ }^{130}$ A Convenção define os seus destinatários e, simultaneamente, resguarda a soberania dos Estados que a internalizarem, não atribuindo a condição de sujeitos de Direito Internacional Público às populações tribais. ${ }^{131}$

\footnotetext{
130 Informações obtidas em: http://www.ilo.org/global/topics/equality-and-discrimination/indigenous-andtribal-peoples/lang--es/index.htm. Acesso: 18.03.2016.

${ }^{131}$ Segundo a MSC 327/1991.
} 
MENSAGEM DO PODER EXECUTIVO (MSC 327/1991)

A Mensagem 327, de 28.06.1991, foi redigida pelo Ministro das Relações Exteriores, senhor Francisco Rezek, e enviada ao Poder Legislativo pelo Presidente Fernando Collor em 16.07.1991. ${ }^{132}$ O Ministro faz breve comparação entre a Convenção 169 e a Convenção 107 da OIT (DIN - F), destacando que a primeira não se refere a "princípios gerais", mas a uma "política geral” que deverá balizar o relacionamento entre governos e povos indígenas que se encontram em seus territórios.

Conforme o art. 19 da Constituição da OIT, os governos dos Estados-membros devem encaminhar às autoridades nacionais competentes os textos das Convenções adotadas na Conferência Internacional do Trabalho (DIN - F). O Ministro solicita, então, o envio da Convenção ao Congresso.

\section{PARECER DA COMISSÃO DE RELAÇÕES EXTERIORES (CD), LUIZ GUSHIKEN, 1993}

[Câmara - Parecer 1]

O parecer, de autoria do Deputado Luiz Gushiken, é de 24.03.1993, e expõe o histórico da Convenção 169 da OIT, que fez uma revisão parcial da Convenção 107/1957 sobre as populações indígenas e tribais, ratificada pelo Brasil em 1965 (DIN - F). Com a revisão da Convenção 107, o Conselho de Administração da OIT, no qual o Brasil detém assento permanente, estabeleceu algumas finalidades, como (i) a eliminação do caráter integracionista; (ii) o fortalecimento dos direitos indígenas e tribais sobre as terras e (iii) a promoção e o fomento ao autodesenvolvimento. A revisão era necessária porque a Convenção 107, apesar de ser o único tratado sobre os direitos dessas populações, era limitada pelas percepções etnocêntricas e meramente integracionistas do momento de sua elaboração. O Deputado faz uma exposição minuciosa dos termos da Convenção 169, e das diferenças entre ela e a Convenção 107. A nova Convenção teria sido resultado de um esforço coletivo dos membros da OIT, o que se refletiu na sua aprovação.

\footnotetext{
${ }^{132}$ A Convenção 107 da OIT sobre populações indígenas e tribais, de 18.06.1965, sofreu denúncia automática em 25.07.2003, com a Convenção 169. Informação obtida em: http://www.ilo.org/dyn/ normlex/en/f?p=1000:11200:0::NO:11200:P11200_COUNTRY_ID:102571. Acesso: 18.03.2016. 
Apesar de não ser o objetivo deste trabalho descrever todos os aspectos da Convenção, como, de qualquer maneira, não se fez em nenhum dos instrumentos anteriormente analisados, descrevo as partes do tratado que serão objeto de discussão acirrada no âmbito do Poder legislativo nos pareceres que seguem. A Convenção está dividida em dez partes:

(i) Parte I: Política Geral

(ii) Parte II: Terras

(iii) Parte III: Contratação e Condições de Emprego

(iv) Parte IV: Formação Profisssional, artesanato e Indústrias Rurais

(v) Parte V: Seguridade Social e Saúde

(vi) Parte VI: Educação e Meios de Comunicação

(vii) Parte VII: Contatos e Cooperação através das Fronteiras

(viii) Parte VIII: Administração

(ix) Parte XIX: Disposições Gerais

(x) Parte X: Disposições Finais

Segundo o Deputado, a Parte que trata das Terras é a mais relevante da Convenção (e é, justamente, a que foi objeto de parte significativa dos pareceres analisados). A Convenção não exige o reconhecimento simultâneo da propriedade e da posse das terras, mas exige que os Estados reconheçam os direitos dos povos interessados sobre tais terras, seja por intermédio da posse, seja por intermédio da propriedade. Determina, ainda, que, caso removidos, os povos interessados devem, necessariamente, ser reassentados; a remoção é admitida, apenas, em casos excepcionais.

O relator inicia o seu voto dizendo que as disposições da Convenção são completamente coerentes com o texto constitucional, no que se refere aos direitos dos indígenas (DBR - F). ${ }^{133}$ Qualquer contradição entre os textos seria decorrente de equívoco ou de má-fé. Segundo ele, as contradições alegadas entre a Convenção e a Constituição seriam decorrentes de dispositivos existentes na Convenção 107, o que não implicou a sua denúncia (PBR - F). Os desdobramentos da Convenção são relevante referência para que a matéria seja tratada no âmbito nacional, o que, por si só, seria suficiente para recomendar a

\footnotetext{
${ }^{133}$ Para conhecimento, a Constituição Federal de 1988, além de disposições esparsas, tem um capítulo dedicado às populações indígenas: Capítulo VIII - DOS ÍNDIOS, artigos 231 e 232.
} 
sua internalização (PBR - F). O Estatuto do Índio (DBR - F), de 1973, publicado em decorrência da Convenção 107, precisa ser reformado e atualizado, fato demonstrado pelos diversos projetos que tramitam na Câmara nesse sentido, e a Convenção 169 serviria de diretriz importante para que isso ocorresse (PBR - F).

A diversidade de etnias e de culturas deve ser respeitada em todos os seus âmbitos, e deve ser reconhecida como patrimônio dos países que as abrigam (DH - índios - F). Outros países da região ratificaram a Convenção, não podemos ficar para trás (PEB - F).

O parecer é, pois, pela aprovação da Convenção.

\section{PARECER DA COMISSÃO DE DEFESA DO CONSUMIDOR, MEIO AMBIENTE E MINORIAS (CD), FÁBIO FELDMANN, 1993}

[Câmara - Parecer 2]

O parecer, de 14.04.1993, é de autoria do Deputado Fábio Feldmann. Após relatório a respeito do tema, o Deputado explica a estrutura da OIT, cuja Conferência, órgão máximo da Organização, tem estrutura tripartite, na qual são representados os governos dos Estados, os empregadores e os trabalhadores, o que a confere legitimidade ímpar no sistema internacional (DIN - F).

No Brasil, a tramitação interna da Convenção, segundo o Deputado, levou mais tempo do que a tramitação do tratado que institui a OIT. O Executivo demorou para remeter a matéria ao Poder Legislativo, e, na Câmara, o prosseguimento também foi obstruído (PBR - F). Nesse aspecto, o Deputado ressalta a relevância da atuação das entidades de apoio à luta indígena, particularmente importante na fase anterior à apreciação da Convenção pelo Congresso (PBR - F). Ao esforço dessa entidade somou-se o apoio de intelectuais, como o professor Dalmo de Abreu Dallari, que redigiu parecer a respeito do tema em 1991.

Para o Deputado, os instrumentos internacionais têm a faculdade de estabelecer padrões mínimos de referência para os Estados elaborarem suas leis domésticas (PEB - F). No momento, eram discutidas, na Câmara, diversas propostas para a reforma do Estatuto do Índio, que demanda atualização diante da nova Constituição. Deste modo, a aprovação da Convenção 169 adquire particular relevância, sendo diretriz importante para essas discussões, não condicionando a vontade do legislador pátrio (PBR - F).

O parecer é pela aprovação da Convenção. 


\section{PARECER DA COMISSÃO DE CONSTITUIÇÃO E JUSTIÇA (CD), ÁTILA LINS,} 1993

[Câmara - Parecer 3]

O parecer, de 21.06.1993, é de autoria do Deputado Átila Lins. Nele, o Deputado concorda com o parecer de Luiz Gushiken, destacando que assuntos referentes à matéria são discutidos intensamente no Brasil, particularmente no que se refere à terra destinada aos indígenas e aos potenciais perigos à soberania nacional (PBR - F). O caso concreto é uma tentativa de encontrar soluções para o problema das minorias sociais, com as quais o Brasil tem dívida secular (PBR - F).

Considerando que o assunto em pauta é condizente com as disposições da Constituição (DBR - F); e que, particularmente, tem como objetivo garantir às comunidades indígenas brasileiras os meios jurídicos para sua plena cidadania e desenvolvimento, o parecer é favorável ao projeto.

\section{PARECER DA COMISSÃO DE RELAÇÕES EXTERIORES E DEFESA NACIONAL (n. 603 - SF), JARBAS PASSARINHO, 1994}

[Senado - Parecer 1]

O parecer, de 11.05.1994, é de autoria do Senador Jarbas Passarinho, que apresenta em seu relatório a descrição da Convenção. Segundo o Senador, após a aprovação da Convenção, seria necessário adotar uma política indigenista anti-integracionista, que considere as normas do Estatuto do Índio (DBR - F). ${ }^{134}$ Para ele, é necessário contrapor a Convenção à Constituição, particularmente seu art. $231,{ }^{135}$ no que se refere à propriedade de

\footnotetext{
${ }^{134}$ Lei 6.001, de 19.12.1973.

135 Art. 231. São reconhecidos aos índios sua organização social, costumes, línguas, crenças e tradições, e os direitos originários sobre as terras que tradicionalmente ocupam, competindo à União demarcá-las, proteger e fazer respeitar todos os seus bens.

$\S 1^{\circ}$ São terras tradicionalmente ocupadas pelos índios as por eles habitadas em caráter permanente, as utilizadas para suas atividades produtivas, as imprescindíveis à preservação dos recursos ambientais necessários a seu bem-estar e as necessárias a sua reprodução física e cultural, segundo seus usos, costumes e tradições.

$\S 2^{\circ}$ As terras tradicionalmente ocupadas pelos índios destinam-se a sua posse permanente, cabendo-lhes o usufruto exclusivo das riquezas do solo, dos rios e dos lagos nelas existentes.

$\S 3^{\circ} \mathrm{O}$ aproveitamento dos recursos hídricos, incluídos os potenciais energéticos, a pesquisa e a lavra das riquezas minerais em terras indígenas só podem ser efetivados com autorização do Congresso Nacional,
} 
terras, e seu art. 20, XI, que determina serem bens da União as terras tradicionalmente ocupadas pelos índios (DBR - F). A Convenção não exclui os bens da União, não existindo, portanto, contradição.

Em relação à trasladação dos povos indígenas, as propostas do art. 16 da Convenção, que prescreve que as condições desse traslado podem ocorrer, mesmo em caráter definitivo, por troca de terras para assentamento, seriam contrárias ao dispositivo constitucional do art. $231, \S 5^{\circ}, \mathrm{CF}(\mathrm{DBR}-\mathrm{C})$, que reza:

\begin{abstract}
Art. 231, §5 $5^{\circ}$ CF: É vedada a remoção dos grupos indígenas de suas terras, salvo, "ad referendum" do Congresso Nacional, em caso de catástrofe ou epidemia que ponha em risco sua população, ou no interesse da soberania do País, após deliberação do Congresso Nacional, garantido, em qualquer hipótese, o retorno imediato logo que cesse o risco.
\end{abstract}

Aprovar a Convenção, nesse aspecto, seria um retrocesso. Também haveria retrocesso na aprovação do art. 17 da Convenção, que colide com o art. 231, §4 ${ }^{\circ}$, CF (DBR - C), que diz "As terras de que trata este artigo são inalienáveis e indisponíveis, e os direitos sobre elas, imprescritíveis"; ao admitir a alienação das terras, ou a transmissão de seus direitos, para fora de sua comunidade, após consulta aos interessados. Outro artigo da Convenção, o art. 32, poderia ampliar a suspeição da opinião pública em relação à possibilidade de manifestações separatistas (PBR-C), apesar de o Senador acreditar que a sociedade está "prevenida quando a essa pretensa ameaça de desmembramento".

O Senador menciona a aprovação de parecer a respeito de Convenção da OIT sobre a proibição do trabalho de menores de 14 anos, exceto na condição de aprendiz (DIN - C), que colidia com as normas constitucionais (DBR - C).

ouvidas as comunidades afetadas, ficando-lhes assegurada participação nos resultados da lavra, na forma da lei.

$\S 4^{\circ}$ As terras de que trata este artigo são inalienáveis e indisponíveis, e os direitos sobre elas, imprescritíveis. $\S 5^{\circ}$ É vedada a remoção dos grupos indígenas de suas terras, salvo, "ad referendum" do Congresso Nacional, em caso de catástrofe ou epidemia que ponha em risco sua população, ou no interesse da soberania do País, após deliberação do Congresso Nacional, garantido, em qualquer hipótese, o retorno imediato logo que cesse o risco.

$\S 6^{\circ}$ São nulos e extintos, não produzindo efeitos jurídicos, os atos que tenham por objeto a ocupação, o domínio e a posse das terras a que se refere este artigo, ou a exploração das riquezas naturais do solo, dos rios e dos lagos nelas existentes, ressalvado relevante interesse público da União, segundo o que dispuser lei complementar, não gerando a nulidade e a extinção direito a indenização ou a ações contra a União, salvo, na forma da lei, quanto às benfeitorias derivadas da ocupação de boa-fé.

$\S 7^{\circ}$ Não se aplica às terras indígenas o disposto no art. $174, \S 3^{\circ} \mathrm{e} \S 4^{\circ}$. 
O parecer é pela aprovação da Convenção com restrição aos artigos 16, 17 e 32. Pede, ademais, a manifestação da Comissão de Constituição e Justiça e Cidadania a respeito do art. 14, com consequências para os artigos 15 e 16, no capítulo que trata de Terras.

PARECER DA COMISSÃo de CONSTITUIÇÃO E JUSTIÇA (n. 604 - SF), ROMERO JUCÁ, 1995

[Senado - Parecer 2]

O parecer, de autoria do Senador Romero Jucá, é de 20.09.1995. Após relato a respeito da Convenção e de seu encaminhamento após o parecer do Senador Jarbas Passarinho, aponta efetiva contradição entre o art. 14 da Convenção, que sugere o reconhecimento dos direitos de propriedade e de posse sobre as terras que tradicionalmente ocupam aos povos interessados, e o art. 20, IX, da CF. Combinando os textos dos artigos 20, XI e 231, §2, CF, percebe-se que o regime constitucional pátrio, apesar de reconhecer aos índios os direitos originários sobre as terras que ocupam, estabeleceu que o domínio dessas terras é da União (DBR - C).

O relator ressalta que a Constituição, ao manter essas terras como bens da União, assegurou que as terras tradicionalmente ocupadas pelos índios fossem bens públicos, e, como tal, ficassem garantidas contra a alienação; o que configura maior segurança aos direitos dos indígenas (DBR - F). Isso é favorável ao que determina a Convenção, que, em seus artigos 34 e 35, aponta que sua aplicação não prejudicará outros direitos e vantagens garantidos aos indígenas. A Constituição da OIT, ademais, (DIN - F) estipula que, em nenhum momento, a adoção de tratado ou de recomendação da Organização prejudicará garantia nacional mais favorável no caso concreto.

Assim, o Senador aponta que, se a Constituição é eficiente para proteger os direitos territoriais dos povos indígenas, restam atendidas as disposições da Convenção 169, e resolvida a aparente antinomia entre seu art. 14 e o art. 20, XI, CF (DBR - F). O parecer é, pois, pela aprovação do Projeto.

\section{PARECER DA COMISSÃO DE RELAÇÕES EXTERIORES E DEFESA NACIONAL (SF), BERNARDO CABRAL, 1999}

[Senado - Parecer 3] 
O parecer, sem data especificada, de autoria do Senador Bernardo Cabral, nega a aprovação do Decreto Legislativo 34/1993. Após relatório, no qual aponta ter sido a Convenção aprovada em todas as Comissões da Câmara dos Deputados, diz que a mesma foi aprovada, na CREDNA/SF, conforme parecer do Senador Jarbas Passarinho, com restrição aos artigos 16, 17 e 32; e solicitada interpretação à CCJC sobre os artigos 14, 15 e 16 da Convenção. Ressalta que o Senador Romero Jucá, relator da matéria, "curiosamente" apresentou à casa o requerimento 1.304/1995, solicitando o adiamento da discussão do projeto para que sua matéria fosse reexaminada pela CREDNA e pela CCJ, "tendo em vista novas ponderações do Governo Federal quanto à forma disposta na Convenção 169, em seus aspectos legais". ${ }^{136}$

O Senador reconhece a pertinência dos argumentos exarados por Jarbas Passarinho. Para ele, existem restrições não apenas aos artigos 16, 17 e 32, mas aos dispositivos 14 e 15 . Seria prematura, ou mesmo inconstitucional (DBR - C), a adesão à Convenção, instrumento comprometedor em matéria de direitos reais concedidos aos silvícolas. A questão agrária é de extrema relevância, e seria inadequado aumentar as possibilidades de conflito nesse âmbito (PBR - C).

Seria constrangedor a um país membro da OIT adotar uma de suas Convenções com restrições, a serem transformadas por reservas pelo Poder Executivo (PEB - C). Isso ocorre pois, sendo as convenções da OIT omissas em relação às reservas, presume-se a sua impossibilidade (DIN - C). Em virtude desse impasse, o Senador opta pela não aprovação in totum da Convenção.

\section{VOTO EM SEPARADO, SENADORA BENEDITA DA SILVA, 1997}

[Senado - Vt Sep 1]

O voto, de 02.12.1997, é de autoria da Senadora Benedita da Silva. Nele, após relatório a respeito da questão, a Senadora destaca a impropriedade do parecer do Senador Bernardo Cabral. Segundo ela, "o temor de que a Convenção possa interferir negativamente nos direitos que a Constituição brasileira assegura às comunidades não tem razão de ser". A Constituição, ao assegurar os direitos dos indígenas em seu texto, não entraria em conflito com a Convenção (DBR - F). Em nenhum momento a adoção de Convenção ou de

\footnotetext{
${ }^{136}$ Conforme o Requerimento do Senador Romero Jucá, de 1995, aprovado em 04.10.1995.
} 
recomendação da OIT poderá prejudicar o direito garantido pela legislação nacional, do que decorre que, em todos os pontos em que for mais favorável a norma interna, esta será adotada. Isso é garantido pelo art. 19 da Constituição da OIT (DIN - F). O receio do Senador Bernardo Cabral, portanto, não teria fundamento.

Prossegue ao apontar para o temor de Cabral em relação ao risco de desmembramento do território brasileiro, em virtude da previsão, no tratado, de interação entre os povos. Segundo ela, esse temor seria infundado. Cita trecho do parecer do Senador Jarbas Passarinho, que diz estar opinião pública brasileira "prevenida quanto a essa pretensa ameaça de desmembramento do território brasileiro". Para a Senadora, a opinião pública brasileira nunca manifestou esse temor, apenas mencionado por alguns grupos durante a constituinte, estes claramente interessados em diminuir as áreas ocupadas por grupos indígenas (PBR - F). Para a Senadora, caso fosse possível considerar a propriedade de terras e a manutenção de relações com grupos estrangeiros como um risco à soberania nacional e à integridade territorial brasileira, seria necessário proibir que fazendeiros - proprietários de terras - exportassem sua produção, o que seria um argumento absurdo (PBR - F). Aos índios não é concedida a propriedade das terras, que é da União, que, por sua vez, acompanha tudo o que nelas ocorre, o que demonstra que a ameaça inexiste (PBR - F).

Deste modo, não há de se falar em risco para a soberania nacional na aprovação da Convenção 169 (PBR - F). A Constituição pátria é com ela condizente (DBR - F), e eventual recusa de sua ratificação contribuiria para uma imagem internacional negativa do Brasil (PEB - F), o que não se coaduna com o momento histórico de relevância do respeito aos Direitos Humanos (DH - F). Esse fato restou claro quando da manifestação do Parlamento Europeu de oposição às negociações entre a União Europeia (UE) e o Mercosul, se os integrantes deste não assegurassem a dignidade e a subsistência dos povos indígenas (PEB F).

O parecer é, portanto, pela aprovação da Convenção.

\section{VOTO EM SEPARADO, ARTUR DA TÁVOLA, MENCIONADO PELOS PARECERES DOS SENADORES TIÃO VIANA E ROMEU TUMA}

[Senado - Vt Sep 2] 
O Senador Artur Távola, em voto separado, ${ }^{137}$ argumenta que as incompatibilidades entre a Convenção e as normas nacionais não existem quando se considera a Constituição da OIT, particularmente seu art. 19.8, que determina que a adoção de tratado não resulta no desprezo às leis nacionais que garantam condições mais favoráveis aos beneficiados pelo tratado (DIN - F). Apesar de, isoladamente, o art. 14 da Convenção parecer contrário ao art. 20, XI, CF, a leitura dos artigos 34 e 35 da mesma Convenção demonstra a flexibilidade usual dos textos da OIT, que determinam que a sua aplicação considerará os ordenamentos de cada signatário, e que a aplicação da Convenção não prejudica direitos garantidos aos povos interessados por outros tratados, ou mesmo pela legislação interna.

Ainda segundo o Senador, o art. 16 da Convenção trata da remoção como uma exceção, indicando que, a princípio, ela deve ser temporária, sendo seus motivos aqueles determinados pelo ordenamento de cada Estado signatário. De qualquer maneira, o Senador admite que a Convenção possibilita remoções permanentes, e nisso estaria a incompatibilidade entre o tratado e a Constituição. A Carta Magna, porém, remete a lei complementar para dispor sobre casos em que a remoção poderá ser permanente, em seu art. $231, \S 6^{\circ}$ :

\footnotetext{
$\S 6^{\circ}$ São nulos e extintos, não produzindo efeitos jurídicos, os atos que tenham por objeto a ocupação, o domínio e a posse das terras a que se refere este artigo, ou a exploração das riquezas naturais do solo, dos rios e dos lagos nelas existentes, ressalvado relevante interesse público da União, segundo o que dispuser lei complementar, não gerando a nulidade e a extinção direito a indenização ou a açôes contra a União, salvo, na forma da lei, quanto às benfeitorias derivadas da ocupação de boa fé. (grifo nosso)
}

O Senador ressalta que, apesar de a Constituição admitir remoção permanente (caso de uma hidrelétrica situada em terras indígenas, por exemplo) não admite que a remoção, além de permanente, seja total. Entretanto, a Convenção deixa ao direito nacional a regulamentação das hipóteses de remoção. Ou seja, tampouco há de se falar em contradição nesse aspecto (DBR - F).

O voto em separado é pela aprovação, sem ressalvas, da Convenção.

\footnotetext{
137 O voto, mencionado pelos Senadores Tião Viana e Romeu Tuma, não se encontra no dossiê do PDS, tampouco foi mencionado na página eletrônica do Senado Federal que apresenta a tramitação do PDS. Deste modo, foram incluídos e analisados, apenas, os trechos mencionados por esses Senadores.
} 
PARECER DA COMISSÃO DE RELAÇÕES EXTERIORES (n. 1.315 - SF), TIÃO VIANA, 1999

[Senado - Parecer 4]

O parecer é de autoria do Senador Tião Viana, data de 26.05.1999, e trata de um reexame da Convenção 169 da OIT, no qual o Senador detalha a sua tramitação. Aponta para o fato de a Convenção ter sido examinada, antes de seu envio ao Congresso, por Comissão Tripartite, instituída pelo Ministério do Trabalho e da Previdência Social, na qual o Ministro da Justiça foi representado por José Nazareno Santana Dias, da Secretaria Nacional dos Direitos da Cidadania e Justiça, que destacou "a inocorrência de obstáculos na ordem jurídica constitucional pátria a impedirem a ratificação da Convenção 169 pelo Governo brasileiro". A autora destaca que essa Comissão não foi mencionada por nenhum parecer anterior.

Após descrição da Convenção, particularmente dos artigos que suscitaram dúvidas, o relator aponta os questionamentos apresentados, mencionando trechos de outros votos, ou apreciando-os de punho próprio: ${ }^{138}$

(i) Art. 14 da Convenção, relativo à atribuição dos direitos de propriedade e de posse aos povos indígenas, violaria o art. 20, IX, CF; além do art. 231, CF;

(ii) Art. 15 da Convenção, relativo às consultas e às indenizações para povos indígenas em caso de exploração de recursos naturais existentes em terras por eles ocupadas, por parte dos Estados: essas disposições não estariam previstas pelo art. 20, $\S 1^{\circ}, \mathrm{CF}$. O art. $231, \S 3^{\circ}$ seria ainda menos amplo. A lei brasileira tampouco preveria indenizações por eventuais danos. O artigo, segundo o Senador, por ser mais abrangente, pode ser lido de modo a fazê-lo compatível com as disposições constitucionais (DBR - F);

(iii) Art. 16 da Convenção: refere-se ao traslado de povos das terras ocupadas, possibilitando sua ocorrência mediante reassentamento, o que foi considerado um retrocesso em relação à legislação nacional. A alegação é que o art. 231, CF, veda expressamente essa remoção, salvo em caso de aprovação pelo Congresso, em casos determinados.

\footnotetext{
${ }^{138}$ Não serão, aqui, reiterados os argumentos previamente utilizados por outros Senadores, para evitar duplicação.
} 
(iv) Art. 17 da Convenção: entraria em conflito com o art. 231, $\S 4^{\circ}, \mathrm{CF}$, que determina que as terras indígenas são inalienáveis e indisponíveis, e que os direitos sobre elas são imprescritíveis, sendo mais favorável do que o texto convencional. Para o relator, o artigo constitucional refere-se à alienação para indivíduo alheio à comunidade indígena que ocupa a terra; enquanto o artigo da Convenção trata da transmissão entre membros do povo interessado, hipótese permitida pelo direito nacional, que supõe, uma vez demarcadas as terras indígenas, a transmissão entre gerações;

(v) Art. 32: referente à interação étnica entre povos indígenas e tribais. A dúvida em relação a esse artigo, para o relator, seria mais política do que constitucional; pois, para alguns, haveria ameaça de desmembramento do território nacional. O relator, porém, não compartilha com essa percepção (PBR - F), considerando que o contato entre povos indígenas e entre esses e não-indígenas seria relevante para a cooperação e a paz entre os países envolvidos, particularmente em virtude da viabilização de acordos que permitiram a formação do Mercosul e da União Europeia (PEB - F). Seria de grande importância regulamentar esses acordos, para coibir práticas ilícitas, permitindo o maior controle, por parte do governo brasileiro, de suas fronteiras (PEB - F).

Segundo o relator, a Convenção teria, para os povos indígenas, a mesma relevância atribuída à DUDH (DIN - F), por estabelecer diretrizes que viabilizam a adoção de medidas garantidoras do respeito às diferenças étnicas por parte dos signatários ( $\mathrm{DH}$ - indígenas - F). Sendo a Constituição brasileira, inclusive, mais avançada na proteção dos direitos indígenas do que a legislação de muitos dos signatários da Convenção, resta claro que seus princípios fundamentais são condizentes com a orientação geral da Convenção (DBR - F).

O parecer é, pois, pela aprovação da Convenção, texto que reconhece a responsabilidade dos povos indígenas no projeto da nação brasileira e seu direito efetivo “(...) à integridade, à cidadania e ao desenvolvimento moral. Cultural e econômico" (PBR - F). 
PARECER dA COMISSÃO DE CONSTITUIÇÃO, JUSTIÇA E CIDADANIA (n. 1.316 - SF), ROMEU TUMA, 2000

[Senado - Parecer 5]

O parecer, um reexame do tema, de autoria do Senador Romeu Tuma, data de 06.12.2000. Nele, após explicação da tramitação e dos principais artigos da Convenção, o Senador aponta as principais controvérsias a respeito da sua aprovação.

Quanto ao alegado conflito entre a Constituição (artigos 20, XI e 231, §2 $2^{\circ}$ ) e o art. 14 da Convenção, que sugere o reconhecimento dos direitos de propriedade e de posse dos indígenas sobre as terras que tradicionalmente ocupam, o Senador retoma o voto em separado do Senador Artur Távola, que os interpreta em conjunto com os artigos 34 e 35 da Convenção. Ressalta, também, o parecer do Deputado Luiz Gushiken, no que trata da compatibilidade da Convenção com a Carta Magna pátria. Para Tuma, "A ratificação da Convenção 169 vem sendo ansiosamente aguardada pelos povos indígenas do Brasil, que ao longo da História têm sido sistematicamente vilipendiados nos seus direitos e integridade física e socioeconômica" (PBR - F). Seria justo que o Senado, no momento de comemoração dos 500 anos do Descobrimento do Brasil, homenageasse esses povos, aprovando o PDS $34 / 1993$.

A Constituição seria a mais avançada das legislações nacionais no que se refere aos direitos dos povos indígenas, servindo, inclusive, de referência a diversos países (PEB - F). A Carta, por sua vez, tem princípios fundamentais que se coadunam com a orientação da OIT (DBR - F). A Convenção será relevante para a soberania nacional, por seu caráter humanista, e por reconhecer a essa parte da população brasileira parte da responsabilidade e dos direitos que lhe são devidos no projeto do país (PBR - F). O Senador diz, como apontado anteriormente, que a Convenção é tão relevante quanto a DUDH (DIN -F).

O Senador sugere a referência, no PDS, a três dispositivos do tratado que podem parecer lesivos ao interesse nacional: o art. 16, que estabelece as medidas necessárias para traslado e reassentamento de tribos indígenas definidas na Constituição; e art. 14 e 17, que dispõem sobre o direito de propriedade e alienação de terras pelos indígenas, matéria regulada pelos artigos 20, XI e 231, $\S 2^{\circ}$, da CF. Sugere, portanto, declarações interpretativas, e não reservas, a serem incluídas no projeto de Decreto Legislativo, que seriam as seguintes: 


\begin{abstract}
"No caso do Brasil, a expressão "procedimentos adequados estabelecidos pela legislação nacional", constante do texto do art. 16 da Convenção 169 da OIT (...) refere-se às disposições do art. 231, caput e $\$ 5^{\circ}$, da Constituição.

"As expressões "direitos de propriedade" e "sempre que for considerada sua capacidade para alienarem suas terras para fora da comunidade", constantes (...) dos artigos 14 e 17 da Convenção (...) não têm aplicação, no caso do Brasil, em face do estabelecido nos arts. 20, XI e 231, $\$ 2^{\circ}, C F ”$.
\end{abstract}

O parecer é, portanto, pela aprovação da Convenção com a emenda supracitada.

\title{
DISCUSSÃO EM PLENÁRIO, DSF 20.06.2002
}

[Senado - SF PLEN]

A discussão em plenário, publicada no DSF de 20.06.2002, retrata a última discussão entre Senadores antes da aprovação do PDS referente à Convenção.

A primeira Senadora a manifestar-se foi a Marina Silva. A Senadora demonstra sua preocupação com o fato de que a Convenção tramita no Congresso há mais de nove anos (PBR - F). Haveria expectativa favorável por parte de diversas comunidades indígenas no sentido de sua aprovação (PBR - F). A Senadora ressalta, ainda, a polêmica a respeito da aprovação da Convenção e eventual desrespeito à Constituição Federal, não sendo esse entendimento correto, e não existindo, portanto, incompatibilidade entre esses instrumentos (DBR - F). Ressalta, ainda, a presença de lideranças indígenas no plenário, e que seria de interesse do Congresso aprovar a Convenção sem as ressalvas apresentadas (PBR - F). De acordo com ela, essa questão estaria solucionada pelo fato de a Convenção prever a prevalência do texto constitucional; e tendo os Senadores responsáveis pelo projeto chegado à conclusão de que seria possível ratificar a Convenção sem quaisquer modificações. Marina Silva parabeniza seus colegas pela iniciativa e pela aprovação da Convenção.

Segue a manifestação do Senador Jefferson Péres, que menciona os onze anos de tramitação da Convenção, divididos em dois na Câmara e nove no Senado; o que teria, provavelmente, ocorrido por temores infundados a respeito da propriedade das terras ocupadas pelos povos indígenas (PBR - F). Necessário destacar, assinala, que permanece a disposição constitucional que concede o domínio das terras indígenas à União, e apenas o usufruto àquelas populações (DBR - F). Tampouco seriam essas populações consideradas sujeitos de Direito Internacional Público, o que significa que não terão reconhecido o direito à independência; o que é, inclusive, descartado pela Convenção (DIN - F). O Senador 
menciona, inclusive, a necessidade de aprovação do Estatuto dos Povos Indígenas, que tramitava na Câmara (DBR - F). ${ }^{139}$

O Senador Romero Jucá, por sua vez, ressalta que os índios são brasileiros, defendem o território nacional, e que suas terras são da União, com usufruto para eles, não cabendo qualquer tipo de desconfiança nesse sentido (PBR - F). As sociedades indígenas têm o direito de terem suas terras demarcadas, e de integrar a sociedade com a dignidade que lhes é de direito (PBR - F). As emendas à Convenção apenas dificultariam sua aprovação, devendo ser discutidas, inclusive, no âmbito da OIT, o que não seria interessante para o país (PEB F). ${ }^{140}$

A Senadora Emília Fernandes também ressalta que a matéria tramita no Senado Federal desde 1993 (PBR - F), e que, para os povos indígenas, a Convenção é tão relevante quanto a DUDH (DIN - F). Teria grande valor para a soberania nacional, por reafirmar os princípios previstos na Constituição (DBR - F), reconhecendo os direitos de parte relevante da sociedade brasileira (PBR - F). Devem ser adotadas medidas que protejam esses indivíduos, e possibilitem o usufruto de seus direitos dentro do contexto da sociedade brasileira (PBR - F). Apesar dos esforços do Poder Legislativo em combater a falta de políticas públicas voltadas a essa população, há espaço para avanço (PBR - F), particularmente no que se refere à aprovação do Estatuto do Índio, que tramita no Congresso há mais de uma década (DBR - F). O governo deve liberar recursos e demarcar territórios indígenas, além de proteger os conhecimentos tradicionais dessas populações e o patrimônio genético existente em suas terras (PBR - F). A Fundação Nacional do Índio também deve ser reformulada, assim como, no âmbito da educação, é necessária uma Política Nacional para a Educação Escolar Indígena (PBR - F). É preciso evitar a mortalidade dos índios, e proteger esses povos, sanando uma dívida histórica e social com essas populações (PBR F). A Senadora apresenta trechos de uma manifestação indígena exposta no $2^{\circ}$ Fórum Mundial de Porto Alegre, na qual são feitas diversas reivindicações, e solicita a publicação

\footnotetext{
139 Projeto de Lei 2.057/91, que dispõe sobre o Estatuto das Sociedades Indígenas, tramita na Câmara até a entrega desta tese. A este PL foram apensados diversos outros, que tratam de diversos aspectos referentes à população indígena. O Estatuto do Índio em vigor hodiernamente é de 1973 (Lei 6.001, de 19.12.1973, e está em desconformidade com a evolução do pensamento nacional e internacional a respeito da temática. Informações sobre a tramitação do PL 2.057/91 obtidas em: http://www.camara.gov.br/ proposicoesWeb/fichadetramitacao?idProposicao=17569. Acesso: 07.09.2016.

${ }_{140}$ Nota-se a confusão, no discurso do Senador, a respeito de emendas à Convenção e a aposição de ressalvas ao texto convencional.
} 
integral do "Manifesto dos Povos Kaigang e Guarani - Movimento de Resistência Indígena do Rio Grande do Sul”.

O Senador Romeu Tuma, autor da emenda ao PDS, manifesta-se e diz que, após consultas com outros Senadores, acredita que o Projeto deve ser aprovado integralmente, sem qualquer modificação à Convenção.

O Senador Geraldo Melo aponta que, apesar dos receios na aprovação do tratado, não haveria nada que pudesse ser sobreposto à Constituição, e, assim, não haveria nenhum risco em aprová-lo (DBR - F).

\section{MANIFESTAÇÕES DA SOCIEDADE CIVIL}

Nesta tramitação foi possível encontrar algumas manifestações da sociedade civil, que serão mencionadas em virtude de seu caráter excepcional, posto que ocorreram em poucos dos instrumentos analisados. A Associação Latino-americana de Antropologia manifestouse em 23.04.1993; o Conselho Indigenista Missionário em 10.05.1993; e os povos Kaigang e Guarani do Rio Grande do Sul, em nome do Movimento de Resistência Indígena, em 2002. Todas as entidades que se manifestaram deram seu apoio à aprovação da Convenção 169 , OIT. 


\section{ANÁLISE: CONVENÇÃO SOBRE O DIREITO DAS CRIANÇAS}

A Convenção sobre os Direitos da Criança, de 20.11.1989, entrou em vigor internacional em 02.09.1990, de acordo com as disposições de seu artigo art. 49.1. Essa Convenção foi assinada pelo plenipotenciário brasileiro em 26.01.1990 e ratificada em 24.09.1990, entrando em vigor para o Brasil em 23.10.1990, conforme seu art. 49.2. Foi enviada ao Congresso Nacional pela Mensagem Presidencial 445, de 1990. Seu processo de aprovação tramitou na Câmara dos Deputados como Projeto de Decreto Legislativo 242, de 1990, e no Senado Federal como Projeto de Decreto Legislativo 47, de 1990. Foi aprovada pelo Decreto Legislativo 28, de 14.09.1990, e promulgada pelo Decreto Presidencial 99.710, de 21.11.1990.

A Convenção foi um esforço dos Estados signatários em respeitar e assegurar os direitos civis, políticos, econômicos, sociais e culturais das crianças. O tratado estabelece diretrizes para a efetivação desses direitos, por meio de padrões para cuidar da saúde, da educação e de serviços legais, civis e sociais para as crianças. Existem três Protocolos facultativos referentes à Convenção, o Protocolo Facultativo à Convenção sobre os Direitos da Criança referentes à venda de criança, à prostituição infantil e à pornografia infantil, de 25.05.2000, entrou em vigor em 18.01.2002; e requer que os Estados signatários proíbam a venda de crianças, a prostituição e a pornografia infantil. O Protocolo facultativo à Convenção sobre os direitos da criança relativos ao envolvimento de crianças em conflitos armados, de 25.05.2000, entrou em vigor em 12.02.2002; e demanda que os Estados parte adotem as medidas necessárias para assegurar que crianças não tenham participação direta em situações de hostilidade. O Protocolo facultativo à Convenção sobre os Direitos da Criança sobre procedimentos de comunicação, de 19.12.2011, prevê mecanismo para que se submetam comunicações pela criança ou em nome de grupos individuais ou grupos de supostas vítimas de violação da Convenção sobre os Direitos das Crianças. Essas comunicações são recebidas e analisadas pelo Comitê sobre os Direitos das Crianças, estabelecido pela Convenção. Esse último Protocolo ainda não entrou em vigor. ${ }^{141}$

\footnotetext{
${ }^{141}$ Informações obtidas em: http://legal.un.org/avl/ha/crc/crc.html. Acesso: 21.03.2016. 


\section{STATUS NA ONU}

https://treaties.un.org/pages/ViewDetails.aspx?src=TREATY\&mtdsg_no=IV$11 \&$ chapter $=4 \&$ clang $=$ en

MENSAGEM DO PODER EXECUTIVO (MSC 445/1990)

A Mensagem 445, de 16.05.1990, foi enviada pelo Presidente Fernando Collor ao Congresso Nacional em 31.05.1990, e elaborada pelo Ministro das Relações Exteriores, Francisco Rezek. Segundo o Ministro, o Brasil participou ativamente no processo de negociação que culminou na elaboração do tratado, tendo o representante brasileiro assinado a Convenção no dia de abertura às assinaturas (PEB - F). Sua adoção seria “(...) evidência de que emerge no âmbito dos povos e Governos uma nova consciência com relação à proteção integral da criança e do adolescente". ${ }^{142} \mathrm{O}$ Ministro ressalta a vontade de que a Convenção seja ratificada pelo Brasil em prazo breve (PBR - F). Destaca que o texto em português da Convenção deverá ser elaborado em reunião dos representantes dos sete países de língua portuguesa, realizada em Maputo (Moçambique) de 29.06.1990 a 02.07.1990.

\section{PARECER DA COMISSÃO DE RELAÇÕES EXTERIORES (CD), MARIA DE LOURDES ABADIA, 1990}

[Câmara - Parecer 1]

O parecer da Comissão de Relações Exteriores é de autoria da Deputada Maria de Lourdes Abadia, e foi apresentado em 08.08.1990. Após relato do tratado e de menção ao teor da MSC 445/1990, a relatora aponta para a conveniência de aprovar o texto da Convenção, sem, porém, apresentar argumentos para tanto.

PARECER DA COMISSÃO DE CONSTITUIÇÃO E JUSTIÇA (CD), JORGE ARBAGE, 1990

[Câmara - Parecer 2]

O Parecer, de 22.08.1990, é de autoria do Deputado Jorge Arbage. O relator vota pela constitucionalidade, juridicidade e técnica legislativa do Projeto de Decreto Legislativo

${ }^{142}$ DCN 19.06.1990, p. 7.134, col. 2. 
242/1990. Indica que foram atendidos os pressupostos constitucionais para a admissibilidade do projeto. A matéria é de competência exclusiva do Congresso Nacional (art. 49, I), e deve ser objeto de Decreto Legislativo (art. 59, VI). A iniciativa da Comissão da Câmara dos Deputados é respaldada pelo art. 109, $§ 2^{\circ}$, RICD. (DBR - F)

\section{PARECER COMISSÃO DE SEGURIDADE SOCIAL E FAMÍLIA (CD), ARNALDO}

\section{FARIA DE SÁ, 1990}

\section{[Câmara - Parecer 3]}

O parecer, de 23.08.1990, é de autoria do Deputado Arnaldo Faria de Sá. Após relatório a respeito da tramitação do projeto, ressalta a relevância da garantia dos direitos fundamentais de liberdade, justiça e dignidade da criança (DH - criança - F). Destaca, também, que a Convenção não deve, conforme o próprio projeto de decreto legislativo, sofrer modificações antes de sua apreciação pelo Congresso (PBR - F). O parecer é pela aprovação da Convenção, em sua totalidade.

\section{REQUERIMENTO DE URGÊNCIA}

Foi feito um requerimento de urgência para a tramitação dos Protocolos relativos à Convenção sobre os Direitos da Criança, em 2001, aprovado em abril de 2002 (não consta a data no documento analisado). ${ }^{143} \mathrm{O}$ requerimento foi solicitado pela Deputada Rita Camata, coordenadora da Frente Parlamentar pelos Direitos da Criança e do Adolescente.

\section{MANIFESTAÇÕES DA SOCIEDADE CIVIL}

Ressalto as manifestações da sociedade civil em prol da aprovação da Convenção aqui analisada. A Associação Brasileira dos Fabricantes de Brinquedos (ABRINQ) enviou, em 21.08.1990, solicitação para que o tratado fosse aprovado o mais rapidamente possível. Segue-se à manifestação da ABRINQ um abaixo-assinado de dezenas de páginas, no qual

\footnotetext{
${ }^{143}$ Os dados sobre o requerimento de urgência foram obtidos na manifestação, na Câmara, da Deputada Maria do Rosário, publicada no DCD de 26.02.2003.
} 
os cidadãos brasileiros fazem o apelo para que o Congresso Nacional aprove a Convenção de modo urgente.

\section{PARECER DO PLENÁRIO (SF), AFONSO SANCHO, 1990}

[Senado - Parecer 1]

O parecer, de 13.09.1990, é de autoria do Senador Afonso Sancho. Após relatório a respeito da Convenção, o relator aponta que ela incorpora, de maneira eficaz, ao ordenamento jurídico nacional, princípio enunciado na DUDH, conforme o qual a infância tem direito a cuidados e a assistência especiais (DIN - F). O Senador ressalta que o preâmbulo da Convenção lembra da relevância da cooperação para melhorar as condições de vida de suas crianças, particularmente nos países em desenvolvimento, como é o caso do Brasil, que deve cooperar com outros Estados para implementar os direitos reconhecidos pela Convenção (PEB - F). Alguns direitos previstos na Convenção são protegidos, de maneira inovadora, pela Constituição brasileira (DBR - F).

O parecer é pela aprovação da Convenção.

\section{1. e 16.2. ANÁLISE: PROTOCOLOS FACULTATIVOS À CONVENÇÃO}

A tramitação dos Protocolos à Convenção sobre o Direitos das Crianças é conjunta, apenas foram promulgados por Decretos Executivos distintos. Ambos foram enviados para apreciação do Congresso pela Mensagem 1.035, de 2001; e tramitaram na Câmara dos Deputados pelo PDC 4, de 2003; e no Senado Federal pelo PDS 7, de 2003. O Congresso aprovou os Protocolos por meio do Decreto Legislativo 230, de 29.05.2003. O Decreto Presidencial 5.007, de 08.03.2004, promulgou o Protocolo Facultativo à Convenção sobre os Direitos da Criança referente à venda de crianças, à prostituição infantil e à pornografia infantil. O Decreto Presidencial 5.006, de 08.03.2004, por sua vez, promulgou o Protocolo facultativo à Convenção sobre os direitos da criança relativos ao envolvimento de crianças em conflitos armados. O Protocolo Facultativo sobre procedimentos de comunicação, de 19.12.2011, não será analisado, pois sua tramitação não foi finalizada até a entrega desta tese. 


\section{STATUS NA ONU}

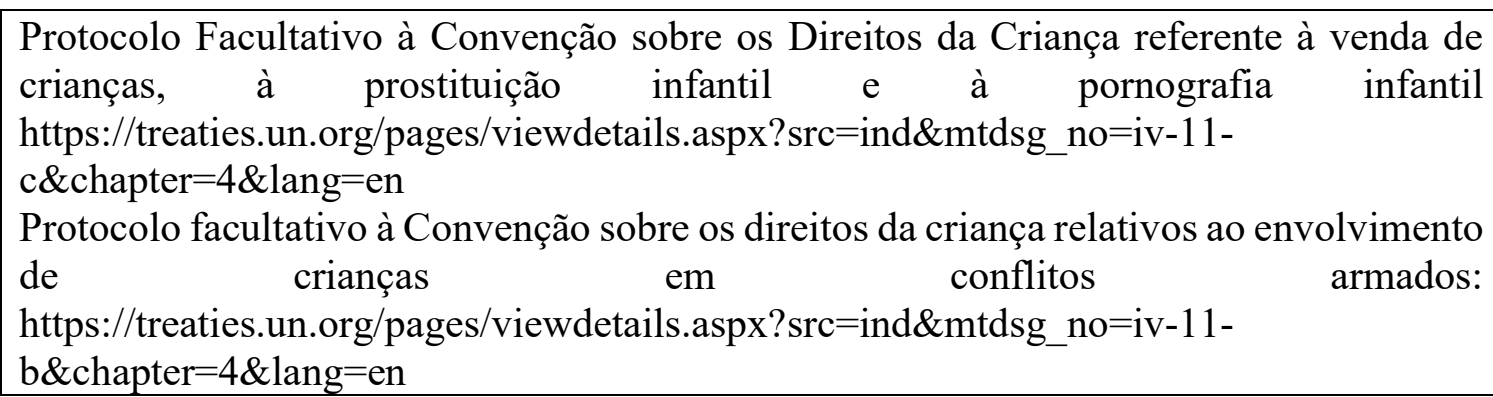

\section{MENSAGEM DO PODER EXECUTIVO}

A Mensagem 1035/2001 do Poder Executivo foi elaborada pelo Ministro das Relações Exteriores, Celso Lafer, em 10.09.2001, e enviada pelo Presidente Fernando Henrique Cardoso ao Congresso em 25.09.2001. Essa Mensagem analisou ambos os protocolos facultativos à Convenção sobre os Direitos da Criança, relativos ao envolvimento de crianças em conflitos armados e à venda de crianças, prostituição infantil e pornografia infantil. Segundo Lafer, os Protocolos, além de ampliar a abrangência da Convenção, são instrumentos que apresentam princípios internacionais relevantes para a proteção das crianças (DH - crianças - F).

Na Mensagem, descreve o procedimento de aprovação dos Protocolos no âmbito da ONU, ressaltando o apoio do governo brasileiro aos Protocolos (PEB - F). Uma das principais determinações do Protocolo sobre o envolvimento de crianças em conflitos armados aponta para a necessidade dos Estados signatários impediram a que menores de 18 anos participem diretamente de conflitos armados, e que não ocorra o recrutamento compulsório desses menores. As disposições desse Protocolo também determinam que os Estados elevem a idade mínima de recrutamento voluntário para 16 anos, o que não se aplicaria às escolas operadas ou controladas pelas forças armadas dos Estados partes, desde que respeitados os artigos 28 e 29 da Convenção. ${ }^{144}$ O Protocolo destaca que, no momento

\footnotetext{
${ }^{144}$ Artigo 28: 1. Os Estados Partes reconhecem o direito da criança à educação e, a fim de que ela possa exercer progressivamente e em igualdade de condições esse direito, deverão especialmente:
} 
de sua ratificação ou adesão, cada Estado deve depositar uma declaração de compromisso, indicando a idade mínima para o recrutamento voluntário de suas forças armadas, descrevendo as salvaguardas adotadas para garantir que o recrutamento não será nem forçado nem realizado por intermédio de meios coercitivos. Segundo o Ministro, o Ministério da Defesa foi consultado a respeito da coerência entre o Protocolo e a legislação nacional, e não encontrou conflitos, tampouco fez oposições à sua assinatura (PBR - F).

Quanto ao Protocolo sobre a venda de crianças, a prostituição infantil e a pornografia infantil, aponta, após descrição, que a Secretaria de Estado dos Direitos Humanos, por intermédio do Departamento da Criança e do Adolescente, recomendou que o Brasil assinasse o Protocolo (PBR - F). A Consultoria Jurídica do Ministério das Relações Exteriores apontou que os Protocolos foram redigidos com o objetivo de oferecer maior proteção aos direitos das crianças, considerando imprescindível submeter os protocolos à análise do Congresso (PBR - F), e, ademais, que é necessário adotar reserva ou declaração interpretativa do parágrafo $9^{\circ}$ das consideranda do Protocolo Facultativo sobre a Venda de crianças, prostituição infantil e pornografia infantil.

a) tornar o ensino primário obrigatório e disponível gratuitamente para todos; b) estimular o desenvolvimento do ensino secundário em suas diferentes formas, inclusive o ensino geral e profissionalizante, tornando-o disponível e acessível a todas as crianças, e adotar medidas apropriadas tais como a implantação do ensino gratuito e a concessão de assistência financeira em caso de necessidade; c) tornar o ensino superior acessível a todos com base na capacidade e por todos os meios adequados; d) tornar a informação e a orientação educacionais e profissionais disponíveis e accessíveis a todas as crianças; e) adotar medidas para estimular a frequência regular às escolas e a redução do índice de evasão escolar.

2. Os Estados Partes adotarão todas as medidas necessárias para assegurar que a disciplina escolar seja ministrada de maneira compatível com a dignidade humana da criança e em conformidade com a presente convenção.

3. Os Estados Partes promoverão e estimularão a cooperação internacional em questões relativas à educação, especialmente visando a contribuir para a eliminação da ignorância e do analfabetismo no mundo e facilitar o acesso aos conhecimentos científicos e técnicos e aos métodos modernos de ensino. A esse respeito, será dada atenção especial às necessidades dos países em desenvolvimento.

Artigo 29: 1. Os Estados Partes reconhecem que a educação da criança deverá estar orientada no sentido de:

a) desenvolver a personalidade, as aptidões e a capacidade mental e física da criança em todo o seu potencial;

b) imbuir na criança o respeito aos direitos humanos e às liberdades fundamentais, bem como aos princípios consagrados na Carta das Nações Unidas; c) imbuir na criança o respeito aos seus pais, à sua própria identidade cultural, ao seu idioma e seus valores, aos valores nacionais do país em que reside, aos do eventual país de origem, e aos das civilizações diferentes da sua; d) preparar a criança para assumir uma vida responsável numa sociedade livre, com espírito de compreensão, paz, tolerância, igualdade de sexos e amizade entre todos os povos, grupos étnicos, nacionais e religiosos e pessoas de origem indígena; e) imbuir na criança o respeito ao meio ambiente.

2. Nada do disposto no presente artigo ou no Artigo 28 será interpretado de modo a restringir a liberdade dos indivíduos ou das entidades de criar e dirigir instituições de ensino, desde que sejam respeitados os princípios enunciados no parágrafo 1 do presente artigo e que a educação ministrada em tais instituições esteja acorde com os padrões mínimos estabelecidos pelo Estado. 


\section{APROVAÇÃO DOS PROTOCOLOS PELA CÂMARA DOS DEPUTADOS - MANIFESTAÇÕES EM PLENÁRIO}

[CD PLEN]

O Diário da Câmara dos Deputados de 26.02.2003 analisa os Protocolos quando ainda estavam pendentes os pareceres das Comissões de Relações Exteriores e de Defesa Nacional, de Seguridade Social e Família, e de Constituição e Justiça e de Redação. O Deputado Professor Luizinho manifesta-se para oferecer parecer à Mensagem 1035/2001, em substituição à CRE. Apresenta breve explicação dos Protocolos, apontando para o fato de que os países signatários deverão, segundo o texto dos Protocolos, cooperar para combater a utilização de crianças em conflitos armados, apresentando relatório ao Comitê sobre os Direitos da Criança sobre as medidas adotadas para o cumprimento dos Protocolos. O Deputado, com isso, aponta que os Protocolos são aprovados em conjunto.

O Deputado Fernando Ferro, manifestando-se em nome da Comissão de Constituição e Justiça e de Redação, diz que ambos atendem à boa técnica legislativa e correspondem aos requisitos da Comissão (DBR - F), opinando por sua aprovação.

O Deputado Eduardo Barbosa, manifestando-se em nome da Comissão de Seguridade Social e Família, dá parecer favorável à aprovação dos Protocolos.

No momento de aprovação da matéria é feita uma intervenção pela Deputada Maria do Rosário, que aponta que o Brasil, com a aprovação desses textos, faz uma contribuição de grande importância no contexto internacional (PEB - F). O projeto teria chegado na Casa há anos, e teria que ser aprovado rapidamente, ainda mais considerando o requerimento de urgência solicitado, em abril de 2002, pela Deputada Rita Camata (PBR - F). Segundo a Deputada, o objetivo da Mensagem é destacar o compromisso do Brasil em relação às graves questões de que tratam os Protocolos:

\footnotetext{
"Neste momento em que estamos movidos pelo desejo de paz e de fazer cumprir princípios fundamentais contidos na própria Constituição brasileira (DBR - F), que situam nosso país, no plano internacional, como uma das nações mais importantes que se posicionam contra a guerra no mundo, é importante que tenhamos uma preocupação objetiva, especifica (...) com as crianças e adolescentes do mundo, que são as principais vítimas da guerra. ( $\mathrm{DH}-$ crianças - F)" ${ }^{145}$
}

${ }^{145}$ DCD 26.02.2003, p. 4.276, col. 2. 
A Deputada prossegue, destacando que a aprovação dos Protocolos pela Câmara situa o país em uma posição relevante no momento histórico da época (PEB - F). Menciona, ainda, dados do Rio Grande do Sul sobre pornografia infantil (PBR - F). Os Protocolos estabeleceriam um sistema internacional de Direitos Humanos (PEB - F), e sua aprovação reforçaria o compromisso histórico e ético dos parlamentares brasileiros com as crianças e os adolescentes (PBR - F). Diz, ainda, que:

\begin{abstract}
"Por isso, propomos às Sras. e aos Srs. Deputados a aprovação dessas medidas, que são urgentes, pelo conteúdo social, histórico e pelo compromisso que devemos ter com as crianças e adolescentes do mundo, contra um sistema de opressão que os joga na guerra, os vitimiza e os explora sexualmente"
\end{abstract}

Aprovada a matéria, ela segue para o Senado Federal.

\title{
PARECER DA COMISSÃO DE RELAÇÕES EXTERIORES (n. 204 - SF), PATRÍCIA SABOYA GOMES, 2003
}

[Senado - Parecer 1]

O parecer, de 03.04.2003, é de autoria da Senadora Patrícia Saboya Gomes. Segundo a Senadora, o Ministério da Defesa, a Secretaria de Estado dos Direitos Humanos e a Consultoria Jurídica do MRE foram consultados a respeito da internalização dos Protocolos, sendo todos favoráveis à mesma. ${ }^{146}$

Para a Senadora, os Protocolos protegem as crianças de condutas inaceitáveis, e o Brasil não poderia deixar de atuar nos sistemas jurídicos nacional (PBR - F) e internacional (PEB - F) para combater todos os tipos de violação aos direitos da criança. Os protocolos são atos internacionais convenientes e oportunos aos interesses nacionais, o que é interessante para as relações exteriores do Brasil e para a sua imagem perante a sociedade internacional (PEB - F).

O parecer é pela aprovação dos Protocolos. ${ }^{147}$

\footnotetext{
${ }^{146}$ Apesar da menção a esses pareceres, eles não estavam disponíveis na tramitação do PDC ou do PDS.

${ }^{147}$ A Senadora faz menção à aprovação desses protocolos no DSF de 29.05.2003, p. 13.369 e seguintes. A descrição dos argumentos da Senadora encontra-se no item 19, referente à Convenção sobre o Crime Organizado Transnacional.
} 


\section{ANÁLISE: CONVENÇÃO INTERNACIONAL SOBRE A PROTEÇÃO DOS DIREITOS DE TODOS OS TRABALHADORES MIGRANTES E DOS MEMBROS DAS SUAS FAMÍLIAS}

A Convenção Internacional sobre a Proteção dos Direitos de Todos os Trabalhadores Migrantes e dos Membros das suas Famílias, de 18.12.1990, entrou em vigor internacional em 01.07.2003. Essa Convenção ainda não foi assinada pelo Brasil, tendo sido, primeiramente, enviada para a apreciação do Congresso. Foi enviada ao Congresso Nacional por intermédio da Mensagem Presidencial 696, de 2010. Seu processo de aprovação ainda não começou a tramitar na Câmara dos Deputados. Os argumentos utilizados para a internalização da Convenção, portanto, não serão contabilizados para fins dessa tese.

A Convenção não foi assinada pelo Brasil até o momento de depósito desta tese, tendo sido, portanto, enviada a MSC antes da ação do Poder Executivo em âmbito internacional. Não será feita análise exaustiva desta Convenção, porque não se completou sua tramitação no âmbito do Poder Legislativo. Serão apresentados, porém, os argumentos presentes nos documentos da tramitação aos quais a autora teve acesso. ${ }^{148}$

A Convenção define os direitos dos trabalhadores migrantes sob dois títulos principais: (i) a parte referente aos Direitos Humanos dos trabalhadores migrantes e membros de suas famílias é aplicável a todos os trabalhadores migrantes, o que inclui aqueles que não possuem documentação; e (ii) outros direitos, aplicável apenas aos trabalhadores migrantes em situação regular. A Convenção não propõe direitos novos aos trabalhadores migrantes, apenas reitera aqueles previstos, anteriormente, na DUDH. O objetivo da Convenção foi chamar a atenção da comunidade internacional para a desumanização dos trabalhadores migrantes, aos quais, muitas vezes, são negados os Direitos Humanos mais básicos, como o devido processo legal, direito à privacidade, igualdade entre esses trabalhadores e os

\footnotetext{
${ }^{148}$ Para informações a respeito da tramitação dessa Convenção, remete-se o leitor à Nota Técnica da Câmara dos Deputados, elaborada por Maria Ester Mena Barreto Camino e Vicente Marcos Fontanive, consultores legislativos da área de Direito Internacional Público e Relações Internacionais; intitulada "Tramitação da Convenção Internacional sobre a Proteção dos Direitos de todos os Trabalhadores Migrantes e dos membros das suas Famílias nos Poderes Executivo e Legislativo (Mensagem 696/2010, do Poder Executivo). Disponível em: $\quad$ http://www2.camara.leg.br/documentos-e-pesquisa/publicacoes/estnottec/areas-da-conle/ tema3/2014 11685.pdf. Acesso: 22.03.2016.
} 
nacionais dos países nos quais se encontram, possibilidade de transferência de seus ganhos, direito à informação, entre outros. ${ }^{149}$

\section{STATUS NA ONU}

https://treaties.un.org/Pages/ViewDetails.aspx?src=IND\&mtdsg_no=IV$13 \&$ chapter $=4 \&$ lang $=$ en

\section{MENSAGEM DO PODER EXECUTIVO (MSC 696/2010)}

A Mensagem 696, de 30.04.2010, redigida pelo Ministro das Relações Exteriores, senhor Celso Amorim, foi enviada ao Congresso Nacional pelo Presidente Luís Inácio Lula da Silva em 13.12.2010. Após descrição da Convenção, o Ministro aponta que sua ratificação pelo Brasil garantiria a proteção dos direitos nela previstos a todos os migrantes em território brasileiro, que, à época, somavam cerca de um milhão (PBR - F). Considerando o contexto de crescente restrição ao ingresso, permanência e proteção dos direitos dos migrantes, a ratificação fortaleceria a posição favorável do Brasil em relação aos Direitos Humanos, legitimando o país nos foros internacionais e estimulando a universalização da ratificação desse relevante instrumento (PEB - F).

O Ministro menciona pareceres exarados pelos Ministérios das Relações Exteriores, da Justiça e do Trabalho e Emprego, que destacaram que, em caso de adesão, deveriam ser apostas reservas a dois artigos. O primeiro deles (art. 18, $\S 3^{\circ}$, "g") afirma que "o trabalhador migrante ou membro da sua família acusado de ter infringido a lei penal tem, no mínimo, direito a não ser obrigado a testemunhar ou a confessar-se culpado". Apesar do direito, previsto no ordenamento brasileiro, de não se incriminar, o entendimento é que qualquer pessoa tem o dever de testemunhar quando chamada em juízo. O segundo, art. $22, \S 3^{\circ}$, trata da expulsão do trabalhador migrante, e admite que a decisão sobre sua expulsão seja, excepcionalmente, não fundamentada. No Brasil, a expulsão do estrangeiro, apesar de ser considerada ato de império, submete-se às condições estabelecidas pela Lei 6.815/1980, que define a situação jurídica do estrangeiro no Brasil e cria o Conselho Nacional de Imigração

\footnotetext{
${ }^{149}$ Informações obtidas em: http://www.unesco.org/new/en/social-and-human-sciences/themes/ international migration/international-migration-convention/. Acesso: 22.03.2016.
} 
(DBR - F), que assegura a ele o direito de defesa. O Brasil defende a adoção dessa postura por parte da comunidade internacional, com o objetivo de proteger os migrantes das arbitrariedades cometidas por autoridades estrangeiras, responsáveis pelo controle da imigração (PEB - F).

O Ministro aponta que o tratado deva tramitar no Congresso como projeto de emenda constitucional (PBR - F), considerando (i) tratar-se de instrumento fundamental sobre Direitos Humanos (DH - F); (ii) o exemplo bem-sucedido da aprovação da Convenção sobre os Direitos das Pessoas com deficiência, aprovada como emenda constitucional (DIN - F); e (iii) a necessidade de garantir a devida discussão parlamentar, tendo em vista a relevância do tema em pauta (PBR -F).

\section{REQUERIMENTO DA COMISSÃO DE RELAÇÕES EXTERIORES E DE DEFESA NACIONAL (n. 1826 - CD), CARLOS ALBERTO LERÉIA, 2011}

O requerimento, de autoria do Deputado Carlos Alberto Leréia, data de 24.05.2011, solicita a inclusão da Comissão de Direitos Humanos e Minoria no despacho inicial aposto à MSC 696/2010; pelo fato de a Mensagem tratar de tema afeto à competência dessa Comissão. Também solicita a criação de Comissão Especial para a apreciação da matéria.

Para o Deputado, a adesão do Brasil à Convenção seria um passo importante para a inserção do país no sistema internacional de proteção aos Direitos Humanos (PEB - F). A aprovação, ainda, traria importante avanço para a proteção dos direitos dos cerca de um milhão de estrangeiros que vivem no Brasil (PBR - F).

Os integrantes da Mesa Câmara dos Deputados, ao receber a MSC 696/2010, distribuíram a matéria às Comissões e Relações Exteriores e de Defesa Nacional; Trabalho, de Administração e Serviço Público e Constituição e Justiça e Cidadania. A proposição encontra-se, inclusive, sujeita à apreciação do Plenário em regime de prioridade. O despacho inicial, entretanto, excluiu da distribuição a Comissão de Direitos Humanos e Minorias, que, para o Deputado, é a principal competente para tratar da matéria (PBR - F). Porém, caso essa Comissão fosse considerada competente para manifestar-se a respeito do tema, segundo o art. 34, II, RICD, seria necessária a criação de Comissão Especial (DBR - F) e, com isso, a tramitação da Convenção seguiria o rito comum aos demais atos internacionais apreciados pela Câmara. 
Assim, para o Deputado, seria cabível estabelecer tratamento diferenciado para a apreciação do tema em pauta. Menciona o art. $5^{\circ}, \S 3^{\circ}, \mathrm{CF}$, que trata da aprovação de tratados com quórum de Emenda Constitucional (DBR - F). Para ele, o despacho da Mesa da CD não considerou essa hipótese e, portanto, requer que a apreciação da matéria siga o trâmite previsto no artigo citado, para ser apreciada em cada uma das Casas do Congresso, em dois turnos e, se aprovada por 3/5 dos votos dos membros, equivalha a EC (PBR - F).

A Convenção é tratado fundamental do sistema da ONU de Direitos Humanos, e corresponde aos interesses brasileiros de política externa firmar-se como país garantidor e defensor dos Direitos Humanos (PEB - F). Ratificar a Convenção como norma supra-legal representaria "um importante passo na consolidação de país que protege os Direitos Humanos". 150

\section{ATOS DA PRESIDÊNCIA DA CÂMARA DOS DEPUTADOS}

Em 03.08.2011, o Presidente da Câmara dos Deputados, Marcos Maia, criou Comissão Especial destinada a proferir parecer à MSC 696/2010. A Comissão seria composta por vinte e cinco membros titulares e o mesmo número de suplentes, mais um titular e um suplente, atendendo ao rodízio entre as bancadas não contempladas, designados conforme o art. 33, parágrafos $1^{\circ}$ e $2^{\circ}$ do RICD.

Em 11.06.2015, foi publicado ato da presidência da Câmara quase idêntico ao anteriormente mencionado, assinado por Eduardo Cunha, que apenas alterou o número de membros da Comissão Especial para vinte e seis.

${ }^{150}$ DCD 25.05.2011, p. 25.462, col. 2 


\section{ANÁlise: TRATADO DE ROMA DO TRIBUNAL PENAL INTERNACIONAL}

O Estatuto de Roma do Tribunal Penal Internacional, de 17.07.1998, entrou em vigor internacional em 01.07.2002. Essa Convenção foi assinada pelo plenipotenciário brasileiro em 07.02.2000 e ratificada em 20.06.2002, entrando em vigor para o Brasil em 01.09.2002 (art. 126). Foi enviada ao Congresso Nacional pela Mensagem Presidencial 1.084, de 2001. Seu processo de aprovação tramitou na Câmara dos Deputados como Projeto de Decreto Legislativo 1661, de 2002, e no Senado Federal como Projeto de Decreto Legislativo 152, de 2002. Foi aprovada pelo Decreto Legislativo 112, de 06.06.2002, e promulgada pelo Decreto Presidencial 4.388, de 25.09.2002.

O Tribunal Penal Internacional, instituído pelo Estatuto de Roma, é a primeira corte internacional permanente, estabelecida por tratado, que tem como objetivo impedir a impunidade de perpetradores de crimes de extrema gravidade, preocupação constante dos membros da comunidade internacional. O Tribunal é uma organização internacional independente, e, como tal, não integra o Sistema ONU. Trata-se de inovação apenas possível após o consenso a respeito da definição dos crimes de genocídio, contra a humanidade e de guerra. Na década de 1990, após o fim da Guerra Fria, foram estabelecidos tribunais penais como o Tribunal para a ex-Iugoslávia e para Ruanda, como demonstração de que a impunidade era inaceitável. Entretanto, como foram criados para julgar crimes cometidos apenas em um conflito determinado e durante período de tempo restrito, chegou-se à conclusão de que era necessário estabelecer uma corte penal permanente. Esse passo histórico ocorreu em 1998, quando 120 Estados adotaram o Estatuto de Roma, a base legal para o TPI. ${ }^{151}$

Destaco, antecipadamente, para facilitar a leitura da descrição dessa tramitação, a cláusula de recepção que consta na Constituição Federal brasileira:

\footnotetext{
Art. $5^{\circ}, \mathrm{CF}$

$\S 4^{\circ}$ O Brasil se submete à jurisdição de Tribunal Penal Internacional a cuja criação tenha manifestado adesão. (Incluido pela Emenda Constitucional $n^{\circ} 45$, de 2004)
}

\footnotetext{
${ }^{151}$ Informações obtidas em: https://www.icc-cpi.int/en menus/icc/about $\% 20$ the $\% 20$ court/Pages/about $\% 20$ the \%20court.aspx. Acesso: 22.03.2016
} 
Note que, apesar de alguns doutrinadores referirem-se a essa inovação da CF como uma cláusula que recepciona apenas o TPI, a mesma não se refere, apenas, a essa organização. É, portanto, uma cláusula genérica de recepção.

Ressalto, ainda, que, conforme o art. 120 do Estatuto, não são aceitas reservas a seu conteúdo. Assim, a discussão a respeito de reservas não cabe nesse particular caso. $\mathrm{O}$ art. 80, porém, reza: “Nada no presente Capítulo prejudicará a aplicação, pelos Estados, das penas previstas nos respectivos direitos internos, ou a aplicação da legislação de Estados que não preveja as penas referidas neste Capitulo". Esse artigo foi utilizado para embasar declarações interpretativas, como sugerido por alguns votos em separado de Deputados brasileiros. O Decretos Legislativo, que aprovou o tratado, e Executivo, que o promulgou, porém, não consideraram esses votos, sendo o seu texto executado e cumprido integralmente. A apresentação de alterações ao texto do TPI, entretanto, é possível, mas apenas após sete anos de sua entrada em vigor (art. 121.1).

\section{STATUS NA ONU}

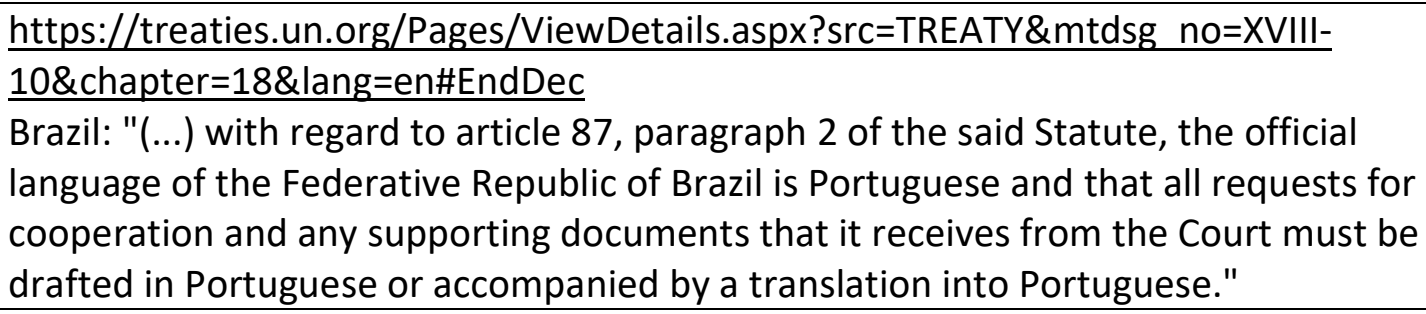

\section{MENSAGEM DO PODER EXECUTIVO (MSC 1.084/2001)}

A Mensagem 1.084, de 26.07.2001, redigida pelo Ministro das Relações Exteriores, senhor Celso Lafer, e pelo Ministro da Justiça, José Gregori, foi enviada ao Congresso Nacional pelo Presidente Fernando Henrique Cardoso em 10.10.2001. Os Ministros dizem que a criação do TPI é um avanço importante nos esforços da comunidade internacional para combater crimes de extrema gravidade, fornecendo instrumentos para punir seus perpetradores (DH - TPI). A formação do TPI tem relevância não apenas jurídica, mas política, e difere dos tribunais ad hoc formados após a $2^{\mathrm{a}}$ Guerra Mundial, além das iniciativas mais recentes de cortes para Ruanda e para a ex-Iugoslávia: o novo Tribunal 
permitirá superar a seletividade e a politização que caracterizaram, no contexto internacional, o tratamento penal de crimes de altíssima gravidade (DH - TPI). Segue-se relatório minucioso a respeito dos principais aspectos do tratado.

Os Ministros apontam que o Brasil atuou ativa e construtivamente durante o processo que culminou na aprovação do Estatuto (PEB - F); e que essa atuação reflete o comprometimento com a defesa dos Direitos Humanos e o interesse em acabar com a impunidade dos responsáveis por crimes graves, agora sob a jurisdição do Tribunal (DH TPI - F). O país, inclusive, votou a favor da adoção do Estatuto, apoio confirmado pela assinatura do Estatuto do TPI em 2000 (PEB - F). O país deve seguir adiante, e juntar-se aos que já ratificaram o instrumento, para apressar sua entrada em vigor (PEB - F). ${ }^{152}$

A ratificação do Estatuto seria coerente com os princípios que regem as Relações Internacionais brasileiras, como a prevalência dos Direitos Humanos, e da dignidade da pessoa humana como fundamento do Estado, ambos inscritos na Carta Magna (DBR - F). O ADCT, em seu art. $7^{\circ}$, determina que o Brasil propugnará pela formação de tribunal internacional dos Direitos Humanos (DBR - F).

A ratificação do Estatuto coadunar-se-ia, ademais, com a tradição brasileira de apoio à cooperação internacional no âmbito do direito penal (PEB - F) e com as intenções reiteradas, segundo os Ministros, pelo Presidente - de contribuir para o fortalecimento da proteção e da promoção dos Direitos Humanos, interna e internacionalmente (PBR - F). Em 2001, o Brasil teria dado passo importante nesse sentido, no momento em que aceitou a competência contenciosa da Corte Interamericana de Direitos Humanos (DIN - F). Ratificar o Estatuto significaria, ademais, favorecer um dos objetivos centrais da política externa brasileira, a manutenção da paz e da segurança internacionais, algo para o qual seguramente, o TPI irá contribuir (PEB - F).

Os Ministros ressaltam aspecto importante da processualística internacional adotada pelo TPI: uma vez em vigor, serão adotadas decisões a respeito do funcionamento do Tribunal, o que ocorrerá durante as primeiras sessões da Assembleia dos Estados Partes. Os países que, apesar de terem assinado o Estatuto, não o tiverem ratificado, poderão participar

\footnotetext{
152 Destaca-se que, à época da Mensagem, o Estatuto ainda não estava em vigor. Entraria em vigor alguns meses depois, com o depósito do $60^{\circ}$ instrumento de ratificação, de aceitação, de aprovação ou de adesão junto do Secretário-Geral da ONU, conforme o seu art. 126.
} 
na condição de observadores, sem direito a voto. O Brasil tem profundo interesse em constar entre os membros fundadores do TPI (PEB - F).

Desde a Conferência de Roma, ocorreram diversas consultas a respeito da compatibilidade do Estatuto com o Direito nacional. Essas análises determinaram que não há óbices legais para a adesão brasileira (DBR - F), como bem apontado pelo Parecer do consultor jurídico do MRE, analisado abaixo. As disposições relativas ao Tribunal, na verdade, são coerentes com os princípios consagrados na CF/1988, uma vez que seu objetivo é a efetivação dos Direitos Humanos (DH - DBR - F). O Tribunal é, ademais, regido pelo princípio da complementariedade, mantendo o Estado brasileiro, portanto, a competência para tornar desnecessária a intervenção do Tribunal em todos os casos sujeitos à jurisdição nacional (PBR - F).

A respeito da compatibilidade com Constituição, os Ministros entendem ser recomendável que a ratificação seja precedida de aprovação, no Brasil, de dispositivo constitucional que se refira, expressamente, ao Tribunal. Seria, portanto, essencial a decisão adotada pelo Congresso sobre a PEC 203/2000, pela qual seria autorizado o reconhecimento da jurisdição do TPI pelo Brasil. ${ }^{153}$

\section{PARECER DA CONSULTORIA JURÍdicA DO MRE, ANTÔNIO PAULO CACHAPUZ DE MEDEIROS, 2001}

[Executivo - Parecer MRE]

O parecer, de 26.01.2001, é de autoria do Consultor Jurídico do Itamaraty, senhor Antônio Paulo Cachapuz de Medeiros. O consultor ressalta que a MSC inclui os argumentos do Parecer CJ/MRE n. 33, de 22.11.1999, que recomendou a assinatura do tratado pelo Brasil. Cachapuz relata as PECs que propõem a inserção do reconhecimento expresso da competência do TPI na Constituição brasileira (o que, hodiernamente, foi efetivado pela EC 45/2004, resultado direto da PEC 96/1992, igualmente mencionada pelo parecer). Para ele, levando em consideração a tramitação no Poder Legislativo das referidas PECs, é forçoso acreditar que a submissão do Estatuto de Roma à apreciação do Congresso deve estar baseada na convicção do Presidente da República de sua constitucionalidade (PBR - F). O

\footnotetext{
${ }^{153}$ A PEC 203/2000, de autoria do Deputado Nilmário Miranda, foi analisada nesta tese, no capítulo 2.5.1.1. Propostas de Emendas Constitucionais.
} 
consultor apresenta, assim, os dispositivos do tratado que foram objeto de indagações, e que poderiam ser considerados inconstitucionais:

(i) Exceções ao princípio do respeito à coisa julgada (art. 20, III, Estatuto):

O Estatuto prevê exceções ao princípio da coisa julgada, proclamando que o TPI não pode julgar ninguém que tenha sido previamente julgado por outra jurisdição, mas estabelece exceções a esse fato, que serão decididas a critério do próprio TPI. A Constituição brasileira, por seu lado, prescreve, em seu art. $5^{\circ}$, XXXVI, que "a lei não prejudicará o direito adquirido, o ato jurídico perfeito e a coisa julgada" (grifo nosso) (DBR - C). No procedimento pátrio de extradição, é importante lembrar que a Lei 6.815/1980, art. 74, impede o deferimento do pedido caso o extraditando estiver sendo processado ou tiver sido processado no Brasil pelo fato que motiva o pedido (DBR C).

Seria possível argumentar, favoravelmente à constitucionalidade do Estatuto, que interessa ao Direito Internacional, particularmente na área de atuação do Tribunal, a efetividade do julgamento e da punição do acusado (DIN - F). Se a justiça interna usasse o direito nacional apenas para inocentar o acusado, o TPI seria competente para processar e para condenar o réu. A simulação de julgamento nacional implicaria a violação do Estatuto, sendo permitido ao TPI ordenar a entrega do acusado para responder em âmbito internacional. Isso possibilitaria, destarte, a interpretação em favor da constitucionalidade do Estatuto.

(ii) Irrelevância da Qualidade Oficial: A jurisdição do TPI será exercida independentemente de imunidades e de prerrogativas de foro por exercício de função previstas no direito interno (art. 27, Estatuto);

A CF/1988, nos artigos $53, \S 1^{\circ} ; 85 ; 86 ; 102$ e 105 , prevê prerrogativas de foro por exercício de função oficial e imunidades, o que seria contrário às disposições do Estatuto (DBR - C). A constitucionalidade do tratado poderia ser alegada atentando ao fato de que a Carta Magna, ao estabelecer foro (interno, ressaltamos) privilegiado para determinados indivíduos que desempenham funções oficiais, tinha como objeto os crimes reprimidos pelo ordenamento jurídico nacional, e não aqueles crimes previstos pelo Direito Internacional (PBR - F) 
Crimes de guerra, crimes contra a humanidade, genocídio e agressão são delitos gravíssimos, que afetam toda a comunidade internacional; e são, frequentemente, cometidos por aqueles que gozam de proteção jurídica em seus ordenamentos nacionais (PEB - F). Ademais, a CF não impede a aceitação, pelo Brasil, da jurisdição de tribunais internacionais, o que pode ser percebido pela leitura do art. $7^{\circ}, \mathrm{ADCT}$, que, aliás, não estabelece exceções para que cidadãos brasileiros, investidos ou não de cargos públicos, sejam levados a julgamento em corte internacional (DBR F).

(iii) Imprescritibilidade dos Crimes (art. 29, Estatuto);

A CF/1988 proclama que os crimes de racismo e de ação de grupos armados, civis ou militares, contra a ordem constitucional e o Estado democrático são imprescritíveis (art. $5^{\circ}$, XLII e XLIV). Esse fato excluiria a possibilidade de novas hipóteses de imprescritibilidade. No Código Penal brasileiro, a prescrição atinge a maior parte dos crimes (DBR - C).

A possibilidade de declarar o Estatuto constitucional seria respaldada pela regra que diz "inclusio unius alterius est exclusio", ou seja, a inclusão de um é a exclusão de outro: mencionar algumas hipóteses não exclui, necessariamente, todas as outras. O argumento, porém, é perigoso, e pode ser refutado pela expressão oposta, que diz que a especificação de uma hipótese não redunda na exclusão das demais. Além disso, a AGNU aprovou resolução, concernente aos crimes de guerra, que aponta que "o fato de a Lei interna não estipular pena para um ato consistente em crime de Direito Internacional não exime o criminoso de sua responsabilidade perante o Direito Internacional" (DIN - F). ${ }^{154}$

(iv) Entrega de nacionais ao TPI (art. 58, Estatuto);

A previsão entraria em conflito com o dispositivo da Constituição (art. $5^{\circ}$, LII) que prescreve que "nenhum brasileiro será extraditado, salvo o naturalizado, em caso de crime comum, praticado antes da naturalização, ou de comprovado

\footnotetext{
154 Trata-se do princípio II da Resolução 95 da AGNU, relativa aos crimes de guerra, crimes contra a paz e crimes contra a humanidade, elaborada em Nova Iorque, dezembro de 1946.
} 
envolvimento em tráfico ilícito de entorpecentes e drogas afins, na forma da lei" (DBR - C).

Em favor da constitucionalidade do Estatuto, teríamos que distinguir entre o instituto da extradição, que trata do envio de indivíduo de um país para outro, e o da entrega, envio de indivíduo para o TPI. O Tribunal é instituição internacional criada para processar e para julgar, de modo imparcial, os crimes mais atentatórios contra a dignidade humana, no contexto de conflitos armados. Por se tratar de órgão internacional, e não de jurisdição estrangeira, a entrega de acusado de perpetrar esses delitos ao Tribunal não poderia ser equiparada à extradição, pois dela não se trata. (DIN - F)

Soma-se a esse o fato de que uma das principais razões para evitar a extradição de nacionais é a possível imparcialidade do Judiciário estrangeiro, o que não se pode dizer do TPI. Seria, ademais, inviável que esse órgão efetivasse seus julgamentos se não pudesse ter, à sua disposição, os acusados pelos crimes previstos.

(v) Previsão da pena de prisão perpétua (art. 77, Estatuto); e

$\mathrm{O}$ artigo $5^{\circ}$, XLVII, b, CF, determina que não haverá penas de caráter perpétuo, o que não seria condizente com o art. 77 do Estatuto (DBR - C). Apesar disso, o STF tem deferido extradições, sem ressalva, para países cujas legislações preveem a pena de prisão perpétua (PBR - F). A constitucionalidade do TPI poderia ser arguida se entendêssemos que a proibição da pena perpétua restringe, somente, o legislador pátrio (PBR - F).

Ademais, no momento de elaboração da Constituição, o TPI inexistia. Seria impossível, portanto, exigir que o constituinte considerasse a questão de pena perpétua prevista nesse instrumento internacional. De qualquer modo, a Constituição sustenta o princípio de dignidade da pessoa humana como fundamento da República (art. $1^{\circ}$, III), e propugna pela formação de "tribunal penal de Direitos Humanos", conforme o art. $7^{\circ}$, ADCT (DBR - F).

Seria, portanto, apenas aparente a colisão entre o Estatuto e a Constituição, no que se refere à prisão perpétua, não apenas porque o primeiro pretende reforçar o princípio da dignidade da pessoa humana; mas porque a proibição prescrita pela CF é direcionada aos poderes constituídos brasileiros para os crimes previstos no 408 
ordenamento nacional, e não aos crimes contra os Direitos das Gentes, previstos em tratado.

De qualquer maneira, o Estatuto prevê, em seu art. 80, que, no que tange às penas, o Tribunal não poderá se manifestar em prejuízo da aplicação, pelos Estados, das penas previstas em seus ordenamentos pátrios; ou da aplicação da legislação de países que não prevejam as penas fixadas pelo Estatuto. Para a entrega de brasileiro ao TPI, o país poderá, com base no art. 80 do Estatuto, interpretar que a jurisdição internacional não irá, apenas, considerar a nacionalidade do acusado, mas que a pena que lhe será imposta não será, necessariamente, a de prisão perpétua (PEB - F).

O consultor sugere a apresentação de Declaração interpretativa nesse caso.

(vi) Ausência de individualização de penas para cada um dos tipos penais (arts. 77 a 80 , Estatuto)

$\mathrm{O}$ art. 77 do Estatuto noticia apenas o máximo da pena aplicável, genérica e indistintamente, a todos os delitos, não considerando a especificidade de cada tipo penal. A Constituição determina, no art. $5^{\circ}$, XLVI, que a lei regulará a individualização da pena e adotará, entre outras, as penas de privação ou de restrição da liberdade, perda de bens, multa, prestação social alternativa e suspensão ou interdição de direitos (DBR - C). Para o consultor, entretanto, não haveria incompatibilidade entre a CF e o Estatuto, pois este individualiza as penas, apesar de adotar meio distinto daquele da legislação penal nacional (DBR - F). No Estatuto encontram-se discriminadas as penas, e o Tribunal, em sua determinação, atenderá a fatores tais como a gravidade do crime e as condições pessoais do condenado. Apesar da maior liberdade na fixação da pena, o Estatuto restringiu a decisão ao máximo previsto pelo tratado.

Descritos todos os argumentos que questionam a constitucionalidade do instrumento, o consultor pondera que não deveriam existir dúvidas a respeito da constitucionalidade e da necessidade de se internalizar "um dos maiores avanços já obtidos na promoção do respeito aos direitos humanos" (DH - TPI), e que "o Brasil honraria suas tradições participando afirmativamente de sua consolidação." (PEB - F). 


\section{PARECER DA COMISSÃO DE RELAÇÕES EXTERIORES E DEFESA NACIONAL (CD), NILMÁRIO MIRANDA, 2002}

[Câmara - Parecer 1]

O parecer, de 07.03.2002, é de autoria do Deputado Nilmário Miranda. Após breve relato a respeito do conteúdo e da tramitação do tratado, o relator apresenta a definição de genocídio, que consta na Convenção para a Prevenção e a Repressão do Crime de Genocídio, destacando que esta foi ratificada pelo Brasil (DIN - F). Menciona que o tratado define tipos penais que, de uma maneira ou se outra, estão previstos no ordenamento nacional: existem tipos penais similares no direito brasileiro, como o crime comum, militar em tempo de paz ou em tempo de guerra (DBR - F). Os crimes contra a humanidade, por sua vez, protegem bens consagrados no ordenamento nacional (DBR - F), além de bens protegidos por tratados ratificados pelo Brasil (DIN - F). Os crimes de guerra, do mesmo modo, integram nosso ordenamento por intermédio de mais de 35 tratados ratificados pelo Brasil acerca do tema, como as Convenções de Genebra de 1949 e seus protocolos adicionais, de 1977 (DIN - F).

O Estatuto do TPI representaria avanço histórico para atingir relações humanas mais justas, nacional (PBR - F) e internacionalmente (PEB - F). Os diversos massacres ocorridos nos séculos passados, e a impunidade de seus perpetradores, culminaram na assinatura de tratados que garantiram tratamento humanitário em tempos de guerra, tentaram coibir genocídios e proteger a dignidade humana, criando instituições internacionais com órgãos de monitoramento. Passou a existir algo que pode ser intitulado de "Direito Penal Intercultural", o que possibilita aos Estados avocar jurisdição sobre fatos ocorridos em outros territórios, e sem a participação de nacionais, como o direito brasileiro prevê no Código Penal, em seus artigos 7 , I, “d” (para genocídio), e II, “a” (obrigação baseada em tratados) e na Lei 9.455, de 07.04.1997 (para tortura) (DBR - F).

O TPI possibilitaria a repressão penal democrática e desvinculada de casos concretos, por tipificar os crimes que julgará no futuro, diferentemente do que ocorreu com tribunais que o antecederam. Ademais, respeita a soberania estatal, por ser a ela complementar, somente julgando o indivíduo se o Estado não o fizer (PEB - F). As condições prévias para que essa jurisdição seja exercida perante o Estado, conforme o art. 57 do Estatuto, serão a de crime cometido em seu território ou o acusado ser seu nacional.

O parecer é, pois, pela aprovação do Estatuto. 


\section{VOTO EM SEPARADO, HAROLDO LIMA}

[Câmara - Vt Sep 1]

O voto, proferido em 03.04.2002, é de autoria do Deputado Haroldo Lima. Segundo ele, a ONU e a DUDH foram extremamente importantes para a busca pela liberdade e pela justiça para os seres humanos (DIN - F). O TPI, entretanto, demonstra a disparidade existente entre os países do mundo, entre os ricos e os pobres, e deve ser analisado dentro desse contexto de disparidade política e de impossibilidade de real isenção em seus julgamentos. Não seria, portanto, nem oportuno nem conveniente criar tribunal penal com jurisdição internacional nesse particular momento histórico (PEB - C).

O Deputado tem dúvidas a respeito da compatibilidade entre o Estatuto do TPI e a Constituição Federal (DBR - C). Assinala, nesse sentido, a necessidade de consultar a Ordem dos Advogados do Brasil (OAB) a respeito do tema; cujo Conselho de Defesa dos Direitos Humanos, inclusive, manifestou-se contra o Estatuto em oportunidade anterior, assinalando a falta de individualização da pena no TPI e a inconstitucionalidade da pena de caráter perpétuo (DBR - C). Para o Deputado, a argumentação da Consultoria do MRE que refuta essas inconstitucionalidades não seria convincente, particularmente no que se refere (i) à complementariedade da jurisdição do TPI, por questionar a própria legitimidade do Tribunal, que analisará se a decisão do Poder Judiciário nacional foi espúria ou não, como pressupõe seu Estatuto (PBR - C); (ii) à constitucionalidade da previsão de pena perpétua, percebendo como uma falha da diplomacia brasileira, que assinou um tratado sem considerar o direito interno (PBR - C).

A impossibilidade de reservas ao tratado rechaça uma adesão parcial, o que dificultaria, ainda mais, sua concordância com o instrumento. Apesar disso, ressalta a possibilidade, também mencionada pelo parecer da CJ-MRE, de elaborar declarações interpretativas em relação ao tratado, quando da sua ratificação. Isso possibilitaria a primazia da interpretação constitucional sobre o disposto no tratado (DBR - F).

O Deputado sugere, ainda, outra declaração interpretativa, que ressaltaria a interpretação brasileira de que o TPI é instituição autônoma e independente de manobras políticas (PEB - F). Segue:

“O Tribunal Penal Internacional, em sua ação judicante, para assegurar a plena independência e isenção de seus julgados, não pode sofrer interferências de outros órgãos internacionais, multilaterais ou estatais, não estando sujeito à 
suspensão dos processos nele instaurados por quaisquer outras instituições ou instâncias, inclusive o Conselho de Segurança da ONU."

A matéria em pauta não poderia, em virtude das diversas dúvidas que a cercam, tramitar com tanta rapidez nas Casas. Não haveria urgência para sua aprovação, e, portanto, o Deputado entende que o debate deve prosseguir. Se isso não ocorrer, espera que a aprovação do Projeto esteja condicionada às declarações interpretativas sugeridas, que deveriam integrar o Decreto.

\section{PARECER DA COMISSÃO DE CONSTITUIÇÃO E JUSTIÇA E DE REDAÇÃO (CD), NELSON PELLEGRINO, 2002}

[Câmara - Parecer 2]

O parecer, de 10.04.2002, é de autoria do Deputado Nelson Pellegrino. Após explicação a respeito dos principais artigos do Estatuto, e da tramitação do projeto, o Deputado assinala que o TPI é resultado de instrumento internacional que apresenta avanço significativo em relação aos tribunais penais ad hoc, como os de Nuremberg, de Ruanda e da Bósnia (DIN - F). As normas do TPI teriam sido resultado de consenso internacional, e, por essa razão, seria desnecessário que todas as legislações nacionais estivessem de acordo com sus disposições; o que pode ser confirmado na iniciativa brasileira de criar, internamente, os tipos penais previstos no Estatuto (PBR - F).

Destaca que, apesar da incerteza de alguns juristas a respeito dos conflitos entre o texto do Estatuto e a legislação interna, é necessário lembrar que o tratado tipifica crimes graves, que afetam a humanidade (DH - TPI - F). O projeto, ademais, está em conformidade com as disposições do art. $7^{\circ}, \mathrm{ADCT}$, além dos parágrafos $1^{\circ}$ e $2^{\circ}$ do art. $5^{\circ}, \mathrm{CF}$, que reforçam o compromisso brasileiro com a jurisdição internacional (DBR - F).

O instituto da entrega, por sua vez, difere da extradição, e aquela apenas ocorrerá em caso de não julgamento no âmbito interno, conforme o art. 20 do Estatuto, que determina que o Tribunal não poderá julgar ninguém que o tenha sido em outra jurisdição; com exceções que apenas reforçam a proteção dos Direitos Humanos pelo TPI, e reiteram seu caráter complementar. O Tribunal, acrescenta, não será uma jurisdição estrangeira, mas internacional. O Brasil, por intermédio de seus juristas e de seus diplomatas, participou dos debates destinados a criar um tribunal com essas características (PEB - F). 
Das discussões sobre o TPI participaram diversos membros da sociedade civil. As maiores dúvidas, referentes ao instituto da entrega e da pena perpétua, foram debatidas e são, segundo o Deputado, consenso entre os juristas (PBR - F). A aprovação do projeto de decreto legislativo é um passo importante para que o Brasil faça parte dos primeiros sessenta países a ratificar o Estatuto, viabilizando a entrada em vigor do TPI (PEB - F).

\section{VOTO EM SEPARADO, COMISSÃO DE CONSTITUIÇÃO E JUSTIÇA E DE REDAÇÃO (CD), DEPUTADO ALDO ARANTES, 2002}

[Câmara - Vt Sep 2]

O voto, de 2002, é de autoria do Deputado Aldo Arantes. Segundo ele, a instituição do TPI é coerente com a busca pelo respeito aos Direitos Humanos (DH - TPI), sendo a ONU fundamental nesse sentido, assim como a DUDH (DIN - F). O Brasil é respeitador desses direitos, um dos princípios expressamente respeitados pela Constituição (DBR - F). O constituinte pátrio, inclusive, determinou que o país propugnaria pela criação de tribunal penal internacional, o que se coaduna com a proposta do TPI (DBR - F).

O Deputado preocupa-se, particularmente, com a coerência entre o Estatuto e a Constituição, principalmente no que se refere à individualização da pena e à pena de caráter perpétuo. Acredita ser importante adotar a recomendação da CJ-MRE de fazer declaração interpretativa em relação ao TPI (PBR - F), que deveria ser inserida no Decreto Legislativo que aprovaria o texto do Estatuto.

O voto em separado é pela aprovação do TPI, com a declaração interpretativa sugerida.

\section{PARECER DA COMISSÃO DE RELAÇÕES EXTERIORES E DEFESA NACIONAL (n. 448 - SF), LUDIO COELHO, 2002}

[Senado - Parecer 1]

O parecer, de autoria do Senador Ludio Coelho, relator ad hoc para o Senador José Agripino, é de 21.05.2002. Após relatório a respeito do TPI, assinala que o crime de genocídio é definido como aquele previsto na Convenção para a Prevenção e a Repressão do Crime de Genocídio (DIN - F), ratificada pelo Brasil, sendo, também, similar aos tipos penais brasileiros (DBR - F). Muitos dos direitos protegidos pelo Estatuto também o são pelo direito interno (DBR - F) ou por instrumentos de Direitos Humanos ratificados pelo Brasil; 
do mesmo modo os crimes de guerra, presentes em tratados ratificados pelo Brasil, como as quatro Convenções de Genebra de 1949 e seus Protocolos Adicionais (DIN - F).

O Senador aponta que, conforme o RISF, não cabe à Comissão analisar a matéria do tratado, mas conclui pela inexistência de obstáculos constitucionais, considerando o parecer da CJ-MRE e da CCJR/CD. Reitera que o ADCT, art. $7^{\circ}$, determina que o país propugnará pela formação de tribunal internacional de Direitos Humanos (DBR - F). O TPI é um organismo internacional que irá contribuir para a prevenção de violações (DH - TPI - F).

O parecer é, portanto, pela aprovação do tratado.

\section{MANIFESTAÇÃO DA CÂMARA MUNICIPAL DE SANTO ANDRÉ}

Consta, no apensado do PDC, uma Moção de Apelo da presidência da Câmara Municipal de Santo André, ocupada por Carlinhos Augusto, pela ratificação do Estatuto do TPI. ${ }^{155}$

\subsection{ACORDO DE IMUNIDADES E PRIVILÉGIOS DO TPI}

O Acordo sobre Privilégios e Imunidades do Tribunal Penal Internacional, elaborado entre 3 e 10.09.2002, entrou em vigor internacional em 22.07.2004, de acordo com as disposições de seu artigo 35.1. Foi assinado pelo plenipotenciário brasileiro em 17.05.2004, e ratificado em 12.12.2011, entrando em vigor para o Brasil em 11.01.2012. Foi enviado ao Congresso Nacional pela Mensagem Presidencial 110, de 2010. Seu processo de aprovação tramitou na Câmara dos Deputados como Projeto de Decreto Legislativo 2.845, de 2010, e no Senado Federal como Projeto de Decreto Legislativo 136, de 2011. Foi aprovado pelo Decreto Legislativo 291, de 22.09.2011, e promulgado pelo Decreto Presidencial 8.604, de 18.12.2015.

O Acordo foi delineado para que integrantes do TPI detivessem certos privilégios e imunidades necessárias para exercer seus deveres de modo incondicional. A assinatura do

\footnotetext{
${ }^{155}$ A manifestação teria sido aprovada após requerimento dos Vereadores Raulino Lima, Antonio Leite, Ivete Garcia, Dr. José Dilson, José Montoro Filho, Maria F. de Souza e Sargento Juliano.
} 
Acordo é essencial para a garantia, provida pelos Estados signatários, de que seus agentes estão cientes dos privilégios detidos pelos funcionários do TPI, respeitando-os. ${ }^{156}$

\section{STATUS NA ONU}

https://treaties.un.org/pages/ViewDetails.aspx?src=TREATY\&mtdsg_no=XVIII$13 \&$ chapter $=18 \&$ lang $=$ en

MENSAGEM DO PODER EXECUTIVO (MSC 110/2010)

A Mensagem 110, de 07.07.2008, foi redigida pelo senhor Samuel Pinheiro Guimarães, e enviada ao Congresso Nacional pelo Presidente Luís Inácio Lula da Silva em 11.03.2010. Segundo o Diplomata, o Acordo está em conformidade com a posição defendida pelo Brasil, porque estabelece privilégios e imunidades para o desempenho das funções previstas pelo Estatuto por parte de juízes, do Procurador, do Secretário e de seus assessores - bem como vítimas, advogados, testemunhas e peritos (PEB - F). Defender a integridade do Estatuto de Roma, e, portanto, do TPI, é parte relevante da política externa brasileira (PEB - F). A aprovação e a ratificação do tratado são mais necessária em razão do início dos trabalhos do Tribunal no ano corrente, tendo o Brasil uma juíza no quadro, doutora Sylvia Steiner (PBR - F).

\section{PARECER DA COMISSÃO DE RELAÇÕES EXTERIORES E DEFESA NACIONAL (CD), ARNALDO MADEIRA, 2010}

[Câmara - Parecer 1]

O parecer, de 2010, é de autoria do Deputado Arnaldo Madeira. ${ }^{157}$ Após relatório a respeito do tratado, o relator diz que suas disposições coadunam-se com a posição defendida pelo Brasil, que advogou pelo estabelecimento de imunidades e de privilégios limitados ao estritamente necessário para o desempenho das funções previstas no Estatuto (PEB - F).

\footnotetext{
${ }^{156}$ Informações obtidas em: http://www.iccnow.org/?mod=apic. Acesso: 22.03.2016.

${ }^{157}$ Ressalto que o relator William Woo foi designado relator substituto da proposição na reunião ordinária deliberativa da CREDNA de 18.08.2010, em decorrência da ausência do relator, Deputado Arnaldo Madeira. Como o Deputado Woo acatou, integralmente, o parecer do Deputado Madeira, apenas esse primeiro foi relatado.
} 
O TPI, primeiro tribunal permanente da história da humanidade, representa substancial avanço em direção à universalização dos Direitos Humanos, e respeito ao Direito Internacional (DH - TPI). O Acordo em pauta tem como objetivo instrumentalizar as ações do TPI, e sua apreciação não pode, portanto, prescindir da análise do Tribunal em si. A aprovação, portanto, é relevante e urgente, para que seu funcionamento comece o quanto antes. Por essa razão, o parecer é favorável à adesão do Brasil.

\section{PARECER DA COMISSÃO DE CONSTITUIÇÃO E JUSTIÇA E DE CIDADANIA (CD), EDUARDO CUNHA, 2010}

[Câmara - Parecer 2]

O parecer, de 2010, é de autoria do Deputado Eduardo Cunha. Segundo ele, o Acordo respeita as previsões constitucionais pertinentes (DBR - F), sendo, portanto, favorável o parecer pela sua aprovação.

\section{PARECER DA COMISSÃO DE RELAÇÕES EXTERIORES E DEFESA NACIONAL (SF), ALOYSIO NUNES, 2011}

[Senado - Parecer 1]

O parecer, de 01.09.2011, é de autoria do Senador Aloysio Nunes Ferreira. Após relato a respeito do tratado e do Tribunal, o Senador aponta que sua fundação concretizou anseios da sociedade internacional, manifestados anteriormente nos tribunais ad hoc do pós II Guerra Mundial. O Brasil compartilha dos anseios dos idealizadores do TPI, com a esperança de paz para o século XXI (PEB - F). Para que o TPI possa operar, é preciso estabelecer detalhadamente seus procedimentos.

Formalmente, é um acordo adequado ao contexto internacional, produzido após negociações travadas entre Estados com diferentes sistemas legais. Os objetivos do Tribunal coadunam-se com os do Brasil, particularmente se considerarmos o art. $5^{\circ}, \S 4^{\circ}, \mathrm{CF}$, incluído pela EC 45/2004 (DBR - F). O tratado é, portanto, favorável aos interesses nacionais e merece ser aprovado, (PBR - F) gesto que contribuirá para o fomento da justiça e da paz entre as nações (PEB - F). 


\section{ANÁliSE: CONVENÇÃO DAS NAÇÕES UNIDAS CONTRA O CRIME ORGANIZADO TRANSNACIONAL}

A Convenção das Nações Unidas contra o Crime Organizado Transnacional (“Convenção de Palermo"), de 15.11.2000, entrou em vigor internacional em 29.09.2003, de acordo com as disposições de seu art. 38. Essa Convenção foi assinada pelo plenipotenciário brasileiro em 12.12.2000 e ratificada em 29.01.2004, entrando em vigor para o Brasil em 28.02.2004. Foi enviada ao Congresso Nacional pela Mensagem Presidencial 48, de 2002. Seu processo de aprovação tramitou na Câmara dos Deputados como Projeto de Decreto Legislativo 6, de 2003, e no Senado Federal como Projeto de Decreto Legislativo 13, de 2003. Foi aprovada pelo Decreto Legislativo 231, de 29.05.2003, e promulgada pelo Decreto Presidencial 5.015, de 12.03.2004. Seus dois protocolos, relativos ao Combate ao tráfico de Migrantes por via terrestre, marítima e aérea, em vigor desde 28.01.2004; e à Prevenção, Repressão e Punição do Tráfico de Pessoas, em especial Mulheres e Crianças, em vigor desde 25.12.2003; foram celebrados na mesma data da Convenção, e apreciados conjuntamente.

A Convenção foi o resultado de um esforço da Comissão sobre a prevenção do Crime e Justiça Criminal em elaborar relatório sobre atividades criminais transnacionais organizadas. O trabalho elaborado no âmbito dessa Comissão fez que governos desejassem elaborar instrumento multilateral contra o crime organizado, intenção apoiada pela Comissão, pela AGNU e pelo ECOSOC. O texto da Convenção foi aprovado em conjunto com os dois protocolos aqui analisados; sendo um terceiro protocolo, sobre a produção ilícita e tráfico de armas de fogo, elaborado posteriormente, em 2001. O principal objetivo da Convenção é a criminalização, por seus signatários, da participação em grupos criminais organizados. Os Estados devem, ademais, tomar medidas necessárias para processar os criminosos e confiscar os produtos dos crimes, auxiliando o combate ao crime organizado transnacional. ${ }^{158}$

\footnotetext{
${ }^{158}$ Informações obtidas em: http://legal.un.org/avl/ha/unctoc/unctoc.html. Acesso: 23.03.2016. 


\section{STATUS NA ONU}

https://treaties.un.org/Pages/ViewDetails.aspx?src=IND\&mtdsg_no=XVIII$12 \&$ chapter $=18 \&$ lang $=$ en

Brazil - 15 August 2005

"... the Brazilian government has designated its Ministry of Justice as the central authority for matters related to mutual legal assistance, in accordance with article 18, paragraph 13 of the United Nations Convention against Transnational Organized Crime (Palermo Convention).

Any requests for international legal assistance under the Palermo Convention shall be directed, in Portuguese or in English, to the following focal points:

* International legal assistance - Department of Asset Recovery and International Legal Cooperation (DRCI)

* Extradition and transference of convicted criminals Department of Foreigners

\section{MENSAGEM DO PODER EXECUTIVO (MSC 48/2002)}

A Mensagem 48, de 27.11.2001, redigida pelo Ministro das Relações Exteriores, Celso Lafer, foi enviada ao Congresso Nacional pelo Presidente da República, Fernando Henrique Cardoso, em 30.01.2002. Segundo o Ministro, os representantes do país participaram ativamente das negociações que culminaram na Convenção e em seus protocolos (PEB - F), cujos objetivos são coerentes com os esforços do governo brasileiro no combate ao crime organizado (PBR - F). A delegação brasileira, ressalta, foi composta por representantes do Ministério da Justiça e por diplomatas da Embaixada de Viena, que participaram de todas as sessões do comitê ad hoc que detinha mandato da AGNU para elaborar o instrumento, com o objetivo de promover a cooperação internacional na área de combate ao crime organizado (PEB - F).

A atuação da delegação brasileira foi pautada pela busca de consensos, sem abdicar do respeito à soberania nacional. Nesse sentido, cooperou com o grupo de países da América Latina e Caribe (GRULAC), que, em geral, defendem posições semelhantes (PEB - F). A Convenção foi, inclusive, recebida no âmbito da OEA, objeto de Resolução aprovada, que também contou com o copatrocínio brasileiro (PEB - F).

O Ministro destaca que o signatário brasileiro da Convenção foi o Ministro da Justiça, que solicitou o início do trâmite para a aprovação do tratado no Brasil (PBR - F). 


\section{REQUERIMENTO DE URGÊNCIA}

Foi feito, em 25.02.2003, requerimento de urgência, na Câmara dos Deputados, para a apreciação da MSC 48/2002. O requerimento foi aceito, com 356 votos a favor, 2 contrários e uma abstenção. ${ }^{159}$

\section{PARECER DO RELATOR DESIGNADO PELA MESA EM SUBSTITUIÇÃO À COMISSÃO DE RELAÇÕES EXTERIORES E DE DEFESA NACIONAL}

[Câmara - Parecer 1]

O parecer, de autoria do Deputado Toroni Morgan, data de 2003. Nele, o Deputado ressalta que a Convenção, do mesmo modo que o TPI (DIN - F), foi o resultado de um esforço da comunidade internacional em combater o crime que ultrapassa as fronteiras dos Estados (PEB - F). O Brasil atuou de maneira ativa nas negociações da Convenção e de seus protocolos (PEB - F), cujos objetivos são coerentes com os esforços do governo no combate ao crime organizado (PBR - F).

Ao tratar dos Protocolos facultativos à Convenção, o relator aponta que estes são consequência direta de Resoluções da AGNU (Resoluções 54/212, de 22.12.1999 e 53/111, de 09.12.1998) (DIN - F). ${ }^{160}$ A celebração desses tratados decorre, igualmente, da necessidade de tratar os migrantes com humanidade e de proteger os seus direitos, em virtude da inexistência de instrumentos internacionais que tratem dos diversos aspectos do tráfico de pessoas. Acertou o tratado em não penalizar os migrantes, mas sim os indivíduos que obtém vantagens ao traficar pessoas (DH - tráfico - F).

O Protocolo Facultativo sobre a prevenção, repressão e punição do tráfico de pessoas, em especial de mulheres e de crianças, demonstra o consenso internacional relativo à necessidade de ações eficazes para prevenir e para combater esse tipo de tráfico; o que exige uma abordagem internacional, que inclua os países de origem, de trânsito e de destino desses indivíduos (PEB - F). É necessário protegê-los e garantir seus direitos fundamentais (DH -

159 A votação desse requerimento está disponível em: http://www2.camara.leg.br/atividade-legislativa/ plenario/chamadaExterna.html?link=http://www.camara.gov.br/internet/votacao/mostraVotacao.asp?ideVota cao=1839\&tipo=partido. Acesso: 23.03.2016.

160 Apesar de não serem tratados internacionais, optou-se por classificar as Resoluções da AGNU como instrumentos de Direito Internacional, por serem instrumentos importantes para a codificação do Direito Internacional. 
F). Esse protocolo também é consequência direta de Resolução adotada pela AGNU Resolução 53/111, mencionada acima.

A participação do Brasil tem sido firme nos foros internacionais dedicados a promover as medidas relativas ao combate à criminalidade transfronteiriça, mediante a elaboração de tratados internacionais (PEB - F). O país reconhece a existência dessas atividades e a necessidade de cooperação entre países como a única forma de combatê-las (PEB - F). O Brasil é particular interessado nessa Convenção, por lidar, diariamente, com atividades ilícitas que transpõem as fronteiras do país (PBR - F).

O voto é pela aprovação da Convenção e de seus protocolos.

PARECER dA COMISSÃO DE RELAÇÕES EXTERIORES (n. 484 - SF), PATRÍCIA SABOYA GOMES, 2003

[Senado - Parecer 1]

O parecer, de 15.03.2003, é de autoria da Senadora Patrícia Saboya Gomes. Após relato a respeito da Convenção, a Senadora aponta que tanto ela como seus protocolos são convenientes e oportunos aos interesses brasileiros (PBR - F), tendo sido celebrados no contexto da ONU e recepcionados pela OEA. A ratificação e a implementação desses instrumentos internacionais pelo Brasil serão positivas para as relações internacionais do país e para a sua imagem perante seus pares na sociedade internacional (PEB - F). Por serem os tratados, ademais, condizentes com a ordem constitucional (DBR - F), o voto é pela aprovação do projeto.

\section{MANIFESTAÇÃO EM PLENÁRIO NO SENADO FEDERAL} [SF PLEN]

Foi publicada, no DSF de 29.05.2003, p. 13.369 e seguintes, manifestação da Senadora Patrícia Saboya Gomes a respeito da aprovação dos Protocolos da Convenção de que tratamos aqui e que menciona, também, os protocolos que complementam a Convenção sobre os Direitos da Criança, analisada no item 16 deste capítulo. A Senadora apenas aponta para a necessidade de aprovar o projeto, congratulando os demais parlamentares nesse sentido. 


\section{ANÁLISE: CONVENÇÃO SOBRE OS DIREITOS DAS PESSOAS COM DEFICIÊNCIA}

A Convenção sobre os Direitos das Pessoas com Deficiência, de 30.03.2007, entrou em vigor internacional em 03.05.2008, de acordo com o seu artigo 45(1), e entrou em vigor para o Brasil em 31.08.2008. Essa Convenção foi assinada pelo plenipotenciário brasileiro em 30.03.2007, ratificada em 01.08.2008, e promulgada pelo Decreto Presidencial 6.949, de 25.08.2009, sem reservas. Foi enviada ao Congresso Nacional pela Mensagem do Poder Executivo 711, de 26.07.2007. Seu processo de aprovação tramitou na Câmara dos Deputados como Projeto de Decreto Legislativo 563-A de $2008^{161}$, e no Senado Federal como Projeto de Decreto Legislativo 90, de 2008. O Congresso aprovou a Convenção e seu protocolo facultativo por meio do Decreto Legislativo 186, de 09.07.2008, conforme o procedimento do art. $5^{\circ}, \S 3^{\circ}, \mathrm{CF}$. O governo brasileiro depositou o instrumento de ratificação desses instrumentos junto ao Secretário-Geral das Nações Unidas em 01.08.2008, que entraram em vigor para o Brasil em 31.08.2008.

A Convenção é o primeiro instrumento internacionalmente vinculante que estabelece patamares mínimos para a proteção dos direitos das pessoas com deficiência, e determina uma diretriz para a implementação desses direitos. Seus signatários devem mobilizar-se no desenvolvimento e na implementação de políticas, de leis e de medidas administrativas para assegurar a proteção aos direitos desses indivíduos; além de abolir leis, costumes e práticas discriminatórias. A mudança na percepção a respeito das pessoas com deficiência é essencial para melhorar a sua condição de vida, e, portanto, combater estereótipos e preconceitos, promovendo a conscientização a respeito das capacidades dessas pessoas. ${ }^{162}$

Esse tratado tem particular relevância no âmbito interno, pois foi o primeiro, e o único, até o depósito desta tese, a ser internalizado com status de Emenda Constitucional. A aprovação de emendas, segundo o artigo $60, \S 2^{\circ}, \mathrm{CF}$, deverá ser discutida e votada em cada Casa do Congresso, em dois turnos; e será aprovada a proposta que obtiver, em ambos, três quintos dos votos dos respectivos membros. Nesse contexto, o art. 60 deve ser apreciado em conjunto com o art. $5^{\circ}, \S 3^{\circ}, \mathrm{CF}$, inserido pela EC 45/2004; que prevê a possibilidade de

\footnotetext{
${ }^{161}$ Que tramitou no regime de urgência, conforme o art. 155 RICD

${ }^{162}$ Informações obtidas em: http://www.un.org/disabilities/convention/convention.shtml. Acesso: 24.03.2016.
} 421 
considerar a aprovação de tratados sobre Direitos Humanos como equivalentes às emendas constitucionais, desde que respeitado o quórum, surgindo a possibilidade de garantir patamar constitucional a esses tratados.

Por se tratar do primeiro instrumento internacional para o qual esse procedimento foi adotado, houve extensa discussão, no âmbito do Poder Legislativo, a respeito do procedimento para que essa aprovação ocorresse. Parte significativa do debate abordou o envio do tratado pelo Executivo com o pedido de que fosse aprovado como EC. Os parlamentares discutiram essa faculdade, e, também, qual seria o Poder competente para definir o regime de tramitação de um tratado. As discussões, apresentadas a seguir, demonstram o interesse dos parlamentares em decidir a respeito da equivalência de instrumentos internacionais à Constituição nacional, o que será analisado pormenorizadamente no capítulo 3, que trata da relação entre o Executivo e o Legislativo na internalização de tratados. Não se trata, portanto, de discussão a respeito da substância ou do mérito do tratado, mas do procedimento para sua internalização.

A respeito do PDC 563/2008, em razão de sua pela originalidade, destaco que a sua tramitação foi um pouco diferente daquela dos PDCs anteriormente apresentados. A discussão em primeiro turno foi realizada em 13.05.2008, e o segundo turno ocorreu no dia 28.05.2008.

\section{STATUS NA ONU:}

https://treaties.un.org/Pages/ViewDetails.aspx?src=TREATY\&mtdsg_no=iv$15 \&$ chapter $=4 \&$ lang $=$ en

\section{MENSAGEM DO PODER EXECUTIVO (MSC 711/2007)}

A Mensagem 711, de 26.07.2007, foi elaborada pelo Ministro das Relações Exteriores, senhor Celso Amorim, e enviada pelo Presidente Luís Inácio Lula da Silva ao Congresso em 26.09.2007. O Ministro destaca, no início da Mensagem, que a Convenção foi resultado de empenho técnico e político de órgãos do governo, que participou ativamente de seu processo negociador (PEB - F), e da sociedade civil brasileira. A Convenção é "um dos grandes 
instrumentos de direitos humanos do sistema ONU e representa considerável avanço na luta pela promoção dos direitos das pessoas com deficiência" (DH - deficientes).

Sugere, finalmente, que a Convenção e o Protocolo sejam encaminhados ao Congresso com menção do interesse do Poder Executivo em incorporá-los ao ordenamento brasileiro como equivalentes a emenda constitucional, conforme o art.5 $5^{\circ}, 3^{\circ}, \mathrm{CF}(\mathrm{PBR}-\mathrm{F})$.

\section{MANIFESTO AO CONGRESSO NACIONAL DO CONSELHO NACIONAL DOS DIREITOS DA PESSOA PORTADORA DE DEFICIÊNCIA, 10.08.2007}

[Executivo - Outras Manif]

O Conselho Nacional dos Direitos da Pessoa Portadora de Deficiência, órgão da Secretaria Especial dos Direitos Humanos, da Presidência da República, manifestou-se em 10.08.2007 para defender a ratificação, pelo Brasil, da Convenção e de seu Protocolo. ${ }^{163} \mathrm{O}$ Manifesto sugere, inclusive, que a tramitação siga o regime de urgência.

Segundo o Manifesto, a Convenção encontra-se em harmonia com a Constituição, no que se refere à dignidade da pessoa humana e a cidadania como fundamentos da República, além de apontar outros artigos constitucionais que se coadunam com as previsões da Convenção (DBR - F). Ressalta que o país é signatário de diversos acordos internacionais de proteção dos Direitos Humanos, seja no âmbito da ONU ou da OEA (DIN - F), o que não justificaria a exclusão da Convenção, instrumento relevante de proteção dos direitos das pessoas com deficiência (DH - deficientes). Sua ratificação estaria de acordo com a vontade da sociedade civil brasileira (PBR - F).

\section{REQUERIMENTO DE URGÊNCIA, CD, 09.05.2008}

Em 09.05.2008, foi aprovado requerimento para regime de urgência na apreciação da MSC 711/2007.

\footnotetext{
${ }^{163}$ A autora destaca a imprecisão jurídica do Manifesto, que, endereçado ao Congresso Nacional, intitula-se "Manifesto ao Congresso Nacional em defesa da ratificação pelo Brasil da Convenção Internacional da ONU sobre os Direitos das Pessoas com Deficiência e seu Protocolo Facultativo" (grifo nosso). O responsável pela ratificação de tratado é o Poder Executivo, na pessoa do Presidente da República. O certo seria falar em aprovação, ou internalização do tratado, e não em ratificação.
} 


\section{DISCUSSÃO EM PRIMEIRO TURNO NA CÂMARA DOS DEPUTADOS:}

14.05.2008

[CD PLEN]

Descreverei, neste item, a discussão travada no primeiro turno de discussão sobre o PDC, na Câmara dos Deputados. Houve significativa discórdia a respeito da quantidade de turnos que ocorreriam para que fosse finalizada a apreciação do tratado. Seria necessária votação de três quintos, no mínimo, para que a matéria fosse para o segundo turno, e, caso aprovada conforme exigido pelo art. $60, \S 2^{\circ}, \mathrm{CF}$, fosse equivalente a emenda constitucional. Entretanto, caso não fosse atingido esse mínimo constitucionalmente previsto, o tratado ainda seria enviado ao Senado; mas, neste caso, não equivaleria a emenda constitucional, mas a legislação infraconstitucional, como todos os tratados internalizados até então. Apesar da longa discussão, em plenário, a respeito da tramitação da matéria como emenda constitucional, destacarei, aqui, os argumentos relacionados com a matéria do tratado. Os argumentos dos parlamentares serão destacados, portanto, no que se referirem ao teor da Convenção e de seu Protocolo.

O Deputado Marcelo Itagiba parabeniza a inserção da Convenção na pauta, por ser ela tão relevante para todos os que desejam maior segurança para os direitos dos portadores de deficiências (DH - deficientes).

O Deputado João Almeida critica a tramitação “apressada” da Convenção. Isso porque tratar-se-ia de algo inédito na história do Legislativo brasileiro. A Convenção começou a tramitar com o rito próprio de Emenda Constitucional, não havendo parecer da Comissão de Relações Exteriores, como é de praxe para os tratados. Sugere que a matéria seja tratada com a devida cautela (PBR - F).

A essa indagação, segue a explicação do Presidente da Câmara, Arlindo Chinaglia, que reitera ser o art. 34.II o responsável pela constituição de Comissão Especial, e não o art. 34.I, que trata das propostas de emenda à Constituição - o que teria sido sugerido pelo Deputado João Almeida. Descreve as diversas Comissões envolvidas (dez) no processo para justificar a formação de Comissão Especial, criada em 23.11.2007. Não se teria criado Comissão Especial em um primeiro momento em virtude do requerimento de urgência, que, uma vez aprovado, fez a matéria ir diretamente ao plenário, justamente pela manifestação positiva dos Deputados em relação ao mérito e à relevância do tema. 
A partir dessa explanação, a discussão travada no âmbito da Câmara refere-se, basicamente, ao modo de internalização do tratado. Os Deputados discutem o modus operandi da questão, completamente inédita. O Deputado Paulo Pimenta interpreta a expressão "equivalente a emenda constitucional", que consta do art. $5^{\circ}, \S 3^{\circ}, \mathrm{CF}$, como prova de que o tratado não seria, de fato, uma emenda à Constituição, mas equivalente a uma, não sendo, portanto, necessário seguir exatamente o rito de tramitação das emendas constitucionais.

O Deputado Leonardo Picciani, por sua vez, é enfático ao dizer que PECs não podem tramitar em regime de urgência, e que precisam ser apreciadas pela CCJC, para receberem parecer de admissibilidade, devendo, depois, ser apreciadas por Comissão Especial, para que seja aberto prazo de 10 sessões para emendas. Afinal, se está em pauta matéria de equivalência constitucional, com mais razão o rito deveria ser aquele das PECs. É necessário zelar pela Constituição e, portanto, seu voto é pela aprovação do tratado como decreto legislativo, e não nos moldes das emendas constitucionais (DBR - C - contra a aprovação como EC, mas não é contra a aprovação do tratado).

Para o Deputado Marcelo Itagiba, trata-se de equivalência a emenda constitucional, que permitiria a defesa dos direitos daqueles que o necessitam no país, e, portanto, necessário para resguardar os direitos dos deficientes (DH - deficientes).

Manifesta-se o Deputado Antônio Carlos Magalhães Neto, que aponta a existência (i) de um problema de procedimento, pois, afinal, não se sabe como devem tramitar esses tratados; e (ii) de consequência jurídica, a respeito do que se deveria entender por algo "equivalente a emenda constitucional”, termo jurídico inédito inscrito na Carta Magna. Apresenta, ainda, uma nova questão: o fato de o Poder Executivo ter a prerrogativa de definir de que maneira deve tramitar a matéria. A Constituição, afinal, diz que, se aprovada com o quórum que define, a matéria será equivalente a emenda constitucional: seria, portanto, uma faculdade do Poder Legislativo, e não do Poder Executivo. Este, prossegue, não teria o direito de impor o procedimento de votação, o que fragilizaria o Congresso Nacional. Seria, portanto, "um absurdo o Executivo encaminhar essa mensagem com a obrigatoriedade ao Congresso nacional". ${ }^{164}$ Não se trata, destaca, de discussão a respeito do mérito do tratado, mas de seu procedimento. Quanto ao mérito, o Deputado é favorável à aprovação do tratado

${ }^{164}$ DCD 14.05 .2008 , p. 20.428, col. 2 
com o status de emenda constitucional, apenas não está de acordo com o modo como ocorreu sua tramitação. Destaca que o Brasil deveria ter maior atenção aos direitos dos portadores de deficiência, que não poderiam viver às margens da sociedade, devendo ser consistentemente incluídos, uma responsabilidade do Estado (PBR - F).

Segundo Arlindo Chinaglia, o Presidente está, tão somente, submetendo o tratado à apreciação do Congresso, que dará a última palavra em relação à sua internalização como emenda constitucional ou não. Seria necessário, de qualquer maneira, regulamentar esse procedimento, para que não houvesse dúvidas futuras quanto às tramitações dessa sorte (PBR - F). O fato de o Plenário poder aprovar a matéria por maioria qualificada ou não prova que não se trata de emenda constitucional, argumento que atribui ao Deputado José Eduardo Cardozo. ${ }^{165}$

O Deputado Maurício Rands dá atenção ao mérito do tratado, dizendo que, se os membros do Congresso Nacional desejam uma legislação que melhore os direitos das pessoas com deficiência, é necessário votar nesse sentido, inserindo a temática como emenda constitucional (PBR - F). O art. $5^{\circ}, \S 3^{\circ}, \mathrm{CF}$, viria para complementar o art. $5^{\circ}, \S 2^{\circ}$, que reza: "Os direitos e garantias expressos nesta Constituição não excluem outros decorrentes do regime e dos princípios por ela adotados, ou dos tratados internacionais em que a República Federativa do Brasil seja parte" (DBR - F). Ora, esse artigo deu margem ao entendimento, por parte de juízes e de doutrinadores, de que os tratados, uma vez internalizados, passavam a integrar o rol de direitos previstos pela Constituição. O parágrafo $3^{\circ}$ não pressupõe identidade, mas equivalência à Constituição, uma vez que os tratados não integrarão o texto constitucional propriamente dito. Tratar-se-ia, portanto, de norma de hierarquia constitucional no plano formal: tanto não se trata de emenda que não segue a mesma tramitação que as emendas constitucionais. O constituinte garantiu a necessidade de quórum qualificado para justificar o novo status dos tratados de Direitos Humanos. Caberia, portanto, ao Presidente enviar ao Congresso um tratado celebrado "pela boa política externa do Brasil" (PEB - F), ${ }^{166}$ sendo a Câmara soberana para recebe-lo com a equivalência de norma constitucional; e, para tanto, teria que seguir o quórum e o número definido de votações. Caberia, portanto, ao Congresso a decisão última; que, para o Deputado, deveria ser a de

\footnotetext{
${ }^{165}$ DCD 14.05.2008, p. 20.431, col. 1.

${ }^{166}$ DCD 14.05.2008, p. 20.430, col. 1.
} 
aprovar o tratado por $3 / 5$ dos membros da Câmara, por se tratar de política de fortalecimento aos portadores de deficiência (DH - deficientes).

O Deputado Zenaldo Coutinho destaca a insegurança jurídica que se percebe na discussão do projeto, mas assinala que ele será, apenas, equivalente à Constituição. Insta os outros Deputados a votarem favoravelmente.

O Deputado José Carlos Aleluia, por sua vez, diz que o problema que resultou nas discussões na Câmara foi criado pelo Ministro das Relações Exteriores, que sugeriu a aprovação pelo art. $5^{\circ}, \S 3^{\circ}$; e não pela Convenção em si. Propõe que os Deputados se abstenham, para que o projeto seja aprovado, mas sem quórum de emenda (PBR - C).

O Deputado Otávio Leite diz que o Brasil, como líder da América Latina (PEB - F), deveria dar o exemplo e incorporar a Convenção ao ordenamento nacional de maneira inovadora, mais forte e eficaz, ou seja, em patamar equivalente à Constituição. Com isso, asseguraria o pleno exercício dos direitos das pessoas deficientes (DH - deficientes), que constituem $15 \%$ da população brasileira (PBR - F). Isso se faz ainda mais premente no momento de comemoração dos 60 anos da DUDH (DIN - F).

Para o Deputado Jovair Arantes, a aprovação é do interesse de toda a sociedade brasileira (PBR - F).

O Deputado Rodrigo Rollemberg reitera a posição de José Eduardo Cardoso, apresentada por Arlindo Chinaglia, de que o tratado não fará parte da Constituição, porque uma PEC pode ser emendada, o que não é verdade para um tratado multilateral como o que se tem em pauta. Entende, ademais, que a aprovação do tratado é coerente com as aspirações da sociedade brasileira no que se refere à matéria (PBR - F).

O Deputado João Almeida pondera sobre a improbabilidade de qualquer parlamentar ser contrário ao mérito do tratado. Entretanto, chama atenção ao fato de estarem inserindo dispositivos na Constituição sem a devida atenção; posto que "equivalência", para ele, é sinônimo de igualdade. A matéria deveria, portanto, ser rejeitada no que se refere à equivalência constitucional (DBR - C).

O Deputado Tarcísio Zimmermann reitera a relevância da matéria para os Direitos Humanos das pessoas com deficiência (DH - deficientes). Seria importante votar a matéria com equivalência constitucional.

O Deputado Ibsen Pinheiro aponta a unanimidade em relação ao mérito, mas há divergência sobre o rito a ser seguido. Para ele, assim como para Antônio Carlos Magalhães 
Neto, não caberia ao Presidente definir a tramitação do ato; o Ministro das Relações Exteriores teria sido mais modesto, ao sugerir a tramitação. Haveria, sim, igualdade entre o tratado e a CF, caso internalizado como emenda constitucional. Tratar-se-iam, inclusive, de cláusulas pétreas; e, segundo o art. $60, \S 4^{\circ}, \mathrm{IV}, \mathrm{CF}$, “não serão objeto de deliberação a proposta de emenda tendente a abolir (...) IV. Os direitos e garantias individuais" (DBR C). O Deputado aponta para a aprovação recente de resolução da ONU sobre os povos indígenas, sendo que muitos dos países com populações indígenas, exceto o Brasil, foram contrários à mesma, por medo do surgimento de enclaves autônomos em seus territórios. Segundo ele, o que o tranquiliza em relação à resolução seria o fato de ela não ter força de lei internamente. ${ }^{167} \mathrm{O}$ Deputado pede a aprovação da Convenção como um tratado, mantendo a integridade da Constituição (PBR - C).

O Deputado José Genoíno ressalta que a declaração da ONU não é um tratado propriamente dito, e, portanto, completamente diferente da Convenção. Segundo o Deputado, o Presidente deveria respeitar o art. $5^{\circ}, \S 3^{\circ}, \mathrm{CF}$, e, portanto, encaminhar a Convenção dentro do trâmite previsto por esse artigo. A DHDU (DIN - F) foi responsável por incorporar os Direitos Humanos como algo universal, e assim têm procedido os integrantes do mundo civilizado, incorporando-os aos seus ordenamentos (DH - F). A Convenção que se pretende aprovar não é um tratado que concerne a parcela específica da população, como algumas Convenções da OIT (DIN - F), mas se refere aos mesmos direitos protegidos pela DUDH. Ser contrário ao procedimento adotado para sua internalização é o mesmo que ser contrário à Constituição.

No momento de votação, alguns Deputados se manifestam para encaminhar o voto de seus partidos. O Deputado Ivan Valente diz que a Convenção importa um salto de qualidade para a vida das pessoas com deficiência, colocando o Brasil em outro patamar no que se refere ao respeito aos Direitos Humanos, protegidos pelo Estado (PBR - F). O Deputado Paulo Pimenta afirma que a Convenção será um avanço nas questões sobre Direitos Humanos dos deficientes (DH - deficientes). O Deputado Jovair Arantes diz que a sociedade brasileira tem negado acesso ao gozo de diversos serviços por parte dos deficientes (PBR -

\footnotetext{
${ }^{167}$ O Deputado, em sua manifestação, apesar de não mencionar, expressamente, o instrumento ao qual se refere, provavelmente trata da Declaração das Nações Unidas sobre os Direitos dos Povos Indígenas, aprovada na 107 Sessão Plenária da AGNU, de 13.09.2007. Menciona-a como instrumento internacional vinculante - ou tratado. A autora destaca a imprecisão, uma vez que resoluções da ONU não podem ser transformadas em legislação interna, sem que haja previsão legal para isso no ordenamento jurídico nacional.
} 
F), e que a Convenção vai no sentido contrário a essa situação de fato. O Deputado Fernando Coruja diz que é necessário estabelecer procedimento adequado para a tramitação desse tipo de instrumento internacional, e que desejaria que o Pacto de São José da Costa Rica (DIN F) também seguisse esse iter. Segue-se a manifestação do Deputado Dr. Talmir, que apresenta dados a respeito da população brasileira deficiente, e acrescenta a necessidade de incluir essas pessoas à sociedade (PBR - F).

Após manifestações de Deputados que seguiram a discussão a respeito do regime de tramitação da Convenção, foi efetuada a votação: 418 votos favoráveis, nenhum contrário, com 11 Abstenções, num total de 429 votos. A matéria prossegue para segundo turno, para fins de confirmação da equivalência a Emenda Constitucional, com interstício de 5 sessões ordinárias entre os turnos.

Após a votação, o Presidente da Câmara, Deputado Arlindo Chinaglia, manifesta sua satisfação pela aprovação do tratado com quórum de emenda constitucional. Para ele, se o Presidente da República, na MSC, encaminhou o instrumento como efetivamente fez, o único embasamento legal possível para rejeitar o encaminhamento seria a votação em plenário. Assim foi feito, o que não feriu a autonomia da Câmara, porque foram os próprios Deputados que decidiram de que maneira o tratado seria internalizado. Menciona, ainda, parlamentares que aventaram a possibilidade de surgimento de outras propostas do tipo que poderiam ferir a soberania nacional. Segundo ele, essa possibilidade inexiste, em virtude da clareza do art. $5^{\circ}, \S 3^{\circ}$, que determina a possibilidade de status de emenda constitucional apenas aos tratados de Direitos Humanos. O Presidente diz que a matéria deve, sim, ser regulamentada pelo RICD, e, inclusive, pela Constituição, mediante emenda constitucional que esclareça o termo "equivalente".

PARECER DA COMISSÃO ESPECIAL (CD) SOBRE A MSC 711/2007, EDUARDO BARBOSA, 2008

[Câmara - Parecer 1] 
O parecer, de 2008, é de autoria do Deputado Eduardo Barbosa. Após relatório a respeito do tema, acrescenta necessidade de criação de Comissão Especial para tratar do tema, referente a emenda constitucional, nos termos do art. 34, II, RICD. ${ }^{168}$

Segundo o Deputado, a ONU vem, desde a DUDH, aperfeiçoando a construção do sistema internacional de Direitos Humanos, composto, hodiernamente, por uma série de tratados (DIN - F). ${ }^{169} \mathrm{Se}$, em um primeiro momento, os tratados referiam-se a direitos gerais e que deveriam ser respeitados para todos os seres humanos, passaram, na segunda metade do século XX, a direcionar-se para grupos mais vulneráveis, sendo as pessoas com deficiência os últimos favorecidos. A especial atenção aos grupos vulneráveis tem como objetivo estabelecer instrumentos jurídicos hábeis para tornar eficazes aqueles direitos universais de natureza individual e social ( $\mathrm{DH}$ - deficientes - F).

A Convenção é de extrema relevância para o Brasil, país no qual as pessoas com deficiência, apesar das normas que as protegem, não têm pleno amparo; seja em razão da inexistência de sanções aos seus transgressores, seja porque a multiplicidade de leis dificulta a correta aplicação por parte dos responsáveis (PBR - F). O Brasil tem uma população crescente de pessoas com algum tipo de deficiência, e esse grupo de cidadãos precisa ser acolhido.

Assim como a Convenção, o Protocolo Facultativo que a acompanha é de suma relevância. Mediante esse Protocolo, os países comprometem-se a reconhecer a competência do Comitê sobre os Direitos das Pessoas com Deficiência para receber e para analisar denúncias de violações da Convenção, submetidas por indivíduos ou por grupos sujeitos à sua jurisdição. Internalizando o Protocolo, o Estado submete-se voluntariamente ao crivo da ONU no que diz respeito ao cumprimento da Convenção, sempre que esgotados os recursos jurídicos internos. Essa prática tem sido adotada pelo Brasil ao ratificar convenções relacionadas aos Diretos Humanos (PEB - F).

\footnotetext{
${ }^{168}$ Art. 34. As Comissões Especiais serão constituídas para dar parecer sobre: (...)

II - proposições que versarem matéria de competência de mais de três Comissões que devam pronunciar-se quanto ao mérito, por iniciativa do Presidente da Câmara, ou a requerimento de Líder ou de Presidente de Comissão interessada. (...)

169 O Deputado menciona, além da DUDH, o Pacto Internacional sobre Direitos Econômicos, Sociais e Culturais; Pacto Internacional sobre Direitos Civis e Políticos; Convenção Internacional sobre a Eliminação de todas as formas de Discriminação Racial; Convenção sobre a eliminação de todas as formas de Discriminação contra a Mulher; Convenção sobre a Tortura e outros tratamentos ou penas cruéis, desumanos ou degradantes; Convenção sobre os Direitos da Criança e Convenção Internacional sobre a Proteção dos Direitos de todos os Trabalhadores Migrantes e Membros de suas Famílias.
} 
Para o Deputado, a "sugestão" do Executivo, contida na MSC 711/2007, de tramitação da Convenção nos moldes do art. $5^{\circ}, \S 3^{\circ}, \mathrm{CF}$, é excelente. Ressalta que a aprovação do tratado nesses termos não viola a soberania brasileira (PBR - F), e fortalece o papel do país na proteção internacional dos Direitos Humanos (PEB - F).

O parecer é pela aprovação da Convenção e de seu Protocolo Facultativo, nos termos do PDC.

\section{DISCUSSÃO EM SEGUNDO TURNO NA CÂMARA DOS DEPUTADOS: 29.05.2008 [CD PLEN]}

A votação, publicada no Diário da Câmara dos Deputados de 29.05.2008, teve 357 Deputados presentes, de um total de 513, com 4 abstenções e 353 votos favoráveis. A Discussão em segundo turno é menos intensa do que aquela travada no primeiro turno da votação. De qualquer maneira, alguns Deputados manifestaram-se.

O Deputado Rodrigo Rollemberg diz que a matéria é importante para o interesse nacional, por criar novas diretrizes para as instituições nacionais (PBR - F), que deverão respeitar os direitos das pessoas com deficiência.

A Deputada Rita Camata diz que se trata de matéria importante e emblemática. Deseja que a Convenção seja aprovada com quórum de emenda constitucional, “(...) assegurando aos milhões de deficientes físicos a possibilidade de serem incluídos como cidadãos que contribuem com a sociedade brasileira. (DH - )". ${ }^{170}$

\section{DECLARAÇÃO DE VOTO DOS DEPUTADOS GUSTAVO FRUET E BRUNO ARAÚJO, DCD 29.05.2008}

Após a aprovação do Projeto, é apresentada Declaração de voto dos Deputados Gustavo Fruet e Bruno Araújo. Esse voto em separado conjunto dos Deputados não discute o mérito do tratado, mas sua inserção no ordenamento jurídico brasileiro. Não serão, portanto, contados os seus argumentos para os fins da tese, e a discussão será igualmente apresentada no capítulo que trata da relação entre os Poderes.

\footnotetext{
${ }^{170}$ DCD 29.05.2008, p. 23.838, col. 2.
} 
Apesar de favoráveis, no mérito, à aprovação da Convenção, os Deputados fazem a Declaração de Voto para discutir a aprovação, pioneira, de tratado conforme o dispositivo recentemente inserido na Constituição Federal. Antes da promulgação da EC 45/2004, que acrescentou o $\S 3^{\circ}$ ao art. $5^{\circ}$, os tratados internacionais, mesmo aqueles que tratavam de Direitos Humanos, eram equiparados a leis ordinárias. Esse entendimento era defendido não apenas pela doutrina, mas pelos Ministros do STF.

Não teria ocorrido, no caso concreto, análise preliminar, por parte da CCJC, a respeito da possibilidade de conferir equivalência constitucional ao tratado. Tampouco foi verificada eventual afronta a cláusula pétrea: seria necessário verificar se a Convenção é mais ou menos protetiva do que a Constituição. Por inexistir cláusula regimental específica a respeito do tema, o tratado deveria ter sido submetido, preliminarmente, à CCJC. Ademais, como ressaltado durante a discussão em $1^{\circ}$ turno, a matéria tramitou sob regime de urgência, previsto no art. 155, RICD, que não é aplicável às PECs. Em teoria, portanto, esse instrumento internacional não deveria ter se submetido a essa tramitação.

Em relação à possibilidade de propor emendas, sabe-se que é possível emendar as PECs, o que não é verdadeiro para tratados, particularmente aqueles que não admitem reservas. De qualquer maneira, deveria ter sido aberto prazo para que se propusessem emendas ao projeto, mesmo que, em momento posterior, os Deputados chegassem à conclusão a respeito da incompatibilidade das emendas com a natureza do instrumento sob análise.

Os Deputados indagam, ademais, a respeito da iniciativa para apresentar ao Congresso o tratado de Direitos Humanos. Não há norma regimental que trate do assunto, mas, qualquer que seja a solução encontrada, não se pode negligenciar o art. $60, \mathrm{CF}$, que trata das emendas constitucionais. Questionam também a introdução de novos artigos no texto da Constituição, dispositivos que, por integrarem instrumento multilateral internacional, são, geralmente, vagos e de interpretação complexa.

Em relação ao quórum de aprovação, indagam o que ocorreria com o tratado caso não atingida a marca de $3 / 5$ (três quintos), em dois turnos, nas duas Casas. Haveria rejeição dos tratados ou eles, simplesmente, não seriam aprovados como emendas constitucionais?

Os Deputados finalizam sua Declaração de Voto indagando a respeito do tratamento a ser dado ao instrumento que, aprovado conforme o art. $5^{\circ}, \S 3^{\circ}, \mathrm{CF}$, ainda não tenha sido ratificado pelo Presidente da República, ou não tenha entrado em vigor internacionalmente. 
Chegaríamos à situação, sui generis e inédita, de um tratado não existir no plano externo, mas ter valor constitucional no ordenamento jurídico interno.

\section{PARECER DA COMISSÃO DE RELAÇÕES EXTERIORES E DE DEFESA} NACIONAL (n. 587 - SF), EDUARDO AZEREDO, 2008

[Senado - Parecer 1]

O parecer, de 25.06.2008, é de autoria do Senador Eduardo Azeredo, que descreve minuciosamente o tratado e as definições nele contidas. Segundo o Senador, o fato de a Convenção reconhecer que os indivíduos com deficiência integram segmento marginalizado das sociedades nas quais se encontram, justifica a sua aprovação, por assegurar base jurídica para os direitos civis, políticos, econômicos, sociais e culturais dessa população (DH deficientes). O Senador apresenta dados do Brasil, segundo os quais 14,5\% da população, ou cerca de 25 milhões de pessoas, têm algum tipo de deficiência (PBR - F). Apesar de a legislação nacional ser avançada, menciona o Benefício de Prestação continuada e a Lei de Acessibilidade (DBR - F); o tratamento internacional da matéria amplia o espectro de direitos, e parece ser o meio adequado para tutelar esses direitos. A proteção das pessoas com deficiência é paradigma de política pública brasileira, e, por isso, não podemos deixar de incorporar a Convenção (PBR - F).

O tratado é instrumento conveniente e oportuno aos interesses nacionais (PBR - F), portador de status constitucional, por se referir a Direitos Humanos. Portanto, por força do art. $5^{\circ}, \S 3^{\circ}, \mathrm{CF}$, a Convenção, após tramitação em conformidade com esse artigo, será equivalente a emenda constitucional; caso contrário, a lei ordinária. Em face da aprovação em dois turnos por parte da Câmara, caberia ao Senado fazer o mesmo (PBR - F).

\section{DISCUSSÃO EM PRIMEIRO TURNO NO SENADO FEDERAL: DSF 03.07.2008 [SF PLEN]}

No Senado Federal, não há discussão intensa no primeiro turno, como ocorreu na Câmara dos Deputados. Alguns parlamentares, entretanto, ao encaminhar a votação, manifestam seu apoio ao projeto. O Senador José Agripino diz que a matéria, além de relevante, é de interesse nacional (PBR - F). Segundo o Senador Arthur Virgílio, o Brasil, apesar de possuir legislação avançada a respeito da temática da Convenção, faz um esforço importante ao tentar diminuir as desigualdades que persistem no território no que se refere 
aos deficientes (PBR - F). O Senador Inácio Arruda ressalta a importância do tratado para a melhora da situação dos deficientes no Brasil (PBR - F). O Senador Romeu Tuma, por sua vez, diz que a Convenção deveria refletir não apenas no Brasil, mas nos outros países do Mercosul e da OEA (PEB - F).

A Senadora Ideli Salvatti ressalta o fato de o tratado estar sendo internalizado como emenda à Constituição, e que essa modalidade de incorporação seria relevante para as relações internacionais do Brasil, (PEB - F) e para garantir os direitos das pessoas com deficiência (DH - deficientes).

O Senador Flávio Arns destaca a importância da atuação do Senado ao aprovar a Convenção (PBR - F). Nesse sentido, também o Senador Paulo Paim ressalta a aprovação, pela Casa, do Estatuto da Pessoa com Deficiência, legislação em harmonia com a Convenção (DBR - F).

O Senador Marco Maciel ressalta que é necessário prestar atenção ao tema dos deficientes, para construir no Brasil uma nação justa (PBR - F). O Senador José Agripino aponta que a internalização do tratado possibilita o maior amparo legal ao deficiente em todo o Brasil, por norma que será constitucionalmente assegurada (PBR - F).

A votação contou com 60 (sessenta) votos, com 59 votos positivos e uma abstenção. Logo após a divulgação desse dado, o Senador João Ribeiro solicita, da Tribuna, a retificação de seu voto para "sim".

\section{REQUERIMENTO n. 854 (SF) - DISPENSA DE INTERSTÍCIO}

O requerimento n. 854, SF, de 02.07.2008, requer a dispensa de interstício entre o primeiro e o segundo turno do PDS 90/2008 (PDC 563/2008). Foi aprovado.

\section{DISCUSSÃO EM SEGUNDO TURNO NO SENADO FEDERAL: DSF 03.07.2008} [SF PLEN]

O segundo turno da votação no Senado Federal foi publicado no mesmo DSF que publicou a votação em primeiro turno. A Senadora Patrícia Saboya destaca que a Convenção é uma conquista para a sociedade brasileira, que ainda discrimina os portadores de deficiência (PBR - F). Foram contabilizados 56 votos favoráveis à Convenção, sem abstenções ou votos contrários. 


\section{ANÁliSE: CONVENÇÃo INTERNACIONAL PARA A PROTEÇÃo DE TODAS AS PESSOAS CONTRA O DESAPARECIMENTO FORÇADO}

A Convenção Internacional para a proteção de todas as pessoas contra o desaparecimento forçado foi celebrada em 20.12.2006, e entrou em vigor internacional em 23.12.2010, conforme o seu art. 39(1). Essa Convenção foi assinada pelo plenipotenciário brasileiro em 06.02.2007, ratificada em 29.11.2010, entrando em vigor para o Brasil em 28.12.2010. Foi enviada ao Congresso Nacional pela Mensagem Presidencial 400, de 2009. Seu processo de aprovação tramitou na Câmara dos Deputados como Projeto de Decreto Legislativo 2.230, e 2009, e no Senado Federal como Projeto de Decreto Legislativo 206, de 2010. Foi aprovada pelo Decreto Legislativo 661, de 01.09.2010, e promulgada pelo Decreto Presidencial 8.767, de 11.05.2016.

A Convenção foi o primeiro instrumento universal vinculante que definiu o desaparecimento forçado como violação dos Direitos Humanos, proibindo-o. O desaparecimento forçado é definido como a prisão, a detenção, a abdução ou qualquer outra forma de privação de liberdade efetivada por agentes estatais ou por pessoas que atuem com autorização, apoio ou aquiescência do Estado; situação agravada pela recusa estatal em admitir essa privação de liberdade - escondendo o paradeiro da pessoa desaparecida.

Com o objetivo de proibir o desaparecimento forçado, a Convenção tem quatro aspectos principais: combater a impunidade, prevenção, direitos das vítimas e observância do tratado. A Convenção estabelece aos signatários uma obrigação de investigar casos de desaparecimento forçado, e de julgar os responsáveis. Para reduzir a probabilidade de novas ocorrências de desaparecimentos forçados, apresenta medidas preventivas, como o direito de as pessoas detidas serem mantidas em locais oficiais e registradas, tendo o direito de se comunicar com suas famílias e com assistência legal. Estabelece também um comitê internacional de especialistas independentes, que deverão monitorar a implementação do tratado. $^{171}$

\footnotetext{
${ }^{171}$ Informações obtidas em: https://www.icrc.org/applic/ihl/ihl.nsf/Treaty.xsp?documentId =8FA7B12BDE34 D1DFC1257E2700449699\&action=openDocument. Acesso: 25.03.2016.
} 
O Brasil, até o momento de depósito dessa tese, não efetuou as declarações reconhecendo a competência do Comitê contra Desaparecimentos forçados (art. 31 e 32 da Convenção). ${ }^{172}$

\section{STATUS NA ONU}

https://treaties.un.org/pages/ViewDetails.aspx?src=TREATY\&mtdsg_no=IV$16 \&$ chapter $=4 \&$ lang $=$ en

\section{MENSAGEM PRESIDENCIAL}

A Mensagem 400, de 01.11.2007, elaborada pelo Ministro interino das Relações Exteriores, senhor Samuel Pinheiro Guimarães Neto, foi enviada ao Congresso pelo Presidente da república, senhor Luís Inácio Lula da Silva, em 04.07.2009. A Mensagem ressalta, em primeiro lugar, a relevância da Convenção no contexto da proteção dos Direitos Humanos no âmbito internacional, em virtude dos mais de vinte e cinco anos de esforços das famílias de desaparecidos, bem como de ONGs e por agências da ONU, além de outros atores (DH - desap).

A Convenção tratar-se-ia de esforço para reforçar os direitos garantidos pela legislação pátria (DBR - F) e por outros tratados dos quais o Brasil é parte, entre os quais o Pacto Internacional sobre Direitos Civis e Políticos (DIN - F). O reconhecimento da competência do Comitê contra Desaparecimentos forçados, que deverá ser estabelecido pela Convenção, com o objetivo de examinar petições de indivíduos que demandem a localização de pessoa desaparecida, representa um acréscimo importante à política nacional para os Direitos Humanos (PBR - F). O Brasil, ademais, reconhece a competência para a análise de casos individuais de violação desses direitos a importantes órgãos internacionais, nos contextos mundial e regional. A Comissão e a Corte Interamericana de Direitos Humanos, o Comitê para a Eliminação da Discriminação Racial, o Comitê para a Eliminação da Discriminação

\footnotetext{
${ }^{172}$ Segundo o endereço eletrônico da ONU, fizeram essa declaração os seguintes países: Albânia, Alemanha, Argentina, Áustria, Bélgica, Bósnia Herzegovina, Chile, Equador, Eslováquia, Espanha, França, Holanda, Japão, Lituânia, Mali, Montenegro, Portugal, Sérvia, Ucrânia, Uruguai. Informações obtidas em: https://treaties.un.org/pages/ViewDetails.aspx?src=TREATY\&mtdsg_no=IV-16\&chapter=4\&lang=en. Acesso: 26.03.2016.
} 
contra as Mulheres e o Comitê contra a Tortura podem ser citados como exemplos (DIN F). O Brasil também é signatário, no âmbito regional, da Convenção Interamericana sobre o Desaparecimento Forçado de Pessoas, o que reforça a sua intenção em proteger esses direitos no âmbito internacional (DIN- F).

O Ministro solicita a aprovação do instrumento internacional pelo Congresso.

\section{PARECER DA COMISSÃO DE DIREITOS HUMANOS E MINORIAS (CD), PEDRO WILSON, 2009}

[Câmara - Parecer 1]

O parecer, de 14.12.2009, foi elaborado pelo Deputado Pedro Wilson. Nele, o Deputado, após explanação a respeito do tratado, aponta que sua finalidade, de prevenir e de combater a impunidade em casos de crime de desaparecimento forçado, deve ser louvada em termos de proteção aos Direitos Humanos (DH - desap). A Convenção seria um reforço a direitos garantidos não apenas pela legislação brasileira (DBR - F), mas por tratados internacionais dos quais o Brasil é signatário, como a Convenção Interamericana sobre o Desaparecimento de Pessoas e o PIDCP (DIN - F).

A Convenção representa demanda histórica do movimento brasileiro em prol dos Direitos Humanos, demanda apoiada pela Comissão de Direitos Humanos e Minorias desde a sua instalação, em 1995 (PBR - F). Outro exemplo disso no âmbito governamental foi a instauração da Comissão Memória e Verdade (PBR - F).

O parecer é pela aprovação do projeto, e foi aprovado por unanimidade.

\section{PARECER DA COMSSÃO DE CONSTITUIÇÃO E JUSTIÇA E DE CIDADANIA (CD), LUIZ COUTO, 2009}

[Câmara - Parecer 2]

O parecer, de 21.12.2009, é de autoria do Deputado Luiz Couto. Segundo o relator, a Convenção é compatível com a Constituição, sendo o projeto legislativo o instrumento adequado para disciplinar a matéria, conforme o art. 109, I, RICD (DBR - F). A técnica legislativa e a redação também estão em conformidade com a Lei Complementar 95/1998, alterada pela Lei Complementar 107/2001 (DBR - F). 
Quanto ao mérito, o tratado será um reforço aos direitos e às garantias asseguradas pelas leis nacionais (DBR - F), e por outros instrumentos internacionais dos quais o Brasil é signatário (DIN - F). O parecer é, portanto, pela aprovação do projeto.

O parecer foi aprovado por unanimidade.

\section{PARECER DA COMISSÃO DE RELAÇÕES EXTERIORES E DE DEFESA NACIONAL (CD), ÍRIS DE ARAÚJO, 2009}

[Câmara - Parecer 3]

O parecer, de 20.11.2009, é de autoria da Deputada Íris de Araújo. Após relatório detalhado a respeito da Convenção, a Deputada aponta que se trata de instrumento que complementa os direitos garantidos pela legislação nacional (DBR - F) e por outros tratados celebrados pelo Brasil, como a Convenção Interamericana sobre o Desaparecimento Forçado de Pessoas e o PIDCP (DIN - F). O tratado é resultado da necessidade de a comunidade internacional adotar medidas de cooperação para prevenir o desaparecimento forçado de pessoas praticado por agentes estatais (DH - desap).

A Deputada ressalta ser favorável à adesão do Brasil à Convenção, e que, nesse momento, o país reconheça, mediante a apresentação das declarações previstas nos artigos 31 e 32 da Convenção (PBR - F). Esses artigos referem-se à competência do Comitê contra Desaparecimentos Forçados para receber comunicações apresentadas por indivíduos, ou em nome de indivíduos, submetidos à sua jurisdição, que alegam a condição de vítimas de violações da Convenção por parte de um signatário; além de reconhecer a competência do Comitê para receber e analisar comunicações nas quais um Estado alega que um de seus pares descumpre as obrigações decorrentes do tratado.

O parecer é, portanto, pela aprovação do projeto, e foi aprovado por unanimidade.

\section{PARECER DA COMISSÃO DE RELAÇÕES EXTERIORES E DEFESA NACIONAL (n. 1322 - SF), PAULO PAIM, 2010}

[Senado - Parecer 1]

O parecer, de 31.08.2010, é de autoria do Senador Paulo Paim. Após descrição da Convenção, o relator aponta para o fato de que seu texto teve como "ponto intermediário" a Declaração para a Proteção de todas as pessoas contra o desaparecimento forçado ou Involuntário, de 1992 (DIN - F). No âmbito regional, aponta para a conclusão da Convenção 
Interamericana sobre Desaparecimentos Forçados de Pessoas (DIN - F). A Convenção seria uma evolução significativa se comparada à Declaração, uma vez que trata de norma cogente, que define o desaparecimento, dispõe sobre sua prevenção e repressão, bem como sobre as reparações às vítimas.

A Convenção consagra a proibição ao desaparecimento forçado e define essa conduta. Esse esforço, segundo o relator, tem inspiração na Declaração de 1992 e também no Estatuto de Roma do TPI, ratificado pelo Brasil (DIN - F).

O relator aponta que a Convenção em pauta está de acordo com o ordenamento jurídico pátrio (DBR - F), e com "as ações governamentais em execução atualmente" (PBR - F). Além disso, a Convenção é considerada:

\footnotetext{
"um instrumento jurídico moderno, que combate um dos crimes mais cruéis gerados pelas sociedades contemporâneas e que tanta chaga provocou nos países latino-americanos, inclusive no nosso. (DH - desap - F) A ratificação dessa Convenção, pelo Brasil, significará sinal político importante de que não se repetirá erros do passado" (PBR - F).
}

O parecer é pela aprovação do projeto. Foi aprovado por unanimidade. 


\section{ANÁLISE: CONVENÇÃO AMERICANA SOBRE DIREITOS HUMANOS - PACTO DE SÃO JOSÉ DA COSTA RICA}

A Convenção Americana sobre Direitos Humanos ("Pacto de São José da Costa Rica”), de 22.11.1969, entrou em vigor internacional em 18.07.1978, logo após o depósito do $11^{\circ}$ instrumento de ratificação (art. 74). O governo brasileiro depositou a carta de adesão à Convenção em 25.09.1992, e ratificada em 09.07.1992, e promulgada pelo Decreto Presidencial 678 de 06.11.1992, com declaração interpretativa relativa aos artigos 43 e 48.d. Foi enviada ao Congresso Nacional pela Mensagem Presidencial 621, de 1985. Seu processo de aprovação tramitou na Câmara dos Deputados como Projeto de Decreto Legislativo 132, de 1986, e no Senado Federal como Projeto de Decreto Legislativo 10, de 1989. O Tratado entrou em vigor para o Brasil em 25.09.1992.

A Convenção busca consolidar um regime de liberdade pessoal e de justiça social na região, baseado no respeito aos Direitos Humanos, independentemente de Estado. ${ }^{173}$ A entrada em vigor da Convenção estabeleceu uma Corte Interamericana de Direitos Humanos e modificou a configuração das estruturas regionais. A Convenção estabelece, em sua primeira parte, as obrigações dos signatários, além de enunciar os Direitos Humanos por ela salvaguardados. Na segunda parte, estabelece meios de proteção desses direitos, por seus órgãos. ${ }^{174}$

Após a tramitação da MSC da Câmara, transformada no PDC 132/1986 em 21.05.1986, o PDC foi enviado ao Senado Federal em 21.08.1989. O PDS 10/1989 tramitou no Senado e foi reenviado, com emendas, para a Câmara em 06.11.1989, onde sua tramitação prosseguiu. Em 07.05.1992, foi efetuada votação, em turno único, na qual foram aprovadas as emendas do Senado Federal. Em 19.05.1992, a matéria foi remetida ao Senado para publicação do Decreto Legislativo 27, de 26.05.1992.

O Decreto Legislativo 27/1992 foi aprovado sem qualquer reserva ou declaração interpretativa, apenas expressando a advertência, que se tornou constante nesse tipo de instrumento normativo, de que "são sujeitos à aprovação do Congresso Nacional quaisquer

\footnotetext{
173 Informações obtidas em: http://www.stf.jus.br/portal/cms/verNoticiaDetalhe.asp?idConteudo=116380. Acesso: 26.03.2016.

174 Informações obtidas em: http://www.cidh.org/basicos/english/Basic1.\%20Intro.htm\# ftn5. Acesso: 26.03.2015.
} 
atos que possam resultar em revisão da presente Convenção, bem como aqueles que se destinem a estabelecer-lhe ajustes complementares". Apesar disso, consta, no Decreto Presidencial 678/1992, que promulga a Convenção, a seguinte declaração interpretativa:

\footnotetext{
"Ao depositar a carta de adesão a esse ato internacional, em 25 de setembro de 1992, o Governo brasileiro fez a seguinte declaração interpretativa: "O Governo do Brasil entende que os arts. 43 e 48, alínea d, não incluem o direito automático de visitas e inspeções in loco da Comissão Interamericana de Direitos Humanos, as quais dependerão da anuência expressa do Estado".
}

\section{STATUS NA ORGANIZAÇÃO DOS ESTADOS AMERICANOS}

\section{http://www.oas.org/dil/treaties B- \\ 32 American_Convention_on_Human_Rights_sign.htm}

Brazil: (Interpretative declaration made at the time of adhesion)

The Government of Brazil understands that Articles 43 and 48, (D) do not include the automatic right of on site visits and inspections by the Inter-American Commission of Human Rights, which will depend on the express consent of the State.

Reconocimiento de Competencia: "The Government of the Federative Republic of Brazil declares its recognition as binding, for an indefinite period of time, ipso jure, of the jurisdiction of the Inter-American Court of Human Rights on all matters relating to the interpretation or application of the American Convention on Human Rights, according to Article 62 of that Convention, on the condition of reciprocity, and for matters arising after the time of this declaration." (10.12.1998)

\section{PARECER DO CONSULTOR JURÍDICO DO ITAMARATY, ANTONIO AUGUSTO CANÇADO TRINDADE, 1985}

O parecer, de 16.08.1985, é de autoria do jurista Antonio Augusto Cançado Trindade, e, segundo o próprio consultor, será válido tanto para o Pacto de São José como para os Pactos de 1966. Como, entretanto, o foco principal do parecer é o primeiro tratado, será aqui apresentado. Serão destacados, apenas, os argumentos a respeito da adesão do Brasil ao Pacto e aos tratados, uma vez que o parecer, além desses argumentos, apresenta extensa explicação doutrinária, que não é o foco desta pesquisa.

Cançado Trindade aponta que, para um exame da matéria, é necessário desenvolver duas linhas de raciocínio. Seria preciso examinar os argumentos centrais, correspondentes à fundamentação jurídica de um posicionamento a respeito do tema, abordando os seguintes assuntos: 
“(...) a questão da soberania, a interpretação dos tratados humanitários e as relações entre as jurisdições internacional e nacional em seus múltiplos aspectos, quais sejam, os recursos de direito interno no direito internacional; as derrogações ou cláusulas de exceção; as relações entre dispositivos convencionais e de direito interno; o sistema de reservas; as salvaguardas dos Estados nos mecanismos de proteção; o conteúdo e efeitos jurídicos dos instrumentos de proteção; e a questão dos meios de solução de controvérsias." 175

Após descrever e analisar minuciosamente os tópicos acima apresentados, o consultor inicia sua reflexão a respeito da necessidade de o Brasil ser signatário do Pacto. Em primeiro lugar, assevera, é possível que órgão internacional zele pelo respeito e pela observância dos Direitos Humanos, independentemente de ratificação por parte dos Estados de tratado como a Convenção Americana de Direitos Humanos; porém, o apoio a instrumento de caráter de mera recomendação, como é o caso da Declaração Americana e da DUDH, é insuficiente. A ratificação de instrumentos juridicamente vinculantes, como a Convenção ou os Pactos de 1966, é condição sine qua non para a proteção dos Direitos Humanos nos âmbitos internacional e interno (PEB - F). Ademais, os Estados não se encontram isolados uns dos outros, e a conquista da democracia no Brasil, se verdadeira, deve ser projetada na relação com seus pares (PEB - F). A conquista da proteção interna dos Direitos Humanos é motivo extremamente relevante para afirmar esse compromisso no âmbito internacional (PEB - F). A proteção aos Direitos Humanos tem como testemunho eloquente a assinatura, em âmbito regional, da Convenção.

Para Cançado Trindade, o alcance da Convenção deve ser medido pelos possíveis efeitos jurídicos que terá no direito interno dos Estados signatários, o que pode ser, inclusive, percebido por seu art. 2, que reza:

Art. 2: se o exercício dos direitos e liberdades mencionados no artigo $1^{\circ}$ ainda não estiver garantido por disposições legislativas ou de outra natureza, os Estadospartes comprometem-se a adotar, de acordo com as suas normas constitucionais e com as disposições desta convenção, as medidas legislativas ou de outra natureza que forem necessárias para tornar efetivos tais direitos e liberdades. (grifo nosso).

O objetivo desse artigo seria fazer uma recomendação aos Estados que incorporassem à legislação interna as disposições programáticas da Convenção.

${ }^{175}$ Pareceres dos Consultores Jurídicos do Itamaraty, vol. VIII, p. 59. 
Ao tratar do mecanismo de solução de controvérsias, diz que foi alegado que, como o país não havia firmado a cláusula facultativa de jurisdição obrigatória da CIJ nos anos que se seguiram ao seu Estatuto, a adesão - posterior - a cláusula semelhante, relativa à Corte Interamericana de Direitos Humanos, não se justificaria. Para o consultor, mesmo desconsiderando a contribuição brasileira aos meios diplomáticos de solução pacífica de controvérsias internacionais, é necessário ressaltar que, após a elaboração do Estatuto da antiga Corte de Haia, a cultura jurídica nacional foi internacionalmente respeitada, em virtude do desempenho do representante brasileiro, Raul Fernandes, na consagração da cláusula facultativa de jurisdição obrigatória referente à Corte Permanente de Justiça Internacional. Esse paralelo entre as Cortes, para tentar justificar a não-adesão do Brasil à Convenção Americana de Direitos Humanos, não seria cabível, constituindo "lamentável distorção da posição do Brasil na matéria", dando o ensejo a "(...) procurar corrigir as impropriedades e desvios que nortearam a atitude do Governo brasileiro sobre proteção internacional dos direitos humanos nos últimos anos" (PEB - F). ${ }^{176}$

O artigo 7, CF de 1967, que trata da solução pacífica dos conflitos internacionais, ${ }^{177}$ não é pertinente à proteção internacional dos Direitos Humanos; e tampouco deve ser aplicado, nesse contexto, o artigo referente à indelegabilidade de atribuições, que trata das relações entre os três Poderes da União (art. $6^{\circ}$, parágrafo único (DBR - F). Pensar o contrário significaria implicar que, diante de órgão internacional, petição de um indivíduo contra seu Estado equivaleria a uma pendência externa, o que seria um absurdo. Para o consultor, não existem empecilhos constitucionais para a adesão do Brasil à Convenção (DBR - F).

A melhor e a verdadeira tradição diplomática brasileira possuem manifestações nos âmbitos doutrinário e prático. A delegação brasileira foi a responsável pela proposta da criação de uma Corte Interamericana de Direitos Humanos (PEB - F). A exposição de motivos brasileira é, inclusive, apresentada integralmente no parecer.

Além de mencionar diversas outras ocasiões de protagonismo da diplomacia nacional, o parecer menciona Exposição de Motivos de 07.08.1969, endereçada à Presidência da República, sobre a convocação da Conferência Especializada Interamericana sobre Direitos

\footnotetext{
176 Pareceres dos Consultores Jurídicos do Itamaraty, vol. VIII, p. 89.

177 Art. $7^{\circ}$ - Os conflitos internacionais deverão ser resolvidos por negociações diretas, arbitragem e outros meios pacíficos, com a cooperação dos organismos internacionais de que o Brasil participe.

Parágrafo único - É vedada a guerra de conquista.
} 
Humanos, que ocorreria em São José da Costa Rica. Essa Exposição, elaborada pelo senhor Ministro das Relações Exteriores, José de Magalhães Pinto, enumerou uma série de considerações que justificariam a participação ativa do Brasil na elaboração da Convenção; o que, além de favorecer a imagem do país no exterior, seria contribuição valiosa para a introdução de possíveis emendas e salvaguardas que tornassem o texto mais palatável para os países (PEB - F). Cançado Trindade aponta, porém, que houve discussão a respeito da participação do Brasil na Conferência naquele momento, inclusive por despacho do então Presidente da República, Costa e Silva, que favorecia tratar de temas relativos aos Direitos Humanos no âmbito da ONU. Mesmo tendo prevalecido a decisão de participar da Conferência de São José de 1969, a delegação, por ordens, restringiu-se a uma atuação técnica. De qualquer modo, foi intensa a atuação da delegação brasileira na elaboração da Convenção (PEB - F).

Segundo o consultor, durante as décadas de 1970 e 80, o governo ateve-se aos argumentos que, apesar de coerentes com o autoritarismo pelo qual o país passou, não possuem fundamentação jurídica (PBR - F).

Não existiriam, assim, motivos jurídicos para a não adesão a tratados para a proteção internacional dos Direitos Humanos, como a Convenção e os Pactos de 1966. O Brasil participou ativamente dos trabalhos preparatórios desses tratados, e a adesão a eles estaria em conformidade com:

(i) A evolução do Direito Internacional Público, sempre considerado pelo MRE ao formular e executar a PEB; (PEB - F)

(ii) A doutrina e a tradição jurídico-diplomática nacional (PEB - F);

(iii) A evolução do cenário político interno, ainda mais considerando a nova Assembleia Nacional Constituinte (PBR - F).

A tradição do Brasil milita em favor da proteção internacional dos Direitos Humanos, tendo o país participado ativamente da elaboração dos atuais instrumentos de proteção internacional dos Direitos Humanos; e estaria em conformidade com a melhor tradição do país e com o Direito Internacional (PEB - F). Essa condição alterou-se, apenas, durante a década de 1970, momento no qual a posição brasileira adequou-se ao autoritarismo no país. 
O país é signatário e ratificou diversos tratados relevantes relacionados à temática da proteção dos Direitos Humanos, enumerados por Cançado Trindade (DIN - F). ${ }^{178} \mathrm{O}$ jurista aponta, ainda, que algumas das ressalvas feitas ao Pacto, formuladas em 1970 (particularmente quanto aos artigos 13.4 e 23 da Convenção) foram superadas pela revogação do AI-5 (DBR - F).

Cançado Trindade sugere que, em caso de persistência da preocupação a respeito da adequada execução de determinados dispositivos da Convenção, o Brasil poderia fazer declarações interpretativas (PEB - F). Seria possível, inclusive, proceder por etapas, primeiro aderindo à Convenção para, depois, efetuar a declaração de reconhecimento da jurisdição da Corte nos casos relativos à interpretação ou à aplicação do tratado.

Em relação aos Pactos de 1966, menciona dois pareceres, um de junho de 1970, de autoria da Consultoria Jurídica do Ministério da Justiça, e outro de março de 1971, do Ministério do Trabalho e Previdência Social. O primeiro teria apontado para a "inexistência de inconvenientes" à assinatura dos Pactos, apresentando ressalvas a alguns artigos e opinando pela não assinatura do Protocolo Facultativo ao PIDCP, além da não-declaração de reconhecimento do Comitê de Direitos Humanos para receber e examinar petições interestatais. ${ }^{179} \mathrm{O}$ segundo foi contrário à assinatura do PIDESC, pois o artigo referente às liberdades sindicais não estaria afinado com a Constituição brasileira e com o ordenamento pátrio. Para o consultor, não existiriam motivos reais para a assinatura, mesmo que se entendesse a necessidade de reserva a determinado artigo, se fosse o caso.

O Brasil é um dos países que não assinou os Pactos de 1966. Em relação ao PIDCP, seria possível proceder por etapas: primeiramente, efetivar-se-ia a adesão ao Pacto para, em momento posterior, efetuar a declaração de reconhecimento da competência do Comitê de

\footnotetext{
${ }^{178}$ São mencionados os seguintes tratados: Convenção sobre a Prevenção e Repressão do Crime de Genocídio, de 1948; Convenção relativa ao Status dos Refugiados, de 1951; Convenção Internacional das Nações Unidas sobre Eliminação de Todas as Formas de Discriminação Racial, de 1966; Convenção para a Supressão do Tráfico de Mulheres Maiores (de 1933) e de Mulheres e Crianças (de 1921), emendadas por Protocolos de 1947; Convenção para a Repressão do Tráfico de Pessoas e do Lenocínio, de 1950; Convenção Interamericana sobre a Concessão dos Direitos Civis à Mulher, de 1948; Convenção Interamericana sobre a Concessão dos Direitos Políticos à Mulher, de 1948; Convenção (emendada) sobre Abolição da Escravatura, de 1953; Acordo relativo à Concessão de Título de Viagem para Refugiados que Estejam sob Jurisdição do Comitê Intergovernamental de Refugiados, de 1946; conforme dados da Coordenadoria de Atos Internacionais do MRE.

${ }^{179}$ Pareceres dos Consultores Jurídicos do Itamaraty, vol. VIII, p. 100.
} 
Direitos Humanos para examinar petições ou comunicações interestatais e aderir ao seu protocolo, que reconhece e regulamenta as petições individuais.

Seria imprescindível reorientar a posição brasileira, para que estivesse em conformidade com a “(...) real tradição jurídico-diplomática” (PEB - F). ${ }^{180}$ Seria, ademais, fator fundamental para a projeção do Brasil como país que respeita e que garante os Direitos Humanos no âmbito internacional (PEB - F), além de constituir compromisso no âmbito interno, para todas as gerações de brasileiros, de proteção efetiva contra violações dos direitos fundamentais (PBR - F).

\section{MENSAGEM DO PODER EXECUTIVO (MSC 621/1985)}

São apresentadas duas manifestações do Poder Executivo para submeter a Convenção à apreciação das Comissões de Relações Exteriores e de Constituição e Justiça. Uma delas, de 28.11.1985, é de autoria do Presidente José Sarney, que encaminha a MSC 621/1985; a outra, de autoria do Ministro das Relações Exteriores, Olavo Setúbal, é a MSC 621, de 29.10.1985. A primeira mensagem é praticamente idêntica à segunda, uma cópia com alguns pontos de paráfrase. Será analisada, portanto, a mensagem de Setúbal.

Após breve descrição do tratado, o Ministro aponta os motivos pelos quais o Brasil deve aderir à Convenção:

(i) O Brasil participou ativamente dos trabalhos de preparação do Pacto, o que reitera sua atuação na formação dos instrumentos de proteção internacional dos Direitos Humanos desde a década de 1940 (PEB - F); além de ter se manifestado em prol da proteção internacional dos Direitos Humanos, apresentando projetos em conferências internacionais; (DH - F)

(ii) Aderir ao Pacto estaria em conformidade com a tradição jurídico-diplomática brasileiras; (PEB - F)

(iii) O país ratificou instrumentos relevantes de proteção dos Direitos Humanos, como a Convenção relativa ao status dos Refugiados e a Convenção das Nações Unidas sobre a eliminação de todas as formas de discriminação racial; (DIN - F)

${ }^{180}$ Pareceres dos Consultores Jurídicos do Itamaraty, vol. VIII, p. 101. 
(iv) Essa adesão estaria em conformidade com a evolução do Direito Internacional hodierno, sempre considerado na elaboração da política externa brasileira; (PEB)

(v) No âmbito da proteção internacional dos Direitos Humanos, os Estados contraem obrigações internacionais no pleno exercício de sua condição de soberanos (PBR - F). Essa condição, ressalta o Ministro, não pode ser invocada como elemento de interpretação dos tratados, uma vez que esses não devem ser interpretado de maneira restritiva, pois têm como objetivo proteger os direitos do ser humano; (DH F)

(vi) O Pacto busca compatibilizar seus dispositivos ao direito interno, prevendo mecanismos para prevenir ou para evitar conflito entre a jurisdição interna e a internacional. O Pacto não faz analogias como os instrumentos clássicos de solução de controvérsias no contexto das relações interestatais, possuindo especificidade própria; $(\mathrm{DIN}-\mathrm{F})$

(vii) Finalmente, a adesão do Brasil seria compromisso adicional, nos âmbitos nacional e internacional, de proteção efetiva contra quaisquer violações dos direitos humanos (PEB - F); além de contribuir para a proteção da conquista de um regime democrático no país (PBR - F), fortalecendo a percepção do Brasil como um país que respeita os Direitos Humanos. (PEB - F)

O Brasil deveria, ao efetuar as declarações interpretativas a respeito dos artigos 43 e 48, "d", declarar que, para o governo nacional, esses dispositivos não incluem o direito automático de visitas ou de inspeções in loco da $\mathrm{CIDH}$, visitas estas que dependeriam da concordância expressa do país (PEB - F). Para o Ministro, não seria recomendável a adesão às cláusulas facultativas previstas no Pacto: a primeira delas está descrita no art. $45, \S 1^{\circ},{ }^{181}$ que se refere à competência da CIDH para examinar queixas apresentadas por outros Estados a respeito do não cumprimento de obrigações; a segunda, no art. $62, \S 1^{\circ}$, e é relativo à

\footnotetext{
${ }^{181}$ Artigo 45 - 1. Todo Estado-parte pode, no momento do depósito do seu instrumento de ratificação desta Convenção, ou de adesão a ela, ou em qualquer momento posterior, declarar que reconhece a competência da Comissão para receber e examinar as comunicações em que um Estado-parte alegue haver outro Estado-parte incorrido em violações dos direitos humanos estabelecidos nesta Convenção.
} 
jurisdição obrigatória da Corte. ${ }^{182}$

O Ministro não menciona o motivo para essa recomendação.

No que se refere ao art. 27 , a respeito de medidas de emergência e suspensão de garantias, particularmente em relação ao $\S 3^{\circ}$, sobre a obrigação dos Estados de manifestar a adoção dessas medidas aos demais signatários da Convenção, mediante comunicação ao Secretário-Geral da OEA; o Ministro aponta ser esse um dispositivo padrão de tratados sobre Direitos Humanos (DIN - F), que não afeta o direito de adotar essas medidas, desde que não ocorra derrogação de alguns direitos básicos, como os mencionados no segundo parágrafo do artigo. ${ }^{183}$

Deste modo, o Ministro propõe a adesão ao Pacto.

\section{PARECER DA COMISSÃo DE RELAÇÕES EXTERIORES (CD), NELSON MORRO, 1986 \\ [Câmara - Parecer 1] \\ O parecer da Comissão de Constituição e Justiça, do Deputado Nelson Morro, data de} 21.05.1986. Conforme o Deputado, o Pacto seria uma maneira de reafirmar o regime de liberdade pessoal e de justiça da sociedade, ambos embasados no respeito aos Direitos Humanos (DH - F). Apesar de os princípios em prol da defesa dos direitos fundamentais

\footnotetext{
${ }^{182}$ Artigo 62 - 1. Todo Estado-parte pode, no momento do depósito do seu instrumento de ratificação desta Convenção ou de adesão a ela, ou em qualquer momento posterior, declarar que reconhece como obrigatória, de pleno direito e sem convenção especial, a competência da Corte em todos os casos relativos à interpretação ou aplicação desta Convenção.

${ }_{183}$ Artigo 27 - Suspensão de garantias

1. Em caso de guerra, de perigo público, ou de outra emergência que ameace a independência ou segurança do Estado-parte, este poderá adotar as disposições que, na medida e pelo tempo estritamente limitados às exigências da situação, suspendam as obrigações contraídas em virtude desta Convenção, desde que tais disposições não sejam incompatíveis com as demais obrigações que lhe impõe o Direito Internacional e não encerrem discriminação alguma fundada em motivos de raça, cor, sexo, idioma, religião ou origem social.

2. A disposição precedente não autoriza a suspensão dos direitos determinados nos seguintes artigos: 3 (direito ao reconhecimento da personalidade jurídica), 4 (direito à vida), 5 (direito à integridade pessoal), 6 (proibição da escravidão e da servidão), 9 (princípio da legalidade e da retroatividade), 12 (liberdade de consciência e religião), 17 (proteção da família), 18 (direito ao nome), 19 (direitos da criança), 20 (direito à nacionalidade) e 23 (direitos políticos), nem das garantias indispensáveis para a proteção de tais direitos.

3. Todo Estado-parte no presente Pacto que fizer uso do direito de suspensão deverá comunicar imediatamente aos outros Estados-partes na presente Convenção, por intermédio do Secretário Geral da Organização dos Estados Americanos, as disposições cuja aplicação haja suspendido, os motivos determinantes da suspensão e a data em que haja dado por terminada tal suspensão.
} 
estarem previstos em tratados anteriores, entre os quais a Carta da OEA, a Declaração Americana de Direitos e Deveres do Homem e a DUDH (DIN - F), a Convenção reitera a necessidade de defesa irrestrita dos direitos à vida, à integridade e liberdade físicas, à nacionalidade, à propriedade e ao acesso às fontes de ciência e de cultura, seja no âmbito civil, seja nos âmbitos político, econômico, social e cultural (DH - F).

O relator analisa o posicionamento da MSC 621 sobre a necessidade de declaração interpretativa em relação aos artigos 43 e 48.d. Para ele, essa declaração seria desnecessária, uma vez que o art. 48.2 determina que as investigações apenas serão realizadas mediante consentimento anterior do Estado em cujo território alega-se ter sido cometida violação (DIN - F). ${ }^{184}$

Sobre a recomendação da MSC 621 de não adesão do Brasil às cláusulas facultativas do art. $45, \S 1^{\circ}$ e $62, \S 1^{\circ}$, aponta que, apesar de se tratarem de cláusulas facultativas, se o governo brasileiro deixar de reconhecer a competência da CIDH para receber e examinar denúncias de violação dos Direitos Humanos no país, o Pacto perderia, em grande medida, sua função de proteger os indivíduos em detrimento do Estado (DH - F). Apesar de o país defender. Internamente, a proteção dos Direitos Humanos (PBR - F), a adesão irrestrita ao Pacto ratificaria internacionalmente esse compromisso. (PEB - F)

O voto do relator é pela aprovação integral do texto do Pacto. O parecer foi aprovado por unanimidade pela Comissão.

\section{PARECER DA COMISSÃO DE CONSTITUIÇÃO E JUSTIÇA (CD), NILSON GIBSON, 1986}

[Câmara - Parecer 2]

O parecer do relator, Deputado Nilson Gibson, de 26.11.1986, mencionou as bases constitucionais para a assinatura de tratados internacionais (art. $8^{\circ}, \mathrm{I}$ ); a competência para resolver sobre a matéria (art. 44, I) por Decreto Legislativo (art. 46, I). A iniciativa de apresentar o Decreto Legislativo pode ser de Comissão da Câmara dos Deputados (art. 56)

\footnotetext{
${ }^{184}$ Artigo 48 - 1. A Comissão, ao receber uma petição ou comunicação na qual se alegue a violação de qualquer dos direitos consagrados nesta Convenção, procederá da seguinte maneira:

2. Entretanto, em casos graves e urgentes, pode ser realizada uma investigação, mediante prévio consentimento do Estado em cujo território se alegue houver sido cometida a violação, tão somente com a apresentação de uma petição ou comunicação que reúna todos os requisitos formais de admissibilidade.
} 
(DBR - F). Assim, vota pela constitucionalidade, juridicidade e boa técnica legislativa do Projeto de Decreto Legislativo.

A Comissão opinou, unanimemente, pela constitucionalidade, juridicidade e boa técnica legislativa do Projeto.

\section{PARECER DE PLENÁRIO (SF), JAMIL HADDAD, 1989}

[Senado - Parecer 1]

O parecer, publicado no DCN de 13.10.1989, é de autoria do Senador Jamil Haddad. Segundo o relator, é crescente a necessidade de proteção internacional que garanta os Direitos Humanos, a principal preocupação da Convenção (DH - F).

Para o Senador, seria desnecessário fazer declaração interpretativa, conforme sugerido pelo Presidente da República, sobre os artigos 43 e 48, “d”, pelos mesmos motivos apontados pelo Deputado Nelson Morro (DIN - F). Da mesma maneira, o Senador posiciona-se contrariamente à não-adesão do Brasil às cláusulas facultativas dos artigos 45 e 62, pois seu não reconhecimento faria a Convenção perder o seu poder impositivo, o que não seria interessante (PEB - F).

O Brasil tem participado ativamente nos foros internacionais de discussão sobre os Direitos Humanos, elaborando instrumentos diplomáticos relativos à matéria (PEB - F). $\mathrm{O}$ país ratificou diversos tratados específicos acerca do tema, como a Convenção relativa ao status dos Refugiados e a Convenção da ONU sobre a Eliminação de todas as formas de Discriminação Racial (DIN - F). O Pacto insere-se nesse contexto.

O Senador destaca a necessidade de serem submetidos ao Congresso quaisquer instrumentos que decorram da Convenção (PBR - F). As parcelas do tratado que se referem aos procedimentos de ratificação, de reserva, de emenda e de denúncia estariam em conformidade com os princípios de Direito Internacional Público (DIN - F). Sua aprovação estaria, igualmente, em consonância com a Constituição (DBR - F).

O parecer é pela aprovação da Convenção. O parecer, com a emenda sugerida, é aprovado por unanimidade, sem discussão, conforme publicado no DCN de 13.10.1989.

\section{PARECER DA COMISSÃO DE RELAÇÕES EXTERIORES (CD), HAROLDO SABOIA, 1989}

[Câmara - Parecer 3] 
Trata de parecer da Comissão de Relações Exteriores, de 29.11.1989, de autoria do Deputado Haroldo Saboia. Segundo o relator, o país tem tradição, em sua postura diplomática, de assegurar a proteção dos Direitos Humanos no contexto internacional (PEB - F), o que ficaria explícito pela adesão brasileira a tratados como a Convenção relativa ao status dos Refugiados e a Convenção das Nações Unidas sobre a eliminação de todas as formas de discriminação racial (DIN - F). Aponta, ainda, para a intensa participação do país nos debates e na redação dos instrumentos acerca da proteção internacional dos Direitos Humanos durante a Conferência Especializada Interamericana sobre Direitos Humanos, que ocorreu em São José da Costa Rica em novembro de 1969, reunião da qual derivou o Pacto (PEB - F).

O relator menciona trecho da MSC 621 para destacar que a adesão demonstraria o compromisso do país, nos âmbitos nacional (PBR - F) e internacional (PEB - F), com a proteção dos Direitos Humanos. Seria imperativa a adesão à Convenção, na qual os países americanos afirmam a intenção de consolidar "um regime de liberdade pessoal e de justiça social fundado no respeito dos direitos essenciais do homem" (DH - F). ${ }^{185}$

Não haveria nada que contrariasse a legislação pátria (DBR - F) ou as tradições diplomáticas nacionais (PEB - F), estando o Pacto, ademais, em consonância com os princípios do Direito Internacional Público (DIN - F). Reforça a posição do Senador Jamil Haddad, no sentido de ser desnecessária a declaração interpretativa e necessária a adesão imediata do Brasil às cláusulas facultativas dos artigos $45, \S 1^{\circ}$ e $62, \S 1^{\circ}(\mathrm{PBR}-\mathrm{F})$. Dá seu parecer pela aprovação da Convenção, com a emenda sugerida pelo Senado Federal.

A Comissão de Relações Exteriores aprovou o parecer por unanimidade.

\section{PARECER DA COMISSÃO DE CONSTITUIÇÃO E JUSTIÇA E DE REDAÇÃO (CD) À EMENDA DO SENADO AO PROJETO DE DECRETO LEGISLATIVO}

O parecer, de 09.05.1990, ressalta que a emenda sugerida pelo Senado Federal está em conformidade com a legislação nacional, aprovando a emenda.

${ }^{185}$ DCN 19.06.1990, p. 7.141. 


\section{1. e 22.2. PROTOCOLOS ADICIONAIS À CONVENÇÃO AMERICANA SOBRE DIREITOS HUMANOS: (I) PROTOCOLO EM MATÉRIA DE DIREITOS ECONÔMICOS, SOCIAIS E CULTURAIS - PROTOCOLO DE SÃO SALVADOR E (II) PROTOCOLO REFERENTE À ABOLIÇÃO DA PENA DE MORTE}

Os Protocolos adicionais à Convenção Americana sobre Direitos Humanos foram analisados em conjunto pelo Congresso. São dois protocolos: (i) Protocolo em matéria de Direitos Econômicos, Sociais e Culturais é o Protocolo de São Salvador, de 17.11.1988 e (ii) Protocolo referente à abolição da Pena de Morte, de 08.06.1990.

(i) O Protocolo referente à abolição da pena de morte foi adotado em 08.06.1990, e assinado pelo Brasil em 07.06.1994. Entrou em vigor internacional em 28.08.1991. Foi aprovado pelo Congresso Nacional pelo Decreto Legislativo 56, de 19.04.1995. O governo brasileiro depositou o Instrumento de Ratificação do Protocolo em 13.08.1996, com aposição de reserva, nos termos do artigo 2.1; passando a vigorar para o Brasil em 13.08.1996;

(ii) O Protocolo de São Salvador foi concluído em 17.11.1988, entrou em vigor internacional em 16.11.1999, e para o Brasil em 16.11.1999. Esse Protocolo foi aprovado pelo Congresso por meio do Decreto Legislativo 56, de 19.04.1995. O Instrumento de adesão do referido protocolo foi depositado em 21.08.1996. O Protocolo foi promulgado pelo Decreto Presidencial 3.321, de 30.12.1999.

O processo de aprovação de ambos os Protocolos tramitou na Câmara dos Deputados como Projeto de Decreto Legislativo 299, de 1993, e no Senado Federal como Projeto de Decreto Legislativo 14, de 1994.

\section{PARECER DA CONSULTORIA JURÍDICA DO MINISTÉRIO DAS RELAÇÕES EXTERIORES, VICENTE MAROTTA RANGEL, 1991}

[Executivo -Parecer MRE]

O parecer, de 06.03.1991, é de autoria do senhor Vicente Marotta Rangel, e analisa a compatibilidade entre o Protocolo relativo à abolição da pena de morte e o direito 
brasileiro. ${ }^{186}$ Após descrever a Convenção, particularmente no que se refere ao direito à vida e à pena de morte, e o teor do Protocolo, que tem como objetivo restringir ainda mais a aplicação da pena de morte; o jurista aponta a possibilidade de os Estados, no momento de ratificação ou de adesão, reservarem para si o direito de aplicar a pena de morte em tempo de guerra, posto que o protocolo não admite reservas. Portanto, possibilita que o Estado, desde que efetue essa Declaração, mantenha na legislação nacional a pena de morte, desde que aplicada somente nos casos em que (i) haja guerra declarada; (ii) esteja em conformidade com o Direito Internacional; (iii) resulte de delitos graves de caráter militar.

A Constituição dispõe que não haverá pena de morte, salvo em caso de guerra declarada. Caberia, ademais, ao Presidente da República declarar guerra, em caso de agressão estrangeira, autorizado ou referendado pelo Congresso, dependendo do momento em que a agressão ocorra. Com isso, tem-se que a exigência constitucional é atendida explicitamente pela primeira condição contemplada pelo Protocolo (DBR - F). A existência de outras condições - (ii) e (iii) - não implica colisão com a Constituição, apenas condições que a ela se somam:

\footnotetext{
Que a aplicação da pena de morte, quando ocorra, se faça de acordo com o direito internacional, é preceito entranhado no próprio corpo do ordenamento jurídico brasileiro, (DBR - F) de sua doutrina, de seus legisladores, dos seus órgãos executivos e judicantes. (PBR - F)

Que a pena de morte, por outro lado, seja cominada apenas a delitos sumamente graves de caráter militar é prescrição seguida pela legislação brasileira que essa pena contempla, precisamente a revestida desse caráter (DBR - F).
}

O consultor menciona diversas normas internas que justificam sua posição, ${ }^{187}$ concluindo que a formulação da declaração prevista no Protocolo possibilita ao governo vincular-se a ele, desde que efetue a declaração no momento da ratificação ou da adesão ao tratado (DBR - F). Não seria possível ao Brasil vincular-se a esse instrumento sem essa declaração.

\footnotetext{
186 Pareceres dos Consultores Jurídicos do Itamaraty, Volume IX (1990-2000), p. 39.

187 Livro II (Dos Crimes Militares em Tempo de Guerra) do Código Penal Militar (Decreto-Lei n. 1001, de 21.10.1969), concernentes aos delitos de traição (art. 355), de favor ao inimigo (art. 356), de tentativa contra a soberania do Brasil (art. 357 cc o art. 142), de informação ou auxílio ao inimigo (art. 359), entre outros delitos, cuja prática conduz à aplicação de penas, entre as quais, em seu grau máximo, se inclui a de morte.
} 


\section{PARECER DA CONSULTORIA JURÍDICA DO MINISTÉRIO DAS RELAÇÕES EXTERIORES, VICENTE MAROTTA RANGEL, 1992}

[Executivo -Parecer MRE]

O parecer, de 22.08.1992, é de autoria do professor Vicente Marotta Rangel, e aprecia o Protocolo adicional à Convenção Americana sobre Direitos Humanos em matéria de direitos econômicos, sociais e culturais. ${ }^{188}$ Ao tratar do Protocolo de São Salvador, o consultor ressalta que poderia haver conflito entre o art. $8^{\circ}, \S 1^{\circ}$, "a" do tratado, no qual os Estados comprometem-se a garantir "os direitos dos trabalhadores de organizar sindicatos (...) para promover e proteger seus interesses". Poderia existir conflito com a norma do art. $8^{\circ}$, II, CF, que veda a criação demais de uma organização sindical na mesma base territorial (DBR - C). O governo brasileiro, deste modo, não poderia garantir o direito previsto no protocolo. Marotta Rangel ressalta, porém, que o parágrafo $2^{\circ}$ do mesmo artigo do tratado ameniza eventual conflito com a Constituição, posto que a restrição constitucional poderia ser qualificada como necessária para proteger a ordem pública e a saúde ou a moral públicas, além dos direitos e das liberdades dos demais. Seria, inclusive, sensato argumentar que a opção pela unidade sindical não é atentatória contra os direitos dos trabalhadores de organizar-se em sindicatos, mas medida utilizada, justamente, para preservar esse direito (PBR - F).

O parecer é pela adesão ao protocolo, sem reservas.

\section{MENSAGEM DO PODER EXECUTIVO (MSC 755/1992)}

A MSC 755, de 20.11.1992, é de autoria do Ministro de Estado das Relações Exteriores, senhor Fernando Henrique Cardoso, enviada ao Congresso pelo Presidente da República, Itamar Franco, em 26.11.1992. Nela, o Ministro informa que, com a adesão do Brasil ao Pacto de São José da Costa Rica, o país preenche os requisitos para aderir aos seus protocolos adicionais. Quanto ao primeiro protocolo, a adesão poderia ser feita sem reservas, em virtude da ausência de conflito com o direito brasileiro (DBR - F).

\footnotetext{
${ }^{188}$ Foi pedida a análise de ambos os protocolos, mas aquele referente à pena de morte já fora analisado anteriormente, como se pode perceber pela data dos pareceres.
} 
O Protocolo sobre a Pena de Morte, entretanto, tem como objetivo tornar o art. $4^{\mathrm{o}}$ da Convenção - sobre o direito à vida - mais restritivo quanto à aplicação da pena de morte. A Constituição Federal, entretanto, destaca que não haverá pena de morte, "salvo em caso de guerra declarada". ${ }^{189}$ (DBR - C). Infere-se, portanto, a admissibilidade da pena capital no ordenamento pátrio, desde que em situação de guerra declarada. $\mathrm{O}$ art. $1^{\circ}$ do Protocolo diz que os signatários não aplicarão a pena de morte em seu território a nenhum indivíduo sob sua jurisdição. O próprio Protocolo, apesar de não admitir reservas (conforme o $\operatorname{art.~} 2^{\circ}$ ), determina que os Estados podem, no momento de ratificação ou adesão, reservar o direito de aplicar a penalidade capital em tempos de guerra, desde que em conformidade com o Direito Internacional. ${ }^{190}$ A reserva a esse artigo do tratado seria essencial para que se coadunasse com o ordenamento pátrio.

Assim, o Ministro propõe a adesão do país aos dois Protocolos, com reserva pontual ao Protocolo referente à pena de morte.

\section{PARECER DA COMISSÃO DE RELAÇÕES EXTERIORES (CD), LUIZ GUSHIKEN, 1993}

[Câmara - Parecer 1]

O relatório, do Deputado Luiz Gushiken, data de 30.06.1993. O relator aprecia, primeiramente, o Protocolo sobre Direitos Econômicos, Sociais e Culturais (Protocolo de São Salvador), que trata de garantir, nos Estados, o exercício dos direitos por ele enunciados. Apesar de esses direitos serem protegidos pelas legislações nacionais, os países latinoamericanos entenderam necessário comprometerem-se a assegurar o gozo desses direitos por parte de seus cidadãos. Estes teriam, assim, maior segurança quanto ao exercício dos seus

\footnotetext{
${ }^{189}$ Art. 5o Todos são iguais perante a lei, sem distinção de qualquer natureza, garantindo-se aos brasileiros e aos estrangeiros residentes no País a inviolabilidade do direito à vida, à liberdade, à igualdade, à segurança e à propriedade, nos termos seguintes:

XLVII - não haverá penas: a) de morte, salvo em caso de guerra declarada, nos termos do art. 84, XIX;

${ }^{190}$ Art. 1: Os Estados-Partes neste Protocolo não aplicarão em seu território a pena de morte a nenhuma pessoa submetida a sua jurisdição.

Art. 2.1. Não será admitida reserva alguma a este Protocolo. Entretanto, no momento de ratificação ou adesão, os Estados-Partes neste instrumento poderão declarar que se reservam o direito de aplicar a pena de morte em tempo de guerra, de acordo com o Direito Internacional, por delitos sumamente graves de caráter militar. (...)
} 
direitos, motivo suficientemente relevante para se recomendar a adesão ao Protocolo (PEB - F). O relator aponta não existir qualquer restrição à assinatura do Protocolo pelo Brasil.

Quanto ao Protocolo referente à abolição da Pena de Morte, aponta o aspecto destacado pela MSC, uma vez que a abolição completa da pena de morte no Brasil conflitaria com a Constituição (DBR - C). O relator aponta, então, para a necessidade de aprovar o Protocolo com declaração que reserva ao país o direito de aplicar a pena em caso de guerra declarada. Acrescenta que é de grande importância que se formalize a abolição da pena capital no continente latino-americano, o que atenderia às "tradições jurídicas e histórico-culturais dos nossos povos". (PEB - F)

Vota, assim, pela aprovação dos textos dos Protocolos, com a ressalva apontada. O parecer foi aprovado por unanimidade pela Comissão.

\section{PARECER DA COMISSÃo DE CONSTITUIÇÃO E JUSTIÇA E DE REDAÇÃo (CD), NELSON JOBIM, 1993}

[Câmara - Parecer 2]

O Parecer é do Deputado Nelson Jobim, de 12.11.1993. Com relação ao Protocolo de São Salvador, aponta ser relevante a adesão do país, para apoiar e respaldar o reconhecimento dos Direitos Humanos no continente (DH - F). Com relação ao protocolo sobre a abolição da pena de morte, o voto é pela adequação do instrumento, em virtude da possibilidade de declaração conforme o art. 2 (DBR - C).

O voto é pela constitucionalidade, juridicidade e boa técnica legislativa do Projeto de Decreto Legislativo 299, de 1993; e pela sua aprovação, no mérito.

A Comissão opinou unanimemente pela aprovação do parecer.

\section{PARECER DA COMISSÃO DE RELAÇÕES EXTERIORES E DEFESA NACIONAL (n. 176 - SF), CASILDO MALDANER, 1995}

[Senado - Parecer 1]

O parecer, de autoria do Senador Casildo Maldaner, é de 06.04.1995. Segundo o Senador, os protocolos estão em conformidade com o direito nacional, que, inclusive, ampara todas as garantias expressas no Protocolo de São Salvador (DBR - F). Com o Protocolo, é alcançado novo patamar de proteção aos Direitos Humanos (DH - F), previamente acolhidos pela Convenção Americana sobre Direitos Humanos (DIN -F). 
O Senador aponta, igualmente, para a necessidade de se aprovar o Protocolo sobre Pena de Morte, com a ressalta de apresentar declaração sobre o artigo que trata da pena de morte em caso de guerra (DBR - C).

O parecer é, portanto, pela aprovação de ambos os protocolos 


\subsection{ANÁLISE: DECLARAÇÃO SOBRE A COMPETÊNCIA OBRIGATÓRIA DA CORTE INTERNACIONAL DE DIREITOS HUMANOS}

\section{PARECER DA CONSULTORIA JURÍDICA DO MINISTÉRIO DAS RELAÇÕES EXTERIORES, ANTÔNIO PAULO CACHAPUZ DE MEDEIROS, 1998}

O parecer, de 19.08.1998, é de autoria de Antônio Paulo Cachapuz de Medeiros. Após explicação a respeito da tramitação interna do tratado, e de seu teor, o consultor ressalta que, no momento de aprovação do Pacto de São José da Costa Rica, o Congresso, apesar das sugestões do Poder Executivo expressas na MSC 621/1985, ${ }^{191}$ aprovou o Pacto sem quaisquer reservas ou declarações interpretativas. Deste modo, o Legislativo brasileiro conferiu assentimento completo ao texto do Pacto, inclusive aos seus artigos $45, \S 1^{\circ}$ e $62, \S^{\circ}$. Isso significa que o Congresso conferiu ao Presidente a faculdade de efetivar a adesão do Brasil às cláusulas facultativas contempladas nos artigos mencionados, desaparecendo as causas que não recomendavam sua efetivação à época da MSC, em 1992 (PBR - F).

Declarar o reconhecimento da competência obrigatória da Corte Interamericana de Direitos Humanos seria ato discricionário do Presidente, pois o próprio art. 62 do tratado afirma que essa declaração pode ser efetuada a qualquer tempo, desde que posterior à adesão. Ao aprovar o art. 62, o Congresso concedeu ao Presidente essa prerrogativa, quando julgasse oportuno. Existiria necessidade de consultar o Congresso Nacional apenas nos casos de revisão do texto convencional ou de celebração de ajustes a ele, o que não é o caso em pauta (PBR - F).

O reconhecimento da competência obrigatória da Corte é efetivado por declaração depositada junto à Secretaria Geral da OEA. Para o consultor, o governo deveria anunciar como sem efeito a declaração interpretativa efetuada em 25.09.1992, reconhecendo, indeterminadamente, a competência da Corte como obrigatória a todos os casos relacionados à interpretação ou à aplicação do Pacto de São José da Costa Rica. Segundo Cachapuz, além de reconhecer a competência da Corte, essa declaração deve, necessariamente, tornar a anterior sem efeito, posto que restringe a ação da Comissão Interamericana de Direitos

\footnotetext{
${ }^{191}$ De fazer declaração interpretativa a respeito dos artigos 43 e 48 "d" e de não aderir às cláusulas facultativas dos parágrafos primeiros art. 45 e 62 .
} 
Humanos, órgão que, assim como os países, tem o direito de submeter casos à apreciação da Corte. Essa declaração, porém, produz efeito no âmbito internacional; para adquirir eficácia no âmbito interno, seria necessária a reedição do decreto que trata desse instrumento internacional.

Em adendo ao parecer, de 20.08.1998, o consultor acrescenta que a MSC, instrumento de comunicação oficial, não é vinculante, não sendo o Legislativo, portanto, obrigado a seus termos (PBR - F). Caso fosse do desejo do Congresso, poderia ter incluído no Decreto Legislativo que aprovou a Convenção uma restrição ao reconhecimento da competência obrigatória da Corte, algo solicitado pelo Presidente da República, o que não foi feito. Assim, o Legislativo aprovou a Convenção integralmente, o que inclui, por óbvio, o art. 62. Não se aplica ao caso o entendimento de que os julgamentos da Corte se reduzem a indenizações e que, portanto, aceitar a sua competência poderia acarretar "encargos ou compromissos gravosos ao patrimônio nacional" - conforme disposto na Constituição. O texto constitucional refere-se a tratados, e não a sentenças provenientes de tribunais internacionais. Ao aprovar a Convenção, o Congresso aceitou a possibilidade que suas sentenças condenassem o Brasil a penas de caráter monetário. Deste modo, não restam dúvidas de que a declaração de reconhecimento da competência obrigatória da Corte não requer nova aprovação legislativa, o que ocorreu por intermédio do Decreto Legislativo 27/1992.

\section{MENSAGEM DO PODER EXECUTIVO (MSC 1070/1998)}

A Mensagem 1.070, de 04.09.1998, redigida pelo Ministro de Estado interino das Relações Exteriores, senhor Sebastião do Rego Barros, foi enviada ao Congresso pelo Presidente da República, senhor Fernando Henrique Cardoso, em 08.09.1998. Segundo o Ministro, no momento de adesão à Convenção, o Presidente optou por não fazer as declarações facultativas referentes (i) à competência da CIDH para examinar queixas apresentadas por outros países a respeito do descumprimento das obrigações e (ii) à jurisdição obrigatória da Corte. O governo do Brasil, entretanto, aprofundou as comunicações com a CIDH, órgão que monitora o processo de implementação do tratado, antes de reconhecer a competência da Corte; avaliando que isso seria preciso para adotar os mecanismos internos necessários para essa implementação (PEB - F). O Brasil, porém, 
sempre ressaltou que a Declaração de reconhecimento da competência contenciosa da Corte poderia ser feita a qualquer tempo.

No Brasil, o Programa Nacional de Direitos Humanos estabelece como meta o fortalecimento da cooperação com a Comissão e com a Corte Interamericana de Direitos Humanos (PBR - F). O país tem fortalecido o relacionamento com a Comissão, aceitando a solução amistosa para casos que tramitam em seu contexto e que envolvem indenizações para vítimas de violações de Direitos Humanos e para seus familiares (PEB - F). O papel crescente do sistema interamericano de proteção dos Direitos Humanos gerou manifestações favoráveis por parte da sociedade civil brasileira, para que o país reconhecesse a jurisdição da Corte (PBR - F).

O Ministro cita os pareceres dos consultores jurídicos do Itamaraty João Grandino Rodas, de 08.11.1995, ${ }^{192}$ que entendeu que as normas constitucionais seriam compatíveis com o reconhecimento da jurisdição da Corte Interamericana (DBR - F), e que a adesão à mesma seria coerente com o princípio da soberania nacional (PBR - F) e do professor Antônio Paulo Cachapuz Medeiros, analisado neste item.

O Ministro aponta, ainda, para as razões enumeradas pelo ex-consultor jurídico do Itamaraty, à época vice-presidente da Corte Interamericana de Direitos Humanos, professor Antônio Augusto Cançado Trindade, que recomendou que o Brasil aceitasse a competência contenciosa da Corte pelas seguintes razões:

(i) $\mathrm{O}$ fato de que o reconhecimento seria uma garantia extra a todos aqueles sujeitos à jurisdição brasileira (PBR - F);

(ii) Seria uma maneira de projetar internacionalmente o compromisso brasileiro com a defesa dos Direitos Humanos, o que fortaleceria a posição do país na Corte (PEB - F);

(iii) A Constituição propugna pela formação de tribunal internacional de Direitos Humanos, que existe na prática, e cuja criação foi proposta pela delegação brasileira, na IX Conferência Interamericana de 1948 (PEB - F);

(iv) O país participou dos trabalhos preparatórios da Convenção (PEB - F);

(v) A doutrina internacionalista nacional apoia o reconhecimento da competência obrigatória da Corte (PBR - F);

${ }^{192}$ A autora não teve acesso a esse parecer. 
(vi) Esse reconhecimento aumentaria o interesse da população pela difusão do conhecimento acerca da jurisprudência dessa e de outras Cortes internacionais para a proteção dos Direitos Humanos (PBR - F);

(vii) Possuímos experiência de relacionamento com outros órgãos internacionais de supervisão do Direitos Humanos, o que é valioso no procedimento contencioso perante a Corte (PEB - F);

(viii) A Corte tem como base o Pacto de São José, e é a forma mais evoluída de proteção dos Direitos Humanos (DIN - F);

(ix) Seria incoerente internalizar o Pacto e não aceitar os mecanismos para sua implementação (PEB - F);

(x) Existe relação entre o direito internacional e o nacional no âmbito da proteção dos Direitos Humanos, sendo as jurisdições nacionais copartícipes na luta contra a impunidade e o arbítrio (PEB - F).

Sob a perspectiva de política externa, aceitar a jurisdição da Corte é coerente com a atuação brasileira nos foros multilaterais e com o interesse do país em assumir responsabilidades cada vez maiores no contexto internacional (PEB - F). Esse gesto ainda reforçaria o papel do Brasil como país protetor dos Direitos Humanos, pronto para aceitar responsabilidades e obrigações nesse sentido (PEB).

A Mensagem, assim, propugna pelo reconhecimento da competência contenciosa da Corte.

\section{PARECER DO RELATOR DESIGNADO PELA MESA, EM SUBSTITUIÇÃO À COMISSÃO DE RELAÇÕES EXTERIORES E DEFESA NACIONAL (CD), ALDO REBELO, 1998}

[Câmara - Parecer 1]

O parecer, de 14.10.1998, é de autoria do Deputado Aldo Rebelo. Segundo o ele, o art. $7^{\circ}, \mathrm{ADCT}$, dispõe que o Brasil irá propugnar pela formação de tribunal internacional de Direitos Humanos (DBR - F). A aprovação da Declaração apenas reitera posição que o país assumiu anteriormente no âmbito internacional, ao subscrever o tratado (PEB - F).

O parecer é, pois, pela aprovação da Declaração. 
PARECER DO RELATOR DESIGNADO PELA MESA, EM SUBSTITUIÇÃO À COMISSÃO DE CONSTITUIÇÃO E JUSTIÇA E DE REDAÇÃO (CD), VIC PIRES FRANCO, 1998

[Câmara - Parecer 2]

O parecer, de autoria do Deputado Vic Pires Franco, é pela constitucionalidade e pela juridicidade da proposição (DBR - F), e endossa o parecer do Deputado Aldo Rebelo. 


\section{ANÁlISE: CONVENÇÃO INTERAMERICANA PARA PREVENIR E PUNIR TORTURA}

A Convenção Interamericana para prevenir e Punir a Tortura, de 09.12.1985, entrou em vigor internacional em 28.02.1987, conforme o disposto em seu artigo 22. Essa Convenção foi assinada pelo plenipotenciário brasileiro em 24.01.1986 e ratificada em 20.07.1989. Foi enviada ao Congresso pela Mensagem Presidencial 235, de 1986. Seu processo de aprovação tramitou na Câmara dos Deputados como Projeto de Decreto Legislativo 154, de 1986, e no Senado Federal como Projeto de Decreto Legislativo 11, de 1988. Foi aprovada pelo Congresso Nacional pelo Decreto Legislativo 05, de 31.05.1989, e promulgada pelo Decreto Presidencial 98.386, de 09.11.1989, sem reservas.

A Convenção foi adotada em meados da década de 1980, no contexto da Assembleia Geral da organização na qual foram adotadas emendas à sua Carta. A Convenção traz definição detalhada do termo "tortura", além de definir a responsabilidade pelo cometimento desse crime. Os signatários não apenas se comprometem a punir severamente os perpetradores, mas concordam em adotar medidas para prevenir e para punir outros tratamentos cruéis, desumanos ou degradantes, dentro de suas respectivas jurisdições. Conforme o tratado, acusados de praticar tortura não podem se furtar da ação da justiça evadindo-se para o território de outro signatário. ${ }^{193}$

\section{STATUS NA OEA}

http://www.oas.org/juridico/english/sigs/a-51.html

MENSAGEM DO PODER EXECUTIVO (MSC 235/1986)

A Mensagem do Poder Executivo 235, de 11.06.1986, foi elaborada pelo Ministro das Relações Exteriores, senhor Roberto de Abreu Sodré, e enviada ao Congresso pelo Presidente José Sarney, em 13.06.1986. Segundo o Ministro, a Convenção atende a posição brasileira a respeito do tema, fato que possibilitou que o país apoiasse sua aprovação na XV

193 Informações obtidas em: http://www.cidh.org/basicos/english/Basic1.\%20Intro.htm\#_ftn5. Acesso: 28.03.2016. 
Assembleia Geral Ordinária da OEA (PEB - F). A Convenção trata, especificamente, da obrigação dos Estados signatários de prevenir e de sancionar a tortura efetuada por membros da administração pública ou por pessoas agindo por ordens suas, e não admite justificações para essa prática. A ratificação desse instrumento demonstraria compromisso do país nos âmbitos interno (PBR - F) e internacional com a proteção dos Direitos Humanos, o que contribuiria para o fortalecimento da imagem do Brasil como país que não somente respeita, mas que garante os Direitos Humanos. (PEB - F)

Isso posto, o Ministro propõe a ratificação da Convenção.

\section{PARECER DA COMISSÃO DE RELAÇÕES EXTERIORES (CD), JOSÉ TAVARES, 1988}

[Câmara - Parecer 1]

O parecer, de autoria do Deputado José Tavares, é pela constitucionalidade (DBR - F), juridicidade e técnica legislativa do projeto.

\section{PARECER DA COMISSÃO DE RELAÇÕES EXTERIORES (CD), AMAURY MÜLLER, 1986}

[Câmara - Parecer 2]

O Parecer da Comissão de Relações Exteriores, de 03.12.1986, elaborado pelo Deputado Amaury Müller, repete expressamente as razões mencionadas na MSC 235/1986 para a ratificação da Convenção. Conclui que ela deve ser aprovada para que haja "um grande avanço na consciência moral e jurídica de nossa Nação". (PBR - F)

A CRE aprovou unanimemente o parecer.

\section{PARECER DA COMISSÃO DE RELAÇÕES EXTERIORES (n. 17 - SF), ITAMAR FRANCO, 1989}

[Senado - Parecer 1]

O parecer, de 27.04.1989, é de autoria do Senador Itamar Franco. Após relatório acerca da Convenção e de sua tramitação, o Senador destaca a objetividade dos artigos do tratado. Ressalta que, quando da aprovação do texto constitucional, foi adotada a imprescritibilidade e a inafiançabilidade do crime de tortura, o que se coaduna com os termos da Convenção (DBR - F). Frisa que as obrigações adquiridas pela aprovação do tratado exigem a 
implementação de medidas normativas no contexto nacional (PBR - F). Em virtude da importância do tema e para uma proteção eficaz dos principais valores protegidos pelo tratado, o respeito à integridade física e psicológica do ser humano; o relator diz que apresenta ao Senado dois projetos de lei, um deles tipificando o crime de tortura e o outro que declara nulas as provas obtidas mediante tortura (PBR - F). 


\section{ANÁliSE: CONVENÇÃO INTERAMERICANA PARA PREVENIR, PUNIR E ERRADICAR A VIOLÊNCIA CONTRA A MULHER}

A Convenção Interamericana para prevenir, punir e erradicar a violência contra a mulher (“Convenção de Belém do Pará”), de 09.06.1994, entrou em vigor internacional em 03.05.1995, 30 dias após o depósito do $2^{\text {o }}$ instrumento de ratificação, conforme seu art. 21. A Convenção foi assinada pelo plenipotenciário brasileiro em 09.06.1994, ratificada em 16.11.1995, passando a mesma a vigorar, para o Brasil, em 15.12.1995, conforme seu art.21. Foi enviada ao Congresso Nacional por intermédio da Mensagem Presidencial 95, de 19.01.1995. Seu processo de aprovação tramitou na Câmara dos Deputados como Projeto de Decreto Legislativo 95, de 1995, e no Senado Federal como Projeto de Decreto Legislativo 109, de 1995. Foi aprovada pelo Decreto Legislativo 107, de 31.08.1995, e promulgada pelo Decreto Presidencial 1.973, de 01.08.1996, sem reservas.

A Convenção define a violência contra a mulher, além de estabelecer seus direitos, como o de viver longe da violência, e estabelece que a violência contra as mulheres é uma violação dos Direitos Humanos e das liberdades fundamentais. É o primeiro instrumento internacional que configura mecanismos de proteção e de defesa aos direitos das mulheres como essenciais para combater a violência física, sexual e psicológica contra elas; no âmbito público ou no privado, assegurando esses direitos em sua vida em sociedade. ${ }^{194}$

\section{STATUS NA OEA}

http://www.oas.org/juridico/english/sigs/a-61.html

\section{MENSAGEM DO PODER EXECUTIVO (MSC 95/1995)}

A Mensagem 95, de 16.01.1995 foi elaborada pelo Ministro das Relações Exteriores, senhor Luiz Felipe Lampreia, e enviada ao Congresso pelo Presidente da República, senhor Fernando Henrique Cardoso, em 19.01.1995. Segundo o Ministro, a adoção da Convenção de Belém do Pará é um avanço importante no âmbito do sistema interamericano de Direitos

\footnotetext{
${ }^{194}$ Informações obtidas em: http://www.oas.org/en/mesecvi/convention.asp. Acesso: 28.03.2016. 
Humanos, uma vez que combate a violência contra a mulher, algo que ocorre em todos os países, independentemente do nível de desenvolvimento (DH - F). Para o Ministro, a OEA realizou ato pioneiro no que tange ao Direito Internacional, ao complementar as obrigações previstas na Declaração sobre a Eliminação da Violência contra a Mulher, de 1990 (DIN F). A assinatura da Convenção reitera o compromisso do país com a defesa dos Direitos Humanos em território nacional (PBR - F).

À época da aprovação do texto da Convenção, durante a reunião de especialistas da OEA, a delegação brasileira fez reserva em relação ao art. $12,{ }^{195}$ referente à apresentação de petições à CIDH sobre denúncias ou queixas de violação de seus artigos por Estados signatários da Convenção. O Brasil, assim como outros países, advogou sua supressão, pois não seria essencial aos objetivos da Convenção, além de ser uma duplicação de dispositivo presente na Convenção Interamericana de Direitos Humanos (PEB - C). Deste modo, a reserva ao art. 12 deve ser reiterada quando do depósito do instrumento de ratificação.

\section{PARECER DA COMISSÃO DE RELAÇÕES EXTERIORES (CD), SANDRA STARLING, 1995}

[Câmara - Parecer 1]

O parecer da Comissão de Relações Exteriores, de autoria da Deputada Sandra Starling, de 17.05.1995, aponta que a Convenção em pauta fora rubricada não apenas pelos representantes do governo brasileiro, mas pelos representantes de todos os presentes na reunião, o que demonstra a sua importância. Ressalta, ainda, que a MSC 95/1995 recomenda que o Brasil faça reserva ao art. 12 da Convenção.

A justificativa do parecer inicia-se com o destaque da prática generalizada da violência contra a mulher, que ocorre tanto em países desenvolvidos como em subdesenvolvidos. A Deputada apresenta dados estatísticos e descrições. A ausência de tipificação de

\footnotetext{
195 Artigo 12: Qualquer pessoa ou grupo de pessoas, ou qualquer entidade não-governamental juridicamente reconhecida em um ou mais Estados membros da Organização, poderá apresentar à Comissão Interamericana de Direitos Humanos petições referentes a denúncias ou queixas de violação do artigo 7 desta Convenção por um Estado Parte, devendo a Comissão considerar tais petições de acordo com as normas e procedimentos estabelecidos na Convenção Americana sobre Direitos Humanos e no Estatuto e Regulamento da Comissão Interamericana de Direitos Humanos, para a apresentação e consideração de petições.
} 
determinadas condutas - como o estupro marital e os abusos psicológicos - ensejaria uma menor proteção das mulheres em sociedades como a brasileira (PBR - F). ${ }^{196}$ Em virtude da ausência de tipificação, à época, no âmbito nacional, a internalização da Convenção far-seia necessária, pois define a violência contra a mulher. A Deputada cita, ademais, as definições que tratam dos direitos protegidos da mulher e dos deveres do Estado na luta contra a violência contra a mulher, de grande valia para o Brasil (PBR - F).

Starling destaca a importância de o Estado incorporar, na legislação nacional, normas nos âmbitos civil, penal, administrativo e afins para que seja atingido o objetivo da Convenção, de prevenir, punir e erradicar a violência contra a mulher (PBR - F). Além de medidas legislativas, práticas jurídicas e mecanismos judiciais devem assegurar $\mathrm{o}$ cumprimento e a efetividade dessas normas.

O principal foco do parecer é a necessidade de o Estado adequar-se, internamente, às diretrizes determinadas pela Convenção (PBR - F). Aponta, nesse sentido, que discorda da reserva ao art. 12 da Convenção, que o Itamaraty sugere. Para ela, esse artigo apenas dispõe a respeito da participação da sociedade civil na fiscalização do cumprimento das obrigações assumidas pelos Estados signatários. Esse mecanismo seria de extrema valia e essencialidade, uma vez que essa fiscalização é fundamental nos sistemas democráticos. Para a Deputada, o artigo, ao contrário do que aponta o MRE, é um dos mais essenciais da Convenção (PBR - F).

Afirma, ainda, que não há duplicação do art. 12 em relação à Convenção Americana de Direitos Humanos, já que esse artigo determina que as petições serão analisadas conforme os mesmos procedimentos estabelecidos pela CADH (DIN - F). Não seria, portanto, uma questão de duplicação, mas um artigo que garante harmonia entre os dois instrumentos,

\footnotetext{
${ }^{196}$ É necessário apontar que a Lei 11.340, de 07.08.2006, popularmente conhecida como "Lei Maria da Penha", "cria mecanismos para coibir a violência doméstica e familiar contra a mulher, nos termos do § 8o do art. 226 da Constituição Federal, da Convenção sobre a Eliminação de Todas as Formas de Discriminação contra as Mulheres e da Convencão Interamericana para Prevenir, Punir e Erradicar a Violência contra a Mulher; (...)." (grifo nosso). $\mathrm{O}$ art. $5^{\circ}$ dessa lei trata da definição de violência doméstica, incluindo o sofrimento físico, sexual ou psíquico. No art. $7^{\circ}$, define formas de violência doméstica, entre as quais a violência física, psicológica, sexual, patrimonial e moral. Informação disponível em: http://www.planalto.gov.br/ccivil_03/ ato20042006/2006/lei/111340.htm. Acesso: 05.02.2015.
} 
sendo que a Convenção de Belém do Pará define diversos direitos e deveres que não constam na CADH (PBR - F). Segundo a Deputada,

\begin{abstract}
"Do nosso ponto de vista, a importância do artigo em questão é tão óbvia e insofismável, que fica a lamentável impressão de que o Ministério das Relações Exteriores quer apenas evitar constrangimentos ao Estado brasileiro, em virtude das possiveis e prováveis denúncias que surgirão com a ratificação deste instrumento." ${ }^{197}$ (grifo nosso). (PBR - F)
\end{abstract}

O voto é, assim, pela aprovação da Convenção Interamericana para Prevenir, Punir e Erradicar a violência contra a Mulher, sem reservas. O parecer foi aprovado por unanimidade.

\title{
PARECER DA COMISSÃO DE CONSTITUIÇÃO E JUSTIÇA E DE REDAÇÃO (CD), RÉGIS DE OLIVEIRA, 1995
}

[Câmara - Parecer 2]

O parecer da Comissão de Constituição e Justiça foi elaborado pelo Deputado Régis de Oliveira, em 03.07.1995. Após descrição da Convenção, o Deputado trata da reserva ao art. 12, presente na MSC 95/1995, dizendo que a Comissão de Relações Exteriores discorda da reserva, conforme parecer unanimemente aprovado. O parecer é pela constitucionalidade (DBR - F) e pela aprovação do Projeto de Decreto Legislativo.

A Comissão de Constituição e Justiça e de Redação opinou unanimemente pela constitucionalidade, juridicidade, técnica legislativa e, no mérito, pela aprovação do Decreto Legislativo 95/95.

\section{PARECER DA COMISSÃ DE SEGURIDADE SOCIAL E FAMÍLIA (CD), MARTA SUPLICY, 1994}

[Câmara - Parecer 3]

O parecer, de setembro de 1994, é de autoria da Deputada Marta Suplicy. A Deputada menciona o art. 18 da Declaração de Viena (DIN - F), resultado da Conferência Mundial dos Direitos Humanos, de 1993, que teria facilitado a discussão a respeito da violência contra as mulheres, que reza:

${ }^{197}$ DCN 17.08 .1995 , p. 18.592. 


\begin{abstract}
"Os Direitos Humanos das mulheres e das meninas são inalienáveis e constituem parte integral e indivisivel dos Direitos Humanos universais (...) A violência e todas as formas de abuso e exploração sexual, incluindo o preconceito cultural e o tráfico internacional de pessoas, são incompativeis com a dignidade e o valor da pessoa humana e devem ser eliminadas (...) Os Direitos Humanos das mulheres devem ser parte integrante das atividades das Nações Unidas na área dos Direitos Humanos".
\end{abstract}

Conforme o disposto na recomendação de Viena, a AGNU adotou, em 10.12.1993, a Declaração sobre a Violência contra a Mulher, que identifica os tipos de violência, marco que reconheceu, no sistema das Nações Unidas, a violência baseada em gênero (DIN - F). A Convenção de Belém do Pará insere-se nesse contexto, e seria incoerente, por parte do MRE, alegar a necessidade de apor ressalva ao art. 12, porque o mesmo é inédito e extremamente relevante (PBR - F). A aprovação desse artigo demonstra a relevância da interação entre a sociedade civil e o Estado, fundamental para construir e manter o sistema democrático (PBR - F). A Convenção é essencial para eliminar uma das mais cruéis formas de violação dos Direitos Humanos (DH - mulher).

O voto é, portanto, pela aprovação do projeto. O parecer foi aprovado por unanimidade.

\title{
REQUERIMENTOS DE URGÊNCIA
}

Foi feito requerimento de urgência para a tramitação do PDC 95/1995 na Câmara, em agosto de 1995. O requerimento foi aprovado em sessão ordinária de 09.08.1995, com 396 votos favoráveis, 01 negativo e 05 abstenções, com um total de 402 votos. ${ }^{198}$

No Senado, também foi feito requerimento de urgência, em 29.08.1995, do Senador Jader Barbalho e de outros líderes, devendo a matéria ser incluída em ordem do dia na segunda sessão ordinária subsequente. ${ }^{199}$

\section{PARECER DA COMISSÃO DE RELAÇÕES EXTERIROES E DEFESA NACIONAL (SF), BENEDITA DA SILVA, 1995}

[Senado - Parecer 1]

\footnotetext{
${ }^{198}$ DCN1 10.08.1995, p. 17.229, col. 02.

${ }^{199}$ DCN2 30.08.1995, p. 14.790.
} 
O parecer, de 31.08.1995, é de autoria da Senadora Benedita da Silva. Após relato a respeito da Convenção e de sua tramitação, a Senadora apresenta diversas estatísticas, do Brasil e do mundo, a respeito da violência contra a mulher. A Convenção é uma inovação legal que fortalece os esforços para superar essa violência, e sua importância para o Brasil seria inquestionável (PBR - F).

Sobre a reserva o art. 12, a Senadora reitera o entendimento da Deputada Sandra Starling, e acredita que não há motivos para efetuar essa reserva, pelo fato de o artigo expressar um dos maiores avanços no âmbito dos organismos internacionais, a participação da sociedade civil nos foros de representação internacional (PEB - F).

O voto é, portanto, pela aprovação da Convenção, sem reservas. O parecer foi aprovado por unanimidade. 


\section{ANÁLISE: CONVENÇÃO INTERAMERICANA SOBRE O DESAPARECIMENTO FORÇADO DE PESSOAS}

A Convenção Interamericana sobre o Desaparecimento Forçado de Pessoas, de 09.06.1994, entrou em vigor internacional em 28.03.1996, de acordo com as disposições de seu artigo XX. Essa Convenção foi assinada pelo plenipotenciário brasileiro em 10.06.1994, e ratificada em 26.07.2013. Foi enviada ao Congresso pela Mensagem Presidencial 1.204, de 1994. Seu processo de aprovação tramitou na Câmara dos Deputados como Projeto de Decreto Legislativo 94, de 1995, e no Senado Federal como Projeto de Decreto Legislativo 116, de 2008. Foi aprovada pelo Decreto Legislativo 127, de 08.04.2011, e promulgada pelo Decreto Presidencial 8.766, de 11.05.2016.

A Convenção foi o primeiro instrumento internacional a tratar especificamente dessa forma complexa de violação dos Direitos Humanos. Nela, os signatários não apenas se isentam da prática, combatendo-a; mas concordam em punir os perpetradores e os cúmplices desse crime, em suas respectivas jurisdições. Devem, inclusive, adotar medidas legislativas para tipificar o desaparecimento forçado como crime, cooperando entre si para prevenir, punir e erradicar essa prática. O tratado também inclui o desaparecimento forçado entre os crimes que justificam a extradição, para evitar a evasão dos acusados. A Convenção reconhece, ademais, a autoridade de uma comissão para adotar medidas preventivas em casos de desaparecimento forçado. ${ }^{200}$

\section{STATUS NA OEA}

http://www.oas.org/juridico/english/sigs/a-60.html

\section{MENSAGEM DO PODER EXECUTIVO (MSC 1.204/1994)}

A Mensagem, de 14.12.1994, redigida pelo Ministro das Relações Exteriores, senhor Celso Amorim, foi enviada ao Congresso pelo Presidente Luís Inácio Lula da Silva, em 25.12.1994. Para o Ministro, que assinou a Convenção em nome do Brasil, a adoção do

200 Informações obtidas em: http://www.cidh.org/basicos/english/Basic1.\%20Intro.htm\# ftn5. Acesso: 28.03.2016. 
tratado é decisiva para o avanço dos Direitos Humanos no âmbito regional, contribuindo para erradicar essa prática do continente (DH - F). A Convenção está em plena conformidade com as perspectivas do governo a respeito do tema, previamente manifestadas durante as negociações acerca da matéria (PEB - F). Está, ainda, em conformidade com a doutrina e o Direito Internacional, incluindo princípios jurídicos consolidados a respeito do tema.

Ao assinar a Convenção, o Ministro diz que aproveita o momento de sua aprovação pela Assembleia Geral da OEA para reiterar o compromisso do governo com a defesa dos Direitos Humanos no país (PBR - F).

\section{PARECER DA COMISSÃO DE RELAÇÕES EXTERIORES (CD), HAROLDO LIMA, 1995}

[Câmara - Parecer 1]

O parecer, de 17.05.1995, é de autoria do Deputado Haroldo Lima. Segundo ele, tratase de um momento oportuno para aprovar a Convenção, para fortalecer os Direitos Humanos em um continente "tantas vezes aviltado sob a vigência de regimes autoritários e, até mesmo, durante os períodos democráticos" (DH - F). O relator cita artigos do PIDCP, que tratam do direito à liberdade e à segurança da pessoa humana, além da liberdade de expressão: a Convenção, deste modo, seria coerente com os princípios consagrados pela ONU (DIN - F).

A Convenção, ademais, respeita a soberania dos países, quando, ao definir os parâmetros para a extradição, afirma que sempre estará sujeita às disposições previstas na Constituição do Estado (DBR - F - menção indireta à CF/1988).

O parecer é, portanto, pela aprovação da Convenção. Foi aprovado por unanimidade pela Comissão.

\section{PARECER DA COMISSÃO DE CONSTITUIÇÃO E JUSTIÇA E DE REDAÇÃO (CD), RÉGIS OLIVEIRA, 1995}

[Câmara - Parecer 2]

O parecer, de 1995, é de autoria do Deputado Régis Oliveira. Após relatório a respeito do tema, o Deputado diz que o projeto atende aos requisitos constitucionais e regimentais (DBR - F), votando por sua aprovação. O parecer foi aprovado por unanimidade pela Comissão. 


\section{REQUERIMENTO, 1999}

Em maio de 199, é feito requerimento, por parte do Deputado Jair Bolsonaro, de retirada do PDS 94/1995 da ordem do dia. Segundo o Deputado, não haveria convergência de pareceres entre os Ministérios do Exército, da Justiça e das Relações Exteriores. Solicita, então, que a matéria fosse retirada da pauta, para melhor discussão do tema.

O requerimento foi aprovado.

\section{PARECER DA COMISSÃO DE RELAÇÕES EXTERIORES E DEFESA NACIONAL (SF), ROMEU TUMA, 2009}

[Senado - Parecer 1]

O parecer, de autoria do Senador Romeu Tuma, é de 2009. Após explanação a respeito da Convenção e de sua tramitação, destaca que a Convenção está em consonância com o direito nacional (DBR - F).

O Senador menciona que, apesar de o MRE entender que a Convenção está em consonância com o direito interno, esse não é o entendimento do Ministério da Defesa, cuja principal alegação é a existência de conflito entre o art. IX da Convenção ${ }^{201}$ e o ordenamento brasileiro - especificamente o princípio do juiz natural combinado com o que a Constituição dispõe a respeito da Justiça Militar (DBR - C). ${ }^{202}$ Ademais, alguns dos crimes tipificados pelo Decreto-Lei 1.001/1969 poderiam estar relacionados com a temática do desaparecimento de pessoas, e seus agentes não poderiam furtar-se do julgamento conduzido pelo juiz constitucionalmente competente para a causa; que, no caso, é o juiz militar (DBR - F). A Justiça Militar brasileira não pode ser considerada tribunal de exceção, e tampouco os julgamentos por ela emitidos podem ser considerados brandos, o que está em conformidade com o que determina a Convenção. Assim, em virtude desse conflito, o parecer sustenta efetuar reserva ao art. IX $(\mathrm{PBR}-\mathrm{C})$.

\footnotetext{
${ }^{201}$ Art. IX: "Os suspeitos dos atos constitutivos do delito de desaparecimento forçado de pessoas só poderão ser julgados pelas jurisdições de direito comum competentes, em cada Estado, com exclusão de qualquer outra jurisdição especial, particularmente a militar".

${ }^{202}$ Considerarei os argumentos mencionados pelo Senador como argumentos do Poder Executivo. A autora, porém, não teve acesso ao conteúdo integral dessa manifestação do Ministério da Defesa, que não constava na tramitação do projeto na Câmara dos Deputados nem no Senado Federal. Trata-se, conforme o parecer, do Ofício 13.206/Aspar-MD, informação n. 417.
} 
Após discutir a respeito da possibilidade de o Congresso apor "reservas" a tratados, e verificar a possibilidade de aposição de reservas à Convenção, o Senador finalmente propõe, com maior correção, que seja expressa uma restrição ao artigo IX da Convenção, que, posteriormente, seria transformada em reserva pelo Poder Executivo.

A relatoria da matéria, no entanto, é redistribuída para o Senador Mozarildo Cavalcanti, que elabora novo parecer em nome da Comissão de Relações Exteriores e Defesa Nacional.

\section{PARECER DA COMISSÃO DE RELAÇÕES EXTERIORES E DEFESA NACIONAL (SF), MOZARILDO CAVALCANTI, 2011}

[Senado - Parecer 2]

O parecer, de 24.03.2011, é de autoria do Senador Mozarildo Cavancanti. O relator cita os antecedentes internacionais da Convenção, que não tinham, contudo, força normativa obrigatória, um avanço no que se refere à Convenção (DIN - F). ${ }^{203}$ Segundo o relator, o fato de o Brasil ter aprovado a Convenção Internacional para a Proteção de Todas as Pessoas Contra o Desaparecimento, que reafirma parte significativa dos princípios fundamentais da Convenção em apreço, demonstra a aceitação de seus preceitos principais (PBR - F).

O Senador menciona também que o Estatuto do TPI, ratificado e promulgado no Brasil, tipifica o desaparecimento forçado de pessoas como crime contra a humanidade, naqueles casos em que praticado generalizada ou sistematicamente, o que confirma dispositivo do preâmbulo da Convenção (DIN - F).

A ratificação da Convenção também se coaduna com a sentença internacional proferida pela Corte Interamericana de Direitos Humanos contra o Brasil, no caso Gomes Lund, que solicitou que o Brasil adotasse, dentro de prazo razoável, as medidas necessárias para ratificar a Convenção em pauta. ${ }^{204}$

O voto é pela aprovação do projeto de decreto legislativo.

\footnotetext{
${ }^{203}$ O Senador menciona a Declaração sobre a Proteção de todas as pessoas contra o Desaparecimento Forçado ou Involuntário (Resolução AGNU 47/133, de 1992) e a Convenção Internacional para a proteção de todas as pessoas contra as desaparições forçadas.

${ }^{204}$ Apesar de não ser um tratado, definiu-se decisão de corte internacional como Direito Internacional, lato sensu.
} 
Em 24.03.2011, a Comissão de Relações Exteriores e Defesa Nacional reúne-se para aprovar o parecer do Senador Mozarildo Cavalcanti, que é aprovado e passa a constituir parecer da Comissão de Relações Exteriores e Defesa Nacional.

\section{DISCUSSÃO, PLENÁRIO DO SENADO FEDERAL}

\section{[SF PLEN]}

A discussão tem apenas a manifestação do Senador Itamar Franco. ${ }^{205}$ Nela, o Senador ressalta que a proposição tramitou durante dezesseis anos no Congresso. Para ele, seria necessário alterar o sistema legislativo do país, que permitiu que um texto "da maior importância" tramitasse internamente durante tanto tempo, tendo sido retirado da pauta diversas vezes (PBR - F).

O projeto é, finalmente, aprovado, e transformado em Decreto Legislativo. 


\section{ANÁLISE: CONVENÇÃO INTERAMERICANA SOBRE TRÁFICO INTERNACIONAL DE MENORES}

A Convenção Interamericana sobre Tráfico Internacional de Menores, de 18.03.1994, entrou em vigor internacional em 15.08.1997. Essa Convenção foi assinada pelo plenipotenciário brasileiro em 18.03.1994, e o instrumento de ratificação da Convenção depositado pelo Governo brasileiro em 08.07.1997, passando a vigorar, para o Brasil, em 15.08.1997. Foi enviada ao Congresso pela Mensagem Presidencial 94, de 1995. Seu processo de aprovação tramitou na Câmara dos Deputados como Projeto de Decreto Legislativo 90, de 1995, e no Senado Federal como Projeto de Decreto Legislativo 73, de 1996. Foi aprovado pelo Congresso Nacional pelo Decreto Legislativo 105, de 30.10.1996, e promulgada pelo Decreto Presidencial 2.740, de 20.08.1998.

A Convenção é considerada instrumento relevante para assegurar a proteção efetiva dos menores, por mecanismos que garantam o respeito aos seus direitos, além da percepção de que o tráfico de menores é uma preocupação universal, devendo ser, portanto, prevenido e punido. A OEA reafirmou, com a Convenção, a importância da cooperação internacional para atingir a proteção efetiva dos interesses dos menores. Os Estados signatários concordam em assegurar a proteção dos direitos e dos interesses dos menores; estabelecer um sistema de assistência mútua entre os Estados-parte, dedicado a prevenir e a punir o tráfico internacional de menores, adotando medidas administrativas e legais nesse sentido; e assegurar o rápido retorno das vítimas desse tipo de tráfico ao país de residência, sempre considerando seus interesses. ${ }^{206}$

\section{STATUS NA OEA}

http://www.oas.org/dil/esp/tratados_b-

57_convencion_interamericana_sobre_trafico_internacional_de_menores_firmas.htm 8.- BRAZIL: Designation of Central Authority (January 26, 2007): Brazil appointed the Ministério da Justiça as the central authority for the Inter-American Convention on International Traffic in Minors:

206 Informações obtidas em: https://www.oas.org/dil/treaties_B-57_Inter-American_Convention_on International Traffic in Minors.htm. Acesso: 29.03.2016 
MENSAGEM DO PODER EXECUTIVO (MSC 94/1995)

A Mensagem 94, de 16.01.1995, foi elaborada pelo Ministro das Relações Exteriores, senhor Luiz Felipe Lampreia, e enviada ao Congresso pelo Presidente da República, Fernando Henrique Cardoso, em 19.01.1995. Segundo o Ministro, a Convenção é a primeira a regular, em instrumento único, significativa quantidade de aspectos civis e penais concernentes ao tráfico de menores. Em razão de sua característica programática, pode auxiliar o aperfeiçoamento da legislação nacional dos países que a adotem, o que seria relevante para a tipificação nacional das condutas (PBR - F).

\section{PARECER DA COMISSÃO DE RELAÇÕES EXTERIORES (CD), RENAN KURTZ, 1995}

[Câmara - Parecer 1]

O parecer, de 10.05.1995, é de autoria do Deputado Renan Kurtz. Após breve descrição do tratado, o relator aponta que o tema do tráfico internacional de menores merece preocupação especial e coordenada por parte dos Estados, uma vez que é de difícil repressão, e que, atualmente, engloba não apenas os menores encaminhados para adoção, mas grupos que os utilizam com o objetivo de extração de órgãos (DH - menores - F).

Sob a perspectiva do Direito Internacional, a Convenção é inovadora, uma vez que inexistem instrumentos internacionais que descrevam as condutas presentes nela como ilícitos. Ela, ademais, regulamenta mecanismos de cooperação entre os signatários, além de determinar a competência para conhecer e para julgar o tráfico internacional de menores. Ainda no âmbito do Direito Internacional, amplia os limites de proteção aos direitos fundamentais, ao reconhecer que a criança tem o direito de crescer e de ser educada por seus genitores em seu país de nascimento. A Convenção não admite, portanto, argumentos em prol da manutenção do menor vítima de tráfico em outro país, mesmo que a justificativa seja a incapacidade econômica dos pais ( $\mathrm{DH}$ - menores - F).

O Deputado destaca a necessidade de atentar ao art. 23 da Convenção:

Artigo 23: Os Estados Partes poderão declarar, seja no momento da assinatura e da ratificação desta Convenção ou da adesão à mesma, ou posteriormente, que reconhecerão e executarão as sentenças penais proferidas em outro Estado Parte 
no que se refere à indenização por perdas e danos decorrentes do tráfico internacional de menores.

No entendimento do Deputado, o art. 23 deve ser esclarecido pelo Brasil "no ato da ratificação ou assinatura". ${ }^{207}$ Ao obrigar-se à Convenção, o país deve afirmar que

\begin{abstract}
"Qualquer sentença estrangeira não será diretamente aplicável no território nacional. Para que a sentença proferida no exterior seja aplicável deverá ser previamente homologada pelo Supremo Tribunal Federal, nos termos do art.102, inciso I, letra " $h$ ", da Constituição Federal." (DBR - C). ${ }^{208}$
\end{abstract}

O Deputado remete o tema à Comissão de Constituição e Justiça e Redação, a quem compete proferir parecer a respeito de aspectos constitucionais (DBR - regimento interno C). A Comissão de Relações Exteriores aprovou unanimemente o parecer.

\title{
PARECER DA COMISSÃO DE SEGURIDADE SOCIAL E FAMÍLIA (CD), RITA CAMATA, 1995
}

[Câmara - Parecer 2]

O parecer da Comissão de Seguridade Social e Família, de autoria da Deputada Rita Camata, data de 08.06.1995. Após relato a respeito da Convenção, a Deputada apresenta o seu relatório. No Brasil, o tema do tráfico internacional de menores foi analisado por duas Comissões Parlamentares de Inquérito (CPI) no Congresso Nacional. Uma delas investigou o extermínio de crianças e de adolescentes, e a outra apurou a responsabilidade pela exploração de atividade de prostituição de crianças e de adolescentes. Uma das conclusões dos trabalhos foi o fato de as adoções internacionais serem usadas como disfarce para o tráfico internacional de crianças. Para coibir o tráfico é necessário criar métodos eficazes de controle para a saída de crianças brasileiras do território nacional (PBR - F).

\footnotetext{
${ }^{207}$ Necessário reiterar que a assinatura de um tratado não significa entrada em vigor do mesmo para o país - a assinatura da presente Convenção deu-se em 1994, e a entrada em vigor para o Brasil, apenas em 1997.

${ }^{208}$ DCN 03.08.1995, p.15.466. O art. 102, I, h, CF foi revogado pela EC 45/2004. Atualmente, a homologação de sentença estrangeira é de competência do Superior Tribunal de Justiça (STJ), conforme o art. 105, I, i, CF: Art. 105. Compete ao Superior Tribunal de Justiça:

I - processar e julgar, originariamente: (...)

i) a homologação de sentenças estrangeiras e a concessão de exequatur às cartas rogatórias; (...)
} 
Para a Deputada, o projeto de decreto legislativo possui manifesta importância, uma vez que, aprovada a Convenção, o país reitera a sua "nova posição no âmbito das Relações Internacionais: (PEB - F) um país coerente com a pregação de absoluta prioridade para crianças e adolescentes, prevista no art. 227 da Constituição Federal (DBR - F)". 209

A Deputada vota pela aprovação do texto da Convenção na forma do Projeto de Decreto Legislativo 90/1995, de autoria da CRE, que não faz nenhuma reserva ao texto da Convenção. A Comissão de Seguridade Social e Família aprovou unanimemente o PDC 90/1995.

\section{PARECER dA COMISSÃO dE CONSTITUIÇÃO E JUSTIÇA E DE REDAÇÃO, (CD), RÉGIS DE OLIVEIRA, 1995}

[Câmara - Parecer 3]

O Parecer, de autoria do Deputado Regis de Oliveira, data de 28.05.1995. Ele aponta, apenas, que o PDC 90/1995 atende os requisitos de constitucionalidade (DBR -F), juridicidade e técnica legislativa, votando pela aprovação. A CCJ aprovou o parecer por unanimidade.

\section{PARECER DA COMISSÃO DE CONSTITUIÇÃO E JUSTIÇA SOBRE EMENDA OFERECIDA EM PLENÁRIO AO PDC 90/1995, NELSON TRAD (AUTOR) E HÉLIO BICUDO (RELATOR)}

[Câmara - Parecer 4]

O parecer, de Hélio Bicudo, data de 20.09.1995. Trata-se de apreciação da emenda oferecida pelo Deputado Nelson Trad, em junho de 1995, com o objetivo de apresentar ressalva ao art. 23 da Convenção, relativo ao reconhecimento e à execução de sentenças e

${ }^{209}$ DCN 03.08.1995, p. 15.471. (grifo nosso).

Artigo 227, CF 1988, texto original (mencionado pela Deputada): É dever da família, da sociedade e do Estado assegurar à criança e ao adolescente, com absoluta prioridade, o direito à vida, à saúde, à alimentação, à educação, ao lazer, à profissionalização, à cultura, à dignidade, ao respeito, à liberdade e à convivência familiar e comunitária, além de colocá-los a salvo de toda forma de negligência, discriminação, exploração, violência, crueldade e opressão. (...)

Redação dada Pela Emenda Constitucional no 65, de 2010: Art. 227, CF 1988: É dever da família, da sociedade e do Estado assegurar à criança, ao adolescente e ao jovem, com absoluta prioridade, o direito à vida, à saúde, à alimentação, à educação, ao lazer, à profissionalização, à cultura, à dignidade, ao respeito, à liberdade e à convivência familiar e comunitária, além de colocá-los a salvo de toda forma de negligência, discriminação, exploração, violência, crueldade e opressão. (...). (grifo nosso). 
penas em outro Estado no que se refere a indenizações decorrentes do tráfico internacional de menores - para que a aceitação do tratado esteja em conformidade com a disposição do art. 102, I, "h”, CF (DBR - C).

Para o relator, apesar da inexistência de inconstitucionalidade na emenda, o seu conteúdo já estaria inserido no art. 23 da Convenção, que destaca que as partes poderão, em qualquer caso, reconhecer e executar as sentenças proferidas em outro país signatário, no que tange à indenização decorrente do tráfico internacional de menores.

O relator propõe, portanto, a rejeição da emenda, e a aprovação do texto da Convenção tal como recomendado pelas Comissões de Reações Exteriores e de Constituição e Justiça e de Redação.

\section{COMISSÃO DE RELAÇÕES EXTERIORES, RELATÓRIO A RESPEITO DA EMENDA OFERECIDA, MÁRIO CAVALAZZI, 1996}

[Câmara - Parecer 5]

O parecer, de 08.05.1996, é de autoria do Deputado Mário Cavalazzi, e refere-se à emenda proposta pelo Deputado Nelson Trad. Segundo o relator, a Convenção trata de tema que tem preocupado a sociedade brasileira (PBR - F).

O relator, ao apreciar a questão da emenda, entende que o texto do art. 23 da Convenção, ao dizer "poderão declarar", faculta aos Estados o reconhecimento e a execução de sentenças penais estrangeiras em determinados casos, deixando aberto à discricionariedade estatal fazê-lo ou não. Ademais, diz-se convicto de que o texto não vincula a assinatura e a ratificação do tratado à obrigatoriedade desse artigo, por essa declaração de vontade poder ocorrer quando da assinatura e da ratificação/adesão ao tratado, ou mesmo posteriormente.

Para o relator, o problema destacado pela emenda e pelos relatores que mencionaram a necessidade de atenção ao art. 23 apenas existirá caso o Brasil faça a declaração mencionada pelo tratado. Mesmo nesse caso, entende que essa declaração, caso efetuada, não implica em aplicação direta da sentença estrangeira no Brasil, pois não existe essa determinação no art. 23. Pelo contrário, acredita que a sentença estrangeira seria aplicável em conformidade com as leis internas - no caso do Brasil, após homologação.

A ressalva ao art. 23, ademais, implica a impossibilidade de sua aplicação ao Brasil, impedindo que o país utilize esse instrumento, criado para coibir o tráfico internacional de 
menores, potencialmente permitindo a impunidade de envolvidos nessa prática desumana (DH - F).

O parecer é, portanto, pela rejeição da emenda. É aprovado, por unanimidade, o parecer contrário do relator, Mário Cavalazzi, à emenda de plenário.

\section{PARECER DA COMISSÃO DE RELAÇÕES EXTERIORES E DEFESA} NACIONAL (n. 547 - SF), PEDRO SIMON, 1996

[Senado - Parecer 1]

O parecer, de 15.10.1996, é de autoria do Senador Pedro Simon. Segundo ele, os objetivos da Convenção são de grande importância, não só para os Estados signatários, mas para toda a comunidade internacional (PEB - F). Não existiriam motivos para o país deixar de internalizar a Convenção, compatível com o ordenamento jurídico brasileiro (DBR - F). O parecer é, portanto, pela aprovação do PDS 73/1996.

O parecer foi aprovado por unanimidade. 


\section{ANÁLISE: CONVENÇÃO INTERAMERICANA PARA A ELIMINAÇÃO DE TODAS AS FORMAS DE DISCRIMINAÇÃO CONTRA AS PESSOAS PORTADORAS DE DEFICIÊNCIA}

A Convenção Interamericana para a Eliminação de Todas as Formas de Discriminação contra as Pessoas Portadoras de Deficiência, de 06.08.1999, entrou em vigor internacional em 14.09.2001, 30 dias após o depósito do $6^{\circ}$ instrumento de ratificação. Essa Convenção foi assinada pelo plenipotenciário brasileiro em 08.06.1999, e ratificada em 17.07.200. Foi enviada ao Congresso pela Mensagem 1545, de 1999. Seu processo de aprovação tramitou na Câmara dos Deputados como Projeto de Decreto Legislativo 418, de2000, e no Senado Federal como Projeto de Decreto Legislativo 47, de 2001. A Convenção foi aprovada pelo Decreto Legislativo 198, de 13.06.2001, e promulgada pelo Decreto Presidencial 3.956 de 08.10.2001, e entrou em vigor para o Brasil em 14.09.2001.

Seus objetivos são prevenir e eliminar todas as formas de discriminação contra pessoas com deficiências, além de promover a sua integração à sociedade. A Convenção prevê um Comitê para a eliminação de todas as formas de discriminação contra pessoas com deficiências, formado por um representante escolhido por cada Estado signatário. Esse Comitê deverá monitorar a observância com os compromissos assumidos sob a égide da Convenção. ${ }^{210}$

\section{STATUS NA OEA}

http://www.oas.org/juridico/english/sigs/a-65.html MENSAGEM DO PODER EXECUTIVO (MSC 1.545/1999)

A Mensagem do Poder Executivo de 1545, de 04.10.1999, foi elaborada pelo Ministro das Relações Exteriores, senhor Luiz Felipe Lampreia, e enviada pelo Congresso Nacional pelo Presidente da República, Fernando Henrique Cardoso, em 22.10.1999. Segundo o Ministro, a delegação brasileira da $29^{\mathrm{a}}$ Assembleia-Geral da OEA participou ativamente da

210 Informações obtidas em: http://www.cidh.org/basicos/english/Basic1.\%20Intro.htm\# ftn5. Acesso: 29.03.2016 
elaboração da Convenção, a qual contemplou as expectativas nacionais em relação ao assunto em pauta. (PEB - F) A Convenção tem como objetivo de fortalecer o sistema regional (interamericano) de proteção dos Direitos Humanos (DH - F).

\section{PARECER DA COMISSÃO DE RELAÇÕES EXTERIORES E DEFESA NACIONAL (CD), CLÓVIS VOLPI, 2000}

[Câmara - Parecer 1]

O parecer é de autoria do Deputado Clóvis Volpi, de 29.03.2000. Em seu voto, aponta que a Convenção aumenta a proteção aos Direitos Humanos no âmbito do sistema interamericano, ao introduzir, de modo pioneiro, o princípio da proteção e da não discriminação dos portadores de deficiência. (DH - F) A normatização dos Direitos Humanos é campo relativamente novo, e em constante processo de construção, sendo a DUDH marco de extrema relevância nesse sentido, ao proclamar o princípio da igualdade e liberdade dos seres humanos, além da não discriminação. (DIN - F)

Durante o século XX, direitos foram proclamados conforme os grupos que deveriam ser protegidos, como as mulheres e as crianças; ou as atividades a serem regulamentadas, como a proteção do trabalho e a condenação ao racismo. Os direitos dos portadores de deficiências, porém, é mais recente, e passou a ser codificado no âmbito internacional há pouco tempo (DH - F). Os portadores de deficiência devem ter acesso aos meios que os auxiliem a desenvolver suas capacidades de maneira plena, e a internalização da Convenção reafirma, para a população brasileira $(\mathrm{PBR}-\mathrm{F})$ e para a comunidade internacional, o compromisso do país com os Direitos Humanos (PEB - F).

Assim, o Deputado vota pela aprovação do projeto. A Comissão de Relações Exteriores e de Defesa Nacional aprovou, unanimemente, o parecer.

PARECER DA COMISSÃO DE SEGURIDADE SOCIAL E FAMÍLIA (CD), EDUARDO JORGE, 2000

[Câmara - Parecer 2] 
O Parecer da Comissão de Seguridade Social e Família foi elaborado pelo Deputado Eduardo Jorge, em 09.05.2000. Após breve descrição do tratado, e menção à tramitação da matéria em regime de urgência (art.151, I, “j” do RICD), ${ }^{211}$ o relator profere o seu parecer.

Aponta para a relevância da Convenção, que tem como objetivo reiterar o compromisso dos signatários em relação à adoção de diretrizes que eliminem a discriminação contra portadores de deficiência. Destaca que parte significativa das questões abordadas pela Convenção foram incorporadas ao ordenamento pátrio na lei 7.853/1989, ${ }^{212}$ e no decreto 3.298/1999. ${ }^{213}$ (DBR - F) A adesão a instrumento internacional que tem por objetivo facilitar a inserção do portador de deficiências no mercado de trabalho, como é o caso em pauta, reforçaria a ação das autoridades públicas e da sociedade, para que fossem efetivadas as medidas propostas (PBR - F).

O parecer é pela aprovação do PDC 418/2000. A Comissão aprovou o parecer por unanimidade.

\section{PARECER DA COMISSÃO DE CONSTITUIÇÃO E JUSTIÇA E DE REDAÇÃO (CD), WALDIR PIRES, 2000}

[Câmara - Parecer 3]

O parecer, de 11.10.2000, é de autoria do Deputado Waldir Pires. Após mencionar o parecer positivo da Comissão de Relações Exteriores, profere o seu parecer.

$\mathrm{O}$ relator aponta para as principais conquistas do constitucionalismo do século XX, entre elas a valorização dos direitos da pessoa humana. Menciona as origens históricas dessa transformação, que remontam ao Bill of Rights inglês, às Revoluções americana e francesa, até instrumentos como a DUDH (DIN - F). As Constituições do mundo moderno estariam

${ }^{211}$ RICD: CAPÍTULO VI DO REGIME DE TRAMITAÇÃO

Art. 151. Quanto à natureza de sua tramitação podem ser: I - urgentes as proposições: (...)

j) oriundas de mensagens do Poder Executivo que versem sobre acordos, tratados, convenções, pactos, convênios, protocolos e demais instrumentos de política internacional, a partir de sua aprovação pelo órgão técnico específico, através de projeto de decreto legislativo, ou que sejam por outra forma apreciadas conclusivamente; (...). Informação disponível em: http://www.camara.gov.br/internet/legislacao/ regimento interno/RIpdf/RegInterno.pdf. Acesso: 06.03.2015.

${ }^{212}$ Lei 7.853, de 24.10.1989. Dispõe sobre o apoio às pessoas portadoras de deficiência, sua integração social, sobre a Coordenadoria Nacional para Integração da Pessoa Portadora de Deficiência, institui a tutela jurisdicional de interesses coletivos ou difusos dessas pessoas, disciplina a atuação do Ministério Público, define crimes, e dá outras providências.

213 Decreto 3.298, de 20.12.1999. Regulamenta a Lei 7.853, de 24.10.1989, dispõe sobre a Política Nacional para a Integração da Pessoa Portadora de Deficiência, consolida as normas de proteção, e dá outras providências. 
imbuídas, em seus princípios e nas regras materiais que as compõem, desse "espírito de fraternidade", que contrasta com a real situação de homens e de mulheres nas sociedades atuais, marcadas por injustiças sociais extremas. (DH - F)

A CF/1988 seria um exemplo de instrumento normativo que objetiva o bem-estar da população, consagrando direitos essenciais, como o direito à vida, à liberdade, à igualdade, entre outros. Além disso, prevê a proteção e a não-discriminação dos portadores de deficiência (DBR - F). Deste modo, o relator aponta para a aprovação do PDC.

O parecer é aprovado por unanimidade.

\section{DISCUSSÃO EM PLENÁRIO NA CÂMARA DOS DEPUTADOS, DCD 22.02.2001 [CD PLEN]}

Houve manifestações de alguns Deputados no momento de aprovação do PDC 418/2000. O primeiro a manifestar-se foi o Deputado Aécio Neves, que mencionou sessão solene ocorrida naquele mesmo dia, na Câmara, proposta pelo Deputado Jaques Wagner, que contou com a presença dos atletas que representaram o país nas Paraolimpíadas de Sydney. Caberia, agora, à Câmara a responsabilidade de responder, legislativamente, para a inserção dos portadores de deficiência não apenas no mercado de trabalho, mas na sociedade brasileira como um todo (PBR - F).

Segue a manifestação do Deputado Flávio Arns, que ressalta a importância da aprovação do tratado. Destaca a existência de legislação específica a respeito do tema no Brasil, que contempla muitos dos dispositivos elencados na Convenção (DBR - F). A aprovação por parte do Brasil demonstra o empenho do país não apenas para proteger a sua população (PBR - F), mas para os outros países do mundo (PEB - F).

O Deputado Wellington Dias ressalta que, além do entendimento entre os países signatários e as entidades que tratam do respeito aos deficientes, existe a necessidade da ampla divulgação do texto da Convenção. No Brasil, os deficientes não recebem o atendimento devido, apesar da existência de legislação nesse sentido (PBR- F).

O Deputado Babá destaca a sua iniciativa de emenda constitucional que vinculasse, para fins de concurso público, a definição de deficiência à estabelecida pela Organização Mundial da Saúde (OMS), parâmetro internacional (DIN - F). Apesar de ter sido julgada inconstitucional, o parlamentar diz que irá recorrer. 
O Deputado Arnaldo Faria de Sá diz que a Convenção é essencial para proteger os direitos dos portadores de deficiência (DH - F). O Poder Legislativo deveria ter legislado para dar maior atenção aos problemas dessas pessoas, sendo que, apesar da existência de legislação protetiva, esta é, infelizmente, descumprida (PBR - F). É necessário aprovar não apenas a Convenção, mas outras leis que garantam a cidadania delas (PBR - F).

O Deputado Luiz Antonio Fleury destaca o aspecto urbanístico das barreiras impostas aos cidadãos com deficiência, barreiras estas que precisam ser superadas (PBR - F). O Deputado Inocêncio Oliveira, por sua vez, também destaca as barreiras cotidianas enfrentadas pelos portadores de deficiências, e a necessidade de superá-las na prática (PBR - F).

O Presidente da Casa, senhor Aécio Neves, manifesta-se novamente, falando sobre a necessidade de integrar efetivamente os deficientes à sociedade (PBR - F).

O Deputado Inácio Arruda manifesta-se e atenta para a necessidade de uma ação governamental concertada para superar as dificuldades vividas pelos portadores de deficiências (PBR - F). É necessário, também, sancionar gestores públicos que não garantam a acessibilidade e a ausência de discriminação contra pessoas portadoras de deficiência (PBR - F). O Projeto é aprovado por unanimidade.

\section{PARECER DA COMISSÃO DE RELAÇÕES EXTERIORES E DEFESA NACIONAL (n. 484 - SF), ROMEU TUMA, 2001}

[Senado - Parecer 1]

O parecer, de autoria do Senador Romeu Tuma, data de 29.05.2001. ${ }^{214}$ Segundo o relator, a Convenção reforça a adesão do continente americano aos princípios da DUDH, e da Convenção Americana de Direitos do Homem (DIN - F). É matéria de extrema relevância, por almejar aumentar a sociabilidade das pessoas com deficiências (DH - F).

O parecer é favorável à aprovação do tratado. Foi aprovado por unanimidade pela Comissão.

\footnotetext{
${ }^{214}$ Apesar de o endereço eletrônico do Senado Federal informar que o parecer é de autoria do Senador Fernando Matusalém, este redigiu o parecer publicado em seguida ao parecer 484, de autoria do Senador Romeu Tuma. O parecer elaborado por Fernando Matusalém, de número 485/2001, diz respeito ao PDC 55/2001, que aprova o texto do Acordo sobre Cooperação Científica e Tecnológica celebrado entre o governo brasileiro e o ucraniano, em 15.11.1999.
} 


\section{DISCUSSÃO EM PLENÁRIO, DSF 13.06.2001}

\section{[SF PLEN]}

O PDS 47/2001 foi votado no Senado Federal em junho de 2001. Antes da votação, manifestou-se a Senadora Emília Fernandes, que explicou os aspectos principais da Convenção e a tramitação do projeto até o momento de sua votação na Casa. O Brasil, ressalta, assinou previamente acordos do tipo, e a Convenção viria a somar-se a eles (DIN F). A matéria seria relevante não apenas sob o aspecto humanitário (DH - F), mas social (PBR - F). 


\section{ANÁLISE: PROTOCOLO DE ASSUNÇÃO SOBRE COMPROMISSO COM A PROMOÇÃO E PROTEÇÃO DOS DIREITOS HUMANOS DO MERCOSUL}

O Protocolo de Assunção sobre Compromisso com a Promoção e Proteção dos Direitos Humanos do Mercosul, de 20.06.2005, entrou em vigor internacional 03.04.2010. Essa Convenção foi assinada pelo plenipotenciário brasileiro em 20.06.2005, e ratificada em 04.03.2010, entrando em vigor para o Brasil em 03.04.2010. Foi enviada ao Congresso pela Mensagem Presidencial 897, de 2006. Seu processo de aprovação tramitou na Câmara dos Deputados como Projeto de Decreto Legislativo 495, de 2008, e no Senado Federal como Projeto de Decreto Legislativo 486, de 2009. Foi aprovada pelo Decreto Legislativo 592, de 27.08.2009, e promulgada pelo Decreto Presidencial 7.225, de 01.07.2010.

O Protocolo determina que os signatários deverão cooperar para promover e para proteger os Direitos Humanos, as liberdades fundamentais e as instituições democráticas, condições essenciais para o processo de integração no Mercosul. O Protocolo deve ser aplicado em casos de violações graves e sistemáticas aos Direitos Humanos, nos casos em que o país se encontra em situação de crise institucional ou em estado de exceção. Se as consultas forem ineficazes, os demais Estados do bloco deverão avaliar providências a serem tomadas, considerando a gravidade da situação. Podem ser tomadas medidas que vão da interrupção do direito do país de participar do processo de integração até a suspensão de seus direitos e obrigações. Essas medidas deverão ser adotadas por consenso, e informadas à parte afetada, que não participa do processo decisório; e cessarão quando o país afetado comunicar aos demais que as causas que as justificaram foram solucionadas. ${ }^{215}$

\section{STATUS NO MERCOSUL}

http://www.mre.gov.py/tratados/public_web/DetallesTratado.aspx?id=1\%2frUWpYuZN nue7PIseEbYg\%3d\%3d\&em=lc4aLYHVB0dF+kNrtEvsmZ96BovjLlz0mcrZruYPcn8\% $3 d$

215 Informações obtidas em: http://www.sdh.gov.br/importacao/noticias/ultimas noticias/2009/09/MySQL Noticia.2009-09-01.2658. Acesso: 30.03.2016 
MENSAGEM DO PODER EXECUTIVO (MSC 897/2006)

A Mensagem, de 11.09.2006, redigida pelo Ministro Celso Amorim, foi enviada ao Congresso pelo Presidente da República, Luís Inácio Lula da Silva, em 13.10.2006. Após explicação a respeito do protocolo, o Ministro diz que o instrumento complementa o Protocolo de Ushuaia sobre Compromisso Democrático, celebrado entre os países do Mercosul, Bolívia e Chile (DIN - F). O fato de o Protocolo precisar da ratificação de todos os membros para entrar em vigor destaca a importância de sua ratificação pelo Brasil (PBR - F); demonstração do seu desempenho para o fortalecimento político e institucional do Mercosul, particularmente no âmbito dos Direitos Humanos, e na rápida internalização das normas provenientes do bloco (PEB - F).

\section{PARECER DA COMISSÃO PARLAMENTAR CONJUNTA DO MERCOSUL - REPRESENTAÇÃO BRASILEIRA, 2008}

[Câmara - Parecer 1]

Trata-se de parecer exarado pela representação brasileira da Comissão Parlamentar Conjunta do Mercosul, de 21.02.2008, pelo Deputado Geraldo Thadeu. ${ }^{216}$ Segundo ele, o Protocolo complementa o Protocolo de Ushuaia sobre Compromisso Democrático no Mercosul, Bolívia e Chile (DIN - F). Em razão da relevância da proteção dos Direitos Humanos para os membros do bloco, e da prioridade da manutenção da ordem democrática para garantir o exercício desses direitos, o parecer é pela aprovação do Protocolo (PEB - F). O parecer foi aprovado por unanimidade.

\section{PARECER DA COMISSÃO DE RELAÇÕES EXTERIORES E DEFESA NACIONAL (CD), ANTONIO CARLOS MENDES THAME, 2008}

[Câmara - Parecer 2]

O parecer, de 29.05.2008, é de autoria do Deputado Antonio Carlos Mendes Thame. O Deputado recorda as menções aos Direitos Humanos na Carta da ONU (DIN - F), que

\footnotetext{
${ }^{216}$ De acordo com o art. $3^{\circ}$, I, da Resolução 1/2007 do Congresso, compete à Representação Brasileira no Parlamento do Mercosul "apreciar e emitir parecer a todas as matérias de interesse do Mercosul que venham a ser submetidas ao Congresso Nacional, inclusive as emanadas dos órgãos decisórios do Mercosul, nos termos do art. $4^{\circ}$, XII do Protocolo Constitutivo do Parlamento do Mercosul". No caso de MSC, a Representação brasileira "examinará a matéria quanto ao mérito e oferecerá o respectivo projeto de decreto legislativo".
} 
estabelece diretrizes a proteção desses direitos. O texto do protocolo, um acordo regional, tem como objetivo reafirmar princípios gerais, criando mecanismo para manter o equilíbrio no continente, dotando os países de mecanismos para a defesa efetiva dos direitos fundamentais (PEB - F).

O voto é pela aprovação do projeto. O parecer foi aprovado por unanimidade.

\section{PARECER dA COMisSÃo de DiREITOS huMANOS E MiNORIAS (CD), GERALDO THADEU, 2008}

[Câmara - Parecer 3]

O parecer, de 22.10.2008, é de autoria do Deputado Geraldo Thadeu. Segundo ele, o Protocolo em análise complementa o Protocolo de Ushuaia sobre compromisso democrático do Mercosul, Bolívia e Chile, incorporado ao ordenamento brasileiro (DIN - F). O Protocolo reafirma os princípios democráticos e de respeito aos Direitos Humanos que embasam a integração regional (PEB - F), além de estarem em conformidade com a prevalência dos Direitos Humanos, prevista no art. $4^{\circ}$, II, CF (DBR - F).

O parecer é pela aprovação do projeto, e foi aprovado por unanimidade pela Comissão.

\section{PARECER DA COMISSÃO DE CONSTITUIÇÃO E JUSTIÇA E DE CIDADANIA (CD), CEZAR SCHIRMER, 2008}

[Câmara - Parecer 4]

O relatório, de 29.05.2008, é de autoria do Deputado Cezar Schirmer. Nele, o relator aponta para a constitucionalidade do projeto (DBR - F), que é, ademais, coerente com outras convenções internacionais assinadas pelo Brasil (DIN - F).

O parecer é, pois, pela aprovação do projeto, e foi aprovado por unanimidade pela Comissão.

\section{PARECER DA COMISSÃO DE RELAÇÕES EXTERIORES E DEFESA NACIONAL (n. 1.301 - SF), EFRAIM MORAIS, 2009}

[Senado - Parecer 1]

O parecer, de 13.08.2009, é de autoria do Senador Efraim Morais. Segundo ele, o Protocolo fortalece o Mercosul no que se refere à proteção dos Direitos Humanos, aspecto que se encontrava incompleto no arcabouço institucional do bloco (PEB - F). Condicionar a 
integração à proteção dos Direitos Humanos complementa o Protocolo de Ushuaia sobre Compromisso Democrático no Mercosul, Bolívia e Chile (DIN - F), sendo, inclusive, similares os mecanismos de consulta previstos nesses dois instrumentos internacionais.

O parecer é pela aprovação do projeto, e foi aprovado por unanimidade pela Comissão. 


\section{CONVENÇÃO INTERAMERICANA CONTRA O RACISMO, A DISCRIMINAÇÃO RACIAL E FORMAS CORRELATAS DE INTOLERÂNCIA}

Esta Convenção não entrou em vigor internacionalmente, tampouco começou o processo de tramitação no Brasil, até o depósito desta tese. Não será, portanto, analisada.

\section{CONVENÇÃO INTERAMERICANA CONTRA TODA FORMA DE DISCRIMINAÇÃO E INTOLERÂNCIA}

Esta Convenção não entrou em vigor internacionalmente, tampouco começou o processo de tramitação no Brasil, até o depósito desta tese. Não será, portanto, analisada. 


\section{ANÁLISE: CONVENÇÃO DE VIENA SOBRE DIREITO DOS TRATADOS}

A Convenção de Viena sobre Direito dos Tratados, de 23.05.1969, entrou em vigor internacional em 27.01.1980, 30 dias após o depósito do 35 instrumento de ratificação. Essa Convenção foi assinada pelo plenipotenciário brasileiro no mesmo dia e ratificada em 25.09.2009. Foi enviada ao Congresso pela Mensagem Presidencial 116, de 1992. Seu processo de aprovação tramitou na Câmara dos Deputados como Projeto de Decreto Legislativo 214, de 1992, e no Senado Federal como Projeto de Decreto Legislativo 387, de 2009. Foi aprovada pelo Decreto Legislativo 496, de 17.07.2009, e promulgada pelo Decreto Presidencial 7.030, de 14.12.2009, com reserva aos Artigos $25^{217}$ e $66 .^{218}$ O Decreto Presidencial 7.030, de 14.12.2009, confirma as ressalvas feitas pelo Legislativo como reservas. A CVDT entrou em vigor para o Brasil em 24.10.2009, 30 dias após o depósito do instrumento de ratificação, conforme o art. 84.2 da Convenção.

A Convenção foi o resultado da Conferência da ONU sobre o direito dos tratados, a última grande conferência a utilizar, com sucesso, votações como seu método de trabalho, adotando os artigos que vieram a fazer parte da Convenção por maioria significativa. Isso foi possível em virtude da confluência de duas circunstâncias: por um lado, o direito costumeiro que se referia a aspecto mais técnico da elaboração de tratados era, com a exceção de alguns detalhes, praticamente isento de discordâncias; por outro, a possível controvérsia a respeito da terminação de tratados foi solucionada pelos Estados, que balancearam, em

${ }^{217}$ Artigo 25: Aplicação Provisória

1. Um tratado ou uma parte do tratado aplica-se provisoriamente enquanto não entra em vigor, se:

a) o próprio tratado assim dispuser; ou

b) os Estados negociadores assim acordarem por outra forma.

2. A não ser que o tratado disponha ou os Estados negociadores acordem de outra forma, a aplicação provisória de um tratado ou parte de um tratado, em relação a um Estado, termina se esse Estado notificar aos outros Estados, entre os quais o tratado é aplicado provisoriamente, sua intenção de não se tornar parte no tratado.

${ }^{218}$ Artigo 66: Processo de Solução Judicial, de Arbitragem e de Conciliação

Se, nos termos do parágrafo 3 do artigo 65 , nenhuma solução foi alcançada, nos 12 meses seguintes à data na qual a objeção foi formulada, o seguinte processo será adotado:

a) qualquer parte na controvérsia sobre a aplicação ou a interpretação dos artigos 53 ou 64 poderá, mediante pedido escrito, submetê-la à decisão da Corte Internacional de Justiça, salvo se as partes decidirem, de comum acordo, submeter a controvérsia a arbitragem;

b) qualquer parte na controvérsia sobre a aplicação ou a interpretação de qualquer um dos outros artigos da Parte V da presente Convenção poderá iniciar o processo previsto no Anexo à Convenção, mediante pedido nesse sentido ao Secretário-Geral das Nações Unidas. 
virtude de eventualidades futuras desconhecidas, o desejo de se furtar das obrigações proveniente de um tratado e o desejo de mantê-lo. ${ }^{219} \mathrm{~A}$ CVDT é um instrumento paradigmático na história do Direito Internacional Público, pois, ao reconhecer a relevância dos tratados - fontes de Direito Internacional - para o relacionamento dos Estados no âmbito internacional, e ao regulamentar sua elaboração, traz maior segurança jurídica a um cenário em que não existe poder soberano - como ocorre nos Estados. A Convenção aplica-se a tratados celebrados entre Estados, e destina-se a regular a sua conclusão e a sua entrada em vigor.

\section{STATUS NA ONU}

https://treaties.un.org/Pages/ViewDetailsIII.aspx?src=TREATY\&mtdsg_no=XXIII$1 \&$ chapter $=23 \&$ Temp $=$ mtdsg $3 \&$ lang $=$ en

\section{MENSAGEM DO PODER EXECUTIVO (MSC 116/1992)}

A Mensagem do Ministro das Relações Exteriores, à época o jurista Celso Lafer, de 16.04.1992, foi enviada ao Congresso pelo Presidente da República, Fernando Collor de Mello, em 22.04.1992. A Mensagem destaca a importância da Convenção como instrumento de codificação do Direito Internacional, ressaltando que o Brasil foi um dos trinta e dois Estados a assiná-la (PEB - F). Apesar de a própria Convenção reconhecer sua insuficiência para abranger todos os aspectos do Direito dos Tratados, em razão do avanço do Direito Consuetudinário, seria o instrumento mais importante e mais completo de Direito Internacional Público.

De acordo com o Ministro, "infelizmente, o Brasil até hoje não ratificou a CVDT, em cuja elaboração participaram brilhantes especialistas nacionais" (PBR - F). A Mensagem menciona que os receios quanto à internalização da Convenção podem ser atribuídos ao próprio Poder Executivo, em virtude da possível incompatibilidade de algumas cláusulas sobre a entrada em vigor de tratados e as disposições constitucionais brasileiras (DBR - F). Esse receio seria injustificado, pois existiriam possibilidades de apor reservas ou de elaborar declarações interpretativas ao tratado. Para Lafer, mesmo sem reservas, seria inadmissível

${ }^{219}$ Informações obtidas em: http://legal.un.org/avl/ha/vclt/vclt.html. Acesso: 30.03.2016. 
que esse tratado se sobrepusesse à Constituição, norma máxima do ordenamento nacional (DBR - F).

A demora na internalização desse tratado pelo Brasil seria ainda mais lamentável por ser o país pioneiro na codificação do Direito Internacional (PBR - F). Representantes do país teriam integrado a comissão de jurisconsultos que estabeleceu a base da Convenção sobre Tratados celebrada em Havana, em 1928, único antecedente, no âmbito regional, da CVDT (DIN - F). Ao internalizá-la, o Brasil estaria honrando sua tradição diplomática (PEB - F).

\section{CONSULTA 7-A, PRESIDÊNCIA DA CÂMARA, 1993}

[Câmara - Parecer 1]

A Consulta 7-A/1993, da Presidência da Câmara, solicitou o pronunciamento da Comissão de Constituição e Justiça e de Redação a respeito da possibilidade de o Congresso Nacional, conforme sua atribuição de referendar tratados internacionais celebrados pelo Presidente da República, fazê-lo parcialmente. O parecer aponta para a possibilidade, o que será analisado a seguir.

O Deputado Nelson Jobim apontou as ressalvas feitas pela CRE e disse que a emenda oferecida pelo seu partido ${ }^{220}$ - tendente a suprimir do caput do art. $1^{\mathrm{o}}$ a expressão “ressalvados os arts. 25 e 66" do Projeto de Decreto Legislativo 214/1992 221 - destinar-seia a um propósito mais amplo, o da participação do Poder Legislativo nas negociações internacionais do Poder Executivo. A justificativa da Emenda oferecida em plenário é que existiria controvérsia sobre a possibilidade de o Congresso, dentro de sua competência de referendar tratados internacionais, fazê-lo parcialmente. ${ }^{222}$ Segundo o Deputado Jobim, essa matéria deveria ser disciplinada por um projeto de resolução a ser votado pela Câmara, para que, em tratados bilaterais, pudessem ser feitas reservas e, ademais, "emendamentos para reencaminhamento das negociações internacionais" (PBR - F). ${ }^{223}$

O relatório referente a essa consulta foi proferido apenas em 27.04.1995, pelo Deputado Edinho Araújo. O parecer encontra-se apresentado abaixo, seguindo a cronologia dos outros pareceres apresentados no âmbito desse projeto.

\footnotetext{
${ }^{220}$ Emenda oferecida em Plenário, em 04.05.1992.

${ }^{221}$ DCN 11.03.1995, p. 3.019, col. 1.

222 DCN 31.08.1995, p. 20.475, col. 2.

${ }^{223}$ DCN 11.03.1995, p. 3.019, col. 1.
} 


\section{PARECER DA COMISSÃO DE RELAÇÕES EXTERIORES (CD), ANTONIO CARLOS MENDES THAME, 1992}

[Câmara - Parecer 2]

O parecer, de 02.12.1992, é de autoria do Deputado Antonio Carlos Mendes Thame. Após resumir as partes mais importantes do instrumento, destaca o fato de o Congresso ser chamado a analisar a Convenção apenas depois de 23 anos de sua conclusão (PBR - F). O Deputado ressalta a importância da Convenção para o Brasil e para a comunidade internacional. No voto, é apresentada explicação minuciosa sobre o Direito Internacional, sua gênese e sua importância para as relações entre países. A CVDT seria uma tentativa de codificação do Direito Consuetudinário, de extrema relevância para a segurança jurídica entre Estados, que tem como precedente a Convenção de Havana, também mencionada na MSC 116/1992 (DIN - F). Apesar da inexistência de hierarquia entre as fontes do Direito Internacional, descritas no Estatuto da CIJ (art. 38), existiria maior segurança quanto à aplicação de instrumentos escritos e formalizados do que de costumes internacionais, estes de efetivação mais complexa (DIN - F). ${ }^{224}$

O relator analisa as possíveis reservas a serem apostas à Convenção pelo Brasil. Uma delas, referente ao art. 25, trata da possibilidade de aplicação provisória de tratados:

\footnotetext{
Artigo 25: Aplicação Provisória

1. Um tratado ou uma parte do tratado aplica-se provisoriamente enquanto não entra em vigor, se:

a) O próprio tratado assim dispuser; ou

b) Os Estados negociadores assim acordarem por outra forma.

2. A não ser que o tratado disponha ou os Estados negociadores acordem de outra forma, a aplicação provisória de um tratado ou parte de um tratado, em relação a um Estado, termina se esse Estado notificar aos outros Estados, entre os quais o tratado é aplicado provisoriamente, sua intenção de não se tornar parte no tratado.
}

\section{Artigo 38}

1. O Tribunal, cuja função é decidir em conformidade com o direito internacional as controvérsias que lhe forem submetidas, aplicará:

a. As convenções internacionais, quer gerais, quer especiais, que estabeleçam regras expressamente reconhecidas pelos Estados litigantes;

b. O costume internacional, como prova de uma prática geral aceite como direito;

c. Os princípios gerais de direito, reconhecidos pelas nações civilizadas;

d. Com ressalva das disposições do artigo 59, as decisões judiciais e a doutrina dos publicistas mais qualificados das diferentes nações, como meio auxiliar para a determinação das regras de direito.

2. A presente disposição não prejudicará a faculdade do Tribunal de decidir uma questão ex aequo et bono, se as partes assim convierem.

Disponível em: http://www.planalto.gov.br/ccivil_03/decreto/1930-1949/d19841.htm. Acesso: 08.04.2016. 
Esse artigo não poderia ser aceito pelo Brasil, por sua incompatibilidade com a Constituição (DBR - C). Para que um compromisso internacional seja incluído no ordenamento brasileiro, é necessário cumprir o procedimento de internalização de tratados, que é complexo por envolver as duas Casas do Congresso. O direito brasileiro, salvo no caso dos Acordos Executivos, não admite a aplicação provisória de tratado. O relator menciona que outros países manifestaram reservas a esse artigo, afirmando a incompatibilidade do dispositivo com suas constituições.

O outro artigo ao qual se fez ressalva, art. 66, trata da regulamentação do processo de solução judicial, de arbitragem e de conciliação:

\footnotetext{
Artigo 66: Processo de Solução Judicial, de Arbitragem e de Conciliação Se, nos termos do parágrafo 3 do artigo 65 , nenhuma solução foi alcançada, nos 12 meses seguintes à data na qual a objeção foi formulada, o seguinte processo será adotado:

a) Qualquer parte na controvérsia sobre a aplicação ou a interpretação dos artigos 53 ou 64 poderá, mediante pedido escrito, submetê-la à decisão da Corte Internacional de Justiça, salvo se as partes decidirem, de comum acordo, submeter a controvérsia a arbitragem;

b) Qualquer parte na controvérsia sobre a aplicação ou a interpretação de qualquer um dos outros artigos da Parte V da presente Convenção poderá iniciar o processo previsto no Anexo à Convenção, mediante pedido nesse sentido ao SecretárioGeral das Nações Unidas.
}

O costume internacional, segundo o relator, é que os meios de solução de controvérsia sejam descritos em cada compromisso internacional. A discordância a respeito do art. 66 deriva de sua rigidez, uma vez que qualquer das partes de uma controvérsia a respeito da aplicação ou da interpretação de qualquer tratado poderia submetê-la à apreciação da Corte Internacional de Justiça, supletivamente e de comum acordo, à arbitragem ou à Comissão de Conciliação descrita no anexo da Convenção. Esse empecilho existia no momento da elaboração da Convenção de Viena, e, em razão deste problema, foi criada a "cláusula facultativa de jurisdição obrigatória", presente no art. 36(6) do Estatuto da CIJ, à qual o Brasil não se vinculou (PEB - C).

Com relação aos meios de manifestar o consentimento em obrigar-se por um tratado, descritos nos artigos 11 a 16 da CVDT, o relator opina que o governo brasileiro, ao aderir à Convenção, deve declarar que, em regra, o país apenas obrigar-se-ia no âmbito internacional 
após o cumprimento do trâmite constitucional necessário para a internalização de tratados (PBR - C - mas sem oposição de reserva).

Com exceção dos artigos 25 e 66, o relatório é favorável à aprovação da Convenção.

\section{PARECER DA COMISSÃO DE CONSTITUÇÃO E JUSTIÇA E DE REDAÇÃo (CD), JESUS TAJRA, 1993}

[Câmara - Parecer 3]

O parecer, de 02.01.1993, é de autoria do Deputado Jesus Tajra. Segundo o relator, o projeto é constitucional (DBR - F), sendo seu voto por sua aprovação. A Comissão aprovou o parecer por unanimidade.

\section{PARECER DA COMISSÃO DE CONSTITUIÇÃO, JUSTIÇA E REDAÇÃO (CD), JOSÉ THOMAZ NONÔ, 1993}

[Câmara - Parecer 4]

O voto do relator, Deputado José Thomaz Nonô, de 11.03.1993, é no sentido da constitucionalidade, juridicidade e boa técnica legislativa do Projeto de Decreto Legislativo 214/1992, concordando com a aposição de ressalvas, por parte da Comissão de Relações Exteriores, aos artigos 25 e 66 da CVDT. O relator destaca que a ressalva feita ao art. 25 seria necessária em virtude de disposições constitucionais (DBR - C); e a ressalva ao art.66 assentar-se-ia em argumentos de conveniência e de oportunidade e, portanto, de mérito, extrapolando a competência regimental da Comissão de Justiça.

O relator discute a possibilidade de o Poder Legislativo emendar tratados, tema polêmico na doutrina nacional, mencionando as disposições constitucionais que se referem ao tema, mesmo que sem muita minúcia, os artigos 49 e 84. Separa em cinco as etapas do processo de elaboração até a entrada em vigor de um tratado: (i) negociação; (ii) assinatura; (iii) ratificação; (iv) promulgação e (v) publicação.

A etapa de negociação, conforme os ditames constitucionais, seria de competência exclusiva do Poder Executivo. O procedimento de internalização de um tratado, porém, deve ser exercido conjuntamente entre Executivo e Legislativo. Trata-se, portanto, de um procedimento complexo, por envolver dois Poderes; e sui generis, pois sua tramitação segue procedimento próprio, sem paralelos no direito interno. A ratificação do tratado seria, geralmente, o procedimento mais extenso do processo, compreendendo duas fases: 
$1^{a}$ fase do processo de ratificação: uma vez concluída a negociação e assinado o tratado, o Poder Executivo deve enviar cópia do documento para a apreciação do Congresso. A tramitação do tratado no Poder Legislativo será iniciada pela Câmara. O tratado será devidamente acompanhado por Mensagem do Poder Executivo e de Exposição de Motivos do Ministro de Estado, geralmente o Ministro encarregado da paste de Relações Exteriores. Uma vez recebido esse material, cada uma das Casas do Congresso examinará e será editado, em caso de concordância, Decreto Legislativo, assinado pelo Presidente do Congresso;

(ii) $\quad 2^{\text {a }}$ fase do processo de ratificação: apreciado o texto pelo $\mathrm{CN}$, o tratado deverá retornar ao Poder Executivo, que optará pela sua ratificação ou não. Deste modo, mesmo que o Poder Legislativo concorde com o texto submetido à sua apreciação, a ratificação do Executivo é discricionária.

O relator aponta para o fato de que o Legislativo brasileiro, apesar de sua faculdade de rejeitar tratados, não fez uso dessa prerrogativa com intensidade. Menciona o único caso de rejeição de que se teve notícia no Legislativo, a Convenção 90 da OIT, relativa ao Trabalho de Menores na Indústria, (DIN - F) que, segundo ele, ocorreu mais em virtude da MSC, que sugeria sua rejeição, do que da iniciativa parlamentar (PBR - F).

A tese de que o Congresso poderia aprovar com ressalvas os tratados submetidos a sua apreciação foi defendida por Haroldo Valladão, que emitiu opinião a esse respeito quando ocupava o cargo de Consultor Jurídico do MRE. Uma vez que a Constituição confere a esse poder a competência para apreciar tratados, não estaria ele limitado nessa competência. Afinal, "qui potest maius, potest et minus": quem pode o mais, pode o menos. Entretanto, as emendas porventura aprovadas ao texto do tratado pelo Legislativo não teriam o condão de obrigar a outra parte signatária do tratado. Deste modo, as eventuais modificações propostas pelo Legislativo devem ser comunicadas, pelo Executivo, aos seus pares no âmbito internacional, independentemente da quantidade de partes contratantes. As ressalvas, portanto, devem ser transformadas em reservas.

O relator conclui pela validade, constitucionalidade (DBR - F) e conveniência (PBR F) da aposição de ressalvas, pela CRE, aos artigos 25 e 66 da CVDT. O parecer foi aprovado por unanimidade pela Comissão. 


\section{PARECER DA COMISSÃO DE CONSTITUIÇÃO E JUSTIÇA E DE REDAÇÃO (CD), EDINHO ARAÚJO, 1995}

[Câmara - Parecer 5]

Em 27.04.1995 foi exarado parecer da CCJ, cujo relator foi o Deputado Edinho Araújo, em razão de emenda oferecida em plenário ao projeto de Decreto Legislativo n.214-A/1992. Essa emenda, como explicado acima, requeria a supressão do "caput" do art. $1^{\circ}$ do Projeto a expressão "ressalvados os arts. 25 e 66" - ou seja, excluindo as ressalvas feitas anteriormente. A opinião do relator é pela constitucionalidade formal da emenda (DBR - F). Quanto ao mérito, porém, aponta que a competência do Congresso restringir-se-ia à aprovação ou à rejeição completa de tratado sob sua apreciação. Não seria possível, pois, emendar ou rejeitar parte de um tratado, o que acarretaria a necessidade de o Executivo refazer o acordo com a outra parte, como se esse acordo tivesse sido, efetivamente, rejeitado.

\section{PARECER REFORMULADO DA COMISSÃO DE CONSTITUIÇÃO E JUSTIÇA E DE REDAÇÃO (CD), EDINHO ARAÚJO, 1995}

[Câmara - Parecer 5]

A Comissão analisa, novamente, o mérito da questão da emenda supra descrita, em 29.08.1995. É apresentada uma compilação doutrinária acerca do tema, sobre a faculdade de o Congresso apresentar ressalvas a artigos de tratados. O relator apresenta, novamente, a discussão doutrinária descrita no primeiro relatório, mas acrescenta a elas algumas informações. Segundo ele, entre 1946 e 1981 haveria apenas um exemplo de aprovação de tratado com emendas, o Acordo de Comércio e Pagamentos celebrado entre os Estados Unidos do Brasil e a República da Checoslováquia, em 24.06.1960.

O Executivo, que pretendia desconsiderar as emendas apostas pelo Legislativo, argumentou que não caberia ao Congresso a faculdade de introduzir emendas a tratado, podendo, apenas, rejeitá-los ou aprová-los em sua totalidade. Eventual reconhecimento, por parte do Executivo, dessa faculdade de elaborar emendas por parte do Legislativo seria precedente perigoso; podendo o Executivo, portanto, desconsiderar as emendas feitas pelo Legislativo. Foi proferido parecer acerca da questão pelo então consultor jurídico do Itamaraty, professor Haroldo Valladão, que concluiu pela constitucionalidade da aprovação com emendas pelo Poder Legislativo. Se cabe ao Congresso, por disposição constitucional, deliberar e decidir sobre os atos internacionais, não faria sentido limitar sua deliberação a 
extremos, aprovação ou rejeição total. Não existiria nenhuma disposição constitucional que evitasse a faculdade do Congresso de emendar tratados.

O relator conclui da seguinte maneira:

1. O Congresso Nacional ao resolver definitivamente sobre trados, acordos ou atos internacionais que acarretem encargos ou compromissos gravosos ao patrimônio nacional, de acordo com o art. 49, I da Constituição Federal, poderá: a) aprová-Ios totalmente;

b) rejeitállos totalmente, ou

c) aprová-los com emendas.

2. A aprovação com emendas, ou seja, com ressalvas, só poderá ocorrer quando o tratado as admita ou, ao menos, não as proíba.

3. A Convenção sobre o Direito dos Tratados ora em análise não faz qualquer restrição à elaboração de ressalvas.

4. Assim, entendemos descabida a emenda apresentada em Plenário ao PDL 214 A/1992, que procura eliminar as ressalvas feitas pela Comissão de Relações Exteriores à citada Convenção.

Sendo assim, conclui pela constitucionalidade da emenda ao Projeto de Decreto Legislativo n.214/1992, mas sua rejeição no mérito. A Comissão opinou, contra os votos dos Deputados Ciro Nogueira e Vicente Cascione, pela aprovação do parecer do Deputado Edinho Araújo.

\section{DECLARAÇÃO DE VOTO DO DEPUTADO RÉGIS DE OLIVEIRA, 1995}

Foram apresentados votos contrários a esse entendimento, como a Declaração de Voto do Deputado Régis de Oliveira, de 05.06.1995. O Deputado, após descrever o procedimento interno de tramitação de tratados, aponta que, em primeiro lugar, é necessário verificar qual a repercussão das normas resultantes de tratados no direito interno. Foi o primeiro voto a mencionar o direito interno na discussão, apontando para a necessidade de verificar a hierarquia existente entre tratados e a legislação interna. Menciona a jurisprudência do STF, que reconhece, no RE 80.004/1977, a paridade entre tratados e a legislação federal. Conforme o entendimento do Deputado, seria redundante reiterar que as normas decorrentes de tratados estão submetidas à Constituição, o que estaria claro pela disposição do art. 102, III, "b", CF, que confere competência ao STF para julgar, mediante Recurso Extraordinário, as causas decididas em única ou última instância se a decisão recorrida "declarar a inconstitucionalidade de tratado ou lei federal". Assim, a Carta Magna repudia normas 
provenientes de tratados que a contrariem. O primeiro momento em que se examinaria a constitucionalidade de instrumento internacional seria quando da sua submissão à CCJ, num controle preventivo de constitucionalidade. Sendo assim, mesmo que essa Comissão aprovasse um tratado inconstitucional, ele poderia ser, posteriormente, repelido pelo Judiciário.

Deste modo, entre aprovar inteiramente um tratado com dispositivos inconstitucionais e rejeitar inteiramente um tratado que poderia ser altamente benéfico para o Brasil, seria interessante escolher um terceiro caminho: sua aprovação com ressalvas. Não há dispositivos, no ordenamento interno, que impeça o Congresso de fazê-lo; exceto aquelas previstas no art. 63, quando houver aumento de despesa, nos projetos de iniciativa exclusiva do Presidente da República, e às que versem sobre a organização dos serviços administrativos da Câmara dos Deputados, do Senado, dos tribunais federais e do Ministério Público; e do art. 166, parágrafos $3^{\circ}$ e $4^{\circ}$, condicionando o direito de emenda ao orçamento e às diretrizes orçamentárias. Como, em hermenêutica, não se presume a exceção, a impossibilidade de emendar um tratado deveria estar expressa na Constituição. Não se pode, portanto, negar ao Legislativo a faculdade emendar os textos normativos internos que internalizam tratados internacionais.

O Deputado menciona, nesse sentido, a aprovação com ressalvas pelo Congresso dos Decretos Legislativos 17/1961, referente ao supramencionado Acordo de Comércio e Pagamentos entre o Brasil e a República da Checoslováquia, e 93/1983, relativo à Convenção sobre a eliminação de todas as formas de discriminação contra a Mulher; por entender que alguns dispositivos desse último eram incompatíveis com a legislação civil vigente, em relação aos direitos da mulher casada.

O relator reitera que as modificações feitas pelo Congresso não vinculam a outra parte contratante, e que caberia ao Executivo lidar com essa questão em âmbito internacional. Destaca que, como as regras de tratados encontram-se no plano das leis federais, eventual conflito entre elas seria solucionado conforme o princípio de que lei posterior derroga a anterior. Conclui pelo cabimento das ressalvas parlamentares ao texto dos tratados internacionais celebrados pelos plenipotenciários brasileiros. 


\section{DECLARAÇÃO DE VOTO DO DEPUTADO VICENTE ARRUDA, 1995}

A manifestação do Deputado Vicente Arruda segue a de Régis Oliveira. Em sua manifestação, o Deputado ressalta que a discussão se trata mais de questão de forma do que de fundo. Concorda que o instrumento é um contrato assinado por Estados soberanos, cuja formalização e cujo cumprimento dependem de um acordo de vontades. Ademais, todos concordam que o Congresso tem poder constitucional de deliberar a respeito de tratado, seja aprovando-o, seja rejeitando-o. Se, portanto, detém o poder de aceitar ou de rejeitar integralmente, também o tem de fazê-lo parcialmente. Não existe divergência em relação a isso.

A divergência estaria no seguinte fato: em caso de emenda a tratado, depende da outra parte aceita-la, sendo a emenda ineficaz até que isso ocorra. O Poder Legislativo, então, ao aprovar um Decreto Legislativo referente ao tratado, transformando-o em lei interna, estaria promulgando uma legislação sob condição suspensiva, tendo que a revogar em caso de não aceitação pela outra parte do tratado. Por outro lado, aqueles que, como o Deputado Régis de Oliveira, opinam pela competência do Congresso em emendar um tratado, sabem que essa emenda apenas terá eficácia se aceita pela outra parte do tratado; mas, mesmo assim, admitem a emenda como um sinal enviado pelo Congresso à Presidência, no sentido da intenção de aprovar o tratado, com as alterações sugeridas. A partir daí, caberia ao Executivo propor novas negociações com o outro Estado-parte do instrumento internacional. Apenas em caso de concordância, o tratado passaria a vigorar.

O Deputado conclui que ambas as opiniões - as do relator e as do Deputado Régis de Oliveira - têm base comum, sendo a diferença entre elas uma questão de fundo pessoal. O Deputado, por sua vez, concorda com a apreciação de Régis de Oliveira.

\section{PARECER DA COMISSÃO DE RELAÇÕES EXTERIORES (CD), PEDRO VALADARES, 1995}

[Câmara - Parecer 6]

Em 01.11.1995, foi exarado parecer do Deputado Pedro Valadares, analisando a emenda do plenário que tinha como objetivo suprimir a parte final do art. $1^{\circ}$ do PDC 214B/1992, referente às ressalvas acrescidas pela CRE ao apreciar a CVDT. 
$\mathrm{O}$ voto do relator divide a apreciação da matéria em três partes. Nas duas primeiras, analisa as ressalvas apostas pela CRE; e, na terceira, discute a possibilidade de o Legislativo propor emendas a tratados internacionais.

Com relação às ressalvas, o relator concorda plenamente com ambas, porque:

A ressalva ao art. 25 seria necessária, pois esse artigo violaria preceito constitucional, que prevê a apreciação do Poder Legislativo para a internalização de tratado, que seria prejudicada pela possibilidade de vigência provisória de tratados. A vigência provisória criaria, ademais, a possibilidade de produção de efeitos por parte do tratado, e poderia ser impossível a restituição do status quo ante, caso o tratado fosse recusado pelo Congresso;

(ii) A ressalva ao art. 66, que trata do processo de resolução de controvérsias, teria sido feita por motivo de oportunidade. Conforme esse artigo, seria obrigatória a submissão de uma controvérsia à solução judicial, à arbitragem ou à conciliação - seja à CIJ, ao procedimento arbitral ou, ainda, à Comissão de Conciliação, prevista no Anexo da CVDT. O Brasil, conforme sua tradição diplomática, não costumaria abdicar da negociação, seja bilateral, seja multilateral, para a solução de litígios no âmbito internacional $(\mathrm{PEB}-\mathrm{C})$. Ele destaca, ainda, que o Brasil não se submete à cláusula facultativa de jurisdição obrigatória, prevista no Estatuto da CIJ que, se assinada, obriga o Estado a aceitar a jurisdição dessa Corte, sempre que demandado por Estado também aceitador dessa cláusula (DIN - C). Ao voto do relator, que menciona o aspecto negativo da ausência de capacidade coercitiva da CIJ para implementar suas decisões, acrescenta que o descumprimento de acórdão da Corte é um ilícito internacional, que pode ser denunciado ao Conselho de Segurança da ONU (CNU); que, conforme o caso, pode tomar medidas necessárias para sua efetivação.

A respeito da terceira parte a ser apreciada pelo voto, a possibilidade de o Poder Legislativo emendar tratado internacional, retoma os votos anteriores, e menciona o art. 84, VIII, CF, referente à apreciação de tratados. Para o Deputado, como a celebração de tratados é de competência exclusiva do Presidente, fica fragilizada a possibilidade de o Legislativo, não incluído nas negociações, propor emendas após a aprovação do tratado ( $\mathrm{PBR}-\mathrm{C}$ ). Apesar disso, após mencionar a doutrina pátria e o parecer do Deputado Thomaz Nonô, previamente analisado, que conclui pela possibilidade de apresentação das emendas, aponta que o fato de terem sido aprovadas ressalvas não tem como consequência que o país passa a 
estar obrigado internacionalmente pelo tratado modificado (PBR - C). Aponta, então, para a necessidade de nova atuação do Poder Executivo, que teria duas maneiras de atuar:

(i) Em tratados bilaterais: seria necessário retornar às negociações entre o Brasil e o outro Estado signatário;

(ii) Em tratados multilaterais: as ressalvas deveriam ser transformadas em reservas. Estas, porém, não são permitidas em alguns tratados, ou são permitidas apenas a determinados artigos. A apreciação, portanto, teria que ocorrer no caso concreto: conforme a apreciação do Legislativo, o Executivo estaria, em alguns casos, impedido de ratificar certo tratado.

A CVDT, em seu art. 19, faz prescrições a respeito da possibilidade de reservas:

Artigo 19: Formulação de Reservas: Um Estado pode, ao assinar, ratificar, aceitar ou aprovar um tratado, ou a ele aderir, formular uma reserva, a não ser que:

a) A reserva seja proibida pelo tratado;

b) O tratado disponha que só possam ser formuladas determinadas reservas, entre as quais não figure a reserva em questão; ou

c) Nos casos não previstos nas alíneas a e b, a reserva seja incompatível com o objeto e a finalidade do tratado. (grifo nosso).

Como a própria CVDT admite reservas, e não sendo as ressalvas aos artigos 25 e 66 incompatíveis com seu objeto e finalidade, o relator conclui pela sua admissibilidade. $\mathrm{O}$ parecer é aprovado por unanimidade pela Comissão.

\section{PARECER COMISSÃO DE RELAÇÕES EXTERIORES E DEFESA NACIONAL (n. 1.026 - SF), CRISTOVAM BUARQUE, 2009}

[Senado - Parecer 1]

O Parecer do Senador Cristovam Buarque, de 02.07.2009, aponta que a CVDT foi aprovada pelo plenário da Câmara dos Deputados em 14.05.2009, após o crivo das Comissões de Relações Exteriores e Defesa Nacional e da Comissão de Constituição e Justiça e de Cidadania.

O Senador aponta que a CVDT é um dos instrumentos internacionais mais importantes desde o fim da Segunda Guerra Mundial, e que, no âmbito interno, equivaleria a "uma lei 
disciplinando a forma de produção legislativa". ${ }^{225}$ Destaca a importância da CVDT conforme o enunciado no art. 13.1.a da Carta da ONU (DIN - F), que reza:

\footnotetext{
Artigo 13:

1. A Assembleia Geral iniciará estudos e fará recomendações, destinados a: a) promover cooperação internacional no terreno político e incentivar o desenvolvimento progressivo do direito internacional e a sua codificação; (...) (grifo nosso).
}

Segue apontando a importância do direito consuetudinário para a codificação do Direito Internacional feita pela CVDT, em virtude da crescente "necessidade de se positivar o direito dos tratados", 226 além de destacar o árduo trabalho dos relatores da Convenção para aprovar um texto que tivesse o maior apoio possível entre os membros da ONU. O Senador reitera o fato, mencionado na MSC 116/1992, por Lafer, de que a Convenção demorou a ser enviada ao Legislativo pelo Poder Executivo, com demora injustificável (PBR - F).

Após descrever as ressalvas indicadas pelo PDS 387//2009 (aos artigos 25 e 66, CVDT), aponta que o governo, "conhecedor dos limites constitucionais de sua plenipotência no campo das relações internacionais" 227 não negociaria tratado que contemplasse a possibilidade de aplicação provisória (PBR - F). Em relação ao art. 66, aponta que o Brasil se vincula a diversos instrumentos internacionais com a mesma prescrição - a obrigatoriedade de solucionar eventual conflito, em relação à aplicação de um tratado, na CIJ. Entretanto, as ressalvas não desautorizam a aprovação pelo Senado, tampouco seriam discrepantes em relação a reservas apostas por outras partes à Convenção.

Conclui pela conformidade da CVDT com o ordenamento constitucional e infraconstitucional brasileiros (DBR - F), aprovando o PDS 387/2009.

\footnotetext{
225 Página 2 do Parecer.

${ }^{226}$ Página 3 do Parecer.

${ }^{227}$ Página 4 do Parecer.
} 


\section{APÊNDICE II \\ TABELA DOS DADOS AGREGADOS REFERENTES AOS ARGUMENTOS UTILIZADOS}




\section{Número Fr Tratado}

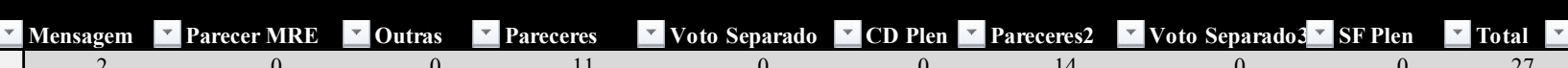

\begin{tabular}{|c|c|c|c|c|c|c|c|c|c|c|c|}
\hline & 1. Convençáo para a prevençáo e a repressáo do crmme de genocidio & 2 & 0 & 0 & 11 & 0 & 0 & 14 & 0 & 0 & \\
\hline 2 & 2. Convencão para a repressão do tráfico de pessoas e do Lenocínio & 9 & 0 & 0 & 7 & 0 & 0 & 8 & 0 & 0 & 24 \\
\hline 3 & 3. Convenção relativa ao Estatuto dos Refugiados & 7 & 12 & 0 & 19 & 0 & 0 & 2 & 0 & 14 & 54 \\
\hline 3,1 & 3.1. Protocolo sobre o Estatuto dos Refugiados & 8 & 0 & 0 & 5 & 0 & 0 & 4 & 0 & 0 & 17 \\
\hline 4 & 4. Convenção sobre os Direitos Politicos da Mulher & 4 & 0 & 0 & 5 & 0 & 0 & 1 & 0 & 0 & 10 \\
\hline 5 & 5. Convenção sobre o Estatuto dos Apátridas & 11 & 0 & 0 & 3 & 0 & 0 & 3 & 0 & 0 & 17 \\
\hline 6 & 6. Convenção sobre a Nacionalidade da Mulher Casada & 2 & 0 & 0 & 9 & 3 & 0 & 15 & 0 & 0 & 29 \\
\hline 7 & $\begin{array}{l}\text { 7. Convenção concernente à abolição do trabalho forçado (Convenção } \\
105, \text { OIT) }\end{array}$ & 4 & 0 & 7 & 3 & 0 & 0 & 1 & 0 & 0 & 15 \\
\hline 8 & 8. Convenção para a Redução dos Casos de Apatridia & 5 & 4 & 0 & 5 & 0 & 0 & 8 & 0 & 0 & 22 \\
\hline 9 & $\begin{array}{l}\text { 9. Convenção internacional sobre a eliminação de todas as formas de } \\
\text { discriminação racial }\end{array}$ & 2 & 0 & 0 & 5 & 5 & 0 & 9 & 0 & 0 & 21 \\
\hline 9,1 & $\begin{array}{l}\text { 9.1. Declaração Facultativa à Convenção que reconhece a competência } \\
\text { do Comitê }\end{array}$ & 3 & 2 & 0 & 3 & 0 & 0 & 5 & 0 & 0 & 13 \\
\hline 10 & 10. Pacto Internacional sobre Direitos Civis e Políticos & 20 & 2 & 7 & 5 & 0 & 0 & 8 & 0 & 0 & 42 \\
\hline 10,1 & $\begin{array}{l}\text { 10.1. e 10.2. Protocolo Facultativo ao Pacto Internacional sobre } \\
\text { Direitos Civis e Politicos e Segundo Protocolo Facultativo ao Pacto } \\
\text { Internacional sobre Direitos Civis e Políticos, com vistas à Abolição da } \\
\text { Pena de Morte }\end{array}$ & 12 & 0 & 0 & 17 & 0 & 0 & 8 & 0 & 0 & 37 \\
\hline 10,2 & $\begin{array}{l}\text { 10.2. Segundo Protocolo Facultativo ao Pacto Internacional sobre } \\
\text { Direitos Civis e Políticos, com vistas à Abolicão da Pena de Morte }\end{array}$ & 0 & 0 & 0 & 0 & 0 & 0 & 0 & 0 & 0 & 0 \\
\hline 11 & 11. Pacto Internacional sobre Direitos Econômicos, sociais e culturais & 0 & 0 & 0 & 0 & 0 & 0 & 0 & 0 & 0 & 0 \\
\hline 12 & $\begin{array}{l}\text { 12. Convenção sobre a Prevenção e Punição de Crimes Contra Pessoas } \\
\text { que Gozam de Proteção Internacional, incluindo agentes diplomáticos }\end{array}$ & 4 & 4 & 0 & 4 & 0 & 0 & 2 & 0 & 0 & 14 \\
\hline 13 & $\begin{array}{l}\text { 13. Convenção sobre a eliminação de todas as formas de discriminação } \\
\text { contra a mulher }\end{array}$ & 5 & 5 & 0 & 5 & 0 & 0 & 2 & 0 & 0 & 17 \\
\hline 13,1 & 13.1. Retirada de Reservas á Convenção & 8 & 0 & 0 & 5 & 0 & 0 & 3 & 0 & 1 & 17 \\
\hline 13,2 & $\begin{array}{l}\text { 13.2. Protocolo facultativo à Convenção sobre eliminação de todas as } \\
\text { formas de discriminação contra a mulher }\end{array}$ & 1 & 4 & 22 & 12 & 0 & 26 & 5 & 0 & 0 & 70 \\
\hline 14 & $\begin{array}{l}\text { 14. Convenção contra a tortura e outros tratamentos ou penas cruéis, } \\
\text { desumanos ou degradantes }\end{array}$ & 3 & 0 & 0 & 5 & 0 & 11 & 2 & 0 & 0 & 21 \\
\hline 14,1 & $\begin{array}{l}\text { 14.1. Protocolo Facultativo à Convenção contra a Tortura e Outros } \\
\text { Tratamentos ou Penas Cruéis, Desumanos ou Degradantes }\end{array}$ & 6 & 0 & 0 & 35 & 0 & 0 & 4 & 0 & 0 & 45 \\
\hline 14,2 & $\begin{array}{l}\text { 14.2. Declaração que reconhece a competência do Comitê previsto na } \\
\text { Convenção }\end{array}$ & 3 & 8 & 0 & 21 & 0 & 0 & 5 & 0 & 0 & 37 \\
\hline
\end{tabular}




\begin{tabular}{|c|c|c|c|c|c|c|c|c|c|c|c|}
\hline 15 & 15. Convenção 169 da OIT sobre Povos Indígenas e Tribais & 2 & 0 & 0 & 16 & 0 & 0 & 28 & 12 & 21 & 79 \\
\hline 16 & 16. Convenção sobre os Direitos da Criança & 2 & 0 & 0 & 3 & 0 & 0 & 3 & 0 & 0 & 8 \\
\hline 16,1 & $\begin{array}{l}\text { 16.1. Protocolo Facultativo à Convenção sobre os Direitos da Criança } \\
\text { referentes à venda de criança, à prostituição infantil e à pornografia } \\
\text { infantil - a tramitação dos dois primeiros protocolos foi conjunta }\end{array}$ & 5 & 0 & 0 & 0 & 0 & 9 & 3 & 0 & 0 & 17 \\
\hline 16,2 & $\begin{array}{l}\text { 16.2. Protocolo facultativo à Convenção sobre os direitos da criança } \\
\text { relativos ao envolvimento de crianças em conflitos armados }\end{array}$ & . & . & . & . & . & . & . & . & . & . \\
\hline 16,3 & 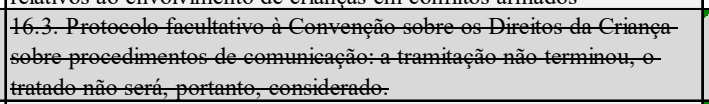 & . & . & . & . & . & . & . & . & . & . \\
\hline 17 & $\begin{array}{l}\text { 17. Convenção Internacional sobre a Proteção dos Direitos de Todos os } \\
\text { Trabalhadores Migrantes e dos Membros das stas Famílias: a- } \\
\text { tramitação não terminou, o tratado não será, pertanto, considerado. }\end{array}$ & . & . & . & . & . & . & . & . & . & . \\
\hline 18 & 18. Estatuto de Roma do Tribunal Penal Internacional & 17 & 21 & 0 & 16 & 13 & 0 & 6 & 0 & 0 & 73 \\
\hline 18,1 & $\begin{array}{l}\text { 18.1. Acordo sobre Privilégios e Imunidades do Tribunal Penal } \\
\text { Internacional }\end{array}$ & 3 & 0 & 0 & 3 & 0 & 0 & 4 & 0 & 0 & 10 \\
\hline 19 & \begin{tabular}{|l} 
19. Convenção das Nações Unidas contra o crime organizado \\
Transnacional ("Convenção de Palermo")
\end{tabular} & 5 & 0 & 0 & 11 & 0 & 0 & 3 & 0 & 0 & 19 \\
\hline 19,1 & $\begin{array}{l}\text { 19.1. Protocolo adicional para o Combate ao tráfico de Migrantes por } \\
\text { via terrestre, marítima e aérea }\end{array}$ & 0 & 0 & 0 & 0 & 0 & 0 & 0 & 0 & 0 & 0 \\
\hline 19,2 & $\begin{array}{l}\text { 19.2. Protocoolo para a Prevenção, Repressão e Punição do Tráfico de Pessoas, em } \\
\text { especial Mulheres e Crianças }\end{array}$ & 0 & 0 & 0 & 0 & 0 & 0 & 0 & 0 & 0 & 0 \\
\hline 20 & $\begin{array}{l}\text { 20. Convenção sobre os Direitos das Pessoas com Deficiência e de seu } \\
\text { Protocolo Facultativo }\end{array}$ & 3 & 0 & 4 & 6 & 0 & 32 & 6 & 0 & 11 & 62 \\
\hline 21 & $\begin{array}{l}\text { 21. Convenção Internacional para a Proteção de Todas as Pessoas } \\
\text { Contra o Desaparecimento Forçado }\end{array}$ & 6 & 0 & 0 & 13 & 0 & 0 & 7 & 0 & 0 & 26 \\
\hline 22 & 22. Convenção Americana sobre Direitos Humanos & 13 & 20 & 0 & 18 & 0 & 0 & 8 & 0 & 0 & 59 \\
\hline 22,1 & \begin{tabular}{|l|} 
22.1. Protocolo adicional à Convenção Americana sobre Direitos \\
Humanos em matéria de direitos econômicos, sociais e culturais - 22.1 e \\
22.2. foram analisados na mesma tramitação
\end{tabular} & 2 & 7 & 0 & 5 & 0 & 0 & 4 & 0 & 0 & 18 \\
\hline 22,2 & 22.2. Protocolo referente à abolição da pena de morte & 0 & 0 & 0 & 0 & 0 & 0 & 0 & 0 & 0 & 0 \\
\hline 22,3 & $\begin{array}{l}\text { 22.3. Aceitação da Competência obrigatória da corte internacional de } \\
\text { direitos humanos }\end{array}$ & 18 & 3 & 0 & 3 & 0 & 0 & 0 & 0 & 0 & 24 \\
\hline 23 & 23. Convenção Interamericana para prevenir e punir tortura & 3 & 0 & 0 & 2 & 0 & 0 & 3 & 0 & 0 & 8 \\
\hline 24 & $\begin{array}{l}\text { 24. Convenção Interamericana para prevenir, punir e erradicar a } \\
\text { violência contra a mulher }\end{array}$ & 4 & 0 & 0 & 14 & 0 & 0 & 2 & 0 & 0 & 20 \\
\hline 25 & $\begin{array}{l}\text { 25. Convenção Interamericana sobre o Desaparecimento Forçado de } \\
\text { Pessoas }\end{array}$ & 3 & 0 & 1 & 4 & 0 & 0 & 6 & 0 & 1 & 15 \\
\hline 26 & 26. Convenção Interamericana sobre tráfico internacional de menores & 1 & 0 & 0 & 11 & 0 & 0 & 2 & 0 & 0 & 14 \\
\hline 27 & $\begin{array}{l}\text { 27. Convenção Interamericana para a eliminação de todas as formas de } \\
\text { discriminação contra as pessoas portadoras de deficiência }\end{array}$ & 2 & 0 & 0 & 10 & 0 & 14 & 2 & 0 & 3 & 31 \\
\hline 28 & \begin{tabular}{|l|} 
28. Protocolo de Assunção sobre Compromisso com a Promoção e \\
Proteção dos Direitos Humanos do Mercosul
\end{tabular} & 3 & 0 & 0 & 9 & 0 & 0 & 2 & 0 & 0 & 14 \\
\hline 29 & 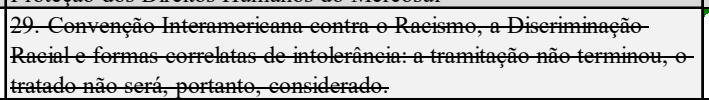 & . & . & . & & . & . & . & . & . & \\
\hline 30 & $\begin{array}{l}\text { 30. Convenção Interamericana contra toda forma de discriminação e- } \\
\text { intolerância: a tramitação não terminou, o tratado não será, portanto,- } \\
\text { considerado. }\end{array}$ & . & . & . & & . & . & . & . & . & . \\
\hline 31 & 31. Convenção de Viena sobre o Direito dos Tratados & 7 & 0 & 0 & 18 & 0 & 0 & 4 & 0 & 0 & 29 \\
\hline
\end{tabular}





\section{APÊNDICE III}

TABELA DOS ARGUMENTOS UTILIZADOS PELOS MEMBROS DOS PODERES EXECUTIVO E LEGISLATIVO 
TABELAS REFERENTES AO GRUPO 1 (1945-1964)

Manifestações do Poder Executivo

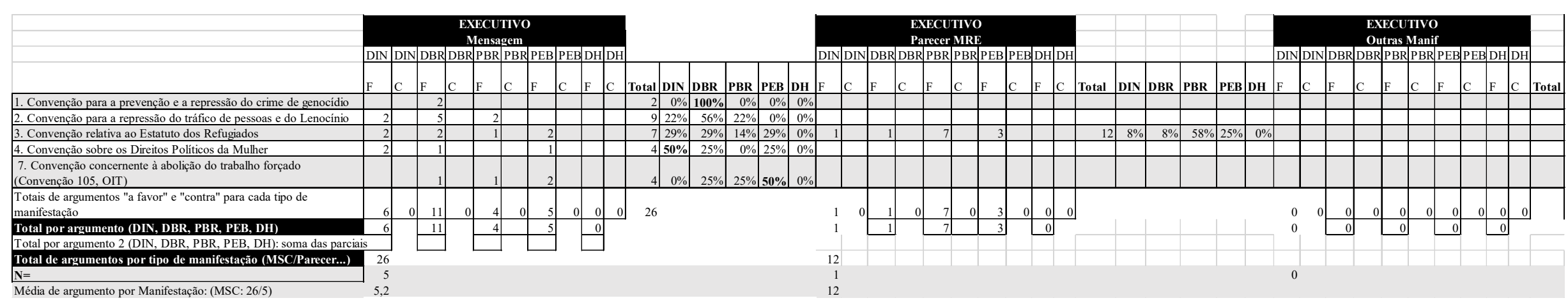

\section{Manifestações do Poder Legislativo: Câmara dos Deputados}

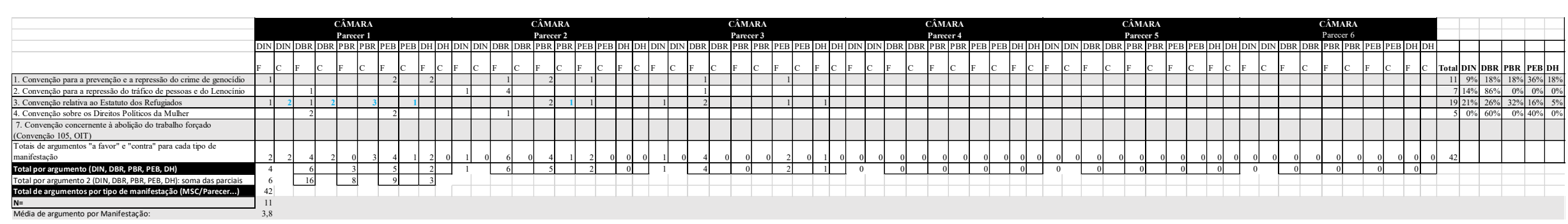

No G1, não há voto em separado nem manifestação no Plenário da Câmara dos Deputados. 
Manifestações do Poder Legislativo: Senado Federal

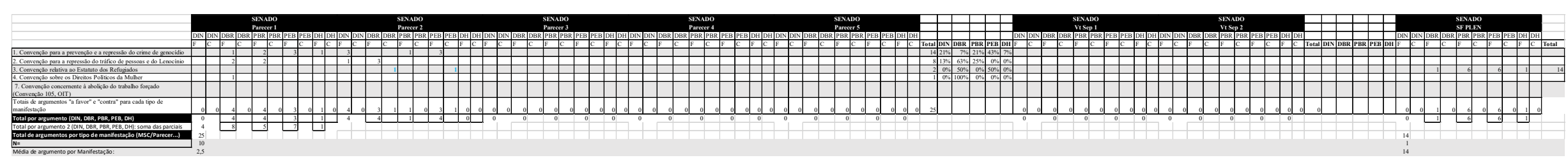

TABELAS REFERENTES AO GRUPO 2 (1964-1985)

\section{Manifestações do Poder Executivo}

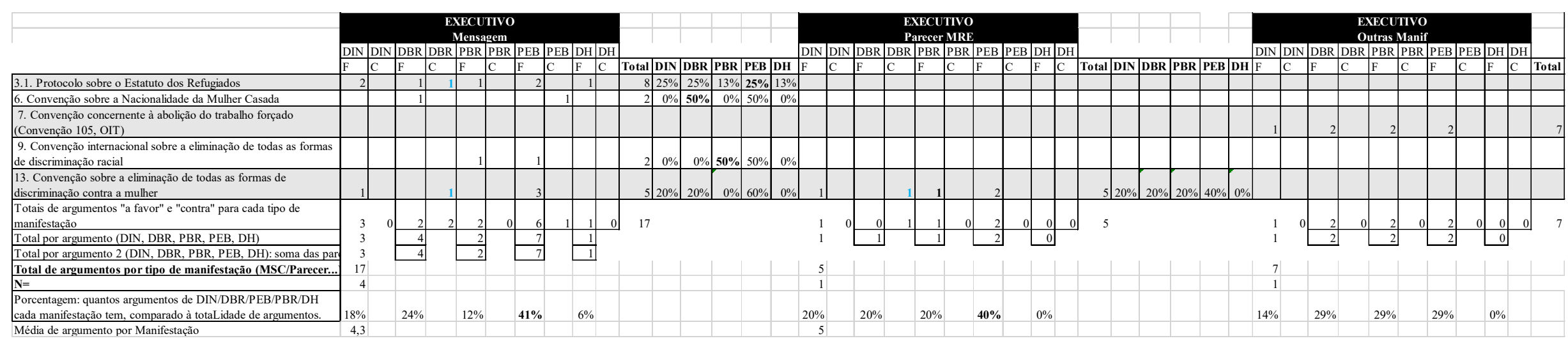




\section{Manifestações do Poder Legislativo: Câmara dos Deputados}

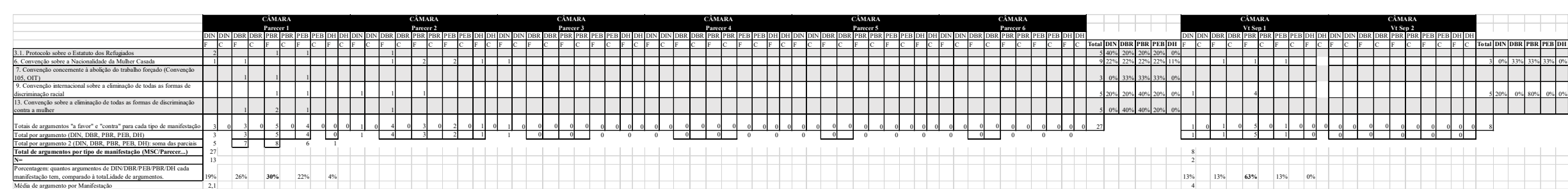

No G2, não há manifestação no Plenário da Câmara dos Deputados.

\section{Manifestações do Poder Legislativo: Senado Federal}

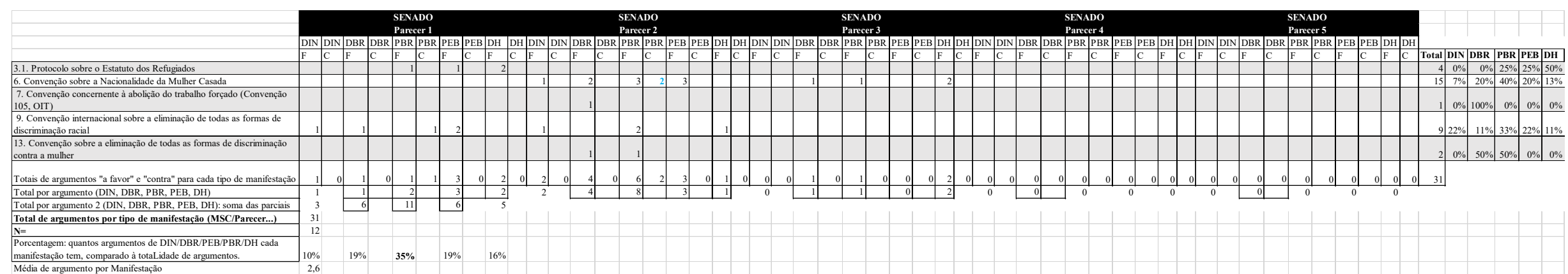

No G2, não há manifestação voto em separado nem manifestação no Plenário do Senado Federal. 
TABELAS REFERENTES AO GRUPO 3 (1985 em diante)

Manifestações do Poder Executivo 


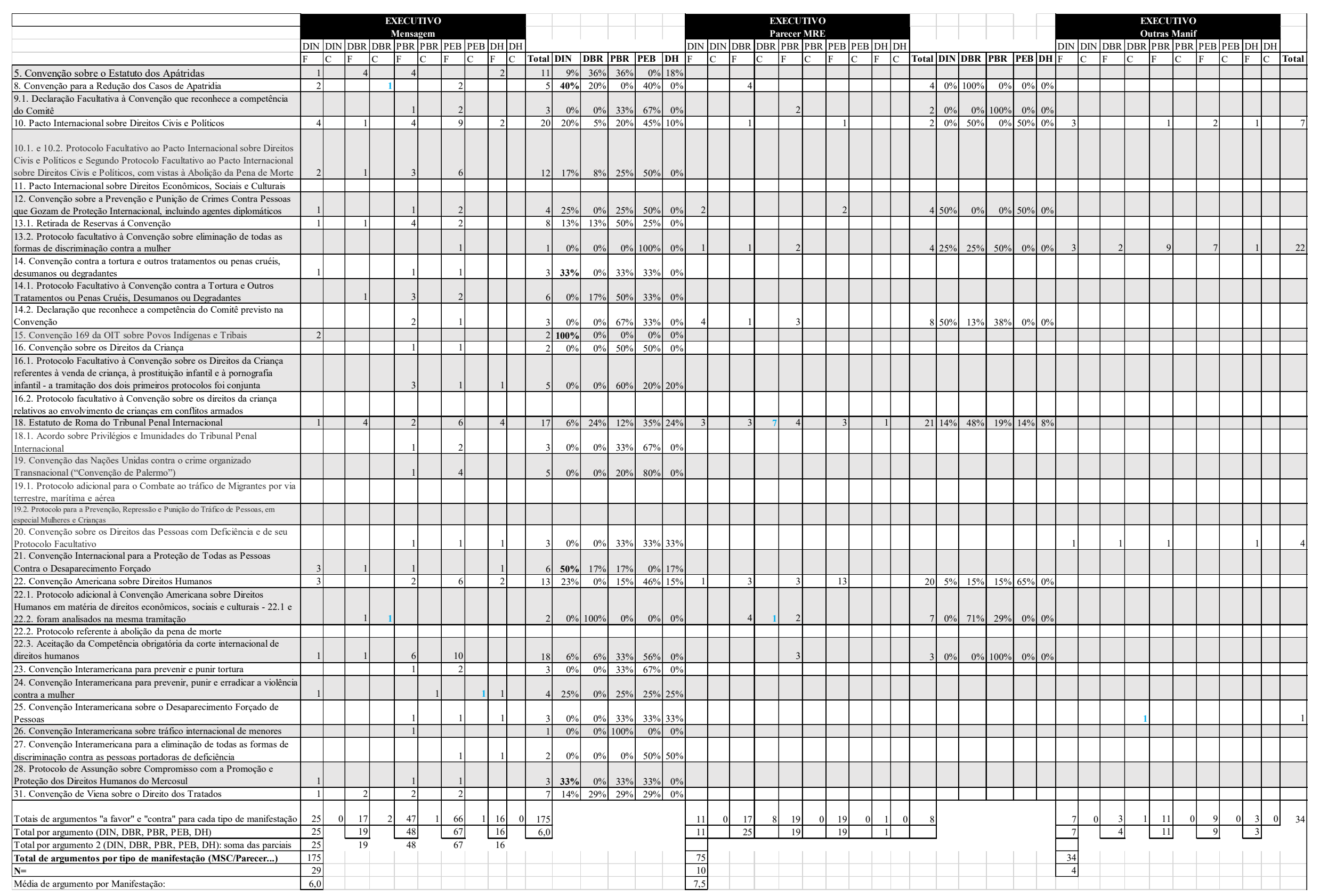




\section{Manifestações do Poder Legislativo: Câmara dos Deputados}

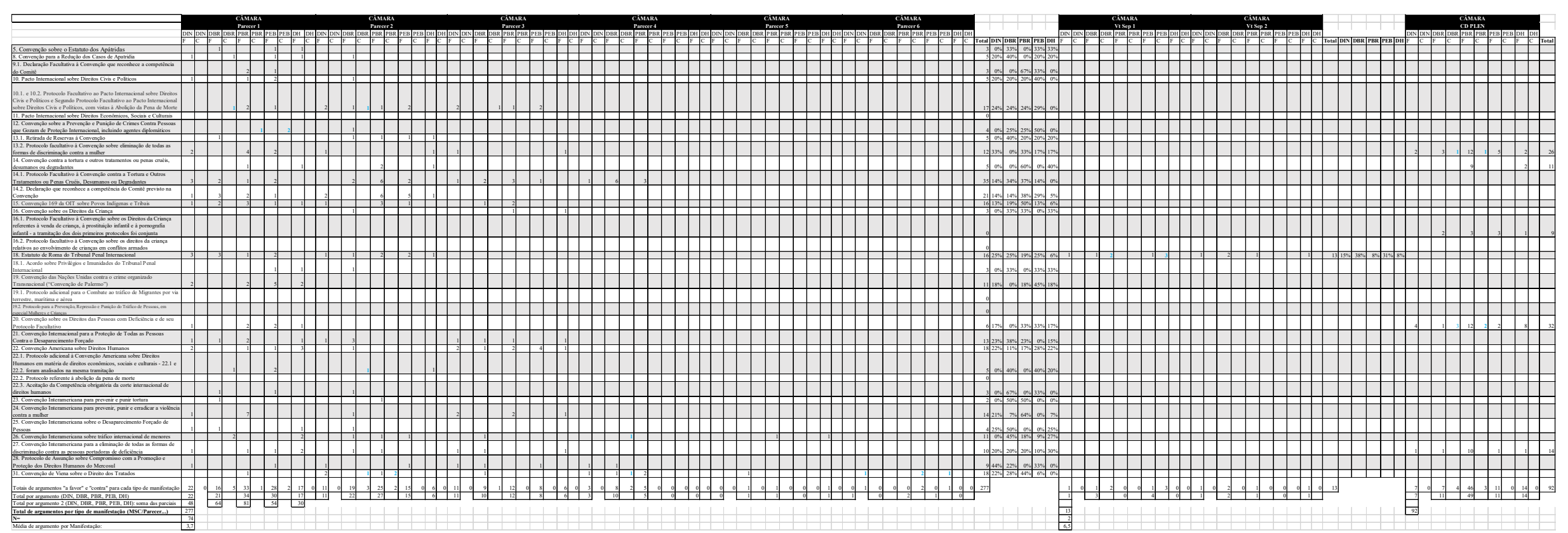


Manifestações do Poder Legislativo: Senado Federal

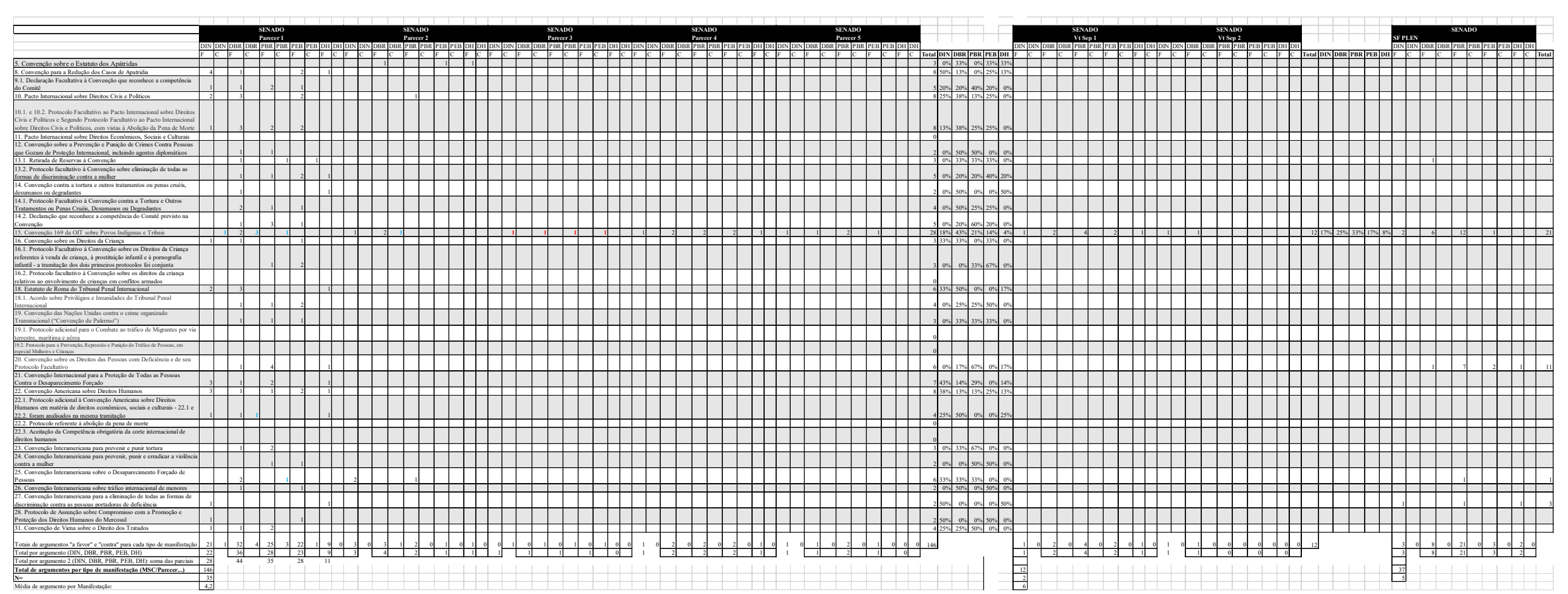




\section{APÊNDICE IV}

TABELAS REFERENTES AOS ATOS INTERNACIONAIS E INTERNOS ANALISADOS 


\begin{tabular}{|c|c|c|c|c|c|c|c|c|c|c|c|}
\hline & & & ate & (D) & 安 & The & (C) & (t) & (i) & 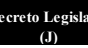 & (א) \\
\hline 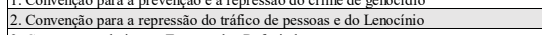 & 2010311950 & 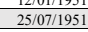 & $12 / 12 / 1958$ & 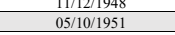 & 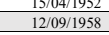 & 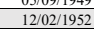 & $14 / 02 / 1952$ & $\frac{180661958}{1809}$ & $\frac{041 / 11 / 1955}{0.055}$ & $\frac{111047931}{1110601958}$ & 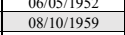 \\
\hline 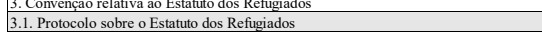 & $281001 / 1951$ & 22201441954 & $\frac{15 / 722961}{0704 / 1972}$ & $\frac{15077952}{0770411922}$ & $\frac{1611 / 1960}{07081972}$ & $\frac{30.07 / 1957}{20091 / 1971}$ & $280108 / 1957$ & $\frac{140551959}{2411 / 1971}$ & $\frac{140881999}{271 / 1971}$ & $\frac{0707 / 1960}{3011 / 1971}$ & $\frac{28101 / 1961}{007 / 1972}$ \\
\hline 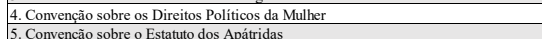 & $\begin{array}{lllll}31 / 103 / 1953 \\
28091 / 1954\end{array}$ & 0707071954 & $\frac{11 / 1 / 1 / 1963}{13 / 19696}$ & $\frac{21 / 05 / 1953}{2809 / 1954}$ & $\frac{13081963}{130.18966}$ & 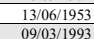 & $\frac{19 / 661953}{07(19493}$ & $\frac{01 / 07 / 1953}{02066939}$ & $\frac{060991955}{21066194}$ & $20.11 / 1955$ & $\frac{12 / 09 / 1963}{22015202}$ \\
\hline 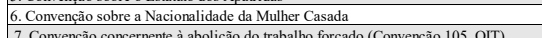 & 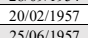 & 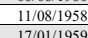 & $\begin{array}{l}0403 / 1969 \\
01806966\end{array}$ & 260771966 & 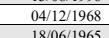 & 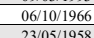 & $23 / 11 / 1966$ & $\begin{array}{l}1901 / 1967 \\
01071964\end{array}$ & $\frac{3005 / 1967}{281067}$ & $\begin{array}{l}2506061968 \\
20.014956\end{array}$ & $1803 / 1969$ \\
\hline 8. Convençāo para a Reduchäo dos Casos de Apatridia & 300881961 & 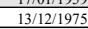 & $\frac{18001960}{23 / 1 / 2008}$ & 3010811961 & $\frac{1000100}{25 / 1022007}$ & $\frac{2901390}{166042001}$ & $24 / 04 / 2001$ & 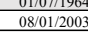 & 2861019042007 & 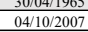 & $\frac{1401 / 960}{18 / 08 / 2015}$ \\
\hline 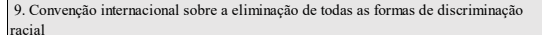 & $0703 / 1966$ & $04 / 01 / 1969$ & $2604 / 1968$ & $07 / 03 / 1966$ & $27 / 03 / 1968$ & $11 / 10 / 1966$ & $23 / 11 / 1966$ & 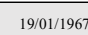 & $200 / 44 / 1967$ & $21 / 0661967$ & $08 / 12 / 1969$ \\
\hline 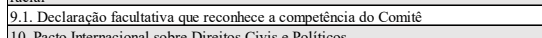 & 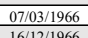 & $03 / 12 / 1982$ & 24041099 & $\frac{N / A}{24009}$ & 24040902 & 0609022000 & $20090 / 2000$ & $0404 / 2001$ & 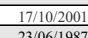 & $\frac{2604 / 2002}{10(12092}$ & 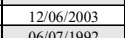 \\
\hline 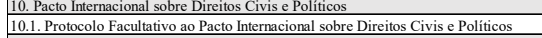 & $\frac{161 / 1 / 1966}{16 / 1211966}$ & 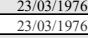 & $\frac{24(04 / 1992}{24 / 22009}$ & 24:01/1/1992 2009 & & $\frac{22 / 1 / 1 / 1955}{077102005}$ & $\frac{281 / 1 / 1985}{27122005}$ & $\frac{21.0551966}{31105 / 2006}$ & $\frac{23066197}{122062008}$ & $\frac{121 / 1 / 21991}{166062009}$ & 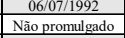 \\
\hline 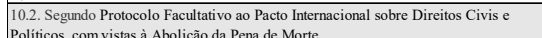 & $15 / 12 / 1999$ & $11 / 07 / 1991$ & $24 / 12 / 2009$ & $25 / 09 / 2009$ & & $07 / 102005$ & 27/12/2/2005 & $31 / 05 / 2006$ & $12 / 0662008$ & 16106622009 & Nâo promulgado \\
\hline 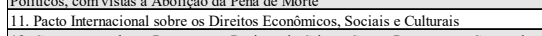 & $16 / 12 / 1966$ & $03 / 01 / 1976$ & $24 / 04 / 1992$ & $24 / 01 / 1992$ & $24 / 01 / 1992$ & $22 / 11 / 1985$ & $28 / 11 / 1985$ & $21 / 05 / 1986$ & $23 / 0661987$ & $12 / 12 / 1991$ & $06 / 107 / 1992$ \\
\hline 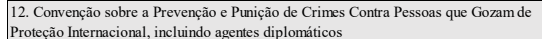 & $14 / 12 / 1973$ & $200.02 / 1977$ & $07 / 06 / 1999$ & $07 / 06 / 1999$ & $07 / 06 / 1999$ & $15 / 10 / 1997$ & $21 / 10 / 1997$ & $17 / 06 / 1998$ & $09 / 12 / 1998$ & $31 / 03 / 1999$ & 1409/1999 \\
\hline 13. Convenzăa sobre a elimininąão de todas as formas de discriminacăo contra a mulher & 18/12/1979 & $03 / 09 / 1981$ & $02 / 03 / 1984$ & $31 / 03 / 1981$ & $01 / 02 / 1984$ & $08: 07 / 1982$ & $2607 / 1982$ & 10/08/1982 & $28 / 06 / 1983$ & 14/11/1983 & 2003/1984 \\
\hline 13.1. Retirada das reservas à Convennão & N/A & $\mathrm{N} / \mathrm{A}$ & N/A & N/A & N/A & $31 / 05 / 1993$ & 220661993 & $23 / 03 / 1994$ & 080661994 & 220661994 & $1309 / 2002$ \\
\hline 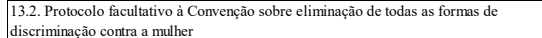 & $06 / 10 / 1999$ & 22/12/2000 & $28 / 99 / 2002$ & $13 / 03 / 2001$ & $30 / 07 / 2002$ & 16/104/2001 & $25 / 04 / 2001$ & 17/10/2001 & 21/12/2001 & $06606 / 2002$ & $3007 / 2002$ \\
\hline $\begin{array}{l}\text { 14. Convenceäa contra a tortura e outros tratamentos ou penas cruéis, desumanos ou } \\
\text { deraddres }\end{array}$ & 10/12/1994 & 2606061987 & $28110 / 1999$ & $23 / 09 / 1985$ & $28 / 09 / 1989$ & $2905 / 1986$ & 030661986 & $03 / 12 / 1986$ & $23 / 06 / 1987$ & $2305 / 1989$ & 1502/1991 \\
\hline 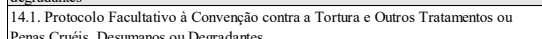 & 18/12/2002 & $22 / 0662006$ & 11102/2007 & $13 / 10 / 2003$ & $111 / 01 / 2007$ & $22 / 04 / 2004$ & $18106 / 2004$ & $18 / 11 / 2004$ & $28 / 11 / 2006$ & $20 / 12 / 2006$ & 1904/2007 \\
\hline 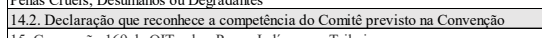 & $101 / 2 / 1984$ & 260661987 & Nä́p promulgata & $\mathrm{N} / \mathrm{A}$ & & 2506062002 & 0407072002 & $08: 01 / 2003$ & $13 / 1222005$ & 1770420066 & Nâo promulgado \\
\hline 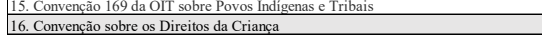 & $27061 / 19899$ & 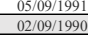 & $\frac{2507 / 2003}{23101 / 1990}$ & $\frac{\mathrm{NA}}{2601 / 1990}$ & $\frac{25570 / 2002}{2409 / 1990}$ & $\frac{2806659191}{166511900}$ & $\frac{166 / 07 / 1991}{31 / 05 / 990}$ & 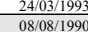 & $25108 / 9933$ & $\frac{20.06 / 2002}{140091 / 990}$ & $\frac{19.04 / 2004}{21 / 1 / 1 / 990}$ \\
\hline 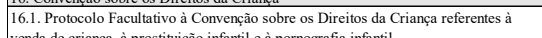 & $2505 / 2000$ & $1801 / 2002$ & $2702 / 2004$ & $06 / 109 / 2000$ & $2701 / 2004$ & 10/09/2001 & $25 / 09 / 2001$ & $25 / 02 / 2003$ & $11 / 03 / 2003$ & $2905 / 2003$ & $08 / 03 / 2004$ \\
\hline 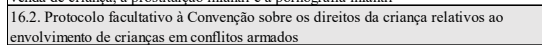 & $2505 / 2000$ & 12/02/2002 & $27 / 02 / 2004$ & $06 / 109 / 2000$ & $27 / 01 / 2004$ & 10/09/2001 & 25/09/2001 & $25 / 02 / 2003$ & 11/03/2003 & $2905 / 2003$ & $08 / 03 / 2004$ \\
\hline 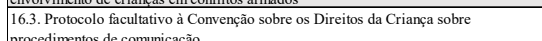 & 19/12/2011 & 14/04/2014 & Näo promulgado & 28/02/2012 & & $04 / 02 / 2015$ & $2705 / 2015$ & $17 / 12 / 2015$ & & & \\
\hline 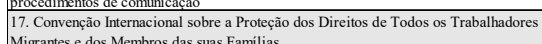 & 18/12/1990 & $01 / 07 / 2003$ & Não promulgada & Näo assinda pelo Brasil & & 30/04/2010 & 13/12/2010 & & & & \\
\hline 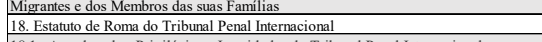 & $17707 / 1998$ & $0107 / 2002$ & $01 / 09 / 2002$ & $\begin{array}{c}\text { (outubro/2016) } \\
07722000 \\
\end{array}$ & 2006012002 & $26077 / 2001$ & 1010102001 & $05 / 04 / 2002$ & $2404 / 2002$ & 0601662002 & $25 / 09 / 2002$ \\
\hline 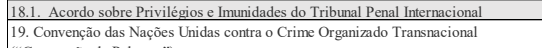 & $\begin{array}{ll}10092002 \\
15 / 11 / 2000\end{array}$ & $22909 / 20003$ & 2810222004 & $12 / 12 / 2000$ & $\begin{array}{l}12 / 12 / 2011 \\
29 / 01 / 2004\end{array}$ & $\begin{array}{ll}07 / 07 / 2008 \\
27 / 1 / 2001\end{array}$ & $\begin{array}{ll}11103 / 2010 \\
30 / 1 / 2002\end{array}$ & $\frac{1808 / 2010}{2602 / 2003}$ & $12032 / 2003$ & $29095 / 2003$ & 120322004 \\
\hline 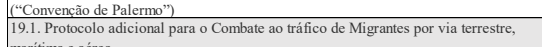 & $15 / 11 / 2000$ & $2909 / 2003$ & $28 / 02 / 2004$ & $12 / 12 / 2000$ & $29 / 01 / 2004$ & $27 / 11 / 2001$ & 30/01/2002 & $261022 / 2003$ & $12 / 203 / 2003$ & $2905 / 2003$ & 12003/2004 \\
\hline 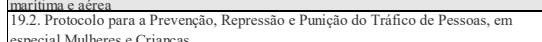 & $15 / 11 / 2000$ & $25 / 1212003$ & $28002 / 2004$ & $12 / 12 / 2000$ & $29 / 01 / 2004$ & $27 / 11 / 2001$ & 30/01/2002 & $26102 / 2003$ & $12 / 03 / 2003$ & $29 / 05 / 2003$ & 12/03/2004 \\
\hline 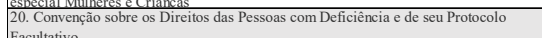 & 13/12/2006 & $03 / 05 / 2008$ & $31 / 08 / 2008$ & $30 / 03 / 2007$ & $01 / 08 / 2008$ & $26,07 / 2007$ & $26109 / 2007$ & 13/05/2008 & $2805 / 2008$ & 0907/2008 & $25 / 08 / 2009$ \\
\hline $\begin{array}{l}\text { 21. Convencano Internacional para a Proteção de Todas as Pessoas Contra o } \\
\text { D. }\end{array}$ & 20/12/2006 & $23 / 12 / 2010$ & $28 / 12 / 2010$ & $06 / 02 / 2007$ & $29 / 11 / 2010$ & $01 / 11 / 2007$ & 0406/2009 & $25 / 11 / 2009$ & $07 / 04 / 2010$ & $01 / 09 / 2010$ & 11/05/2016 \\
\hline
\end{tabular}




\begin{tabular}{|c|c|c|c|c|c|c|c|c|c|c|c|}
\hline & & (B) & 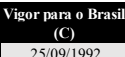 & $\begin{array}{ll}\text { Acessẵ } \\
(D)\end{array}$ & & (F) & (G) & (H) & (I) & (J) & 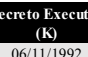 \\
\hline 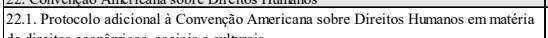 & $17 / 11 / 1988$ & $16 / 11 / 999$ & $16 / 11 / 1999$ & $21 / 08 / 1996$ & Informąăōo nãe encontrada & $20 / 11 / 1992$ & $26 / 11 / 1992$ & 30/66/1993 & $0203 / 1994$ & 19/04/1995 & $30 / 12 / 1999$ \\
\hline 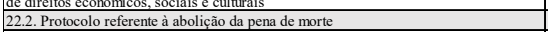 & $08 / 06 / 1990$ & 28081991 & $1308 / 1996$ & $07066_{1994}$ & 13081996 & $20111 / 1992$ & $26111 / 1992$ & $30106 / 1993$ & $02 / 03 / 1994$ & $1904 / 1995$ & 270881998 \\
\hline $\begin{array}{l}22.3 . \text { Recoonhecinento da Competênnia obrigatória da Corte Interamericana de Diretitos } \\
\text { Humnos }\end{array}$ & $22 / 11 / 1969$ & $\mathrm{~N} / \mathrm{A}$ & $08 / 11 / 2002$ & 10/12/1998 & Informucăo não encontrada & $0409 / 1998$ & $0809 / 1998$ & 14/10/1998 & 19/10/1998 & $03 / 12 / 1998$ & $08 / 11 / 2002$ \\
\hline Himanos 23. Convencão Interamericana para prevenenir e punir tortura & $09 / 12 / 1985$ & $2902 / 1987$ & $1908 / 1989$ & $2401 / 1986$ & 200771989 & $11 / 06 / 1986$ & $1306 / 1986$ & $03 / 12 / 1986$ & 070661988 & $31 / 05 / 1989$ & $09 / 11 / 1989$ \\
\hline 24. Convennâa Interamericana para prevenir, punir e erradicar a violênncia contra a & $09 / 06 / 1994$ & $05 / 03 / 1995$ & $15 / 12 / 1995$ & $06 / 199 / 1994$ & 16/11/1995 & 1601/1995 & 1901/1995 & 17/05/1995 & $23 / 08 / 1995$ & $31 / 08 / 1995$ & $01 / 08 / 1996$ \\
\hline 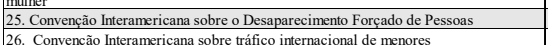 & $\frac{090611994}{0.031094}$ & $28 / 03 / 1996$ & $\frac{25 / 08 / 2013}{15 / 08 / 1997}$ & $\frac{100611994}{18031 / 1994}$ & $2607 / 2013$ & $\frac{14412 / 1994}{1601 / 1995}$ & $\frac{25 / 1211994}{1901 / 1995}$ & $\frac{1705 / 1995}{10695 / 195}$ & $\begin{array}{ll}3005 / 2008 \\
07001896\end{array}$ & $\frac{08042011}{30101 / 196}$ & $\frac{1105 / 2016}{20081 / 198}$ \\
\hline 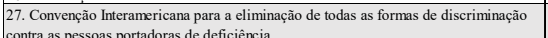 & $08 / 06 / 1999$ & 1409/2001 & $1409 / 2001$ & $08 / 061999$ & $17707 / 2001$ & $04 / 10 / 1999$ & $22 / 10 / 1999$ & $2903 / 2000$ & $06013 / 2001$ & 1306/2001 & $08 / 10 / 2001$ \\
\hline 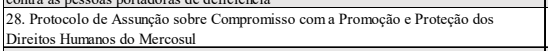 & 20/06/2005 & $03 / 04 / 2010$ & $03 / 04 / 2010$ & 20/06/2005 & $0403 / 2010$ & 11/09/2006 & 13/10/2006 & 19/03/2008 & 16/66/2009 & $27 / 08 / 2009$ & $01 / 07 / 2010$ \\
\hline 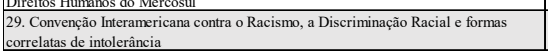 & $0605 / 2013$ & Nâo está em vigor intermacionalmente (05.01.2017) & Nâo promulgada & $06 / 17 / 2013$ & & & & & & & \\
\hline 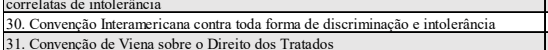 & $\begin{array}{ll}0605 / 2013 \\
2305 / 1699\end{array}$ & \begin{tabular}{|l} 
Não está em vigor intemacionalmente (05.01.2017) \\
$27 / 711 / 1890$
\end{tabular} & \begin{tabular}{|l} 
Não promulgada \\
24 lit2 2009
\end{tabular} & $\begin{array}{ll}066 / 27 / 2013 \\
2305 / 1169\end{array}$ & $25 / 09 / 2009$ & $16 / 04 / 1992$ & $22 / 04 / 1992$ & $02 / 1 / 1 / 1992$ & 210.052009 & $1707 / 2009$ & $144 / 12 / 2009$ \\
\hline
\end{tabular}

Fonte: elaboração própria 


\begin{tabular}{|c|c|c|c|c|c|c|}
\hline $\begin{array}{l}\text { TRATADOS E } \\
\text { ENTRADA EM VIGOR } \\
\text { INTERNACIONAL }\end{array}$ & $\begin{array}{l}\text { ASSINATURA } \\
\text { E } \\
\text { RATIFICAÇÃO } \\
\text { PELO BRASIL }\end{array}$ & $\begin{array}{l}\text { MENSAGEM } \\
\text { PRESIDENCIAL }\end{array}$ & $\begin{array}{l}\text { PROJETO DE } \\
\text { DECRETO } \\
\text { LEGISLATIVO }\end{array}$ & $\begin{array}{l}\text { DECRETO } \\
\text { LEGISLATIVO }\end{array}$ & $\begin{array}{l}\text { DECRETO } \\
\text { EXECUTIVO }\end{array}$ & $\begin{array}{l}\text { OBSERVAÇÕES: RESERVAS E } \\
\text { LEIS BRASILEIRAS }\end{array}$ \\
\hline $\begin{array}{l}\text { A. SISTEMA } \\
\text { GLOBAL }\end{array}$ & & & & & & \\
\hline \multicolumn{7}{|c|}{ DEMOCRACIA NO BRASIL } \\
\hline $\begin{array}{l}\text { 1. Convenção para a } \\
\text { prevenção e a repressão do } \\
\text { crime de genocídio } \\
(09.12 .1948) \\
\text { Em vigor internacional } \\
\text { desde: } 12.01 .1951 \\
\text { Em vigor para o Brasil } \\
\text { desde: } 15.07 .1952 \text { (art. } \\
\text { XIII.3) }\end{array}$ & $\begin{array}{l}\text { Assinatura: } \\
11.12 .1948 \\
\text { Ratificação: } \\
15.04 .1952\end{array}$ & $\begin{array}{l}\text { MSC 450/1949 } \\
\text { De: } 05.09 .1949 \\
\text { Enviada ao } \\
\text { Legislativo em: } \\
17.09 .1949 \\
\text { Transformada } \\
\text { em PL em: } \\
28.07 .1950\end{array}$ & $\begin{array}{l}\text { Câmara: } \\
\text { PL 633/1950 } \\
\text { COMDIP } \\
\text { Remessa ao SF } \\
\text { em: } 10.11 .1950 \\
\\
\text { Senado: } 36 \text {, de } \\
13.11 .1950\end{array}$ & $\begin{array}{l}\text { Decreto } \\
\text { Legislativo 02, } \\
\text { de 11.04.1951 } \\
\text { (SF) }\end{array}$ & $\begin{array}{l}\text { Decreto } \\
\text { Presidencial } \\
\text { 30.822, de } \\
06.05 .1952\end{array}$ & $\begin{array}{l}\text { Essa MSC foi transformada em PL } \\
\text { da Comissão de Diplomacia } \\
\text { (COMDIP) }\end{array}$ \\
\hline $\begin{array}{l}\text { 2. Convenção para a } \\
\text { repressão do tráfico de } \\
\text { pessoas e do Lenocínio } \\
(21.03 .1950) \\
\text { Em vigor internacional } \\
\text { desde: } 25.07 .1951 \text { (art. } 24) \\
\text { Em vigor para o Brasil } \\
\text { desde: } 12.12 .1958 \text { (art. } \\
24.2 \text { ) }\end{array}$ & $\begin{array}{l}\text { Assinatura: } \\
05.10 .1951 \\
\text { Ratificação: } \\
12.09 .1958\end{array}$ & $\begin{array}{l}\text { MSC } 41 / 1952 \\
\text { De: } 12.02 .1952 \\
\text { Enviada ao } \\
\text { Legislativo em: } \\
14.02 .1952 \\
\\
\text { Transformada } \\
\text { em PDC em: } \\
18.06 .1958\end{array}$ & $\begin{array}{l}\text { PDC 29/1955 } \\
\text { Remessa ao SF } \\
\text { em: } 04.11 .1955 \\
\text { PDS 58/1955 }\end{array}$ & $\begin{array}{l}\text { Decreto } \\
\text { Legislativo 6, de } \\
11.06 .1958\end{array}$ & $\begin{array}{l}\text { Decreto } \\
\text { Presidencial } \\
46.981, \text { de } \\
08.10 .1959\end{array}$ & \\
\hline
\end{tabular}




\begin{tabular}{|c|c|c|c|c|c|c|}
\hline $\begin{array}{l}\text { TRATADOS E } \\
\text { ENTRADA EM VIGOR } \\
\text { INTERNACIONAL }\end{array}$ & $\begin{array}{l}\text { ASSINATURA } \\
\text { E } \\
\text { RATIFICAÇÃO } \\
\text { PELO BRASIL } \\
\end{array}$ & $\begin{array}{l}\text { MENSAGEM } \\
\text { PRESIDENCIAL }\end{array}$ & $\begin{array}{l}\text { PROJETO DE } \\
\text { DECRETO } \\
\text { LEGISLATIVO }\end{array}$ & $\begin{array}{l}\text { DECRETO } \\
\text { LEGISLATIVO }\end{array}$ & $\begin{array}{l}\text { DECRETO } \\
\text { EXECUTIVO }\end{array}$ & $\begin{array}{l}\text { OBSERVAÇÕES: RESERVAS E } \\
\text { LEIS BRASILEIRAS }\end{array}$ \\
\hline $\begin{array}{l}\text { 3. Convenção } \\
\text { relativa ao Estatuto dos } \\
\text { Refugiados (28.07.1951) } \\
\text { Em vigor internacional } \\
\text { desde: } 22.04 .1954 \text { (art. } \\
\text { 43) } \\
\text { Em vigor para o Brasil } \\
\text { desde: } 15.02 .1961 \\
\text { (art. 43.2) }\end{array}$ & $\begin{array}{l}\text { Assinatura: } \\
15.07 .1952 \\
\text { Ratificação: } \\
16.11 .1960\end{array}$ & $\begin{array}{l}\text { MSC } 355 / 1957 \\
\text { De: } 30.07 .1957 \\
\text { Enviada ao } \\
\text { Legislativo em: } \\
28.08 .1957 \\
\\
\text { Transformada } \\
\text { em PDC em } \\
\text { 14.05.1959: }\end{array}$ & $\begin{array}{l}\text { Câmara: 7A e 7B, } \\
\text { de } 1959 \\
\text { Remessa ao SF } \\
\text { em: } 14.08 .1959 \\
\text { PDS 9/1959 }\end{array}$ & $\begin{array}{l}\text { Decreto } \\
\text { Legislativo 11, } \\
\text { de 07.07.1960 }\end{array}$ & $\begin{array}{l}\text { Decreto } \\
\text { Presidencial } \\
50.215, \text { de } \\
28.01 .1961\end{array}$ & $\begin{array}{l}\text { Reserva aos artigos } 15 \text { e } 17 . \text { Em } \\
07.04 .1972 \text {, quando da acessão do } \\
\text { Brasil ao Protocolo sobre o Estatuto } \\
\text { dos Refugiados, de } 31.01 .1967, \text { o } \\
\text { governo brasileiro retirou suas } \\
\text { reservas aos artigos } 15 \text { e } 17, \\
\text { parágrafos } 1 \text { e } 3 \text {, de sua aplicação da } \\
\text { Convenção. }\end{array}$ \\
\hline $\begin{array}{l}\text { 3.1. Protocolo sobre o } \\
\text { Estatuto dos Refugiados } \\
\text { (31.01.1967) } \\
\text { Em vigor internacional } \\
\text { desde: } 04.10 .1967 \text { (art. } \\
\text { VIII.) } \\
\text { Adesão do Brasil: } \\
\text { 07.04.1972 } \\
\text { Em vigor para o Brasil } \\
\text { desde: } 07.04 .1972\end{array}$ & $\begin{array}{l}\text { Assinatura: } \\
07.04 .1972 \\
\text { Ratificação: } \\
07.08 .1972\end{array}$ & $\begin{array}{l}\text { MSC 410/1971 } \\
\text { De: } 20.09 .1971 \\
\\
\text { Enviada ao } \\
\text { Legislativo em: } \\
26.10 .1971 \\
\\
\text { Transformada } \\
\text { em PDC em: } \\
24.11 .1971\end{array}$ & $\begin{array}{l}\text { PDC 53-B/1971 } \\
\text { Remessa ao SF } \\
\text { em: } 27.11 .1971 \\
\text { PDS: } 43 / 1971\end{array}$ & $\begin{array}{l}\text { Decreto } \\
\text { Legislativo 93, } \\
\text { de 30.11.1971 }\end{array}$ & $\begin{array}{l}\text { Decreto } \\
\text { Presidencial } \\
70.946, \text { de } \\
07.08 .1972\end{array}$ & $\begin{array}{l}\text { PL 410/1971 } \\
\text { Senado: 43/1971: aprova o texto do } \\
\text { protocolo sobre o estatuto dos } \\
\text { refugiados, adotado em Nova York } \\
\text { em } 31 / 01 / 1967 \text {, e dá autorização para } \\
\text { que o brasil possa aderir ao protocolo, } \\
\text { bem como retirar as reservas feitas } \\
\text { aos artigos } 15 \text { e } 17 \text {, parágrafo } 1^{\circ} \text { e } 3^{\circ} \\
\text { da convenção relativa ao estatuto dos } \\
\text { refugiados de } 1951 \text {. }\end{array}$ \\
\hline
\end{tabular}




\begin{tabular}{|c|c|c|c|c|c|c|}
\hline $\begin{array}{l}\text { TRATADOS E } \\
\text { ENTRADA EM VIGOR } \\
\text { INTERNACIONAL }\end{array}$ & $\begin{array}{l}\text { ASSINATURA } \\
\text { E } \\
\text { RATIFICAÇÃO } \\
\text { PELO BRASIL }\end{array}$ & $\begin{array}{l}\text { MENSAGEM } \\
\text { PRESIDENCIAL }\end{array}$ & $\begin{array}{l}\text { PROJETO DE } \\
\text { DECRETO } \\
\text { LEGISLATIVO }\end{array}$ & $\begin{array}{l}\text { DECRETO } \\
\text { LEGISLATIVO }\end{array}$ & $\begin{array}{l}\text { DECRETO } \\
\text { EXECUTIVO }\end{array}$ & $\begin{array}{l}\text { OBSERVAÇÕES: RESERVAS E } \\
\text { LEIS BRASILEIRAS }\end{array}$ \\
\hline $\begin{array}{l}\text { 4. Convenção sobre } \\
\text { os Direitos Políticos da } \\
\text { Mulher (31.03.1953) } \\
\text { Em vigor internacional } \\
\text { desde: } \\
07.07 .1954 \text { (art. VI) } \\
\text { Em vigor para o Brasil } \\
\text { desde: } 11.11 .1963 \\
\text { (art. V) }\end{array}$ & $\begin{array}{l}\text { Assinatura: } \\
21.05 .1953 \\
\text { Ratificação: } \\
13.08 .1963\end{array}$ & $\begin{array}{l}\text { MSC } 247 / 1953 \\
\text { De: } 13.06 .1953 \\
\text { Enviada ao } \\
\text { Legislativo em: } \\
19.06 .1953 \\
\text { Transformada } \\
\text { em PDC em: } \\
01.07 .1953 \\
\end{array}$ & $\begin{array}{l}\text { PDC } 17 / 1955 \\
\text { Remessa ao SF } \\
\text { em: } 06.09 .1955 \\
\text { PDS } 49 / 1955\end{array}$ & $\begin{array}{l}\text { Decreto } \\
\text { Legislativo } 123 \text {, } \\
\text { de } 20.11 .1955\end{array}$ & $\begin{array}{l}\text { Decreto } \\
\text { Presidencial } \\
52.476, \text { de } \\
12.09 .1963\end{array}$ & \\
\hline $\begin{array}{l}\text { 5. Convenção sobre } \\
\text { o Estatuto dos Apátridas } \\
(28.09 .1954) \\
\text { Em vigor internacional } \\
\text { desde: } \\
\text { 06.06.1960 (art. 39) } \\
\text { Em vigor para o Brasil } \\
\text { desde: } \\
\begin{array}{l}\text { 13.11.1996 (art. } 39, \\
\text { parágrafo } 2^{\circ} \text { ) }\end{array}\end{array}$ & $\begin{array}{l}\text { Assinatura: } \\
28.09 .1954 \\
\text { Ratificação: } \\
13.08 .1996\end{array}$ & $\begin{array}{l}\text { MSC } 171 / 1993 \\
\text { De: } 09.03 .1993 \\
\text { Enviada ao } \\
\text { Legislativo em: } \\
07.04 .1993 \\
\text { Transformada } \\
\text { em PDC em: } \\
02.06 .1993\end{array}$ & $\begin{array}{l}\text { PDC } 285 / 1993 \\
\text { Remessa ao SF } \\
\text { em: } 21.06 .1994 \\
\text { PDS 56/1994 }\end{array}$ & $\begin{array}{l}\text { Decreto } \\
\text { Legislativo 38, } \\
\text { de 05.04.1995 }\end{array}$ & $\begin{array}{l}\text { Decreto } \\
\text { Presidencial } \\
4.246, \text { de } \\
22.05 .2002\end{array}$ & \\
\hline
\end{tabular}




\begin{tabular}{|c|c|c|c|c|c|c|}
\hline $\begin{array}{l}\text { TRATADOS E } \\
\text { ENTRADA EM VIGOR } \\
\text { INTERNACIONAL }\end{array}$ & $\begin{array}{l}\text { ASSINATURA } \\
\text { E } \\
\text { RATIFICAÇÃO } \\
\text { PELO BRASIL }\end{array}$ & $\begin{array}{l}\text { MENSAGEM } \\
\text { PRESIDENCIAL }\end{array}$ & $\begin{array}{l}\text { PROJETO DE } \\
\text { DECRETO } \\
\text { LEGISLATIVO }\end{array}$ & $\begin{array}{l}\text { DECRETO } \\
\text { LEGISLATIVO }\end{array}$ & $\begin{array}{l}\text { DECRETO } \\
\text { EXECUTIVO }\end{array}$ & $\begin{array}{l}\text { OBSERVAÇÕES: RESERVAS E } \\
\text { LEIS BRASILEIRAS }\end{array}$ \\
\hline $\begin{array}{l}\text { 6. Convenção sobre } \\
\text { a Nacionalidade da Mulher } \\
\text { Casada (20.02.1957) } \\
\text { Em vigor internacional } \\
\text { desde: } 11.08 .1958 \text { (Art. 6) } \\
\text { Em vigor para o Brasil } \\
\text { desde: } \\
04.03 .1969\left(\operatorname{art.5}, \S 2^{\circ}\right)\end{array}$ & $\begin{array}{l}\text { Assinatura: } \\
26.07 .1966 \\
\text { Ratificação: } \\
04.12 .1968\end{array}$ & $\begin{array}{l}\text { MSC } 749 / 1966 \\
\text { De: } 06.10 .1966 \\
\text { Enviada ao } \\
\text { Legislativo em: } \\
23.11 .1966 \\
\text { Transformada } \\
\text { em PDC em: } \\
19.01 .1967\end{array}$ & $\begin{array}{l}\text { PDC 306/1967 } \\
\text { Remessa ao SF } \\
\text { em: } 30.05 .1967 \\
\text { (esse PDC foi e } \\
\text { voltou do Senado, } \\
\text { após emenda) } \\
\text { PDS 27/1967 }\end{array}$ & $\begin{array}{l}\text { Decreto } \\
\text { Legislativo 27, } \\
\text { de 25.06.1968 }\end{array}$ & $\begin{array}{l}\text { Decreto } \\
\text { Presidencial } \\
64.216, \text { de } \\
18.03 .1969\end{array}$ & $\begin{array}{l}\text { Reserva ao artigo 10: } \\
\text { Artigo 10: Toda questão que surja } \\
\text { entre dois ou mais contratantes sobre } \\
\text { a interpretação ou a aplicação da } \\
\text { presente Convenção, que não seja } \\
\text { resolvida por meio de negociações, } \\
\text { será submetida ã Corte Internacional } \\
\text { de Justiça, para que esta a resolva, a } \\
\text { petição de qualquer das partes em } \\
\text { conflito, salvo que as partes } \\
\text { interessadas concordem em um outro } \\
\text { modo de solucioná-la. }\end{array}$ \\
\hline $\begin{array}{l}7 . \quad \text { Convenção } \\
\text { concernente à abolição do } \\
\text { Trabalho Forçado } \\
\text { (Convenção } 105, \text { OIT) } \\
(25.06 .1957) \\
\text { Em vigor internacional } \\
\text { desde: } 17.01 .1959 \text { (art. } 4^{\circ} \text { ) } \\
\text { Em vigor para o Brasil } \\
\text { desde: } 18.06 .1966 \\
\left(\text { art. } 4^{\circ}, \S 3^{\circ}\right)\end{array}$ & $\begin{array}{l}\text { Ratificação: } \\
18.06 .1965\end{array}$ & $\begin{array}{l}\text { MSC } 143 / 1958 \\
\text { De: } 23.05 .1958 \\
\text { Enviada ao } \\
\text { Legislativo em: } \\
28.05 .1958 \\
\text { Transformada } \\
\text { em PDC em: } \\
01.07 .1964\end{array}$ & $\begin{array}{l}\text { PDC164/1964 } \\
\text { Remessa ao SF } \\
\text { em: } 28.10 .1964 \\
\text { PDS 113/1964 } \\
\text { (não tem NADA } \\
\text { aqui) }\end{array}$ & $\begin{array}{l}\text { Decreto } \\
\text { Legislativo 20, } \\
\text { de 30.04.1965 }\end{array}$ & $\begin{array}{l}\text { Decreto } \\
\text { Presidencial } \\
58.822, \text { de } \\
14.07 .1966\end{array}$ & \\
\hline
\end{tabular}




\begin{tabular}{|c|c|c|c|c|c|c|}
\hline $\begin{array}{l}\text { TRATADOS E } \\
\text { ENTRADA EM VIGOR } \\
\text { INTERNACIONAL }\end{array}$ & $\begin{array}{l}\text { ASSINATURA } \\
\text { E } \\
\text { RATIFICAÇÃO } \\
\text { PELO BRASIL } \\
\end{array}$ & $\begin{array}{l}\text { MENSAGEM } \\
\text { PRESIDENCIAL }\end{array}$ & $\begin{array}{l}\text { PROJETO DE } \\
\text { DECRETO } \\
\text { LEGISLATIVO }\end{array}$ & $\begin{array}{l}\text { DECRETO } \\
\text { LEGISLATIVO }\end{array}$ & $\begin{array}{l}\text { DECRETO } \\
\text { EXECUTIVO }\end{array}$ & $\begin{array}{l}\text { OBSERVAÇÕES: RESERVAS E } \\
\text { LEIS BRASILEIRAS }\end{array}$ \\
\hline $\begin{array}{l}8 . \quad \text { Convenção para a } \\
\text { Redução dos Casos de } \\
\text { Apatridia (30.08.1961) } \\
\text { Em vigor internacional } \\
\text { desde: } 13.12 .1975 \text { (art. 18) } \\
\text { Em vigor para o Brasil } \\
\text { desde: } 23.01 .2008\end{array}$ & $\begin{array}{l}\text { Assinatura: } \\
\text { 30.08.1961 } \\
\text { Ratificação: } \\
25.10 .2007\end{array}$ & $\begin{array}{l}\text { MSC } 370 / 2001 \\
\text { De: } 16.04 .2001 \\
\text { Enviada ao } \\
\text { Legislativo em: } \\
24.04 .2001 \\
\text { Transformada } \\
\text { em PDC em: } \\
08.01 .2003\end{array}$ & $\begin{array}{l}\text { PDC 2999/2003 } \\
\text { Remessa ao SF } \\
\text { em: } 26.02 .2007 \\
\text { PDS 26/2007 }\end{array}$ & $\begin{array}{l}\text { Decreto } \\
\text { Legislativo } 274, \\
\text { de } 04.10 .2007\end{array}$ & $\begin{array}{l}\text { Decreto } \\
\text { Presidencial } \\
8.501, \text { de } \\
18.08 .2015\end{array}$ & $\begin{array}{l}\text { Nesse caso, similarmente ao que } \\
\text { ocorre com o item } 5 \text { (Estatuto dos } \\
\text { apátridas), a assinatura ocorreu antes } \\
\text { do regime militar, e a MSC foi } \\
\text { enviada apenas após (e muitos anos } \\
\text { após) a volta da democracia ao } \\
\text { Brasil. } \\
\text { Ao assinar, o Brasil "conservou o } \\
\text { direito previsto no art. } 8, \S 3^{\circ} \text {, ii" }\end{array}$ \\
\hline \multicolumn{7}{|c|}{ REGIME MILITAR NO BRASIL } \\
\hline $\begin{array}{l}9 . \quad \text { Convenção } \\
\text { internacional sobre a } \\
\text { eliminação de todas as } \\
\text { formas de } \\
\text { Discriminação Racial } \\
(07.03 .1966) \\
\text { Em vigor internacional } \\
\text { desde: } 04.01 .1969 \\
\text { Em vigor para o Brasil } \\
\text { desde: } \\
\text { 26.04.1968 }\end{array}$ & $\begin{array}{l}\text { Assinatura: } \\
07.03 .1966 \\
\text { Ratificação: } \\
27.03 .1968\end{array}$ & $\begin{array}{l}\text { De: } 11.10 .1966 \\
\text { Enviada ao } \\
\text { Legislativo em: } \\
23.11 .1966 \\
\text { Transformada } \\
\text { em PDC em: } \\
19.01 .1967\end{array}$ & $\begin{array}{l}\text { Câmara: PDC } \\
\text { 305-A/1967 } \\
\text { Remessa ao SF } \\
\text { em: } 20.04 .1967 \\
\text { Senado: PDS } \\
\text { 20/1967 }\end{array}$ & $\begin{array}{l}\text { Decreto } \\
\text { Legislativo 23, } \\
\text { de 21.06.1967 }\end{array}$ & $\begin{array}{l}\text { Decreto } \\
\text { Presidencial } \\
65.810, \text { de } \\
08.12 .1969\end{array}$ & \\
\hline
\end{tabular}




\begin{tabular}{|c|c|c|c|c|c|c|}
\hline $\begin{array}{l}\text { TRATADOS E } \\
\text { ENTRADA EM VIGOR } \\
\text { INTERNACIONAL }\end{array}$ & $\begin{array}{l}\text { ASSINATURA } \\
\text { E } \\
\text { RATIFICAÇÃO } \\
\text { PELO BRASIL }\end{array}$ & $\begin{array}{l}\text { MENSAGEM } \\
\text { PRESIDENCIAL }\end{array}$ & $\begin{array}{l}\text { PROJETO DE } \\
\text { DECRETO } \\
\text { LEGISLATIVO }\end{array}$ & $\begin{array}{l}\text { DECRETO } \\
\text { LEGISLATIVO }\end{array}$ & $\begin{array}{l}\text { DECRETO } \\
\text { EXECUTIVO }\end{array}$ & $\begin{array}{l}\text { OBSERVAÇÕES: RESERVAS E } \\
\text { LEIS BRASILEIRAS }\end{array}$ \\
\hline $\begin{array}{l}9.1 . \text { Declaração } \\
\text { facultativa da Convenção } \\
\text { acima } \\
\text { Em vigor internacional } \\
\text { desde: } 03.12 .1982 \\
\text { Data do depósito da } 10^{a} \\
\text { declaração, conforme o art. } \\
14, \S 1^{\circ} \text { da Convenção }\end{array}$ & Não cabe & $\begin{array}{l}\text { MSC } 1309 / 2000 \\
\text { De: } 06.09 .2000 \\
\text { Enviada ao } \\
\text { Legislativo em: } \\
20.09 .2000 \\
\text { Transformada } \\
\text { em PDC em: } \\
04.04 .2001\end{array}$ & $\begin{array}{l}\text { PDC 895/2001 } \\
\text { Remessa ao SF } \\
\text { em: } 17.10 .2001 \\
\text { PDS 369/2001 }\end{array}$ & $\begin{array}{l}\text { Decreto } \\
\text { Legislativo 57, } \\
\text { de 26.04.2002 }\end{array}$ & $\begin{array}{l}\text { Decreto } \\
\text { Presidencial } \\
4.738, \mathrm{de} \\
12.06 .2003\end{array}$ & \\
\hline $\begin{array}{l}10 . \quad \text { Pacto } \\
\text { Internacional sobre } \\
\text { Direitos Civis e Políticos } \\
(16.12 .1966) \\
\text { Em vigor internacional } \\
\text { desde: } 23.03 .1976 \text { (art.49) } \\
\text { Em vigor para o Brasil } \\
\text { desde: } 24.04 .1992 \text { (art.49, } \\
\left.\S 2^{\circ}\right)\end{array}$ & $\begin{array}{l}\text { Assinatura: } \\
\text { [acessão direta] } \\
\text { O Brasil acedeu } \\
\text { ao tratado em } \\
24.01 .1992 \\
\text { Ratificação: } \\
24.04 .1992\end{array}$ & $\begin{array}{l}\text { MSC 620/1985 } \\
\text { De: } 22.11 .1985 \\
\text { Enviada ao } \\
\text { Legislativo em: } \\
28.11 .1985 \\
\text { Transformada } \\
\text { em PDC em: } \\
21.05 .1986\end{array}$ & $\begin{array}{l}\text { PDC } 131 / 1986 \\
\text { Remessa ao SF } \\
\text { em: } 23.06 .1987 \\
\text { Senado: PDS } \\
\text { 4/1987 }\end{array}$ & $\begin{array}{l}\text { Decreto } \\
\text { Legislativo 226, } \\
\text { de 12.12.1991 }\end{array}$ & $\begin{array}{l}\text { Decreto } \\
\text { Presidencial 592, } \\
\text { de } 06.07 .1992\end{array}$ & \\
\hline
\end{tabular}




\begin{tabular}{|c|c|c|c|c|c|c|}
\hline $\begin{array}{l}\text { TRATADOS E } \\
\text { ENTRADA EM VIGOR } \\
\text { INTERNACIONAL }\end{array}$ & $\begin{array}{l}\text { ASSINATURA } \\
\text { E } \\
\text { RATIFICAÇÃO } \\
\text { PELO BRASIL } \\
\end{array}$ & $\begin{array}{l}\text { MENSAGEM } \\
\text { PRESIDENCIAL }\end{array}$ & $\begin{array}{l}\text { PROJETO DE } \\
\text { DECRETO } \\
\text { LEGISLATIVO }\end{array}$ & $\begin{array}{l}\text { DECRETO } \\
\text { LEGISLATIVO }\end{array}$ & $\begin{array}{l}\text { DECRETO } \\
\text { EXECUTIVO }\end{array}$ & $\begin{array}{l}\text { OBSERVAÇÕES: RESERVAS E } \\
\text { LEIS BRASILEIRAS }\end{array}$ \\
\hline $\begin{array}{l}\text { 10.1. Protocolo } \\
\text { Facultativo ao Pacto } \\
\text { Internacional sobre } \\
\text { Direitos Civis e Políticos } \\
\text { (16.12.1966) } \\
\text { Em vigor internacional } \\
\text { desde: } 23.03 .1976 \\
\text { (art. 9) }\end{array}$ & $\begin{array}{l}\text { 10.1. Acessão: } \\
\text { 25.09.2009 } \\
\text { Em vigor para o } \\
\text { Brasil desde: } \\
24.12 .2009 \\
\left(\text { art. 9 }^{\mathbf{0}}\right)\end{array}$ & $\begin{array}{l}\text { MSC 924/2005 } \\
\text { (Ambos os } \\
\text { Protocolos foram } \\
\text { apreciados pela } \\
\text { mesma MSC) }\end{array}$ & $\begin{array}{l}\text { PDC 2253/2006 } \\
\text { Remessa ao SF } \\
\text { em: } 12.06 .2008 \\
\text { PDS } 139 / 2008\end{array}$ & $\begin{array}{l}\text { Decreto } \\
\text { Legislativo } 311 \\
\text { de 16.06.2009 }\end{array}$ & $\begin{array}{l}\text { Ainda não foi } \\
\text { promulgado }\end{array}$ & $\begin{array}{l}\text { Reserva ao art. } 2 \text { do Segundo } \\
\text { Protocolo (pena de Morte). }\end{array}$ \\
\hline $\begin{array}{l}\text { 10.2. Segundo } \\
\text { Protocolo Facultativo ao } \\
\text { Pacto Internacional sobre } \\
\text { Direitos Civis e Políticos, } \\
\text { com vistas à Abolição da } \\
\text { Pena de Morte } \\
\text { (15.12.1989) } \\
\text { Em vigor internacional } \\
\text { desde: } 11.07 .1991 \\
\text { (art. } 8 .(1))\end{array}$ & $\begin{array}{l}\text { 10.2. Acessão: } \\
25.09 .2009 \\
\text { (com reserva } \\
\text { expressa ao art. 2) } \\
\text { Em vigor para o } \\
\text { Brasil desde: } \\
\text { 24.12.2009 }\end{array}$ & $\begin{array}{l}\text { De: } 07.10 .2005 \\
\text { Enviada ao } \\
\text { Legislativo em: } \\
27.12 .2005 \\
\text { Transformada } \\
\text { em PDC em: } \\
\text { 31.05.2006 }\end{array}$ & & & & \\
\hline
\end{tabular}




\begin{tabular}{|c|c|c|c|c|c|c|}
\hline $\begin{array}{l}\text { TRATADOS E } \\
\text { ENTRADA EM VIGOR } \\
\text { INTERNACIONAL }\end{array}$ & $\begin{array}{l}\text { ASSINATURA } \\
\text { E } \\
\text { RATIFICAÇÃO } \\
\text { PELO BRASIL } \\
\end{array}$ & $\begin{array}{l}\text { MENSAGEM } \\
\text { PRESIDENCIAL }\end{array}$ & $\begin{array}{l}\text { PROJETO DE } \\
\text { DECRETO } \\
\text { LEGISLATIVO }\end{array}$ & $\begin{array}{l}\text { DECRETO } \\
\text { LEGISLATIVO }\end{array}$ & $\begin{array}{l}\text { DECRETO } \\
\text { EXECUTIVO }\end{array}$ & $\begin{array}{l}\text { OBSERVAÇÕES: RESERVAS E } \\
\text { LEIS BRASILEIRAS }\end{array}$ \\
\hline $\begin{array}{l}11 . \quad \text { Pacto } \\
\text { Internacional sobre } \\
\text { Direitos Econômicos, } \\
\text { Sociais e Culturais } \\
(16.12 .1966) \\
\text { Em vigor internacional } \\
\text { desde: } 03.01 .1976 \\
\text { Em vigor para o Brasil } \\
\text { desde: } 24.04 .1992 \text { (art. } 27 \text {, } \\
\left.\S 2^{\circ}\right)\end{array}$ & $\begin{array}{l}\text { O Brasil acedeu } \\
\text { ao tratado em } \\
24.01 .1992 \\
\text { Ratificação: } \\
24.01 .1992\end{array}$ & $\begin{array}{l}10 \text { e } 11: \text { mesma } \\
\text { MSC }\end{array}$ & $\begin{array}{l}10 \text { e } 11: \text { MESMO } \\
\text { PDC }\end{array}$ & $\begin{array}{l}10 \text { e } 11: \text { mesmo } \\
\text { Decreto } \\
\text { Legislativo }\end{array}$ & $\begin{array}{l}\text { Decreto } \\
\text { Presidencial 591, } \\
\text { de 06.07.1992 }\end{array}$ & \\
\hline $\begin{array}{l}12 . \quad \text { Convenção sobre } \\
\text { a Prevenção e Punição de } \\
\text { Crimes Contra Pessoas } \\
\text { que Gozam de Proteção } \\
\text { Internacional, incluindo } \\
\text { agentes diplomáticos } \\
(14.12 .1973) \\
\text { Em vigor internacional } \\
\text { desde: } 20.02 .1977 \text { (art. } \\
\text { 17(1)) } \\
\text { Em vigor para o Brasil } \\
\text { desde: } 07.06 .1999\end{array}$ & $\begin{array}{l}\text { Adesão: } \\
07.06 .1999\end{array}$ & $\begin{array}{l}\text { MSC } 1213 / 1997 \\
\text { De: } 15.10 .1997 \\
\text { Enviada ao } \\
\text { Legislativo em: } \\
21.10 .1997 \\
\text { Transformada } \\
\text { em PDC em: } \\
17.06 .1998\end{array}$ & $\begin{array}{l}\text { PDC } 696 / 1998 \\
\text { Remessa ao SF } \\
\text { em: } 09.12 .1998 \\
\text { PDS } 147 / 1998\end{array}$ & $\begin{array}{l}\text { Decreto } \\
\text { Legislativo } 25, \\
\text { de } 31.03 .1999, \\
\text { que fez a } \\
\text { reserva prevista } \\
\text { no parágrafo } 2^{\circ} \\
\text { do art. } 13 \text { da } \\
\text { Convenção; }\end{array}$ & $\begin{array}{l}\text { Decreto } \\
\text { Presidencial } \\
3.167, \text { de } \\
14.09 .1999\end{array}$ & $\begin{array}{l}\text { Reserva prevista no parágrafo } 20 \text { do } \\
\text { art. } 13 \text { da Convenção. } \\
\text { Aprovação legislativa prévia à } \\
\text { adesão (está na MSC, último } \\
\text { parágrafo) }\end{array}$ \\
\hline
\end{tabular}




\begin{tabular}{|c|c|c|c|c|c|c|}
\hline $\begin{array}{l}\text { TRATADOS E } \\
\text { ENTRADA EM VIGOR } \\
\text { INTERNACIONAL }\end{array}$ & $\begin{array}{l}\text { ASSINATURA } \\
\text { E } \\
\text { RATIFICAÇÃO } \\
\text { PELO BRASIL } \\
\end{array}$ & $\begin{array}{l}\text { MENSAGEM } \\
\text { PRESIDENCIAL }\end{array}$ & $\begin{array}{l}\text { PROJETO DE } \\
\text { DECRETO } \\
\text { LEGISLATIVO }\end{array}$ & $\begin{array}{l}\text { DECRETO } \\
\text { LEGISLATIVO }\end{array}$ & $\begin{array}{l}\text { DECRETO } \\
\text { EXECUTIVO }\end{array}$ & $\begin{array}{l}\text { OBSERVAÇÕES: RESERVAS E } \\
\text { LEIS BRASILEIRAS }\end{array}$ \\
\hline $\begin{array}{l}13 . \quad \text { Convenção sobre } \\
\text { a eliminação de todas as } \\
\text { formas de discriminação } \\
\text { contra a } \\
\text { mulher (18.12.1979) } \\
\text { Em vigor internacional } \\
\text { desde: } \\
\text { 03.09.1981 (art. 27(1)) } \\
\text { Em vigor para o Brasil } \\
\text { desde: } \\
\text { 02.03.1984 }\end{array}$ & $\begin{array}{l}\text { Assinatura: } \\
31.03 .1981 \\
\text { Ratificação: } \\
01.02 .1984\end{array}$ & $\begin{array}{l}\text { MSC } 320 / 1982 \\
\text { De: } 08.07 .1982 \\
\text { Enviada ao } \\
\text { Legislativo em: } \\
26.07 .1982 \\
\text { Transformada } \\
\text { em PDC em: } \\
10.08 .1982\end{array}$ & $\begin{array}{l}\text { Câmara: PDC } \\
\text { 141-B/1982 } \\
\text { Remessa ao SF } \\
\text { em: } 28.06 .1983 \\
\text { PDS } 13 / 1983\end{array}$ & $\begin{array}{l}\text { Decreto } \\
\text { Legislativo 93, } \\
\text { de 14.11.1983; }\end{array}$ & $\begin{array}{l}\text { Decreto } \\
\text { Executivo 89.460, } \\
\text { de 20.03.1984; }\end{array}$ & $\begin{array}{l}\text { Reservas feitas e retiradas } \\
\text { posteriormente, com o surgimento do } \\
\text { CC/2002. Atualmente, o Brasil só faz } \\
\text { reserva ao art.29 da Convenção, } \\
\text { relativo ao mecanismo de solução de } \\
\text { controvérsias. } \\
\text { Mencionada expressamente pela Lei } \\
\text { Maria da Penha, 2006. }\end{array}$ \\
\hline $\begin{array}{l}\text { 13.1. } \\
\text { reservas à Convenção }\end{array}$ & $\mathbf{N} / \mathbf{A}$ & $\begin{array}{l}\text { MSC } 345 / 1993 \\
\text { De: } 31.05 .1993 \\
\text { Enviada ao } \\
\text { Legislativo em: } \\
22.06 .1993 \\
\\
\text { Transformada } \\
\text { Em PDC em: } \\
\text { 23.03.1994 }\end{array}$ & $\begin{array}{l}\text { Câmara: PDC } \\
407 / 1994 \\
\text { Remessa ao SF } \\
\text { em: 08.06.1994 } \\
\text { PDS: } 44 \text { DE } 1994\end{array}$ & $\begin{array}{l}\text { Decreto } \\
\text { Legislativo 26, } \\
\text { de 22.06.1994: } \\
\text { Aprova o texto } \\
\text { da Convenção, } \\
\text { revoga o } \\
\text { Decreto } \\
\text { Legislativo } \\
93 / 1983 . \text { O } \\
\text { Brasil retirou as } \\
\text { mencionadas } \\
\text { reservas em } \\
\text { 20.12.1994 }\end{array}$ & $\begin{array}{l}\text { Decreto } \\
\text { Presidencial } \\
4.377, \text { de } \\
13.09 .2002 \\
\text { (revogou o } \\
\text { Decreto } 89.460 \text {, } \\
\text { de } 20.03 .1984 \text { ) }\end{array}$ & \\
\hline
\end{tabular}




\begin{tabular}{|c|c|c|c|c|c|c|}
\hline $\begin{array}{l}\text { TRATADOS E } \\
\text { ENTRADA EM VIGOR } \\
\text { INTERNACIONAL }\end{array}$ & $\begin{array}{l}\text { ASSINATURA } \\
\text { E } \\
\text { RATIFICAÇÃO } \\
\text { PELO BRASIL }\end{array}$ & $\begin{array}{l}\text { MENSAGEM } \\
\text { PRESIDENCIAL }\end{array}$ & $\begin{array}{l}\text { PROJETO DE } \\
\text { DECRETO } \\
\text { LEGISLATIVO }\end{array}$ & $\begin{array}{l}\text { DECRETO } \\
\text { LEGISLATIVO }\end{array}$ & $\begin{array}{l}\text { DECRETO } \\
\text { EXECUTIVO }\end{array}$ & $\begin{array}{l}\text { OBSERVAÇÕES: RESERVAS E } \\
\text { LEIS BRASILEIRAS }\end{array}$ \\
\hline $\begin{array}{l}\text { 13.2. Protocolo } \\
\text { facultativo à Convenção } \\
\text { sobre eliminação de todas } \\
\text { as formas de } \\
\text { discriminação contra a } \\
\text { mulher (06.10.1999) } \\
\text { Em vigor internacional } \\
\text { desde: } 22.12 .2000 \text { (art. } \\
\text { 16.1) } \\
\text { Em vigor para o Brasil } \\
\text { desde: } 28.09 .2002 \text { (art. } \\
\text { 16.1) }\end{array}$ & $\begin{array}{l}\text { Assinatura: } \\
\text { 13.03.2001 } \\
\text { Ratificação: } \\
\text { 30.07.2002 }\end{array}$ & $\begin{array}{l}\text { MSC } 374 / 2001 \\
\text { De: } 16.04 .2001 \\
\text { Enviada ao } \\
\text { Legislativo em: } \\
25.04 .2001 \\
\text { Transformada } \\
\text { em PDC em: } \\
17.10 .2001\end{array}$ & $\begin{array}{l}\text { PDC } 1357 / 2001 \\
\text { Remessa ao SF } \\
\text { em: } 21.12 .2001 \\
\text { PDS } 01 / 2002\end{array}$ & $\begin{array}{l}\text { Decreto } \\
\text { Legislativo 107, } \\
\text { de } 06.06 .2002\end{array}$ & $\begin{array}{l}\text { Decreto } \\
\text { Presidencial } \\
4.316, \text { de } \\
30.07 .2002\end{array}$ & \\
\hline $\begin{array}{l}14 . \quad \text { Convenção contra } \\
\text { a tortura e outros } \\
\text { tratamentos ou penas } \\
\text { cruéis, desumanos } \\
\text { ou degradantes } \\
(10.12 .1984) \\
\text { Em vigor internacional } \\
\text { desde: } 26.06 .1987 \text { (art. } \\
27.1) \\
\text { Em vigor para o Brasil } \\
\text { desde: } 28.10 .1989\end{array}$ & $\begin{array}{l}\text { Assinatura: } \\
23.09 .1985 \\
\text { Ratificação: } \\
28.09 .1989\end{array}$ & $\begin{array}{l}\text { MSC } 195 / 1986 \\
\text { De: } 29.05 .1986 \\
\text { Enviada ao } \\
\text { Legislativo em: } \\
03.06 .1986 \\
\text { Transformada } \\
\text { em PDC em: } \\
03.12 .1986\end{array}$ & $\begin{array}{l}\text { PDC } 153 / 1986 \\
\text { Remessa ao SF } \\
\text { em: } 23.06 .1987 \\
\text { PDS } 2 / 1987\end{array}$ & $\begin{array}{l}\text { Decreto } \\
\text { Legislativo 4, de } \\
23.05 .1989\end{array}$ & $\begin{array}{l}\text { Decreto } \\
\text { Presidencial 40, } \\
\text { de 15.02.1991 }\end{array}$ & \\
\hline
\end{tabular}




\begin{tabular}{|c|c|c|c|c|c|c|}
\hline $\begin{array}{l}\text { TRATADOS E } \\
\text { ENTRADA EM VIGOR } \\
\text { INTERNACIONAL }\end{array}$ & $\begin{array}{l}\text { ASSINATURA } \\
\text { E } \\
\text { RATIFICAÇÃO } \\
\text { PELO BRASIL }\end{array}$ & $\begin{array}{l}\text { MENSAGEM } \\
\text { PRESIDENCIAL }\end{array}$ & $\begin{array}{l}\text { PROJETO DE } \\
\text { DECRETO } \\
\text { LEGISLATIVO }\end{array}$ & $\begin{array}{l}\text { DECRETO } \\
\text { LEGISLATIVO }\end{array}$ & $\begin{array}{l}\text { DECRETO } \\
\text { EXECUTIVO }\end{array}$ & $\begin{array}{l}\text { OBSERVAÇÕES: RESERVAS E } \\
\text { LEIS BRASILEIRAS }\end{array}$ \\
\hline $\begin{array}{l}\text { 14.1. Protocolo } \\
\text { Facultativo à Convenção } \\
\text { contra a Tortura e Outros } \\
\text { Tratamentos ou Penas } \\
\text { Cruéis, } \\
\text { Desumanos ou } \\
\text { Degradantes } \\
(18.12 .2002) \\
\text { Em vigor internacional } \\
\text { desde: } 22.06 .2006 \text { (art. } \\
28.1) \\
\text { Em vigor para o Brasil } \\
\text { desde: } 11.02 .2007\end{array}$ & $\begin{array}{l}\text { Assinatura: } \\
13.10 .2003 \\
\text { Ratificação: } \\
11.01 .2007\end{array}$ & $\begin{array}{l}\text { MSC } 335 / 2004 \\
\text { De: } 22.04 .2004 \\
\text { Enviada ao } \\
\text { Legislativo em: } \\
18.06 .2004 \\
\text { Transformada } \\
\text { em PDC em: } \\
18.11 .2004 \\
\text { AV 683/2004 }\end{array}$ & $\begin{array}{l}\text { PDC } 1425 / 2004 \\
\text { Remessa ao SF } \\
\text { em: } 28.11 .2006 \\
\text { PDS 478/2006 } \\
\text { Aprova o texto do } \\
\text { Protocolo }\end{array}$ & $\begin{array}{l}\text { Decreto } \\
\text { Legislativo } 483, \\
\text { de } 20.12 .2006\end{array}$ & $\begin{array}{l}\text { Decreto } \\
\text { Presidencial } \\
6.085, \text { de } \\
19.04 .2007\end{array}$ & \\
\hline $\begin{array}{l}\text { 14.2. Declaração que } \\
\text { reconhece a competência } \\
\text { do Comitê previsto na } \\
\text { Convenção }\end{array}$ & $\begin{array}{l}\text { Não cabe no caso } \\
\text { concreto, pois se } \\
\text { trata de } \\
\text { Declaração } \\
\text { prevista na } \\
\text { Convenção de que } \\
\text { trata o item } 14 .\end{array}$ & $\begin{array}{l}\text { MSC } 579 / 2002 \\
\text { De: } 25.06 .2002 \\
\text { Enviada ao } \\
\text { Legislativo em: } \\
04.07 .2002 \\
\text { Transformado } \\
\text { no PDC em: } \\
08.01 .2003\end{array}$ & $\begin{array}{l}\text { PDC } 3003 / 2003 \\
\text { Remessa ao SF } \\
\text { em: } 13.12 .2005 \\
\text { PDS } 32 / 2006\end{array}$ & $\begin{array}{l}\text { Decreto } \\
\text { Legislativo 57, } \\
\text { de 17.04.2006 }\end{array}$ & $\begin{array}{l}\text { Ainda não foi } \\
\text { promulgada }\end{array}$ & $\begin{array}{l}\text { Aprova a solicitação de o Brasil fazer } \\
\text { a declaração prevista no artigo } 22 \text { da } \\
\text { Convenção das Nações Unidas } \\
\text { contra a Tortura e outros } \\
\text { Tratamentos ou Penas Cruéis, } \\
\text { Desumanos ou Degradantes, } \\
\text { reconhecendo a competência do } \\
\text { Comitê contra a Tortura para receber } \\
\text { e analisar denúncias de violações dos } \\
\text { dispositivos da Convenção. }\end{array}$ \\
\hline
\end{tabular}




\begin{tabular}{|c|c|c|c|c|c|c|}
\hline $\begin{array}{l}\text { TRATADOS E } \\
\text { ENTRADA EM VIGOR } \\
\text { INTERNACIONAL }\end{array}$ & $\begin{array}{l}\text { ASSINATURA } \\
\text { E } \\
\text { RATIFICAÇÃO } \\
\text { PELO BRASIL } \\
\end{array}$ & $\begin{array}{l}\text { MENSAGEM } \\
\text { PRESIDENCIAL }\end{array}$ & $\begin{array}{l}\text { PROJETO DE } \\
\text { DECRETO } \\
\text { LEGISLATIVO }\end{array}$ & $\begin{array}{l}\text { DECRETO } \\
\text { LEGISLATIVO }\end{array}$ & $\begin{array}{l}\text { DECRETO } \\
\text { EXECUTIVO }\end{array}$ & $\begin{array}{l}\text { OBSERVAÇÕES: RESERVAS E } \\
\text { LEIS BRASILEIRAS }\end{array}$ \\
\hline $\begin{array}{l}\text { 15. Convenção } 169 \\
\text { da OIT sobre Povos } \\
\text { Indígenas e Tribais } \\
(27.06 .1989) \\
\text { Em vigor internacional } \\
\text { desde: } 05.09 .1991 \\
\text { Em vigor para o Brasil } \\
\text { desde: } 25.07 .2003 \text { (art. } \\
\text { 38.3) }\end{array}$ & $\begin{array}{l}\text { Assinatura: }\left[{ }_{[}\right] \\
\text {Ratificação: } \\
25.07 .2002\end{array}$ & $\begin{array}{l}\text { MSC 367/1991 } \\
\text { MSC de: } \\
28.06 .1991 \\
\text { Enviada ao } \\
\text { Legislativo em: } \\
16.07 .1991 \\
\text { Transformada } \\
\text { em PDC em: } \\
24.03 .1993\end{array}$ & $\begin{array}{l}\text { PDC } 237 / 1993 \\
\text { Remessa ao SF } \\
\text { em: } 25.08 .1993 \\
\text { PDS (SF) } 34 / 1993\end{array}$ & $\begin{array}{l}\text { Decreto } \\
\text { Legislativo } 143 \\
\text { de } 20.06 .2002\end{array}$ & $\begin{array}{l}\text { Decreto } \\
\text { Presidencial } \\
5.051, \text { de } \\
19.04 .2004\end{array}$ & $\begin{array}{l}\text { - Relação com a Convenção 107, } 57 \\
\text { (anterior, portanto, à 169) } \\
\text { Enviaram ao Congresso antes da } \\
\text { ratificação. }\end{array}$ \\
\hline $\begin{array}{l}\begin{array}{l}16 . \quad \text { Convenção sobre } \\
\text { os Direitos da Criança } \\
(20.11 .1989)\end{array} \\
\text { Em vigor internacional } \\
\text { desde: } \\
\text { 02.09.1990 (art. } 49.1) \\
\text { Em vigor para o Brasil } \\
\text { desde: } 23.10 .1990 \\
\text { (art.49.2) }\end{array}$ & $\begin{array}{l}\text { Assinatura: } \\
26.01 .1990 \\
\text { Ratificação: } \\
24.09 .1990\end{array}$ & $\begin{array}{l}\text { MSC } 445 / 1990 \\
\text { De: } 16.05 .1990 \\
\text { Enviada ao } \\
\text { Legislativo em: } \\
31.05 .1990 \\
\text { Transformada } \\
\text { em PDC em: } \\
08.08 .1990 \\
\end{array}$ & $\begin{array}{l}\text { PDC 242-B/1990 } \\
\text { Remessa ao SF } \\
\text { em: } 11.09 .1990 \\
\text { PDS } 47 / 1990\end{array}$ & $\begin{array}{l}\text { Decreto } \\
\text { Legislativo 28, } \\
\text { de 14.09.1990 }\end{array}$ & $\begin{array}{l}\text { Decreto } 99.710 \text {, } \\
\text { de } 21.11 .1990\end{array}$ & \\
\hline
\end{tabular}




\begin{tabular}{|c|c|c|c|c|c|c|}
\hline $\begin{array}{l}\text { TRATADOS E } \\
\text { ENTRADA EM VIGOR } \\
\text { INTERNACIONAL }\end{array}$ & $\begin{array}{l}\text { ASSINATURA } \\
\text { E } \\
\text { RATIFICAÇÃO } \\
\text { PELO BRASIL } \\
\end{array}$ & $\begin{array}{l}\text { MENSAGEM } \\
\text { PRESIDENCIAL }\end{array}$ & $\begin{array}{l}\text { PROJETO DE } \\
\text { DECRETO } \\
\text { LEGISLATIVO }\end{array}$ & $\begin{array}{l}\text { DECRETO } \\
\text { LEGISLATIVO }\end{array}$ & $\begin{array}{l}\text { DECRETO } \\
\text { EXECUTIVO }\end{array}$ & $\begin{array}{l}\text { OBSERVAÇÕES: RESERVAS E } \\
\text { LEIS BRASILEIRAS }\end{array}$ \\
\hline $\begin{array}{l}\text { 16.1. Protocolo Facultativo } \\
\text { à Convenção sobre os } \\
\text { Direitos da Criança } \\
\text { referentes à venda de } \\
\text { criança, à prostituição } \\
\text { infantil e à pornografia } \\
\text { infantil (25.05.2000) } \\
\text { Em vigor internacional } \\
\text { desde: } 18.01 .2002 \\
\text { Em vigor para o Brasil } \\
\text { desde: } 27.02 .2004\end{array}$ & $\begin{array}{l}\text { Assinatura: } \\
06.09 .2000 \\
\text { Ratificação: } \\
27.01 .2004\end{array}$ & $\begin{array}{l}\text { MSC } 1035 / 2001 \\
\text { De: } 10.09 .2001 \\
\text { Enviada ao } \\
\text { Legislativo em: } \\
25.09 .2001 \\
\text { Transformada em } \\
\text { PDC em: } \\
25.02 .2003\end{array}$ & $\begin{array}{l}\text { PDC 4/2003 } \\
\text { (aprova ambos os } \\
\text { protocolos) } \\
\text { Remessa ao SF } \\
\text { em: } 11.03 .2003 \\
\text { PDS } 7 / 2003\end{array}$ & $\begin{array}{l}\text { Decreto } \\
\text { Legislativo } 230 \text {, } \\
\text { de } 29.05 .2003\end{array}$ & $\begin{array}{l}\text { Decreto } \\
\text { Presidencial } \\
\text { 5.007, de } \\
08.03 .2004\end{array}$ & $\begin{array}{l}\text { Há discussão sobre a adoção de } \\
\text { reserva ou declaração interpretativa } \\
\text { do parágrafo } 9^{\circ} \text { das consideranda do } \\
\text { Protocolo Facultativo à Convenção } \\
\text { sobre os Direitos da criança sobre a } \\
\text { Venda de crianças, prostituição } \\
\text { infantil e pornografia infantil. }\end{array}$ \\
\hline $\begin{array}{l}\text { 16.2. Protocolo facultativo } \\
\text { à Convenção sobre os } \\
\text { direitos da criança } \\
\text { relativos ao } \\
\text { envolvimento de crianças } \\
\text { em conflitos armados } \\
(25.05 .2000) \\
\text { Em vigor internacional } \\
\text { desde: } 12.02 .2002 \\
\text { Vigor para o Brasil: } \\
27.02 .2004\end{array}$ & $\begin{array}{l}\text { Assinatura: } \\
06.09 .2000 \\
\text { Ratificação: } \\
27.01 .2004\end{array}$ & MSC 1035/2001 & & & $\begin{array}{l}\text { Decreto } \\
\text { Executivo 5.006, } \\
\text { de } 08.03 .2004\end{array}$ & \\
\hline
\end{tabular}




\begin{tabular}{|c|c|c|c|c|c|c|}
\hline $\begin{array}{l}\text { TRATADOS E } \\
\text { ENTRADA EM VIGOR } \\
\text { INTERNACIONAL }\end{array}$ & $\begin{array}{l}\text { ASSINATURA } \\
\text { E } \\
\text { RATIFICAÇÃO } \\
\text { PELO BRASIL }\end{array}$ & $\begin{array}{l}\text { MENSAGEM } \\
\text { PRESIDENCIAL }\end{array}$ & $\begin{array}{l}\text { PROJETO DE } \\
\text { DECRETO } \\
\text { LEGISLATIVO }\end{array}$ & $\begin{array}{l}\text { DECRETO } \\
\text { LEGISLATIVO }\end{array}$ & $\begin{array}{l}\text { DECRETO } \\
\text { EXECUTIVO }\end{array}$ & $\begin{array}{l}\text { OBSERVAÇÕES: RESERVAS E } \\
\text { LEIS BRASILEIRAS }\end{array}$ \\
\hline $\begin{array}{l}\text { 16.3. Protocolo facultativo } \\
\text { à Convenção sobre os } \\
\text { Direitos da Criança sobre } \\
\text { procedimentos de } \\
\text { comunicação }(19.12 .2011) \\
\text { Em vigor internacional } \\
\text { desde: } 14.04 .2014\end{array}$ & $\begin{array}{l}\text { Assinatura: } \\
28.02 .2012\end{array}$ & $\begin{array}{l}\text { MSC 164/2015 } \\
\text { De: } 04.02 .2015 \\
\text { Enviada ao } \\
\text { Legislativo em: } \\
27.05 .2015 \\
\text { Não consta data } \\
\text { de quando foi } \\
\text { transformada em } \\
\text { PDC. Será } \\
\text { adotada a } 1^{\text {a data }} \\
\text { que consta na } \\
\text { tramitação do } \\
\text { PDC: } 17.12 .2015\end{array}$ & $\begin{array}{l}\text { PDC } 301 / 2015 \\
\text { Remessa ao SF } \\
\text { em: ainda não foi } \\
\text { enviado ao SF } \\
\text { (em } 13.09 .2016 \text { ) }\end{array}$ & [_] & [ & $\begin{array}{l}\text { A tramitação desse protocolo ainda } \\
\text { não foi finalizada. }\end{array}$ \\
\hline $\begin{array}{l}17 . \quad \text { Convenção } \\
\text { Internacional sobre a } \\
\text { Proteção dos Direitos de } \\
\text { todos os Trabalhadores } \\
\text { Migrantes e dos Membros } \\
\text { das suas Famílias } \\
\text { (18.12.1990) } \\
\text { Em vigor internacional } \\
\text { desde: } 01.07 .2003\end{array}$ & & $\begin{array}{l}\text { MSC 696/2010, } \\
\text { De: } 30.04 .2010 \\
\text { Enviada ao } \\
\text { Legislativo em: } \\
13.12 .2010 \\
\text { Situação: } \\
\text { Aguardando } \\
\text { Constituição de } \\
\text { Comissão } \\
\text { Temporária pela } \\
\text { Mesa }\end{array}$ & & & $\begin{array}{l}\text { A tramitação } \\
\text { ainda não foi } \\
\text { completada. }\end{array}$ & $\begin{array}{l}\text { Aqui, o Poder Executivo preferiu } \\
\text { obter o aval legislativo a priori. }\end{array}$ \\
\hline & & & & & & \\
\hline
\end{tabular}




\begin{tabular}{|c|c|c|c|c|c|c|}
\hline $\begin{array}{l}\text { TRATADOS E } \\
\text { ENTRADA EM VIGOR } \\
\text { INTERNACIONAL }\end{array}$ & $\begin{array}{l}\text { ASSINATURA } \\
\text { E } \\
\text { RATIFICAÇÃO } \\
\text { PELO BRASIL }\end{array}$ & $\begin{array}{l}\text { MENSAGEM } \\
\text { PRESIDENCIAL }\end{array}$ & $\begin{array}{l}\text { PROJETO DE } \\
\text { DECRETO } \\
\text { LEGISLATIVO }\end{array}$ & $\begin{array}{l}\text { DECRETO } \\
\text { LEGISLATIVO }\end{array}$ & $\begin{array}{l}\text { DECRETO } \\
\text { EXECUTIVO }\end{array}$ & $\begin{array}{l}\text { OBSERVAÇÕES: RESERVAS E } \\
\text { LEIS BRASILEIRAS }\end{array}$ \\
\hline $\begin{array}{l}\text { 18. Estatuto de Roma } \\
\text { do Tribunal Penal } \\
\text { Internacional (17.07.1998) } \\
\text { Em vigor internacional } \\
\text { desde: } 01.07 .2002 \\
\text { Vigor para o Brasil: } \\
01.09 .2002 \text { (art.126) }\end{array}$ & $\begin{array}{l}\text { Assinatura: } \\
07.02 .2000 \\
\text { Ratificação: } \\
20.06 .2002\end{array}$ & $\begin{array}{l}\text { Mensagem } \\
1084 / 2001 \\
\text { De: } 26.07 .2001 \\
\text { Enviada ao } \\
\text { Legislativo em: } \\
10.10 .2001 \\
\text { Transformada } \\
\text { em PDC em: } \\
\text { Não consta data } \\
\text { de quando foi } \\
\text { transformada em } \\
\text { PDC. Será } \\
\text { adotada a } 1^{\text {a data }} \\
\text { que consta na } \\
\text { tramitação do } \\
\text { PDC: } 05.04 .2002\end{array}$ & $\begin{array}{l}\text { PDC } 1661 / 2002 \\
\text { Remessa ao SF } \\
\text { em: } 24.04 .2002 \\
\text { PDS } 152 / 2002\end{array}$ & $\begin{array}{l}\text { Decreto } \\
\text { Legislativo } 112 \text {, } \\
\text { de } 06.06 .2002\end{array}$ & $\begin{array}{l}\text { Decreto } \\
\text { Presidencial } \\
4.388, \mathrm{de} \\
25.09 .2002\end{array}$ & \\
\hline
\end{tabular}




\begin{tabular}{|c|c|c|c|c|c|c|}
\hline $\begin{array}{l}\text { TRATADOS E } \\
\text { ENTRADA EM VIGOR } \\
\text { INTERNACIONAL }\end{array}$ & $\begin{array}{l}\text { ASSINATURA } \\
\text { E } \\
\text { RATIFICAÇÃO } \\
\text { PELO BRASIL }\end{array}$ & $\begin{array}{l}\text { MENSAGEM } \\
\text { PRESIDENCIAL }\end{array}$ & $\begin{array}{l}\text { PROJETO DE } \\
\text { DECRETO } \\
\text { LEGISLATIVO }\end{array}$ & $\begin{array}{l}\text { DECRETO } \\
\text { LEGISLATIVO }\end{array}$ & $\begin{array}{l}\text { DECRETO } \\
\text { EXECUTIVO }\end{array}$ & $\begin{array}{l}\text { OBSERVAÇÕES: RESERVAS E } \\
\text { LEIS BRASILEIRAS }\end{array}$ \\
\hline $\begin{array}{l}\text { 18.1. Acordo sobre } \\
\text { Privilégios e Imunidades } \\
\text { do Tribunal Penal } \\
\text { Internacional } \\
(3-10.09 .2002) \\
\text { Em vigor internacional: } \\
\text { desde: } 22.07 .2004 \text { (art. } \\
35.1) \\
\text { Vigor para o Brasil: } \\
\text { 11.01.2012 }\end{array}$ & $\begin{array}{l}\text { Assinatura: } \\
\text { 17.05.2004 } \\
\text { Ratificação: } \\
\text { 12.12.2011 }\end{array}$ & $\begin{array}{l}\text { MSC 110/2010 } \\
\text { De 07.07.2008 } \\
\text { Enviada ao } \\
\text { Legislativo em: } \\
11.03 .2010 \\
\text { Transformada } \\
\text { em PDC em: } \\
\text { Não consta data } \\
\text { de quando foi } \\
\text { transformada em } \\
\text { PDC. Será } \\
\text { adotada a } 1^{\text {a data }} \\
\text { que consta na } \\
\text { tramitação do } \\
\text { PDC: } \\
\text { 18.08.2010 }\end{array}$ & $\begin{array}{l}\text { PDC } 2845 / 2010 \\
\text { Remessa ao SF } \\
\text { em: } 01.06 .2011 \\
\text { PDS } 136 / 2011\end{array}$ & $\begin{array}{l}\text { Decreto } \\
\text { Legislativo 291, } \\
\text { de } 22.09 .2011\end{array}$ & $\begin{array}{l}\text { Decreto } \\
\text { Presidencial } \\
8.604, \mathrm{de} \\
18.12 .2015\end{array}$ & \\
\hline
\end{tabular}




\begin{tabular}{|c|c|c|c|c|c|c|}
\hline $\begin{array}{l}\text { TRATADOS E } \\
\text { ENTRADA EM VIGOR } \\
\text { INTERNACIONAL }\end{array}$ & $\begin{array}{l}\text { ASSINATURA } \\
\text { E } \\
\text { RATIFICAÇÃO } \\
\text { PELO BRASIL } \\
\end{array}$ & $\begin{array}{l}\text { MENSAGEM } \\
\text { PRESIDENCIAL }\end{array}$ & $\begin{array}{l}\text { PROJETO DE } \\
\text { DECRETO } \\
\text { LEGISLATIVO }\end{array}$ & $\begin{array}{l}\text { DECRETO } \\
\text { LEGISLATIVO }\end{array}$ & $\begin{array}{l}\text { DECRETO } \\
\text { EXECUTIVO }\end{array}$ & $\begin{array}{l}\text { OBSERVAÇÕES: RESERVAS E } \\
\text { LEIS BRASILEIRAS }\end{array}$ \\
\hline $\begin{array}{l}\text { 19. Convenção das } \\
\text { Nações Unidas contra o } \\
\text { Crime Organizado } \\
\text { Transnacional } \\
\text { (“Convenção de } \\
\text { Palermo") (15.11.2000) } \\
\text { Em vigor internacional } \\
\text { desde: } 29.09 .2003 \text { (art. 38) } \\
\text { Vigor para o Brasil: } \\
\text { 28.02.2004 }\end{array}$ & $\begin{array}{l}\text { Assinatura: } \\
12.12 .2000 \\
\text { Ratificação: } \\
\text { 29.01.2004 }\end{array}$ & $\begin{array}{l}\text { MSC } 48 / 2002 \\
\text { De: } 27.11 .2001 \\
\text { Enviada ao CN } \\
\text { em: } 30.01 .2002 \\
\text { Transformada } \\
\text { em PDC em: } \\
26.02 .2003\end{array}$ & $\begin{array}{l}\text { PDC 6/2003 } \\
\text { Remessa ao SF } \\
\text { em: } 12.03 .2003 \\
\text { PDS } 13 / 2003\end{array}$ & $\begin{array}{l}\text { Decreto } \\
\text { Legislativo } 231 \text {, } \\
\text { de } 29.05 .2003\end{array}$ & $\begin{array}{l}\text { Decreto } \\
\text { Presidencial } \\
5.015, \text { de } \\
12.03 .2004\end{array}$ & \\
\hline $\begin{array}{l}\text { 19.1. Protocolo } \\
\text { adicional para o Combate } \\
\text { ao tráfico de Migrantes } \\
\text { por via terrestre, marítima } \\
\text { e aérea (15.11.2000) } \\
\text { Em vigor internacional } \\
\text { desde: } 28.01 .2004 \\
\text { Em vigor para o Brasil } \\
\text { desde: }\end{array}$ & & $\begin{array}{l}\text { Apreciação pela } \\
\text { mesma MSC }\end{array}$ & & & $\begin{array}{l}\text { Decreto } \\
\text { Presidencial } \\
5.016, \text { de } \\
12.03 .2004\end{array}$ & \\
\hline
\end{tabular}




\begin{tabular}{|c|c|c|c|c|c|c|}
\hline $\begin{array}{l}\text { TRATADOS E } \\
\text { ENTRADA EM VIGOR } \\
\text { INTERNACIONAL }\end{array}$ & $\begin{array}{l}\text { ASSINATURA } \\
\text { E } \\
\text { RATIFICAÇÃO } \\
\text { PELO BRASIL }\end{array}$ & $\begin{array}{l}\text { MENSAGEM } \\
\text { PRESIDENCIAL }\end{array}$ & $\begin{array}{l}\text { PROJETO DE } \\
\text { DECRETO } \\
\text { LEGISLATIVO }\end{array}$ & $\begin{array}{l}\text { DECRETO } \\
\text { LEGISLATIVO }\end{array}$ & $\begin{array}{l}\text { DECRETO } \\
\text { EXECUTIVO }\end{array}$ & $\begin{array}{l}\text { OBSERVAÇÕES: RESERVAS E } \\
\text { LEIS BRASILEIRAS }\end{array}$ \\
\hline $\begin{array}{l}\text { 19.2. Protocolo para a } \\
\text { Prevenção, Repressão e } \\
\text { Punição do Tráfico de } \\
\text { Pessoas, em especial } \\
\text { Mulheres e Crianças } \\
\text { (15.11.2000) } \\
\text { Em vigor internacional } \\
\text { desde: } 25.12 .2003\end{array}$ & & & & & $\begin{array}{l}\text { Decreto } \\
\text { Presidencial } \\
5.017, \mathrm{de} \\
12.03 .2004\end{array}$ & \\
\hline $\begin{array}{l}20 . \quad \text { Convenção } \\
\text { Internacional sobre os } \\
\text { Direitos das Pessoas com } \\
\text { Deficiência e Protocolo } \\
\text { Facultativo ( } 30.03 .2007) \\
\text { Em vigor para o Brasil } \\
\text { desde: } 31.08 .2008\end{array}$ & $\begin{array}{l}\text { Assinatura: } \\
30.03 .2007 \\
\text { Ratificação: } \\
01.08 .2008\end{array}$ & $\begin{array}{l}\text { MSC } 711 / 2007 \\
\text { De: } 26.07 .2007 \\
\text { Enviada ao CN } \\
\text { em: } 26.09 .2007 \\
\text { Transformada } \\
\text { em PDC em: } \\
\text { 13.05.2008 } \\
\end{array}$ & $\begin{array}{l}\text { PDC 563/2008 } \\
\text { Remessa ao SF } \\
\text { em: } 28.05 .2008 \\
\text { PDS 90/2008 }\end{array}$ & $\begin{array}{l}\text { Decreto } \\
\text { Legislativo } \\
186, \text { de } \\
09.07 .2008\end{array}$ & $\begin{array}{l}\text { Decreto } \\
\text { Presidencial } \\
6.949, \text { de } \\
25.08 .2009\end{array}$ & \\
\hline
\end{tabular}




\begin{tabular}{|c|c|c|c|c|c|c|}
\hline $\begin{array}{l}\text { TRATADOS E } \\
\text { ENTRADA EM VIGOR } \\
\text { INTERNACIONAL }\end{array}$ & $\begin{array}{l}\text { ASSINATURA } \\
\text { E } \\
\text { RATIFICAÇÃO } \\
\text { PELO BRASIL } \\
\end{array}$ & $\begin{array}{l}\text { MENSAGEM } \\
\text { PRESIDENCIAL }\end{array}$ & $\begin{array}{l}\text { PROJETO DE } \\
\text { DECRETO } \\
\text { LEGISLATIVO }\end{array}$ & $\begin{array}{l}\text { DECRETO } \\
\text { LEGISLATIVO }\end{array}$ & $\begin{array}{l}\text { DECRETO } \\
\text { EXECUTIVO }\end{array}$ & $\begin{array}{l}\text { OBSERVAÇÕES: RESERVAS E } \\
\text { LEIS BRASILEIRAS }\end{array}$ \\
\hline $\begin{array}{l}21 . \quad \text { Convenção } \\
\text { Internacional para a } \\
\text { Proteção de Todas as } \\
\text { Pessoas Contra o } \\
\text { Desaparecimento Forçado } \\
(20.12 .2006) \\
\text { Em vigor internacional } \\
\text { desde: } 23.12 .2010 \\
\text { Em vigor para o Brasil } \\
\text { desde: } 28.12 .2010\end{array}$ & $\begin{array}{l}\text { Assinatura: } \\
06.02 .2007 \\
\text { Ratificação: } \\
\text { 29.11.2010 }\end{array}$ & $\begin{array}{l}\text { MSC } 400 / 2007 \\
\text { De } 01.11 .2007 \\
\text { Encaminhada ao } \\
\text { CN em: } \\
04.06 .2009 \\
\text { Transformada } \\
\text { em PDC em: } \\
25.11 .2009\end{array}$ & $\begin{array}{l}\text { PDC 2230/2009 } \\
\text { Remessa ao SF } \\
\text { em: } 07.04 .2010 \\
\text { PDS } 206 / 2010\end{array}$ & $\begin{array}{l}\text { Decreto } \\
\text { Legislativo } 661 \text {, } \\
\text { de } 01.09 .2010\end{array}$ & $\begin{array}{l}\text { Decreto } \\
\text { Presidencial } \\
8.767, \text { de } \\
11.05 .2016\end{array}$ & \\
\hline $\begin{array}{l}\text { B. SISTEMA } \\
\text { REGIONAL } \\
\text { INTERAMERICANO }\end{array}$ & & & & & & \\
\hline $\begin{array}{l}22 . \quad \text { Convenção } \\
\text { Americana sobre Direitos } \\
\text { Humanos }(22.11 .1969) \\
\text { Em vigor internacional } \\
\text { desde: } \\
\left.\text { 18.07.1978 (art. } 74, \S 2^{\circ}\right) \\
\text { Vigor para o Brasil: } \\
25.09 .1992\left(\text { art. } 74, \S 2^{\circ}\right)\end{array}$ & $\begin{array}{l}\text { Adesão/ } \\
\text { Assinatura: } \\
07.09 .1992 \\
\text { Ratificação: } \\
25.09 .1992\end{array}$ & $\begin{array}{l}\text { MSC 621/1985 } \\
\text { De: } 29.10 .1985- \\
\text { - consulta } \\
\text { PRÉVIA ao } \\
\text { Legislativo } \\
\text { Enviada ao CN } \\
\text { em: } 28.11 .1985 \\
\text { Transformada } \\
\text { em PDC em: } \\
\text { 21.05.1986 } \\
\end{array}$ & $\begin{array}{l}\text { PDC 132-B/1986 } \\
\text { Remessa ao SF } \\
\text { em: } 21.08 .1989 \\
\text { PDS 10/1989 }\end{array}$ & $\begin{array}{l}\text { Decreto } \\
\text { Legislativo 27, } \\
\text { de 26.05.1992 }\end{array}$ & $\begin{array}{l}\text { Decreto } \\
\text { Presidencial 678, } \\
\text { de } \\
06.11 .1992\end{array}$ & $\begin{array}{l}\text { Declaração interpretativa: "O } \\
\text { Governo do Brasil entende que os } \\
\text { arts. } 43 \text { e 48, alínea d, não incluem o } \\
\text { direito automático de visitas e } \\
\text { inspeções in loco da Comissão } \\
\text { Interamericana de Direitos } \\
\text { Humanos, as quais dependerão da } \\
\text { anuência expressa do Estado". }\end{array}$ \\
\hline
\end{tabular}




\begin{tabular}{|c|c|c|c|c|c|c|}
\hline $\begin{array}{l}\text { TRATADOS E } \\
\text { ENTRADA EM VIGOR } \\
\text { INTERNACIONAL }\end{array}$ & $\begin{array}{l}\text { ASSINATURA } \\
\text { E } \\
\text { RATIFICAÇÃO } \\
\text { PELO BRASIL }\end{array}$ & $\begin{array}{l}\text { MENSAGEM } \\
\text { PRESIDENCIAL }\end{array}$ & $\begin{array}{l}\text { PROJETO DE } \\
\text { DECRETO } \\
\text { LEGISLATIVO }\end{array}$ & $\begin{array}{l}\text { DECRETO } \\
\text { LEGISLATIVO }\end{array}$ & $\begin{array}{l}\text { DECRETO } \\
\text { EXECUTIVO }\end{array}$ & $\begin{array}{l}\text { OBSERVAÇÕES: RESERVAS E } \\
\text { LEIS BRASILEIRAS }\end{array}$ \\
\hline $\begin{array}{l}\text { 22.1. Protocolo adicional } \\
\text { à Convenção Americana } \\
\text { sobre Direitos Humanos } \\
\text { em } \\
\text { matéria de direitos } \\
\text { econômicos, sociais e } \\
\text { culturais (17.11.1988) } \\
\text { Em vigor internacional } \\
\text { desde: } 16.11 .1999 \\
\text { Vigor para o Brasil } \\
\text { desde: } 16.11 .1999\end{array}$ & $\begin{array}{l}\text { Instrumento de } \\
\text { Adesão } \\
\text { depositado em: } \\
21.08 .1996 \\
\text { Ratificação: [_] }\end{array}$ & $\begin{array}{l}\text { MSC } 755 / 1992 \\
\text { De: } 20.11 .1992 \\
\text { Enviada ao CN } \\
\text { em: } 26.11 .1992 \\
\\
\text { Transformada } \\
\text { em PDC em: } \\
30.06 .1993\end{array}$ & $\begin{array}{l}\text { PDC } 299 / 1993 \\
\text { Remessa ao SF } \\
\text { em: } 02.03 .1994 \\
\text { PDS } 14 / 1994\end{array}$ & $\begin{array}{l}\text { Decreto } \\
\text { Legislativo 56, } \\
\text { de 19.04.1995 }\end{array}$ & $\begin{array}{l}\text { Decreto } \\
\text { Presidencial } \\
3.321, \text { de } \\
30.12 .1999\end{array}$ & $\begin{array}{l}\text { Reserva, nos termos do } \\
\text { artigo } 2.1\end{array}$ \\
\hline $\begin{array}{l}\text { 22.2. Protocolo } \\
\text { referente à abolição da } \\
\text { pena de morte } \\
(08.06 .1990) \\
\text { Em vigor internacional } \\
\text { desde: } 28.08 .1991 \\
\text { Vigor para o Brasil: } \\
\text { 13.08.1996 }\end{array}$ & $\begin{array}{l}\text { Assinatura: } \\
07.06 .1994 \\
\text { Ratificação: } \\
13.08 .1996\end{array}$ & $\begin{array}{l}\text { MSC 755/1992 } \\
\text { (idem acima) }\end{array}$ & $\begin{array}{l}\text { PDC 299/1993 } \\
\text { PDS 14/1994 }\end{array}$ & $\begin{array}{l}\text { Decreto } \\
\text { Legislativo 56, } \\
\text { de 19.04.1995 }\end{array}$ & $\begin{array}{l}\text { Decreto } \\
\text { Presidencial } \\
2.754, \text { de } \\
27.08 .1998\end{array}$ & $\begin{array}{l}\text { Aposição de reserva, nos termos do } \\
\text { Artigo II, no qual é assegurado aos } \\
\text { Estados Partes o direito de aplicar a } \\
\text { pena de morte em tempo de guerra, } \\
\text { de acordo com o Direito } \\
\text { Internacional, por delitos sumamente } \\
\text { graves de caráter militar. }\end{array}$ \\
\hline
\end{tabular}




\begin{tabular}{|c|c|c|c|c|c|c|}
\hline $\begin{array}{l}\text { TRATADOS E } \\
\text { ENTRADA EM VIGOR } \\
\text { INTERNACIONAL }\end{array}$ & $\begin{array}{l}\text { ASSINATURA } \\
\text { E } \\
\text { RATIFICAÇÃO } \\
\text { PELO BRASIL }\end{array}$ & $\begin{array}{l}\text { MENSAGEM } \\
\text { PRESIDENCIAL }\end{array}$ & $\begin{array}{l}\text { PROJETO DE } \\
\text { DECRETO } \\
\text { LEGISLATIVO }\end{array}$ & $\begin{array}{l}\text { DECRETO } \\
\text { LEGISLATIVO }\end{array}$ & $\begin{array}{l}\text { DECRETO } \\
\text { EXECUTIVO }\end{array}$ & $\begin{array}{l}\text { OBSERVAÇÕES: RESERVAS E } \\
\text { LEIS BRASILEIRAS }\end{array}$ \\
\hline $\begin{array}{l}22.3 \text { Competência } \\
\text { obrigatória da corte } \\
\text { interamericana de direitos } \\
\text { humanos } \\
\text { - ref. à Convenção } \\
\text { Americana sobre Direitos } \\
\text { Humanos } \\
\text { A aceitação da } \\
\text { competência obrigatória da } \\
\text { Corte Interamericana de } \\
\text { Direitos Humanos foi } \\
\text { depositada junto à } \\
\text { Secretaria-Geral da OEA } \\
\text { em 10.12.1998. }\end{array}$ & $\begin{array}{l}\text { Não há de se } \\
\text { falar em } \\
\text { assinatura nesse } \\
\text { caso }\end{array}$ & $\begin{array}{l}\text { MSC } 1070 \\
\text { De: } 04.09 .1998 \\
\text { Enviada ao } \\
\text { Congresso } \\
\text { Nacional em: } \\
08.09 .1998 \\
\text { Transformada } \\
\text { em PDC em: } \\
14.10 .1998\end{array}$ & $\begin{array}{l}\text { PDC } 711 / 1998 \\
\text { Remessa ao SF } \\
\text { em: } 19.10 .1998 \\
\text { PDS 94/1998 }\end{array}$ & $\begin{array}{l}\text { Decreto } \\
\text { Legislativo 89, } \\
\text { de 03.12.1998 }\end{array}$ & $\begin{array}{l}\text { Decreto } \\
\text { Presidencial } \\
4.463, \mathrm{de} \\
08.11 .2002\end{array}$ & $\begin{array}{l}\text { O Decreto } 89 / 1998 \text { aprova a } \\
\text { solicitação de reconhecimento da } \\
\text { competência obrigatória da corte } \\
\text { internacional de direitos humanos em } \\
\text { todos os casos relativos a } \\
\text { interpretação ou aplicação da } \\
\text { convenção americana de direitos } \\
\text { humanos para fatos ocorridos a partir } \\
\text { do reconhecimento, de acordo com o } \\
\text { previsto no parágrafo primeiro do } \\
\text { artigo } 62 \text { daquele instrumento } \\
\text { internacional. } \\
\text { O Decreto Presidencial promulga a } \\
\text { Declaração de Reconhecimento da } \\
\text { Competência Obrigatória da Corte } \\
\text { Interamericana de Direitos Humanos, } \\
\text { sob reserva de reciprocidade, em } \\
\text { consonância com o art. } 62 \text { da } \\
\text { Convenção Americana sobre Direitos } \\
\text { Humanos (Pacto de São José), de } 22 \\
\text { de novembro de } 1969 \text {. }\end{array}$ \\
\hline
\end{tabular}




\begin{tabular}{|c|c|c|c|c|c|c|}
\hline $\begin{array}{l}\text { TRATADOS E } \\
\text { ENTRADA EM VIGOR } \\
\text { INTERNACIONAL }\end{array}$ & $\begin{array}{l}\text { ASSINATURA } \\
\text { E } \\
\text { RATIFICAÇÃO } \\
\text { PELO BRASIL } \\
\end{array}$ & $\begin{array}{l}\text { MENSAGEM } \\
\text { PRESIDENCIAL }\end{array}$ & $\begin{array}{l}\text { PROJETO DE } \\
\text { DECRETO } \\
\text { LEGISLATIVO }\end{array}$ & $\begin{array}{l}\text { DECRETO } \\
\text { LEGISLATIVO }\end{array}$ & $\begin{array}{l}\text { DECRETO } \\
\text { EXECUTIVO }\end{array}$ & $\begin{array}{l}\text { OBSERVAÇÕES: RESERVAS E } \\
\text { LEIS BRASILEIRAS }\end{array}$ \\
\hline $\begin{array}{l}23 . \quad \text { Convenção } \\
\text { Interamericana para } \\
\text { prevenir e punir tortura } \\
(09.12 .1985) \\
\text { Em vigor internacional } \\
\text { desde: } 29.02 .1987 \\
\text { (art. } 22) \\
\text { Em vigor para o Brasil } \\
\text { desde: } 19.08 .1989 \text { (art. } 22)\end{array}$ & $\begin{array}{l}\text { Assinatura: } \\
24.01 .1986 \\
\text { Ratificação: } \\
20.07 .1989\end{array}$ & $\begin{array}{l}\text { MSC } 235 \\
\text { De: } 11.06 .1986 \\
\text { Enviada ao CN } \\
\text { em: } 13.06 .986 \\
\text { Transformada } \\
\text { em PDC em: } \\
03.12 .1986\end{array}$ & $\begin{array}{l}\text { PDC } 154 / 1986 \\
\text { Remessa ao SF } \\
\text { em: } 07.06 .1988 \\
\text { PDS } 11 / 1988\end{array}$ & $\begin{array}{l}\text { Decreto } \\
\text { Legislativo 5, de } \\
31.05 .1989\end{array}$ & $\begin{array}{l}\text { Decreto } \\
\text { Presidencial } \\
98.386, \text { de } \\
09.11 .1989\end{array}$ & \\
\hline $\begin{array}{l}24 . \quad \text { Convenção } \\
\text { Interamericana para } \\
\text { prevenir, punir e erradicar } \\
\text { a violência } \\
\text { contra a mulher } \\
(09.06 .1994) \\
\text { Em vigor internacional } \\
\text { desde: 05.03.1995 } \\
\text { Em vigor para o Brasil } \\
\text { desde: } 15.12 .1995\end{array}$ & $\begin{array}{l}\text { Assinatura: } \\
06.09 .1994 \\
\text { Ratificação: } \\
16.11 .1995\end{array}$ & $\begin{array}{l}\text { MSC 95/1995 } \\
\text { De: } 16.01 .1995 \\
\text { Enviada ao CN } \\
\text { em: } 19.01 .1995 \\
\text { Transformada } \\
\text { em PDC em: } \\
17.05 .1995\end{array}$ & $\begin{array}{l}\text { PDC 95/1995 } \\
\text { Remessa ao SF } \\
\text { em: } 23.08 .1995 \\
\text { PDS 109/1995 }\end{array}$ & $\begin{array}{l}\text { Decreto } \\
\text { Legislativo } 107 \\
\text { de } 31.08 .1995\end{array}$ & $\begin{array}{l}\text { Decreto } \\
\text { Presidencial } \\
1.973, \text { de } \\
01.08 .1996\end{array}$ & $\begin{array}{l}\text { A MSC 95/1995 recomenda que o } \\
\text { Brasil faça reserva ao art. } 12 \text { da } \\
\text { Convenção. }\end{array}$ \\
\hline
\end{tabular}




\begin{tabular}{|c|c|c|c|c|c|c|}
\hline $\begin{array}{l}\text { TRATADOS E } \\
\text { ENTRADA EM VIGOR } \\
\text { INTERNACIONAL }\end{array}$ & $\begin{array}{l}\text { ASSINATURA } \\
\text { E } \\
\text { RATIFICAÇÃO } \\
\text { PELO BRASIL } \\
\end{array}$ & $\begin{array}{l}\text { MENSAGEM } \\
\text { PRESIDENCIAL }\end{array}$ & $\begin{array}{l}\text { PROJETO DE } \\
\text { DECRETO } \\
\text { LEGISLATIVO }\end{array}$ & $\begin{array}{l}\text { DECRETO } \\
\text { LEGISLATIVO }\end{array}$ & $\begin{array}{l}\text { DECRETO } \\
\text { EXECUTIVO }\end{array}$ & $\begin{array}{l}\text { OBSERVAÇÕES: RESERVAS E } \\
\text { LEIS BRASILEIRAS }\end{array}$ \\
\hline $\begin{array}{l}25 . \quad \text { Convenção } \\
\text { Interamericana sobre o } \\
\text { Desaparecimento Forçado } \\
\text { de Pessoas } \\
(09.06 .1994) \\
\text { Em vigor internacional } \\
\text { desde: } 28.03 .1996 \\
\text { (art. XX) } \\
\text { Em vigor para o Brasil } \\
\text { desde: } 25.08 .2013\end{array}$ & $\begin{array}{l}\text { Assinatura: } \\
10.06 .1994 \\
\text { Ratificação: } \\
\text { 26.07.2013 }\end{array}$ & $\begin{array}{l}\text { MSC 1.204 } \\
\text { De:14.12.1994 } \\
\text { Enviada ao CN } \\
\text { em: } 25.12 .1994 \\
\\
\text { Transformada } \\
\text { em PDC em: } \\
\text { 17.05.1995 }\end{array}$ & $\begin{array}{l}\text { PDC 94/1995 } \\
\text { Remessa ao SF } \\
\text { em: } 30.05 .2008 \\
\text { PDS } 116 / 2008\end{array}$ & $\begin{array}{l}\text { Decreto } \\
\text { Legislativo } 127 \text {, } \\
\text { de } 08.04 .2011\end{array}$ & $\begin{array}{l}\text { Decreto } \\
\text { Presidencial } \\
8.766, \text { de } \\
11.05 .2016\end{array}$ & $\begin{array}{l}\text { Ofício 13.206/Aspar-MD, } \\
\text { informação n. } 417 .\end{array}$ \\
\hline $\begin{array}{l}26 . \quad \text { Convenção } \\
\text { Interamericana sobre } \\
\text { tráfico internacional de } \\
\text { menores }(18.03 .1994) \\
\text { Em vigor internacional } \\
\text { desde: } 15.08 .1997 \\
\text { Vigor para o Brasil: } \\
\text { 15.08.1997 }\end{array}$ & $\begin{array}{l}\text { Assinatura: } \\
18.03 .1994 \\
\text { Ratificação: } \\
08.07 .1997\end{array}$ & $\begin{array}{l}\text { MSC } 94 \\
\text { De: } 16.01 .1995 \\
\text { Enviada ao CN } \\
\text { em: } 19.01 .1995 \\
\text { Transformada } \\
\text { em PDC em: } \\
10.05 .1995\end{array}$ & $\begin{array}{l}\text { PDC 90/1995 } \\
\text { Remessa ao SF } \\
\text { em: } 07.08 .1996 \\
\text { PDS 73/1996 }\end{array}$ & $\begin{array}{l}\text { Decreto } \\
\text { Legislativo } 105, \\
\text { de } 30.10 .1996\end{array}$ & $\begin{array}{l}\text { Decreto } \\
\text { Presidencial } \\
2.740, \text { de } \\
20.08 .1998\end{array}$ & \\
\hline
\end{tabular}




\begin{tabular}{|c|c|c|c|c|c|c|}
\hline $\begin{array}{l}\text { TRATADOS E } \\
\text { ENTRADA EM VIGOR } \\
\text { INTERNACIONAL }\end{array}$ & $\begin{array}{l}\text { ASSINATURA } \\
\text { E } \\
\text { RATIFICAÇÃO } \\
\text { PELO BRASIL }\end{array}$ & $\begin{array}{l}\text { MENSAGEM } \\
\text { PRESIDENCIAL }\end{array}$ & $\begin{array}{l}\text { PROJETO DE } \\
\text { DECRETO } \\
\text { LEGISLATIVO }\end{array}$ & $\begin{array}{l}\text { DECRETO } \\
\text { LEGISLATIVO }\end{array}$ & $\begin{array}{l}\text { DECRETO } \\
\text { EXECUTIVO }\end{array}$ & $\begin{array}{l}\text { OBSERVAÇÕES: RESERVAS E } \\
\text { LEIS BRASILEIRAS }\end{array}$ \\
\hline $\begin{array}{l}27 . \quad \text { Convenção } \\
\text { Interamericana para a } \\
\text { eliminação de todas as } \\
\text { formas de } \\
\text { discriminação contra as } \\
\text { pessoas portadoras de } \\
\text { deficiência (08.06.1999) } \\
\text { Em vigor internacional } \\
\text { desde: } 14.09 .2001 \\
\text { Em vigor para o Brasil } \\
\text { desde: } 14.09 .2001\end{array}$ & $\begin{array}{l}\text { Assinatura: } \\
08.06 .1999 \\
\text { Ratificação: } \\
\text { 17.07.2001 }\end{array}$ & $\begin{array}{l}\text { MSC } 1545 \\
\text { De: } 04.10 .1999 \\
\text { Enviada ao CN } \\
\text { em: } 22.10 .1999 \\
\text { Transformada } \\
\text { em PDC em: } \\
\text { 29.03.2000 }\end{array}$ & $\begin{array}{l}\text { PDC } 418 / 2000 \\
\text { Remessa ao SF } \\
\text { em: } 06.03 .2001 \\
\text { PDS } 47 / 2001\end{array}$ & $\begin{array}{l}\text { Decreto } \\
\text { Legislativo 198, } \\
\text { de } 13.06 .2001\end{array}$ & $\begin{array}{l}\text { Decreto } \\
\text { Presidencial } \\
3.956, \text { de } \\
08.10 .2001\end{array}$ & \\
\hline
\end{tabular}




\begin{tabular}{|c|c|c|c|c|c|c|}
\hline $\begin{array}{l}\text { TRATADOS E } \\
\text { ENTRADA EM VIGOR } \\
\text { INTERNACIONAL }\end{array}$ & $\begin{array}{l}\text { ASSINATURA } \\
\text { E } \\
\text { RATIFICAÇÃO } \\
\text { PELO BRASIL } \\
\end{array}$ & $\begin{array}{l}\text { MENSAGEM } \\
\text { PRESIDENCIAL }\end{array}$ & $\begin{array}{l}\text { PROJETO DE } \\
\text { DECRETO } \\
\text { LEGISLATIVO }\end{array}$ & $\begin{array}{l}\text { DECRETO } \\
\text { LEGISLATIVO }\end{array}$ & $\begin{array}{l}\text { DECRETO } \\
\text { EXECUTIVO }\end{array}$ & $\begin{array}{l}\text { OBSERVAÇÕES: RESERVAS E } \\
\text { LEIS BRASILEIRAS }\end{array}$ \\
\hline $\begin{array}{l}28 . \quad \text { Protocolo de } \\
\text { Assunção sobre } \\
\text { Compromisso com a } \\
\text { Promoção e Proteção dos } \\
\text { Direitos Humanos do } \\
\text { Mercosul (20.06.2005) } \\
\text { Em vigor internacional } \\
\text { desde: } 03.04 .2010 \\
\text { Em vigor para o Brasil } \\
\text { desde: } \\
\text { 03.04.2010 }\end{array}$ & $\begin{array}{l}\text { Assinatura: } \\
\text { 20.06.2005 } \\
\text { Ratificação: } \\
04.03 .2010\end{array}$ & $\begin{array}{l}\text { MSC } 897 \\
\text { De: } 11.09 .2006 \\
\text { Enviada ao } \\
\text { Legislativo em: } \\
13.10 .2006 \\
\text { Transformada } \\
\text { em PDC em: } \\
\text { Não consta data } \\
\text { de quando foi } \\
\text { transformada em } \\
\text { PDC. Será } \\
\text { adotada a } 1^{\text {a data }} \\
\text { que consta na } \\
\text { tramitação do } \\
\text { PDC: } \\
\text { 19.03.2008 }\end{array}$ & $\begin{array}{l}\text { PDC } 495 / 2008 \\
\text { Remessa ao SF } \\
\text { em: } 16.06 .2009 \\
\text { PDS } 486 / 2009\end{array}$ & $\begin{array}{l}\text { Decreto } \\
\text { Legislativo 592, } \\
\text { de 27.08.2009 }\end{array}$ & $\begin{array}{l}\text { Decreto } \\
\text { Presidencial } \\
7.225, \text { de } \\
01.07 .2010\end{array}$ & \\
\hline $\begin{array}{l}29 . \quad \text { Convenção } \\
\text { Interamericana contra o } \\
\text { Racismo, } \\
\text { a Discriminação Racial e } \\
\text { formas correlatas de } \\
\text { intolerância (06.05.2013) } \\
\text { Ainda não entrou em vigor } \\
\text { internacionalmente }\end{array}$ & $\begin{array}{l}\text { Assinatura: } \\
06.07 .2013 \\
\text { Ratificação: } \\
\text { [__ }\end{array}$ & $\begin{array}{l}\text { Não começou a } \\
\text { tramitar no } \\
\text { Brasil }\end{array}$ & & & & \\
\hline
\end{tabular}




\begin{tabular}{|c|c|c|c|c|c|c|}
\hline $\begin{array}{l}\text { TRATADOS E } \\
\text { ENTRADA EM VIGOR } \\
\text { INTERNACIONAL }\end{array}$ & $\begin{array}{l}\text { ASSINATURA } \\
\text { E } \\
\text { RATIFICAÇÃO } \\
\text { PELO BRASIL } \\
\end{array}$ & $\begin{array}{l}\text { MENSAGEM } \\
\text { PRESIDENCIAL }\end{array}$ & $\begin{array}{l}\text { PROJETO DE } \\
\text { DECRETO } \\
\text { LEGISLATIVO }\end{array}$ & $\begin{array}{l}\text { DECRETO } \\
\text { LEGISLATIVO }\end{array}$ & $\begin{array}{l}\text { DECRETO } \\
\text { EXECUTIVO }\end{array}$ & $\begin{array}{l}\text { OBSERVAÇÕES: RESERVAS E } \\
\text { LEIS BRASILEIRAS }\end{array}$ \\
\hline $\begin{array}{l}30 . \quad \text { Convenção } \\
\text { Interamericana } \\
\text { contra toda forma de } \\
\text { discriminação e } \\
\text { intolerância }(06.05 .2013) \\
\text { Ainda não entrou em vigor } \\
\text { internacionalmente }\end{array}$ & $\begin{array}{l}\text { Assinatura: } \\
06.07 .2013 \\
\text { Ratificação: }\end{array}$ & $\begin{array}{l}\text { Não começou a } \\
\text { tramitar no Brasil }\end{array}$ & & & & $\begin{array}{l}\text { http://www.itamaraty.gov.br/index.p } \\
\text { hp?option=com_content\&view=artic } \\
\text { le\&id=2361:oea-aprova-a- } \\
\text { convencao-interamericana-contra-o- } \\
\text { racismo-a-discriminacao-racial-e- } \\
\text { formas-correlatas-de-intolerancia-e- } \\
\text { a-convencao-interamericana-contra- } \\
\text { toda-forma-de-discriminacao-e- } \\
\text { intolerancia\&catid=42\&Itemid=280 } \\
\& \text { lang=pt-BR }\end{array}$ \\
\hline \multicolumn{7}{|l|}{$\begin{array}{l}\text { B. INSTRUMENTOS } \\
\text { SOBRE TRATADOS }\end{array}$} \\
\hline $\begin{array}{l}\text { 31. Convenção de Viena } \\
\text { sobre o Direito dos } \\
\text { Tratados (23.05.1969) } \\
\text { Em vigor internacional } \\
\text { desde: } 27.01 .1980 \\
\text { Em vigor para o Brasil } \\
\text { desde: } 24.10 .2009\end{array}$ & $\begin{array}{l}\text { Assinatura: } \\
23.05 .1969 \\
\text { Ratificação: } \\
25.09 .2009\end{array}$ & $\begin{array}{l}\text { MSC } 116 / 1992 \\
\text { De: } 16.04 .1992 \\
\text { Enviada ao CN } \\
\text { em: } 22.04 .1992 \\
\text { Transformada } \\
\text { em PDC em: } \\
02.12 .1992\end{array}$ & $\begin{array}{l}\text { Câmara: } \\
214 / 1992 \\
\text { Remessa ao SF } \\
\text { em: } 21.05 .2009 \\
\text { Senado: } 387 / 2009\end{array}$ & $\begin{array}{l}\text { Decreto } \\
\text { Legislativo } 496 \text {, } \\
\text { de } 17.07 .2009\end{array}$ & $\begin{array}{l}\text { Decreto } \\
\text { Presidencial } \\
7.030, \text { de } \\
14.12 .2009\end{array}$ & Reserva aos artigos 25 e 66 \\
\hline
\end{tabular}





\section{APÊNDICE V \\ PROPOSTAS DE EMENDAS CONSTITUCIONAIS DO SENADO FEDERAL}




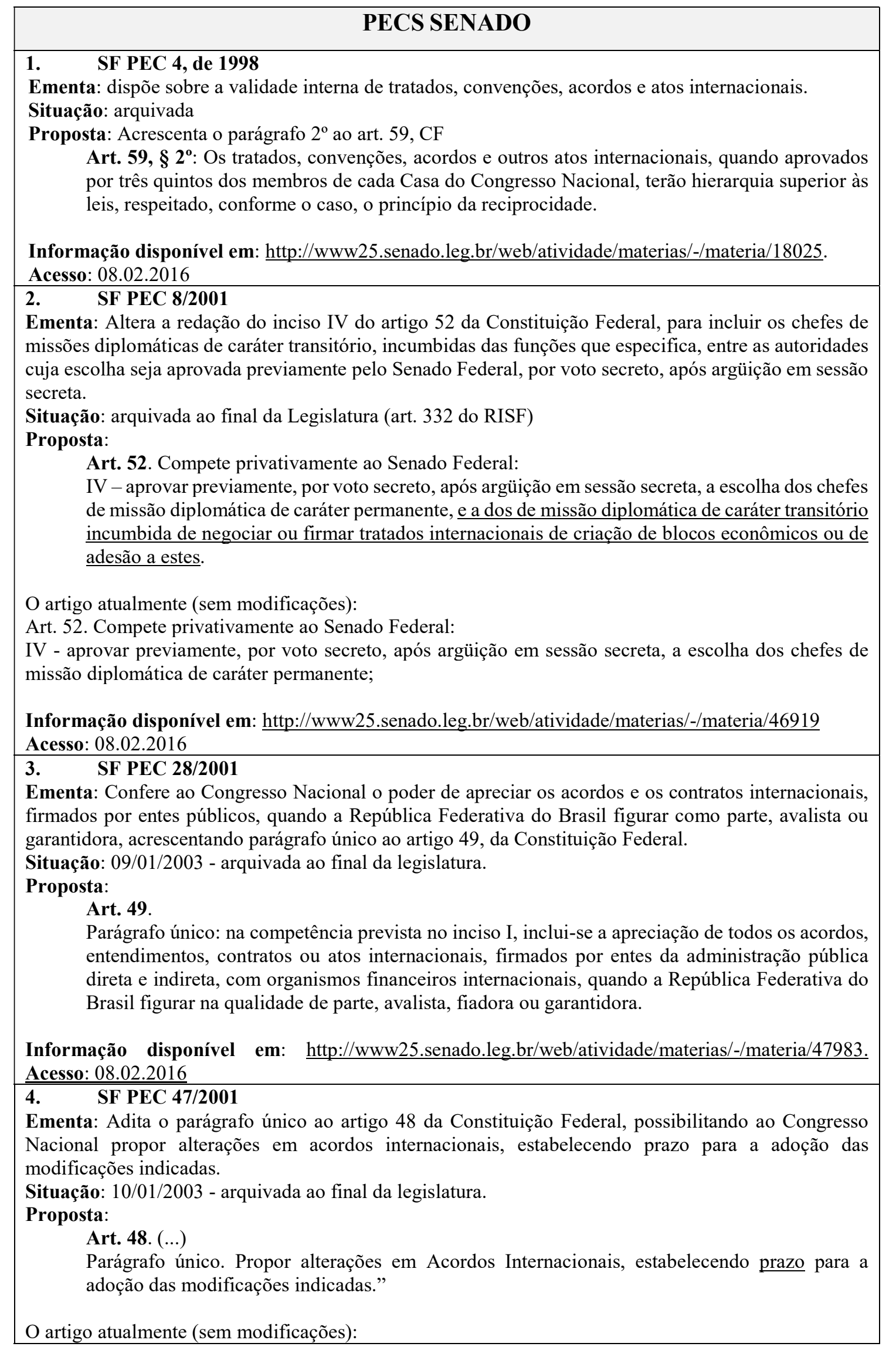




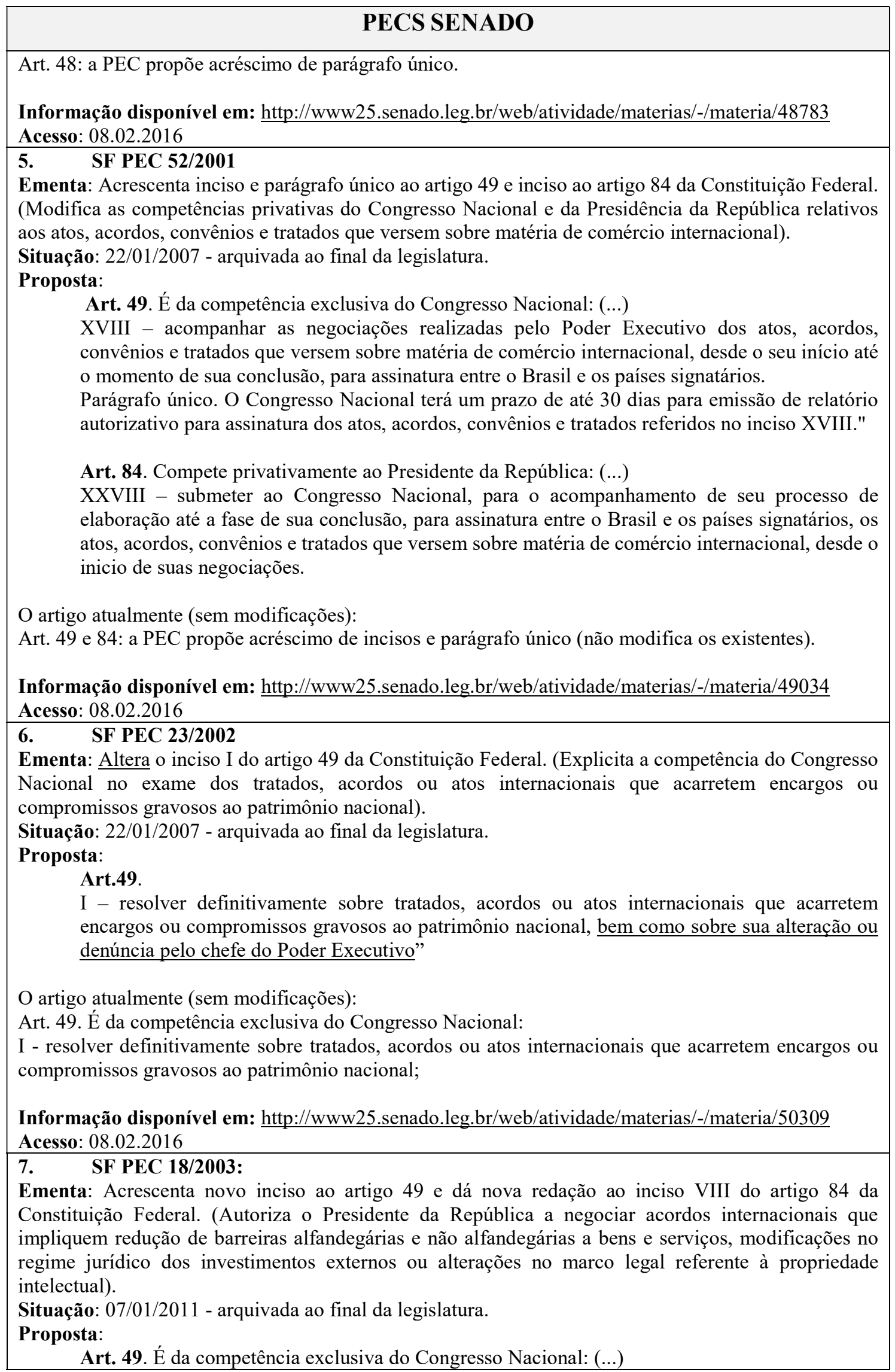




\section{PECS SENADO}

Inciso novo: autorizar o Presidente da República a negociar acordos internacionais que impliquem redução de barreiras alfandegárias e não alfandegárias a bens e serviços, modificações no regime jurídico dos investimentos externos ou alterações no marco legal referente à propriedade intelectual."

Art. 84. Compete privativamente ao Presidente da República: (...)

VIII - celebrar tratados, convenções e atos internacionais, sujeitos a referendo do Congresso Nacional, sendo que, no caso da negociação de acordos que impliquem redução de barreiras alfandegárias e não alfandegárias a bens e serviços, modificações no regime de investimentos externos ou alterações no marco legal referente à propriedade intelectual, será necessária a autorização prévia do Poder Legislativo."

$\mathrm{O}$ artigo atualmente (sem modificações):

A PEC sugere acrescentar um inciso ao art.49 e modificar a redação do inciso VIII do art.84:

VIII - celebrar tratados, convenções e atos internacionais, sujeitos a referendo do Congresso Nacional;

Informação disponível em: http://www25.senado.leg.br/web/atividade/materias/-/materia/56606 Acesso: 08.02.2016

\section{SF PEC 20/2003}

Ementa: Acrescenta novo inciso ao artigo 49 da Constituição Federal. (Dispõe sobre a aprovação dos negociadores de atos internacionais multilaterais que impliquem redução de barreiras alfandegárias e não alfandegárias a bens e serviços, modificações no regime jurídico dos investimentos externos ou alterações no marco legal referente à propriedade intelectual).

Situação: 7/01/2011 - arquivada ao final da legislatura.

Proposta:

Art. 49. É da competência exclusiva do Congresso Nacional: (...)

Inciso - aprovar previamente, após argüição em sessão secreta, a escolha dos negociadores de atos internacionais multilaterais que impliquem redução de barreiras alfandegárias e não alfandegárias a bens e serviços, modificações no regime jurídico dos investimentos externos ou alterações no marco legal referente à propriedade intelectual.

Informação disponível em: http://www25.senado.leg.br/web/atividade/materias/-/materia/56604 Acesso: 08.02.2016

\section{SF PEC 34/2003}

Ementa: Altera o inciso I, do artigo 49, da Constituição Federal, e acrescentam-se os $\S \S 1^{\circ}, 2^{\circ}$ e $3^{\circ}$, para que o Congresso Nacional tenha conhecimento prévio dos tratados, convenções e atos internacionais em negociação pelo Presidente da República.

Situação: 11/01/2011 - arquivada ao final da legislatura.

Proposta:

Art. 49. (...)

I - Resolver definitivamente sobre tratados, acordos ou atos internacionais que acarretem encargos ou compromissos gravosos ao patrimônio nacional, excetuados os que visem executar ou interpretar obrigações ou direitos estabelecidos em tratados anteriores, os que ajustem a prorrogação de tratados e os que tenham natureza administrativa.

$\S 1^{\circ}$ Para a execução do inciso I do caput deste artigo, o Congresso Nacional deverá ter conhecimento prévio dos tratados, convenções e atos internacionais em negociação pelo Presidente da República.

$\S 2^{\circ}$ A apreciação legislativa poderá ser dispensada por lei que autorize o Executivo a firmar atos internacionais sobre tema discriminado na lei.

$\S 3^{\circ} \mathrm{O}$ Congresso Nacional poderá determinar que qualquer tratado incluso nas exceções dispostas no inciso 1 do caput venha a passar pela apreciação legislativa.

Fica acrescido ao Ato das Disposições Constitucionais Transitórias o art. $7^{\circ}-\mathrm{A}$ :

Art. $7^{\circ}$-A. A disciplina do art. 49, inciso I, recai sobre todos os atos internacionais assinados pela República Federativa do Brasil, ainda que em tramitação no Congresso Nacional.” 


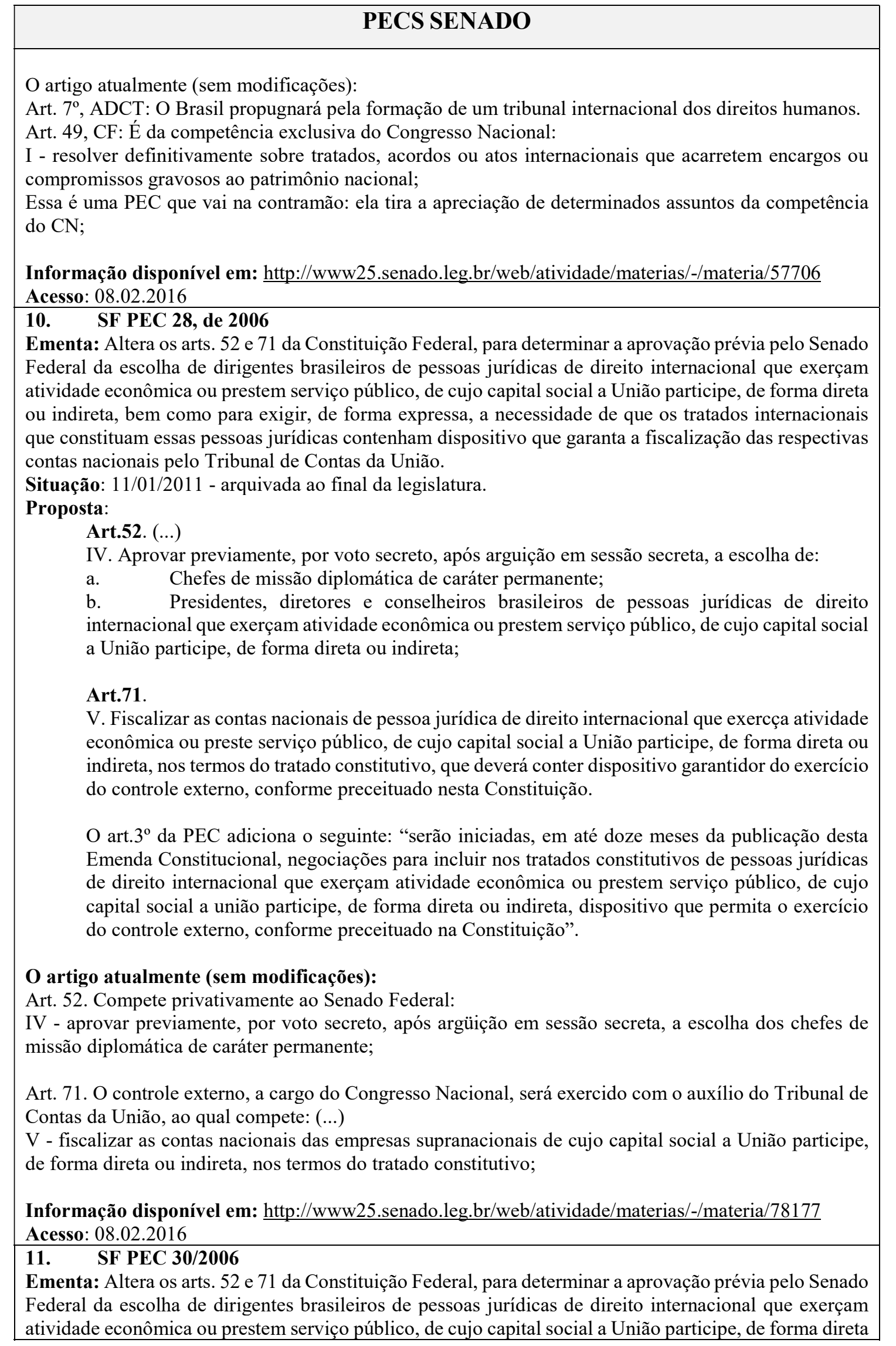




\section{PECS SENADO}

ou indireta, bem como para exigir, de forma expressa, a necessidade de que os tratados internacionais que constituam essas pessoas jurídicas contenham dispositivo que garanta a fiscalização das respectivas contas nacionais pelo Tribunal de Contas da União.

Situação: 26/12/2014 - arquivada ao final da legislatura.

Proposta:

Art. 52. (...)

IV - aprovar previamente, por voto secreto, após argüição em sessão secreta, a escolha de: a) chefes de missão diplomática de caráter permanente;

b) presidentes, diretores e conselheiros brasileiros de pessoas jurídicas de direito internacional que exerçam atividade econômica ou prestem serviço público, de cujo capital social a União participe, de forma direta ou indireta: (...)"(NR)

Art. 71. (...)

$\mathrm{V}$ - fiscalizar as contas nacionais de pessoa jurídica de direito internacional que exerça atividade econômica ou preste serviço público, de cujo capital social a União participe, de forma direta ou indireta, nos termos do tratado constitutivo, que deverá conter dispositivo garantidor do exercício do controle externo, conforme preceituado nesta Constituição; (...) NR)"

Art. $3^{\circ}$ Serão iniciadas, em até doze meses da publicação desta Emenda Constitucional, negociações para incluir nos tratados constitutivos de pessoas jurídicas de direito internacional que exerçam atividade econômica ou prestem serviço público, de cujo capital social a União participe, de forma direta ou indireta, dispositivo que permita o exercício do controle externo, conforme preceituado na Constituição

Informação disponível em: http://www25.senado.leg.br/web/atividade/materias/-/materia/78329 Acesso: 08.02.2016

12. SF PEC 35/2011

Ementa: Revoga o inciso I do art. 49, acrescenta inciso ao art. 52 e altera a redação do inciso VIII do art. 84 da Constituição Federal, a fim de tornar privativa do Senado Federal a competência para decidir sobre tratados, acordos ou atos internacionais.

Situação: Aprovada pelo Plenário. 06/08/2014 - remetida à Câmara dos Deputados.

Proposta:

Art. 52.

XVI: resolver definitivamente sobre tratados, acordos ou atos internacionais que acarretem encargos ou compromissos gravosos ao patrimônio nacional

Art. 84.

VIII - celebrar tratados, convenções e atos internacionais, sujeitos a referendos do Senado Federal, nos termos do art. 52, XVI

Ficaria revogado o art.49, I, CF.

Informação disponível em: http://www25.senado.leg.br/web/atividade/materias/-/materia/100215 Acesso: 08.02.2016

\section{SF PEC 31/2014}

Ementa: Altera o art. 49 da Constituição Federal para fixar a competência do Congresso Nacional quanto à denúncia de atos internacionais.

Situação: Comissão de Constituição, Justiça e Cidadania (Secretaria de Apoio à Comissão de Constituição, Justiça e Cidadania). 10/03/2015 - aguardando designação do relator (informação de 11.02.2016).

Proposta:

Art. 49, I: resolver definitivamente sobre tratados, acordos ou atos internacionais que acarretem encargos ou compromissos gravosos ao patrimônio nacional, especialmente sobre sua internalização e denúncia.

Informação disponível em: http://www25.senado.leg.br/web/atividade/materias/-/materia/118566 Acesso: 11.02.2016 


\section{PECS SENADO}

\section{SF PEC 44/ 2015}

Ementa: Altera os arts. 52 e 71 da Constituição Federal, para determinar a aprovação prévia pelo Senado Federal da escolha de dirigentes brasileiros de pessoas jurídicas de direito internacional que exerçam atividade econômica ou prestem serviço público, de cujo capital social a União participe, de forma direta ou indireta, bem como para exigir, de forma expressa, a necessidade de que os tratados internacionais que constituam essas pessoas jurídicas contenham dispositivo que garanta a fiscalização das respectivas contas nacionais pelo Tribunal de Contas da União.

Situação: Comissão de Constituição, Justiça e Cidadania (Secretaria de Apoio à Comissão de Constituição, Justiça e Cidadania). 08/04/2015 - aguardando designação do relator (informação de 11.02.2016).

Proposta:

Art.52, III. Aprovar previamente, por voto secreto, após arguição pública, a escolha de:

g. presidentes, diretores e conselheiros brasileiros de pessoas jurídicas de direito internacional que exercçam atividade econômica ou prestem serviço público, de cujo capital social a União participe, de forma direta ou indireta.

Art. 71, V: fiscalizar as contas nacionais de pessoa jurídica de direito internacional que exerça atividade econômica ou preste serviço público, de cujo capital social a União participe, de forma direta ou indireta, nos termos do tratado constitutivo, sendo pré requisito para a participação da União a inclusão em seu tratado constitutivo de dispositivo garantidor do exercício do controle externo, conforme preceituado nesta Constituição.

Art. $3^{\circ}$ (PEC): Serão iniciadas, em até doze meses da publicação desta Emenda Constitucional, negociações para incluir nos tratados constitutivos de pessoas jurídicas de direito internacional que exerçam atividade econômica ou prestem serviço público, de cujo capital social a União participe, de forma direta ou indireta, dispositivo que permita o exercício do controle externo, conforme preceituado na Constituição.

Informação disponível em: http://www25.senado.leg.br/web/atividade/materias/-/materia/120557 Acesso: 11.02 .2016

\section{SF PEC 87/2015}

Ementa: Altera o art. $5^{\circ}$ e o inciso I do art. 49 da Constituição Federal, para alterar as competências do Congresso Nacional no que concerne à denúncia de tratados internacionais.

Situação: Último local: 02/07/2015 - Comissão de Constituição, Justiça e Cidadania (Secretaria de Apoio à Comissão de Constituição, Justiça e Cidadania). Último estado: 02/07/2015 - aguardando designação do relator. (informação de 11.02.2016).

Proposta:

\section{Art. $5^{\circ}$}

$\S 5^{\circ}$ A República Federativa do Brasil não celebrará acordos com países que violem sistematicamente os direitos humanos e os princípios da democracia representativa.

$\S 6^{\circ}$ Ao Congresso Nacional, por decisão de cada uma de suasCasas, em dois turnos, por três quintos dos votos dos respectivos membros, é facultado o poder de determinar ao Poder Executivo a denúncia de tratados internacionais em vigor com países que, pela análise congressual, violem sistematicamente os direitos humanos e a democracia representativa.

$\S 7^{\circ} \mathrm{O}$ Congresso Nacional deverá conceder sua prévia eexpressa autorização ao Poder Executivo para a denúncia de quaisquer outros atos internacionais em vigor, em procedimento idêntico ao da aprovação do ato."

Art. 49, I: resolver definitivamente sobre tratados, acordos ou atos internacionais que acarretem encargos ou compromissos gravosos ao patrimônio nacional, bem como requerer ao Poder Executivo a denúncia desses atos ou anuir à denúncia, nos casos constitucionalmente previstos.

Informação disponível em: http://www25.senado.leg.br/web/atividade/materias/-/materia/122078 Acesso: 11.02 .2016

\section{SF PEC 100/2015}

Ementa: Acrescenta inciso e parágrafo único ao art. 49 e inciso ao art. 84 da Constituição Federal, para prever a participação do Congresso Nacional nas negociações de atos, acordos, convênios e tratados que versem sobre matéria de comércio internacional. 


\section{PECS SENADO}

Situação: Comissão de Constituição, Justiça e Cidadania (Secretaria de Apoio à Comissão de Constituição, Justiça e Cidadania). Último estado: 15/07/2015 - aguardando designação do relator.

Proposta:

Art. 49. (...)

XVIII - acompanhar as negociações realizadas pelo Poder Executivo dos atos, acordos, convênios e tratados que versem sobre matéria de comércio internacional, desde o seu início até adoção do texto, para assinatura entre o Brasil e os países signatários.

Parágrafo único. O Congresso Nacional terá um prazo de até trinta dias para emissão de um relatório autorizativo para assinatura dos atos, acordos, convênios e tratados referidos no inciso XVIII."

Art. 84. (...)

XXVIII - submeter ao Congresso Nacional, para o acompanhamento de seu processo de elaboração até a fase de sua conclusão, para assinatura entre o Brasil e os países signatários, os atos, acordos, convênios e tratados que versem sobre matéria de comércio internacional, desde o início de suas negociações. (acrescenta o inciso ao art.84)

Informação disponível em: http://www25.senado.leg.br/web/atividade/materias/-/materia/122357 Acesso: 11.02 .2016 


\section{APÊNDICE VI \\ PROPOSTAS DE EMENDAS CONSTITUCIONAIS DA CÂMARA DOS DEPUTADOS}




\section{PECS CÂMARA \\ 1. CD PEC 96/1992}

Ementa: Introduz modificações na estrutura do Poder Judiciário. NOVA EMENTA DA EMENDA CONSTITUCIONAL No 45: Altera dispositivos dos artigos $5^{\circ}, 36,52,92,93,95,98,99,102,103,104$, 105, 107, 109, 111, 112, 114, 115, 125, 126, 127, 128, 129, 134 e 168 da Constituição Federal, e acrescenta os artigos 103-A, 103-B, 111-A e 130-A, e dá outras providências.

Situação: Transformada na Emenda Constitucional 45/2004. Apensados à PEC 96/1992: PEC 500/1997; PEC 112/1995; PEC 215/1995; PEC 127/1995; PEC 368/1996.

Proposta:

\section{Art 50}

$\S 3$ Os tratados e convenções internacionais sobre direitos humanos aprovados, em cada Casa do Congresso Nacional, em dois turnos, por três quintos dos votos dos respectivos membros, serão equivalentes às emendas constitucionais

Art. 109.

$\S 6 \mathrm{O}$ Brasil se submete à jurisdição de Tribunal Penal Internacional a cuja criação tenha manifestado adesão.”

Informação disponível em:

http://www2.camara.leg.br/proposicoesWeb/fichadetramitacao?idProposicao=14373

Acesso: 12.02 .2016

\section{CD PEC 36/1999}

Ementa: Altera a redação do inciso I do art. 49 da Constituição Federal. Explicação da Ementa: dispondo sobre apreciação e decisão do congresso nacional sobre todo e qualquer ato internacional, podendo ingerir alterações e aperfeiçoamentos; alterando a Constituição Federal de 1988. (arquivada):

Situação: arquivada.

Proposta:

Art. 49. (...)

I. Apreciar e decidir definitivamente sobre todo e qualquer ato internacional firmado pelo Presidente da República ou por autoridade por ele delegada, inclusive tratados e acordos, podendo sugerir alterações e aperfeiçoamentos que serão necessariamente negociados pelo Poder Executivo com os demais signatários do documento, sustando-se a sua apreciação até o retomo da matéria.

Informação disponível em:

http://www2.camara.leg.br/proposicoesWeb/fichadetramitacao?idProposicao=14285\&ord=1

Acesso: 12.02 .2016

\section{CD PEC 122/1999}

Ementa: Altera a redação do inciso I do art. 49 da Constituição Federal e acrescenta novo inciso ao mesmo artigo. Explicação da Ementa: estabelecendo que o congresso nacional tem competência para decidir definitivamente sobre toda denúncia de ato internacional multilateral e sobre todo ato internacional firmado pelo presidente da república ou por autoridade delegada, a exceção de acordos executivos, podendo a decisão referente ao ato incluir ressalvas, emendas e cláusulas interpretativas; alterando a Constituição Federal de 1988.

Situação: Apensada à PEC 36/1999

Proposta:

Art. 49.

I. Decidir definitivamente sobre todo ato internacional firmado pelo Presidente da República ou por autoridade por ele delegada. Á exceção dos acordos executivos ou acordos de forma simplificada que não tenham modificado $o$ ato que lhes deu origem ou que sejam de natureza estritamente inerente á rotina diplomática ordinária, podendo a dccisão referente ao ato incluir ressalvas, emendas e cláusulas interpretativas.

II. Decidir definitivamente sobre toda denúncia de ato internacional multilateral.

Informação disponível em:

http://www2.camara.leg.br/proposicoesWeb/fichadetramitacao?idProposicao=14417

Acesso: 12.02.2016 


\section{PECS CÂMARA \\ 4. CD PEC 203/2000}

Ementa: Estabelece disposição sobre o Tribunal Penal Internacional. Explicação da Ementa: estabelecendo que o Brasil poderá reconhecer a jurisdição do tribunal penal internacional; alterando a Constituição Federal de 1988.

Situação: arquivada.

Proposta:

Art. $5^{\circ}, \S 3^{\circ}$ :

A República Federativa do Brasil poderá reconhecer a jurisdição do Tribunal Penal Internacional nas condições previstas no Estatuto aprovado em Roma no dia 17 de julho de 1998.

Informação disponível em:

http://www2.camara.leg.br/proposicoesWeb/fichadetramitacao?idProposicao=14542

Acesso: 12.02 .2016

\section{CD PEC 345/2001}

Ementa

Acrescenta novo inciso ao art. 49 e dá nova redação ao inciso VIII do art. 84 da Constituição Federal.

Situação: arquivada.

Proposta:

Art. 49. É da competência exclusiva do Congresso Nacional

Inciso: autorizar o Presidente da República a negociar acordos internacionais que impliquem redução de barreiras alfandegárias e não alfandegárias a bens e serviços, modificações no regime jurídico dos investimentos externos ou alterações no marco legal referente à propriedade intelectual".

Art. 84. Compete privativamente ao Presidente da República (...)

VIII - Celebrar tratados, convenções e atos internacionais, sujeitos a referendo do Congresso Nacional, sendo que, no caso da negociação de acordos que impliquem redução de barreiras alfandegárias e não alfandegárias a bens e serviços, modificações no regime de investimentos externos ou alterações no marco legal referente à propriedade intelectual, será necessária a autorização prévia do Poder Legislativo.

Informação disponível em:

http://www2.camara.leg.br/proposicoesWeb/fichadetramitacao?idProposicao=28111

Acesso: 12.02 .2016

\section{CD PEC 387/2001}

Ementa: Acrescenta novo inciso ao art. 49 da Constituição Federal. Explicação da Ementa: Fixando a competência do Congresso Nacional para aprovar, após arguição, a escolha dos negociadores de atos internacionais multilaterais referentes a redução de barreiras alfandegárias e não-alfandegárias a bens e serviços, regime jurídico dos investimentos externos e propriedade intelectual; alterando a Constituição Federal de 1988.

Situação: arquivada.

Proposta:

Art. 49. É da competência exclusiva do Congresso Nacional (...)

Inciso: aprovar previamente, após arguição em sessão secreta, a escolha dos negociadores de atos internacionais multilaterais que impliquem redução de barreiras alfandegárias e não alfandegárias a bens e serviços, modificações no regime jurídico dos investimentos externos ou alterações no marco legal referente à propriedade intelectual.

\section{Informação disponível em:}

http://www2.camara.leg.br/proposicoesWeb/fichadetramitacao?idProposicao=30681

Acesso: 12.02 .2016

\section{CD PEC 402/2001}

Ementa: Incluindo na competência exclusiva do Congresso Nacional, dispositivos para emendar, suprimir, acrescentar, aceitar, modificar ou substituir ato internacional que acarrete encargo ou compromisso gravado ao patrimônio nacional, firmados pelo Presidente da República ou por autoridade por ele delegada; alterando a Constituição Federal de 1988. 


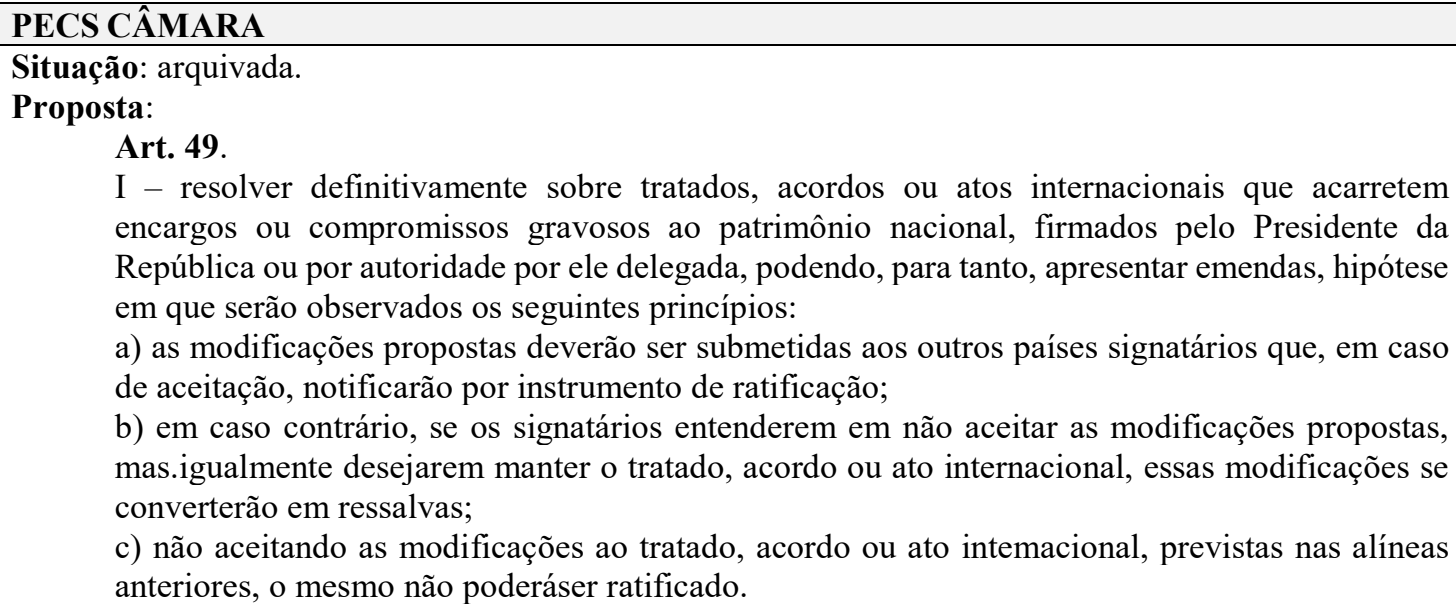

a) as modificações propostas deverão ser submetidas aos outros países signatários que, em caso de aceitação, notificarão por instrumento de ratificação;

b) em caso contrário, se os signatários entenderem em não aceitar as modificações propostas, mas.igualmente desejarem manter o tratado, acordo ou ato internacional, essas modificações se converterão em ressalvas;

c) não aceitando as modificações ao tratado, acordo ou ato intemacional, previstas nas alíneas anteriores, o mesmo não poderáser ratificado.

\section{Informação disponível em:}

http://www2.camara.leg.br/proposicoesWeb/fichadetramitacao?idProposicao=32392

Acesso: 12.02 .2016

\section{CD PEC 478/2001}

Ementa: Altera os Arts. 49 e 84 da Constituição Federal, a respeito da apreciação e celebração de Tratados Internacionais. Explicação da Ementa: Estabelecendo a apreciação prévia do Congresso Nacional, quando da celebração de ato internacional por parte do presidente da República que implica em alienação provisória de bens do Patrimônio Nacional ou risco de adoção de valores culturais e sociais diferenciados dos nacionais: alterando a Constituição Federal de 1988.

Situação: arquivada.

Proposta:

Art.49. (...)

I - resolver definitivamente sobre Tratados, (...) gravados (sic) ao patrimônio nacional, ou que representem risco à soberania nacional;"

Art.84. (...)

VIII- celebrar tratados, convenções e atos internacionais, sujeitos a referendo do Congresso Nacional, ou mediante diretrizes prévias do mesmo, quando se tratar de alienação provisória de bens do patrimônio nacional ou risco de adoção de valores culturais e sociais diferenciados dos nacionais.

Informação disponível em:

http://www2.camara.leg.br/proposicoesWeb/fichadetramitacao?idProposicao $=42562$

Acesso: 12.02 .2016

\section{CD PEC 31/2003}

Ementa: Altera os arts. 49 e 84 da Constituição Federal e acrescenta o art. 69-A, visando estabelecer autorização prévia do Congresso Nacional para negociação de tratados, acordos e atos internacionais.

Situação: Devolvida ao Autor.

Proposta:

Art. 49. É da competência exclusiva do Congresso Nacional:

I - resolver definitivamente sobre tratados, acordos ou atos internacionais que acarretem encargos ou compromissos gravosos ao patrimônio nacional, bem como autorizar previamente a negociação dos tratados, acordos e atos internacionais, inclusive alterações ou aditivos daqueles já firmados, que repercutam, direta ou indiretamente, no comércio externo de bens ou serviços ou regulem as garantias da propriedade intelectual;

Art. 84. Compete privativamente ao Presidente da República:

(...)

VIII - celebrar tratados, convenções e atos internacionais, sujeitos a referendo do Congresso Nacional e respeitada a autorização prévia de que trata o art. 49, inciso I; 


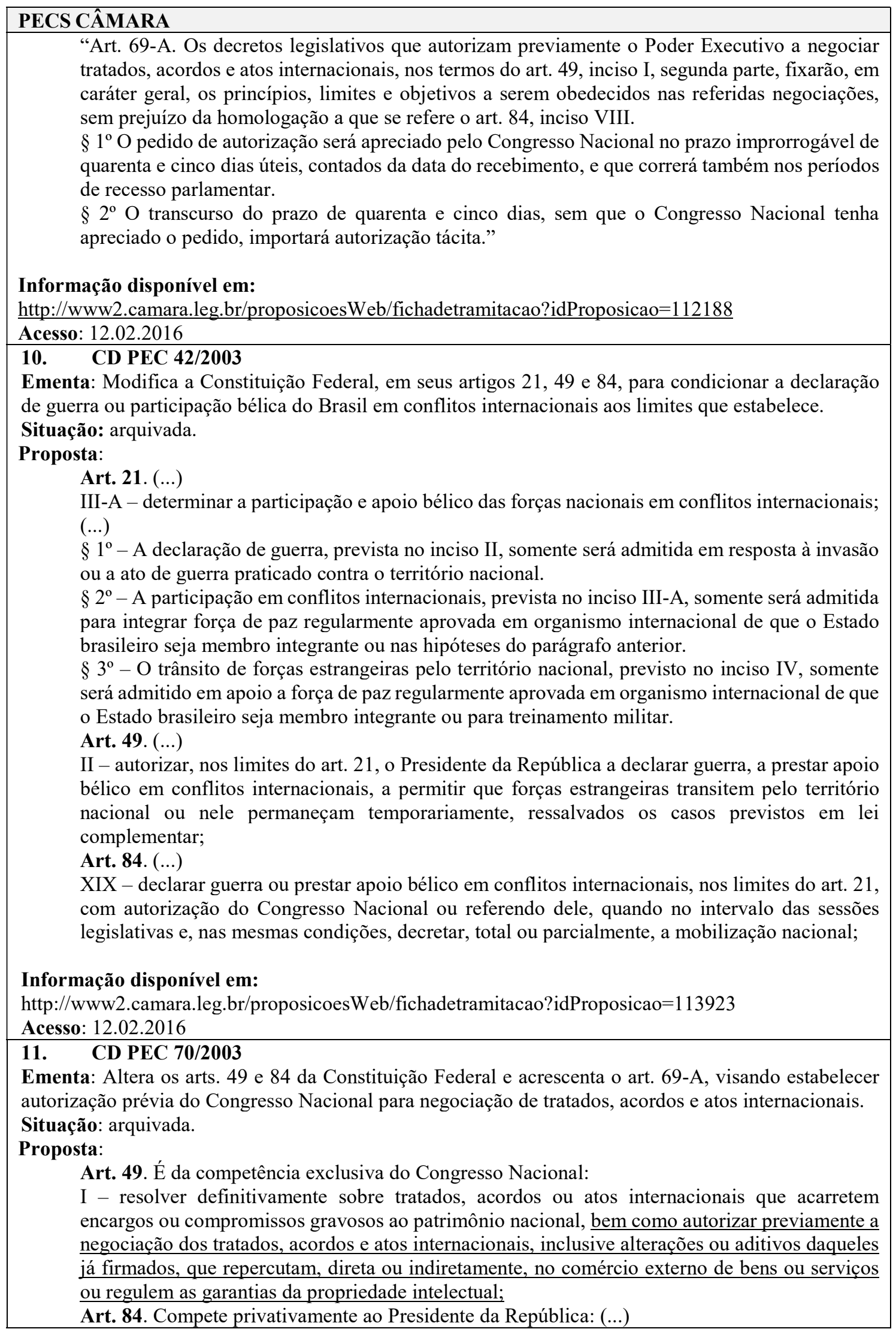




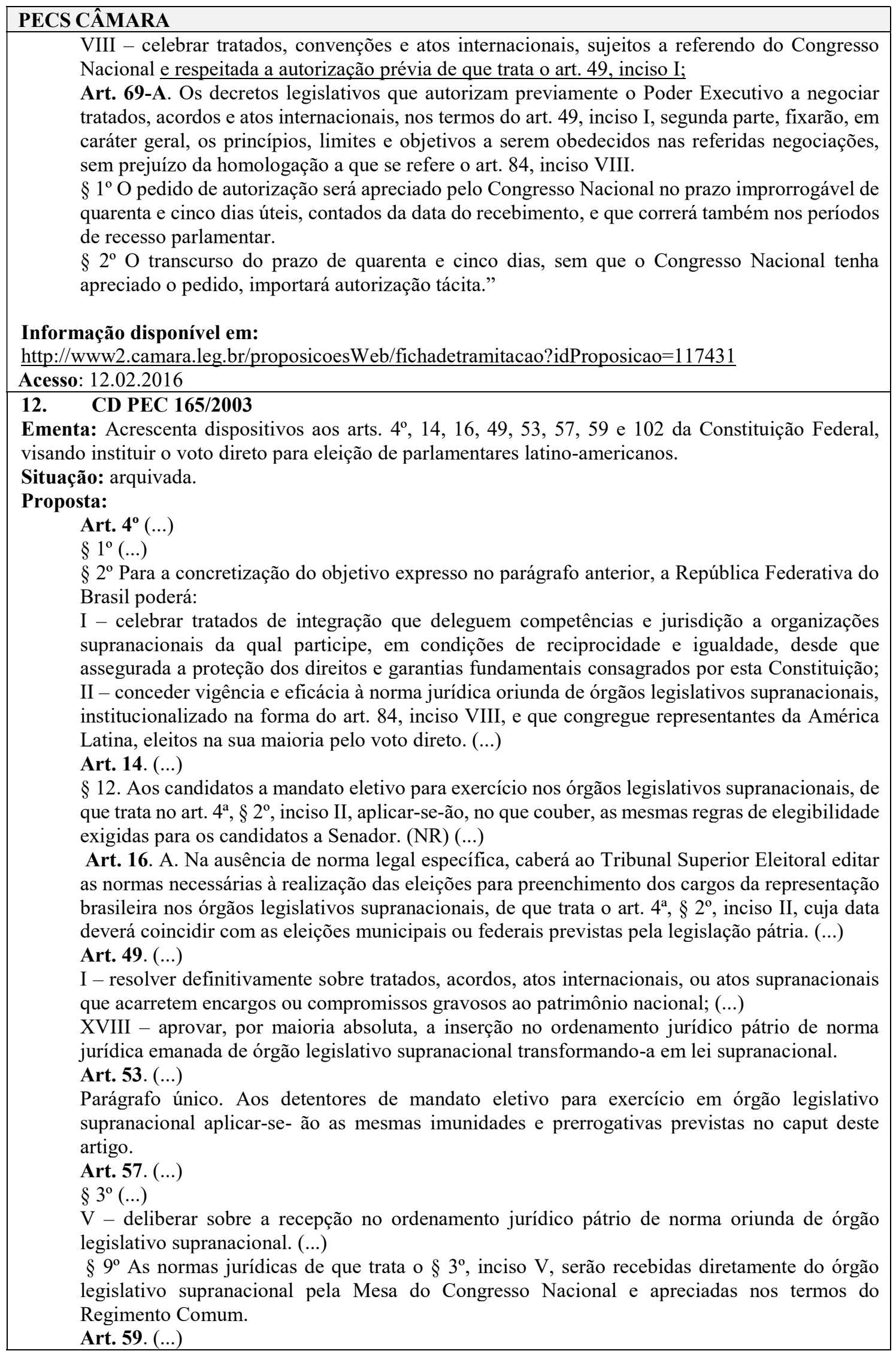




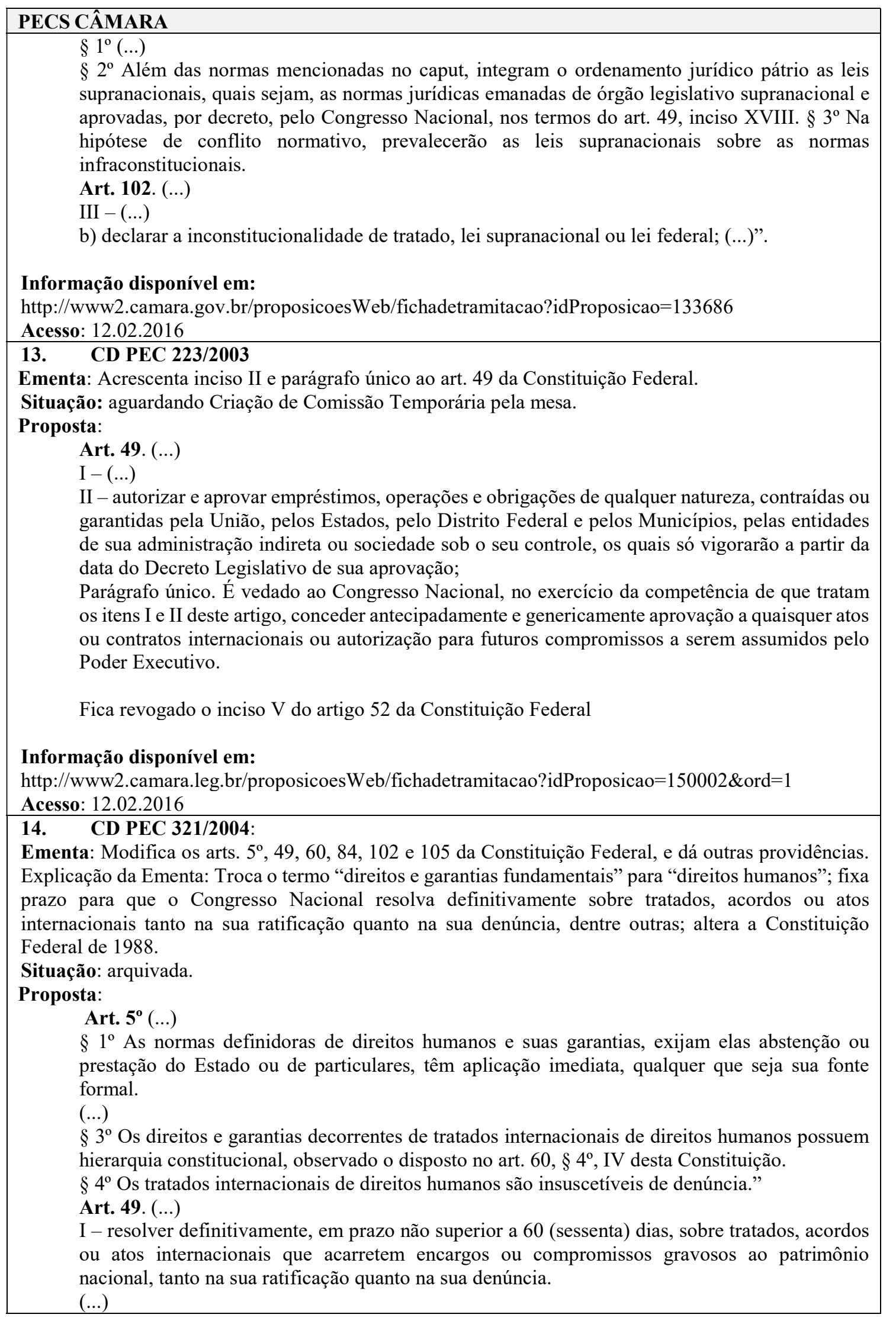




\section{PECS CÂMARA}

Parágrafo Único. Esgotado o prazo a que se refere o inciso I deste artigo, todas as demais deliberações legislativas da Casa em que estiver tramitando a matéria ficarão sobrestadas, até que se ultime sua votação." (NR)

Art. 60. (...)

$\S 4^{\circ}(\ldots)$

IV - os direitos humanos e suas garantias, inclusive quando decorram de tratados internacionais.

Art. 84.

VIII - celebrar tratados, convenções e atos internacionais, submetendo-os ao referendo do Congresso Nacional em prazo não superior a 30 (trinta) dias; (...)

$\S 1^{\circ}(\ldots)$

$\S 2^{\circ}$ Os tratados, convenções e atos internacionais referendados pelo Congresso Nacional serão ratificados em prazo não superior a 15 (quinze) dias." (NR)

Art. 102. (...)

III $-(\ldots)$

a) contrariar dispositivo desta Constituição ou de tratados internacionais de direitos humanos;

b) declarar a inconstitucionalidade de lei federal ou tratado internacional, excetuados aqueles a que se refere art. $5^{\circ}, \S 3^{\circ}$ desta Constituição;

Art. 105. (...)

III $-(\ldots)$

a) contrariar tratado ou lei federal, ou negar-lhes vigência, ressalvado o disposto nos arts. $5^{\circ}, \S 3^{\circ}$ e 102 , III, a, ambos desta Constituição;

Art. $2^{\circ}$ (PEC). Os tratados, convenções, acordos e atos internacionais já celebrados quando da promulgação desta Emenda Constitucional e que não tenham sido submetidos ao referendo do Congresso Nacional o serão em prazo não superior a 30 (trinta) dias.

Art. $3^{\circ}$ (PEC). Os tratados, convenções, acordos e atos internacionais que já estejam tramitando no Congresso Nacional para referendo na data de publicação desta Emenda Constitucional, serão objeto de deliberação em prazo não superior a 120 (cento e vinte) dias.

Art. $4^{\circ}$ (PEC). Os tratados, convenções, acordos e atos internacionais que já tenham sido referendados pelo Congresso Nacional na data de publicação desta Emenda Constitucional serão ratificados pelo Presidente da República em prazo não superior a 60 (sessenta) dias.

Parágrafo Único. O Presidente da República, caso entenda que a ratificação dos instrumentos internacionais a que se refere o caput deste artigo não atende ao interesse público, deverá solicitar ao Congresso Nacional, no mesmo prazo, permissão para denunciá-los ou, quando for o caso, realizar outra forma de distrato.

Informação disponível em:

http://www2.camara.leg.br/proposicoesWeb/fichadetramitacao?idProposicao $=266125$

Acesso: 13.02 .2016

\section{CD PEC 389/2005}

Ementa: Altera o art. $4^{\circ}$ e o inciso I do art. 49 da Constituição Federal. Estabelece que os tratados, acordos e atos internacionais que possam comprometer a soberania nacional, ou que transfiram atribuições do Estado brasileiro a organismos supranacionais, serão submetidos a referendo popular; altera a Constituição Federal de 1988.

Situação: arquivada.

Proposta:

Art. $4^{\circ}(\ldots)$

$\S 1^{\circ}$. A República Federativa do Brasil buscará a integração econômica, política, social e cultural dos povos da América Latina, visando à formação de uma comunidade latino-americana de nações.

$\S 2^{\circ}$. Os tratados, acordos e atos internacionais que possam comprometer a soberania nacional, ou que transfiram atribuições do Estado brasileiro a organismos supranacionais, serão submetidos a referendo popular. 


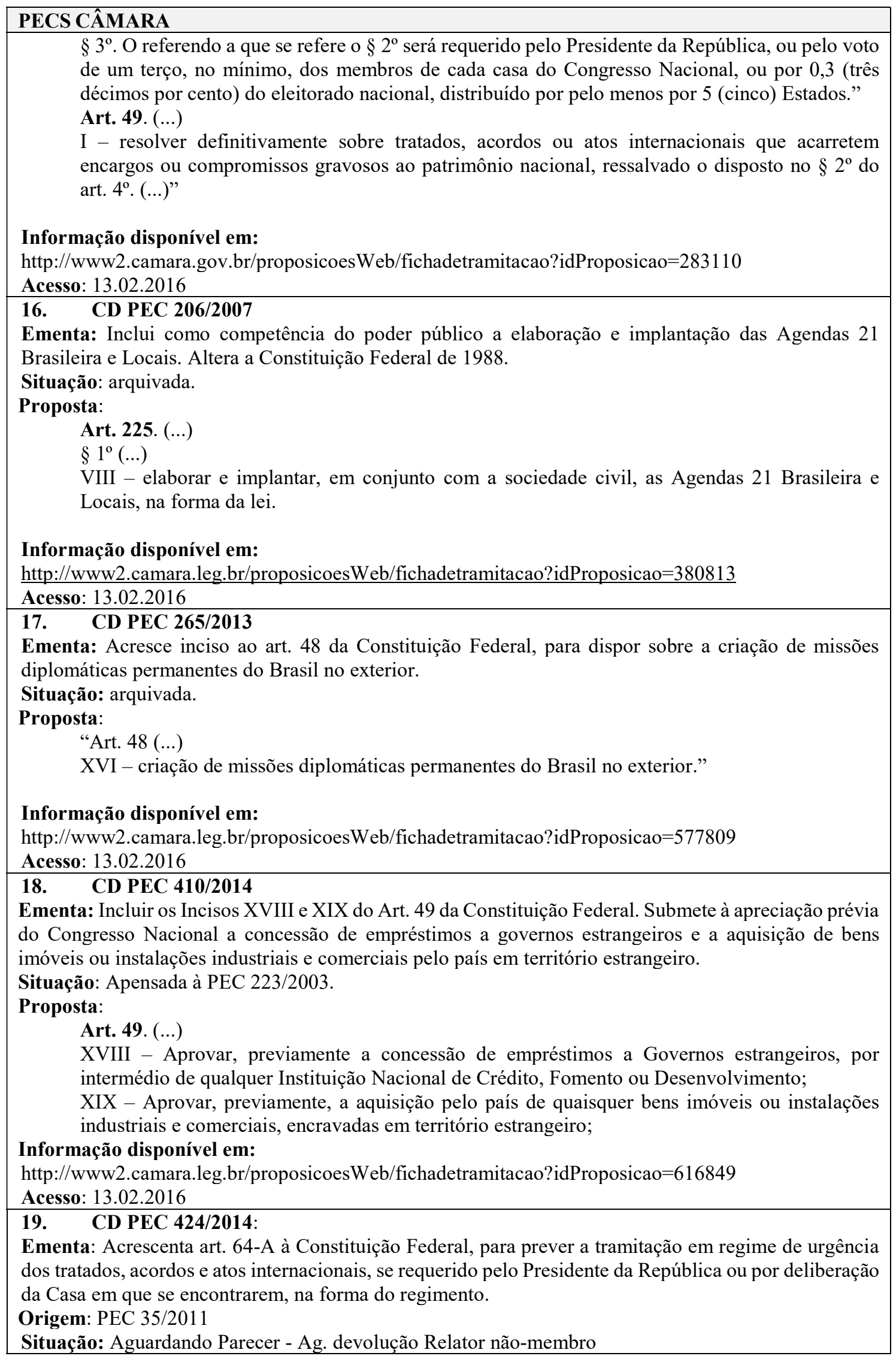




\section{PECS CÂMARA}

Proposta:

Art. 64-A. Os tratados, acordos e atos internacionais submetidos ao Congresso Nacional para o fim previsto no inciso I do art. 49 poderão tramitar em regime de urgência, se requerido pelo Presidente da República ou por deliberação da Casa em que se encontrarem, na forma do regimento."

Informação disponível em:

http://www2.camara.leg.br/proposicoesWeb/fichadetramitacao?idProposicao $=621723$

Acesso: 13.02 .2016

\section{CD PEC 68/2015}

Ementa: Altera o Artigo 52 da Constituição Federal, incluindo alínea "g" que estabelece a necessidade de sabatina prévia de representante indicado pelo país em funções diretivas de instituições financeiras multilaterais.

Situação: aguardando Designação de Relator na Comissão de Constituição e Justiça e de Cidadania (CCJC).

Proposta:

Art. 52. Compete privativamente ao Senado Federal: (...)

III - aprovar previamente, por voto secreto, após arguição pública, a escolha de: (...)

$\mathrm{G}$ - representante do país para exercer funções diretivas em instituições financeiras multilaterais;

Informação disponível em:

http://www2.camara.leg.br/proposicoesWeb/fichadetramitacao?idProposicao=1307168

Acesso: 13.02 .2016

21. CD PEC 75/2015:

Ementa: Altera o artigo 49 da Constituição Federal, dispondo sobre a competência exclusiva do Congresso Nacional em matéria de tratados, acordos ou atos internacionais.

Situação: aguardando Parecer - Ag. devolução relator não-membro.

Proposta:

Art. 49. (...)

I - resolver definitivamente sobre tratados, acordos ou atos internacionais que acarretem encargos ou compromissos gravosos ao patrimônio nacional, ou determinar a sua denúncia, sem prejuízo da competência do Poder Executivo.

Informação disponível em:

http://www2.camara.leg.br/proposicoesWeb/fichadetramitacao?idProposicao=1526956

Acesso: 13.02 .2016 
APÊNDICE VII

TABELAS RELATIVAS AOS INSTRUMENTOS INTERNACIONAIS 
Tabela 9: Estatísticas 1945-64 G1

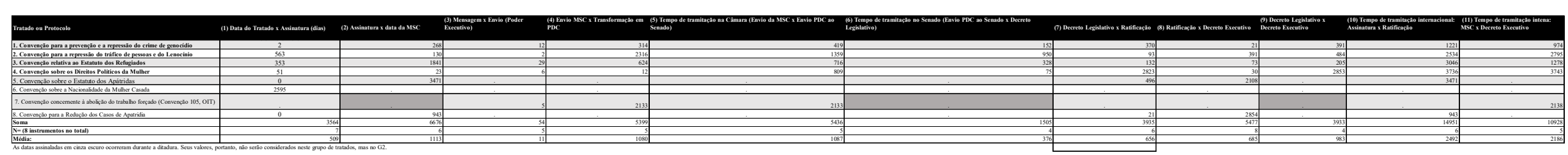

\begin{tabular}{|l|r|}
\hline Médias: & (1) Data do Tratado x Assinatura (dias) \\
\hline Tratados Assinados: $\mathrm{N}=6$ & \\
\hline Tratados NÃO assinados: $\mathrm{N}=1$ & \\
\hline & \\
\hline Médias: & (10) Assinatura x Ratificação (dias) \\
\hline Tratados Ratificados: $\mathrm{N}=4$ & \\
\hline Tratados Não ratificados: $\mathrm{N}=2$ & \\
\hline & \\
\hline Médias: & (8) Assinatura x data da MSC \\
\hline Tratados MSC enviada: $\mathrm{N}=4$ & \multicolumn{1}{|c|}{5634} \\
\hline Tratados MSC NÃO env.: $\mathrm{N}=2$ & 2207 \\
\hline & \\
\hline Médias: & \\
\hline Tratados D Ex no regime: $\mathrm{N}=4$ & (9) MSC x Decreto Executivo \\
\hline Tratados D Ex NÃO no reg: $\mathrm{N}=1$ & \\
\hline
\end{tabular}


Tabela 10: Estatísticas 1964-85 G2

\begin{tabular}{|c|c|c|c|c|c|c|c|c|c|c|c|}
\hline Tratado ou Protocolo & $\begin{array}{l}\text { (1) Datat do Tratado } \\
\text { Assinatura (dias) }\end{array}$ & $\begin{array}{l}x(2) \text { Assinatura } x \\
\text { data da MSC }\end{array}$ & $\begin{array}{l}\text { (3) Mensagem x Envio } \\
\text { (Poder Executivo) }\end{array}$ & $\begin{array}{l}\text { (4) Envio MSC } \mathrm{x} \\
\text { Transformaģio em PDC }\end{array}$ & $\begin{array}{l}\text { (5) Envio da MSC X Evio PDC a a Senalo } \\
\text { (Tempo de tramitaşă na Camara) }\end{array}$ & 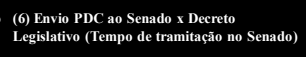 & $\begin{array}{l}\text { (7) Decreto Legislativo } x \\
\text { Ratificasio }\end{array}$ & $\begin{array}{l}\text { (8) Ratificacąio } x \\
\text { Decreto Executivo }\end{array}$ & $\begin{array}{l}\text { (9) Decreto Legislativo } x \\
\text { Deereto Executivo }\end{array}$ & 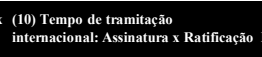 & $\begin{array}{l}\text { (il) Tempo de tramitacąa interma: } \\
\text { MSC } \times \text { Decreto Evecutivo }\end{array}$ \\
\hline 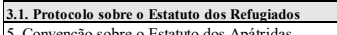 & 1893 & & & & & & & & & & \\
\hline 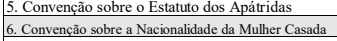 & 847 & $\frac{7654}{72}$ & 48 & & 188 & 392 & 162 & 104 & 266 & 76562 & 894 \\
\hline 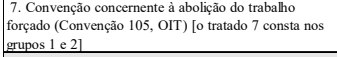 & & & & & & & & 3911 & 440 & & \\
\hline $\begin{array}{l}8 \text { Convengaía para a Reduçă dos Casos de Apatridia } \\
\text { S }\end{array}$ & & 7654 & & & & & & & & 7654 & \\
\hline 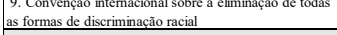 & 0 & 218 & 43 & & 148 & 62 & 280 & 621 & 901 & 751 & 1154 \\
\hline 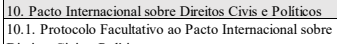 & & & & & & & & & & & \\
\hline 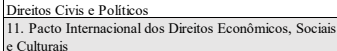 & . & & & & & & & & & & \\
\hline 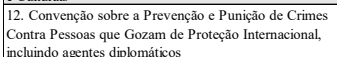 & & & & & & & & & & & \\
\hline 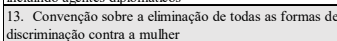 & 469 & 464 & & & 337 & 139 & 79 & 48 & 127 & 1037 & 621 \\
\hline 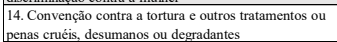 & . & & & & & & & & & & \\
\hline 22. Conventaio Americana sobre Diretoso Humanos & 559 & & & & & & & & & & \\
\hline 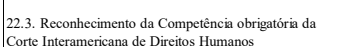 & & & & & & & & & & & \\
\hline $\begin{array}{l}\text { 31. Convençá de Viena sobre o Diretio dos Tratados } \\
\text { Soma }\end{array}$ & 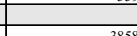 & 5775 & 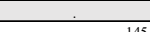 & & 80 & 5007 & 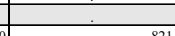 & 16 & 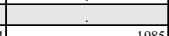 & 5775 & 30 \\
\hline 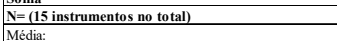 & $\frac{11}{321}$ & $\frac{366}{364}$ & & & $\frac{5}{5}$ & $\frac{5}{156}$ & $\frac{525}{5}$ & $\frac{5}{5}$ & $\frac{5}{5}$ & $\frac{7}{7}$ & $\frac{506}{5}$ \\
\hline & & 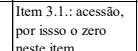 & & & & & & & & & \\
\hline
\end{tabular}

\begin{tabular}{|l|r|}
\hline Médias: & (1) Data do Tratado x Assinatura (dias) \\
\hline Tratados Assinados: $\mathrm{N}=5$ & \\
\hline Tratados NÃO assinados: $\mathrm{N}=7$ & 5054 \\
\hline & \\
\hline & \\
\hline Médias: & \multicolumn{1}{|c|}{ 693 } \\
\hline Tratados Ratificados: 4 & (10) Assinatura x Ratificação (dias) \\
\hline Tratados Não ratificados: 3 & \multicolumn{2}{|c|}{} \\
\hline & \\
\hline Médias: & (2) Assinatura x data da MSC \\
\hline Tratados MSC enviada: $\mathrm{N}=3$ & \\
\hline Tratados MSC NÃO env.: $\mathrm{N}=3$ & \\
\hline
\end{tabular}


Tabela 11: Estatísticas 1985-2016 G3

\begin{tabular}{|c|c|c|c|c|c|c|c|c|c|c|c|}
\hline Tritado ou Protocolo & $\begin{array}{l}\text { (1) Data do Tratado } x \\
\text { Assinatura (dias) }\end{array}$ & $\begin{array}{l}x \\
x \text { (2) Assinatura } x \\
\text { datat da MSC }\end{array}$ & 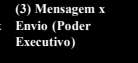 & 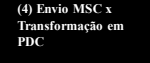 & 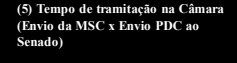 & 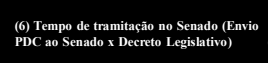 & (7) Decerto Legisiataivo x ratifiestyio & (8) Ratificasaíio $\mathrm{X}$ Decreto Executivo & 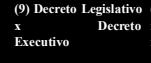 & 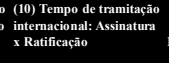 & 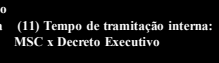 \\
\hline 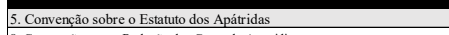 & & & & & & & & & & & \\
\hline 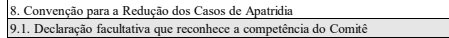 & & & & $\frac{62}{196}$ & $\frac{213}{39}$ & $\frac{2201}{191}$ & & & $\frac{2875}{412}$ & 8259 & $\frac{3277}{1009}$ \\
\hline 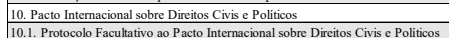 & $\frac{2506}{8060}$ & & & $\frac{174}{155}$ & $\frac{572}{889}$ & $\frac{2633}{130}$ & 134 & & 207 & 91 & 2418 \\
\hline 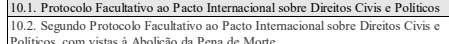 & $\frac{8960}{7224}$ & & & $\begin{aligned} 155 \\
155 \\
1\end{aligned}$ & 55. & 3009 & & & & & \\
\hline 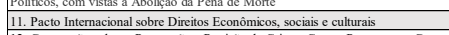 & 2506 & & & $\frac{193}{174}$ & 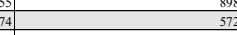 & 1633 & & & 20 & & \\
\hline 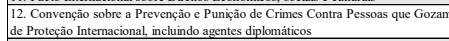 & 5197 & & & 239 & 414 & 112 & 68 & 99 & 167 & & 699 \\
\hline 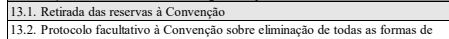 & & & & & & & & & 3005 & & 3392 \\
\hline 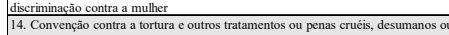 & 24 & & & & 240 & 167 & 54 & & 54 & 504 & 470 \\
\hline degandantes & ${ }^{192}$ & 248 & & 183 & 38.5 & 700 & 128 & 505 & 633 & 1466 & 1723 \\
\hline 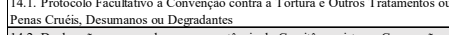 & 299 & 192 & & 153 & 893 & 22 & & 98 & 120 & 1186 & 1092 \\
\hline 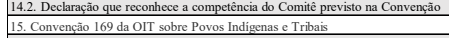 & & & & $\frac{188}{617}$ & $\frac{1258}{9771}$ & $\frac{1225}{3221}$ & 35 & 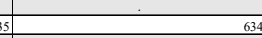 & 669 & 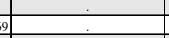 & 4679 \\
\hline 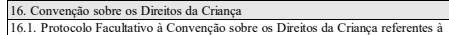 & 67 & 1110 & & & 103 & & & 58 & 68 & 241 & 189 \\
\hline 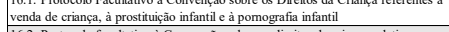 & ${ }^{104}$ & 369 & & 518 & 532 & 79 & 243 & 41 & 284 & 1238 & 910 \\
\hline 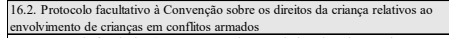 & 104 & 369 & 69 & 518 & 532 & 79 & 243 & 41 & 284 & 1238 & 910 \\
\hline 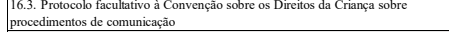 & 71 & 1072 & & 204 & & & & & & & \\
\hline 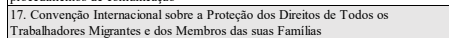 & & & & & & & & & & & \\
\hline 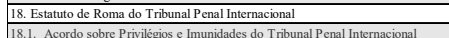 & $\frac{570}{6615}$ & $\frac{535}{1512}$ & & $\frac{1777}{160}$ & $\frac{196}{47}$ & $\frac{43}{113}$ & $\frac{14}{81}$ & $\frac{97}{1467}$ & $\frac{111}{1548}$ & $\frac{864}{2765}$ & $\frac{426}{2720}$ \\
\hline 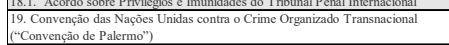 & 27 & $\frac{1512}{350}$ & & $\begin{array}{r}160 \\
392 \\
\end{array}$ & 400 & 78 & 245 & 43 & 288 & ${ }_{1143}$ & 836 \\
\hline 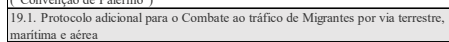 & 27 & 3000 & & 392 & 400 & 78 & 245 & 43 & 288 & ${ }_{1143}$ & 8360 \\
\hline 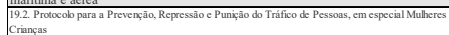 & 27 & 350 & & 392 & 400 & 78 & 245 & 45 & 288 & ${ }_{1143}$ & 836 \\
\hline 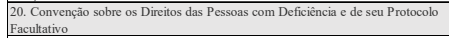 & ${ }_{107}$ & 118 & & 230 & 245 & 42 & 23 & 389 & 412 & 490 & 761 \\
\hline 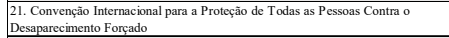 & 48 & 268 & 68 & 177 & 307 & ${ }_{147}$ & & 1990 & 2079 & 1392 & \\
\hline 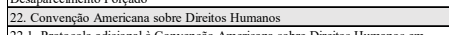 & 2733 & & & 174 & 1362 & 1009 & & & 164 & 1 & 2565 \\
\hline 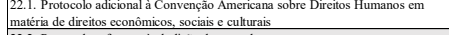 & 2834 & & & 216 & 461 & 413 & 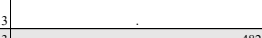 & 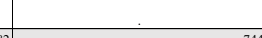 & 1716 & 5 & 2596 \\
\hline 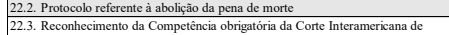 & & & & & & & & & & & 21006 \\
\hline 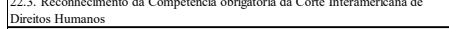 & 5018 & & & 36 & 4 & $4:$ & & & 1436 & & 1520 \\
\hline 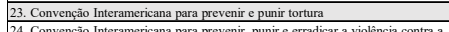 & 46 & 138 & & 173 & & 358 & 50 & & 162 & & 1247 \\
\hline 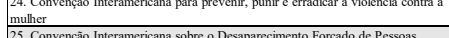 & 89 & 132 & & 118 & 216 & 8 & 77 & 259 & 336 & 436 & 5 \\
\hline 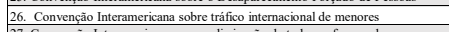 & 0 & 304 & & 1111 & 566 & 84 & 251 & 408 & 659 & 1208 & $\frac{1312}{1312}$ \\
\hline 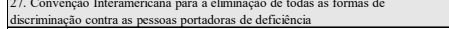 & o & 118 & & 159 & 501 & 99 & 34 & 83 & 1177 & .700 & 735 \\
\hline 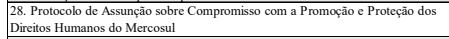 & o & 448 & & S233 & 977 & 72 & 189 & 1119 & 308 & 1771 & 1389 \\
\hline 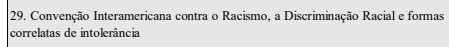 & ${ }_{61}$ & & & & & & & & & & \\
\hline 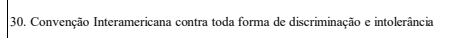 & ${ }_{61}$ & & & & & & & & & & \\
\hline 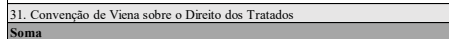 & 41478 & & & $\frac{2241}{8682}$ & $\frac{24}{28}$ & + & $\frac{755}{455}$ & $\frac{80}{13614}$ & $\frac{150}{243737}$ & $\frac{8960}{494909}$ & $\frac{6451}{66345}$ \\
\hline 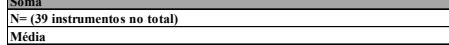 & $\begin{array}{c}\frac{4148}{31} \\
\frac{4338}{1338}\end{array}$ & $\frac{18583}{24}$ & & $\frac{8024}{361}$ & $\frac{36}{86}$ & 385] & $\frac{28}{\frac{283}{163}}$ & $\frac{\frac{228}{280}}{480}$ & $\frac{32}{737}$ & $\frac{27}{1833]}$ & 2032 \\
\hline
\end{tabular}


Tabela 12: Data x Assinatura na Ditadura e na Democracia

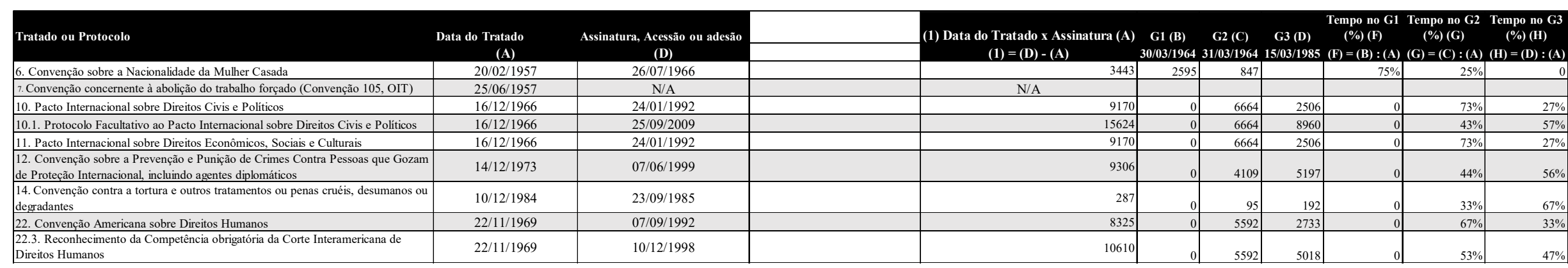

\section{Tabela 13: Assinatura x Ratificação na Ditadura e na Democracia}

\begin{tabular}{|c|c|c|c|c|c|c|c|c|c|}
\hline \multirow{2}{*}{ Tratado ou Protocolo } & Assinatura, Acessão ou adesã & Ratificacão & (10) Assinatura x Ratificação (A) & G1 (B) & G2 (C) & G3 (D) & $\begin{array}{c}\text { Tempo no G1 } \\
\text { (\%) (F) }\end{array}$ & $\begin{array}{l}\text { Tempo no G2 } \\
\text { (\%) (G) }\end{array}$ & $\begin{array}{c}\text { Tempo no G3 } \\
\text { (\%) (H) }\end{array}$ \\
\hline & (D) & (E) & $(2)=(E)-(D)$ & $30 / 03 / 1964$ & $31 / 03 / 1964$ & $15 / 03 / 1985$ & $(\mathbf{F})=(\mathbf{B}):(\mathbf{A})$ & $(\mathbf{G})=(\mathrm{C}):(\mathrm{A})$ & $(\mathrm{H})=(\mathrm{D}):(\mathrm{A})$ \\
\hline 5. Convenção sobre o Estatuto dos Apátridas & $28 / 09 / 1954$ & $13 / 08 / 1996$ & 15295 & 3471 & 7654 & 4169 & $23 \%$ & $50 \%$ & $27 \%$ \\
\hline 8. Convenção para a Redução dos Casos de Apatridia & $30 / 08 / 1961$ & $25 / 10 / 2007$ & 16857 & 943 & 7654 & 8259 & $6 \%$ & $45 \%$ & $49 \%$ \\
\hline 31. Convenção de Viena sobre o Direito dos Tratados & 23/05/1969 & $25 / 09 / 2009$ & 14735 & 0 & 5775 & 8960 & $0 \%$ & $39 \%$ & $61 \%$ \\
\hline
\end{tabular}

Tabela de tratados que foram assinados e ratificados em

regimes diferentes.

\section{Tabela 14: Assinatura x Data MSC}

\begin{tabular}{|c|c|c|c|c|c|c|c|c|c|}
\hline Tratado ou Protocolo & Assinatura, Acessão ou adesão & Mensagem Presidencial & $\begin{array}{l}\text { Data da MSC } \\
\text { (A) }\end{array}$ & G1 (B) & G2 (C) & G3 (D) & $\begin{array}{c}\text { Tempo no G1 } \\
\text { (\%) (F) }\end{array}$ & $\begin{array}{c}\text { Tempo no G2 } \\
(\%)(\mathbf{G})\end{array}$ & $\begin{array}{c}\text { Tempo no G3 } \\
\text { (\%) (H) }\end{array}$ \\
\hline & (D) & (F) & $(8)=(F)-(D)$ & 30/03/1964 & $31 / 03 / 1964$ & $15 / 03 / 1985$ & $(F)=(B):(A)$ & $(G)=(C):(A)$ & $(H)=(D):(A)$ \\
\hline 5. Convenção sobre o Estatuto dos Apátridas & $28 / 09 / 1954$ & $09 / 03 / 1993$ & 14042 & 3471 & 7654 & 2916 & $25 \%$ & $55 \%$ & $21 \%$ \\
\hline 8. Convenção para a Redução dos Casos de Apatridia & $30 / 08 / 1961$ & $16 / 04 / 2001$ & 14474 & 943 & 7654 & 5876 & $7 \%$ & $53 \%$ & $41 \%$ \\
\hline 31. Convenção de Viena sobre o Direito dos Tratados & $23 / 05 / 1969$ & $16 / 04 / 1992$ & 8364 & 0 & 5775 & 2589 & $0 \%$ & $69 \%$ & $31 \%$ \\
\hline
\end{tabular}


Tabela 15: MSC x Decreto Presidencial na Ditadura e na Democracia

\begin{tabular}{|c|c|c|c|c|c|c|c|c|c|}
\hline Tratado ou Protocolo & Mensagem Presidencial & Decreto Executivo & (11) Data MSC x Decreto Executivo (A) & G1 (B) & G2 (C) & G3 (D) & \begin{tabular}{|c|} 
Tempo no G1 \\
(\%) (F) \\
\end{tabular} & \begin{tabular}{|c|} 
Tempo no G2 \\
(\%) (G)
\end{tabular} & 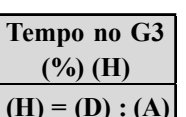 \\
\hline & (F) & (K) & $(1)=(\mathbf{D})-(\mathbf{A})$ & $30 / 03 / 1964$ & $31 / 03 / 1964$ & $15 / 03 / 1985$ & $(\mathrm{~F})=(\mathrm{B}):(\mathrm{A})$ & $(\mathbf{G})=(\mathbf{C}):(\mathbf{A})$ & $(\mathbf{H})=(\mathbf{D}):(\mathbf{A})$ \\
\hline $\begin{array}{l}\text { 7. Convenção concernente à } \\
\text { abolição do trabalho forçado } \\
\text { (Convenção 105, OIT) }\end{array}$ & $23 / 05 / 1958$ & $14 / 07 / 1966$ & 2974 & 2138 & 835 & 0 & $72 \%$ & $28 \%$ & 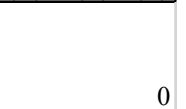 \\
\hline
\end{tabular}

